Doutorado Interinstitucional em Arquitetura e Urbanismo Universidade de São Paulo - Faculdade de Arquitetura e Urbanismo

\title{
Uma metrópole em transição: Reestruturação produtiva e a emergência do turismo na RM de Fortaleza-CE
}

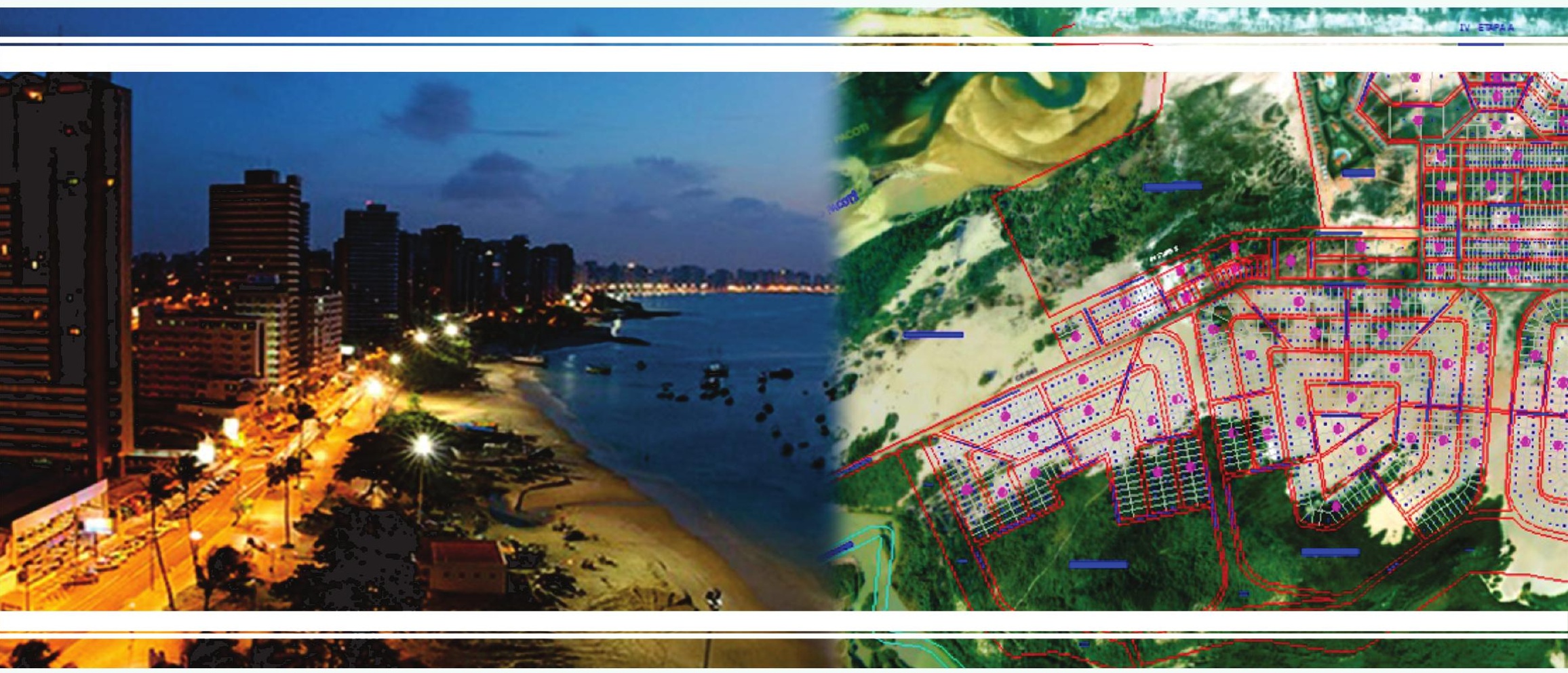

Ignácio Ribeiro Pessoa Montenegro Júnior

São Paulo

Julho de 2012 
Doutorado Interinstitucional em Arquitetura e Urbanismo

Universidade de São Paulo - Faculdade de Arquitetura e Urbanismo Universidade Federal do Ceará - Departamento de Arquitetura e Urbanismo

\section{Uma metrópole em transição: Reestruturação produtiva e a emergência do turismo na RM de Fortaleza-CE}

Ignácio Ribeiro Pessoa Montenegro Júnior

São Paulo

Julho de 2012 


\title{
IGNÁCIO RIBEIRO PESSOA MONTENEGRO JÚNIOR
}

\section{Uma metrópole em transição: Reestruturação produtiva e a emergência do turismo na RM de Fortaleza-CE}

\author{
Tese apresentada à Faculdade de \\ Arquitetura e Urbanismo da \\ Universidade de São Paulo para \\ obtenção do título de Doutor em \\ Arquitetura e Urbanismo \\ Área de Concentração: História e \\ Fundamentos da Arquitetura e \\ Urbanismo \\ Orientador: Prof. Dr. Paulo Cesar \\ Xavier Pereira
}

São Paulo 
Autorizo a reprodução e divulgação total ou parcial deste trabalho, por qualquer meio convencional ou eletrônico, para fins de estudo e pesquisa, desde que citada a fonte.

e-mail: ignacio_montenegro2002@yahoo.com.br / ignacio.montenegro@caixa.gov.br

Montenegro Júnior, Ignácio Ribeiro Pessoa

M777m Uma metrópole em transição: reestruturação produtiva e a emergência do turismo na RM de Fortaleza - CE / Ignácio Ribeiro Pessoa. -- São Paulo, 2012.

XXX p. : il.

Tese (Doutorado - Área de Concentração: História e Fundamentos da Arquitetura e do Urbanismo) - FAUUSP.

Orientador: Paulo Cesar Xavier Pereira

1. Urbanização - Fortaleza (CE) 2. Áreas metropolitanas - Fortaleza (CE) 3. Turismo litorâneo Fortaleza (CE) 4. Empreendimentos imobiliários Fortaleza (CE) 5. Segregação urbana - Fortaleza (CE) I. Título 


\section{Agradecimentos}

Ao Professor Paulo Cesar Xavier Pereira, pela orientação criteriosa, competente e instigante. Não poderia desejar uma orientação mais acessível, mesmo diante dos limites impostos pela distância.

Às Professoras Marta Dora Grostein, Maria Cristina da Silva Leme e Maria Ângela Faggin Pereira Leite, pelo acompanhamento impecável na coordenação do DINTER e pelas valiosas contribuições durante todos os seminários de acompanhamento em São Paulo e Fortaleza.

Aos professores Hugo Segawa, Nabil Bonduki e Suzana Pasternak pelas oportunas sugestões durante os seminários de acompanhamento em Fortaleza, como também pelas brilhantes palestras sobre as atividades de pesquisa desenvolvidas no âmbito da FAUUSP, abertas à comunidade acadêmica local.

À Professora Marta Dora Grostein e ao Professor Ricardo Figueiredo Bezerra pelas valiosas orientações e críticas construtivas durante o processo de qualificação do trabalho.

Aos membros da banca de defesa da tese: Professores José Borzacchiello da Silva, Paulo Cesar Xavier Pereira, Ricardo Figueiredo Bezerra e as professoras Maria Lúcia Caira Githay e Maria Ruth Amaral Sampaio, pelas criteriosas leituras do trabalho e animado debate durante a defesa.

Ao Professor Ricardo Figueiredo Bezerra, pela acessível condução da Coordenação local do DINTER e pela amistosa forma de trocar ideias durante todo o percurso do trabalho.

A toda a equipe que compõe a CPG da FAU USP, em especial a Sra. Cristina Arguejo, que sempre nos acolheu com alegria e boa vontade, atenta a todos os nosso compromissos.

Aos professores e alunos da pós-graduação da FAU USP que tive o prazer de conhecer e com quem pude compartilhar inquietações sobre os temas da arquitetura e da cidade

Aos colegas doutorandos Romeu Duarte, Margarida Andrade, Beatriz Diógenes, Ricardo Fernandes, Paulo Costa, Magda Campelo, Lucila Novaes e Caetano Aragão, pela rica convivência nas trocas de ideias, sempre acompanhadas de amizade e companheirismo.

À Universidade Federal do Ceará, representada pelo Magnífico Reitor Jesualdo Pereira Farias e ao Banco do Nordeste do Brasil, na pessoa do Sr. Roberto Smith, que viabilizaram o convênio para a realização do Doutorado Interinstitucional - DINTER realizado entre a FAU USP e o DAU UFC.

À Pró-Reitoria de Pesquisa e Pós-Graduação da UFC, na pessoa do Professor Gil de Aquino Farias. 
À Fundação Cearense de Pesquisa e Cultura, na pessoa do seu presidente, o Sr. Francisco Antônio Guimarães, e especialmente à equipe do Setor de Prestação de Contas, na pessoa do Sr. Alexandre Pereira, pelo apoio na gerência dos recursos concedidos.

Ao Departamento de Arquitetura e Urbanismo da UFC, nas pessoas dos Professores José Lemenhe e Joaquim Aristides de Oliveira, chefes do Departamento no período de realização do Doutorado, pelo fundamental apoio institucional e logístico.

A minha mãe querida que demostrou com a sua vida e seu exemplo, o valor da fé e da resiliência nos momentos críticos. Ensinou-me a ser humilde e altivo e a meditar com o coração que me fez nunca desistir dos meus sonhos.

Ao meu pai querido pelo incentivo marcante durante todos os momentos e pela força do exemplo em suas atitudes: sempre firmes e amorosas, sem falar na impecável tradução do abstract que me fez revisar toda a redação da tese.

À Márcia, esposa e educadora zelosa do nosso filho como também das suas turmas de alunos: pelos ensinamentos cotidianos de como valorizar a vida e a ética, na prática.

A mana Cida, sempre atuante e presente nos momentos mais significativos da família, pelas orientações na redação final do resumo que acabaram repercutindo também na última revisão do texto.

Ao Dr. Aprígio Sucupira pelo acolhimento e orientações valiosas, no primeiro momento.

À Dra. Karina Saboya pela orientação e acompanhamento, fundamentais para o equilíbrio e finalização do trabalho.

À Dra. Maria do Carmo Latorre pelo acompanhamento afetuoso e presente, nos momentos críticos, desde longas datas.

Ao colega José Oliveira, sempre rigoroso e justo, pelo apoio decisivo em um momento em que só os homens generosos e sábios mostram a sua diferença.

A todos os colegas da Caixa na RESEC-Fortaleza que me apoiaram e dividiram comigo as minhas primeiras angústias diante de cada dificuldade que ia surgindo e sendo resolvida, uma a uma, como por encanto.

A todos os colegas da Caixa na GIDUR-Teresina que me acolheram com amizade, originalidade e sabedoria, demonstrando compreensão no valor do meu esforço.

A todos os nossos entrevistados pelas valiosas informações que ficaram registradas no anexo da tese. 


\section{Dedicatória}

Ao Vitor, nosso amado filho, rapaz focado ao enfrentar os seus novos desafios: em quem me inspirei o tempo todo e a quem especialmente dedico esse trabalho, como forma de ensinar-lhe o valor do esforço pessoal na delicada tarefa de nossa auto superação.

A minha querida família: meus pais Ignácio e Yeda, minha esposa Márcia e meus irmãos e irmãs: João, Emanuel, Miriam, Lúcia e Cida, cada um na sua jornada, mas sempre demonstrando afetuosamente o acompanhar de toda a minha caminhada, torcendo pelo nosso sucesso.

Aos meus queridos sobrinhos: Lucas, Nayara, Heitor, Yeda, Marilia e Ignácio Neto a quem também dedico este trabalho como prova do valor do esforço pessoal e empenho nas atividades que nos motiva e liberta. 


\section{RESUMO}

A pesquisa tem como objetivo lançar luz sobre o debate em torno das transformações socioespaciais recentes nas cidades brasileiras. Nestas, observam-se processos e nichos de mercado vinculados a produtos imobiliários que participam como causas da dissolução urbana nas metrópoles contemporâneas, caracterizadas pela fragmentação territorial e segregação social. Enfocando os produtos imobiliários vinculados ao turismo, buscamos compreender como se dá a articulação dessa forma de produção social do espaço baseada na emergência de um novo quadro de agentes sociais. Tais agentes são considerados como sujeitos que realizam práticas urbanas inovadoras comprometidas, contudo, com a lógica de reprodução do capital. Este enfoque se justifica por provocar uma discussão em torno dos conceitos de "padrão de ocupação" e "estruturação espacial", na perspectiva de compreender o novo papel dos agentes imobiliários articulados ao turismo. No primeiro capítulo, abordamos a discussão teórica sobre a produção da cidade contemporânea no contexto da reestruturação, trabalhando os fundamentos da produção e apropriação do espaço urbano contemporâneo. Como ponto de partida, lançamos mão do conceito de espaço social e sua produção como estratégia de acumulação do capital, ressaltando o papel do mercado e do Estado na organização espacial da produção. Na sequência, discutimos a questão da transição metropolitana e a dissolução urbana das cidades contemporâneas, utilizando o conceito de reestruturação, associado ao de globalização, ressaltando o novo padrão de cidade e a nova configuração espacial. No segundo capítulo fazemos a primeira aproximação com a questão central, analisando a urbanização litorânea no contexto da reestruturação metropolitana de Fortaleza. Desse modo, examinamos as especificidades das Zonas Costeiras, o processo de ocupação do litoral cearense e a consolidação de Fortaleza como capital, enfocando em detalhes, o seu processo de metropolização. Para isso, partimos de uma análise que cobre desde a industrialização tardia no Nordeste à reestruturação produtiva e sócio-territorial do Ceará contemporâneo, a fim de ressaltar a emergência do turismo em sua relação com a produção do novo espaço urbano litorâneo. No terceiro capítulo, tratamos a questão central da reestruturação metropolitana e a emergência do turismo, enfocando a participação dos agentes imobiliários no caso de Aquiraz. Essa escolha deve-se ao fato de que esse trecho do litoral revela de modo mais evidente a questão em foco, proporcionando elementos conclusivos capazes de consolidar nossas considerações finais. Assim, foi possível concluir que a ação desses agentes imobiliários responde à reorganização de um novo processo de produção do espaço para o turismo, frente à necessidade de incorporar novos territórios à lógica de reprodução do capital.

\section{Palavras-chave:}

1. Urbanização - Fortaleza (CE)

2. Áreas metropolitanas - Fortaleza (CE)

3. Turismo litorâneo - Fortaleza (CE)

4. Empreendimentos imobiliários - Fortaleza (CE)

5. Segregação urbana - Fortaleza (CE) 


\begin{abstract}
The objective of this research is to shed light on the debate about recent socio-spatial transformations in Brazilian cities. One can observe in these transformations market processes and niches linked to real-estate products that participate as the causes for the urban dissolution in contemporary large cities, characterized by territorial fragmentation and social segregation. While focusing on those real-estate products that are linked to tourism, we have aimed to understand the process by way of which the articulation of such new form of social production of space, based on an emerging scenario created by social agents, takes place. Such agents are seen as the subjects who bring forth innovative urban practices though intrinsically committed to the logic of quick increase of capital. Such focus can be justified for provoking a discussion about the concepts of occupation pattern and spatial structuring, as an attempt to understand the new role played by real-estate agents involved in tourism. In the first chapter we approach the theoretical discussion on the production of contemporary cities in a re-structuring context, analyzing the fundamentals of production and appropriation of the contemporary urban space. As our point of departure, we took over the concept of social space and its production as a strategy towards the accumulation of capital, emphasizing the role played by the market and the State in the spatial organization of production. Then we discussed both the metropolitan transitional issue and the urban dissolution of contemporary cities, by using the concept of a restructuring standpoint associated with the concept of globalization, emphasizing the new pattern of city as well as the new spatial configuration. In the second chapter we carry out the first approximation to the central issue, analyzing the coastal urbanization in the context of the metropolitan re-structuring of Fortaleza. Thus, we examined the detailed features of the Coastal Areas of Ceará, the 'occupational process' of those areas and the consolidation of Fortaleza as a Capital City, by emphasizing, in detail, the process as it gradually became a metropolis. For that reason, we started from an analysis that comprehends from the belated industrialization of the Northeast of Brazil to the productive and socio-territorial re-structuring of modern Ceará in order to emphasize the emergency of tourism in its relation to the production of a new urban coastal space. In the third chapter we treated the central issue of both the metropolitan restructuring and the emerging need for tourism, focusing on the participation of real-estate agents as in the case of Aquiraz. Such a choice is due to the fact that that coastal line reveals more clearly the issue under analysis, creating conclusive elements capable of consolidating our final considerations. Thus it was possible to say in conclusion that 'the action of those real-estate agents respond to the re-organization of a new process of production of space for tourism, in the face of the need to incorporate new territories into the logic of capital growth'.
\end{abstract}

\title{
Key words:
}

1. Urbanization - Metropolitan Area of Fortaleza (State of Ceará)

2. Coastal Tourism (Urban Aspects)

3. Real-Estate Enterprises (Socio-Spatial Aspects)

4. Urban Segregation 


\section{LISTA DE FIGURAS}

\section{CAPÍTULO II}

Fig.

Pág.

2.1 Casario colonial em Aracati: cidade portuária sertaneja vinculada ao comércio de Pernambuco e Bahia.

2.2 Largo do Theberge em Icó: cidade sertaneja com traçado urbanístico português.

2.3 Atividades do Porto de Aracati no final do século XIX.

$2.4 \quad$ Planta do Porto e Villa de Fortaleza de Silva Paulet (1813).

2.5 Mapa do Projeto do Porto do Ceará (1870), em Fortaleza. 59

2.6 A antiga Praia do Peixe, atual Praia de Iracema, na época da construção 60

2.7 Perfil portuário de Fortaleza no início da década de 1920. Vê-se o trilho 60 de trem, os guindastes e os galpões de armazenagem.

2.8 As duas fotos acima mostram a construção e operação da segunda ponte em concreto, no final da década de 1920 e, abaixo, uma vista das duas pontes nos dias atuais, depois da requalificação da primeira ponte feita no início dos anos 1990.

2.9 A segunda ponte dos Ingleses reconstruída em concreto num dia festivo de 1946 - A coexistência entre o espaço recreativo e o espaço do porto.

2.10 Plano ferroviário cearense com as datas de implantação das estações.

2.11 Praça do Ferreira - 1911. Cartão Postal colorizado a mão

2.12 Cruzamento das Ruas Maj. Facundo e Guilherme Rocha, visto da Praça 63 do Ferreira-1911

2.13 Planta da Cidade da Fortaleza e Sobúrbios - Adolfo Herbster -1875.

2.14 A praia deixava de ser o lugar desprestigiado das atividades portuárias para se tornar o espaço de lazer em família como também de uso medicinal para tratamento de doenças respiratórias.

2.15 Práticas esportivas e de lazer também se difundiram rapidamente junto com a ideia de espaço da saúde. Ao fundo o porto na Praia de Iracema A "nova" dinâmica imobiliária iniciada nos anos 1920, na Praia de Iracema, mostra o início da ocupação litorânea por casas de veraneio pela elite fortalezense

2.17 Planta Cadastral de Fortaleza elaborada no governo de Raimundo Girão 1933.

2.18 Proposta para o Bairro Popular Moura Brasil, previsto no Plano de Remodelação e extensão de Saboya Ribeiro, para Fortaleza em 1947.

2.19 Praia Formosa em 1940: O antigo gasômetro, em primeiro plano, o Arraial Moura Brasil, ao fundo: o espaço dos pobres, a Oeste do antigo porto. 
2.20 Planta do Sistema Viário com indicações do circuito de avenidas do

Plano Diretor para Remodelação e Extensão da Cidade de Fortaleza elaborado por Saboya Ribeiro em 1947.

2.21 Os jangadeiros do Mucuripe e a construção dos trilhos de trem da RVC

(no canto inferior direito) que deu suporte à construção do porto.

2.22 Fases da construção do Porto do Mucuripe - Décadas de 1930-19401950.

2.23 Os efeitos da erosão marinha associada à desativação do antigo porto iniciaram na Praia de Iracema um processo de perda do seu dinamismo recreativo, como também da sua função econômica, entrando numa progressiva fase de estagnação do seu comércio, intensificado com o deslocamento dos armazéns e depósitos para o Mucuripe.

2.24 Esta foto, da primeira metade dos anos 1940, mostra como a cidade (dos ricos) vai se expandindo para o Leste, mesmo distante do litoral e do novo porto (canto superior esquerdo em azul), vai superando a barreira provocada pelo riacho Pajeú, atrás da Catedral (em verde) e dos limites dos Boulevards previstos por Adolfo Herbert em 1875 (em vermelho Av. Dom Manuel).

2.25 Cartão postal da praia dos Diários: início da Av. Beira-mar - Meados dos anos 60. Notam-se as residências de veraneio, à esquerda e o público de veranistas junto ao grande público do lazer local.

2.26 Cartão postal datado de 1976, mostrando a coexistência dos antigos e os novos usos, na Ponta do Mucuripe.

2.27 Mapa RMF - Dinâmica Imobiliária dos Conjuntos Habitacionais Décadas de 1970 - 1980.

2.28 A construção da Av. Beira-Mar (em vermelho) foi iniciada em 1960 e 76 inaugurada em 1963. Nesta foto de 1972, vê-se a ausência da verticalização intensificada depois dos anos 1980.

2.29 Duas fases do mesmo trecho da Av. Beira-Mar: Acima o calçadão dos 76 anos 1970 e abaixo já redesenhado no projeto dos anos 1980.

2.30 Cartão postal da Praia do Náutico (Meireles) na década de 1980 em 77 movimento típico de fim de semana.

2.31 A vista aérea de 1982 mostra o crescente movimento de banhistas que começava a congestionar as praias de Fortaleza, juntamente com o início da verticalização.

2.32 Avenida Leste-Oeste atualmente. Em amarelo o Hotel Marina e em azul 78 escuro, o Pirambu dividido em dois pela avenida.

2.33 Av. Leste-Oeste nos anos 1970. Em vermelho o Moura Brasil removido 78 pela obra da Avenida e em azul o Pirambu dividido.

2.34 Foto acima (colorida) a Praia da Leste-Oeste em dia de lazer: mais $\quad 79$ próximo do padrão da zona Leste. Abaixo, em PB a Praia do Pirambu: lazer diferenciado de padrão popular.

2.35 Praia do Pirambu, em primeiro plano. Na sequência: Cristo Redentor 79 (em vermelho) e ao fundo a Barra do Ceará (em amarelo).

2.36 Beira-mar anos 1990.

Beira-mar anos 2000.

O calçadão da Praia do Futuro (1980).

2.41 Trechos litorâneos com previsão de novas intervenções pela Prefeitura. 
2.42 Padrão de loteamentos de veraneio, do início dos anos 1970 - Praia do

Icaraí. em Caucaia (Litoral Oeste).

2.43 O padrão dos primeiros condomínios fechados de residências secundárias de veraneio no Icaraí, induziu uma verticalização moderada no lugar que foi se transformando, aos poucos, em bairro de residência permanente.

2.44 A ocupação na praia da Caponga, em Cascavel. O veraneio e o turismo chegam aos limites da RM de Fortaleza sem respeitar a legislação ambiental.

2.45 Praia de Majorlândia em Aracati. As casas de veraneio chegaram aos Municípios no extremo Leste do Estado sem demonstrar o menor cuidado com a legislação ambiental. A falta de fiscalização permitiu que as residências fossem sendo construídas indiferentemente, sobre as falésias e na faixa de praia.

2.46 O Porto das Dunas começou como um loteamento de veraneio aprovado em 1979 na Prefeitura de Aquiraz. As mudanças no contexto das políticas públicas de turismo do Estado dos anos 1990 o levaram a tornar-se o maior complexo turístico do Ceará.

2.47 A nova imagem do turismo cearense, veiculada em forte campanha publicitária apoiada pelo Estado, desde os anos 1990 a 2000, em estreita parceria com a iniciativa privada. As antigas referências de seca e pobreza do Ceará são substituídas pelo de paraíso tropical associado ao lazer familiar em um parque aquático com hotelaria de referência internacional.

2.48 O Mapa da Dinâmica Industrial atual do Ceará, mostra os quatro polos industriais do Estado, destacando a maior concentração na RM de Fortaleza.

2.49 Mapa da dinâmica do turismo na RM Fortaleza.

2.50 O Porto do Mucuripe nos anos 1960. Vê-se os moinhos de trigo, ao centro, a fábrica de asfalto e o terminal de combustíveis, à esquerda e os armazéns de carga e descarga e terminal de passageiros em primeiro plano.

2.51 PLANDIRF - 1971: Detalhes da $1^{\mathrm{a}}$ etapa de renovação do centro urbano -. Implantação do circuito de pedestres.

2.52 Legislação Básica do Plano Diretor - 1979. Planta de estruturação urbana.

2.53 Mapa da evolução da mancha urbana na RM de Fortaleza: 1932-1980. Mapa RMF - Sistema Viário - Década de 1980.

2.55 O mapa da dinâmica Industrial da RMF na década de 1980 permite visualizar, sinteticamente a relação entre os eixos industriais e os corredores metropolitanos estruturantes.

2.56 Mapa RMF - Dinâmica Terciário - Década de 1980.

2.57 Mapa da distribuição industrial segundo tipo de atividades - 2007. 122

2.58 RMF - Sistema Viário 2008.

2.59 Mapa de localização do Canal da Integração. 
2.66 Saneamento básico do PRODETUR/CE - I. 149

2.67 Municípios Incluídos No Prodeturis-Ce. 150

2.68 Municípios Do Polo Ceará Costa Do Sol. 150

2.69 Unidades Geoambientais - Ceará. 153

$2.70 \quad$ Macrorregiões Turísticas. 154

2.71 Corredor Turístico Estruturante. 155

2.72 Âncoras Turísticas. 155

2.73 Distribuição das aplicações do PRODETUR. 156

2.74 Tipo de urbanização dispersa provocado pelo turismo. Ao fundo vê-se a 157 cidade de Fortaleza e no primeiro plano o complexo turístico em torno de uma Área de Proteção Ambiental em Aquiraz-CE.

\section{CAPÍTULO III}

3.1 Alcacer Art \& Golf Resort.

3.2 Localização do Alcacer Art \& Golf Resort (em vermelho) na Região 165

3.3 Maquete eletrônica do empreendimento Aquiraz Riviera com oito 166 empreendimentos hoteleiros previstos, na faixa litorânea. Atrás, o campo de golf permeando a malha da vila turística.

3.4 Imagem de satélite atual do Aquiraz Riviera mostrando o primeiro hotel em funcionamento (em amarelo) e uma parte do campo de Golf já construído (em vermelho). Os demais empreendimentos estão em fase de projetos e captação. Embora tenha sido vendido algo em torno de 50\% dos lotes para as vilas turísticas, não há ainda nenhuma casa construída.

3.5 Padrão de ocupação encontrado no litoral do Porto das Dunas, diferente do conceito de Golf Club, mas que também mescla empreendimentos turísticos e imobiliários. Nesse caso, foram implantados em loteamento de veraneio aprovado na prefeitura de Aquiraz, ainda em 1979 que se adequou ao incremento do turismo dos anos 1990.

3.6 Novos padrões de ocupação no Porto das Dunas: em vermelho - condhotel vinculado ao Beach-Park (administrado em regime de pool); em amarelo: condomínio fechado tradicional; em verde: Hotel Resort, integrado ao complexo Beach Park; em azul: o parque aquático. Nos demais lotes vê-se o padrão de residências de veraneio, padrão típico dos anos 1980-1990.

3.7 Maquete eletrônica do Golf Ville Resort Residence. Empreendimento com incorporação e construção promovida por empresa cearense. $\mathrm{O}$ conceito é o mesmo padrão internacional, mas adaptado ao perfil econômico da elite local e regional, diante da crise internacional.

3.8 Empreendimento Golf Ville Resort Residence com obras em andamento, 168 acima à esquerda. Ao lado, à direita, o estande de vendas. Abaixo à esquerda o Outdoor do Estande de vendas e à direita uma maquete eletrônica em foto montagem hiper-realista do projeto, para ajudar a alavancar as vendas.

3.9 O Ceará no Nordeste do Brasil.

3.10 Regiões Metropolitanas e Microrregiões administrativas do Ceará. $\quad 171$

3.11 Região metropolitana de Fortaleza - Posição oficial em 2009. 
3.12 Os quatro vetores de expansão metropolitana da RMF, segundo o PDDU 173 Aquiraz - 2005.

3.13 Vetores de expansão metropolitana da dinâmica turística. 175

3.14 Acima, outdoors de condomínios padrão resort ao longo das vias de $\quad 176$ acesso. Abaixo imagens publicitárias de hotéis em operação.

3.15 Acessos e Localização das Regiões Turísticas. 177

3.16 Mapa de Vegetação e Recursos Hídricos. 178

3.17 Inauguração da ponte sobre o Rio Pacoti em 1958.

$3.18 \quad$ Primeira Linha de ônibus, $1950 . \quad 180$

3.19 Divisão distrital do Município. 181

3.20 Malha do loteamento sobre imagem de 2002. 182

$3.21 \quad$ Foto aérea do Beach Park. 183

3.22 Localização relativa, dos dois modelos opostos no Município de Aquiraz. 185

Entre os dois extremos as quatro localidades praianas que vão se convertendo de espaço de veraneio a pontos turísticos.

3.23 A área do empreendimento com o lago e a comunidade. 185

3.24 Primeira fase do Aquiraz Resort (1999). 186

$\begin{array}{ll}3.25 & 187\end{array}$

3.26 Municípios Incluídos no Prodeturis-Ce. 188

3.27 Municípios Do Polo Ceará Costa Do Sol. 188

3.28 MRT1- Macrorregião turística 1 - Fortaleza Metropolitana. 190

3.29 Macrorregião turística Litoral Leste/Apodi - Âncoras turísticas $\quad 190$

$3.30 \quad$ Praia do Iguape. 192

3.31 Vista da Prainha com as barracas de praia. Ao fundo o loteamento se 193 mistura com a vila de pescadores. Em amarelo um Hotel de proprietário Italiano e em vermelho uma pousada local.

3.32 Vista da Praia do Presídio: o Hotel em amarelo e a pousada em 194 vermelho. Nota-se a ausência de barracas de praia e uma ocupação mais homogênea e menos adensada.

3.33 Vista do Barro Preto. O Hotel, em amarelo. As pousadas em Azul e o 194 camping em vermelho. Abaixo, à esquerda, as barracas de praia com a presença de ônibus de fretamento popular, em verde.

3.34 Vista aérea mostrando a ponte, construída no final dos anos 1970 (em 195 primeiro plano), a APA do Rio Pacoti (em segundo plano) e o loteamento Porto das Dunas (ao fundo).

3.35 Loteamento Porto das Dunas com as etapas de implantação, sob imagem de 1999 (PDDU Aquiraz - 2005). No ano da foto só existia dois grandes empreendimentos: O Beach Park e o Aquaville.

3.36 Detalhe da APA no Mapa de Macrozonas de Ocupação na primeira 198 versão do PDDU de Aquiraz em 2000.

3.37 Paisagem natural "protegida" pela APA e ameaçada, caso o projeto de 199 expansão do loteamento seja aprovado pela SEMACE.

3.38 Detalhe da malha do loteamento sobre a APA, no Mapa de Zoneamento. 199

3.39 Planta de Zoneamento das Áreas de Interesse Turístico 1 e 2, 200 correspondente ao Porto das Dunas.

3.40 Zoneamento da Lei de Parcelamento, Uso e Ocupação do Solo - 2011. 201

3.41 Exemplo esquemático do perfil litorâneo do Ceará. 204

3.42 Maquete eletrônica do Beach Park Well Ness Resort: condomínio 208 vertical adensado (cinco pavimentos) com vários serviços turísticos embutidos, apresentados como diferencial de mercado. 
3.43 Foto aérea atual do empreendimento em fase de acabamento. Embora 208 bastante adensado, o produto agrega serviços sofisticados.

3.44 Foto aérea da região da APA do rio Pacoti e do loteamento porto das dunas (1999). Vê-se o complexo turístico do Beach Park (amarelo) e o Aqua Ville (vermelho) o primeiro grande condomínio com características de hotel. Em azul a área do futuro Alfa Ville, ainda preservada.

3.45 Foto aérea da região da APA do rio Pacoti e do loteamento porto das 210 dunas (2003).

3.46 Foto aérea da região da APA do rio Pacoti e do loteamento porto das 210 dunas (2003). Detalhe da faixa litorânea ocupada por casas pouco adensadas.

3.47 No primeiro plano, o Aquaville e na sequência, o Portamaris e o Vila do Porto. Só o primeiro atua como cond-hotel. Os demais são condomínios residenciais puros, mas que devido ao alto custo de manutenção, alguns proprietários começam a alugar para temporada e datas festivas.

3.48 Detalhe da faixa litorânea num processo de verticalização e adensamento com condomínios de alto padrão. O hexágono do Portamaris ficou todo construído num período de 4 anos (amarelo).

3.49 Detalhe da faixa litorânea do loteamento, a esquerda do parque (em 212 azul). Em vermelho o hotel Beach Park Suites Resort.

3.50 Foto aérea do trecho litorâneo à esquerda do Beach Park. 212

3.51 Cond. Costa Blanca. 213

3.52 Cond. Gran Sol. 213

3.53 Terra Maris. 213

\begin{tabular}{ll}
3.54 & Beach Park Livings. \\
\hline & 213
\end{tabular}

$\begin{array}{ll}3.55 & \text { Scopa Beach. } \\ 3.56 & 213\end{array}$

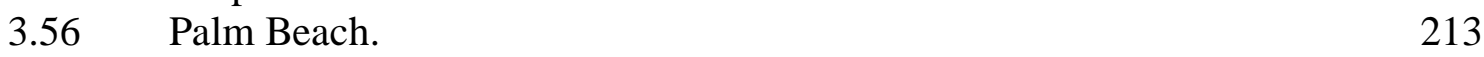

3.57 Mapa de Uso e Ocupação do Solo atual do Porto das Dunas. 214

\section{LISTA DE TABELAS}

\section{CAPÍTULO II}

\section{Tabela}

Pág.

2.1 Taxa média de crescimento anual do PIB- Ceará e Nordeste (\%). 117

2.2 Número de indústria de transformações ativas por município. 121

2.3 Evolução das Exportações de Produtos Selecionados - Ceará. 127

2.4 Síntese dos investimentos do PRODETUR/CE I. 148

2.5 Programas estaduais voltados para a região. 148

\section{CAPÍTULO III}

3.1 Empresas industriais ativas por tipo - 2009-2010. 174

3.2 UH'S e Leitos Inaugurados desde 1997.

3.3 Oferta hoteleira nos municípios turísticos do Ceará - 2011. 189

3.4 Empreendimentos turísticos em implantação no ceará - 2009. 


\section{LISTA DE GRÁFICOS}

Grafico

Pág.

2.1 Evolução do PIB trimestral - Ceará - 1 trimestre/2003. 118

2.2 Taxa de crescimento (\%) do PIB a preços básicos por segmento 118 industrial-Ceará - $1^{\circ}$ Trimestre / $2003-2002$.

2.3 Produção da indústria de transformação - Ceará - Abril/2003. 119

2.4 Taxa de crescimento (\%) do PIB a preços básicos por indústria-Ceará- 119 2004.

2.5 Evolução da Balança Comercial - Ceará 1991 - 2004.

126

2.6 Evolução das exportações para países selecionados - Ceará - 2003-2004. 


\section{SUMÁRIO}

INTRODUÇÃO

CAPÍTULO I -

AGENTES IMOBILIÁRIOS E A PRODUÇÃO DO ESPAÇO

CONTEMPORÂNEO.

1. A produção da cidade e a reestruturação metropolitana 6

1.1 Fundamentos da produção e apropriação do espaço urbano contemporâneo 6

$\begin{array}{lll}\text { 1.1.1 O conceito de espaço social e sua produção } & 6\end{array}$

1.1.2 A produção do espaço urbano como estratégia do capital 8

1.1.3 O capital e a propriedade da terra: renda da terra e produção do espaço 13

1.1.4 Mercado e Estado na organização espacial da produção 19

1.2 Transição metropolitana e a dissolução urbana nas cidades 23 contemporâneas

1.2.1 Reestruturação produtiva no contexto da globalização 24

1.2.2 O novo padrão de cidade: centro-periferia e a nova organização 29

1.2.3 Breve comentário sobre os conceitos de urbano e cidade 37

1.2.4 A ação dos agentes imobiliários na produção das cidades 38 contemporâneas

\section{CAPÍTULO II - \\ URBANIZAÇÃO LITORÂNEA NO CONTEXTO DA REESTRUTURAÇÃO METROPOLITANA}

2. O espaço litorâneo e suas especificidades na ocupação do litoral cearense: a consolidação de Fortaleza.

2.1 Considerações iniciais sobre as zonas costeiras

2.2 A ocupação da costa brasileira e a urbanização contemporânea $\quad 50$

2.3 A ocupação do litoral cearense e a consolidação de Fortaleza como capital 55

2.3.1 Passagem do século XIX para XX: a inserção do Ceará/Fortaleza no 57 mundo

2.3.2 As transformações urbanas na primeira metade do século $\mathrm{XX}$ 
2.3.3 As transformações urbanas na segunda metade do século XX

2.3.4 A expansão para além da Região Metropolitana

2.4 O processo de metropolização de Fortaleza: da industrialização tardia 89 no Nordeste à reestruturação sócio-territorial do Ceará contemporâneo

2.4.1 A industrialização tardia: Nordeste no final dos anos 1950 - 198093

2.4.2 O PLANDIRF: oposição entre a ênfase da integração metropolitana 95 industrial à renovação urbana do centro

2.4.3 A estruturação do sistema viário como base das atividades econômicas e o 102 padrão metropolitano dos anos 1980

2.4.4 Reestruturação produtiva no Ceará contemporâneo e as consequências na 107 RM de Fortaleza

2.4.4.1 Aspectos políticos no processo de reestruturação produtiva do Ceará 109 contemporâneo: o Governo das Mudanças

2.4.4.2 Aspectos socioeconômicos da reestruturação produtiva: alterações e 114 permanências

2.4.4.3 Aspectos socioespaciais da reestruturação produtiva na RM de 120 Fortaleza

2.4.4.4 Intervenções urbanas estruturantes na RM de Fortaleza 128

2.5 A emergência do turismo na produção do espaço contemporâneo 134

2.5.1 O conceito de urbanização turística: especificidade e relevância 134

2.5.2 Da necessidade de novos conceitos ao estado da arte das pesquisas 140 recentes

2.5.3 As bases da política de turismo no Ceará: reflexão sobre a 144 organização do espaço urbano em Fortaleza e RM.

\section{CAPÍTULO III - \\ REESTRUTURAÇÃO METROPOLITANA E A EMERGÊNCIA DO TURISMO: O CASO DE AQUIRAZ}

3. A discussão do método com enfoque em Aquiraz

3.1 Caracterização e justificativa do objeto de estudo no contexto da transição 163 metropolitana 
$\begin{array}{lll}3.2 & \text { O município de Aquiraz } & 171\end{array}$

3.2.1 Aquiraz no contexto da Região Metropolitana de Fortaleza 172

$\begin{array}{lll}\text { 3.2.2 Delimitação e acessos à área de estudo } & 177\end{array}$

3.2.3 Síntese histórica e evolução urbana de Aquiraz 178

3.2.4 O turismo em Aquiraz e o planejamento governamental 181

3.3 Transformações socioespaciais em Aquiraz e os novos padrões de 191 ocupação

3.3.1 As primeiras gerações de loteamento e a reivindicação do espaço 192

3.3.2 A segunda geração de loteamentos: a visão empresarial e o impasse 195 ambiental

3.3.2.1 A interferência dos agentes imobiliários nos PDDU 199

3.3.2.2 A questão ambiental como condicionante dos novos produtos turísticos 201 e imobiliários

3.3.3 O incremento da atividade imobiliária no Porto das dunas 208

4. CONSIDERAÇÕES FINAIS E CONCLUSÕES 217

$\begin{array}{lll}4.1 & \text { Síntese da análise do caso de Aquiraz e conclusões finais } & 217\end{array}$

$\begin{array}{lll}4.2 & \text { Sobre o trabalho de campo e as entrevistas } 220\end{array}$

5. REFERÊNCIAS BIBLIOGRÁFICAS 222

\section{ANEXO - I \\ REFERÊNCIAS SOBRE A PESQUISA DE CAMPO E AS \\ DUAS FASES DAS ENTREVISTAS}

6. APRESENTAÇÃOO 235

6.1. BLOCO - I: A PESQUISA DE CAMPO 236

6.1.1 Os estudos preliminares 236

6.1.1.1 O conceito de "novo" padrão de ocupação 237

6.1.1.2 Procedimentos preliminares utilizados no trabalho de campo 238

6.2 BLOCO - II: AS DUAS FASES DE ENTREVISTAS 242

6.2.1 Aspectos introdutórios: os critérios de seleção dos entrevistados 242 
6.2.1.1 Os questionários e as transcrições da primeira fase de entrevistas: o setor privado

6.2.1.2 Os questionários e as transcrições da primeira fase de entrevistas: o 290 setor público

6.2.1.3 Os questionários e as transcrições da segunda fase de entrevistas 


\section{INTRODUÇÃO}

O problema proposto fundamenta-se na discussão da ação dos agentes imobiliários na produção do espaço contemporâneo das cidades brasileiras no bojo de uma reestruturação produtiva. Considera-se que esse momento configura uma transição metropolitana, a partir do reconhecimento de que esses agentes são, em grande parte, os responsáveis por essas transformações e que nos coloca diante de um novo padrão de cidade.

Sobre esse padrão emergente, podemos indagar se não é mais urbano, porque dilui o antigo padrão representado pelo modelo centro-periferia ou se aponta na direção de uma nova organização socioespacial que podemos considerar como metropolitana porque busca responder à reorganização da produção, frente à necessidade de incorporar novos territórios à lógica da reprodução do capital. Essa reorganização capitalista atribui um novo significado à urbanização, à produção do espaço e às cidades, como desenvolvido por Pereira (2011, p. 26).

Nossa contribuição, com esta Tese, é trazer o foco dessa discussão para a ação dos agentes imobiliários que vêm atuando no processo de reestruturação metropolitana de Fortaleza-CE configurando uma nova forma de produção do espaço para o turismo. Esse processo de transformação e uso é resultante em grande parte da política de turismo adotada ${ }^{1}$, concebida ao longo da elaboração dos três primeiros planos de governo do Estado. Nestes, a partir do ano de $1987^{2}$, o Turismo foi considerado uma das três vertentes estratégicas de desenvolvimento econômico e social, juntamente com a indústria e a agricultura irrigada, num período que se inicia no final dos anos 1980, tem sua feição mais eloquente ao longo dos anos 1990 e se desenvolve de forma diferenciada na primeira década de 2000 , até o presente ${ }^{3}$.

Desse modo, o turismo se institui como uma política de desenvolvimento "sustentável" com horizonte de planejamento previsto para os anos de 1995 a 2020, com diversos

\footnotetext{
${ }^{1}$ O turismo: uma política estratégica para o desenvolvimento sustentável do Ceará: 1995-2020 (SETUR, 1995)

${ }^{2}$ Os Planos de Governo do Estado considerados são os referentes aos períodos (1987-1991); (1991-1995); (1995-1999)

${ }^{3}$ Uma análise da relação entre os Planos de Governo e a Política de Turismo adotada do período considerado, até o presente será apresentada em maiores detalhes nos subcapítulos seguintes.
} 
desdobramentos econômicos e socioespaciais que serão analisados ao longo da tese: entre eles, o fato do turismo ter se transformado em um diferencial na produção do espaço e se convertido em nicho de mercado para o setor imobiliário. Esse movimento pode ser explicado, em parte, pelo alto poder de atratividade e dinamização do fluxo de pessoas e recursos, característicos do turismo.

Essa dinâmica, no entanto, tem propiciado a materialização de diversos empreendimentos que mesclam produtos turísticos com outros de corte típico do mercado imobiliário, implantados em novos padrões de ocupação em pontos estratégicos do litoral da RM de Fortaleza, como também do litoral do Ceará e dos demais estados brasileiros. Esses padrões têm sido inspirados em experiências internacionais consagradas, principalmente no litoral do mediterrâneo e costa atlântica dos países europeus como também em vários países com potencial turístico em todo o mundo.

As bases do debate sobre as implicações socioespaciais desses novos padrões de ocupação e estruturação espacial frente a esta nova proposta de formulação do problema estão fundamentadas nas clássicas revisões do conceito de produção social do espaço, recorrendo a alguns de seus temas centrais relacionados à cidade. Entre eles: a propriedade da terra e o capital; o valor de uso e o valor de troca e a fórmula trinitária, conforme Lefebvre (1999), Harvey (1980) e Gottdiener (1997); e conceitos derivados como: renda da terra; reestruturação imobiliária e fragmentação do urbano; desenvolvidos por Seabra (1979), Pereira (2005) e Botelho (2007), respectivamente.

A questão central da discussão e fio condutor desta exposição está em saber demonstrar: se a ação dos agentes imobiliários responde à reorganização de um novo processo de produção do espaço para o turismo, frente à necessidade de incorporar novos territórios à lógica de reprodução do capital? Ou em outras palavras: como os agentes imobiliários articulados ao turismo participam da reestruturação metropolitana de Fortaleza?

Embora essa indagação aponte para um caminho que revela como operam esses agentes imobiliários frente às mudanças do processo de produção do espaço urbano contemporâneo, respondê-la exige conhecer as características fundamentais do processo 
de metropolização de Fortaleza que faremos sem perder de vista o foco do problema em questão.

Desse modo, escolhemos focalizar a investigação, detalhada e desenvolvida no capítulo III, por um trecho específico do litoral da RM de Fortaleza, no vizinho Município de Aquiraz. Essa escolha supõe que esse trecho do litoral metropolitano revela de modo mais evidente a questão em foco para, ao final, buscarmos uma inferência das nossas conclusões para o restante do litoral.

Para isso escolhemos pinçar uma questão ainda mais específica derivada da primeira que pode ser sintetizada na pergunta: porque os promotores imobiliários reivindicam o caráter turístico para seus projetos residenciais, no caso em estudo? Ou de outro modo: por que os agentes imobiliários chamam turismo quando querem dizer promoção imobiliária?

É preciso esclarecer, primeiramente, que não estamos propondo abordar o problema como um manifesto cujo objetivo seria o de revelar/denunciar que o turismo está sendo usado "indevidamente" como argumento para que os promotores imobiliários desenvolvam seus projetos privados, se apropriando dos benefícios de investimentos públicos em infraestrutura para o turismo. Assunto importante para outro fórum e outro momento.

Propomos, de outro modo, considerar a importância de uma perspectiva que evita utilizar juízos de valor, onde a questão se apresenta, para nós, como a parte visível de um processo pouco compreendido. Isso se deve ao fato dele ter sido tratado, ultimamente, como um campo cego não só porque se apresenta como encoberto, mas como algo capaz de obscurecer a compreensão de sua totalidade. $\mathrm{O}$ fato desse debate ter sido levado, ultimamente, para o campo da polarização entre discursos extremos e excludentes, como as discussões dicotômicas entre ambientalistas e promotores imobiliários, por exemplo, pode ter sido uma dessas razões.

A questão mais específica do problema apresentado foi levantada por Juan Requejo Liberal para o litoral do mediterrâneo espanhol, no artigo: “¿Por qué lo llaman turismo cuando quieren decir promoción inmobiliaria?" (VINUESA, MARCHANTE e HERNANDEZ (coord.), 2008, p. 653), onde discute vários aspectos importantes para o esclarecimento da discussão. Ele argumenta que boa parte das habitações produzidas no 
litoral da Andalucía é oferecida e promovida para os mercados britânicos, alemães e de outros habitantes de países do Norte da Europa, por um critério de aquisição como segunda residência de lazer ou de turismo para serem transformadas em residências (quase) permanentes.

Quando comparamos o caso espanhol com o que ocorre no litoral do Nordeste brasileiro, percebemos algumas semelhanças e diferenças imediatas. No caso brasileiro os promotores imobiliários também trabalham com a produção de segunda residência de apelo turístico e de lazer, a partir de padrões de ocupação semelhantes, utilizando-se de estratégias de comercialização e tipologias arquitetônicas e urbanísticas já consagradas no mercado europeu, adaptadas à realidade local.

A semelhança fundamental, no entanto, aponta para a mesma natureza ambígua das habitações de segunda residência (nos dois casos, identificadas como turismo residencial) que ora operam como aluguel turístico de curta duração, ora como residência eventual de veraneio. Essa característica traz como consequência a aproximação do mercado imobiliário ao do turismo que surge como apelo diferencial de mercado, no qual o marketing aparece como a grande novidade embutida nas estratégias de produção estudadas.

Embora a atividade turística e imobiliária local tenha sua dinâmica própria, integrada ao desenvolvimento da atividade no Estado e na Região Metropolitana, as diferenças situam-se em várias peculiaridades. Entre elas: a mudança do mercado consumidor, as inovações e permanências do processo construtivo, o papel das diversas políticas públicas e os problemas de natureza jurídica no campo do licenciamento ambiental, assunto a ser desenvolvido com maior profundidade na tese.

Outras contribuições que tratam da urbanização litorânea consideram a problemática ambiental das Zonas Costeiras, num contexto mais amplo, como processo de ocupação do território brasileiro constituindo-se em fenômeno estruturante de sua economia. Assim, são referências para a nossa abordagem o trabalho "Contribuições para a Gestão da Zona Costeira no Brasil: Elementos para uma Geografia do Litoral Brasileiro" (MORAES, 1999) e no caso cearense o trabalho "A Zona Costeira do Ceará: Diagnóstico para a Gestão Integrada”, (CAMPOS et al, 2003). 
Mais recentemente, o Observatório das Metrópoles vem trabalhando sobre o tema "Espaço Metropolitano, Turismo e Mercado Imobiliário" convertido em Simpósio em 2008 com várias publicações impressas e outras de acesso eletrônico ${ }^{4}$. Atualmente, desenvolve a segunda fase de sua linha de pesquisa intitulada: "Metropolização Turística: dinâmica e reestruturação dos territórios em Salvador, Recife, Fortaleza e Natal - estudos comparativos para o Nordeste".

Há ainda uma vasta literatura produzida em campos interdisciplinares que tratam do turismo inserido no fenômeno urbano, como as listadas nas referências bibliográficas descritas ao longo do desenvolvimento da Tese.

Desse modo, propomos iniciar nossa exposição pelo aprofundamento da discussão conceitual em torno do problema, como também pela fundamentação teórica adotada que nos orientou durante todo o processo de análise e síntese.

\footnotetext{
${ }^{4}$ https://sites.google.com/a/metrowiki.net/observat-rio-das-metr-poles-workshop-fortaleza/
} 


\section{CAPÍTULO I - AGENTES IMOBILIÁRIOS E A PRODUÇÃO DO ESPAÇO CONTEMPORÂNEO}

\section{A produção da cidade e a reestruturação metropolitana}

Com esse capítulo, iniciamos a apresentação dos aspectos teóricos e conceituais adotados na fundamentação da pesquisa, introduzindo a discussão da produção do espaço urbano contemporâneo, no contexto da globalização, sob os impactos das consequências socioespaciais advindas da reestruturação produtiva mundial. Assim, observamos a emergência de novos espaços produzidos como consequência de uma reestruturação da cidade em escala metropolitana.

Os conceitos de reestruturação e metropolização são conduzidos como enfoques alternativos para os estudos das transformações socioespaciais das cidades brasileiras apontando essas mudanças como características da emergência de um novo padrão de cidade constituída por artefatos arquitetônicos e urbanos destinados ao consumo e às formas contemporâneas de reprodução do capital, como formulado por PEREIRA (2007, p.1).

\subsection{Fundamentos da produção e apropriação do espaço urbano contemporâneo}

As referências teóricas de espaço social e sua produção, utilizados na pesquisa fundamentam-se no desenvolvimento da análise do conceito de espaço e de capital que buscaram identificar a "intensificação das contradições sociais e espaciais tanto nos países centrais como nos periféricos, em virtude da crise geral do capitalismo durante a década de 1960" (SOJA \& HADJIMICHALIS, 1979, p.7). Esses estudos deram uma nova dimensão ao conceito de espaço, considerando-o na perspectiva da produção e de suas múltiplas contradições sociais, que resultaram na necessidade de exercer-se um maior controle sobre a compreensão das relações sociais que apontavam sempre para algum tipo de repercussão espacial.

\subsubsection{O conceito de espaço social e sua produção}

Na qualidade de ciência social, o objeto de estudo da Geografia, segundo Corrêa (2001), é a sociedade. No entanto, é instrumentalizada por cinco conceitos-chave que guardam entre si forte relação e grau de parentesco, uma vez que todos se referem à ação humana 
sobre a superfície terrestre - paisagem, região, espaço, lugar e território. "Cada um deles tem sido objeto de amplo debate, tanto interno como externo à geografia. No bojo do debate cada conceito possui várias acepções, cada uma calcada em uma específica corrente de pensamento" (op.cit. in CASTRO et al org., 2001, p. 16).

No entanto, segundo Correa (2001), o espaço é considerado efetivamente como objeto, somente a partir da obra de Henri Lefebvre. Em seu "Espacio y política", argumenta que o espaço "desempenha um papel ou uma função decisiva na estruturação de uma totalidade, de uma lógica, de um sistema" (LEFÉBVRE, 1976, p. 25 apud CORRÊA op.cit).

As transformações socioespaciais, abordadas na pesquisa, advindas das relações entre os agentes imobiliários e o processo de produção do espaço turístico estão fundamentadas, em sua origem, na noção lefebvriana de espaço vivido, em estreita correlação com a prática social. Segundo o autor o espaço social não é um “espaço absoluto, vazio e puro, lugar por excelência dos números e das proporções” (op.cit. p.29), nem é um simples produto da sociedade. Essa noção de espaço, no entanto, não é nem o ponto de partida (espaço absoluto), nem o ponto de chegada (espaço como produto social). Não é também um instrumento político, um campo de ações de um indivíduo ou grupo, ligado ao processo de reprodução da força de trabalho por meio do consumo. É mais do que isso: engloba esta concepção e a ultrapassa. O espaço, segundo Lefebvre, "é o lócus da reprodução das relações sociais de produção" (CORRÊA, in CASTRO et al org., 2001, p. 25).

Esta concepção de espaço marca profundamente o pensamento dos geógrafos críticos que adotaram o materialismo histórico e dialético como paradigma. O espaço, nesse caso, é concebido como lócus da reprodução da sociedade, tal como Manuel Castells (1972) formulou para o urbano. Podemos perceber isso também na vasta obra de Milton Santos, ainda que não de modo exclusivo, ao apresentar-se fortemente inspirada em Henri Lefebvre e em sua concepção de espaço social.

A contribuição de Milton Santos aparece, de um lado, com o estabelecimento do conceito de formação socioespacial, derivado do conceito de formação socioeconômica e submetido a intenso debate na década de 1970. Santos (1977) ensinou não ser possível conceber uma determinada formação socioeconômica sem se recorrer ao espaço. 
Segundo ele, modo de produção, formação socioeconômica e espaço são categorias interdependentes (CORRÊA, in CASTRO et al org., 2001, p. 26).

A natureza e o significado do espaço aparecem ainda nos diversos estudos em que Santos aborda o papel das formas e interações espaciais, os fixos e os fluxos a que ele se refere. Também produz contribuições significativas para a compreensão da organização espacial dos países subdesenvolvidos nas quais é admitida a coexistência de dois circuitos de economia, resultado de um processo de modernização diferenciadora que os produz e que tem a mesma origem e conjunto de causas interligadas. $\mathrm{Na}$ verdade, "o espaço organizado pelo homem desempenha um papel na sociedade, condicionando-a, compartilhando da existência e reprodução social” (op.cit., p. 27).

A partir de uma noção de espaço de Milton Santos como um conjunto indissociável de sistemas de objetos e de ações, podemos reconhecer suas categorias analíticas internas. "Entre elas, estão: a paisagem, a configuração territorial, a divisão territorial do trabalho, o espaço produzido ou produtivo, as rugosidades e as formas-conteúdo. Da mesma maneira e com o mesmo ponto de partida, levanta-se a questão dos recortes espaciais, propondo debates de problemas como o da região e o do lugar, os das redes e das escalas" (SANTOS, 2006, p. 22).

Desse modo, Santos apresenta a racionalidade do espaço como conceito histórico atual e fruto, ao mesmo tempo, da emergência das redes e da globalização, incluindo também o conteúdo geográfico do cotidiano entre esses conceitos constitutivos e operacionais, próprios à realidade do espaço geográfico, junto à questão de uma ordem mundial e de uma ordem local. Noção que nos será de grande utilidade para a análise dos fenômenos relacionados ao turismo e suas relações interdependentes entre os condicionantes locais e as imposições provocadas pelas diversas demandas oriundas do mercado turístico, imobiliário e financeiro global.

A noção de espaço social e sua produção, portanto, nos parece clara, tendo em vista o entendimento de que a sua totalidade só pode ser compreendida se abordarmos simultaneamente as suas duas dimensões: a física e a social que o anima.

\subsubsection{A produção do espaço urbano como estratégia do capital}

Podemos dizer que as teorias que tratam da produção do espaço nascem no campo da economia política da urbanização, a partir de várias revisões críticas do pensamento 
marxista. No nosso caso, demos um enfoque maior nas contribuições de Lefebvre (1974, 1976, 1999, 1999a), Harvey (1973, 1982, 2001, 2006) e Gottdiener (1997), porque além de considerar os aspectos da base econômica, enfocando a questão da produção do espaço como estratégia de acumulação capitalista, ressaltam também os elementos que compõem os níveis da superestrutura social. Entre eles: o Estado, sua base jurídica, como também os aspectos culturais e ideológicos, na análise dos processos socioespaciais.

O trabalho de Gottdiener (1997) nos parece interessante por que faz uma síntese dessa revisão crítica, reforçando a importância do pensamento lefebvriano, baseado na convicção de que os problemas contemporâneos da sociedade se vinculam estreitamente às questões de natureza espacial.

Seu campo de interesse amplia o debate em torno das pesquisas urbanas naquele momento, propondo-se a desenvolver análises sobre questões como:

"a dinâmica dos processos sociais de desenvolvimento metropolitano $e$ regional; o papel do Estado na construção e manutenção do crescimento da cidade dispersa; o papel da ideologia e dos campos semânticos no ofuscamento e mascaramento dos processos reais que atuam na reestruturação do espaço de assentamento e os padrões de organização social responsáveis pela produção de espaço na sociedade moderna" (GOTTDIENER, 1997. p16).

São questões importantes, discutidas ainda hoje, entranhadas no processo de urbanização contemporânea mundial que pretendemos tomar como referência, na medida em que nos voltamos aos estudos da reestruturação metropolitana de Fortaleza. Assim, consideramos o papel do estado e dos agentes do mercado imobiliário, na produção deste novo espaço urbano litorâneo, em nome do turismo, buscando compreender o ofuscamento dos processos reais que atuam nessa reestruturação espacial. Verificamos que eles se apresentam em novos padrões de organização social no qual propomos tomar a produção do espaço como um dos eixos explicativos da estratégia de acumulação de capital que move cada vez mais, as transformações socioespaciais contemporâneas.

Desse modo, Gottdiener (1997) faz uma análise critica a vários paradigmas e teorias desenvolvidos na Ecologia urbana, Economia urbana e Geografia urbana, discutindo, avaliando e reformulando os modelos teóricos apresentados por essas disciplinas, 
considerando-os insuficientes e ultrapassados para explicar a organização espacial contemporânea.

$\mathrm{O}$ argumento das limitações, segundo o autor, estaria no fato desses estudos privilegiarem ou mesmo restringirem-se às dimensões da morfologia urbana e não alcançarem a organização social que produz e reproduz os padrões de uso da terra, sugerindo a substituição dessa abordagem por outra que considerasse a produção social do espaço.

Assim, elabora também uma revisão crítica da economia política marxista abordando a Teoria da Acumulação de Capital, apoiado na contribuição de David Harvey (1973) e dos teóricos que defendem que "pode-se explicar a forma urbana num sentido marxista se focalizarmos os dois propulsores da sociedade: a acumulação de capital e a luta de classes" (GOTTDIENER, 1997. p94).

Desse modo, reforça o debate em torno do papel do capital financeiro e do Estado intervencionista, fundamentado na contribuição de Harvey que aplica os conceitos marxistas clássicos na análise do desenvolvimento urbano como: a mais-valia, a superprodução, a queda na taxa de lucro e a crise de acumulação para explicar o surgimento do keynesianismo ${ }^{5}$ e a investida hegemônica do capital financeiro.

Ao encerrar sua crítica à economia política marxista Gottdiener se propõe a discutir a teoria do espaço e para isso lança mão de uma comparação entre o que ele chama de estruturalismo marxista de Castells (1972) em oposição à dialética sócio-espacial de Lefebvre (1974). Esta última, baseada no conceito de práxis socioespacial, considera que ambos têm uma visão mais global sobre a produção do espaço e sua relação com a organização social do que a própria economia política marxista.

Embora reconheça a influência de Castells na análise urbana marxista nos EUA, Gottdiener prefere a contribuição de Lefebvre pelo fato de considerá-la mais fecunda e próxima da verdadeira natureza da análise marxista.

Reconhece que na procura dessa concepção mais global de espaço, ambos empregaram epistemologias distintas e singularmente diferentes das análises marxistas anteriores.

\footnotetext{
${ }^{5}$ Sobre o assunto ver: KEYNES, John Maynard. Teoria geral do emprego, do juro e da moeda (General theory of employment, interest and money). Tradutor: CRUZ, Mário Ribeiro da. São Paulo: Editora Atlas, 1992 e KEYNES, John Maynard. The End of Laisses-faire. London: Hogarth Press, 1926.
} 
Por isso considera que eles, de fato, forneceram alternativas para o pensamento marxista sobre a análise do espaço.

\section{Cidade e a acumulação capitalista}

A cidade, antes de servir às necessidades de seus habitantes, é em si mesma uma forma de riqueza e pode ser interpretada como a materialização dessa acumulação capitalizada pelos circuitos privados. Entendê-la sob essa perspectiva exige partir de pressupostos, como considerá-la uma cidade inserida numa economia capitalista e, portanto, portadora de características e problemas próprios, tais como: ser o lugar da divisão do trabalho, da concentração de poder, e de riquezas, além de ser o campo onde se expressam as inúmeras diferenças da sociedade (SEABRA in BOTELHO, 2007.p.9).

Essa é uma noção que aponta para uma definição de cidade que a considera, antes de tudo, um produto capaz de proporcionar acumulação de riquezas, fruto de um complexo processo de produção que a envolve e domina.

A ideia de que a produção do espaço torna-se uma importante estratégia de acumulação do capital foi formulada por Lefebvre (1999-a), ainda no ano de 1970, na sua obra "La révolution Urbaine" 6 e parece manter-se atual devido ao alcance de sua perspectiva filosófica utilizada na intenção de compreender a realidade social que nasce da industrialização e a sucede.

É importante para nós, porque ajuda a confirmar algumas constatações observadas na pesquisa quando verificamos as ações conjugadas entre o Estado e o setor privado que se organizam em torno das oportunidades criadas pelos diversos investimentos públicos proporcionados em nome dos benefícios das políticas públicas de turismo e desenvolvimento urbano que abordaremos em detalhes.

A questão formulada pelo autor partiu da sua reflexão de que a industrialização, de algum modo, vinha perdendo força na determinação da sociedade contemporânea, o que para a época foi considerada uma ousadia uma vez que o pensamento voltado para as influências da industrialização era dominante e orientava boa parte das análises da realidade social e urbana do momento.

\footnotetext{
${ }^{6}$ Original publicado em 1970 pela Éditons Gallimard .
} 
A noção de que a produção do espaço passou a influir decisivamente na constituição da sociedade contemporânea partiu também da análise que o autor desenvolveu sobre as transformações operadas no campo, pelo mundo da mercadoria, acompanhada da decomposição da cidade pela industrialização. Desse modo, ele inverte o argumento afirmando que a urbanização, como sentido e finalidade da industrialização, é essencial e insuficiente ao mesmo tempo.

Com isso, ressalta que a problemática urbana não pode ser conhecida enquanto for considerada como subproduto da industrialização, somente, porque seria como reduzir o urbano ao urbanismo ${ }^{7}$, isto é, submeter à realidade urbana à racionalidade industrial e às exigências de um mundo supostamente lógico, sem contradições nem conflitos (MARTINS in LEFEBVRE, 1999-a, p.7-12).

Assim, é possível concluir da leitura de "A Revolução Urbana" que o espaço inteiro entra na produção como produto, através da compra, da venda ou da troca de parcelas do espaço, embora o autor considere que a produção do espaço não seja novidade, pois os grupos dominantes sempre produziram este ou aquele espaço em particular. O novo, no entanto, é o fato de que a produção desse espaço social passa a ser constituída de modo global e total, no sentido de que a atividade produtiva se realiza em função dos interesses dos que a inventam, dos que a gerem e dos que dela se beneficiam (LEFEBVRE, 1999-a, p.142).

Evidentemente, o espaço sempre ocupou lugar importante no centro das disputas políticas e econômicas, ao longo da história da humanidade. No entanto, o que se apresenta como novidade é uma estratégia de domínio velada e dissimulada de se apropriar do espaço por ocasião das crises estruturais do capitalismo contemporâneo.

O que confirma essa ideia e chama a atenção do autor é que "o urbanismo encobre essa gigantesca operação. Ele dissimula seus traços fundamentais, seu sentido e finalidade. Ele oculta, sob uma aparência positiva, humanista, tecnológica, a estratégia capitalista: o domínio do espaço, a luta contra a queda tendencial do lucro médio, etc." (op.cit.p.143).

\footnotetext{
${ }^{7}$ Uma discussão sobre os conceitos de urbano, urbanismo e cidade seria oportuno agora, se não fosse tema tão complexo. Para evitar o distanciamento do foco da questão proposta, será feito quando tratarmos da questão da reestruturação metropolitana, nas seções subsequentes.
} 
O autor, desse modo, expõe seu argumento como se o capitalismo encontrasse uma solução alternativa para as suas crises cíclicas, naquilo que ele denomina de a "conquista do espaço". Além da simples especulação imobiliária, da construção de grandes obras ou na compra e venda do espaço, sua estratégia vai mais longe porque visa uma reorganização completa dessa produção, subordinada aos centros de informação e decisão.

Assim o autor conclui que o espaço torna-se o lugar de várias funções, das quais a mais importante é velada: a de "formar, realizar, distribuir, de uma nova maneira, o subproduto da sociedade inteira (isto é, no modo de produção capitalista, a mais-valia global)" (op.cit. p.143).

Ao analisarmos a história do modo de produção capitalista, é possível constatar como o espaço passa progressivamente a fazer parte dos circuitos de valorização do capital e como ele atinge uma ascendente inclusão no circuito globalizado do capital financeiro, tornando-se primeiramente uma mercadoria e mais tarde um título financeiro. Assim, comercializado na bolsa ou banco, aproxima-se cada vez mais daquilo que MARX (1983) ${ }^{8}$, chamou de capital fictício: um conceito relacionado ao dinheiro que ao ser emprestado, transforma-se automaticamente em dois: o dinheiro propriamente dito, utilizado nos setor produtivo e os títulos de direito sobre o dinheiro que é o capital fictício. Essa característica faz com que possa ele ser, inclusive, comercializado gerando novos títulos de direito sobre aquele dinheiro ilusório.

Esse tipo de operação é largamente utilizado no contexto dos fundos de investimentos bancários do mercado financeiro tradicional e no ambiente das bolsas de valores que agora passam a negociar títulos imobiliários, fundos de investimentos imobiliários e ações de empresas construtoras. Essa estratégia tem como objetivo, ampliar a base de crédito para o setor de promoção imobiliária que possui um papel destacado na produção da cidade contemporânea. Retomaremos esse tema no subcapítulo 1.2.1, à frente, discutindo as influências da globalização e da financeirização da economia mundializada como fatores indutores da reestruturação metropolitana.

\subsubsection{O capital e a propriedade da terra: renda da terra e produção do espaço urbano contemporâneo}

\footnotetext{
8 A análise do capital fictício é feita por Marx (1983) principalmente nos Capítulos 29 a 31 do Livro III de O Capital.
} 
O conceito de renda da terra é complexo porque se apresenta dentro de um debate que se iniciou ainda nos anos 1970, em torno da validade do seu emprego enquanto categoria de análise, aplicável às condições do capitalismo contemporâneo, que permanece inconclusa, segundo um de seus críticos atuais como Deák (1985).

Nossa intenção, no momento, não é retomar o debate e sua polêmica, mas apenas apresentar alguns caminhos que se propuseram a enfrentar o desafio de analisar a produção do espaço contemporâneo utilizando os conceitos de propriedade e renda da terra. Estes, nos serviram de referência para auxiliar a interpretação de uma realidade que tem chamado à atenção de vários urbanistas contemporâneos: a noção de que o preço da terra se relaciona de alguma forma com a distribuição espacial da atividade humana.

\section{A propriedade como instrumento de controle do espaço}

O conceito de propriedade é entendido como a instituição fundamental do capitalismo que permite vedar, seletivamente, parte da sociedade o acesso aos recursos naturais e aos instrumentos de produção. Historicamente a propriedade foi introduzida na transição do feudalismo para o capitalismo para controlar o acesso às terras produtivas que passaram de feudos para se constituírem em propriedades, transformando os senhores feudais em proprietários de terras no regime capitalista (DEÁK,1985).

O conceito de propriedade proposto pela Economia Política de Adam Smith (1993) baseava-se na ideia de que o trabalho, ao invés da terra, era a real fonte do valor, fundamentado na sua teoria do valor-trabalho. Marx (1991), por sua vez, concebeu a propriedade privada, como um conceito estruturante da sua teoria, entendido dentro de uma dupla concepção: a da essência objetiva que diz respeito a um produto material, onde a terra está inscrita e a da essência subjetiva, tratada como uma atividade para si que se constitui no trabalho, baseado na concepção de Smith.

Ao escrever "A cidade do Capital”, Lefebvre (1999) dedica um capítulo inteiro ao tema "O capital e a propriedade da terra", dentro do objetivo de fazer uma releitura detalhada dos textos que compõem a obra de Marx, elegendo como tema a cidade e consequentemente a problemática urbana, no quadro teórico do materialismo histórico. 
Com isso, busca verificar a validade e abrangência da teoria marxista para os problemas contemporâneos.

Desse modo, o autor inicia sua análise, indagando sobre o seu método, a lógica formal, o discurso teórico lógico e o encadeamento dos conceitos, com a finalidade de recobrir o conjunto da sociedade capitalista, até ao detalhe, recuperando os aspectos do conteúdo do discurso teórico no pensamento de Marx.

Seu foco principal, no entanto, é rever os conceitos de: formação, realização e distribuição da mais-valia, contidos n'O capital para fazer "um exame das funções $e$ estruturas da forma urbana legada pela história à sociedade burguesa" (LEFEBVRE, 1999, p.142.). Assim, busca identificar uma função essencial da cidade, no ponto de vista de cada um desses conceitos, para ao final revelar a importância da propriedade da terra e da renda fundiária ou renda da terra ${ }^{9}$.

Sobre a propriedade da terra, o autor considera que ela se enquadra no conceito de propriedade privada em geral, mas ressalta que embora essa propriedade imobiliária tenha dado lugar à propriedade mobiliária ela persiste e continua importante, consolidando-se desde os tempos de Marx. Nesse tempo, a burguesia já enriquecia comprando terras e constituindo para si propriedades fundiárias e consequentemente, reconstituindo sob a base de um novo monopólio: a propriedade da terra e da renda fundiária. Conclui nesse argumento que "a propriedade, no fundo intacta, reconstituída pelo capitalismo, pesa sobre o conjunto da sociedade" (Op.cit. p.161).

Lefebvre reforça a ideia de que a função da cidade provocaria o motivo que levaria ao corte que ligava a sociedade à natureza. No entanto, apesar deste vínculo ter sido

\footnotetext{
${ }^{9}$ Lefebvre usa, ao longo do texto, os termos: "propriedade da terra e renda fundiária" (op.cit. p.154) como também "propriedade fundiária e renda da terra" (Op. cit. p.161) como se parecessem sinônimos: pelo menos, não faz nenhuma ressalva quando aplica um e outro. Podemos dizer que há diferença entre os dois termos, na língua portuguesa, uma vez que "fundiário" tem origem da palavra latina "fundus" que significa fazenda, bens de raiz e está relacionado a terreno agrário (Ferreira, 1993). Do mesmo modo, o termo "terra" tem um sentido mais genérico podendo significar desde: parte branda do solo, território, propriedade, lugar de origem, planeta, entre outros. Temos que considerar que o uso dos dois termos como sinônimo pode estar associado também a possíveis dificuldades na tradução da língua de origem. Mesmo assim, não poderíamos afirmar que fundiário está relacionado a rural porque o termo "regularização fundiária" também é usado no contexto urbano do presente (Capítulo III-Lei 11.9977 de 2009). Preferimos usar na pesquisa os termos "terra e fundiário", conforme a origem das fontes utilizadas, comportando-se, na maior parte das vezes, como sinônimos e, quando oportuno, enfatizado o seu sentido no contexto do tema abordado. A identificação dessas noções como sinônimas certamente ocorre por se pensar as rendas apenas como função da visão industrial e em sua relação com a produção, seja ela no contexto rural e no urbano; por isso também não distinguem as rendas: fundiária, imobiliária e de extração
} 
desfeito, a troca viva entre a comunidade e a terra não foi substituída por uma regulação racional e, no entanto, a sociedade continua ligada e mesmo amarrada à terra, pela propriedade e pelas múltiplas servidões que ela mantém. Principalmente, pela subordinação da terra ao mercado, transformando-a em um bem comercializável, dependente do valor de troca e da especulação e não do uso e do seu valor de uso ${ }^{10}$.

$\mathrm{Na}$ sua analise, o autor Identifica uma lacuna na obra de Marx quando afirma que a teoria marxista da propriedade da terra, no capitalismo, é incompleta porque ela "não mostra claramente nem os sujeitos (as classes e frações de classes), nem o modo de produção constituído (bem definido como tal), nem os sistemas e subsistemas que ele compreende (jurídico, fiscal, contratual, etc.)” (Op.cit.p139). Também, não identifica “como e porque uma classe de proprietários imobiliários se perpetua no capitalismo, onde predomina fortemente a propriedade mobiliária? de onde vem a renda da terra? O que ela implica?" (op.cit. p.139).

\section{Renda e preço da terra uma proposta de aproximação}

A renda da terra tem seus primeiros estudos, ainda nas formulações dos clássicos da Economia Política como Adam Smith e David Ricardo. Posteriormente foi retomado e modificado por Marx que o reformulou dividindo-o em duas categorias: a da "renda diferencial" "11 e a da "renda absoluta" obtida pelo proprietário decorrente do monopólio exercido por uma classe específica. Porém, "salvo em algumas rápidas considerações (O Capital, cap.XLVI, livro 3, vol.6), Marx não se aprofunda no caso da renda fundiária urbana, atendo-se à renda da terra agrícola”. (BOTELHO, 2007, p.68).

A questão da renda da terra, para Lefebvre (1999), parecia estar fora de moda apesar da importância e necessidade de uma teoria para explicar como os terrenos disponíveis para a construção da cidade industrial tinham seus preços apossados pela especulação.

\footnotetext{
${ }^{10}$ Para Marx, a utilidade constitui o "valor de uso", vinculando-se como tal às propriedades físicas do objeto, sem ter nada a ver de imediato com o trabalho humano, nem com a relação social de produção. Já o "valor de troca" aparece no contexto do mundo da mercadoria primeiramente como relação quantitativa, na proporção pela qual as mercadorias se trocam de gênero a dinheiro sendo esse o valor de troca expresso em papel moeda.

${ }^{11}$ A renda diferencial, por sua vez, se subdivide em duas categorias: a relacionada a características naturais, de localização (diferencial I) e a de produtividade do capital investido na terra ou de equipamento (diferencial II)
} 
"Em toda parte onde existe uma renda, a renda diferencial se estabelece da mesma maneira e segue as mesmas leis que a renda diferencial agrícola. Em toda parte onde forças naturais podem ser monopolizadas e assegurar um sobrelucro ao industrial que as explora [...] esse sobrelucro é extraído, sob a forma de renda, do capital em função, por aquele que um título de propriedade, sob uma parcela do globo, fez dele o proprietário dessas riquezas naturais" (MARX, apud. LEFEBVRE, 1999, p. 162).

Sobre os terrenos utilizados para construção, Lefebvre (1999) afirma que Adam Smith mostrou que a sua renda, como a de todos os terrenos não agrícolas, é baseada na renda agrícola propriamente dita, isto é, na "renda de situação" e "renda de equipamento", correspondentes às rendas diferenciais I e II, segundo Marx. Sendo que a renda de situação (localização) é particularmente mais importante nas grandes cidades (op.cit. p.162).

A divergência quanto à aplicabilidade da teoria da renda para a realidade capitalista foi trabalhada por Csaba Deák (1985) na sua tese de doutorado ${ }^{12}$. Para o autor, o conceito de renda foi erroneamente transposto da Economia Política para a análise da sociedade capitalista, como uma categoria referente ao pagamento por parte dos capitalistas aos senhores de terra, pelo direito de uso da terra na produção de grãos. Do ponto de vista da sua interpretação da Teoria, a renda se refere ao excedente da produção na sociedade feudal na forma de: renda em trabalho, renda em espécie e renda em dinheiro, considerando que a categoria mais próxima da renda, na sociedade capitalista, é o lucro.

$\mathrm{Na}$ verdade, a questão é bem mais complexa e exigiria uma análise em detalhes se estivesse nos nossos objetivos discutir o mérito do debate. No entanto, elucidar alguns de seus pontos fundamentais nos ajudará a apontar a escolha do caminho adotado.

A dificuldade de se adequar o conceito de renda fundiária agrícola é relevante e evidente, mas para nós não implicaria no abandono de sua contribuição, como poderemos verificar no trabalho de Adriano Botelho (2007).

\footnotetext{
${ }^{12}$ DEÁK, Csaba. Rent theory and the price of urban land/ Spatial organization in a capitalist economy. $\mathrm{PhD}$ Thesis, Cambridge (1985)
} 
Na sua tese, reforça a importância dos estudos sobre a "renda fundiária urbana", 13 porque a considera um elemento fundamental para a compreensão da hierarquização dos usos do solo urbano, para a acumulação do capital e para a reprodução das relações de produção capitalistas, além se converter em um importante instrumento de segregação socioespacial.

Seu trabalho, alerta inicialmente sobre os problemas enfrentados pelo pesquisador ao tratar da renda fundiária urbana, do ponto de vista teórico-metodológico e político. No primeiro, realça as dificuldades na coleta de dados usados nos cálculos da renda fundiária, na identificação dos proprietários urbanos, como também na adaptação do caso inglês estudado por Marx. Do ponto de vista político realça o comprometimento ideológico dos autores diante das discussões teóricas e mudanças ocorridas com o colapso da antiga URSS e das experiências socialistas no mundo. Segundo o autor, podem ter influenciado o abandono da questão da renda fundiária urbana pela maior parte de seus analistas.

Para amenizar a dificuldade que o pesquisador teve ao enfrentar o problema da heterogeneidade da classe dos proprietários fundiários urbanos, Botelho (2007, p.70) divide primeiramente de um lado, os proprietários que não auferem renda de sua propriedade e, de outro, os que desta auferem. Outra divisão adotada foi a dos grandes proprietários públicos e privados que formariam um grupo distinto dos pequenos proprietários. Essa simplificação é justificada pelo autor porque para ele o mais importante são as articulações que a renda fundiária faz com a acumulação capitalista, com a reprodução das relações de produção e com o processo da segregação socioespacial.

Essa justificativa também se aplica ao nosso caso porque não faz parte dos nossos objetivos trabalhar com o conceito de classes sociais por ser um conceito complexo e ter sido objeto de muitas revisões no campo da Sociologia trazendo uma dificuldade conceitual desnecessária para o nosso trabalho. Assim, é igualmente mais importante para nós compreender as relações entre capital, propriedade e renda para dar suporte à interpretação da produção do espaço turístico litorâneo.

\footnotetext{
${ }^{13}$ Nesse caso, fundamentada nos estudos de Marx (1989) e dos teóricos marxistas da II internacional, como: Lênin (1945;1980;1987) e Kautskty (1980), além dos estudos desenvolvidos depois dos anos 1970 por: Lipietz (1974), Lojkine (1971;1997), Alquier (1971), Fine (1988), Harvey (1980;1982), Seabra $(1987 ; 1988)$ e Topalov (1984).
} 
Desse modo, para melhor definir "renda da terra"," o autor afirma que ele possui um conceito correspondente para a análise da cidade, ainda que não apareça de modo explícito nas aglomerações urbanas. Isso se deve porque está incluída nos diversos tipos de aluguéis de escritórios, moradias, etc., ou mesmo no preço cobrado pelos imóveis (ALQUIER, 1971, p.82 apud BOTELHO, 2007, p.74). Na verdade, a renda da terra perde sua forma concreta que tinha na agricultura (renda em trabalho, em espécie ou em dinheiro) para ganhar uma forma mais abstrata, como se não fosse mais um produto do solo. Desse modo, se assemelha cada vez mais ao juro de um montante de capital investido.

Outro aspecto relevante ressaltado pelo autor é que o aumento da renda fundiária urbana está diretamente relacionado ao capital fixo que se incorpora à terra na forma de infraestrutura urbana e que o objeto principal da especulação no setor imobiliário não é o imóvel construído, em si, mas a expectativa de renda fundiária a ser cobrada pelos proprietários.

Num sentido mais amplo a renda da terra, incluindo sua condição imobiliária, se afirma cada vez mais nas relações sociais capitalistas, fazendo parte de seu processo de reprodução, criando espaços estratificados em função da renda que proporciona.

\subsubsection{Mercado e Estado na organização espacial da produção}

O aprofundamento da discussão sobre a produção do espaço enquanto estratégia de acumulação do capital acabou nos conduzindo aos conceitos de renda da terra e propriedade, fazendo emergir um aspecto fundamental na compreensão desse espaço urbano contemporâneo: o papel do Estado e do mercado na organização espacial da produção.

Lefebvre, (1999) ao propor explicar a função da cidade a partir do ponto de vista da teoria marxista, usa os conceitos de formação, realização e distribuição da mais-valia porque acredita que eles levam a uma compreensão mais ampla do circuito de acumulação capitalista onde o Estado tem um papel fundamental.

Desse modo, ele inicia esclarecendo que a cidade, para Marx (1983), não tem função essencial na primeira fase da acumulação do capital, isto é, do ponto de vista da

\footnotetext{
${ }^{14}$ Ou renda fundiária urbana que o autor usa, nesse caso, como sinônimo.
} 
"formação da mais-valia" porque "o lugar da exploração" da mão de obra ocorre na unidade de produção: na empresa industrial ou agrária, onde a cidade fornece apenas o pano de fundo. No entanto, o autor reconhece o papel da cidade no interior das forças produtivas, com a sua função concentradora, "no espaço e no tempo, dos elementos da produção: empresas, mercados, informações e decisões, etc." (Op.cit. p.143-142).

Seguindo o seu raciocínio, a cidade passa a ter uma função essencial somente a partir da segunda fase da acumulação, isto é, do ponto de vista da "realização da mais-valia", porque essa realização (a venda da mercadoria para obtenção do lucro/dinheiro) exige: primeiro um mercado e em segundo, um sistema particular de crédito, de transferências de fundos que permitam ao dinheiro completar plenamente a sua função.

Fica claro nesse caso que a extensão do mercado se liga à do fenômeno urbano, uma vez que o comércio suscitou a formação e expansão de centros urbanos, desde a cidade medieval, até os centros econômicos e políticos da sociedade capitalista contemporânea. Desse modo, controlam o mercado mundial por diversos meios: entre eles, a publicidade, as tarifas aduaneiras, etc. inclusive pela ação do Estado.

No entanto, quando Lefebvre (1999) aborda a "distribuição da mais-valia”, como a terceira fase de acumulação do capital, afirma que ela opera no nível mais elevado da sociedade capitalista: o global (nacional e mundial). Neles, há uma concorrência entre os capitais no mercado mundial que se efetua tanto no plano econômico, com os custos de produção, como no político travado na arena nacional e internacional. Ao final, essa massa da mais-valia global se distribui em diversas frações, inclusive de proprietários de terra, comerciantes, industriais e profissionais liberais, etc. que se efetua em diversos níveis, inclusive no global, onde a supervisão do Estado tem a função de impedir as distorções consideradas excessivas.

Ao mesmo tempo, o autor destaca que o próprio Estado retém uma parte considerável dessa mais-valia, por meio do sistema fiscal em particular, para atender às funções de sua responsabilidade (educação, saúde, burocracia, cultura, segurança, etc.), mantendo prioritariamente as necessidades da sociedade burguesa.

Conclui, portanto, que o Estado capitalista, através do seu sistema contratual jurídico, mantém e aperfeiçoa o poder político, tornando-se o responsável pelo controle do 
capital que, em última análise, "repousa na propriedade privada, a da terra (propriedade imobiliária) e a do dinheiro (propriedade mobiliária)” (op.cit. p. 138).

\section{A organização espacial da produção como racionalidade urbana}

Aprofundando a questão da participação do Estado no processo de acumulação capitalista, Csaba Deák (1989) parte da negação da teoria da renda como categoria de análise e propõe outra abordagem constituída de um arcabouço teórico que inclui a análise da organização espacial da (re) produção capitalista. Desse modo, situa o que chama de "dialética da forma-mercadoria" 15 como o antagonismo entre a "forma mercadoria" e a intervenção do Estado que considera ser a mais profunda contradição do capitalismo e, ao mesmo tempo, a sua própria força motriz e razão desta organização espacial. (Op.cit. p. 18).

Para o autor, a categoria "renda da terra" dá lugar à categoria "pagamento pela localização" podendo esta tomar a forma de renda ou de preço de acordo com o período e o nível de controle exercido sobre a localização, enquanto condição de produção. Considera o preço, a forma mais compatível com a "forma-mercadoria" plenamente desenvolvida, sendo a renda uma forma subsidiária em casos como nos estágios inicial e final de desenvolvimento de ramos industriais específicos.

Sua noção de "processo urbano" parece apropriada à análise das condições de produção do espaço sob a influência da industrialização / produção de mercadorias, tanto pelos conceitos que utiliza como também pelos exemplos apresentados e poderia não ser precisa para a nossa análise sobre a produção do espaço turístico.

Mesmo assim, consideramos importante situar a contribuição de Deák (1989) em nossas referências por que além de ser um trabalho consistente sobre a produção do espaço, a divergência identificada não impede de aproveitar sua discussão sobre as relações entre o Estado e o mercado, evidenciando a produção capitalista como uma racionalidade da organização espacial. Embora o seu enfoque seja mais alinhado à realidade industrial, como dissemos, ela explicita aspectos que evidenciam a interferência e participação do

\footnotetext{
${ }^{15}$ Essa dialética, segundo o autor, se constitui fundamentalmente no antagonismo entre a produção de valores de uso enquanto valores de troca (a produção de mercadorias) e a produção direta de valores de uso.
} 
Estado no controle do espaço, comum também à realidade da produção do espaço em geral como o próprio autor reconhece no final.

Embora a sua abordagem parta da divergência em torno da "renda da terra", em última análise, Deák afirma a mesma influência exercida pelo preço da terra sobre a organização espacial e consequentemente sobre a urbanização levantada por Lefebvre (1999) e Botelho (2007). Ao substituir a "categoria renda" por "pagamento pela localização" Deák considera que essa categoria se constitui efetivamente num "meio de organização espacial da produção". Assim, esclarece que "o pagamento pela localização está incluído no preço de produção de uma mercadoria juntamente com os meios de produção, matéria-prima e trabalho" (Op.cit.).

No caso da produção imobiliária, no contexto do turismo, o baixo preço da terra também determina uma série de escolhas a respeito da localização dos empreendimentos na perspectiva de uma maior margem de valorização e lucro, como veremos nas seções seguintes.

No entanto, Deák (1989) afirma que embora a produção seja regulada pelo mercado, a intervenção do Estado na produção é prevista desde os tempos de Engels e que conforme prosseguia o desenvolvimento do capitalismo, ampliava-se o papel do Estado no âmbito da produção e em especial, do seu papel de controle do uso do espaço.

O preço da terra é a forma dominante de pagamento pela localização, para o autor, e constitui-se num dos meios de organização espacial da produção juntamente com outros como: as ações normativas, indutivas e coercivas do Estado. Assim, a regulação econômica se dá através de uma combinação de forças do mercado e do planejamento, como a regulação espacial que se exerce por uma combinação dos mesmos processos que se concretizam tanto no preço da localização como na intervenção do Estado.

Portanto, a combinação particular dos diversos meios de regulação utilizados pelo Estado é determinada pelo estágio de desenvolvimento das forças produtivas que se converteram, segundo o autor, em um dos aspectos da crise atual do capitalismo. Esta, segundo Deák, diz respeito ao aumento do papel do Estado na regulação do capitalismo até um ponto que coloca em questão a própria primazia da forma-mercadoria, o que 
delineia uma perspectiva de abordagem para análise do pagamento pela localização e em particular, do preço da terra na aglomeração urbana.

Embora esse assunto possa tomar uma dimensão mais ampla, caso fossem abordadas as múltiplas dimensões do Estado, nosso interesse se restringe, no momento, a ressaltar o papel antagônico entre Estado e o processo de acumulação do capital que mesmo sendo pensado para o contexto industrial, revela os mesmos processos e contradições do capitalismo em geral. Nesse caso, nos serve de referência teórica para a análise da produção do espaço turístico, quando o Estado e suas políticas públicas apresentam papel destacado, como veremos em detalhes nas sessões seguintes.

O que é verdadeiro para a organização da produção em geral vale também para a organização espacial em particular. Assim como o fluxo de capital entre empresas e ramos industriais é regulado em grau menor ou maior (de acordo com o estágio da acumulação) [...] da mesma maneira a localização espacial é enquadrada mediante zoneamento legal, impostos e taxas de localização, empreendimentos públicos etc., de modo que o preço da localização exerça sua função de organização apenas dentro daquilo que ainda resta de 'liberdade' ao mercado. (DEÁK, 1989, p.18-31).

\subsection{Transição metropolitana e a dissolução urbana nas cidades contemporâneas}

Tradicionalmente, sabemos que as aglomerações urbanas surgiram e cresceram em torno da acumulação do excedente agrícola, do comércio e, mais tarde, da produção de bens manufaturados. No entanto, por ocasião das grandes transformações que se iniciaram no final do século XX, foi imposta uma nova ordem baseada em profundas alterações que repercutiram como uma reestruturação produtiva mundial influenciando todos os países do mundo em escala global.

Essas transformações provocaram alterações no padrão de crescimento das cidades que não cabiam no modelo explicativo de crescimento centro-periferia, adotado anteriormente, caracterizado pela dicotomia campo - cidade, conforme os paradigmas formulados até meados dos anos 1970. Emergiram, no entanto, novas territorialidades baseadas em novas escalas de adensamento e configuração urbana. 
Consideramos oportuno, no entanto, rever inicialmente as bases teóricas explicativas dessas mudanças, captadas por diversos estudiosos do fenômeno urbano para designar essas transformações que se manifestaram no início da década de 1970 e ganharam contornos variados e específicos sob o enfoque de cada autor.

\subsubsection{Reestruturação produtiva no contexto da globalização}

David Harvey (2001) interpreta essas alterações que ocorreram simultaneamente no mundo do trabalho, na produção, no consumo e na cultura, a partir do confronto entre os conceitos de ruptura e continuidade naquilo que considera uma transição dos valores modernistas para os de um período pós-modernista.

Sua questão central foi identificar o que, de fato, é novo na configuração do capitalismo no final do Século XX, em particular nas relações entre capital e trabalho, buscando compreender o conteúdo de permanências e mudanças. Estas, por conseguinte, vão caracterizar as transformações na sociedade contemporânea, a partir de uma nova maneira dominante de se experimentar o tempo e o espaço.

Embora o autor reconheça que a simultaneidade nessas dimensões mutantes de tempo e espaço não seja a prova de conexão causal, conclui que "há algum tipo de relação necessária entre a ascensão de formas culturais pós-modernas, a emergência de modos mais flexíveis de acumulação do capital e um novo ciclo de compressão do tempoespaço na organização do capitalismo" (HARVEY, 2001, p.9).

No entanto, adverte que essas mudanças, "quando confrontadas com as regras básicas de acumulação capitalista, mostram-se mais como transformações de aparência superficial do que como sinais do surgimento de alguma sociedade pós-capitalista ou mesmo pós-industrial inteiramente nova" (idem).

Assim, Harvey expõe sua ideia de que um novo padrão de acumulação, que ele chama de "flexível", se apresenta em contraposição ao modelo keynesiano-fordista, adotado até o início da década de 1970, constituído como um processo de reestruturação produtiva dentro da própria estrutura da sociedade capitalista, sem apresentar o rompimento com os grandes parâmetros que a definem. Com isso, o autor procura desmistificar o novo 
modelo, discutindo de forma crítica os parâmetros do que ele chama de reestruturação produtiva do capital.

Essas profundas transformações ocorridas na sociedade contemporânea foram captadas também por outros autores consagrados que atribuíram denominações diferenciadas para interpretar o mesmo fenômeno de mudanças que ocorreu a nível global sobre as práticas sociais, como: o meio técnico-científico-informacional de Santos (1994, 2006), a lógica cultural do capitalismo tardio de Jameson (2000) e a sociedade em rede de Castells (1999), para citar algumas obras referenciais.

A partir dos anos 1980, outras questões também passaram a ser tratadas como o foco das discussões em torno dessa nova ordem mundial unificada cada vez mais pelas inovações no campo da tecnologia da informação, dos transportes e das técnicas produtivas e organizacionais. Com isso, o conceito de globalização passou a permear praticamente todos os debates, em torno das mudanças verificadas nessa onda de reestruturação cujas características proporcionaram um avanço sem precedentes em direção a uma economia "ultraliberal".

A conformação de uma nova organização geográfica da indústria a nível global foi possibilitada tanto por essa revolução no campo das tecnologias de informação e comunicação como também por um capitalismo renovado pelos princípios "neoliberais", fortalecido pela falência do modelo político-econômico soviético, no final dos anos 1980.

O fenômeno caracterizado pelo processo de mundialização da capacidade produtiva, acompanhada pela ampliação e flexibilização, sem precedentes, do sistema financeiro, incorporando o espaço como elemento estratégico da reprodução ampliada do capital, foi denominado por diversos teóricos como Castells (1999) e Sassen (1998) pelo termo de globalização ou mundialização da economia.

Ambos consideram a globalização como um novo paradigma vinculado a um aumento do patamar de mobilidade internacional do capital, decorrente das mudanças ocorridas principalmente nas tecnologias de informática e comunicações. Esse processo teve como consequência o fortalecimento do mercado internacional e o enfraquecimento do papel dos Estados nacionais. 
Em termos de ajustes espaciais, a velocidade das comunicações e transportes, tornou evidente a compressão do espaço pelo tempo, que sempre esteve no centro da dinâmica capitalista. Ao contrário de uma possível desvalorização do espaço, ele é reforçado pela diminuição das barreiras espaciais, tornando cada região mais ou menos atraente dentro da dinâmica de produção.

O declínio das cidades e regiões industrializadas do Primeiro Mundo, resultante do deslocamento de empregos para algumas cidades do Terceiro Mundo, aumentaram as correntes migratórias em nível internacional, determinadas pelo fortalecimento dos interesses das empresas transnacionais. Como resultado, uma nova hierarquia de cidades surge nesse contexto, enfatizado por Sassen (1999) como "cidades globais", onde se concentra o controle financeiro e organizacional dessa economia mundial.

Existe, há vários séculos, uma economia mundial, mas ela tem sido repetidamente reconstituída ao longo do tempo [...]. Uma das mudanças importantes ocorridas ao longo dos últimos vinte anos foi o aumento da mobilidade do capital, em nível nacional e, sobretudo, transnacional (SASSEN, 1999: 15 apud FERREIRA, 2007: 92).

As mudanças provocadas pela reestruturação produtiva influenciaram também outros aspectos da prática social, agora universalizada por vários fatores como: os novos padrões de consumo; a pressão crescente sobre a procura de recursos renováveis; a valorização de aspectos culturalmente mais significativos e a modernização do sistema financeiro baseada na informatização e automação bancária. Esses fatores, proporcionaram um avanço sem precedentes da "financeirização" da economia mundial.

A expansão do comportamento "financeirizado" da economia mundial contemporânea é trabalhado por vários autores que se dedicaram a explicar as características fundamentais do nosso tempo. Giovanni Arrighi (1996), em "O Longo Século XX: dinheiro, poder e as origens do nosso tempo", vai buscar nos quatro Séculos que o antecederam, em especial o Século XIX, os fundamentos econômicos e políticos para explicação da contemporaneidade.

O ponto de partida e de chegada de sua análise é a expansão material da economia mundial na qual considera fundamental a passagem do comércio da produção para a especulação e intermediação financeiras. Esse fato pode ser interpretado como um 
reflexo da mesma contradição entre a expansão do capital e a expansão material da economia mundial que corresponde ao desenvolvimento das forças produtivas da sociedade.

A questão das raízes sociais e políticas da "finança mundializada", abordando sua configuração e consequências é trabalhada por Françoise Chesnais (2005) que se mostra preocupado com os limites e alcance das questões econômicas sobre os demais aspectos da vida contemporânea. Assim, aponta para a autonomização do capital-dinheiro sob a forma de "capital portador de juros" 16 e a consequente expansão do sistema de crédito que considera os elementos que impulsionam a centralização do capital e promovem a fusão dos interesses entre a alta finança e a indústria.

Esse capital (portador de juros) busca ‘fazer dinheiro' sem sair da esfera financeira, sob a forma de juros de empréstimos, de dividendos e outros pagamentos a titulo de posse de ações e, enfim, de lucros nascidos de 'especulação bem-sucedida'. Ele tem como terreno de ação os mercados financeiros integrados entre si no plano doméstico e interconectados internacionalmente. (CHESNAY, 2005, p35.).

A modalidade de organização capitalista que concretiza essa fusão de interesses, segundo Beluzzo (2005), é a sociedade anônima cujo caráter coletivista sobrepõe aos capitais dispersos e ao mesmo tempo reforça a sua rivalidade. Desse modo, considera que o capital financeiro "é a etapa mais avançada do capitalismo porque nela a capacidade de mobilização dos capitais se transforma em uma força de supressão das barreiras tecnológicas e de mercado nascidas do próprio processo de concentração" (op.cit. in. CHESNAY, 2005, p.7).

Em outras palavras, as instituições financeiras que participam dessas fusões estão interessadas em suprimir a concorrência local e reforçar o caráter monopolista. Ao fazerem isso estimulam a conquista de novos mercados e por consequência o acirramento entre blocos de capital impulsionando a internacionalização crescente da concorrência capitalista.

16 O autor usa esse conceito no mesmo sentido de capital fictício, trabalhado por Marx (1983) já descrito no subcapítulo 1.1.1. 
Esse tipo de operação é largamente utilizado no contexto dos fundos de investimentos bancários do mercado financeiro tradicional e ambiente das bolsas de valores que agora passam a negociar títulos imobiliários, fundos de investimentos imobiliários e ações de empresas construtoras, cujo objetivo é ampliar a base de crédito.

A necessidade de expansão do crédito foi apontada como o fator mais importante para o crescimento da construção civil, na pesquisa organizada em 2011 pela revista Conjuntura da Construção ${ }^{17}$,

Nesse cenário, a revista aplicou questionários com perguntas aos executivos do setor da construção, com foco no segmento imobiliário e de habitação, arguindo sobre duas questões principais: os fundamentos do sucesso setorial obtido nos últimos anos e os fatores necessários para que o crescimento se sustente ao longo do tempo.

Como resultado, houve uma percepção predominante de que o principal elemento para o crescimento do setor nos últimos anos foi justamente a expansão do crédito. Outros fatores surgiram como responsáveis por isso como: a estabilidade econômica, a expansão dos programas de moradia social, a demanda por obras dos governos, a queda do patamar histórico de juros, a desoneração tributária e a abertura de capital das empresas.

A lógica da finança mundializada alcança o Brasil, em vários segmentos e níveis hierárquicos de sua economia, atingindo praticamente todos os Estados da federação que passaram a ter acesso, entre outras facilidades, à automação do sistema bancário nacional, integrado ao sistema financeiro internacional, facilitando o seu ingresso aos circuitos do capital globalizado.

Estudando o caso de Fortaleza, percebemos algumas evidências que associam o desenvolvimento dessa nova forma de urbanização litorânea às mudanças proporcionadas pela expansão da lógica da finança mundializada. Dentre elas, identificamos a instalação de escritórios locais de empresas europeias no Ceará e o RG

\footnotetext{
${ }^{17}$ Ano IX / n ${ }^{\circ} 3$ / Setembro de 2011 - A revista, para ter uma amostra significativa dos executivos que atuam direta ou indiretamente no segmento imobiliário, utilizou os participantes do $83^{\circ}$ Encontro Nacional da Indústria da Construção Civil (Enic), considerado o principal evento promovido pela Câmara Brasileira da Indústria da Construção (CBIC) - realizado anualmente e organizado pelo Sinduscon-sp.
} 
do Norte, atuando como fundos de investimentos internacionais voltados para o mercado imobiliário e turístico brasileiro (EXACT INVEST / SALAMANCA GLOBAL). Outras variantes do mesmo modelo, foram verificadas na especialização de fundos de investimentos específicos voltados para empreendimentos turísticos e imobiliários (ADIT BRASIL / BRASIL INVEST FUND); na disponibilidade de recursos destinados ao desenvolvimento do turismo oriundos de agências internacionais (BID, BIRD,CAF) e na criação de fundos de investimentos para financiar o mercado imobiliário, negociados na bolsa de valores (IMOB/BOVESPA).

Outras evidências marcaram a presença de grandes empresas brasileiras da construção civil, expandindo sua atuação como incorporadoras em diversos estados brasileiros, inclusive no Ceará (Cyrela, Magis, MRV, Rossi, Tecnisa, entre outras), atuando também no litoral de Aquiraz. Outro dado que influenciou a ampliação do acesso ao sistema de crédito em âmbito nacional, tanto para o construtor como para o consumidor, foi ampliação da atuação da Caixa Econômica Federal.

São, portanto, evidências que articulam a urbanização litorânea cearense às mudanças proporcionadas pela lógica da finança mundializada que acreditamos estar relacionada a essa reestruturação produtiva e metropolitana de Fortaleza.

\subsubsection{O novo padrão de cidade: centro-periferia e a nova organização metropolitana}

As transformações operadas nos diversos níveis do processo produtivo repercutiram, evidentemente, em novas maneiras de produzir e apropriar-se do espaço, emergindo daí novos sistemas urbanos mais complexos articulados com o crescimento de áreas metropolitanas com periferias diferenciadas. Este crescimento é constituído, assim, por novas centralidades, com equipamentos especializados, diferentes do antigo modelo da metrópole do período industrial-fordista, caracterizado pela monocentralidade.

O novo padrão de crescimento da cidade contemporânea, portanto, se insere nos debates sobre os novos processos da reestruturação produtiva que resultaram na criação de dinâmicas constituintes de novas redes urbanas, num cenário de profundas mudanças, até então nunca vistos. 
Guerra (2005, p.10) ao tratar dos fenômenos que caracterizam as recentes transformações urbanas e o desenvolvimento territorial mundial, ressalta um aspecto que considera incomum e surpreendente: a simultaneidade de sua aparição no globo, uma vez que ocorrem na imensa maioria das grandes cidades e regiões urbanizadas na Europa, América, Ásia, Austrália e África.

Entre os diversos fenômenos que caracterizam essas transformações, cita alguns que considera representativos de tais mudanças. Entre eles:

- A diminuição relativa ou absoluta das funções produtivas industriais;

- A redução do peso das decisões e dos investimentos públicos no desenvolvimento urbano e territorial;

- A ampliação do raio funcional que afeta as atividades residenciais, produtivas, terciárias, comerciais e de lazer;

- A debilidade dos centros urbanos com a obsolescência e desvalorização dos elementos que dão individualidade à cidade;

- O aumento da dispersão urbana, mesmo em cidades decididamente compactas, com uma extensão fragmentada do seu território;

- O novo tipo de segregação socioespacial emergente, devido a mudanças na distribuição do trabalho e renda como também nos novos estilos de vida;

- O surgimento de relações espaciais tanto nas cidades como no meio rural que já não podem ser descritas e explicadas com as categorias tradicionais de centro e periferia.

Embora vários destes fenômenos já tenham sido verificados nas últimas décadas do século XX, sobretudo nas cidades norte-americanas, podemos dizer que nestes últimos vinte anos eles se manifestam conjuntamente com grande potência, reforçando-se mutuamente, em todas as partes do mundo, a partir dos anos 1990.

A internacionalidade das transformações têm consequências para a sua interpretação e estudo porque essa tendência onipresente dos fenômenos sugere que suas causas só possam ser explicadas a nível global. Portanto, o discurso dominante na América Latina para a explicação de sua origem, segundo o autor, se baseia no termo "globalização". 
Esta interpretação, no entanto, tem parecido pouco produtiva, na medida em que incita a buscar as causas dessas transformações urbanas e territoriais, em processos praticamente impossíveis de influir no âmbito nacional ou local. Para enfrentar esse problema, o autor propõe detectar as causas locais e nacionais da reestruturação espacial, considerando que este é o caminho para encontrar de modo mais claro, os fatores de produção da cidade e do território. Assim argumenta que esses fatores estão associados, em última análise, aos instrumentos que regulam a cidade de modo mais conveniente de ser alterado para o de um desenvolvimento diferente, abordagem que adotamos também na nossa pesquisa.

Assim, o autor faz um breve levantamento do estado da arte das pesquisas sobre o tema das novas transformações metropolitanas na América Latina, associando o trabalho de Carmona (2000) a essa onipresença dos fenômenos relacionados à globalização na análise dos fatores explicativos da realidade local. Cita também os trabalhos desenvolvidos para o caso de Buenos Aires, onde destaca três linhas de pesquisa que se referem: a nova configuração socioespacial, a política-administrativa e a geográficoterritorial, representadas principalmente por Horacio Torres (1993), Pedro Pirez (1994) e Pablo Ciccolella (1999), respectivamente.

Sobre o trabalho de Torres (1993) comenta o desenho do "mapa social" que representa uma linha de análise socioespacial que provê dados sobre a realidade de Buenos Aires. Embora escassos, os dados estruturais se constituem em ferramentas importantes para identificar os novos fenômenos analisados.

Pirez (1994) representa a segunda linha de pesquisa denominada de políticoadministrativa, onde sua abordagem aponta para a gestão metropolitana da cidaderegião formada pela capital federal e a província de Buenos Aires de onde se constata a inexistência de cooperação a nível intercomunal. Assim, conclui que na Argentina, ainda não se conseguiu estabelecer uma discussão comum, interdisciplinar sobre a problemática metropolitana.

No Brasil, os trabalhos de Ribeiro (2004) junto à rede de pesquisa Observatório das Metrópoles, também chegam a essa mesma constatação, a partir de outro argumento: o da necessidade de superarmos a concepção localista de políticas públicas inerentes ao planejamento em moda na sociedade brasileira, como o planejamento estratégico, 
afirmando que esse "quadro de fragmentação institucional também resulta da inexistência de políticas federais de incentivos seletivos à cooperação metropolitana" (Op.cit., p.13).

O trabalho de Ciccollela (1999), por sua vez, representa uma linha de investigação fundamentada nos aportes da escola de Saskya Sassen e François Arsher, afirmando que as transformações decisivas para o desenvolvimento espacial, no caso de Buenos Aires, se relacionam com a sua inserção tardia no mercado global que se produziu a partir da abertura econômica marcada pelos investimentos estrangeiros em imóveis para uso de escritórios dos anos 1990.

No Brasil, Mariana Fix (2007) e João Whitaker Ferreira (2007) também discutem a inserção brasileira no circuito global, apresentando as formas específicas que assumem a produção e o consumo do espaço urbano em SP durante o processo de globalização da economia.

Fix (2007, p.13), de um lado, revela como a mundialização financeira aparece no processo de circulação do capital, no meio ambiente construído e mais especificamente no setor imobiliário voltado à produção da "face globalizada" da cidade. Já Ferreira (2007, p.14), de outro modo, contribui para desmistificar um conceito amplamente divulgado no meio urbanístico brasileiro e internacional: o de que as cidades de hoje, para conseguirem sobreviver ao ambiente competitivo e globalizado da economia atual, devem seguir o receituário específico, de forte perfil neoliberal, cuja implementação deve ser feita por meio de "novas" técnicas de urbanismo como o planejamento estratégico.

Nesse quadro de discussões sobre a questão metropolitana, o trabalho de Guerra (2005, p.13) propõe dedicar-se a uma reconstrução da gênesis das novas estruturas urbanas e territoriais, estudando como primeiro passo, os resultados morfológicos do que vemos como uma nova fase do desenvolvimento espacial. Neste caso, considerado como consequência de maneiras específicas de construir e regular a cidade e o território por parte dos atores públicos e privados, formal ou informalmente constituídos.

Guerra chama a atenção da necessidade de se ampliar as pesquisas interdisciplinares sobre a questão metropolitana, ressaltando os trabalhos do "Programa del Investigación 
Santiago Metropolitano" (PISM, 2000) e o trabalho desenvolvido por Carlos de Mattos (2001) que apresenta uma explicação econômica das transformações espaciais estruturais nas grandes metrópoles latino-americanas. Desse modo, afirma que este fenômeno deve ser entendido como um novo impulso de concentração nas metrópoles que se expressa, entre outras características, por uma nova onda de suburbanização que surge em grande parte, devido a fatores econômicos e políticos. Tais fatores, segundo o autor, são baseados em critérios de rentabilidade, em meio a uma corrida entre a sagacidade dos investidores privados e a capacidade dos instrumentos públicos de regulação.

Sua conclusão vai ao encontro da nossa maneira de perceber as transformações urbanas da cidade contemporânea, no caso em estudo, como também do modo como organizamos o nosso referencial teórico e o consequente encadeamento de conceitos. Por isso, partimos da noção de produção social do espaço como estratégia de acumulação do capital cuja racionalidade, em última análise, fundamenta-se em critérios de rentabilidade proporcionados pela propriedade da terra, intermediada pelo Estado e o mercado através das políticas públicas e in,strumentos de gestão e controle.

Outras abordagens como a de Reis (2006) se voltam a questões relacionadas às novas dinâmicas na configuração da metrópole contemporânea brasileira, caracterizadas pelo surgimento de novas formas de centralização, acompanhada de uma progressiva descentralização de atividades capaz de gerar novas centralidades. Como consequência, surgem padrões caracterizados pela especialização de atividades que provocam a fragmentação territorial e a formação de áreas de urbanização dispersa. Tal movimento, portanto, é constituído por uma desconcentração que embora separada espacialmente, mantêm-se em fortes vínculos como se tratasse de um único sistema urbano.

Entre essas características, levantadas pelo autor, destacam-se as relacionadas à fragmentação, descontinuidade ou dispersão das inúmeras partes que formam a configuração urbana contemporânea, em contraste aos atributos de contiguidade, compacidade e limite do modelo histórico da cidade tradicional. 
Com outro enfoque e partindo de uma abordagem sobre a sociabilidade contemporânea, Sennett (2004, p. 213-220) afirma a mesma lógica dessas mudanças, ressaltando o papel das alterações no processo produtivo capitalista como sendo responsáveis pelas características morfológicas que se repetem como uma padronização do âmbito físico. Tal fenômeno é motivado, segundo o autor, por essa economia inquieta que produz rupturas políticas na cidade criando novas pressões que alcança a esfera da vida privada.

O seu argumento baseia-se numa análise do "capitalismo e a cidade", ressaltando os aspectos sobre as virtudes urbanas, enquanto valor cultural de se morar em cidades, mesmo em meio aos conhecidos problemas urbanos de violência, má gestão que levam a sua decadência. Seu destaque, no entanto, é para a análise entre dois pares dialéticos: "rigidez - estranhamento" e "flexibilidade-indiferença" cujo objetivo é compreender as relações entre estas dualidades para caracterizar essa transição entre as duas fases do capitalismo contemporâneo: a fordista para a flexível. Assim, segundo o autor, essa transição é responsável pelos destinos das "virtudes urbanas" dessa nova cidade, emergindo daí dois de seus valores éticos que a representam: a sociabilidade de conviver com estranhos e a subjetividade baseada na experiência pessoal incompleta.

A primeira dessas virtudes leva a uma trégua ou desejo de paz baseado na indiferença mútua que leva a formação de grupos autossegregados que caracterizam os condomínios fechados contemporâneos. A segunda leva ao autoisolamento social que mesmo diante da percepção de sua subjetividade incompleta, não se evidenciam caminhos que estimulem ao encontro das relações de vizinhança com pessoas estranhas.

A contribuição do autor, portanto, se constitui como uma reflexão sobe a conexão entre os aspectos relacionados às mudanças no processo de produção capitalista e seu rebatimento ao nível da sociabilidade da vida privada que, em última ordem, vai influenciar a configuração espacial e os padrões de ocupação porque a ela se adéqua.

Pesquisas recentes sobre as transformações sofridas pelas cidades, nas últimas décadas do século passado, têm sido associadas também à alteração desse padrão de crescimento urbano que modificou a característica periférica da ocupação territorial da urbanização predominante na América Latina. Essas mudanças levaram a uma alteração que vem sendo assumida como uma verdadeira reestruturação socioespacial, devido a sua dimensão e alcance. 
Tal reestruturação socioespacial recebe designações, associadas, ora ao seu aspecto industrial, urbano, metropolitano ou imobiliário, conforme o objeto de estudo e interesse dos pesquisadores. Há, no entanto, uma coincidência nos resultados de boa parte delas, mesmo em meio a uma diversidade de objetivos, isto é: o fato de que dessas transformações, emergem aglomerações urbanas com padrões de morfologia dispersa, fragmentada e segregada.

Sua ocorrência, de alcance global, atinge desde os grandes centros urbanos dos países centrais como também, as grandes concentrações metropolitanas da América Latina como São Paulo, Santiago e Buenos Aires, conforme tem sido demonstrado nas pesquisas apresentadas no livro organizado por Pereira (2011). No nosso estudo, verificamos que essa mesma lógica penetra também em níveis secundários da economia global atingindo as metrópoles regionais brasileiras, como é o caso da RM de Fortaleza. Assim, estende sua rede de influências a localidades anteriormente isoladas do circuito mundial, alcançando também a escala local, primeiramente pelas atividades ligadas ao turismo, e em seguida pela imobiliária, como teremos a oportunidade de verificar.

Essa constatação global tem levado pesquisadores a indagar se tal transformação, pelas dimensões do fenômeno, pode revelar uma nova ordem de cidade fundamentada em novas maneiras de organizar o espaço da produção, articulado também a uma nova sociabilidade.

Os primeiros sinais de transição para esta nova cidade, para essa cidade emergente, coincidem com a chamada crise do modelo de substituição de importações na América Latina (ou com a superação do modelo de industrialização fordista a nível mundial), que apesar de ter provocado diferentes alternativas de organização produtiva e diversas experiências de ocupação territorial gerou surpreendentemente artefatos arquitetônicos e padrões urbanísticos muito semelhantes em todas as aglomerações. (PEREIRA, 2011, p.24).

Essa nova ordem, segundo o autor, pode ser revelada também pelo interesse que os responsáveis pela administração local e pela elite do planejamento urbano demonstram ao reinterpretar o papel dessas novas cidades, propondo a sua integração ao circuito mundial, como se isso fosse representar um benefício para a maioria, quando na verdade 
esses planos parecem estar acomodados pelas ilusões de urbanização geradas pelo modelo de industrialização fordista.

Notamos, portanto, que a produção dessa nova cidade tem sido estudada por urbanistas de todo o mundo que diante da complexidade do nosso tempo, levantam muito mais caminhos a serem verificados do que conclusões definitivas demonstrando o caráter de permanente mudança e incertezas que marca essa nova fase da humanidade. Esse aspecto, por consequência, transforma em desafio, a tarefa de compreender essas diversas transformações ocorridas em escala global.

Tais mudanças chamam a nossa atenção, não só porque trazem impactos significativos ao espaço urbano, palco dessas profundas transformações, mas porque ocorrem em grande velocidade, num movimento permanente de estruturação-desestruturaçãoreestruturação, denunciando que esse equilíbrio se apresenta de um modo muito mais provisório e em constante movimento, do que poderíamos supor.

No seu estudo sobre "Referências analíticas para a discussão da metamorfose metropolitana", Lencioni (2011) levanta uma série de considerações importantes que a leva propor uma revisão das referências formuladas por Lefebvre (1971), realçando o caráter transitório nas relações entre a nova estrutura e a precedente, apontando para uma verdadeira "metamorfose metropolitana".

A busca pela compreensão das mudanças recentes que têm ocorrido na metrópole vem trilhando vários caminhos interpretativos. Sejam quais forem as interpretações, um fato é inquestionável: as transformações são reconhecidamente tão profundas que expressam uma verdadeira metamorfose, pois o resultado é uma mudança completa na estrutura, forma e função da metrópole. Metamorfoseiam-se as relações sociais e o espaço anunciando que estamos vivendo um período de transição, uma transformação qualitativa para algo diferente do que conhecemos. (Op. cit. p.51)

A questão da transitoriedade na análise da reestruturação da metrópole é importante porque traduz um estado de percepção da realidade contemporânea criada pelo estabelecimento de uma nova ordem que tem suas bases nas transformações porque passa a humanidade, sobretudo nos campos político, econômico, social, ambiental, cultural e tecnológico. 
Essa noção de transitoriedade na metrópole é importante também para a nossa pesquisa porque será possível constatar como a noção de reorganizar-se em torno de uma permanente instabilidade é especialmente marcante na ação dos agentes imobiliários diante da produção do espaço para o turismo.

\subsubsection{Breve comentário sobre os conceitos de urbano e cidade}

Percebemos, ao longo de toda a exposição anterior, que dois conceitos foram utilizados de forma sistemática, tratados com grande amplitude de significado e que nos leva a discuti-lo agora, fechando esse bloco, buscando diminuir os impactos da ambiguidade e imprecisão contidas no seu amplo significado: os conceitos de urbano e de cidade.

Um argumento recorrente encontrado em diversos autores que se dedicam ao estudo da urbanização contemporânea é a necessidade de se dar ao conceito de "urbano" um significado mais preciso diante da complexidade e diversidade de contextos em que ele é empregado o que leva, como consequência, a sua difícil conceituação.

Ramos (2004) trabalha com a contribuição de 20 urbanistas contemporâneos, com o objetivo de melhor esclarecer a questão, enfatizando, em primeiro lugar, a complexidade do conceito "urbano", ressaltando a infinita capacidade que as cidades demonstram ao dar uma variedade de respostas na enorme dimensão de sua constituição, enquanto artefato. Ressalta ainda a associação dos fatores que as provocam sem encontrar limites à inovação, sob as quais se manifestam (RAMOS, 2004, p.8)

Não é à toa que o autor considera a conceituação do "urbano" uma questão substantiva, no sentido de evidenciar a importância de melhor defini-lo num significado mais próximo do concreto ou real e menos ambíguo ou abrangente ao ponto de dissolvê-lo. Assim, alerta para o risco que o termo encerra ao carregar diversos e imprecisos conteúdos em seu significado, apontando para a necessidade de melhor definir o objeto de tal universo de referências.

Françoise Choay (in RAMOS, 2004, p.61-72) ${ }^{18}$ usa o conceito de urbano para anunciar-lhe um reinado sobre a morte da cidade "tradicional", por ocasião da identificação de um estado que se discute o desaparecimento da presença universal da cidade com seus atributos próprios e sua versátil acepção. Desse modo, o urbano passa a

\footnotetext{
18 "Le règne de l'urbaine et la mort de La ville" in "La Ville" (1994).
} 
representar uma nova realidade que se inicia junto com a revolução industrial na Europa e se faz no presente em um permanente processo de mutação.

$\mathrm{Na}$ verdade Choay (Op. cit., p.62) admite sem sentimentalismos o desaparecimento da cidade tradicional, buscando compreender a natureza da urbanização e da não cidade que segundo a autora parece ter se convertido no destino das sociedades ocidentais avançadas. A não cidade, para ela, é a cidade máquina modernista que deu fim à urbanidade anterior ao aplicar o mesmo tipo de desintegração e o mesmo modelo de desenho de cidade, indiferentemente, para Paris, Argel, Saint-Dié, entre outras, dos anos 1920 a 1950.

Ao longo de seu argumento afirma que, em linguagem comum atual, cidade continua designando o lugar ou o suporte estático de uma tripla comunicação que relaciona o intercâmbio de bens, informações e afeto. Em outras palavras, esclarece que ainda se concebe como a união indissociável do que os romanos chamavam de "urbs" (território físico da cidade) e "civitas" (comunidade dos cidadãos que a habitam). Ou seja: a pertença recíproca entre uma população e uma entidade espacial distinta e fixa.

Esse breve comentário não tem a pretensão de fazer um levantamento dos diversos termos empregados para definir o urbano e a cidade, mas apenas ressaltar o reconhecimento da dificuldade que os dois conceitos sofrem em virtude dos seus inúmeros contextos, em uma época de intensas modificações.

\subsubsection{A ação dos agentes imobiliários na produção das cidades contemporâneas}

A produção dessa nova cidade parece se afirmar, com a crise do modelo fordista de crescimento, caracterizado pelo vetor binário centro-perifera que de um lado viabilizava-se como uma "urbanização sem urbanismo" onde, nos extremos da cidade, utiliza-se a mão de obra familiar informal para construir a habitação do trabalhador. Do outro, no centro da aglomeração, produzem-se as formas de construção tecnologicamente mais avançadas que tornaram hegemônico esse modelo periférico na dinâmica imobiliária, até então. Esse modelo caracteriza-se "ao universalizar formas capitalistas de produção do espaço, combinando técnicas intensivas e extensivas de 
construção imobiliária, com as vantagens da utilização rentista da propriedade da terra na valorização do imóvel” (PEREIRA, 2011, p.24).

Segundo o autor, a crise do modelo fordista de desenvolvimento urbano veio por em evidência essa combinação contraditória de forças de crescimento da cidade, como também, a realidade dessa contradição urbana, até então percebida como se fosse um binômio segmentado, simplificadamente explicado no modelo (centro-periferia), como se situação contraditória pudesse ser reduzida a um organismo dual ${ }^{19}$, capaz de explicálo.

Sobre a dinâmica imobiliária hegemônica atual, Pereira (op.cit.p.24-25) ressalta como foram substituídas as alianças entre os antigos agentes que emergiram dos movimentos sociais urbanos dos anos 1970, vistos como portadores de experiências socialmente inovadoras, por outras que passaram a ser definidas por um núcleo de promotores imobiliários e financeiros em estreita e simbiótica relação com empresas de construção civil. Essas alianças, segundo o autor, tendem a confundir seus interesses imediatos de valorização dos imóveis com os do desenvolvimento urbano da cidade, ficando de fora os interesses tradicionais de acesso a equipamentos urbanos coletivos, produzidos, até então pelo Estado, como condição para a reprodução do capital industrial.

Na verdade, emerge dessa nova organização uma aglomeração que se redimensiona pela emergência das novas demandas associadas à reestruturação socioespacial, onde as condições gerais se fundam agora não mais pelas demandas locais da produção industrial, mas sim nas necessidades de comercialização e da logística financeira. Como consequência, surge um novo quadro de alianças urbano-industrial onde as estratégias de crescimento da cidade dependem diretamente dos setores financeiro e imobiliário, configurando novos vínculos entre a valorização e a propriedade da terra.

A cidade contemporânea é cada vez mais um lugar voltado para a produção de espaços exclusivos onde a apropriação do valor a subordina, resultando na realização dessa riqueza social. Ainda que se constitua longe da ordem mais próxima do âmbito territorial local, regional, nacional ou global, sobretudo, por ser financeira, ela se

\footnotetext{
${ }^{19}$ Para aprofundar a compreensão da crítica a esse modelo dual ver Chico de Oliveira (2003) argumentando como se dá a interdependências entre os setores modernos da economia que se alimentam desse 'atraso' dos países ditos "em desenvolvimento". Ver também o trabalho de Milton Santos (2004) enfatizando a existência daquilo que considera os dois circuitos da economia: o inferior e o superior, demonstrando como são igualmente interdependentes.
} 
constitui igualmente na ordem próxima causando repercussões materializadas nos mais variados artefatos arquitetônicos, como também nos novos padrões urbanísticos que exalta a forma de produção imobiliária para o mercado. Como consequência, modifica a cultura urbanística anterior ao não privilegiar o atendimento das condições materiais de reprodução da força de trabalho.

O que se conclui, portanto, é que há uma verdadeira dissolução do urbano, no sentido de que o urbano, como lócus da reprodução da força de trabalho tende a perder a importância para definir o crescimento da cidade e os rumos de sua expansão, dando lugar a produção do imobiliário para o mercado que toma a direção desse processo de produção da cidade contemporânea.

A discussão, proposta por Pereira (2011), aponta para as contradições e os conflitos inerentes ao aumento da importância da produção imobiliária para o mercado enquanto fundamento dessa dissolução urbana e da constituição de uma nova hegemonia na produção social do espaço, atribuída aos agentes imobiliários.

Com efeito, a emergência desse novo quadro de agentes hegemônicos, no crescimento da cidade, revela como os agentes imobiliários tornaram-se não só os sujeitos produtores de experiências urbanas inovadoras, mas agentes orgânicos e funcionais alinhados à lógica de acumulação do capital.

De fato, essa discussão teórica nos leva a questionar o limite e a possibilidade de ação desses agentes na reestruturação da cidade contemporânea, tendo em vista a atual convergência de processos internacionais e locais. Do mesmo modo, nos leva também a redefinir essa questão, superando a noção de que esses agentes são personagens improdutivos e fundados na "especulação", para outra noção que reconheça o papel desses agentes como portadores das transformações das cidades tradicionais. Por isso, podemos dizer que são responsáveis por nos colocar diante de um novo padrão de cidade.

Sobre esse novo padrão de cidade Pereira (2011) indaga se não é mais urbano, no sentido em que até então conhecíamos, ou se metropolitano "porque responde prioritariamente a uma reorganização da produção, à importância crescente do financeiro, inclusive no imobiliário, atribuindo um novo sentido à urbanização, à 
produção do espaço e às cidades" (op.cit.p.26). Isso, diante de um momento em que podemos dizer que se completa a subordinação do espaço ao capital.

Assim, propõe compreender a constituição do metropolitano, para além dessa negação do urbano, mas indagando criticamente sobre as contradições e conflitos essenciais aos processos imobiliário e urbano presentes na sociedade e na cidade no contexto dessas transformações. Desse modo, propõe como fio condutor a compreensão da ação dos agentes imobiliários, diante da atual complexidade das formas de produção do espaço e do valor, a partir da "compreensão crítica da formação, distribuição e apropriação do valor imobiliário, como uma relação particular entre a propriedade da terra e do capital na construção da cidade” (op.cit.p.27).

O essencial nessa proposta, portanto, é compreender as contradições e conflitos na produção e distribuição do valor e do espaço destacando o papel da dissimulação velada das relações de exploração entre os agentes da produção e do consumo do espaço que é articulado entre o Estado e os representantes dos interesses do capital. Esse papel não é novo e já foi levantado por Lefebvre em “A Revolução Urbana” (1999-a, p.142), mas ganha relevância e singularidade atualmente quando exercido por organismos que planejam, fiscalizam e atuam na construção do espaço urbano, com promessas e ilusões urbanísticas que "justificam" equivocadamente as desigualdades e as injustiças na apropriação e uso do espaço urbano.

Essa perspectiva destaca também o papel de cada um dos agentes produtores do espaço que figuram como proprietários do trabalho, da terra e do capital que tal qual na fórmula trinitária marxista, se envolvem no processo de produção capitalista do espaço urbano, apropriando-se da mais-valia resultante da sua formação e distribuição, embutida no valor imobiliário fruto dessa articulação.

O processo imobiliário capitalista, desse modo, segue os mesmos condicionamentos da produção industrial de mercadorias. O preço do imóvel pode ser composto a partir do preço de produção do edifício (incluído o lucro), somado ao preço médio da promoção imobiliária, (comercial, financeira) e ao sobrelucro da localização (a renda da terra). Na análise da formação do preço ou valor de mercado dos imóveis, podemos identificar os elementos que particularizam o setor imobiliário e que o diferencia no atual momento de reestruturação socioespacial da cidade. 
Uma particularidade do setor imobiliário que se destaca no contexto contemporâneo foi levantada por Pereira (2011, p.28-29) e se relaciona ao efeito que a duração do período de circulação do capital, necessário para a sua produção, pode causar no preço final.

Tradicionalmente, o investimento de capital no setor imobiliário era mais para cumprir um papel de refúgio para as crises do capital, do que servir à realização do seu valor. Hoje, no entanto, passou-se a buscar as potencialidades de renda e remuneração na captação desse valor, combinando formas de espoliação financeira e imobiliária.

No centro da questão está o tempo de circulação do capital onde o lucro sobre a produção imobiliária passa a sofrer a dependência externa de capitais de empréstimo. Quanto mais longa a duração da circulação do capital, menor será a rentabilidade da operação que nesse caso pode ser encurtada pela simples aceleração nas vendas através da comercialização antecipada das unidades, ainda em planta, antes da sua construção.

Assim a composição de capitais para essa situação pode ser descrita simplificadamente como formada pelo: capital de promoção ${ }^{20}$, somado aos créditos oriundos dos empréstimos, mais o dinheiro do usuário final que não pode ser considerado capital, uma vez que ele não será remunerado. Esta combinação passa a ser a base do modelo adotado para a promoção imobiliária que atualmente se intensifica pela valorização dos diferentes capitais de circulação e que são normalmente acrescentados à composição formal do preço do imóvel: custo do terreno + custo da produção do edifício + lucro da construção.

É importante ressaltar que a valorização do investimento funciona como suporte de diversas frações de capital especializadas envolvidas na produção e circulação da mercadoria imobiliária (Topalov, 1974 apud PEREIRA, 2011, p.29) remunerando todos eles a partir da valorização e consequentemente da elevação do preço do imóvel.

\footnotetext{
${ }^{20}$ O conceito de promoção imobiliária é novo e no nosso caso estamos utilizando no sentido da atividade de planejamento e gestão do negócio imobiliário, envolvendo desde o projeto financeiro de captação, investimento, marketing e venda, aos estudos preliminares do projeto de arquitetura que simulam a viabilidade do empreendimento e possibilitam a sua comercialização em planta (o projeto executivo de arquitetura entra na composição dos custos da produção do edifício). A atividade de promoção imobiliária é diferenciada da de compra e venda de imóveis, pelo Conselho Regional de Corretores de Imóveis do Estado do Estado de São Paulo (http://www.crecisp.gov.br/cadastro_coaf/login.aspx - 15/05/2012). Escritórios especializados em promoção imobiliária utilizam o termo no sentido de: atividade de transformação de imóveis em investimentos que acrescentam valor. (John Neild \& Associados - http://www.johnneild.pt/gca/?id=6 - 15/05/2012).
} 
Essa composição de investimentos pode ser bem mais complexa e variar de acordo com cada projeto de negócio imobiliário como também com a fonte de recursos. No entanto, a simplificação acima é útil para compreender a lógica básica da estrutura dessa formação que se tornou uma particularidade específica da forma de promoção imobiliária para mercado. Nesta, associa-se a valorização de diferentes capitais e da propriedade da terra na realização da mercadoria imóvel e que fundamenta a construção dessa nova cidade fruto da reestruturação socioespacial contemporânea.

A lógica da diminuição do tempo de rotação do capital investido como variável estratégica de maximização da taxa de lucro criou uma situação nova e diferente da que existia anteriormente quando as práticas do mercado imobiliário buscavam minimizar o investimento industrial na construção. Tais práticas, baseavam-se na "rentabilidade do capital de longa duração do processo imobiliário, na descontinuidade do processo construtivo e na lenta realização da mercadoria imobiliária que buscava se beneficiar de uma valorização ociosa”. (Op.cit. p.29)

Hoje com as mudanças no setor que mais parecem uma "reestruturação imobiliária" 21 passou-se a buscar as potencialidades de captação de valor e renda onde o setor imobiliário transformou-se numa opção de investimentos com elevada taxa de rentabilidade garantindo uma alternativa nova de sobrevida ao capital em momentos de crise.

Entre as estratégias para potencializar a realização de valor do capital no mercado imobiliário, o autor ressalta além do aumento da velocidade de comercialização, a elevação dos preços por meio de campanhas publicitárias e a associação de capitais de empréstimo para alavancar novos negócios e realizar preços especulativos, acima dos praticados no mercado.

No entanto, estas estratégias pareceram não ser suficientes e resultaram em crises ainda mais graves como a dos financiamentos subprime do mercado norte americano que revelaram contradições essenciais dessa reestruturação, ao buscar diluir os riscos dos investimentos imobiliários, repassando a investidores, uma série de pequenos empréstimos bancários em cascata. Estes, eram comercializados de forma semelhante a

\footnotetext{
${ }^{21}$ Conceito trabalhado em Pereira (2005) para o caso de São Paulo
} 
dos CRI - Certificados de Recebíveis Imobiliários ${ }^{22}$, isto é: papéis comercializáveis formados por pacotes de dívidas de adquirentes de imóveis de uso próprio. Essa nova fonte de recursos passou a financiar desde os novos condomínios fechados a megaprojetos multifuncionais (hotéis, vilas turísticas, flats, shoppings, edge-cities, etc.).

Vale salientar que foi com a promoção destes novos produtos imobiliários (artefatos arquitetônicos e urbanos globalizados) que se passou a movimentar um volume de capital nunca antes imaginado, a nível mundial, constituindo-se num antagonismo entre a cidade tradicional e a nova cidade emergente, caracterizada por uma grande aglomeração dispersa, formada de múltiplas centralidades e periferias articuladas em um extenso e impreciso território.

Mesmo com todas essas evidências não temos a certeza se essa reestruturação constituise de fato como um permanente caos urbano ou se apenas mais uma consequência da crise financeira estrutural do capitalismo internacional. No entanto, essa reestruturação parece ser "mais um passo na fragmentação e hierarquização do espaço e consolidação do que pode vir a ser chamado de espaço metropolitano. Um espaço formado pelas forças mundiais homogeneizantes e fragmentadoras que resultam das interações regionais entre as ordens próximas e distantes, entre os níveis global e local" (PEREIRA, 2011, p.30).

O conhecimento desse espaço metropolitano, portanto, parece fornecer a chave para compreensão da intensa dinamização imobiliária provocado pelos novos espaços destinados ao turismo na RM de Fortaleza onde é possível observar o comportamento dos agentes imobiliários adaptando-se à realidade proposta a partir das oportunidades promovidas pelo Estado.

\footnotetext{
22 Papéis comercializados na bolsa / mercado financeiro formado por pacotes de dívidas de adquirentes de imóveis securitizados. Sobre o assunto ver Botelho (2007, p. 165).
} 


\section{CAPÍTULO II - A URBANIZAÇÃO LITORÂNEA NO CONTEXTO DA REESTRUTURAÇÃO METROPOLITANA DE FORTALEZA.}

Já vimos no capítulo anterior como a reestruturação produtiva afetou a urbanização das cidades no âmbito mundial e como essa nova ordem tomou a forma de um espaço metropolitano disperso, articulado às dinâmicas provocadas por novas centralidades polarizadas pela cidade-mãe. No entanto, verificamos como esse processo é movido pela lógica da acumulação do capital tendo como base a estratégia de produção do espaço, fundamentada na renda e na propriedade da terra que a condiciona e dá valor. Nesse contexto, vimos surgir o papel do Estado e do mercado imobiliário como principais agentes protagonistas da construção dessa nova cidade, atingindo uma dimensão cada vez mais destacada e refinada que nos leva a indagar sobre os limites e alcances de suas implicações no planejamento e gestão do espaço urbano contemporâneo.

Agora nossa proposta, nos próximos capítulos, é voltar o foco dessa discussão para a ação dos agentes imobiliários, buscando responder à questão central do problema que é saber se o comportamento desses agentes corresponde à reorganização de um novo processo de produção do espaço para o turismo, frente à necessidade de incorporar novos territórios à lógica de reprodução do capital. Para isso, partimos da hipótese geral de que há um processo de reestruturação produtiva no Estado do Ceará, iniciado no final dos anos 1980 que atingiu Fortaleza em sua dimensão metropolitana, provocando alterações no comportamento dos agentes imobiliários quando da produção do espaço urbano para o turismo.

Nessa exposição verificaremos como na pesquisa essas alterações corresponderam a algum tipo de inovação, adequação, permanência ou conflito intrínseco ao processo produtivo dos negócios imobiliários que se materializaram em novos padrões de ocupação urbana no litoral da RM de Fortaleza. Assim, será possível revelar como os agentes imobiliários se apropriam do espaço planejado para o turismo, tratando esse espaço como um nicho de mercado, passando tanto a influenciar o modelo de desenvolvimento turístico adotado no Ceará, como também a urbanização litorânea, ao configurar um novo padrão de ocupação, fruto de uma nova forma de produção do espaço metropolitano. 
Desse modo, expomos o objetivo da pesquisa que é responder a perguntas que buscam orientar nossa reflexão em torno das transformações socioespaciais recentes nas cidades brasileiras. Nestas, processos e nichos de mercado vinculados a produtos imobiliários participam como causas da dissolução urbana das metrópoles contemporâneas, caracterizadas pela dispersão urbana, fragmentação territorial e uma evidente segregação social.

Enfocar os produtos imobiliários vinculados ao turismo permitirá compreender como se dá a articulação dessa nova forma de produção social do espaço baseada na emergência de um quadro de novos agentes sociais, considerados como sujeitos portadores de práticas urbanas inovadoras e comprometidos com a lógica de reprodução do capital, como formulado na proposta metodológica desenvolvida por Pereira (2011. p23 a 27).

O método utilizado na nossa abordagem de pesquisa poder ser sintetizado em quatro movimentos que combinam pesquisa bibliográfica e documental, apoiada em perspectiva histórica, com a análise de dados estatísticos relacionados à: demografia e aspectos socioeconômicos, interpretação de dados técnicos (mapas, fotografias aéreas, imagens de satélite, planos de desenvolvimento), complementado pelo levantamento de campo. Este último, composto por mapeamento de uso e ocupação do solo, levantamento fotográfico, visitas às prefeituras e institutos de pesquisa e um bloco de entrevistas semiestruturadas de caráter qualitativo aplicadas aos agentes imobiliários, cujos resultados são comparados com o que foi flagrado na análise socioespacial, como descrito abaixo:

- No primeiro movimento, introduziremos a especificidade das zonas costeiras e o processo de ocupação do litoral brasileiro e cearense para situar a importância do litoral e de Fortaleza no âmbito Estadual e no contexto da investigação;

- No segundo, faremos a análise objetiva do processo de metropolização de Fortaleza para elucidar suas relações com a reestruturação produtiva implantada pelo Governo do Estado, desde o final dos anos 1980, apontando particularidades relacionadas à formulação do problema. Para isso, utilizamos pesquisa bibliográfica associada à análise documental e estatística, relacionados à demografia e aspectos socioeconômicos, colhidos nas fontes dos institutos de 
pesquisa como o IBGE - Instituto Brasileiro de Geografia e Estatística e o IPECE- Instituto de Pesquisa e Estratégia Econômica do Ceará;

- No terceiro, faremos a interpretação da emergência do turismo no contexto da produção do espaço urbano contemporâneo, identificando suas especificidades, as bases que fundamentaram a política de turismo e suas implicações na organização do espaço urbano na RM de Fortaleza. Nesse caso, também baseado em pesquisa bibliográfica, documental, estatística e por dados organizados pelo autor. Todos esses três movimentos são desenvolvidos agora neste segundo capítulo.

- O quarto movimento será desenvolvido no próximo capítulo abordando, em detalhes, a caracterização do problema e do objeto de estudo, a partir da análise do recorte espacial adotado, no nosso caso: o litoral do município de Aquiraz, onde o fenômeno se apresenta de uma maneira mais evidente e emblemática. Com isso, seremos capazes de confirmar a hipótese formulada, utilizando-se de levantamento bibliográfico e documental de dados técnicos compostos por mapas e fotos extraídos dos Planos Diretores de Desenvolvimento Urbano e Plano de Ação Turística, complementadas pelo trabalho de campo e entrevistas semiestruturadas aos agentes imobiliários. O trabalho de campo, por sua vez é composto pelo levantamento do uso e ocupação do solo, a análise de fotografias aéreas e de satélite, a interpretação de mapas e plantas, complementados pelo levantamento fotográfico que fundamentam a análise socioespacial. Nesta, adotamos como categoria de análise, a tríade lefebvriana: estrutura-formafunção. Ao final, comparamos a interpretação de todas as análises desenvolvidas aos resultados obtidos nas entrevistas aos agentes imobiliários que nos levará às conclusões e considerações finais.

Passaremos a dar seguimento ao desenvolvimento da abordagem desse primeiro movimento, justificando a necessidade de conhecermos as especificidades da Zona Costeira e o processo de ocupação da costa brasileira e cearense, para situar a importância de Fortaleza e do turismo no contexto da urbanização contemporânea. 


\section{O espaço litorâneo e suas especificidades na ocupação do litoral cearense: a consolidação de Fortaleza.}

As transformações socioespaciais decorrentes da prática do turismo em Fortaleza, evidentemente, não podem ser compreendidas, descoladas do contexto histórico do processo de ocupação litorânea do Estado, uma vez que o turismo só assume uma posição de destaque no final do Século XX. Nesse momento, a cidade passa a funcionar como um pólo metropolitano de recepção e distribuição dos fluxos turísticos articulados aos diversos atrativos existentes, principalmente nas localidades litorâneas, cuja materialidade vai superpor-se a outras camadas sedimentadas em diferentes períodos históricos do processo de ocupação do litoral do Estado e da cidade, deixando marcas visíveis em seu tecido urbano.

Assim, antes de penetrar na escala municipal ou metropolitana propomos abordar, preliminarmente, alguns dos aspectos considerados fundamentais na discussão da problemática ambiental das zonas costeiras e seu processo de ocupação. Nesse caso, são tratados como base e fio condutor para a compreensão das transformações provocadas pela produção do espaço turístico em Fortaleza uma vez que seu litoral foi elevado à categoria de lugar privilegiado de seu desenvolvimento. Com isso, pretendemos evidenciar algumas das contradições contidas nesta singular porção do território para melhor avaliar as repercussões espaciais causadas pelo turismo e sua política de desenvolvimento, no contexto da reestruturação produtiva do Estado.

Propomos, portanto, iniciar essa discussão a partir da análise sintética da evolução histórica das estruturas relacionadas ao processo de ocupação da costa brasileira e, em particular, do litoral cearense e de sua capital, como forma de estabelecer uma referência para a compreensão dos diversos aspectos envolvidos nas transformações socioespaciais e urbanas ocorridas no litoral da RM de Fortaleza.

\subsection{Considerações iniciais sobre as zonas costeiras}

As zonas costeiras possuem aspectos extraordinários, fruto de uma associação excepcional de fatores físicos, ambientais e humanos que as elevam à categoria de lugar 
privilegiado, em todo o mundo. É, ao mesmo tempo, a interface das diversas relações de interesse vital, tanto do ponto de vista ecológico, como também do prisma humano, tendo sido o ponto de interseção e contato das diversas culturas, onde foram fundadas cidades e civilizações do passado, desde a Antiguidade. No presente, sua importância se afirma cada vez mais pelo fato de intermediar relações econômicas e socioespaciais, marcadas amplamente pelas características atuais da sociedade contemporânea em contato com o mar, ocasionando conflitos e suscitando discussões sobre as relações de controle e gestão.

A definição de zona costeira, segundo Moraes (1999, p. 27) é um tema que suscita polêmicas internacionais. "Quando a perspectiva se afasta do formalismo das definições abstratas, do tipo - zona de interação dos meios terrestres, marinhos e atmosféricos - vê-se que a questão não permite uma só resposta, pois tal tema remete a uma variedade de situações que deveriam ser contempladas numa boa definição".

Do ponto de vista geoambiental, a zona costeira é composta pelos diversos sistemas físico-naturais, incluindo a faixa litorânea, o seu entorno continental imediato e a plataforma continental adjacente, seguindo os critérios estabelecidos pelo Macrodiagnóstico da Zona Costeira do Brasil (BRASIL/MMA, 1996).

Estes sistemas, ou unidades geoambientais, são o produto de uma matriz de fatores e variáreis ambientais relativas ao suporte (condições geológicas e geomorfológicas), ao envoltório (condições hidrológicas e climáticas) e à cobertura (solos e cobertura vegetal) de uma determinada região, apresentando características semelhantes de fragilidades e potencialidades que permitem a sua utilização para o planejamento territorial e zoneamento (CAMPOS e.t al., 2003, p. 28).

Do ponto de vista espacial, a zona costeira é a estreita faixa de transição entre o continente e o oceano. Do ponto de vista da gestão, entretanto, é o palco onde se acentuam os conflitos de uso, se aceleram as perdas de recursos e se verificam os maiores impactos ambientais, em virtude, basicamente, da grande concentração demográfica e dos crescentes interesses econômicos e pressões antrópicas (Op. cit. 2003, p.12). 
No que se refere às características de uso e ocupação, o litoral pode ser definido como uma zona de usos múltiplos, sendo possível encontrar inúmeras formas de ocupação do solo, onde se desenvolvem atividades humanas das mais variadas naturezas e complexidades.

Defronta-se na zona costeira do Brasil, desde a presença de tribos coletoras quase isoladas até plantas industriais de última geração, desde comunidades vivendo em gêneros de vida tradicionais até metrópoles dotadas de toda a modernidade que a caracteriza (MORAES, 1999, p. 30).

Por esses e por outros aspectos, a localização litorânea qualifica-se como uma situação geográfica ímpar cujas potencialidades vêm se convertendo num processo de ocupação, em ritmo cada vez mais acelerado, animado por múltiplos vetores de desenvolvimento relacionados à industrialização, urbanização e, mais recentemente, na exploração turística. Em outras palavras, a zona costeira compõe-se de um universo caracterizado pela multiplicidade e diversidade de padrões de atividades, muitas vezes incompatíveis entre si, resultando em conflituosas relações quando postas em contato sem a mediação e gestão adequadas, aumentando a responsabilidade e os desafios dos planejadores e gestores, junto à sociedade.

\subsection{A ocupação da costa brasileira e a urbanização contemporânea.}

Embora nosso objeto de estudo sejam os novos padrões contemporâneos de ocupação litorânea na RM de Fortaleza, consideramos importante proporcionar uma maior intimidade com a especificidade do tema, para aqueles que ainda não tiveram oportunidade de conhecê-lo. Assim, ressaltaremos o modo como a lógica de ocupação precedente vem sendo substituída por uma nova racionalidade que chega com o final do século XX e desenvolve-se no início do século seguinte com força e velocidade capazes de provocar reflexões sobre a necessidade de conhecer na intimidade, a realidade socioespacial litorânea. Esse esforço se justifica na necessidade de se criar subsídios atualizados para a orientação e ajuste permanente das novas políticas públicas do presente e do futuro. 
Evidentemente, as zonas litorâneas foram as primeiras a serem ocupadas em núcleos de povoamento que se transformaram em centros para difusão e polarização dos fluxos de colonização no Novo Continente. Estes centros caracterizavam-se por explorar a produção na hinterlândia interior articulada com as rotas oceânicas que comercializavam o produto da exploração, constituindo-se em um padrão de ocupação e estruturação recorrente utilizado pelos portugueses, denominado de "bacia de drenagem" (MORAES, 1999, p.31).

Foram esses centros portuários que articularam os espaços de produção colonial aos novos circuitos da economia mundial mercantilista que se ampliavam, constituindo-se nos nós entre os fluxos terrestres e marítimos, configurando uma estrutura espacial, fruto das novas relações na divisão do trabalho, influenciando também os lugares subjacentes a esse processo.

O resultado dessa dinâmica é uma estrutura de povoamento ao longo da zona costeira brasileira, seguindo um padrão descontínuo, "que conforma um verdadeiro arquipélago demográfico, onde se identificam zonas de adensamento e núcleos pontuais de assentamento entremeados por vastas porções não ocupadas pelos colonizadores" (idem, 1999, p. 32). Ademais, essa vasta extensão do litoral se manteve isolada ou pouco povoada, servindo de refúgio de tribos indígenas e escravos fugidos que se organizaram em pequenas comunidades voltadas para o autoconsumo que se tornaram nas comunidades litorâneas tradicionais ainda presentes em várias porções do litoral brasileiro, como verificamos em todo o Brasil, no Ceará e igualmente no território de Aquiraz.

Na primeira metade do século XX, no entanto, um grande número de cidades litorâneas, inclusive algumas capitais estaduais e centros regionais de zonas deprimidas, tornaramse portos secundários e passaram à estagnação em virtude das alterações nas novas linhas de transporte rodoviário e uma série de outros fatores ligados à economia. Estas cidades mortas distribuem-se com certa regularidade ao longo de todo o litoral que ao lado das zonas pouco povoadas pelas comunidades tradicionais, tornaram-se locais a sofrerem o assédio do surto de ocupação que ocorrem na segunda metade do século XX (Op. cit, 1999, p. 35). 
A partir do final dos anos 1950, a economia brasileira atinge uma significativa aceleração do processo industrial que ultrapassou o estádio de substituição de importações, passando a recorrer maciçamente ao capital transnacional, em processos dependentes de insumos externos, condicionando a localização industrial a sítios portuários, como Cubatão e Camaçari, por exemplo. Outros fatores, entretanto, levaram a industrialização a localizar-se na periferia das capitais e zonas de adensamento populacional, motivados por dinâmicas específicas a cada situação.

A partir dos anos 1960, no entanto, o litoral foi tomado por dois fenômenos que caracterizaram fortemente a sua configuração e forma de ocupação: o primeiro está relacionado à popularização das residências de veraneio, que se disseminaram largamente por todo o litoral brasileiro, principalmente próximo às regiões metropolitanas, e pode ser considerado o fator numericamente mais expressivo da urbanização ao longo de toda a costa. Seu impacto ambiental está diretamente relacionado à incapacidade dos poderes públicos de ordenarem o uso do solo, desestabilizando a sociabilidade dos locais onde se instalam, promovendo conflitos e tensões na questão fundiária.

O segundo fenômeno está relacionado aos movimentos migratórios, em direção à costa, dos contingentes não absorvidos pela indústria, oriundos do campo, ou de outros centros urbanos menores, atuando no mercado informal, ocorrendo em diversas escalas e nas mais variadas situações. Manifesta-se principalmente em torno das grandes metrópoles e capitais brasileiras, ocorrendo também em cidades do interior de médio porte que polarizam economicamente a região do seu entorno. O resultado da chegada de tais populações, não assimiladas pela economia local, é a formação de um segmento marginal que exerce forte pressão social na demanda de serviços urbanos elementares e que se constitui hoje num quadro marcado por carências que se tornaram históricas em razão da sua amplitude (Op. cit., 1999, p. 39).

Portanto, industrialização, crescimento urbano, favelização e disseminação de segundas residências compuseram o quadro que explica a ocupação do entorno das grandes cidades litorâneas, alargando esses territórios por meio da urbanização de suas periferias e adjacências, marcando profundamente a tragédia urbana brasileira. Como consequência, exigiu do Estado a sua intervenção mediante o planejamento estatal nas 
décadas de 1970 e 1980, caracterizados por orientações baseadas no centralismo autoritário federal, alinhado a uma mentalidade tecnocrática de fé nas virtudes do desenvolvimento econômico, a qualquer custo, sem um conhecimento mais aprofundado da realidade socioespacial.

A ausência de análises consistentes sobre a produção espacial é visível em propostas de políticas públicas, nas quais se planeja o desenvolvimento com metas numéricas, nas quais o espaço onde se concretizarão estas metas é desconhecido (RODRIGUES, 1998, p. 32).

A óptica desenvolvimentista daqueles anos não tinha nenhuma preocupação com a questão ambiental e estabelecia uma complexa divisão territorial do trabalho, surgindo uma rede urbana integrada e dinâmica, ao mesmo tempo produto e consequência da constituição de um mercado nacional. Não havia a primazia metropolitana, como em outras sociedades latino-americanas, como a Argentina, México e Uruguai, onde a capital representa $40 \%$ de sua população. Por outro lado, surgiram no Brasil 14 cidades com população acima de 1 milhão de habitantes, fato ímpar no Continente (RIBEIRO et al, 1997, p. 263).

Tais fatos situaram o Estado como um dos principais agentes de intervenções nos espaços litorâneos, cuja ação criou atrativos locacionais ao mesmo tempo em que dilapidou o patrimônio natural e cultural, como foi o caso do setor petroquímico dos anos 1960 e 1970. Outro fator de intervenção, foi a política urbana financiada pelo SFH - Sistema Financeiro de Habitação gerenciado pelo BNH - Banco Nacional da Habitação que embora tenha sido criada para as classes de renda mais baixa, alimentou a expansão urbana de classe média que se transbordou, no caso de Fortaleza, em direção ao litoral metropolitano, caracterizando a expansão urbana dos anos 1970 e 1980 das cidades litorâneas.

O vetor mais recente responsável pela intensificação dos usos nas zonas costeiras, nas últimas décadas, é justamente o setor turístico que avança conjugado à atividade de veraneio, distintos no sentido estrito das suas relações sócio-espaciais, mas carregando uma enorme ambiguidade ao aproximar o turismo do imobiliário. Assim, torna-se um dos setores que mais cresce, atualmente, numa velocidade de instalação muito maior do que o Estado é capaz de organizar e disciplinar esse espaço construído. 
O turismo manifesta-se associado a vários processos: ora articulado como um setor dentro da estruturação urbana de uma cidade litorânea; ora unida a espaços de segundas residências, geralmente de alto padrão; ora mediante investimentos maciços, criando a função turística e revivendo cidades mortas como os de núcleos portuários deprimidos; ora ainda como indutora da ocupação de novas áreas criadas como as urbanizações vazias em loteamentos de veraneio de uso ocasional e turístico. Este crescimento foi alimentado pela ampliação da classe média, por um lado, e pela demanda estrangeira do outro, sendo relativamente recentes os contatos internacionais. No início, esses movimentos se deslocam a poucas cidades, porém vão abarcando maior número de localidades, até chegar à forma mais atual dos enclaves de turismo de alto padrão, dentro de áreas semidesertas da zona costeira (MORAES, 1999, p. 43).

O turismo ganhou destaque nas políticas públicas brasileiras com a entrada do Estado na elaboração de planos para construção de infraestruturas por meio de novos investimentos, qualificando o litoral brasileiro num espaço de maior atratividade para os fluxos internacionais. São turistas europeus desembarcando no litoral do Nordeste ou argentinos nas praias do sul, transformados em demanda de alto potencial de crescimento que anima a construção de novos equipamentos em ritmo cada vez mais veloz, potencializada com a entrada do Estado na tentativa de ordenamento e alavancagem do processo, por meio de um dos maiores planos estatais já vistos na contemporaneidade brasileira: o PRODETUR-NE, sem dúvida o de maior impacto sobre a zona litorânea no País, em implementação desde o final dos anos 1980 até o momento (idem, 1999, p.44).

Desse modo, o quadro atual da ocupação da zona costeira no Brasil aponta para uma população de 50,7 dos 190 milhões de habitantes (Censo 2010) vivendo em municípios litorâneos, seguindo uma tendência mundial. Assim, temos então 26,7 \% que representa 1/4 da população, habitando a beira-mar é, portanto, um número bastante significativo.

Ainda de acordo com o estudo do IBGE ${ }^{1}$ os 463 municípios da zona costeira possuem 17,4 milhões de domicílios, dos quais 9,2\% são de uso ocasional (segunda residência

\footnotetext{
${ }^{1}$ Atlas Geográfico das Zonas Costeiras e Oceânicas do Brasil divulgado em 2012 pelo Instituto Brasileiro de Geografia e Estatísticas (IBGE) em parceria com a Comissão Interministerial para os Recursos do Mar (CIRM) - http://www.tribunadonorte.com/noticias/economia/34,119142,05,12,um-quarto-da-populacaobrasileira-vive-na-zona-costeira-revela-estudo.shtml - (17/05/2012)
} 
usada para lazer de fins de semana, férias ou outro fim relacionado ao turismo). Esse percentual em outros municípios não litorâneos é de apenas 4,6\%. A proporção é ainda maior em cidades como Balneário Camboriú (SC), onde 30,3\% dos domicílios são de uso ocasional. No caso de Aquiraz (CE) verificamos que o Município possui 19.662 domicílios (72.628 hab.) dos quais 20,94\% são de uso ocasional (Censo 2010) ${ }^{2}$ sendo, portanto, um valor relativo bem acima da média nacional, se aproximando do caso catarinense, o que denota o seu caráter de município balneário de lazer e turismo.

\subsection{A ocupação da costa cearense e a consolidação de Fortaleza como capital.}

A necessidade de introduzirmos um histórico objetivo sobre a ocupação da costa cearense é, para nós, fundamental porque se justifica na percepção de que só poderemos compreender e avaliar o comportamento e a dimensão dos novos padrões de ocupação litorânea se tivermos uma referência sobre as ocupações precedentes. Assim, propomos compreender sua racionalidade para podermos identificar o que é realmente novo e o que se mantém como permanências dos períodos anteriores.

Outra razão que justifica essa síntese é a necessidade de apresentar aos que ainda não conhecem a lógica peculiar que explica os fatores de localização e expansão de Fortaleza como a capital do Estado. Acreditamos, assim que esse conhecimento vai facilitar a compreensão de sua integração ao processo de reestruturação metropolitana emergente, analisado na próxima seção, sem perder de vista o objetivo da pesquisa.

Desse modo, podemos dizer que no Ceará a relação entre o homem e o litoral se desdobra em função de três dinâmicas diferentes: a primeira resultante da estratégia colonial de ocupação do espaço, baseado na economia das charqueadas (séculos XVII e XVIII); a segunda, derivada do movimento de abertura do Ceará ao mercado internacional do algodão (séculos XIX e o início do XX) e a terceira, mais recente, orientada pela valorização das zonas de praia como espaço de lazer e mercadoria turística, do final do século XX até o presente (CAMPOS coord. et.al. -2003, p. 140).

\footnotetext{
${ }^{2}$ Resultado de consulta ao site do IBGE (http://mapasinterativos.ibge.gov.br/censo2010/ - 17/05/2012)
} 
Sobre a fase colonial é importante ressaltar apenas que praticamente durante todo o século XVI e XVII, o Ceará permaneceu isolado do ciclo açucareiro da zona da mata pernambucana, em razão das características impróprias oferecidas pelo seu sítio natural à produção do açúcar em larga escala. Somente no século XVIII o Ceará vai integrar-se à cultura canavieira, com a pecuária extensiva, no momento em que se consolida a penetração das boiadas provenientes de Pernambuco e da Bahia, através das bacias dos rios Jaguaribe e Acaraú, criando as condições necessárias ao desenvolvimento dos núcleos urbanos de Aracati - Icó e Sobral - Camocim.

Embora a criação do gado tenha se dado nas ribeiras dos sertões interiores, ela mantinha uma relação de interdependência com o litoral que desempenhava a função de polo de drenagem da produção, através da comercialização e distribuição dos produtos através dos núcleos portuários. Assim a pecuária foi responsável pelas atividades ligadas às primeiras transformações pré-industriais baseadas no aproveitamento do couro e na produção da "carne seca" para o abastecimento das cidades coloniais do litoral na Zona da Mata.

A perda do peso do gado que se deslocava aos centros de consumo trazia grandes prejuízos aos criadores. Surge a partir desse fato a indústria saladeiril (carne de sol), como resposta ao problema, levando algumas cidades interioranas a tornarem-se importantes, como Icó na bacia do salgado e Aracati, no litoral (SILVA, 1989, p. 81).

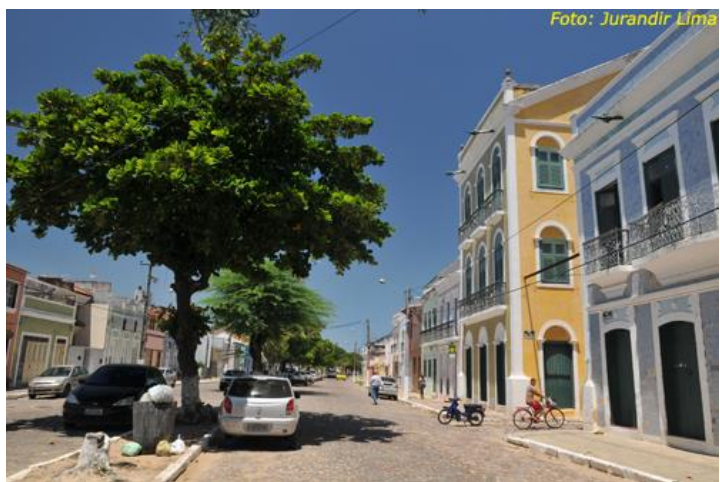

Fig.2.1 Casario colonial em Aracati: cidade portuária vinculada ao comércio de Pernambuco e Bahia. Fonte: http://2.bp.blogspot.com ${ }^{3}$

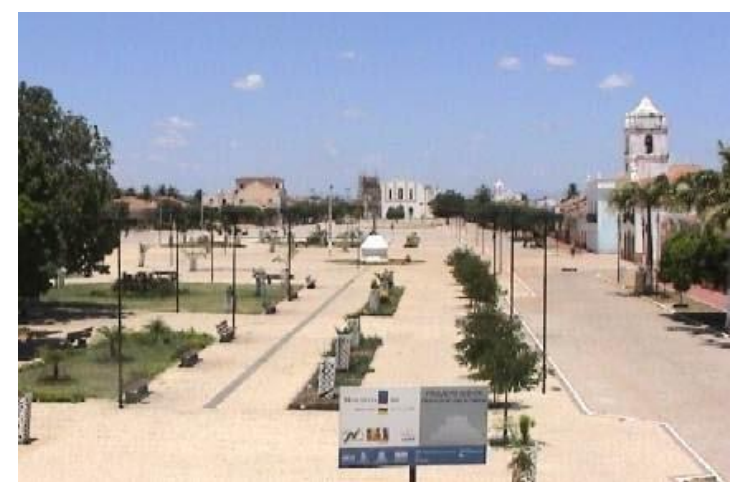

Fig.2.2 Largo do Theberge em Icó: cidade sertaneja com traçado urbanístico português.

Fonte: www.flickr.com ${ }^{4}$

\footnotetext{
${ }^{3}$ http://2.bp.blogspot.com/_6sahCIOgl_k/TGHHJKHyoBI/AAAAAAAADkw/p28wAyhQP70/s1600/sem+t\%C3\%ADtulo.bmp $(19 / 05 / 2012)$

${ }^{4}$ http://www.flickr.com/photos/jurandir_lima/6346683847/in/photostream/ (19/05/2012)
} 
Estas técnicas propiciaram, ao final do século XVIII, forte fluxo comercial entre o Ceará e as capitanias de Pernambuco e Bahia. A importância desses fluxos alimentou a construção de um quadro específico de ocupação caracterizado pela fragmentação espacial que evidenciava dois espaços distintos no Ceará: o litoral e o sertão, em que o sertão dominava o litoral pela constituição das charqueadas (DANTAS in ALMEIDA \& RATTS (org), 2003, p. 215). Pode-se dizer que Aracati e Icó conformavam uma relação típica desse binômio de domínio interdependente que se dava ao longo do vale do rio Jaguaribe até a sua foz: o sertão produzindo a carne e o couro e o litoral intermediando o comércio com as capitanias centrais, pelo mar.

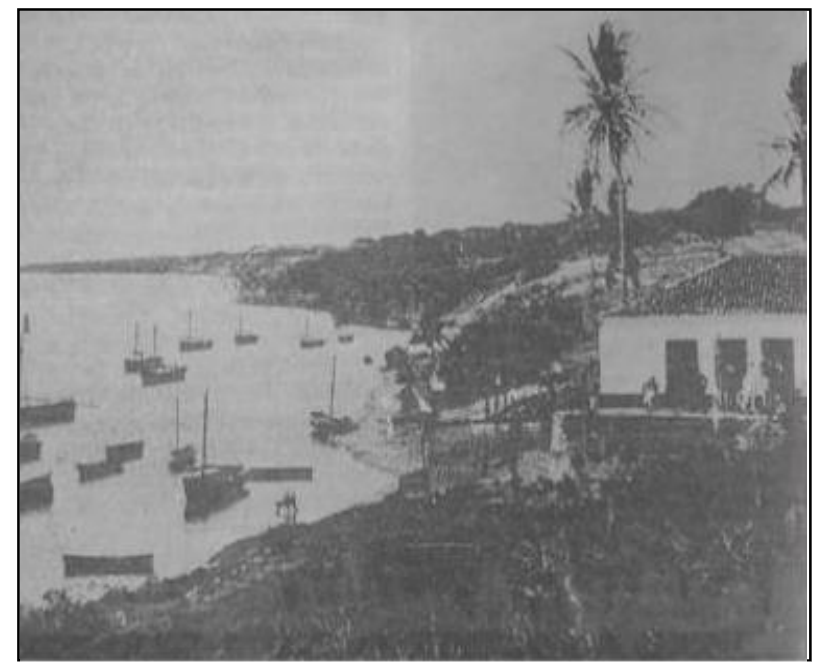

Fig.2.3 Atividades do Porto de Aracati no final do século XIX. Fonte: Espínola, 2007, p. 31 (apud MATOS, 2009, p.95).

Até o final do século XVIII, portanto, Fortaleza permanecia à margem do desenvolvimento econômico do Estado, mantendo apenas funções administrativas. De uma maneira geral, a maior parte do litoral cearense desenvolvia apenas atividade de subsistência com grande contingente indígena e mestiço, tendo em vista que a sua força econômica vinha das charqueadas das fazendas de gado do interior, com exceção das zonas de porto, localizadas principalmente em Aracati, Acaraú e Camocim ${ }^{5}$, onde as trocas comerciais impunham a presença portuguesa.

\subsubsection{Passagem do século XIX para XX: a inserção do Ceará/Fortaleza no mundo.}

É da condição simultânea de capital autônoma da capitania do Ceará ${ }^{6}$ e de porto exportador de algodão que se projetam as novas perspectivas de desenvolvimento para a então Vila do Forte na primeira metade do século XIX, de acordo com CASTRO (1994). Nesse sentido, o século XIX marca o fim da lógica que opôs Fortaleza ao sertão com o movimento de reação fundamentada na estratégia de reforçar o papel de capital

\footnotetext{
${ }^{5}$ Esses dois últimos submetidos à hegemonia de Sobral na região sertaneja do vale do Acaraú.

${ }^{6}$ Desde a expulsão dos holandeses no século XVII o Ceará torna-se província subalterna à capitania de Pernambuco cuja autonomia fora conquistada somente em 1799, através da Carta Régia assinada pela Imperatriz D. Maria I.
} 
na vida econômica, política, social e cultural da Capitania, com base em medidas políticas. Tais intervenções, foram evoluindo lentamente a partir da consolidação de seu porto como novo pólo de concentração e exportação da nova cultura do algodão que se constituiu no segundo grande ciclo econômico do Ceará.

A importância da construção do porto é evidente e nesse contexto, o governador da capitania solicita ao engenheiro português Antônio José da Silva Paulet, a elaboração da Planta do Porto, e Villa da Fortaleza, desenhada em 1813 (fig. 2.4), onde o engenheiro não detalha o plano da vila, mas volta-se ao litoral fortalezense descrevendo informações oceânicas próximas à costa. Destaca principalmente o aspecto do perfil litorâneo e a localização dos arrecifes, demonstrando o desejo de encontrar o melhor lugar para fixação de uma zona portuária que permitisse a atracação de barcos maiores. Esta planta, portanto, possui mais características de uma carta náutica do que propriamente de uma planta urbanística (MATOS, 2009, p.101). No entanto, é atribuída a Paulet, uma série de recomendações que orientavam a retificação das vias e o ordenamento da futura expansão da cidade baseado no traçado em xadrez, como apontavam as tendências urbanísticas da época.

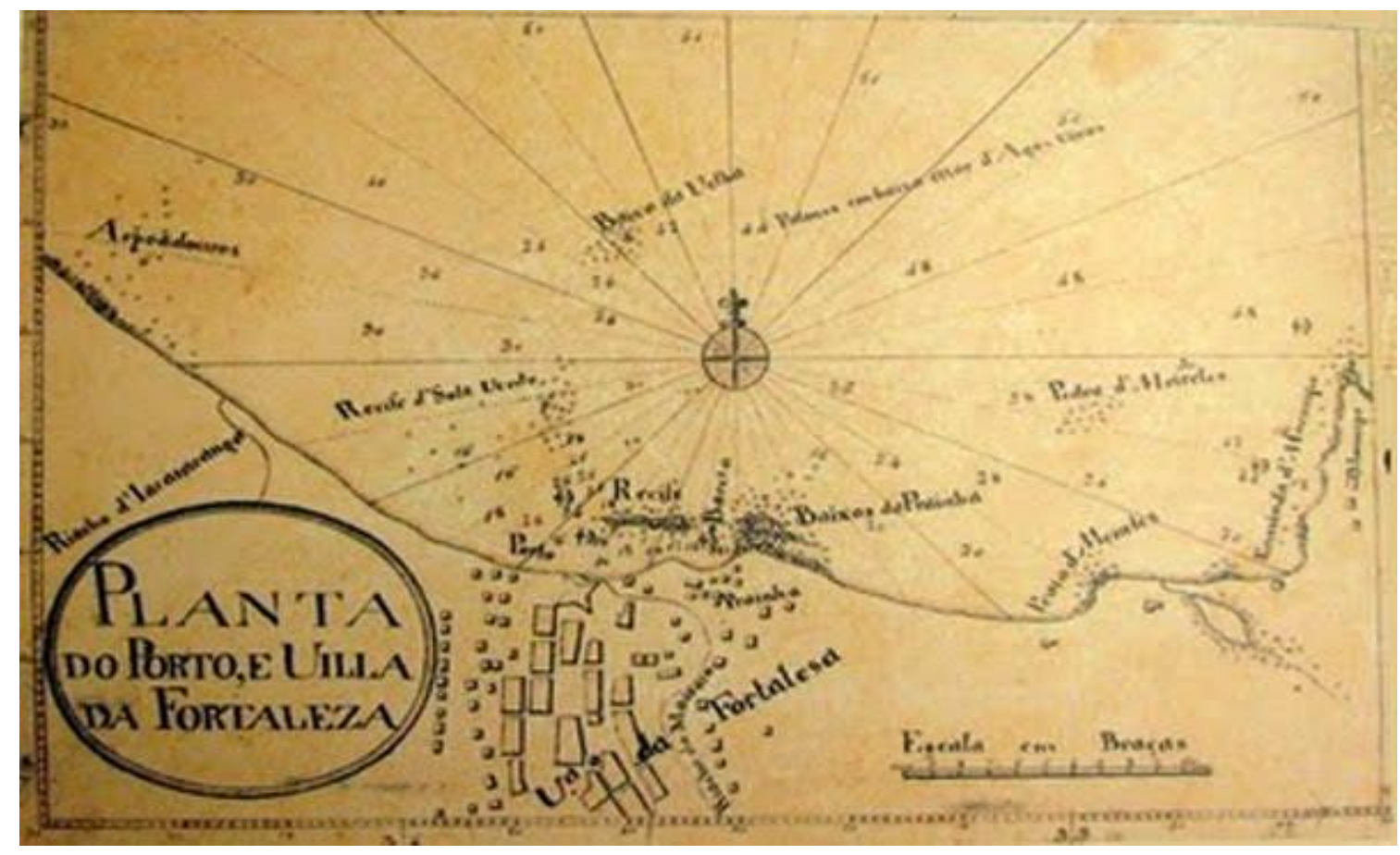

Fig. 2.4 Planta do Porto, e Villa da Fortaleza, de Silva Paulet (1813) Fonte: Chaves et al, 2006, p. 18. 
A forma relativamente convexa do litoral do Ceará transformou a história da implantação do porto de Fortaleza numa conquista, repleta de tentativas fracassadas e persistentes até se chegar à solução definitiva na enseada do Mucuripe, em 1938. No entanto, trouxe como efeito colateral problemas de erosão marítima enfrentadas até hoje e solucionada parcialmente com a construção de quebra-mares no litoral da cidade.

Consideramos importante ressaltar o tema da implantação do porto por ser um elemento chave na compreensão do processo de ocupação litorânea do Ceará, como também da consolidação de Fortaleza como capital, além de revelar detalhes do processo de valorização e desvalorização das terras litorâneas e da coexistência conflituosa do espaço dos ricos e dos pobres.

O projeto do primeiro porto só foi viabilizado em 1870 e a sua construção executada somente em 1883 (PONTE, 1993, p. 35). Os problemas durante sua construção e do posterior assoreamento, inviabilizaram a sua operação, até a construção da ponte dos ingleses, inaugurada em 1906 e reconstruída em concreto em 1928, ao lado da primeira. Antes, porém, foram construídos diversos trapiches que foram sendo substituídos com o tempo, cujo mais conhecido ficou sendo o trapiche do Ellery (1890) que devido a sua precariedade, tornou-se "alvo constante dos jornais da época” (MATOS, 2009, p.129).

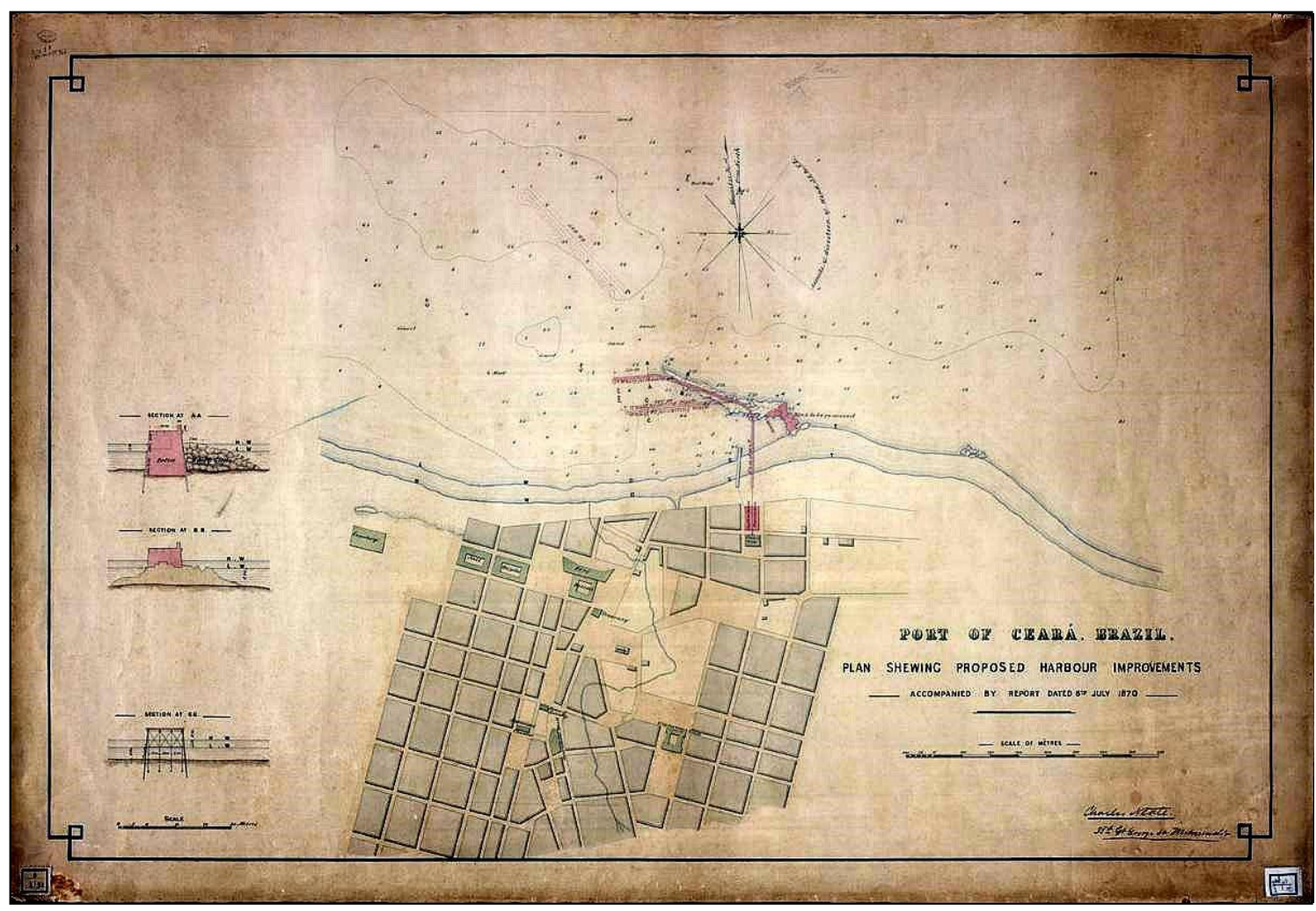

Fig. 2.5 Mapa do Projeto do Porto do Ceará (1870), em Fortaleza.

Fonte: Janja, 1924 (apud PAIVA, 2011, p.67). 


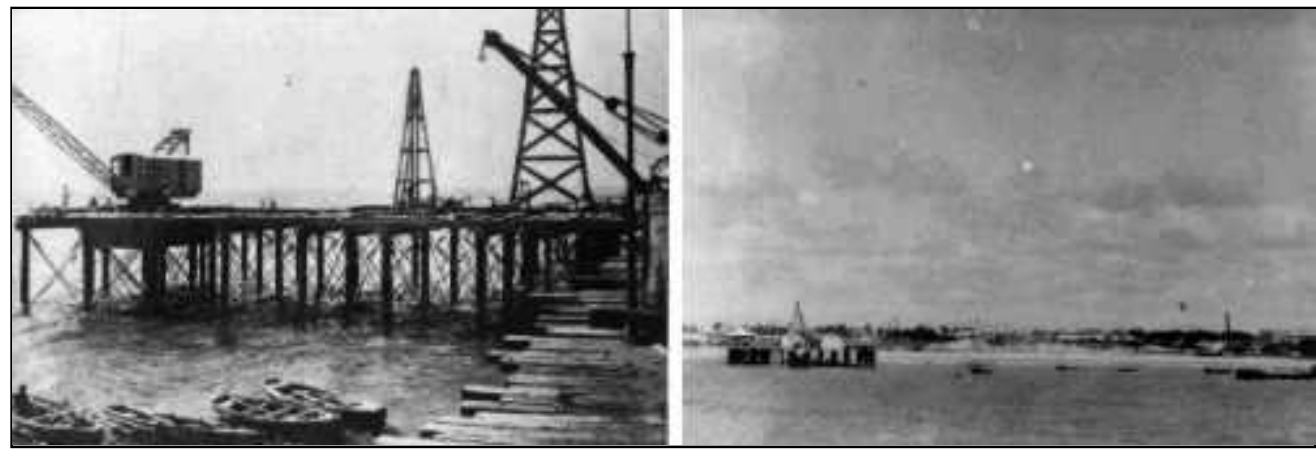

Fig. 2.6 A antiga Praia do Peixe, atual Praia de Iracema, na época da construção da Ponte Metálica - Foto tirada em meados da década de 1910 - Fonte: Arquivo Nirez

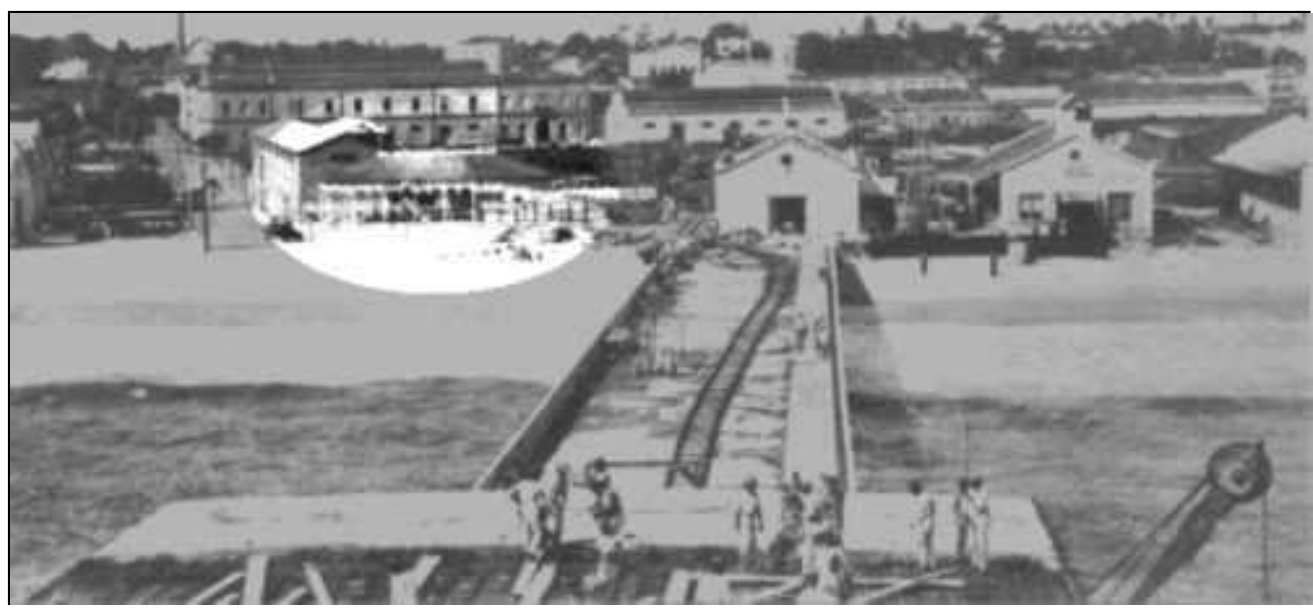

Fig. 2.7 Perfil portuário de Fortaleza no início da década de 1920. Vê-se o trilho de trem, os guindastes e os galpões de armazenagem - Fonte: Arquivo Nirez .
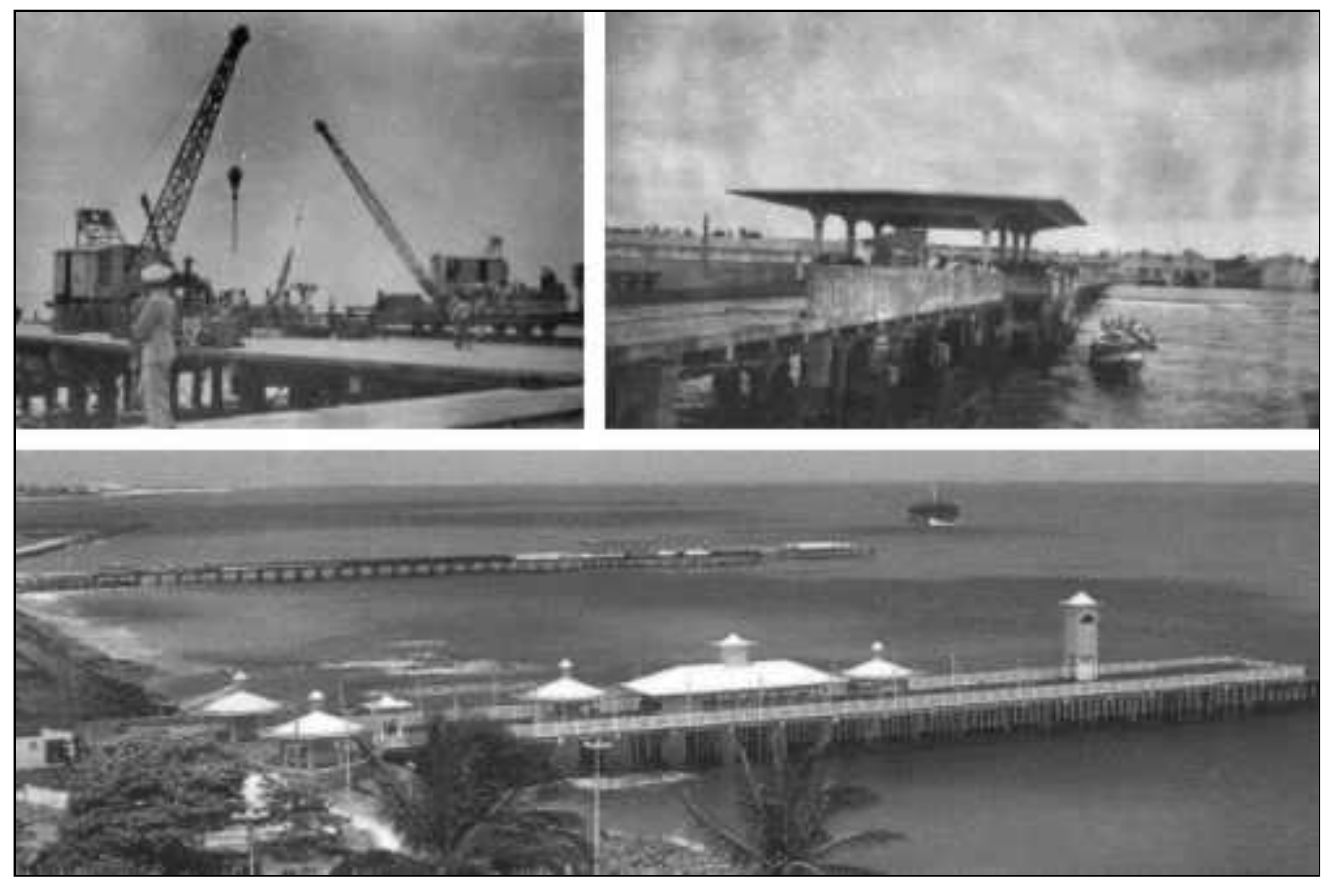

Fig. 2.8 As duas fotos acima mostram a construção e operação da segunda ponte em concreto, no final da década de 1920 e, abaixo, uma vista das duas pontes nos dias atuais, depois da requalificação da primeira ponte feita no início dos anos 1990. Fonte: www.skycrapercity.com 


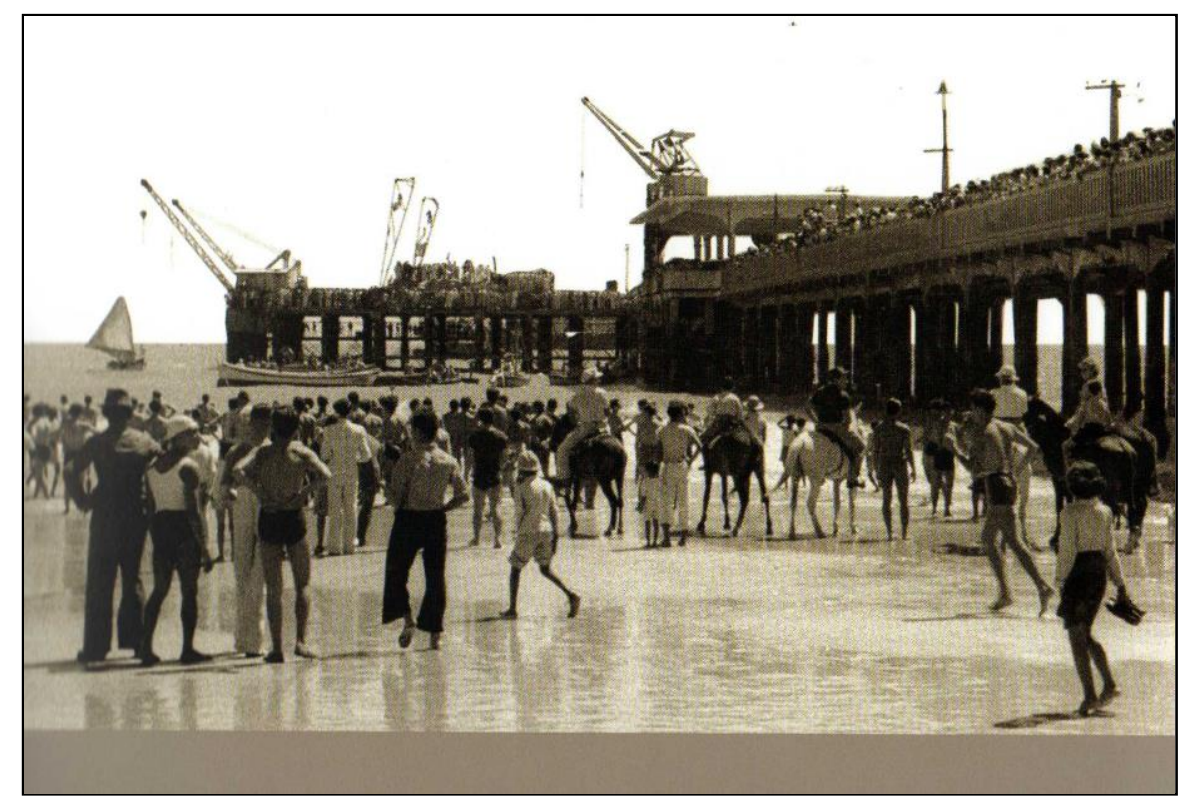

Fig. 2.9. A segunda ponte dos Ingleses reconstruída em concreto num dia festivo de 1946 - A coexistência entre o espaço recreativo e o espaço do porto. Fonte: Arquivo Nirez (apud Chaves et. al., 2006, p. 31).

Assim, a medida político-administrativa que elevou Fortaleza à capital possibilitou gradativamente a incorporação das regiões produtoras de algodão que gravitavam em torno de Sobral. A essa medida foi articulada uma segunda, de caráter tecnológico e complementar à primeira que determinou a construção do sistema ferroviário ligando Fortaleza ao sertão, propiciando a incorporação definitiva da zona produtora de algodão de todo o Estado. Como consequência, desestruturou a antiga lógica de comunicação, fundamentada nas vias de penetração natural (rios) e antigas estradas que impediam Fortaleza de exercer papel relevante no quadro socioespacial urbano do Ceará. Esta política produziu um importante fluxo demográfico do sertão para o litoral, fazendo com que Fortaleza passasse de uma população estimada em 3.000 habitantes em 1800, para 16.000 em 1863 e a 21.372, em 1872 (DANTAS, 2002, p. 29).

A linha férrea proporcionou o desenvolvimento por onde passava. Os antigos caminhos de origem colonial foram sendo substituídos pelos trilhos que se prestavam ao escoamento da produção do algodão e outros gêneros de exportação como o café da região de Baturité. Ao longo dos eixos de circulação de atividade primária se desenvolveram núcleos urbanos distintos, "criando uma dinâmica entre o espaço de produção (sertão) e o espaço de distribuição e consumo (mar), materializando um cenário no qual a capital assume o papel hegemônico” (PAIVA, 2005, p. 32). 
Abaixo, temos o mapa das vias férreas desenhadas segundo o período de sua instalação. Os dois trechos mais antigos: Fortaleza-Baturité-Capistrano e o de Sobral-Camocim que datam do final do século XIX, (entre os anos 1873-1890), estão em vermelho; os trechos entre Sobral-Ipu (Oeste) e o entre Capistrano-Sen. Pompeu (Sul) são de 1891 a 1900 (em azul) e os demais, em verde, são do período entre 1901-1940 que interligou os dois ramais, conectando Fortaleza a Sobral ao mesmo tempo em que estendeu o ramal de Baturité-Capistrano até ao Sul do Estado em direção a Juazeiro do Norte-Crato e o ramal de Sobral-Ipu, a Oeste, na direção de Crateús, chegando até a cidade de Castelo, no Piauí.

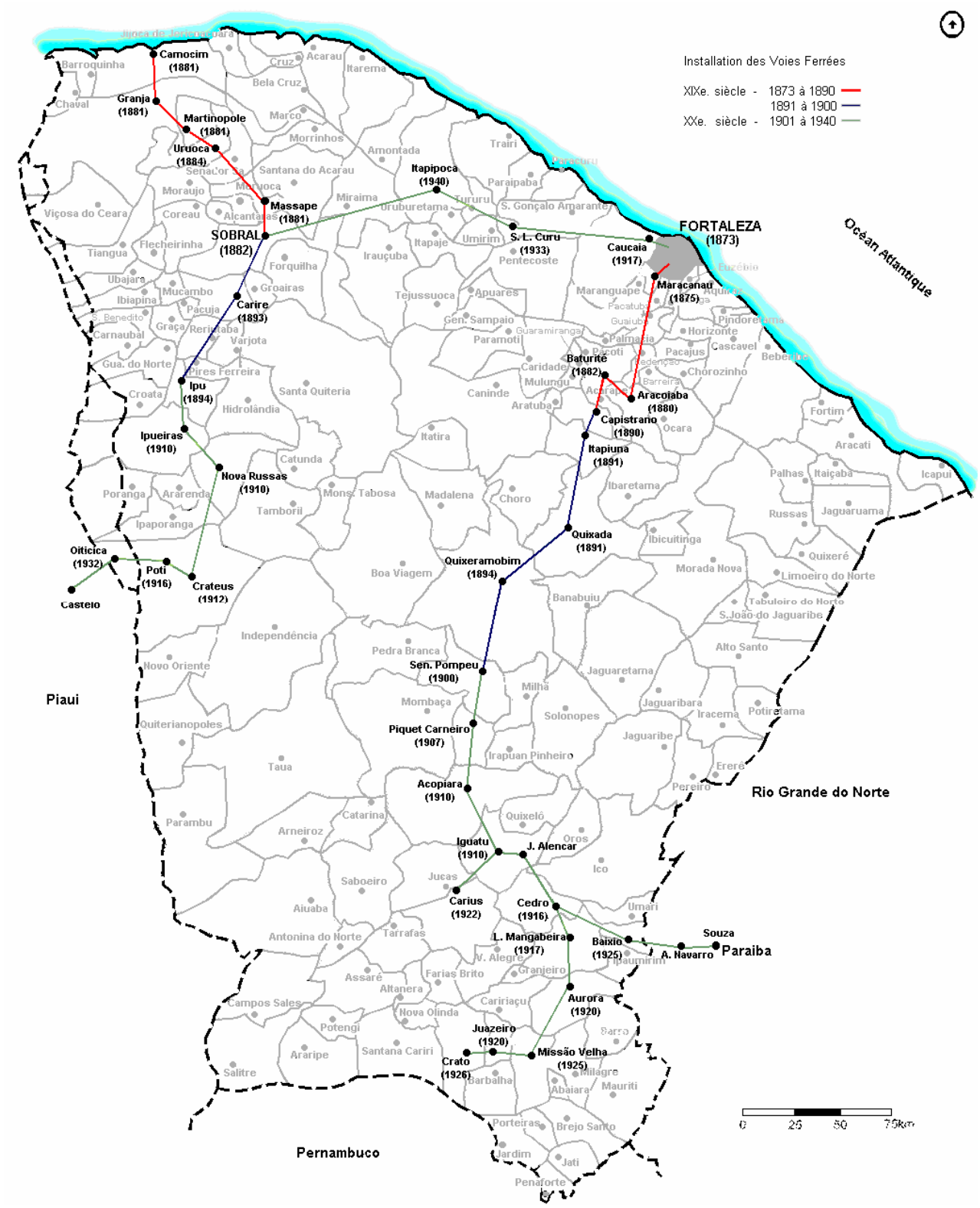

Fig. 2.10 Plano ferroviário cearense com as datas de implantação das estações - Fonte: Dantas, 2003. 
Interessante notar que os dois grandes eixos naturais de penetração colonial: os rios Jaguaribe e Acaraú, foram substituídos progressivamente pelas vias férreas que aos poucos vão submetendo a hegemonia exercida por Fortaleza e seu novo porto.

O comércio do algodão fez de Fortaleza uma cidade de maior porte, proporcionando meios para que ela associasse uma atividade econômica de peso à sua condição de capital administrativa, adquirindo expressão no cenário estadual e regional. Foi, portanto, a partir do algodão que Fortaleza se consolidou como centro urbano polarizador da economia de todo o Estado.

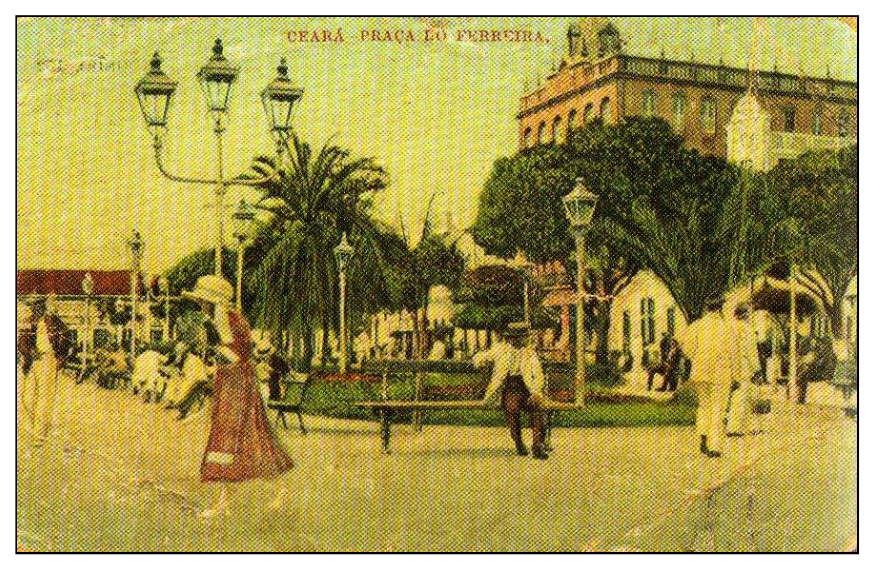

Fig. 2.11 Praça do Ferreira - 1911

Cartão Postal colorizado a mão

Fonte: Arquivo Nirez

(apud Chaves et al, 2006, p. 68).

Fig. 2.12 Cruzamento das Ruas Maj. Facundo e Guilherme Rocha, visto da Praça do Ferreira - 1911. Fonte: Arquivo Nirez (apud Chaves et al, 2006, p. 68).

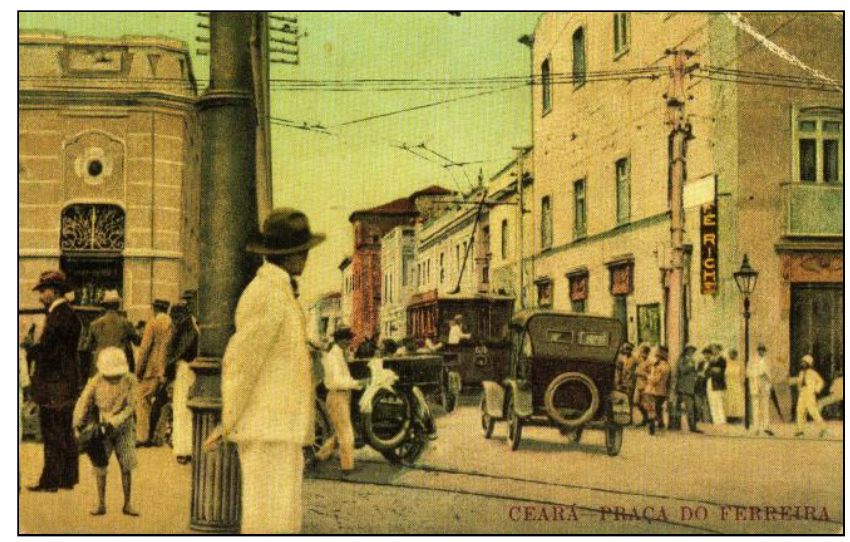

A Planta abaixo revela as reduzidas dimensões do tecido urbano efetivamente construído em Fortaleza no ano de 1875 (em hachura escura) que vai tomar um novo impulso proporcionado pelas novas funções administrativas e comerciais, orientadas pelo traçado urbanístico em xadrez, de Adolfo Herbster. Este articulava uma cinta de grandes boulevards a vias ortogonais projetadas para a nova cidade que emergia. 


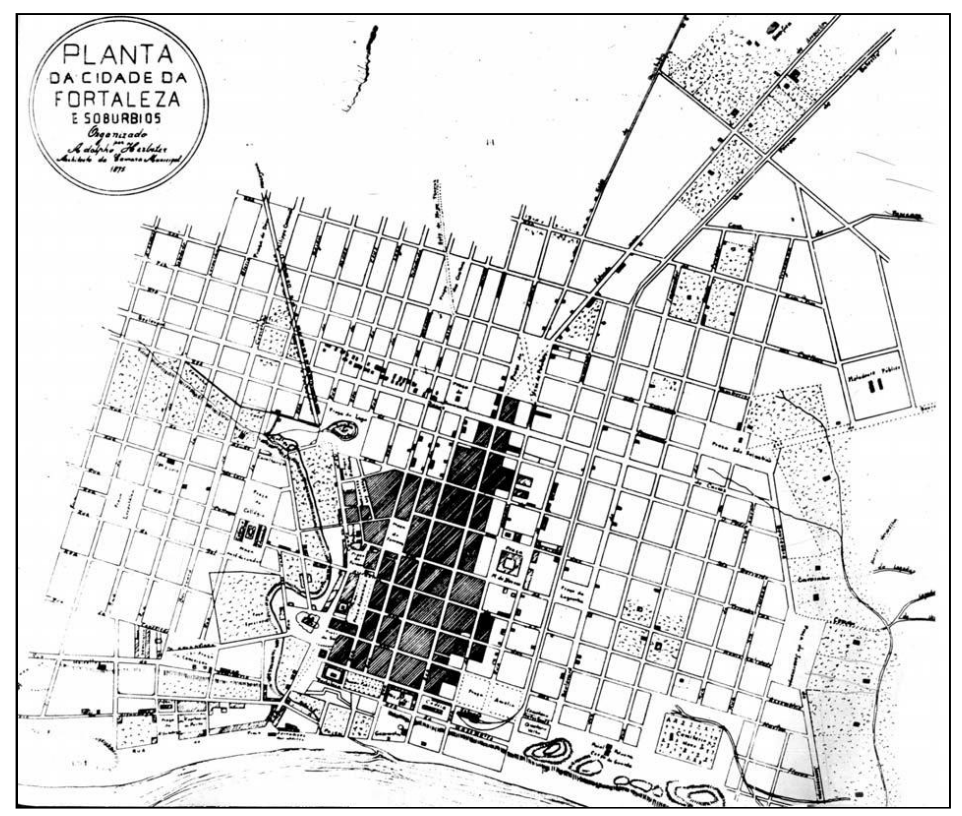

Fig. 2.13 Planta da Cidade da Fortaleza e Sobúrbios Adolfo Herbster -1875. Fonte: FORTALEZA -

De outro modo, o quadro natural da maior parte do litoral do Estado, no início do século $\mathrm{XX}$, possibilitava o estabelecimento de comunidades de pescadores que o caracterizava como território da pesca. O desenvolvimento da pesca consolidou uma relevante zona etnográfica que encontra suas raízes no Brasil colonial, constituindo o testemunho da continuidade da lógica de defesa adotada pelas forças armadas no passado, válida ainda no presente. Na literatura, o litoral aparece como uma zona livre dos tormentos da seca, do latifúndio e da miséria, na obra de Gustavo Barroso (1915), apresentando um quadro complexo em que consagra o mar e o pescador (CAMPOS coord. et.al. -2003, p. 145).

No período de transição para o século XX, o contato da elite fortalezense com a Europa, possibilitou a introdução de novas práticas marítimas que caracterizaram e despertaram o primeiro fenômeno de valorização das zonas de praia no Ceará. Podemos desdobrá-lo em dois movimentos: o da primeira metade do século XX, até a década de 1970, incorporou em escala local as zonas de praia próximas ao centro, inicialmente na Praia de Iracema, expandindo-se até o Meireles com a Beira-mar e posteriormente para toda a costa de Fortaleza. O segundo, numa escala mais ampla, após os anos 1970, representou a expansão dessas novas práticas marítimas, particularmente o veraneio, inicialmente para os municípios limítrofes da sua Região Metropolitana para em seguida se expandir ao longo de todo o litoral do Estado (DANTAS, 2002, p. 48). 


\subsubsection{As transformações urbanas na primeira metade do século XX}

Fortaleza cresceu em função das novas demandas por espaços litorâneos para responder às necessidades criadas pelo veraneio e lazer quando, ainda nos anos 1920, já se criava uma nova dinâmica que passou a inverter o sentido de sua tradicional urbanização perpendicular à linha de praia para outra, orientada paralelamente à linha da costa.

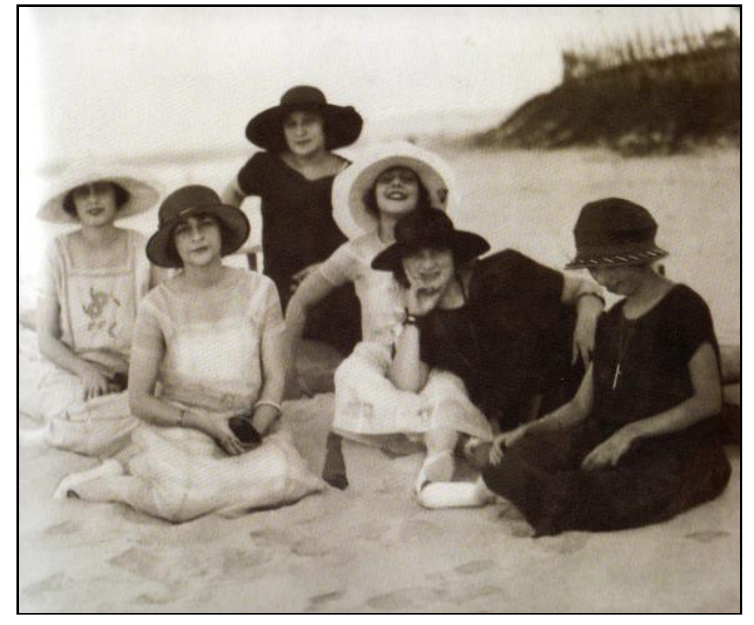

Fig. 2.14 A praia deixava de ser o lugar desprestigiado das atividades portuárias para se tornar o espaço de lazer em família como também de uso medicinal para tratamento de doenças respiratórias. Foto da década de 1920 - Fonte: Arquivo das famílias Fiúza e Moreira da Rocha (apud Chaves et al, 2006, p.79).

Fig. 2.15 Práticas esportivas e de lazer também se difundiram rapidamente junto com a ideia de espaço da saúde. Ao fundo o porto na Praia de Iracema Fonte: arquivo da família Caminha - Foto da década de 1920 (apud Chaves et al, 2006, p.78).

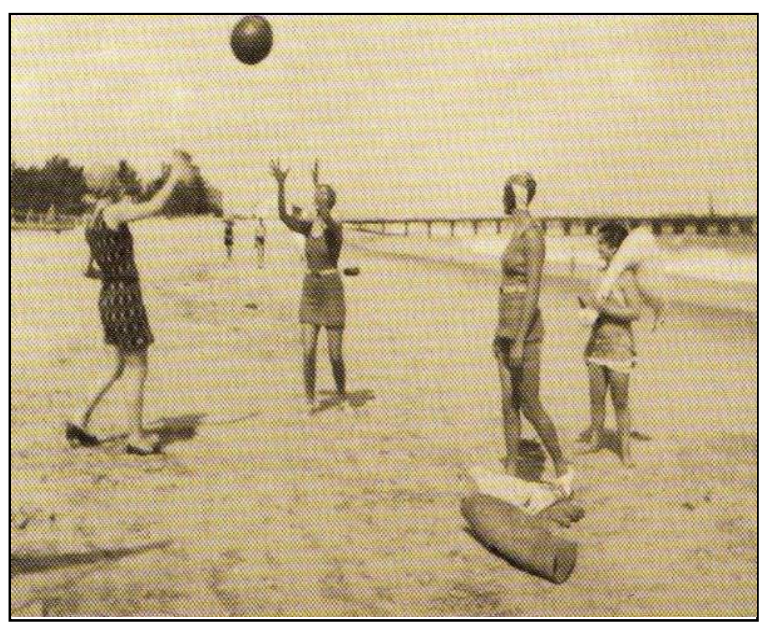

Esta tendência foi reforçada com a chegada da elite fortalezense, expulsando seus antigos habitantes e originando os primeiros conflitos nas zonas de praia, inicialmente na praia de Iracema, com um forte processo de especulação imobiliária que se estendeu até o Meireles.

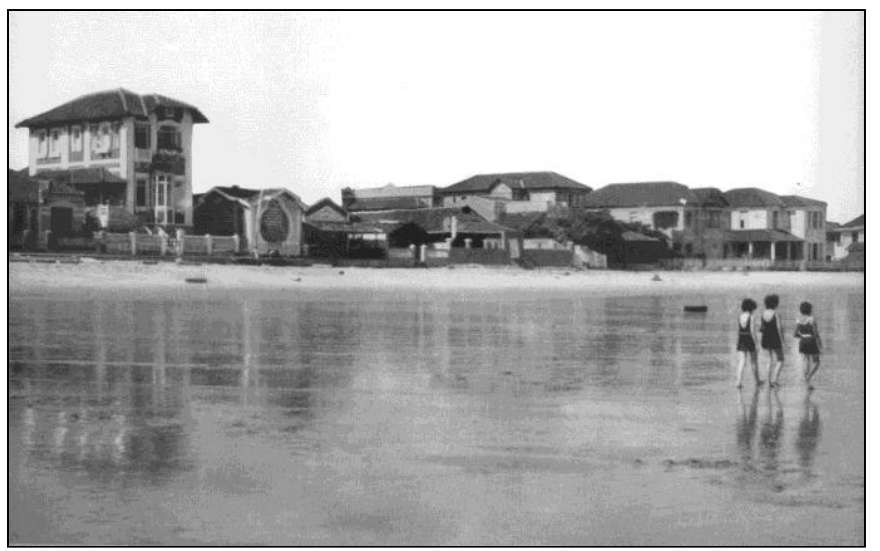

Fig. 2.16 A "nova" dinâmica imobiliária iniciada nos anos 1920, na Praia de Iracema, mostra o início da ocupação litorânea por casas de veraneio pela elite fortalezense - Fonte: Cartão Postal Loja Chrysanthemo - Arquivo Nirez. 
Este quadro ampliou-se com o crescimento da Cidade numa produção de espaços de habitação e lazer para as classes mais abastadas, cercados por outros territórios que se tornaram lugares em coexistência: o território dos pobres, da indústria naval e do porto. Esse crescimento foi ampliado pelas políticas públicas de industrialização dos anos 1950 e 1960, reforçando a imagem de Fortaleza como grande centro urbano. Esse processo encontrou-se nos anos 1970 com outro relacionado aos novos atores ligados ao veraneio, aos fluxos turísticos e ao lazer, apontando para um movimento mais amplo de valorização e contradição nas zonas de praia no restante do Estado que enfocaremos adiante (CAMPOS coord. et.al. - 2003, p. 145).

Esse movimento de coexistência entre os espaços de lazer à beira-mar e o território litorâneo do porto e dos pobres manteve-se relativamente estável até o início do século XX, quando em meados dos anos 1930, as contradições foram se agravando e tornando cada vez mais incompatível essa convivência. Consequentemente, levou à estagnação e desvalorização da primeira frente marítima urbanizada de Fortaleza, caso recorrente em cidades que tiveram a necessidade de deslocamento das atividades portuárias e ao mesmo tempo sofreram com os intensos impactos da migração campo-cidade alocadas justamente nas áreas portuárias deprimidas.

É importante ressaltar que também em Fortaleza, as razões dessas contradições fundamentaram-se, em última análise, nas características da produção do novo espaço capitalista cearense que iniciava a sua inserção numa nova fase de divisão internacional do trabalho (via exportação do Algodão). Outras razões aprofundaram essas contradições, como as verificadas nos conflitos entre a gestão do uso e ocupação do solo e a propriedade da terra, além das consequências do baixo padrão de reprodução da força de trabalho das diversas camadas sociais criando um espaço de permanentes tensões.

A década de 30 representa, portanto, um marco no processo de expansão urbana de Fortaleza quando a cidade atinge a ocupação total da área projetada por Adolfo Herbster em 1875, crescendo a partir dali de forma desordenada orientada pela ocupação espontânea das áreas ao longo das vias de comunicação com o interior. A situação se agrava também pelo aumento sem precedentes dos fluxos migratórios, principalmente a partir de 1932, ano de nova sequência de secas no Estado que se repetiu em 1942. 
Abaixo a Planta Cadastral elaborada no Governo de Raimundo Girão em 1933 mostra a tendência de expansão de Fortaleza na direção dos diversos eixos de penetração para o interior que formarão os demais bairros da cidade. É importante relembrar que até o final do Século XIX e início da década de 1920, Fortaleza se desenvolvia de costas para o mar, considerada uma zona desprestigiada por ser destino do despejo de dejetos e abrigar serviços pesados como as atividades portuárias e de infraestrutura como o gasômetro.

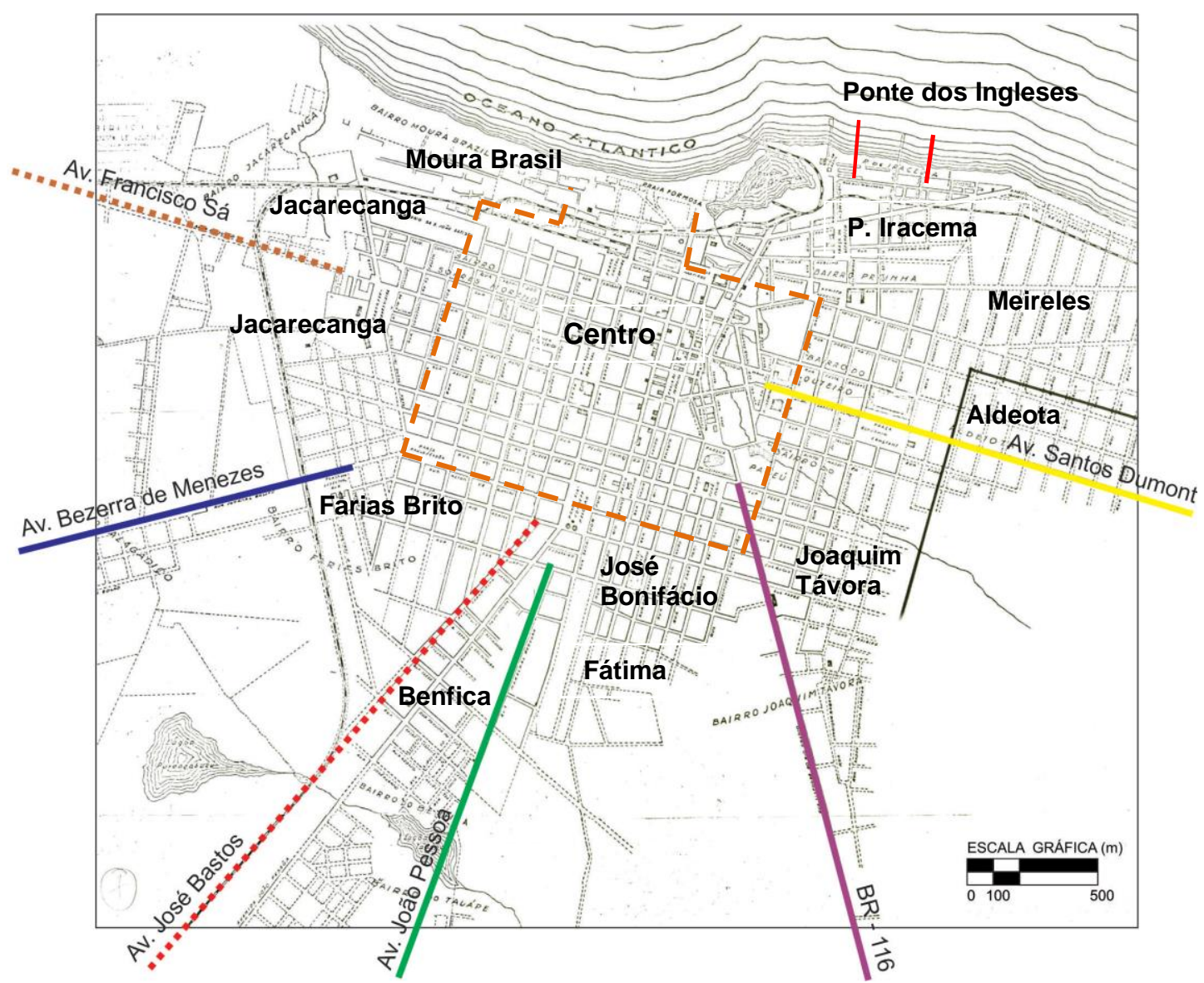

Fig. 2.17: Planta Cadastral de Fortaleza elaborada no governo de Raimundo Girão 1933. Fonte: CASTRO, 1977 (apud PAIVA, 2011, p.80) - Modificado pelo autor: ressaltamos os bairros que foram se formando a partir das vias de expansão (em colorido). Optou-se pela utilização da denominação atual dos bairros.

Além das contradições da produção do espaço capitalista da pequena cidade que se expandia a partir da sua inserção no mercado internacional de exportações, dois fatos se destacaram de modo mais agudo na dinâmica litorânea de Fortaleza, provocando profundas transformações que marcam a cidade até hoje. A chegada de seguidas levas de migrantes fugidos da precariedade da vida no campo, sobretudo, motivada pelas secas que assolaram o Estado desde 1877 se repetiram seguidamente nos anos de 1915, 1932 e 1942, transformando o litoral Oeste, nas sementes das primeiras favelas de Fortaleza. 
Nessa zona litorânea foram criados os "currais" humanos para conter o grande contingente de flagelados das secas de $1877^{7}$, e de $1915^{8}$. A esse contingente que se amontoavam em verdadeiros "campos de concentração" (RIOS, 2001), foi agregada nova leva de cearenses retirantes do Amazonas e do Acre, desempregados com o fim do ciclo da borracha, na década de 1920 (MATOS, 2009, p.170), engrossados pelo novo ciclo de secas: em 1932 e 1945, fixando-se, em boa parte, no Arraial Moura Brasil e no Pirambu, a Oeste do porto, formando um quadro de aguda pobreza verificada até hoje.

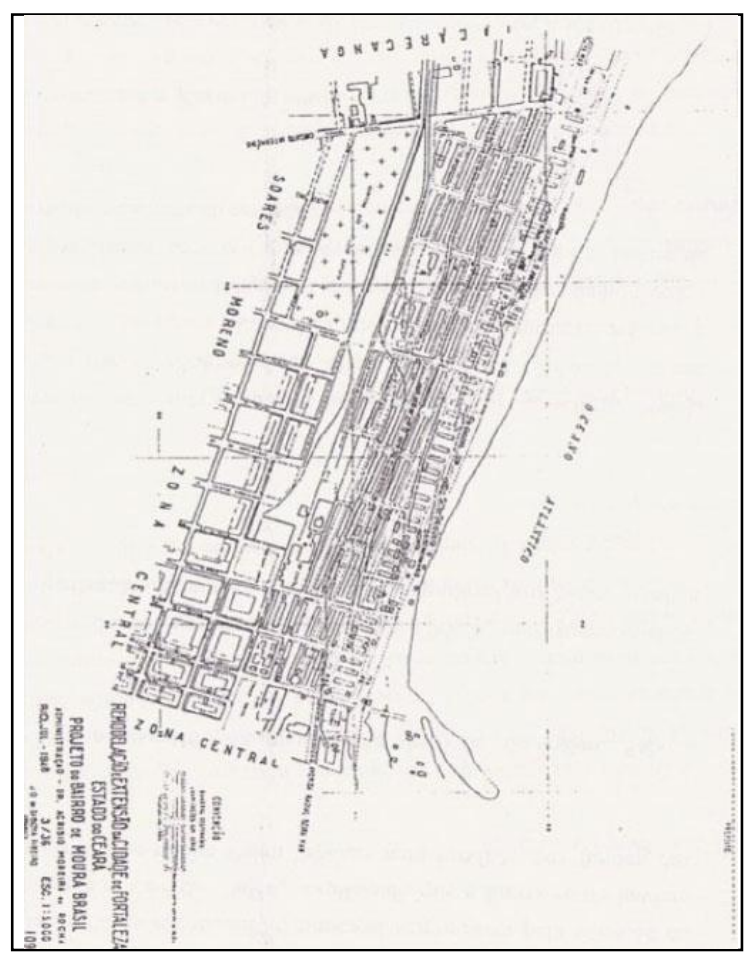

Fig. 2.18: Proposta para o Bairro Popular Moura Brasil, previsto no Plano de Remodelação e extensão de Saboya Ribeiro, para Fortaleza em 1947. Fonte: Ribeiro, 1947 (apud. MATOS, 2009, p.178-179).

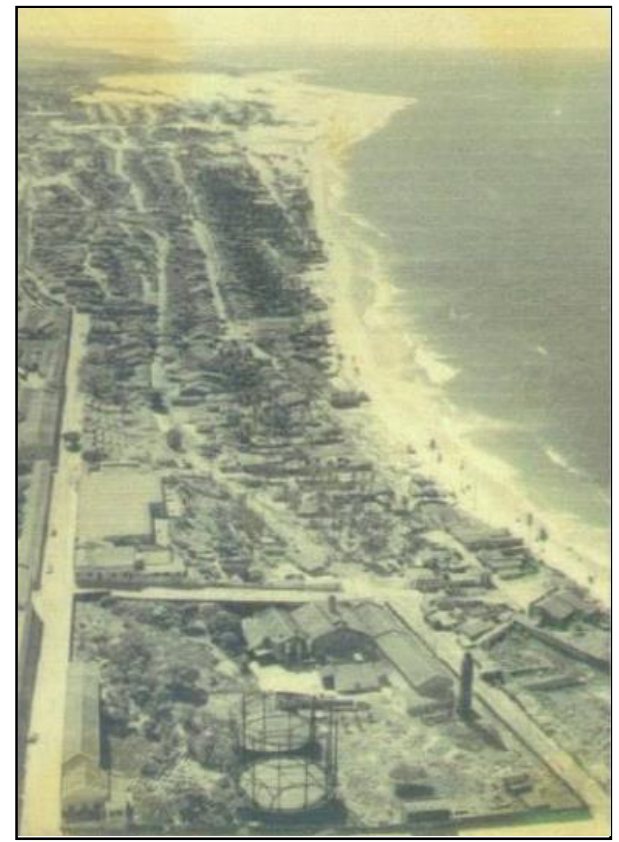

Fig. 2.19 Praia Formosa em 1940: O antigo gasômetro, em primeiro plano, o Arraial Moura Brasil, ao fundo: o espaço dos pobres, a Oeste do antigo porto. Fonte Arquivo Nirez

Somente nos anos 1930 e 1940, depois que a cidade supera os limites previstos por Herbert (1875), Fortaleza vai ser objeto da elaboração de diretrizes e intervenções urbanísticas em dois planos de ordenamento físico-territoriais: o "Plano de Remodelação e Extensão da Cidade de Fortaleza" de Nestor de Figueiredo, finalizado em 1933 e arquivado por não conseguir o apoio do Conselho Municipal e o "Plano

\footnotetext{
${ }^{7}$ Registrado na obra “A Fome” de Rodolfo Teófilo (2011).

${ }^{8}$ Desta vez registrado por Rachel de Queiroz (2004) na sua obra “O Quinze”.
} 
Diretor para Remodelação e Extensão da Cidade de Fortaleza" de autoria do engenheiro e urbanista Saboya Ribeiro, elaborado em 1947. Este, apesar de ter sido aprovado pelo conselho municipal não foi posto em prática devido a forte pressão dos proprietários da terra que se sentiam prejudicados pelas medidas de alargamento de vias e desapropriações de terrenos (FERNANDES, 2004, p32).

O Plano de Saboya Ribeiro é interessante para a nossa análise porque apresentava entre outras virtudes a necessidade de intervenções de melhorias das condições urbanísticas do litoral de Fortaleza, implantando várias áreas livres de uso público como o Parque da Barra do Ceará e o Parque Beira-Mar, com diversas funções recreativas. O fato de não ter sido implantado, apesar de aprovado pelo município, revela o poder dos proprietários de terra na defesa de seus interesses particulares sobre os da coletividade.

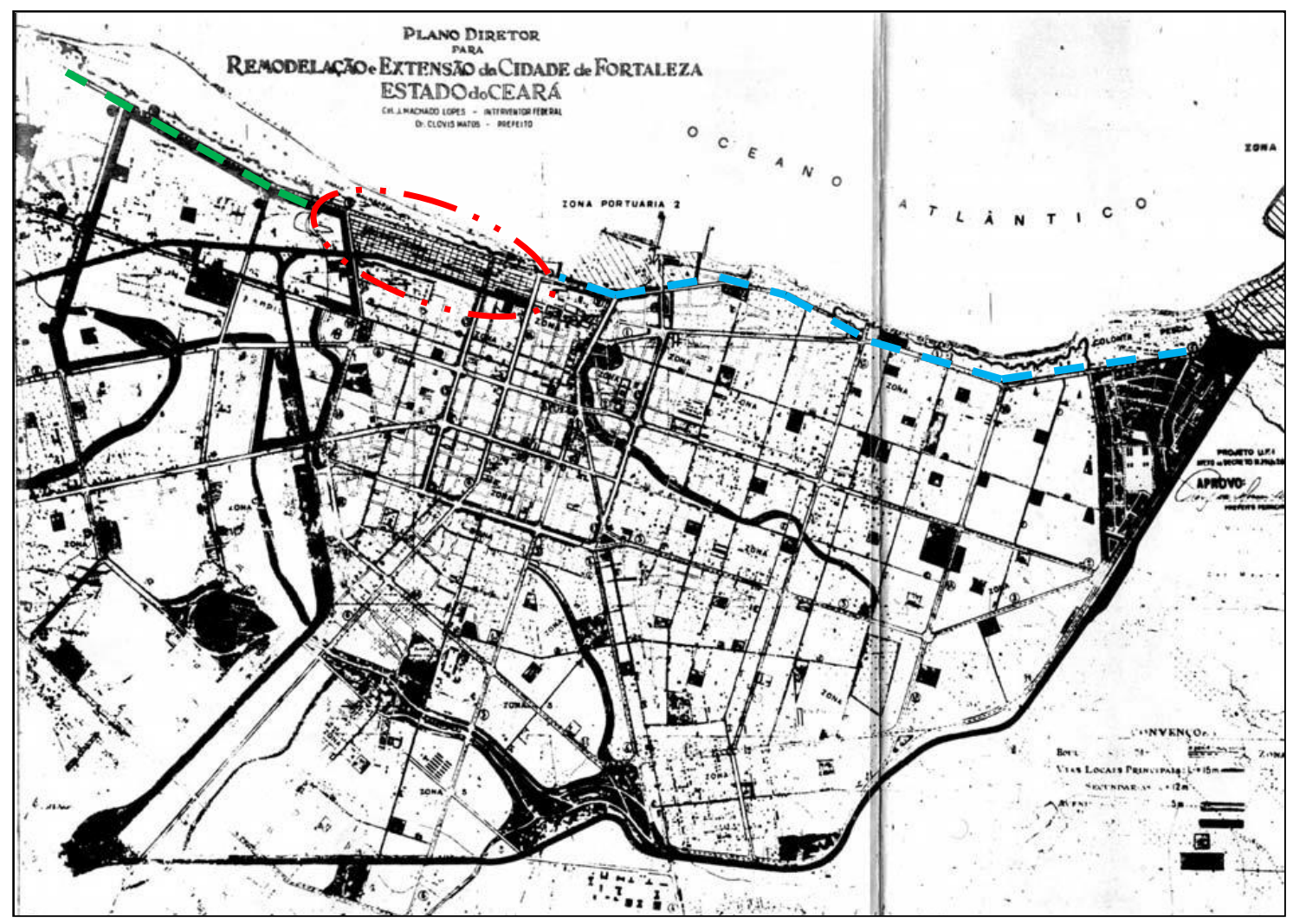

Fig. 2.20 Planta do Sistema Viário com indicações do circuito de avenidas do Plano Diretor para Remodelação e Extensão da Cidade de Fortaleza elaborado por Saboya Ribeiro em 1947. Ver o detalhe (em vermelho) que mostra a proposta do novo bairro para o Moura Brasil e as vias litorâneas do projeto Parque Beira-mar (em azul) e do Parque da Barra do Ceará, (em verde).

Fonte: FORTALEZA - CODEF/PMF, 1979.

As proposições de Saboya Ribeiro referem-se às concepções urbanísticas difundidas à época, concebendo uma estrutura que pretende reforçar a condição radial-perimetral do 
desenho da cidade, conciliando o traçado em xadrez como a abertura de vias diagonais para permitir a disposição harmoniosa dos bairros e, nestes, dos equipamentos urbanos. Priorizava a hierarquia entre o centro principal e os diversos subcentros de que cada bairro disporia, ressaltando também a universalização dos transportes motorizados, (particulares e coletivos), além de projetar a admissão de uma população máxima a ser habitada na área urbanizada prevista (FERNANDES, 2005, p. 36).

Além do problema com a migração e da falta de planejamento da cidade, o segundo grande fator relacionado às intensas transformações socioespaciais no litoral de Fortaleza nos anos 1930-1940 é, sem dúvida, a construção do novo porto, no Mucuripe, aprovada em $1938^{9}$. Sua construção trouxe várias implicações ao perfil litorâneo de Fortaleza, a começar pela extensão da projeção urbana da cidade até a ponta do Mucuripe que naquele momento correspondia aos limites do território dos pescadores, praticamente fora do contexto diário da cidade, mas a ela vinculada. Aos poucos, o processo de implantação do porto foi aproximando esses dois territórios separados por extenso areal, interligados pela linha de trem da RVC - Rede Viação Cearense.

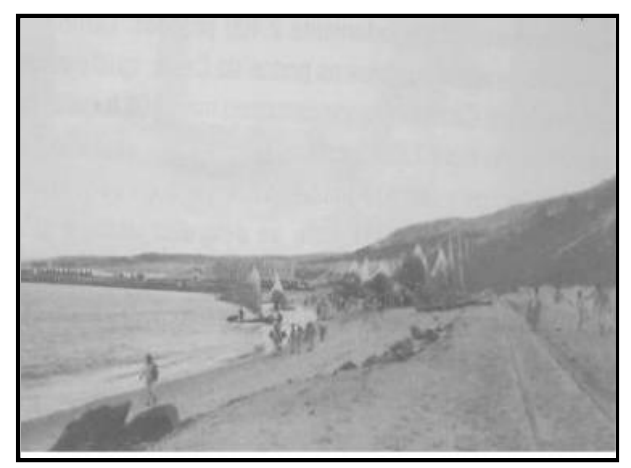

Fig. 2.21 Os jangadeiros do Mucuripe e a construção dos trilhos de trem da RVC (no canto inferior direito) que deu suporte à construção do porto. Fonte: ESPÍNOLA, 2007, p. 81.
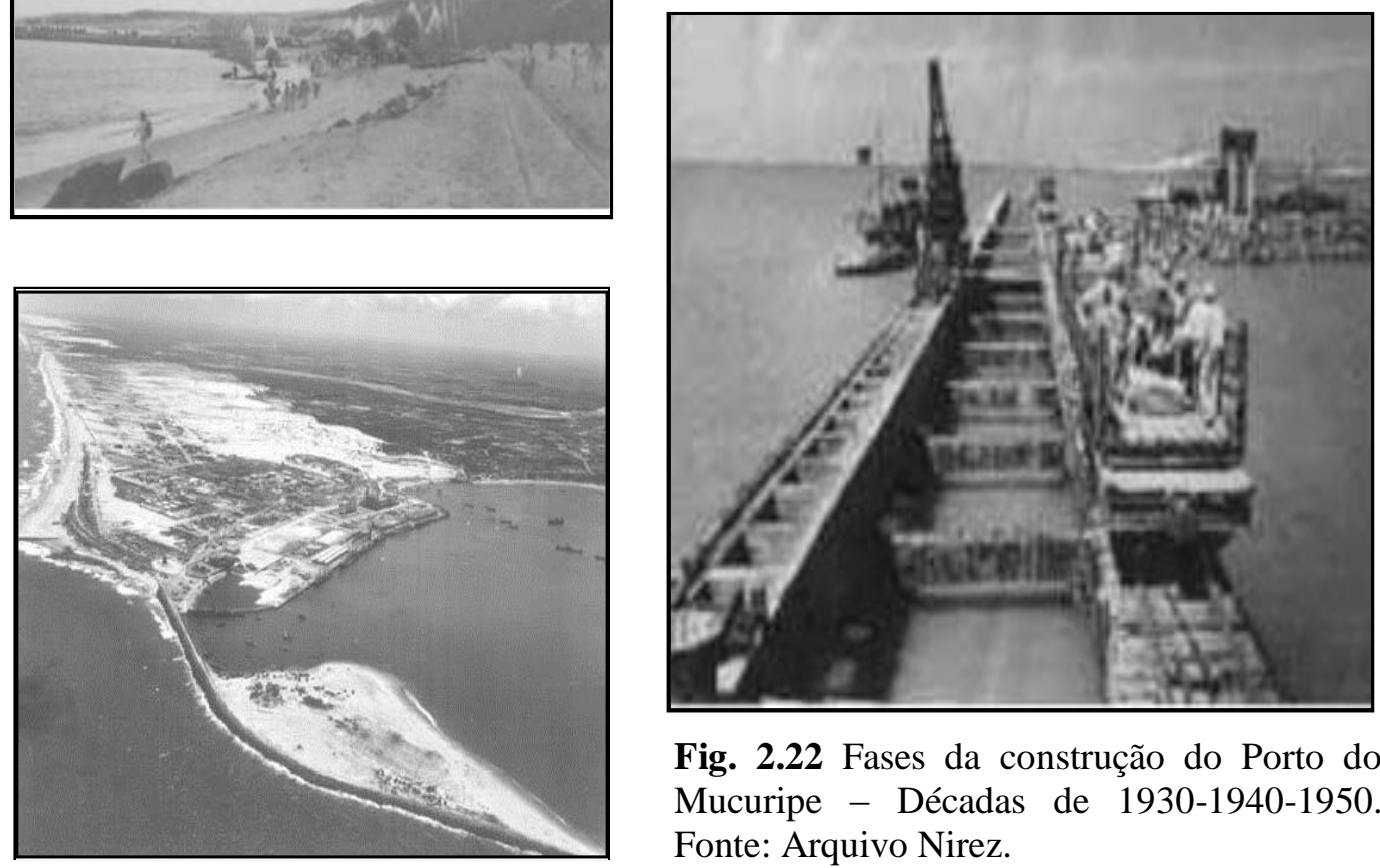

Fig. 2.22 Fases da construção do Porto do Mucuripe - Décadas de 1930-1940-1950. Fonte: Arquivo Nirez.

\footnotetext{
${ }^{9}$ Confiada à Companhia Nacional de Construções Civis e Hidráulicas (Cilvilhidro), sediada no Rio de Janeiro, (RODRIGUES \& SOUSA FILHO, 2007, p. 48). Suas obras levaram mais de doze anos para serem concluídas (MATOS, 2009, p. 175).
} 
A construção do porto não só apontou para uma nova delimitação do perfil urbano da cidade, mas alterou profundamente a dinâmica costeira, no que diz respeito ao transporte de sedimentos marinhos, causando erosões em boa parte da costa a jusante do porto, atingindo também os Municípios litorâneos vizinhos da sua RM. Entretanto, atinge de modo mais visível a Praia de Iracema, já urbanizada, tragando quarteirões inteiros, trazendo preocupações para as autoridades responsáveis que buscaram medidas de contenção da erosão com a construção de quebra-mares em vários pontos da cidade.

Fig. 2.23 Os efeitos da erosão marinha associada à desativação do antigo porto iniciaram na Praia de Iracema um processo de perda do seu dinamismo recreativo, como também da sua função econômica, entrando numa progressiva fase de estagnação do seu comércio, intensificado com o deslocamento dos armazéns e depósitos para o Mucuripe.

O movimento de banhistas, clubes e restaurantes em busca de novas praias a Leste, trouxeram uma maior visibilidade ao processo de diferenciação e segregação espacial, demarcando nitidamente a praia dos ricos (a Leste) e a dos pobres (a Oeste). Fotografia - década de 1940. Fonte: Arquivo Nirez.
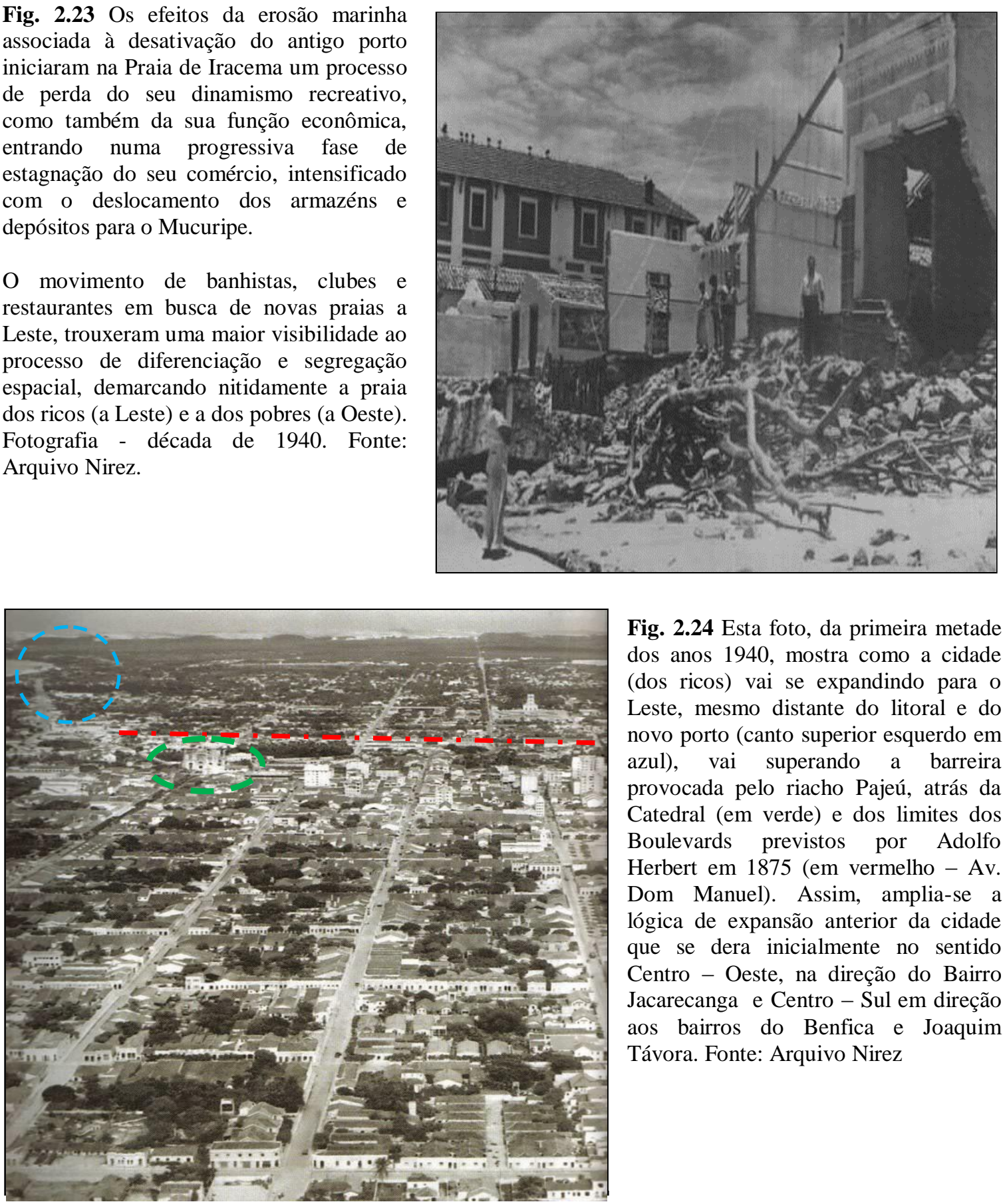

Fig. 2.24 Esta foto, da primeira metade dos anos 1940, mostra como a cidade (dos ricos) vai se expandindo para o Leste, mesmo distante do litoral e do novo porto (canto superior esquerdo em azul), vai superando a barreira provocada pelo riacho Pajeú, atrás da Catedral (em verde) e dos limites dos Boulevards previstos por Adolfo Herbert em 1875 (em vermelho - Av. Dom Manuel). Assim, amplia-se a lógica de expansão anterior da cidade que se dera inicialmente no sentido Centro - Oeste, na direção do Bairro Jacarecanga e Centro - Sul em direção aos bairros do Benfica e Joaquim Távora. Fonte: Arquivo Nirez 


\subsubsection{As transformações urbanas na segunda metade do século XX.}

O quadro de ocupação dos espaços litorâneos após a década de 1940 amplia-se com o crescimento de Fortaleza, embalado pelas consequências de ordem econômica e demográfica, decorrentes do estabelecimento de organismos públicos, no final dos anos 1950. Na década seguinte, as indústrias implantadas pela política de industrialização da SUDENE reforçaram o papel da capital como grande centro urbano, provocando um aumento de sua população urbanizada em relação ao Estado (DANTAS, 2002, p.55).

Durante esse período a Câmara Municipal aprova em 1963 o "Plano Diretor da Cidade de Fortaleza" elaborado pelo urbanista Hélio Modesto que se depara com uma série de problemas urbanos já detectados no plano de Saboya Ribeiro (1947) cujo agravamento, em grande parte, foi motivado pela não aplicação das intervenções propostas pelo seu antecessor.

Embora o urbanista vá defender com insistência as soluções propostas no plano anterior, sua perspectiva se diferencia pelo fato da cidade apresentar sua estrutura mais cosolidada, como também seus problemas e insuficiências urbanas. Assim, não foi possível, nesse caso, delinear proposições urbanísticas de porte que afetassem a estrutura da cidade como um todo. Deteve-se, no entanto, ao enfrentamento da realidade urbana baseado em estudos econômicos e sociais mais apurados, revelando o desejo de que o plano contemplasse diretrizes urbanísticas que minimizassem a condição de segregação social que marcava o desenvolvimento de Fortaleza. (FERNANDES, 2004, p.61).

Esse plano, no entanto, vai orientar o crescimento da cidade para o litoral com a construção da Avenida Beira-Mar em 1963 que impõe a integração das zonas de praia à cidade, na forma de equipamento público de lazer como também enquanto lugar de habitação das camadas sociais mais elevadas. Desse modo, indica o expressivo processo de urbanização paralela à linha da costa, incorporando-se a outros movimentos já consolidados de expansão urbana, fundamentada na valorização do litoral. Progressivamente, vai se transformando de praia ocupada quase que privativamente por veranistas, para o lugar de encontro da sociedade e da habitação das camadas de alta renda, ocupando a antiga função da Praia de Iracema enquanto espaço recreativo, 
atraindo o estabelecimento de clubes, residências, prédios comerciais e de serviços diversos.

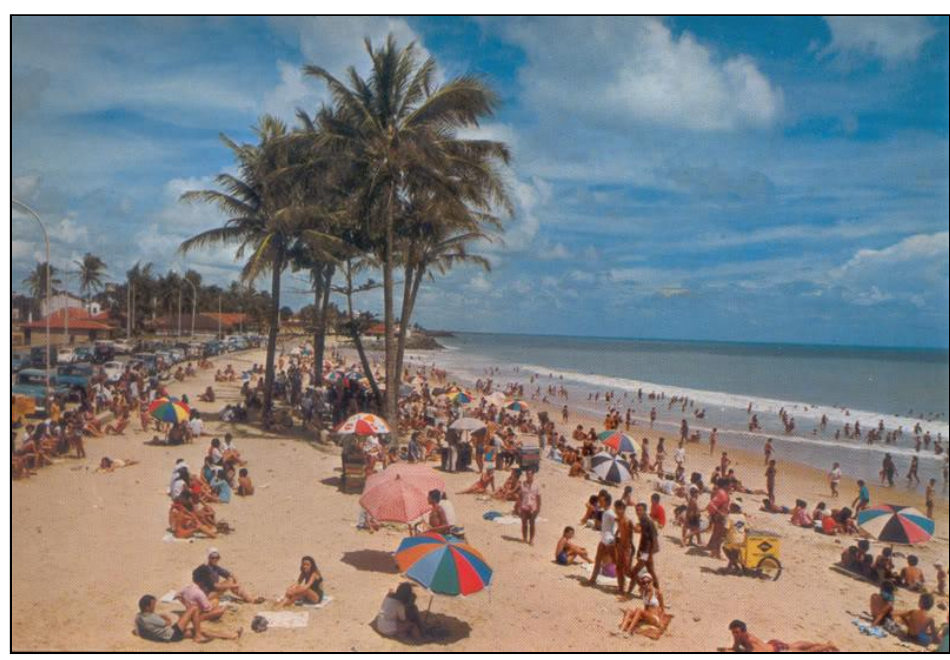

Fig. 2.25 Cartão postal da praia dos Diários: início da Av. Beira-mar Meados dos anos 60. Notam-se as residências de veraneio, à esquerda e o público de veranistas junto ao grande público do lazer local. Fonte: Skyscrapercity.com (http://www.skyscrapercity.com/sh owthread.php?t=1015635)

$(26 / 05 / 12)$

No entanto, essas mudanças e especialização funcional não inviabilizaram todos os seus antigos usos, fazendo com que os pescadores permanecessem lá construindo a sua sede da colônia de pesca, na ponta do Mucuripe. Assim, consolidam-se o porto das jangadas e o mercado do peixe, embora as residências dos pescadores tenham dado lugar aos inúmeros edifícios residenciais, hotéis e restaurantes que compõem sua paisagem atual, juntando-se a outros atores ligados ao lazer e ao turismo.

Fig. 2.26 Cartão postal datado de 1976, mostrando a coexistência dos antigos e os novos usos, na Ponta do Mucuripe. Fonte: Edicard. in skyscrapercity.com. http://www.skyscrapercity.com/s howthread.php?t=1015635 (26/5/2012)

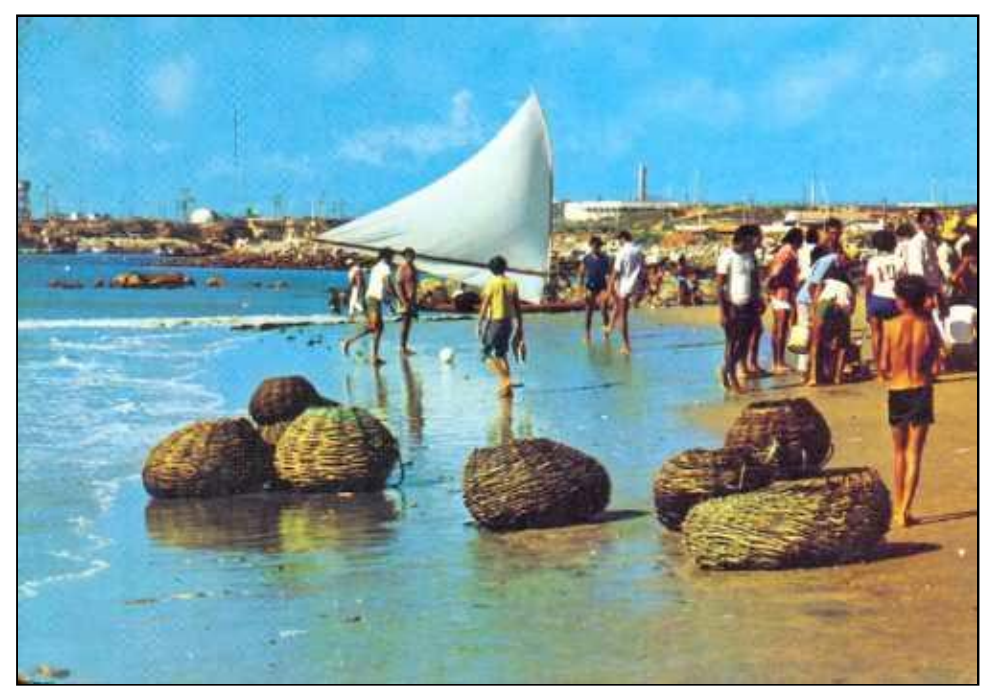

Essa tendência à valorização do novo litoral vai colaborar com as condições materiais para a construção de uma nova policentralidade em Fortaleza que se afirma nos anos 1970, 
induzindo a implantação de infraestrutura de comércio e serviços nos bairros nobres e seu comércio de luxo, na zona Leste da cidade (SOUZA, 1978).

A fuga da elite do Centro para a Aldeota reforçava a ocupação litorânea para o Leste nas praias do Bairro do Meireles que teve sua expansão contida pela localização do porto do Mucuripe, constituindo um quadro socioespacial característico de Fortaleza.

A ligação do porto já no Mucuripe, com a cidade, criou, sem dúvida, contradição insuperável no zoneamento atual que a cidade realizava, tumultuando a ordem histórica com que tinham sido dispostas as funções urbanas; indústria-a oeste, comércio - no centro, e residências abastadas a Leste, porque se localizou mais a Leste ainda o porto (CASTRO, 1977, p.37).

Por consequência, ao redor do porto foram abrigar-se também novos contingentes de população empobrecida, seguidamente expulsa do litoral, desta vez, por ocasião da construção da Beira-Mar, provocando inúmeras remoções de famílias. Algumas foram ocupar os espaços desprestigiados ao lado do porto, próxima a segunda "zona de baixomeretrício" e outras, transferidas para os grandes conjuntos habitacionais da década de 1970 como o Conjunto Palmeiras, no distrito de Messejana e o Marechal Rondon no Município de Caucaia.

A cidade, portanto, tendia a uma divisão Leste - Oeste, onde a primeira caracterizava-se como a "zona nobre" na qual foram se estabelecendo cada vez mais as atividades comerciais e administrativas e a segunda reforçava-se como o lugar da habitação das camadas mais pobres. Nesse caso, estabelecendo-se nas imediações das indústrias implantadas nos anos 1950 e 1960 ao longo da Av. Francisco Sá e da estrada de ferro, permanecendo dependente das funções comerciais do Centro.

Embora essa polarização Leste-Oeste possa ser vista como um movimento hegemônico de estruturação da cidade, não podemos esquecer da dinâmica de ocupação direcionada ao sul de Fortaleza, constituída pela construção dos grandes conjuntos habitacionais das décadas de 1970 e 1980, como também da contínua ocupação da zona de praia atingindo os municípios da sua RM, como Caucaia, no litoral Oeste de Fortaleza e Aquiraz, no sentido oposto, a Leste da capital. 


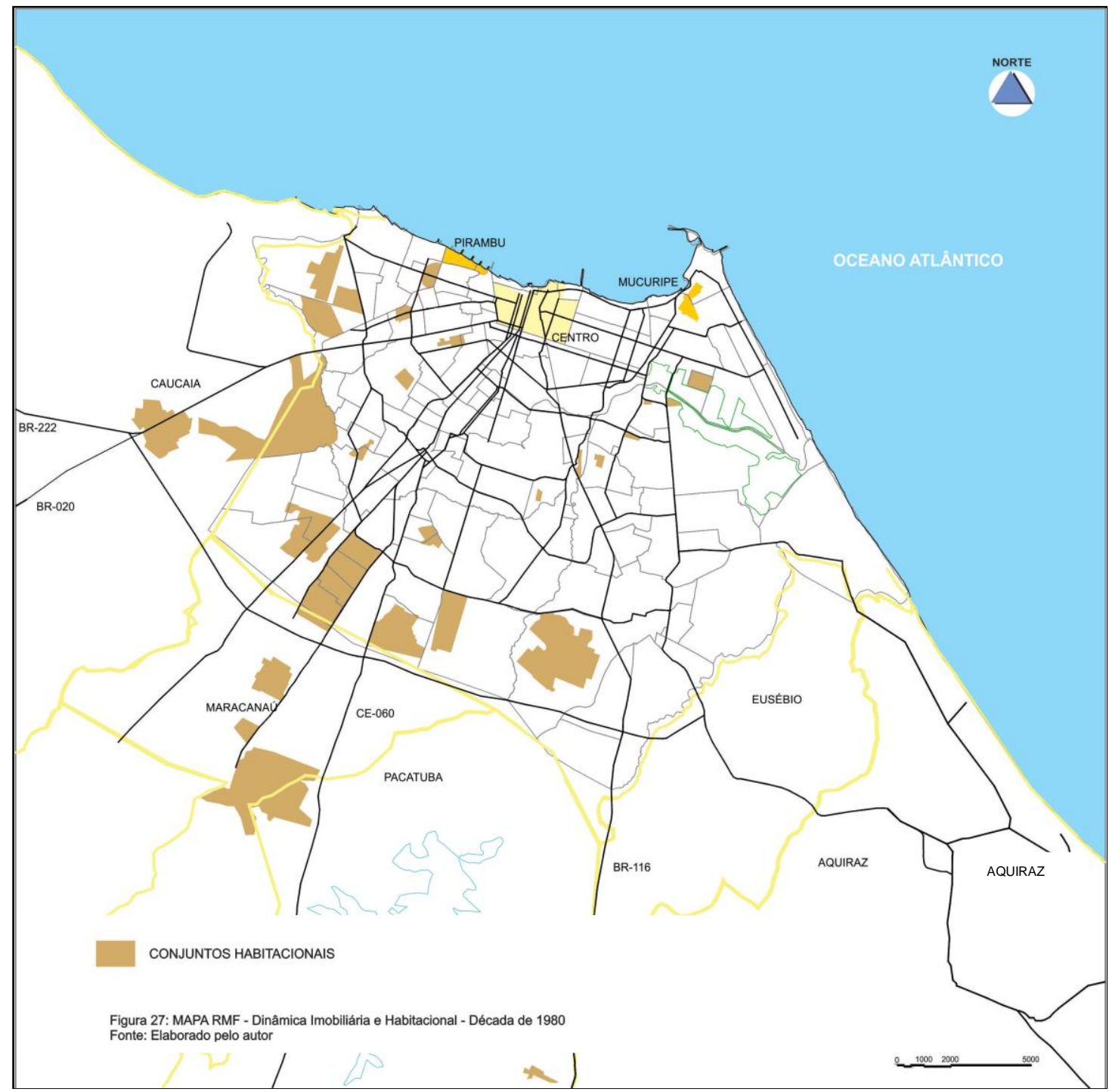

Fig. 2.27 Mapa RMF - Dinâmica Imobiliária dos Conjuntos Habitacionais - Décadas de 1970 - 1980 Fonte: Paiva (2011, p.104)

Esta caracterização traz consequências para o centro que tem a sua centralidade redefinida em virtude da criação dos conjuntos habitacionais na periferia da cidade e de novos centros de bairros, transformando o Centro tradicional em Centro da periferia, conforme Silva (1992).

Assim, reforça-se o papel do Centro como lugar do consumo em oposição ao antigo papel de lugar do encontro e do lazer das camadas sociais mais ricas, iniciando uma progressiva especialização funcional de suas ruas e praças, transformando-se em local de circulação para o comércio, reduzindo progressivamente seus espaços para o lazer. Assim, esta redução se impõe como um dos elementos que vão transformar o litoral em espaços para o lazer, reforçando a construção da cidade poli Centrica (DANTAS, 2002, p. 56). 
Assim, a ocupação da zona Leste evidencia novos aspectos diferenciados: o deslocamento das funções de habitação, poder público, comércio e serviços para a Aldeota, reforça também o deslocamento das demandas de lazer e habitação para a praia do Meireles, onde a construção da Av. Beira-mar e seus calçadões vão ocupando progressivamente o lugar de espaço recreativo deixado pela Praia de Iracema, no efêmero período entre os anos 1920 1930.

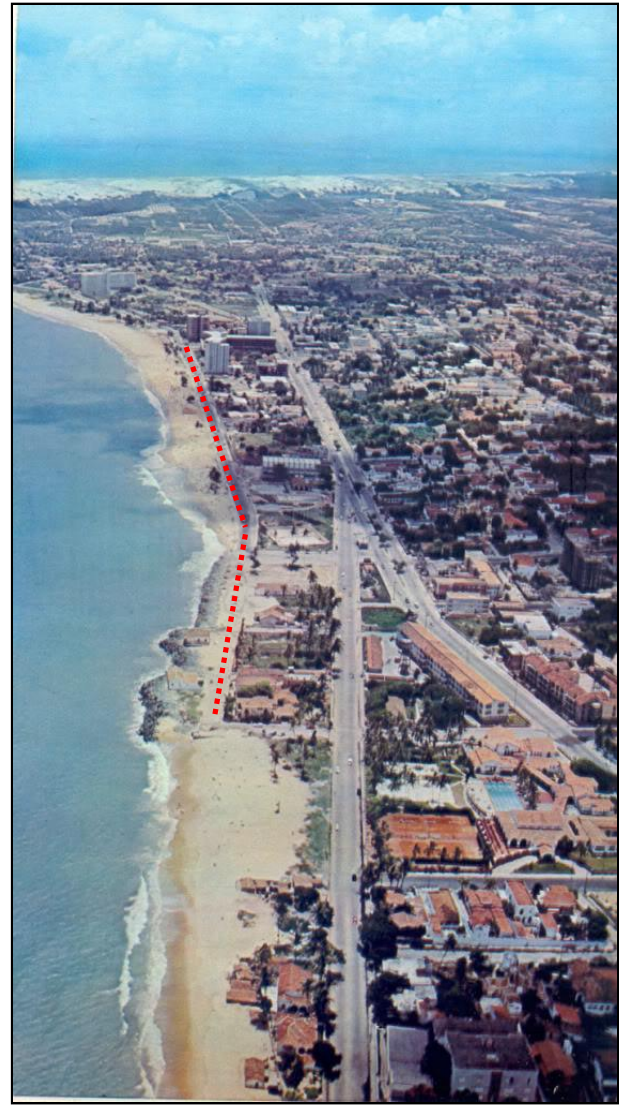

Fig. 2.28 A construção da Av. Beira-Mar (em vermelho) foi iniciada em 1960 e inaugurada em 1963. Nesta foto de 1972, vê-se a ausência da verticalização intensificada depois dos anos 1980.

Fonte: Ed. Especial Manchete - Brazil 72 in Skyscrapercity.com (26/05/2012).
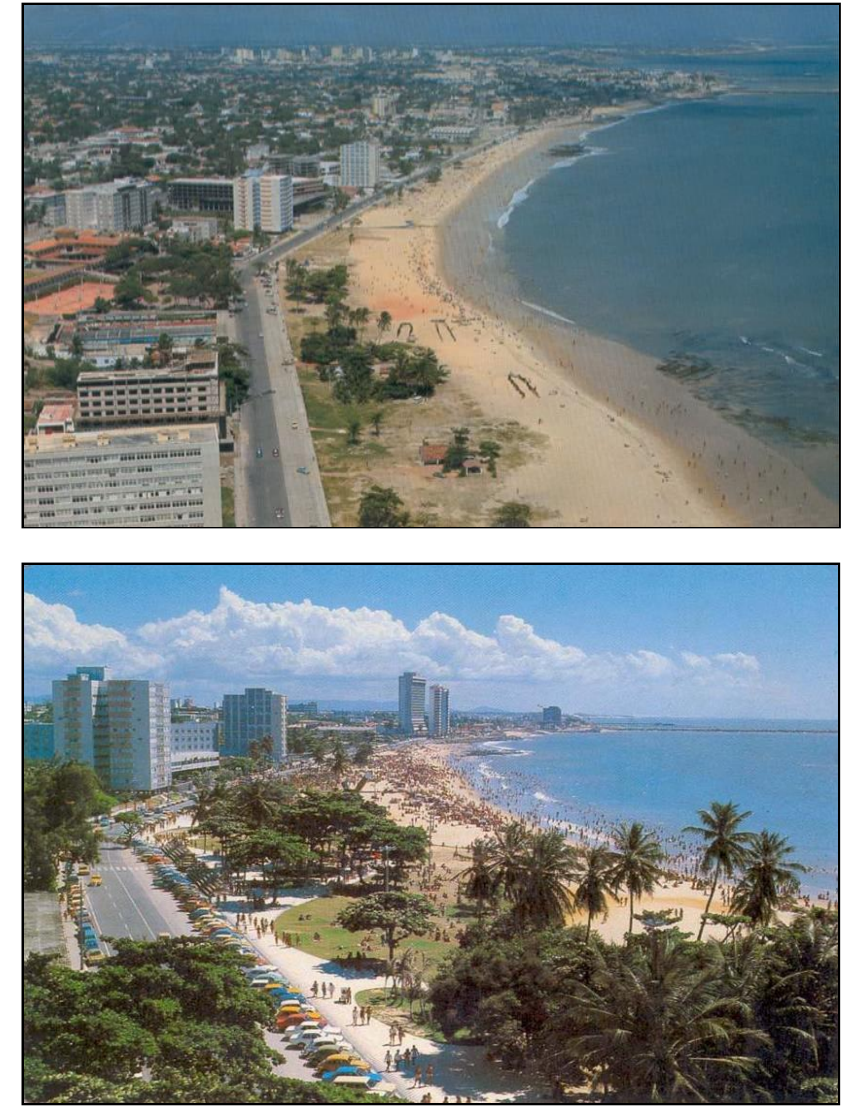

Fig. 2.29 Duas fases do mesmo trecho da Av. Beira-Mar: Acima o calçadão dos anos 1970 e abaixo já redesenhado no projeto dos anos 1980.

Fonte: Skyscrapercity.com.

http://www.skyscrapercity.com/showthread.php?t=10156 35. $(26 / 05 / 2012)$

Assim, a partir dos anos 1970, as políticas públicas em parceria com a iniciativa privada produziram uma cidade litorânea capaz de responder à demanda crescente por lugares de lazer e turismo. Esta valorização dos espaços litorâneos teve no veraneio a sua maior força motriz, ultrapassando os limites de Fortaleza e provocando um movimento de incorporação de cidades, vilas e vilarejos litorâneos à zona de influência da Capital. Este movimento foi viabilizado pelas mudanças tecnológicas ligadas ao transporte, comunicações e energia 
elétrica, condicionantes para a intensificação dos deslocamentos com o automóvel e a viabilização das facilidades proporcionadas pelos equipamentos eletroeletrônicos, ampliando o espaço de consumo.

Os veranistas, oriundos das classes alta e média ascendente nos anos 1970, insatisfeitos com as condições das praias em Fortaleza: congestionadas e poluídas, construíram residências secundárias nas praias de municípios vizinhos, inicialmente em Caucaia (Icaraí e Cumbuco) e Aquiraz (Iguape e Prainha). Esta prática está respaldada a partir da modificação da estrutura de propriedade da terra permitindo inclusive o financiamento pelos programas habitacionais do BNH e dotação de uma infraestrutura mínima, substituindo a antiga chácara no sertão, que prevalecia dos anos 1920 aos 1940 (Op.cit., p. 145).

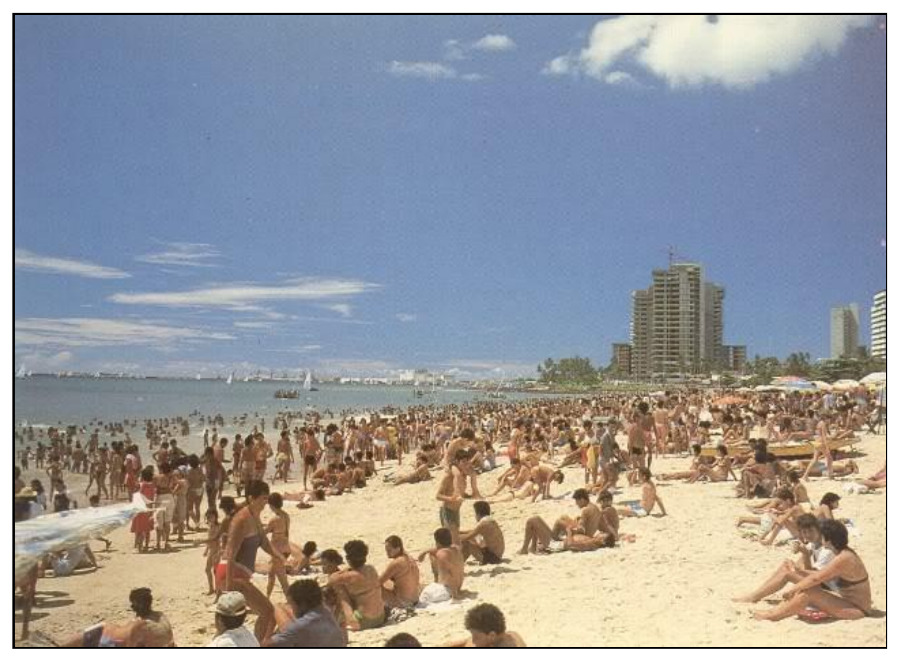

Fig. 2.30 Cartão postal da Praia do Náutico (Meireles) na década de 1980 em movimento típico de fim de semana.

Fonte: skyscrapercity.com http://www.skyscrapercity.com/show thread.php?t=1015635 (26/05/2012)

Fig. 2.31 A vista aérea de 1982 mostra o crescente movimento de banhistas que começava a congestionar as praias de Fortaleza, juntamente com o início da verticalização.

Fonte: Especial Manchete - 30 Anos. In skyscrapercity.com http://www.skyscrapercity.com/ showthread.php?t=1015635 $(26 / 05 / 2012)$

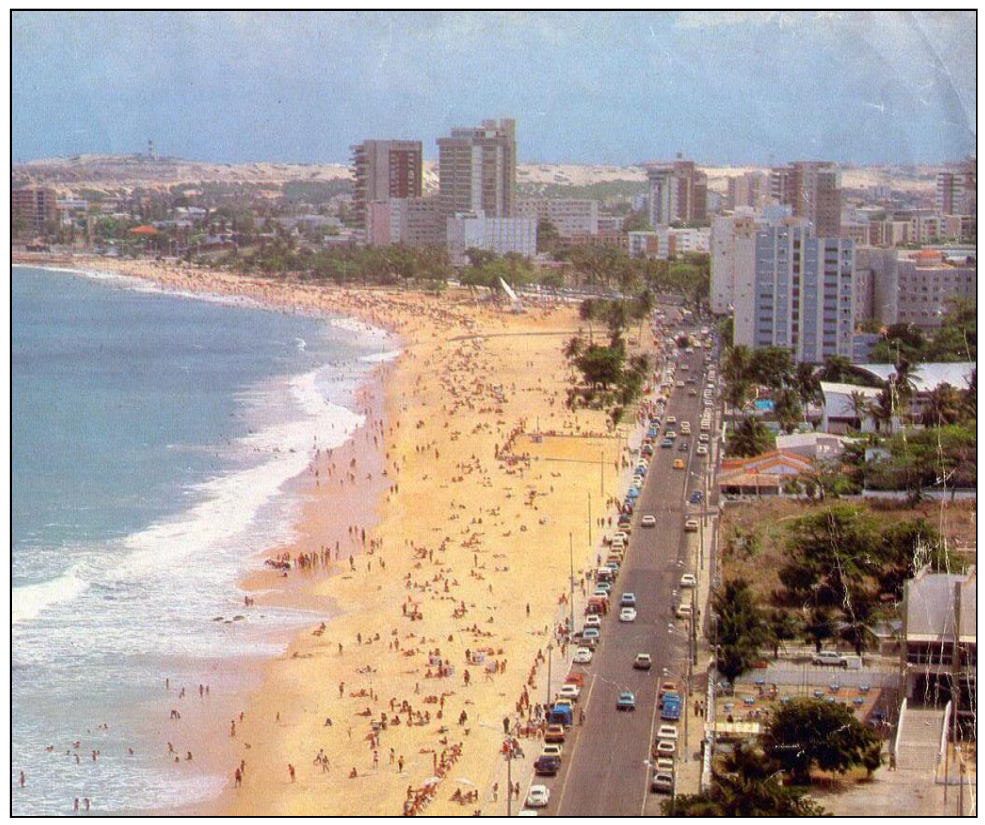


A esta lógica de ocupação voltada para o lazer litorâneo articulou-se outra política pública que objetivou a organização dos espaços ocupados pelos pobres, a Oeste da Praia de Iracema, utilizando-se da estratégia da construção da Avenida Leste-Oeste, inaugurada em 1973. Tal estratégia consistiu em política de controle social visando erradicar a zona de prostituição próxima ao centro, articulando-se ao objetivo de ampliação das vias de circulação no sentido Leste-Oeste permitindo a integração do Porto do Mucuripe à zona industrial da Av. Francisco Sá, a Oeste do Centro (DANTAS, 2002, p.63).

Essa política resultou na remoção de grande parte das famílias do Arraial Moura Brasil (em vermelho - Fig. 2.33) para dar passagem à nova avenida e destinar parte da terra desapropriada à instalação de um grande Hotel Marina (em amarelo - Fig. 2.32). Os antigos habitantes foram deslocados para conjuntos habitacionais populares construídos pelo $\mathrm{BNH}$.

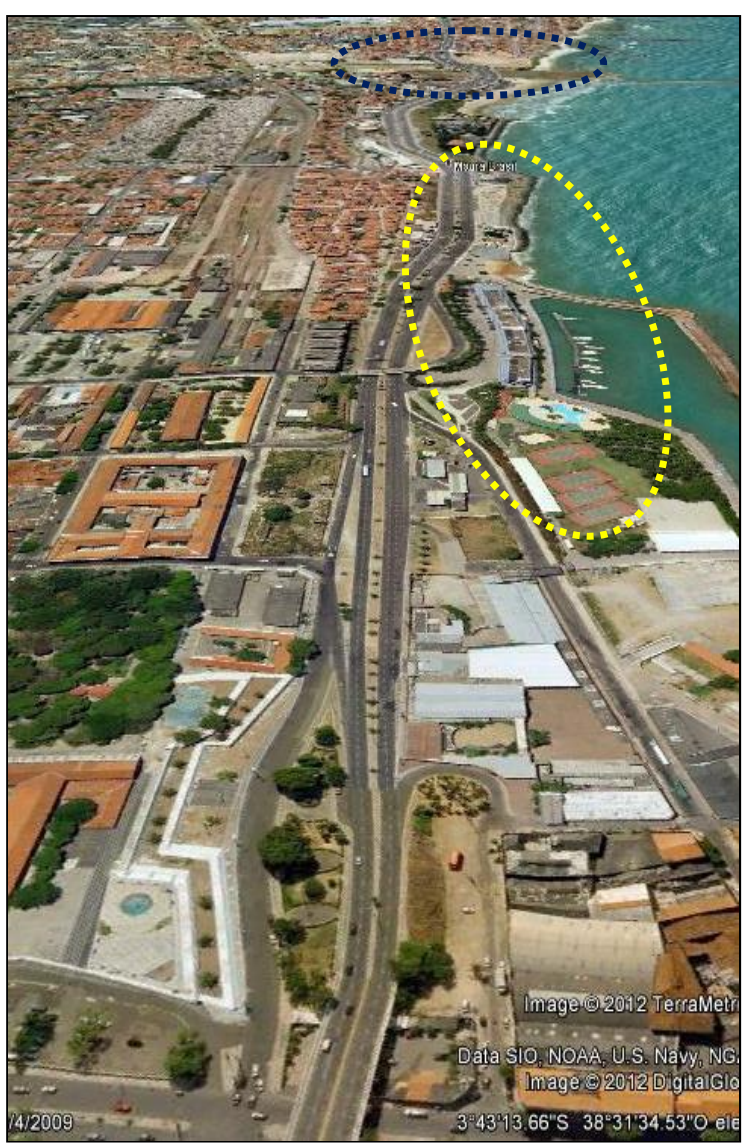

Fig. 2.32 Avenida Leste-Oeste atualmente. Em amarelo o Hotel Marina e em azul escuro, o Pirambu dividido em dois pela avenida. Fonte: Google Earth - imagem 2012

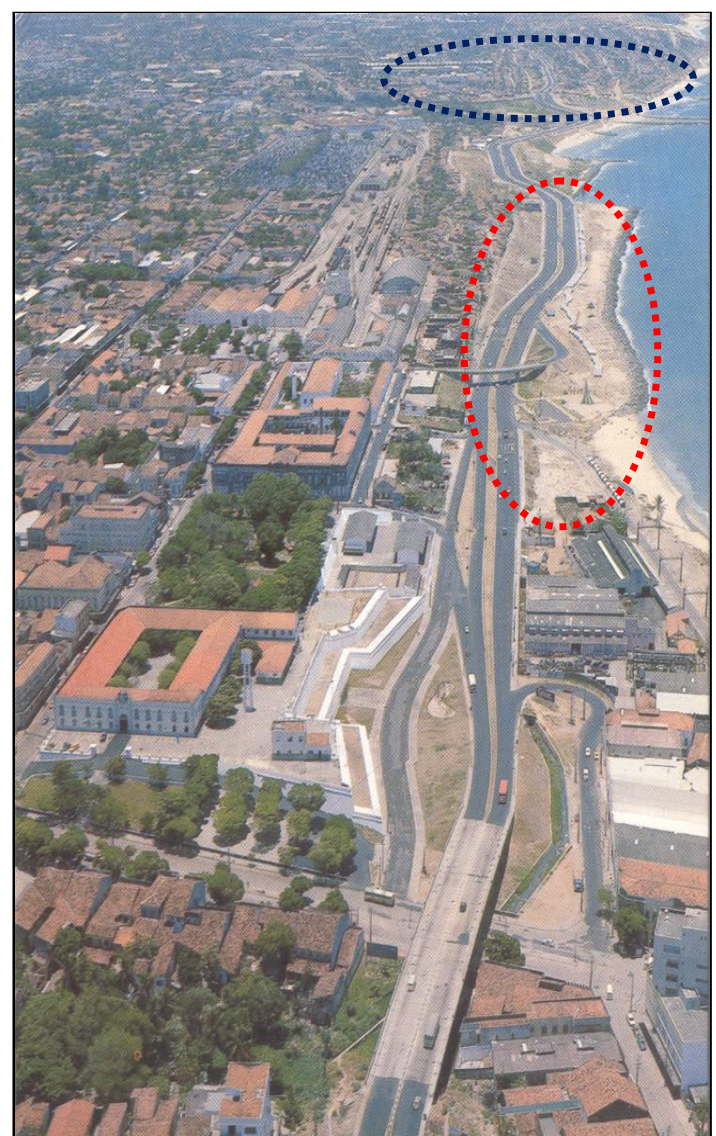

Fig. 2.33 - Av. Leste-Oeste nos anos 1970. Em vermelho o Moura Brasil removido pela obra da Avenida e em azul o Pirambu dividido. Fonte: http://fortalezanobre.blogspot.com.br/2010/05/pi rambu.html

$\mathrm{Na}$ altura do Pirambu, bairro popular com aspecto de favela (em azul escuro - Fig. $2.32 \mathrm{e}$ 2.33), a avenida deixa de ser litorânea e penetra no seu território provocando uma 
especialização ao longo da via proporcionando a instalação de comércio diversificado com a construção de casas com dois pavimentos, perdendo a aparência de favela e dividindo o bairro em dois. O Pirambu passa a ser associado pelos moradores somente pelo seu lado litorâneo. $\mathrm{O}$ outro lado do bairro tenta se distanciar da imagem negativa que sempre possuiu, numa tentativa de diferenciação dos habitantes da zona de praia (Op.cit. p.64).

Embora no Pirambu, ocorra o lazer e o banho de praia durante os fins de semana, com a população apropriando-se do meio litorâneo, como nas praias da zona Leste, sua comparação tem que ser diferenciada tendo em vista que a predominância de uso está relacionada ao do trabalho e da habitação como práticas tradicionalmente estabelecidas.
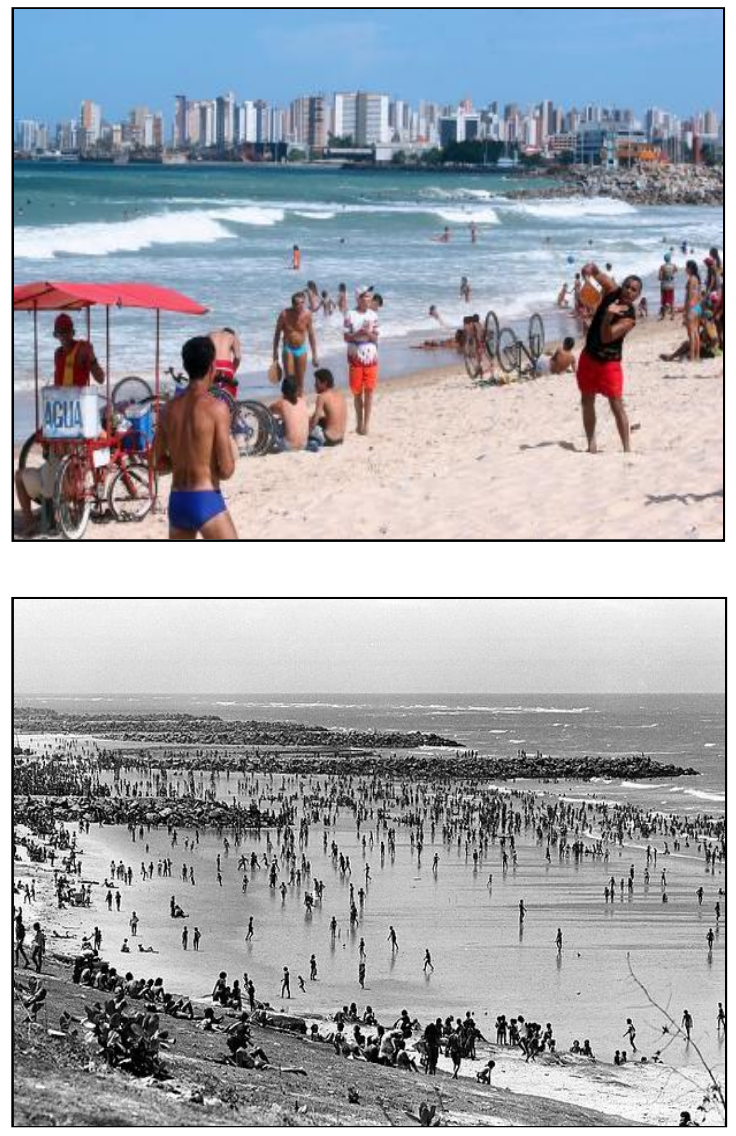

Fig. 2.34 Foto acima (colorida) a Praia da LesteOeste em dia de lazer: mais próximo do padrão da zona Leste. Abaixo, em PB a Praia do Pirambu: lazer diferenciado de padrão popular. Fonte: www.overmundo.com (26/05/2012)

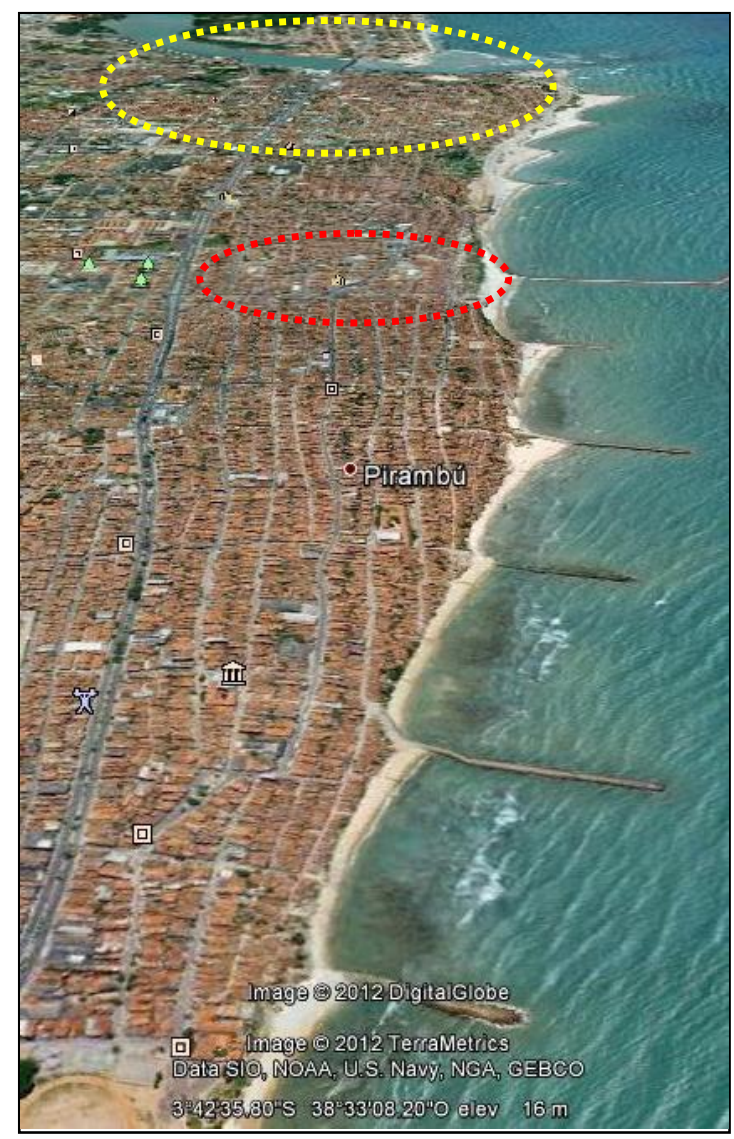

Fig. 2.35 Praia do Pirambu, em primeiro plano. Na sequência: Cristo Redentor (em vermelho) e ao fundo a Barra do Ceará (em amarelo).

Fonte: Google Earth. Imagem 2012. (26/05/2012)

Após a urbanização das praias de Iracema e do Meireles a cidade volta-se definitivamente para o Mar através de políticas públicas do Estado que apoiam a iniciativa privada incentivando a construção de hotéis, pousadas, restaurantes, barracas e parques aquáticos, como também loteamentos e edifícios altos. Esse movimento 
promove a verticalização da zona Leste de Fortaleza, notadamente os bairros do Meireles e Aldeota resultando na construção de uma cidade litorânea, capaz de responder às demandas locais de espaços para o lazer, abrindo-se cada vez mais para o turismo originado por novas demandas externas.

Para se adequar ao perfil de cidade turística, a municipalidade investe na construção de calçadões e polos de lazer nas zonas de praia. O primeiro foi o da Beira-mar no início de 1970 (fig. 2.28 e 2.29), transformando-se no principal ponto de encontro da cidade em detrimento do Centro, reforçada pela nova legislação do "Plano Diretor Físico de 1975”, elaborado no Âmbito da CODEF- Coordenadoria de Desenvolvimento Urbano de Fortaleza, posteriormente atualizado e revisto quando da aprovação da sua Legislação de Uso e Ocupação do Solo em 1979.

Essa Lei proporciona, pela alteração dos parâmetros urbanísticos, a verticalização e a progressiva substituição das últimas residências de pescadores, de famílias da classe média e pequenos restaurantes, por hotéis e edifícios altos e luxuosos, favorecendo o aumento do preço da terra, transferindo bares e restaurantes para a outra Margem da avenida. Assim, foram substituindo aos poucos as antigas barracas de praia por outras mais equipadas incorporando-as ao novo projeto de urbanização dos calçadões (DANTAS, 2002, p.66).

As novas linhas de ônibus, na década de 1980, vão permitir o acesso da população das camadas mais pobres a esse novo espaço de lazer favorecendo a sua apropriação e como consequência, promovendo o deslocamento progressivo do lazer das camadas médias e altas, sobretudo daquelas que possuíam transporte motorizado particular, para a Praia do Futuro (a Leste do novo porto). A nova praia passou, então, a abrigar os novos clubes de profissionais liberais como os dos: médicos, advogados, engenheiros e magistrados.

O resultado desse movimento é que a Avenida Beira-mar vai se tornando um lugar frequentado por atores diversos que vão marcando o seu território conforme usos e horários diferenciados, abrindo-se, cada vez mais, para os fluxos turísticos e suas demandas variadas como: hotéis, flats, restaurantes, conveniências, feira de artesanato, diversões etc.. A partir daí, passa também a combinar o uso turístico com o de habitações das camadas sociais mais altas, consolidando cada vez mais o processo de verticalização e apropriação das faixas litorâneas pelas diversas camadas sociais que 
compõem a cidade. Abaixo, vistas da Beira-mar nas décadas de 1990 e 2000. A combinação de verticalização, lazer litorâneo e serviços variados fazem disparar os preços dos imóveis no bairro considerados os mais caros da cidade.

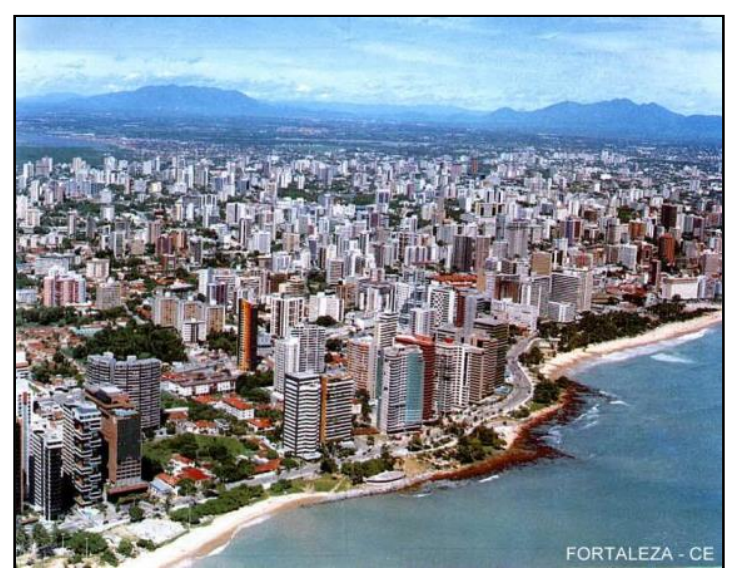

Fig. 2.36 Beira-mar anos 1990

Fonte: skyscrapercity.com. http://www.skyscrapercity.com/showt hread.php?t=1015635 (26/05/2012)

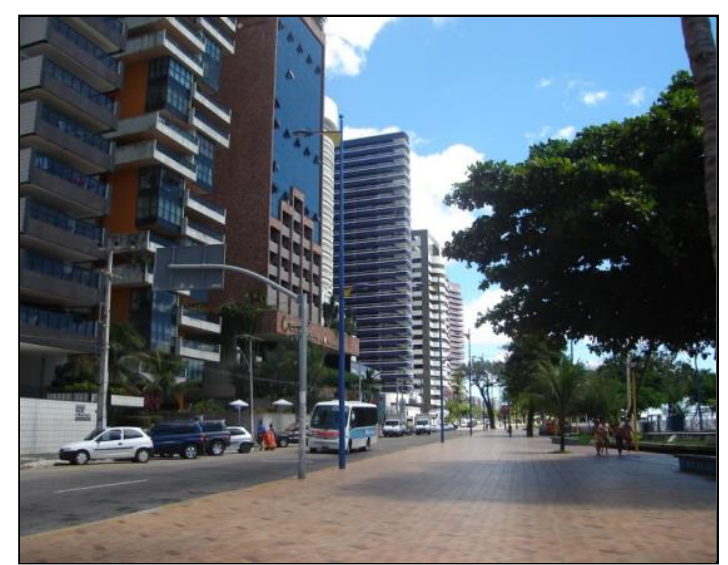

Fig. 2.37 Beira-mar anos 2000

Fonte: skyscrapercity.com.

http://www.skyscrapercity.com/showt hread.php?t=1015635 $(26 / 05 / 2012)$

Outros três calçadões foram construídos a partir dos anos 1980, com o mesmo objetivo de consolidar a incorporação das zonas de praia em Fortaleza, como lugar de lazer e turismo: na Praia do Futuro, na Praia de Iracema e na Leste-Oeste. Cada um deles apresentaram dinâmicas diferenciadas e particulares às condicionantes de cada lugar.
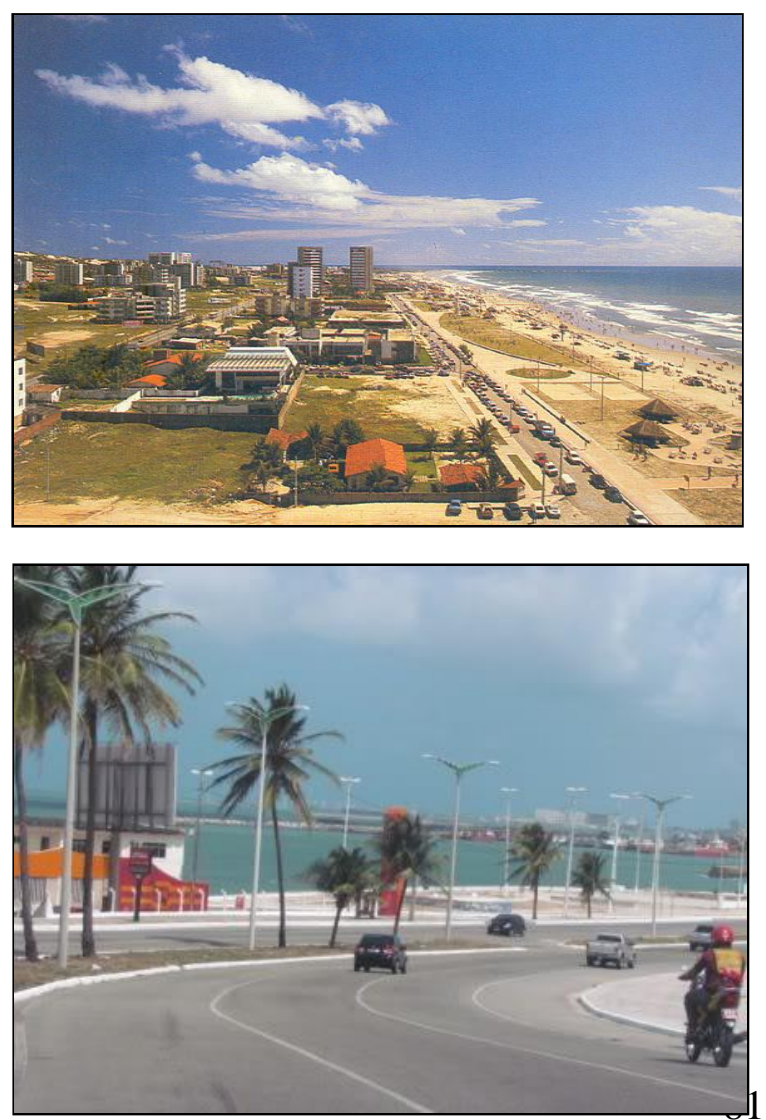

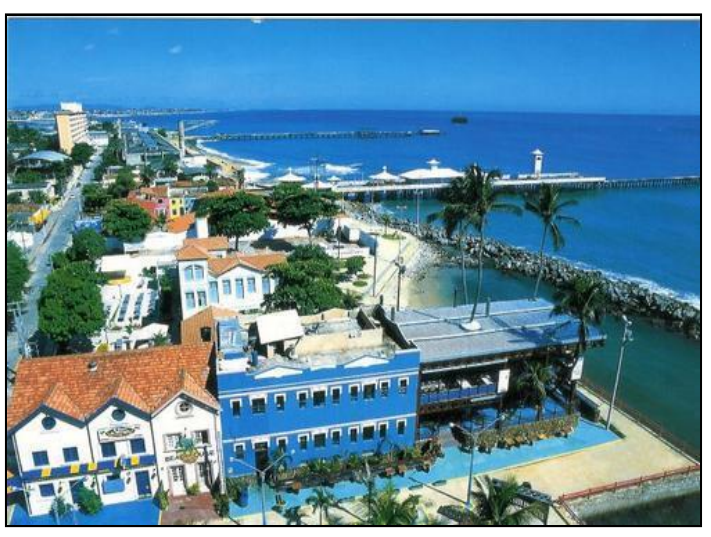

Fig. 2.38 À esquerda o calçadão da Praia do Futuro (1980). Fonte: fortalezanobreblogspot.com.br http://fortalezanobre.blogspot.com.br/2010/06/praia -do-futuro.html (26/05/2012).

Fig. 2.39 Á direita, o calçadão da Praia de Iracema (década de 1980). Fonte: skyscrapercity.com http://www.skyscrapercity.com/showthread.php?t=1 $\underline{015635}(26 / 05 / 2012)$.

Fig. 2.40 Abaixo, à esquerda o da Leste-Oeste (década de 1990). Fonte: skyscrapercity.com. http://www.skyscrapercity.com/showthread.php?t=1 466082 (26/05/2012). 
O processo que envolve a construção de calçadões, dentro da perspectiva da primazia do litoral como área de lazer e turismo, aprofunda-se durante todas as décadas seguintes, até o presente, envolvendo seguidas reformas e adaptações em cada trecho, de acordo com as novas demandas, variando com os objetivos de cada política pública implantada.

Ocorreram desde pequenas recuperações de manutenção a intervenções mais profundas de redesenho em trechos do calçadão, compostas de alterações no mobiliário urbano, iluminação pública, piso, como também na padronização de quiosques e delimitação da área da feira de artesanato, na Beira-mar. Na Praia do Futuro, houve a duplicação de vias, extensão do calçadão e padronização de parâmetros construtivos das barracas de praia. Já na Praia de Iracema, foram implementadas obras de requalificação urbana e medidas de proteção contra a erosão marinha (quebra-mares e aterros).

Outras intervenções nos calçadões se diferenciaram por serem voltadas para a "praia dos pobres", no litoral Oeste, entre a Barra do Ceará e o Pirambu, como o projeto Costa Oeste, entre 2003 e 2007, abrindo profundas discussões na cidade sobre as suas possíveis consequências. A polêmica girava em torno da sua apropriação pelo mercado imobiliário e da possível remoção das famílias originais para outros locais, a exemplo do que ocorreu na Beira-mar. As obras foram paralisadas e retomadas com outro projeto denominado Vila do Mar que se propõe a criar condicionantes que favoreçam a permanência dos moradores atuais, com obras iniciadas recentemente.

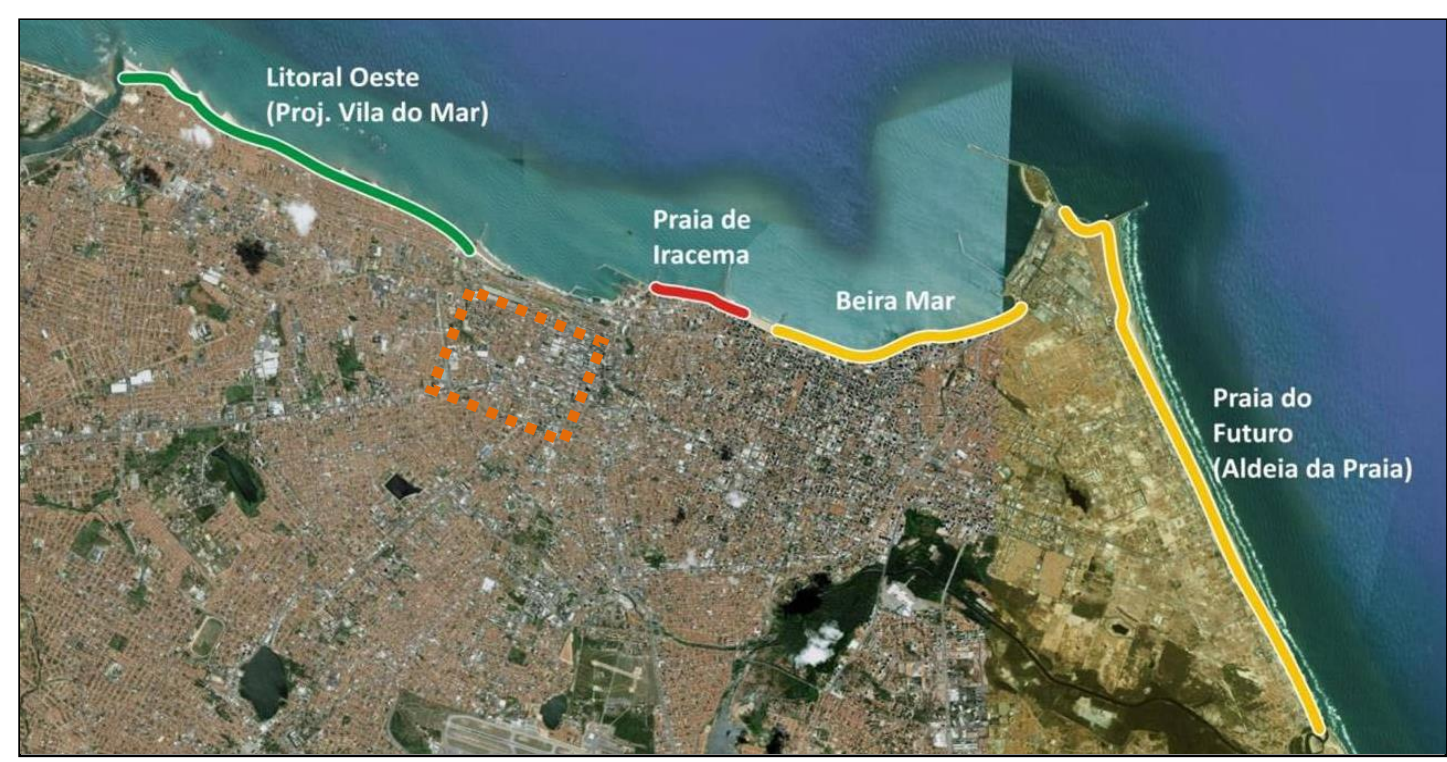

Fig. 2.41 Trechos litorâneos com previsão de novas intervenções pela Prefeitura. Algumas em andamento como na Praia de Iracema (vermelho) e no Litoral Oeste (verde). As outras duas em amarelo, ainda estão em fase de elaboração dos projetos previstos para serem implantados até 2014. Observe que a frente marítima do centro (em laranja) permanece fora dos planos de intervenção. Fonte: Prefeitura Municipal de Fortaleza, (sob imagem Google Earth - 2008). 
Não é nosso objetivo, nesse momento, aprofundar a análise em cada um dos trechos litorâneos sujeitos às intervenções porque se distanciaria muito do foco da nossa proposta de analisar os novos padrões de ocupação na RM de Fortaleza. Todas essas intervenções acabam se reportando a aspectos particulares da dinâmica intraurbana de Fortaleza específica de cada lugar, cuja complexidade e utilidade estariam voltadas para outro tipo de trabalho em escala diferenciada e com outros propósitos.

No nosso caso, a importância dessas intervenções se situa na compreensão do processo de valorização e consolidação do litoral enquanto espaço de lazer, veraneio e turismo, tratado como um movimento hegemônico, fundamentado na mesma racionalidade observada no início do século XX até o presente. Sua lógica se fundamenta na estratégia de acumulação do capital através da produção do espaço urbano, sustentado na ideia de que novas práticas socioespaciais são capazes de alterar o valor da terra e do imobiliário pela possibilidade que elas possuem de gerar renda dentro de atividades capitalistas. Com isso, foi possível verificar a influência da participação do Estado no processo de valorização e desvalorização das terras litorâneas, apresentando variações que pretendemos correlacionar, nos próximos segmentos.

Como foi visto no começo do capítulo, esse processo se inicia em Fortaleza, na faixa litorânea próxima ao centro que num processo de expansão vai superar as fronteiras da cidade a partir dos anos 1970. A procura de novos espaços litorâneos preservados e baratos para o lazer e veraneio vai penetrando nos limites dos municípios da sua Região Metropolitana, atingindo também todo o litoral do Estado.

O que é significativo ressaltar, nesse momento, é como esse movimento de permanente expansão urbana e valorização litorânea vai novamente se diferenciar, descrevendo um novo desenho a partir das novas atribuições que os municípios da RM de Fortaleza adotam. Neste caso, as funções de lazer e turismo são intensificadas pela sua associação ao imobiliário, numa velocidade diferente das anteriores constituindo-se em novas fronteiras de apropriação do espaço para o imobiliário em sua permanente necessidade de alimentar a lógica de acumulação do capital.

Abordaremos, a seguir, o início desse novo processo que se inicia nos anos 1970 e vai se afirmar nos anos 1980, diferenciando-se a partir dos anos 1990 até atingir a primeira 
década de 2000 de maneira singular, coincidindo com o recorte temporal e espacial do nosso objeto de estudo.

\subsubsection{A expansão para além da Região Metropolitana}

Com o veraneio, ocorrido entre os anos 1970-80, o espaço que era destinado à pesca, ao porto e às residências da população pobre, foi aos poucos ocupado por um novo modo de consumo que transformou as relações sociais entre os antigos e os novos moradores, transmudando os antigos em mão-de-obra barata, fazendo surgir pequenos comerciantes e prestadores de serviços domésticos ou ligados ao lazer e turismo.

A construção de estradas vicinais, ligando as rodovias às localidades litorâneas, intensificou a atividade de veraneio, alimentando a especulação imobiliária e conseqüentemente os conflitos sociais e de posse da terra. Estas áreas de veraneio começaram a se expandir de forma centrífuga à Região Metropolitana de Fortaleza em direção às costas ao Oeste e ao Leste, constituindo um importante movimento de transformação e incorporação das zonas de praia no Ceará. No entanto, no final dos anos 1980, sofre uma mudança com a intervenção das novas políticas públicas do Estado, objetivando inserir o Ceará no concorrido mercado turístico internacional.

A infraestrutura iniciada com o veraneio expandiu-se e diversificou-se em função das novas demandas turísticas por zonas de praia, apoiada por uma política regional de desenvolvimento baseado no turismo. Fortaleza foi levada à condição de ponto de recepção e distribuição dos fluxos turísticos do Estado, transformando-se em cidade com imagem eminentemente litorânea e marítima, controlando o fluxo turístico a partir da construção do aeroporto internacional e das vias de integração das zonas de praia, numa lógica que transforma as cidades litorâneas tropicais em espaço privilegiado para o desenvolvimento turístico (CAMPOS, coord. et. al., 2003, p. 146).

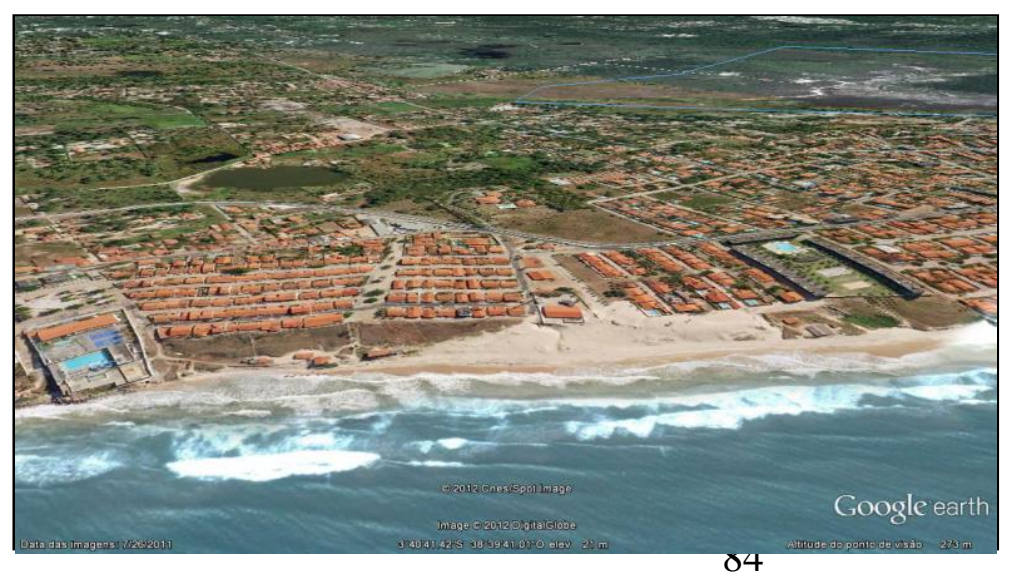

Fig. 2.42 Padrão de loteamentos de veraneio, do início dos anos 1970 - Praia do Icaraí, em Caucaia (Litoral Oeste). Nota-se um clube para veranistas, à esquerda e à direita um dos primeiros condomínios fechados verticais do início dos anos 1980 reproduzido em outras versões, acentuando a verticalização do lugar. Fonte: Google Earth Imagem 2011 


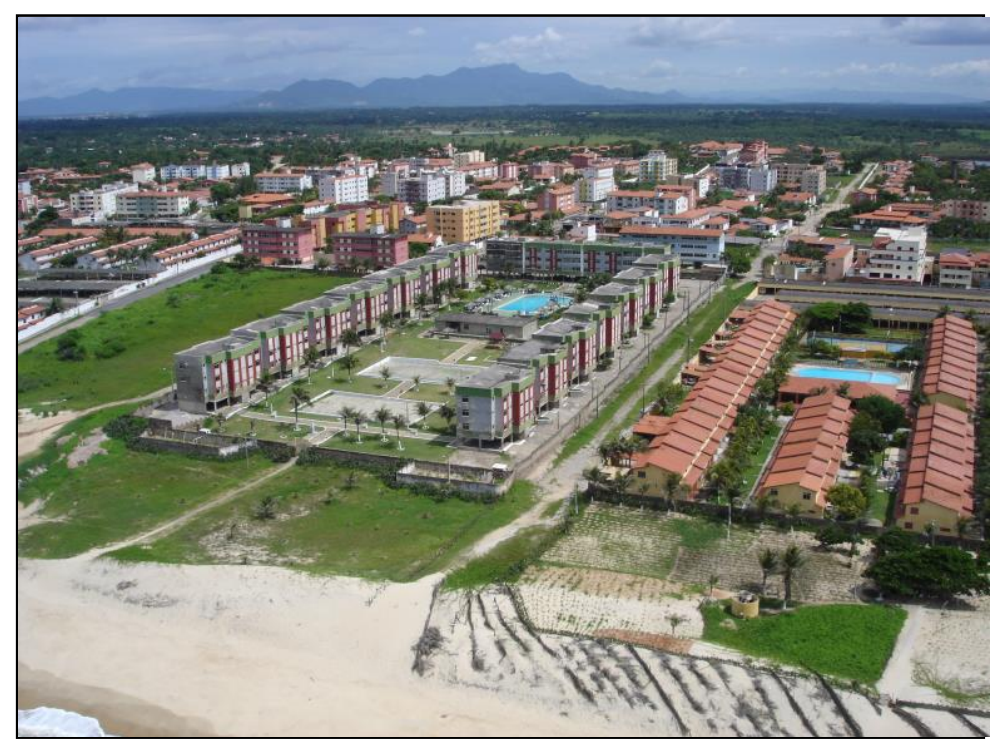

Fig. 2.43 O padrão dos primeiros condomínios fechados de residências secundárias de veraneio no Icaraí, induziu uma verticalização moderada no lugar que foi se transformando, aos poucos, em bairro de residência permanente. Fonte: Fabian Sales, 2006 (apud. PAIVA, 2011)

Fig. 2.44 Abaixo, a ocupação na praia da Caponga, em Cascavel. O veraneio e o turismo chegam aos limites da RM de Fortaleza sem respeitar a legislação ambiental Fonte: Google Earth-2012
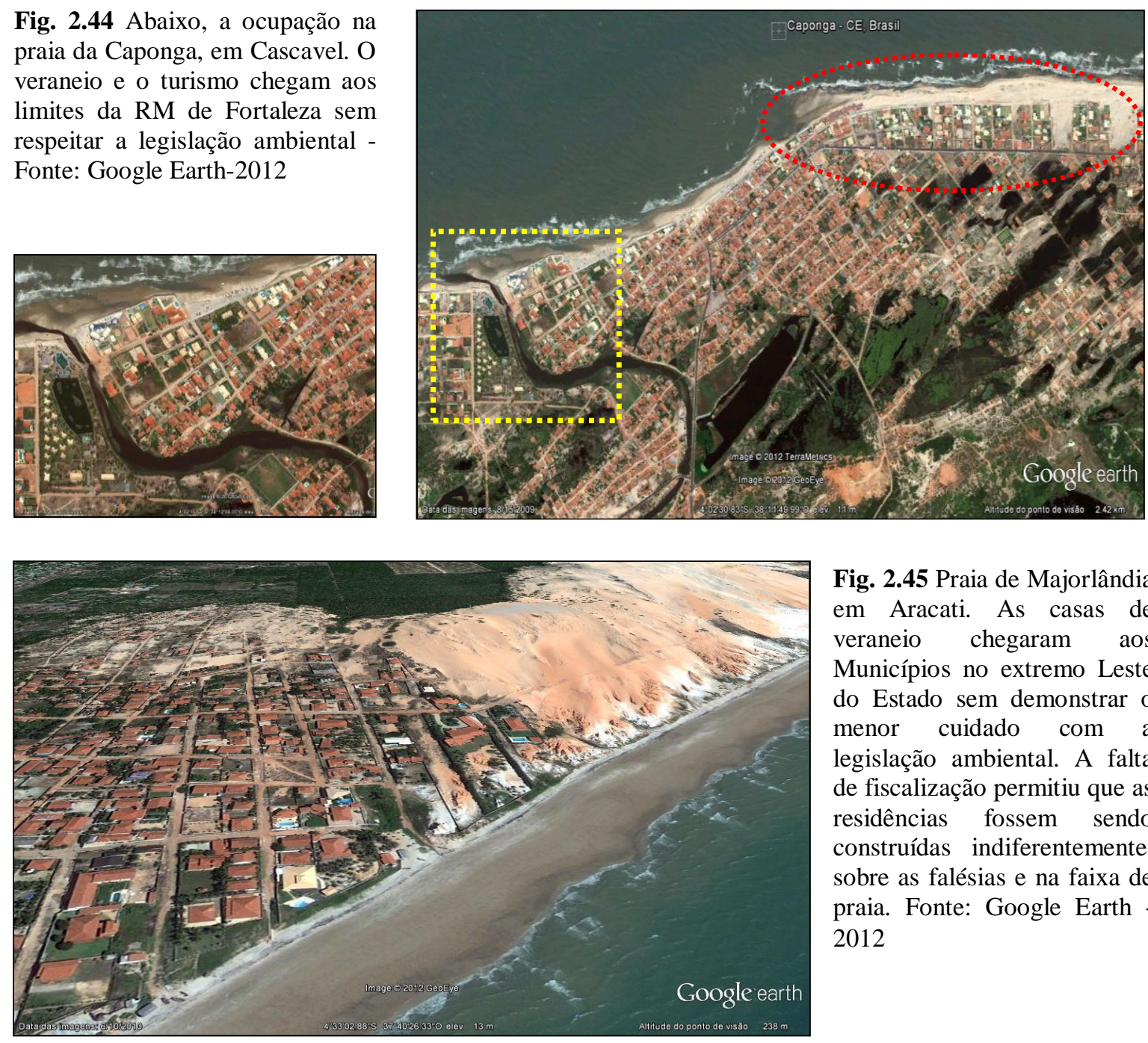

Fig. 2.45 Praia de Majorlândia em Aracati. As casas de veraneio chegaram aos Municípios no extremo Leste do Estado sem demonstrar o menor cuidado com a legislação ambiental. A falta de fiscalização permitiu que as residências fossem sendo construídas indiferentemente, sobre as falésias e na faixa de praia. Fonte: Google Earth 2012 
Após os anos 1980, o Estado adotou uma política pública de planejamento do território que reforçou as relações de Fortaleza com as zonas de praia dos municípios litorâneos, contribuindo para o estabelecimento de uma rede urbana que propiciava a valorização das zonas de praia como mercadoria turística. Esta política se insere numa lógica maior inscrita numa forte intervenção do Estado em dois domínios - a indústria e o turismo - que na escala local imprime as imagens positivas dos espaços litorâneos semiáridos, apresentados como símbolo do sucesso do novo governo, atraindo investimentos estrangeiros na escala internacional, ampliando o fluxo turístico dirigido ao Estado principalmente a Fortaleza, e espaços litorâneos. Assistiu-se ao sucesso da política de desenvolvimento da atividade turística, fortemente nacional, embora se tenha iniciado gradativamente a sua ampliação no concorrido mercado turístico internacional, cujas consequências foram sentidas principalmente no litoral (CAMPOS, coord. et. al., 2003, p. 147).

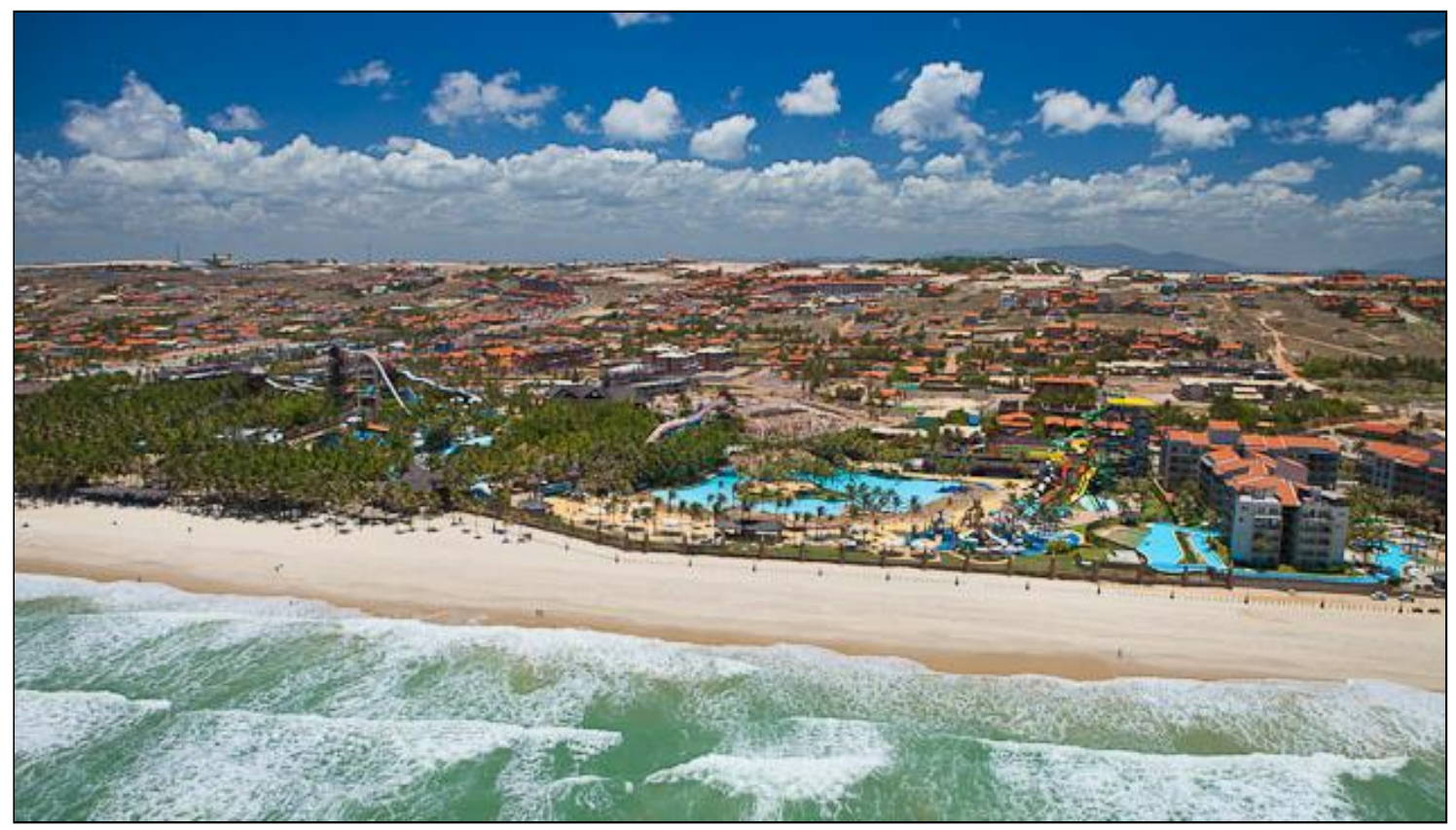

Fig. 2.46. O Porto das Dunas começou como um loteamento de veraneio aprovado em 1979 na Prefeitura de Aquiraz. As mudanças no contexto das políticas públicas de turismo do Estado dos anos 1990 o levaram a tornar-se o maior complexo turístico do Ceará. O desenho do loteamento incentivou a hotelaria e serviços de uso misto nos lotes de frente para o mar que acabaram formando um mix de usos turísticos com o residencial no padrão de condomínios fechados com serviços privados de lazer.

Foto de 2007. Fonte: http://www.pbase.com/alexuchoa/image/140908374 (26/05/2012).

Ao sucesso do turismo associou-se também a supervalorização das faixas litorâneas fronteiriças ao mar, numa relação intrinsecamente relacionada à possibilidade potencial de geração de rendas com as atividades turísticas. Hoje, está em curso um processo de valorização imobiliária jamais vista no Estado, capaz de comprometer a própria 
estabilidade da atividade turística, caso nada seja feito para promover o disciplinamento criterioso do uso e ocupação da faixa litorânea, praticamente descoberta de legislações específicas e eficazes. Quando existem, não são devidamente tratadas nos planos diretores de desenvolvimento urbano, alterados conforme os interesses hegemônicos. Assim, ficam protegidas, apenas, pelas legislações e resoluções ambientais, frequentemente modificadas pelo poder dos conselhos de Meio Ambiente, seguindo o mesmo jogo hegemônico circunstancial e ambíguo marcado pela omissão institucional. Por isso, necessitam de um marco regulatório menos movediço, capaz de ser acompanhado pelos setores da sociedade que ainda se preocupam com as questões socioambientais no Estado.
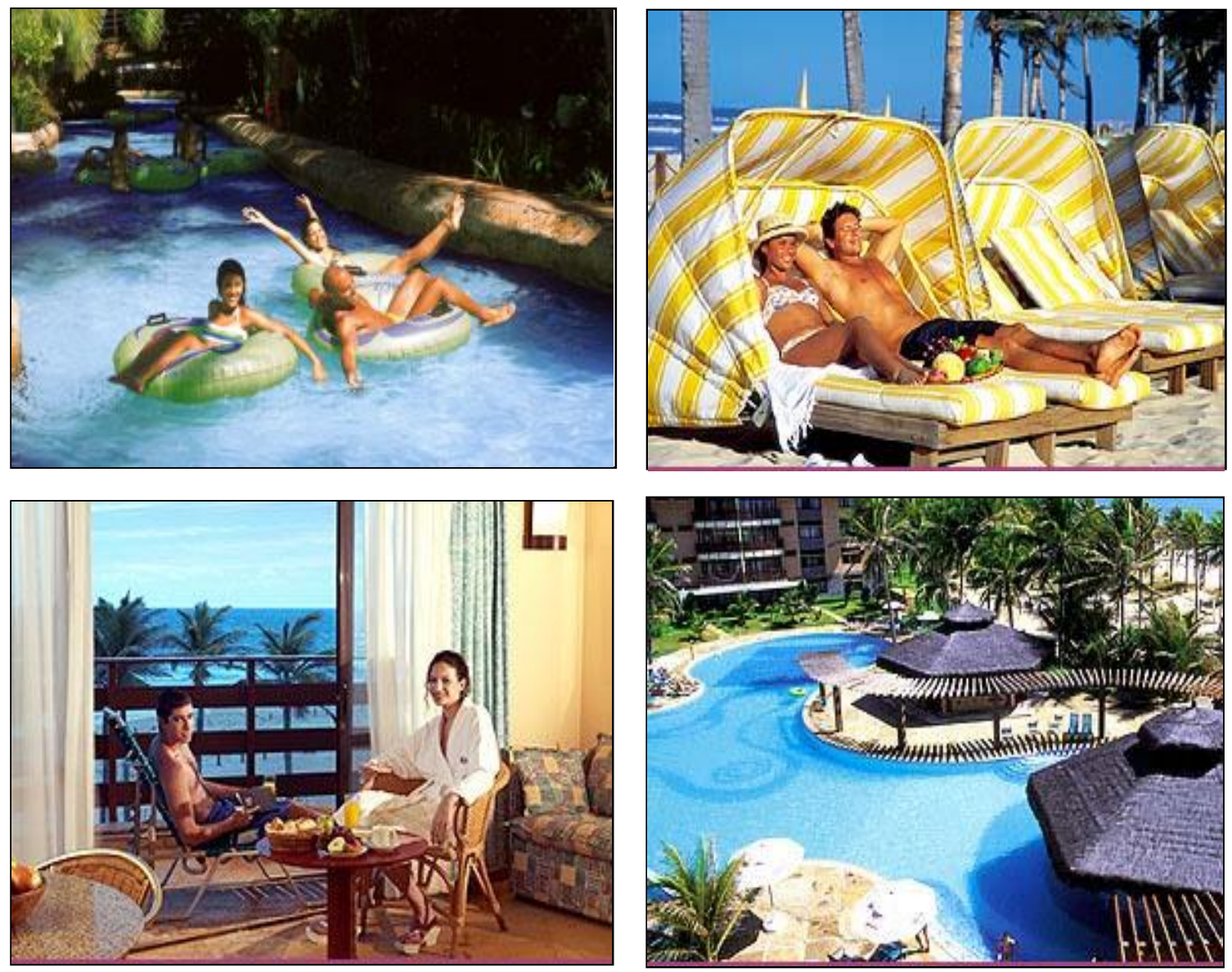

Fig. 2.47 A nova imagem do turismo cearense, veiculada em forte campanha publicitária apoiada pelo Estado, desde os anos 1990 a 2000, em estreita parceria com a iniciativa privada. As antigas referências de seca e pobreza do Ceará são substituídas pelo de paraíso tropical associado ao lazer familiar em um parque aquático com hotelaria de referência internacional. Fonte: www.beachpark.com.br (in MONTENEGRO JR. 2004) 
O final do século XX, portanto, testemunhou notáveis transformações na ocupação da zona costeira no Ceará, haja vista a permissividade das políticas de preservação ambiental e controle urbanístico. A perspectiva que se abre para o século XXI é de agravamento dessas transformações em razão dos grandes investimentos governamentais em infraestrutura para os empreendimentos turísticos ao longo da costa, como também daqueles voltados à consolidação do complexo portuário e industrial do Pecém, a Oeste de Fortaleza. Com estes, haverá uma tendência de deslocamento do eixo de desenvolvimento metropolitano, com grandes consequiências para a região, mas de indiscutível importância econômica para o Estado, no atual contexto.

Com a análise da evolução das estruturas urbanas na Zona Costeira cearense concluímos que um dos fatores mais impactantes, em termos de extensão territorial e velocidade de implantação na sua história recente é, sem dúvida, a explosão imobiliária provocada pela valorização e mercantilização das zonas de praia materializadas nas residências de veraneio e, mais recentemente, nos equipamentos de lazer e turismo.

A leitura do processo de ocupação e valorização das terras litorâneas revela que sua racionalidade permanece ligada à mesma lógica da estratégia de acumulação do capital via produção do espaço mediada pelo Estado / mercado, verificada de modo embrionário ainda nas primeiras décadas do século XX. Constitui-se, portanto, num movimento de expansão que parte de Fortaleza na direção dos Municípios da sua RM atingindo praticamente toda a costa cearense.

Esse movimento, no entanto, encontra na Região Metropolitana alguns elementos que o diferencia dos demais assentamentos, seja pelo padrão de ocupação, como também pelas mudanças incorporadas ao produto e ao processo produtivo. A expansão, por elas provocadas, não se explica somente pela proximidade territorial com a capital, mas vão encontrar outras razões relacionadas às novas estruturas metropolitanas criadas. Estas, por sua vez, reproduzem uma especialização territorial de funções ligadas, em última análise, à reestruturação produtiva implementada pelo Estado, intensificada a partir dos $\operatorname{anos} 1990$.

Assim, propomos analisá-la abordando objetivamente o processo de metropolização de Fortaleza, a partir de uma breve perspectiva histórica, cujo objetivo é compreender a evolução desse processo de reestruturação, desde as suas premissas iniciais até os 
fundamentos que o explicam nos dias de hoje. Com isso será possível compreender as alterações e permanências resultantes do seu encontro com a nova reestruturação sócioterritorial do Ceará contemporâneo, desenvolvido no próximo bloco.

\subsection{O processo de metropolização de Fortaleza: da industrialização tardia no Nordeste à reestruturação sócio-territorial do Ceará contemporâneo.}

A metrópole comporta-se simultaneamente como superação e afirmação da formacidade, operando transformações que reforçam o significado do urbano, no sentido do acúmulo e reunião de redes, como simultaneidade (LEFEBVRE,1999, p.51). Assim, a relação dialética centralidade-policentralidade torna-se o aspecto essencial do fenômeno urbano, como uma criação ininterrupta. A rede integrada no âmbito metropolitano e regional produz no plano da cidade, centro-da-região, as bases do processo de polinucleação pelo incentivo às novas localizações residenciais, possibilitadas pela valorização do solo nas áreas conquistadas para a expansão urbana.

Ressaltando a desconcentração, como padrão característico da reestruturação do espaço de assentamento do capitalismo contemporâneo, Gottdiener (1997, p.241) considera que tal padrão fundamenta-se numa relação dialética entre os princípios de aglomeração e descentralização de atividades baseadas numa rede de circulação, comunicação e transporte em escala regional, derivado da reestruturação produtiva com base na descentralização em escala mundial.

O processo de metropolização das cidades, entendido como o estágio mais avançado da urbanização capitalista, apresenta de fato um padrão de estruturação urbana fundamentado na desconcentração em escala regional criando laços de dependência entre uma rede de conexões altamente hierarquizada. Desse modo, coloca as novas bases para o entendimento da relação cidade-campo, como também das práticas sociais que determinam a identidade dos lugares (LENCIONI, 2003, apud FERNANDES, 2011, p.64).

O conceito de metropolização, portanto, será utilizado na pesquisa como um processo de urbanização, em escala regional, capaz de envolver a articulação de vários núcleos urbanos sob a orientação de um deles que atua como "cidade-mãe" ${ }^{10}$, centro-da-região,

\footnotetext{
${ }^{10}$ A etimologia da palavra metrópole tem origem do grego 'metropolis' e do latino 'metropole' que significa 'cidade-mãe' (FERREIRA, 1993).
} 
intermediada por relações socioespaciais que se dão através da intensificação dos deslocamentos humanos e de produtos. Esse movimento é fomentado pelas dinâmicas de produção, distribuição e consumo, em regime ampliado, num processo simultâneo de descentralização e centralização das funções urbanas no território regional, constituindo-se assim numa de suas características fundamentais.

A descentralização ocorre na escala metropolitana, quando se verifica um expressivo crescimento acompanhado de uma redistribuição de certas funções urbanas que se localizam fora dos limites da cidade-mãe, ocorrendo espacialmente ao longo dos principais eixos viários, pelos quais se intensificam os fluxos de pessoas, bens, produtos e comunicação. Por outro lado a centralização ocorre primeiramente, na função de gestão e controle das atividades relacionadas ao comércio, serviços e indústria, implicando na concentração de empresas e pessoas. No entanto, atua também no nível de comando/subordinação relativos, entre o núcleo central e os demais núcleos da escala intrarregional.

Assim, o fenômeno de metropolização, não corresponde apenas ao crescimento populacional de uma determinada área, mas implica também no modo como se distribuem no espaço essas atividades, funções e grupos interdependentes, segundo uma "dinâmica social amplamente independente da ligação geográfica” (CASTELLS, 2009 apud PAIVA, 2011, p. 90). Por isso, a definição dos limites legais do território de uma região metropolitana não é tarefa fácil e tende a ser imprecisa em função das dificuldades de se quantificar a dimensão e a qualidade dos fluxos metropolitanos, além dos fatores políticos locais.

O fenômeno de metropolização em Fortaleza só se prenuncia quando a cidade integra-se ao processo de industrialização no Brasil, implantado na primeira metade do século XX, momento em que se estruturam as condições para a cidade tornar-se um centro regional. A partir dos anos 1960, intensifica-se a implementação das políticas industriais da SUDENE, estendendo seu ciclo até meados dos anos 1980 quando sofre as consequências da estagnação econômica brasileira. De meados dos anos 1980 para cá o processo de industrialização se descentraliza, ao mesmo tempo em que tende a uma concentração metropolitana, principalmente nos Municípios da RM de Fortaleza, mas ocorre também em torno de outros polos regionais do Estado como em Sobral 
(amarelo), região do Cariri (Juazeiro do Norte-Crato, em azul) e também em Iguatu (rosa), no Centro-Sul do Ceará (fig. 49) que se formam a partir dos anos 1990.

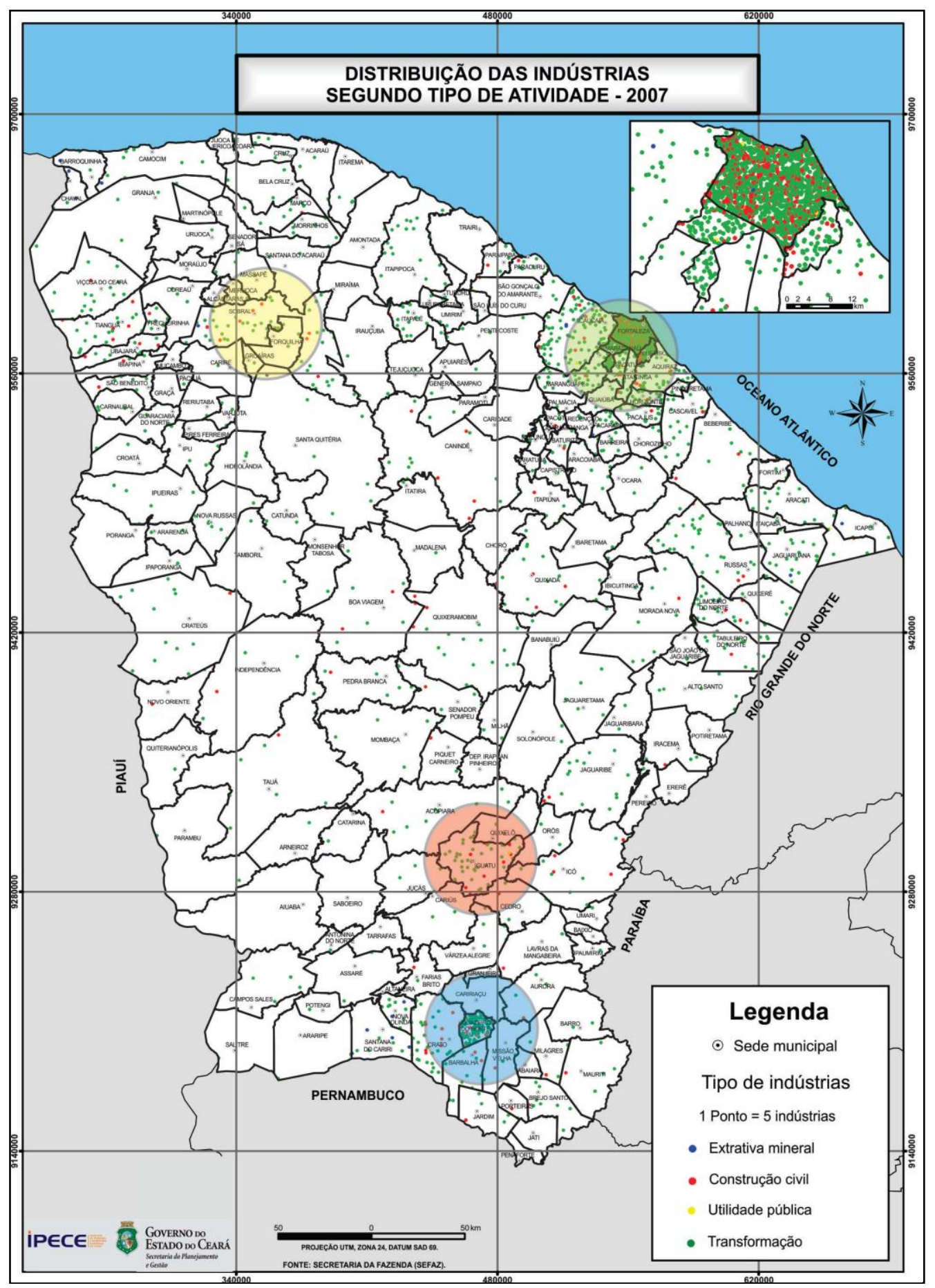

Fig. 2.48 O Mapa da Dinâmica Industrial atual do Ceará, mostra os quatro polos industriais do Estado, destacando a maior concentração na RM de Fortaleza.

Fonte: IPECE

Paralelamente, no final dos anos 1980, o turismo surge como o segundo vetor estratégico de maior importância nos planos de governo do Estado do Ceará, reforçado 
nos governos posteriores, provocando uma alteração na dinâmica metropolitana através da superposição de uma rede urbana que vai sendo estruturada para apoiar as novas funções de lazer associadas ao turismo de massa. Essa estrutura ultrapassa os limites administrativos da RM formal, estendendo-se a todo o litoral do Estado, tendo Fortaleza como polo receptor e distribuidor dos fluxos turísticos.

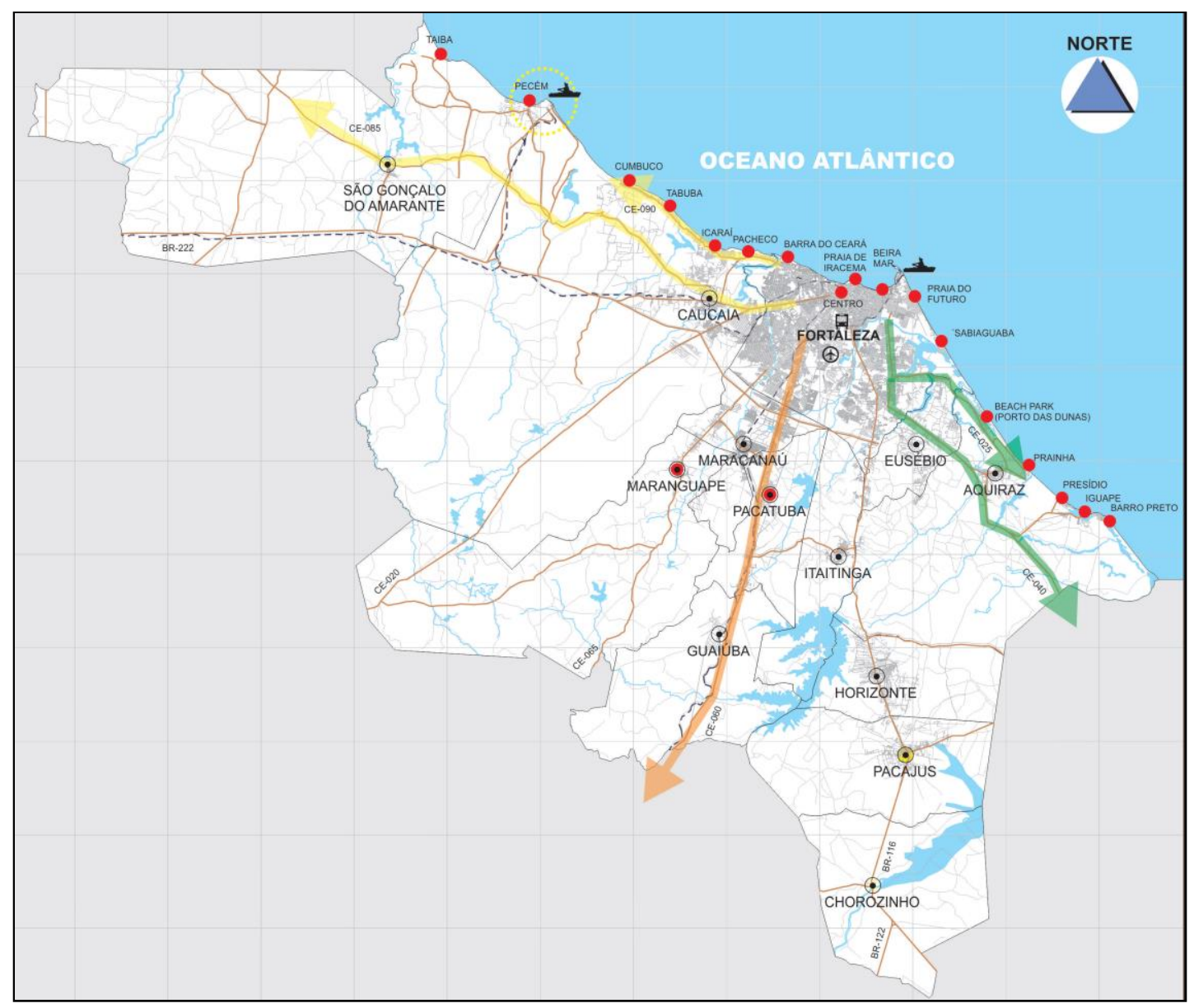

Fig. 2.49 Mapa da dinâmica do turismo na RM Fortaleza. Fonte: Paiva, 2011.

Podemos dizer que há um paralelismo entre o fenômeno da metropolização de Fortaleza e o processo de industrialização do Estado do Ceará, embora os limites temporais não sejam exatamente precisos e coincidentes, porque devem ser entendidos como processos relativamente autônomos. No entanto, a sua observação ajuda a demarcar melhor os detalhes de como o fenômeno da metropolização se articulou com o da industrialização, para em seguida encontrar-se com a dinâmica do turismo. Assim, partimos de uma periodização elaborada por Amora (2007) para o processo de industrialização no Ceará que entre outros aspectos ressaltou a inserção do Estado na divisão internacional e nacional do trabalho, definindo três períodos principais: o primeiro, iniciado no final do 
Século XIX até o final dos anos 1950; o segundo, dos anos 1960 até meados da década de 1980; e o terceiro de meados dos anos 1980 até a atualidade.

Do primeiro período é importante ressaltar apenas que ainda no final do século XIX o Ceará inicia suas atividades industriais no ramo têxtil e de óleos vegetais, tendo como base a cultura do algodão, se estendendo até o final dos anos 1950. A partir daí, entra em crise devido a problemas com a deficiência de infraestrutura básica, principalmente de energia elétrica, como também pela obsolescência do maquinário industrial diante da concorrência interestadual (BERNAL, 2004, p.66). Nesta fase, a industrialização ainda não tem um papel visível na constituição da futura metrópole, a não ser pela infraestrutura ferroviária instalada que serviu de lastro fundamental para o desenvolvimento metropolitano posterior.

\subsubsection{A industrialização tardia: Nordeste no Final dos anos 1950 - 1980}

Podemos considerar que esse período corresponde ao início da integração do Ceará ao processo de industrialização nacional que vai repercutir, de modo mais visível, no processo de metropolização de Fortaleza, ainda que em estágios embrionários, principalmente nos primeiros anos.

No contexto de integração e hierarquização do mercado nacional, o Governo Federal elabora ações com o intuito de atenuar as desigualdades regionais devido aos recorrentes problemas com a seca no Nordeste, que ampliavam as dificuldades enfrentadas na agricultura, resultando em baixos índices de renda e no progressivo aumento do fluxo migratório, em escala regional e nacional. Diante desse quadro foi criada, em 1959, a Superintendência do Desenvolvimento do Nordeste - SUDENE fundamentada nos estudos do Grupo de Trabalho, sob a coordenação de Celso Furtado, em 1956, data em que também foi criado o BNB - Banco do Nordeste do Brasil, para cumprir o papel de agência de desenvolvimento regional. (PAIVA, 2011, p.76)

A industrialização implementada pela SUDENE, portanto, buscava atender a mão de obra excedente no Nordeste, mas acabou provocando uma expansão da industrialização desenvolvida no Sudeste do país. Os incentivos fiscais e financeiros possibilitaram a transferência de grupos econômicos para a região, favorecendo uma homogeneização 
monopolista do espaço nacional, criando oportunidades para a instalação de indústrias filiais que buscavam melhores condições de acumulação do capital (AMORA, 1994).

Desse modo, o objetivo original baseado na atenuação das desigualdades através do desenvolvimento regional acabou não sendo atingido, nesse momento, aprofundando ainda mais as diferenças entre as regiões brasileiras, uma vez que não se conseguiu a estruturação de núcleos industriais com capital constituído na própria Região.

Os incentivos fiscais, no entanto, acabaram favorecendo a concentração dos investimentos nos estados de Pernambuco, Bahia e Ceará, embora a estrutura industrial só mudasse substancialmente na direção da produção de bens de consumo intermediário e bens de capital, nos dois primeiros Estados. No caso do Ceará não teria havido maiores alterações na estrutura industrial predominando, ainda hoje, atividades tradicionais que utilizam matérias primas locais para a produção de gêneros alimentícios, vestuários e têxtil. Entretanto o capital do setor de alimentos foi o responsável pela diversificação industrial, surgindo ramos mais dinâmicos como a metalurgia, química e minerais não metálicos que vão alterar a composição setorial com novas indústrias no ramo de bens duráveis.

Do período inicial da SUDENE (1959) até meados dos anos 1980, o setor industrial do Ceará ampliou a sua participação na composição do PIB de 10,3\% para $26,8 \%$, enquanto a agropecuária declinou de $34 \%$ para $14,6 \%$, refletindo a crise do bicudo na produção algodoeira. Apesar da crescente industrialização, o crescimento do emprego industrial permaneceu insuficiente para absorver o extraordinário aumento da força de trabalho gerado pelo processo de urbanização. (BERNAL, 2004, p.67).

No contexto de Fortaleza, a concentração de fluxos demográficos, de mercadoria e de informações, dos anos 1950, possibilitou a emergência de segmentos específicos da indústria associados às atividades tradicionais de beneficiamento de produtos do setor primário, como o extrativismo, a agricultura e os produtos alimentícios, constituindo-se na primeira zona industrial localizada na via arterial da Francisco Sá, a oeste do centro.

A localização das indústrias nesse setor da cidade reforçou o seu caráter popular de ocupação, concentrando as habitações dos operários no entorno das indústrias e ao longo da via férrea. Essa lógica de ocupação diferenciou-se da ocorrida na região central 
e no Leste da cidade, onde se concentravam as camadas sociais de maior renda aprofundando, progressivamente, uma diferenciação da cidade no sentido Oeste - Leste. Outros fatores que reforçaram essa fragmentação estão relacionados aos problemas do deslocamento do primeiro Porto para o Mucuripe e da migração em massa do campo para a cidade, nos seguidos períodos de secas (CUNHA \& PEDREIRA, org. 2008, p.11).

Nos anos 1970, a política de industrialização implementada pela SUDENE apoia o fortalecimento da Zona da Francisco Sá que embora localizada na zona Oeste da cidade, se beneficia do acesso ao porto do Mucuripe, pela via férrea. No entorno imediato do porto, no litoral Leste da cidade, se instalam a Fábrica de Asfalto de Fortaleza, o Terminal de Gás Butano e os Moinhos de Trigo, caracterizando a área como a segunda zona industrial-portuária da cidade, com peso significativo na economia do Estado.

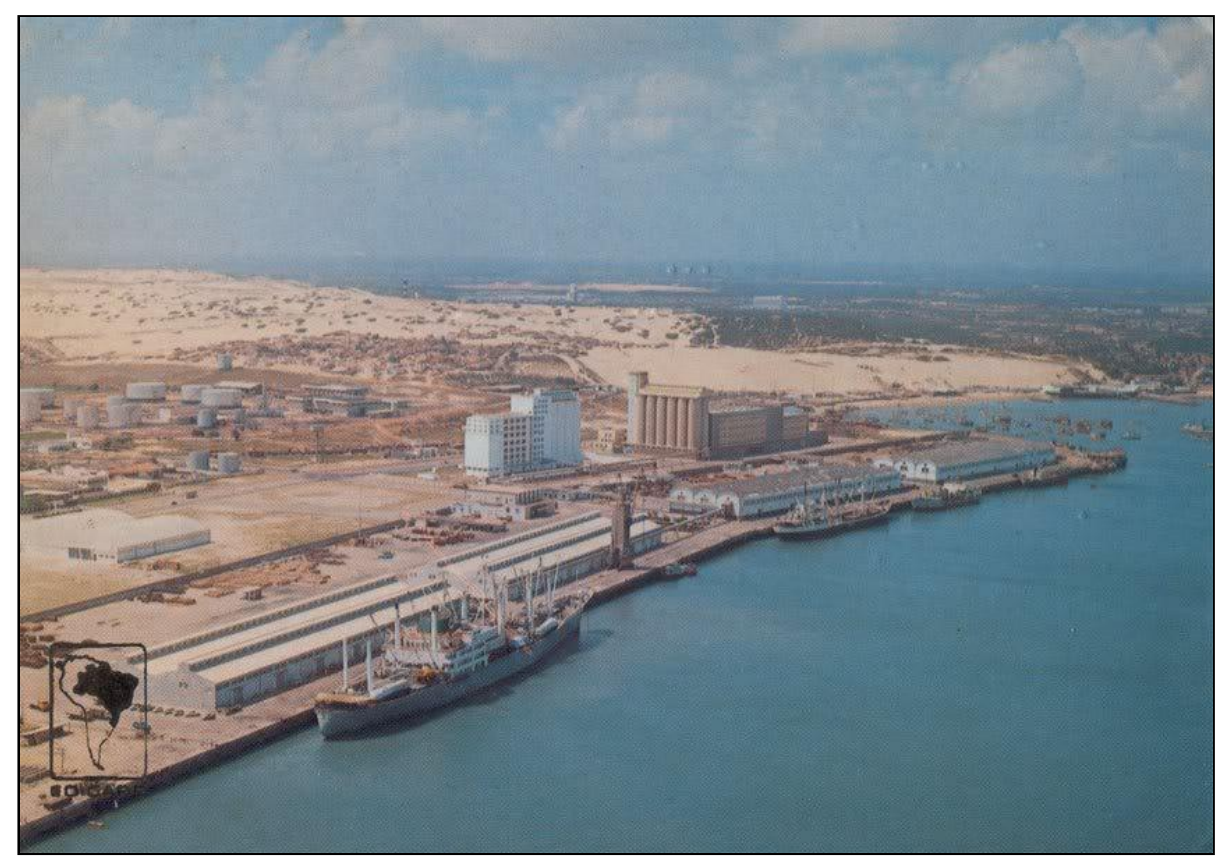

Fig. 2.50 O Porto do Mucuripe nos anos 1960. Vê-se os moinhos de trigo, ao centro, a fábrica de asfalto e o terminal de combustíveis, à esquerda e os armazéns de carga e descarga e terminal de passageiros em primeiro plano. Fonte: skyscrapercity (http://www.skyscrapercity.com/showthread.php?t=774672 - 30/05/2012)

\subsubsection{O PLANDIRF: oposição entre a ênfase da integração metropolitana industrial à renovação urbana do centro.}

A Região Metropolitana de Fortaleza foi institucionalizada por decreto, conforme a Lei Complementar Federal $N^{o}$ 14/73, no contexto da nova orientação de organização 
territorial desenvolvida nos governos militares. Sua racionalidade tinha como base a criação das Regiões Metropolitanas brasileiras que consistia num projeto geopolítico de integração do território nacional e do desenvolvimento industrial, fundamentada em uma sociedade predominantemente urbana.

No início da década de 70, o Município de Fortaleza foi objeto de um plano de ordenamento físico denominado PLANDIRF ${ }^{11}$ - Plano de Desenvolvimento Integrado da Região Metropolitana de Fortaleza que abrangia nos seus objetivos, a adoção de medidas para reestruturação do espaço de assentamento e de expansão urbana fundamentada no investimento em infraestrutura. Assim, pretendia-se que estes investimentos proporcionassem o aumento da fluidez dos mercados e da força de trabalho, favorecendo a dispersão urbana e o crescimento do mercado imobiliário, de forma indireta.

O plano teve o mérito de organizar as informações técnicas que auxiliaram a delimitação da RMF como também a elaboração das ações necessárias à sua gestão metropolitana. Desse modo, foi criado pelo Governo do Estado a AUMEF - Autarquia da Região Metropolitana de Fortaleza, alinhada às diretrizes da Lei Complementar 14/73, que tinha como objetivo, criar uma entidade metropolitana responsável pelo planejamento de diretrizes e ações que alavancassem o desenvolvimento urbano, articulado à dinâmica econômica da região.

A atuação da autarquia foi considerada limitada e as estratégias propostas não se concretizaram como esperado. Destacam- se principalmente as obras viárias realizadas, tais como: a construção do anel viário, interligando todas as vias de penetração de Fortaleza e o alargamento das BRs 116 e 222, os dois principais portões de acesso rodoviário à Fortaleza.

Nesse período, a estratégia da estruturação metropolitana baseou-se fundamentalmente em fatores relacionados às políticas industriais da SUDENE, no contexto da industrialização nacional e na construção de conjuntos habitacionais financiados pelo BNH. No entanto, teve como efeitos colaterais o crescimento da periferia urbana com habitações precárias e a ocupação de trechos da faixa litorânea dos municípios vizinhos,

\footnotetext{
${ }^{11}$ Elaborado pelo consórcio SERETE S.A., S.S. Consultoria e Jorge Wilheim Arquitetos Associados entre os anos de 1969 e 1971.
} 
com habitações de segundas residências. Desse modo, afirma o papel de Fortaleza como polo urbano regional trazendo também repercussões na sua configuração intraurbana (PAIVA, 2011.p.92-96).

O PLANDIRF contrapôs a ênfase da integração metropolitana à renovação urbana do centro da cidade que se pautava na delimitação ainda mais restrita, nas possibilidades de intervenção que as apresentadas no Plano Diretor elaborado por Hélio Modesto em 1963. A não efetivação das proposições do plano anterior limita as intervenções do novo plano somente à perspectiva pontual, embora fossem precisamente demarcadas nas etapas de execução que orientavam as propostas contidas no plano.

No seu diagnóstico, o PLANDIRF se refere ao centro como um espaço carente de ajustes físicos e de funções. Ressalta a permanência do quadro desordenado entre vários fatores como a verticalização, o desequilíbrio entre espaços livres e construídos, a saturação dos conflitos de circulação e a evasão de funções que reforçava a centralidade, tais como a habitacional e a administrativa. Registra também que 54\% das repartições públicas localizadas no centro manifestavam interesse de mudança por razões de dificuldades de acesso, estacionamento e expansão. (FERNANDES, 2004, p.57)

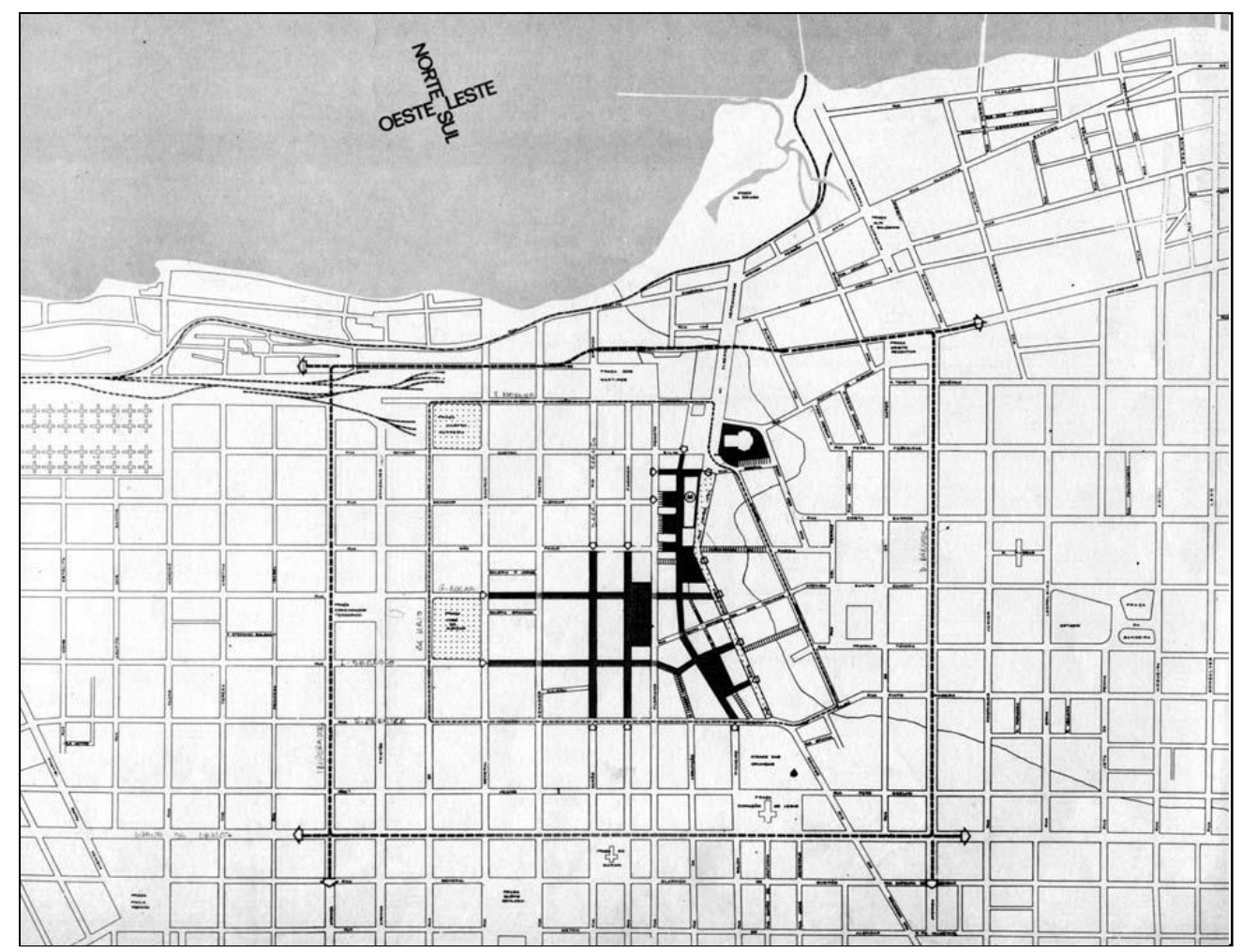

Fig. 2.51 PLANDIRF - 1971: Detalhes da $1^{\text {a }}$ etapa de renovação do centro urbano -. Implantação do circuito de pedestres. Fonte: FORTALEZA - PMF/SUPLAM, 1971. 
Fortaleza, no início da década de 70 , ainda polarizava no centro $2 / 3$ dos empregos urbanos e aproximadamente $70 \%$ do tráfego de passageiros (FORTALEZA PMF/SUPLAM, 1971). O fato de não mais abrigar as residências das camadas média e alta, como também a maior parte de seus espaços de lazer, fez da estrutura urbana central uma configuração de espaços voltados à função comercial, de trabalho e compras, a exemplo do que ocorreu com algumas das grandes cidades brasileiras, naquele período (VILLAÇA, 2001, p. 252).

Outro aspecto que marcou a configuração do centro de Fortaleza foi a concentração das atividades terciárias e do mercado formal e informal que reforçou as localizações residenciais das populações pobres nas vizinhanças abandonadas pelas camadas de alta renda que perdiam valor.

Fortaleza caracterizava-se, então, por uma estrutura urbana mono cêntrica cuja centralização mantinha-se forte pela insuficiência do desenvolvimento da economia urbana na periferia da cidade, consequência da limitada expressão alcançada, naquela época, pela industrialização nos limites da sua região metropolitana (FORTALEZA PMF/SUPLAM, 1971).

Este quadro reforçava-se no pequeno grau de extensão da rede de serviços urbanos, notadamente o saneamento básico e a pavimentação, como também na necessidade das populações pobres de residirem próximas ao centro em função da concentração das oportunidades de trabalho. Outros fatore influenciavam a mono centralidade: o incipiente desenvolvimento dos sub-centros comerciais da Aldeota, Montese e Parangaba e a facilidade de conexões dos bairros com o centro da cidade (FERNANDES, 2004, p.61).

A centralização das funções de administração das atividades primárias do interior do Estado, exercida por Fortaleza, reforçou seu caráter de cidade comercial, influenciando as funções externas de trocas regionais, como também a estruturação das atividades urbanas e do uso do solo em geral. A progressiva evasão de atividades comerciais do centro, verificada pela ocupação dos principais eixos de ligação da capital com o interior, confirma esta influência como tendência metropolitana e mantém a hierarquia viária baseada na configuração rádio-concêntrica. (FORTALEZA - PMF/SUPLAM, 1971). 
De modo complementar, as conexões permitidas pelas vias radiais com os anéis perimetrais, promoveram o preenchimento de vazios urbanos entre os corredores adensados, reduzindo a presença do tráfego de ligação no sentido leste-oeste do centro da cidade. Esta configuração contribuiu, de certo modo, para a ampliação da especialização funcional e diferenciação de fluxos no centro da cidade. Assim, as conexões entre o centro e a periferia se ampliaram, ao mesmo tempo em que as interligações entre bairros passaram, de modo progressivo, a utilizar aquelas vias que cruzavam a zona central (ver fig.2.52).

As políticas de estruturação do assentamento metropolitano tiveram como base, portanto, a ampliação das conexões do centro com a periferia favorecendo a instalação do Distrito Industrial em Maracanaú, Município vizinho ao Sul de Fortaleza, como também a construção de diversos Conjuntos Habitacionais na periferia oeste da cidade.

Estas medidas, complementadas pela oferta natural de empregos relacionados às atividades comerciais do centro, promoveram a concentração populacional naquela área, induzindo intervenções urbanas que modificaram a função de ruas e praças que passaram a abrigar terminais de transporte coletivo.

Como consequência das alterações relacionadas à expansão metropolitana, o Centro amplia sua especialização funcional como polo de comércio varejista, intensificando a presença das camadas sociais periféricas da cidade sustentada pela oferta de trabalho e complementada, por outro lado, pela ausência de estruturação urbana dos núcleos centrais dos municípios vizinhos. Desse modo, compromete o espaço público com intervenções emergenciais em favor do aumento da disponibilidade do transporte rodoviário de massa, fator que agravou os problemas de tráfego e poluição no perímetro central (FERNANDES, 2004, p.62).

Em 1975, o Município promove a elaboração de um novo Plano Diretor Físico que se consolida na promulgação da Lei de Uso e Ocupação do Solo de 1979, estabelecendo novas diretrizes para o desenvolvimento urbano de Fortaleza. Entre outras, o plano fundamentavam-se na verticalização e descentralização da cidade que proporcionaram a predominância dos mecanismos capitalistas de mercado para a produção do espaço de assentamento, com o apoio do investimento estatal, associado às forças econômicas vinculadas ao capital privado. 


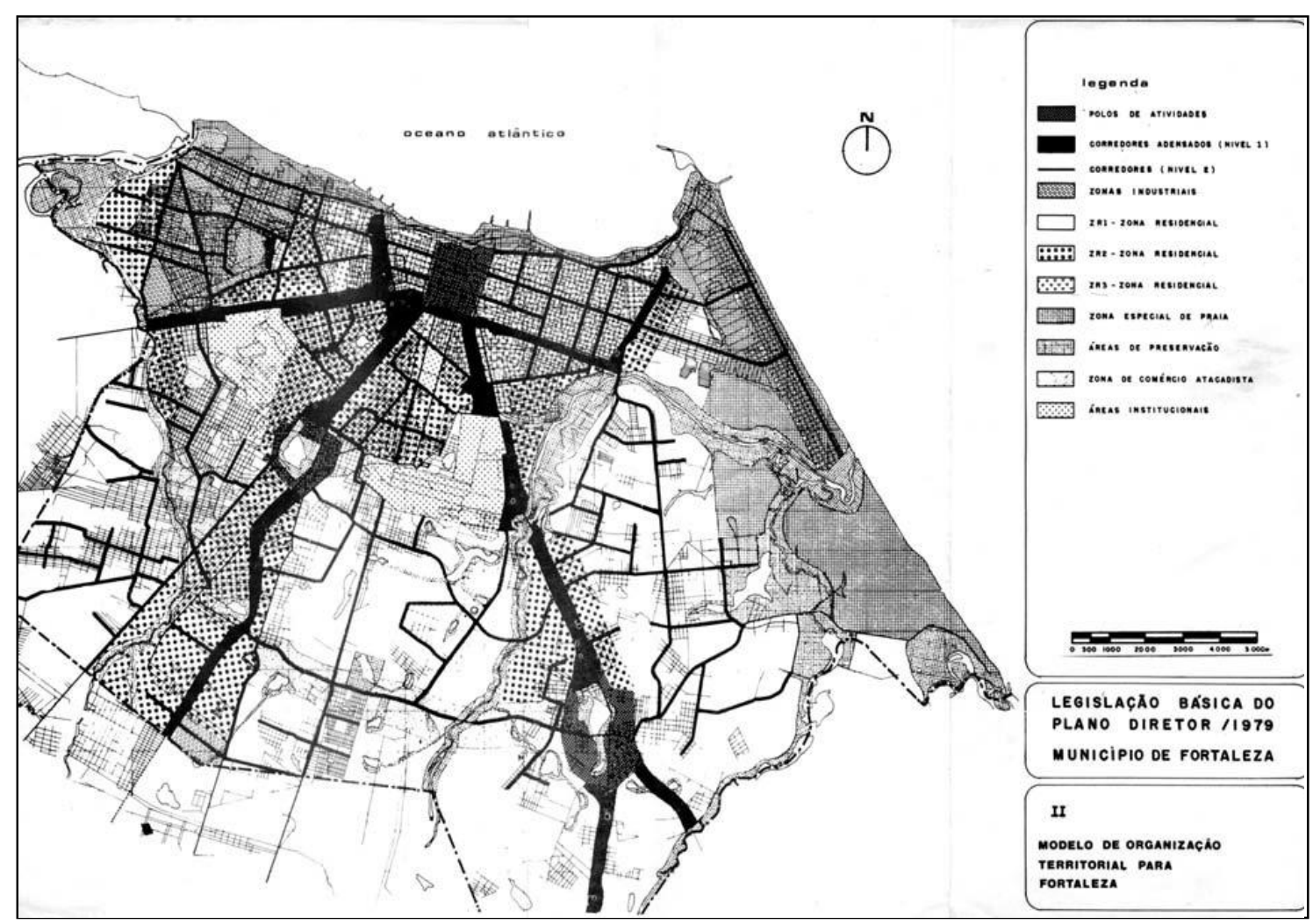

Fig. 2.52 Legislação Básica do Plano Diretor - 1979. Planta de estruturação urbana. Nota-se o destaque dado aos polos e corredores de adensamento ao longo das radiais Bezerra de Menezes, José Bastos e BR116 (em preto, da esquerda para direita) que vão intensificar a conexão com os municípios da RM de Fortaleza, reforçando seu caráter centralizador que marcará a sua especialização funcional de comércio metropolitano. Vê-se também o primeiro anel viário de contorno da área central. Fonte: FORTALEZA PMF/SUPLAM, 1979 (apud FERNANDES, 2004).

Assim, o Plano que pretendia também rever o quadro metropolitano, avaliando parte das diretrizes elaboradas no PLANDIRF, acabou inviabilizando a reestruturação equilibrada da cidade porque não conseguiu consolidar diretrizes importantes como o estabelecimento de uma nova escala adequada à manutenção das funções administrativas, de habitação e lazer das classes médias. Como consequência, essas lacunas resultaram na ausência de investimentos privados para a instalação de novos empreendimentos, inviabilizando também a efetivação de premissas importantes para a qualidade urbana como a preservação ambiental e a remodelação de espaços públicos. Também não conseguiu estimular outras iniciativas em favor da permanência dos fluxos heterogêneos das diversas camadas sociais, imprescindíveis à manutenção da qualidade espacial e do aumento qualitativo da diversidade de funções, capazes de sustentar a dinâmica econômica do Centro. (idem, p.63) 
A década de 1970, portanto, esboçava apenas algumas tendências de expansão do tecido urbano para além dos limites municipais de Fortaleza, materializados primeiramente pela instalação do Distrito Industrial de Maracanaú, ao Sul, seguido da construção de conjuntos habitacionais na periferia da cidade. De outro modo, fazia-se também pela ocupação de trechos da faixa litorânea dos municípios vizinhos com o fenômeno das segundas residências para as práticas de veraneio (PAIVA, 2011, p.88).
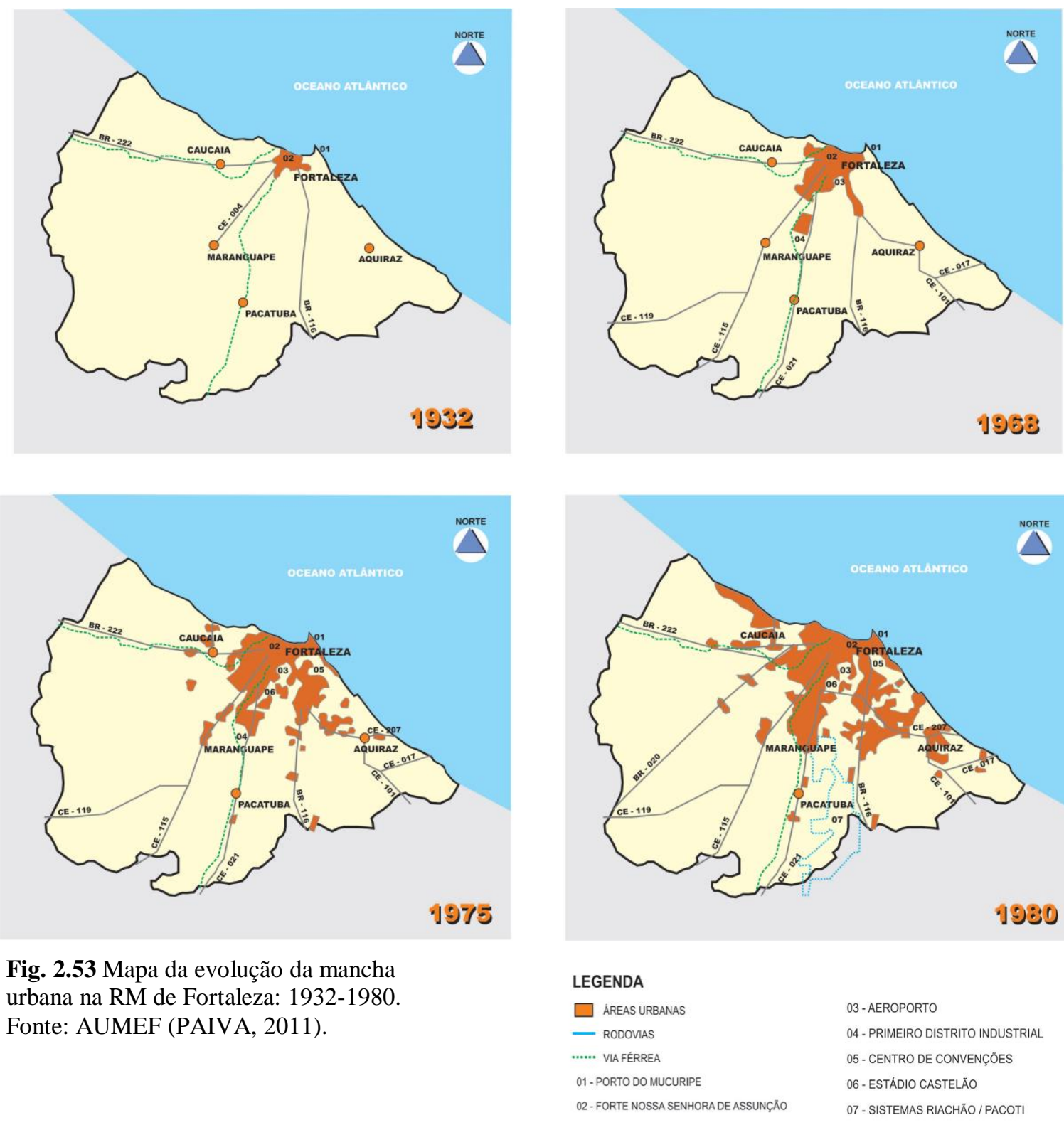

Fig. 2.53 Mapa da evolução da mancha urbana na RM de Fortaleza: 1932-1980. Fonte: AUMEF (PAIVA, 2011).

\subsubsection{A estruturação do sistema viário como base das atividades econômicas e o padrão metropolitano dos anos 1980.}

Os principais elementos que viabilizaram o início da estruturação metropolitana de Fortaleza foram, evidentemente, a constituição do seu sistema viário, com as alterações 
e acréscimos progressivos na infraestrutura ferroviária, rodoviária, portuária e aeroportuária.

Já falamos no primeiro bloco, como a construção do Porto do Mucuripe, na porção leste de Fortaleza, redesenhou profundamente a localização das funções intraurbanas, pelo fato de criar um novo vetor de expansão industrial no sentido leste, na mesma direção da expansão da dinâmica habitacional de alta renda. Com isso, configurou-se uma contradição ao desenvolvimento histórico da cidade, cuja tendência de crescimento verificava-se no sentido sul e oeste, onde suas ligações apontavam na direção do sertão, ao longo da malha ferroviária de traçado radial.

Embora essa contradição caracterize uma singularidade da estruturação urbana de Fortaleza, as malhas radiais Sul e Oeste, recebem progressivas mudanças que vão constituir a infraestrutura de transporte ferroviário e rodoviário de Fortaleza. Sobre esse tema Paiva, (2001, p. 96-99) desenvolve uma síntese que utilizamos como referência.

Assim, segundo o autor, o sistema ferroviário de Fortaleza permaneceu praticamente com o mesmo traçado consolidado historicamente no contexto da exportação do algodão. Apenas duas discretas ampliações por ocasião da criação do porto em 1940 e outra derivação ferroviária criada em 1941, a partir da antiga Estrada de Ferro de Baturité, permitiu a interligação do Bairro da Parangaba ao Mucuripe, viabilizando o escoamento de produtos comercializados pelo novo porto.

Dois trechos desta malha ferroviária inseridos na RMF acolheram o sistema de trem metropolitano para transporte de passageiros, composto por duas linhas: a Tronco Sul, que liga Pacatuba e Maracanaú ao Centro de Fortaleza, e a Tronco Norte, que liga Caucaia também ao Centro. A exceção ficou somente com o sub-ramal que conecta o Porto à linha sul, operando exclusivamente com cargas,

As linhas férreas cortando o município na escala metropolitana foram, portanto, a primeira infraestrutura preexistente que dinamizou os fluxos de pessoas e cargas entre a capital e os demais municípios vizinhos, sendo a responsável pelo início de um processo de conurbação urbana, mais visível nos municípios onde se localizam os grandes conjuntos habitacionais, como: Maracanaú, Caucaia e Pacatuba (fig.2.54). 


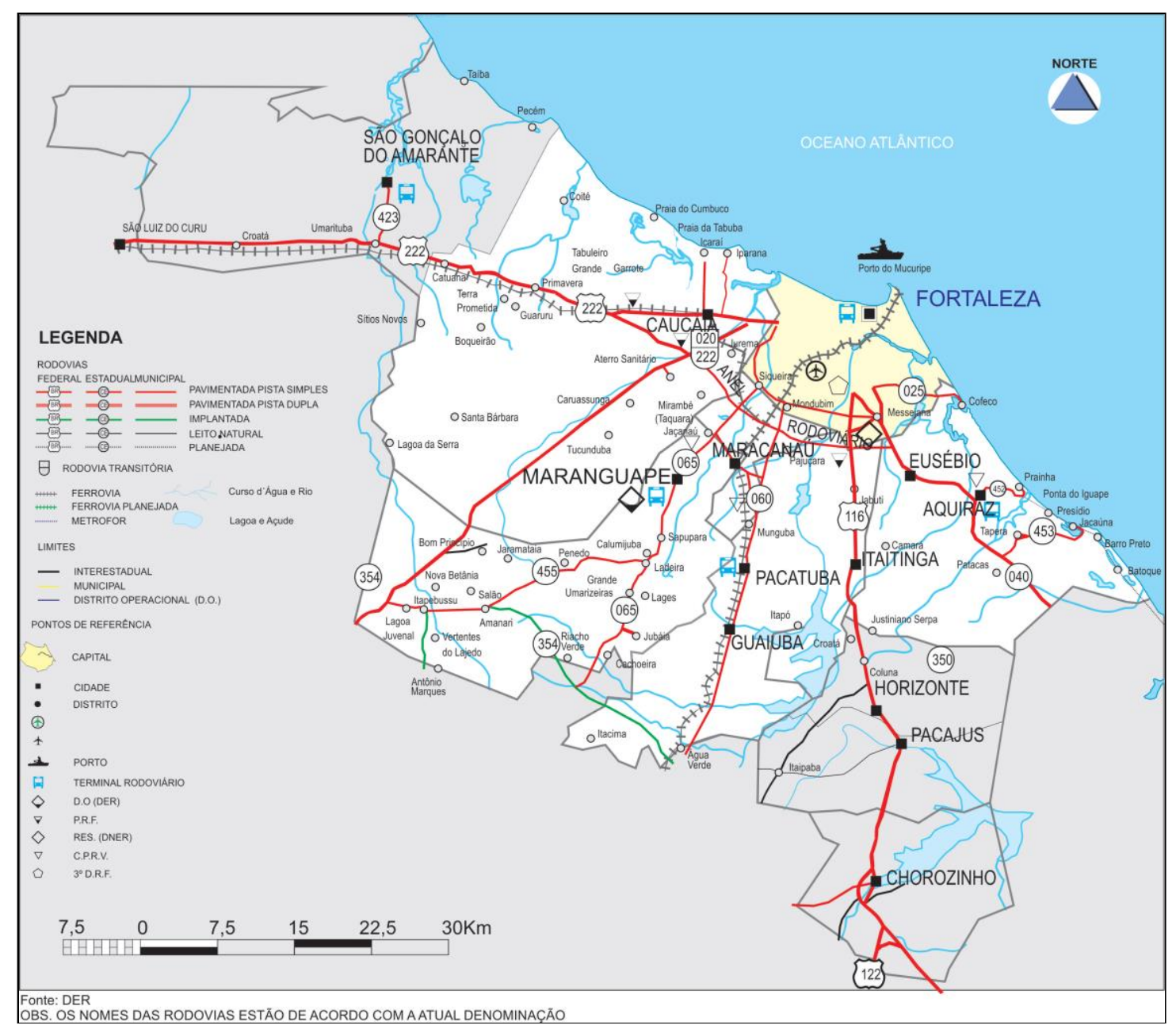

Fig. 2.54: Mapa RMF - Sistema Viário - Década de 1980

Fonte: Paiva, (2011- adaptado da base cartográfica DER - AUMEF - 1988).

Além do sistema ferroviário, as rodovias federais também tiveram papel importante no início da estruturação metropolitana, como a BR 116, interligando Fortaleza ao Sul do país e a BR 222 às cidades do Meio Norte, como Teresina e São Luís (Figura 2.54). Essas duas conexões principais atravessam o território metropolitano, aproximando ainda mais os Municípios vizinhos a Leste: Eusébio, Aquiraz, Itaitinga, Horizonte e Chrozinho (BR 116) e a Oeste: Caucaia e São Gonçalo do Amarante (BR 222).

Outra rodovia federal importante na escala metropolitana é a BR-020, que parte de Caucaia e se liga à Capital Federal, transformando-se no anel viário da RMF, conectando a CE-040 à BR-116, a CE-060, a CE-065 e BR-222. Essas rodovias federais são as mais importantes do sistema viário metropolitano e estadual por promoverem fluxos mais intensos e de abrangência nacional, justificando o fato de que a metropolização de Fortaleza tem motivação exógena e se insere no processo de unificação do mercado nacional. (PAIVA, 2011, p.96) 
As rodovias estaduais complementam o sistema viário de integração do espaço metropolitano: a CE 040 que parte da zona Leste de Fortaleza, segue na direção dos municípios litorâneos entre Fortaleza e Aracati (no extremo Leste do estado), passando por Eusébio, Aquiraz, Pindoretama, Cascavel e Beberibe ${ }^{12}$. Essa conexão vai conferir um importante papel na estruturação do fluxo turístico do litoral Leste, a partir dos anos 1990.

A CE 060 cruza Maracanaú e seu distrito industrial, chegando até Pacatuba no sentido sudoeste, correndo paralelamente ao sentido da CE 065 que conecta Fortaleza à Maranguape, cidade serrana, transformada em destino turístico cultural, de aventura e natureza que se articula com o roteiro turístico das serras úmidas, criado nos anos 1990, na região do Maciço de Baturité - Guaramiranga.

Essas vias estruturantes (federais e estaduais) são tão importantes que, ao passarem pela maioria das sedes dos municípios da RMF, constituem verdadeiros catalisadores do zoneamento dos municípios, concentrando a maioria das atividades de produção, distribuição e consumo, ligados à atividade secundária e terciária, ao passo que os arruamentos secundários tendem a abrigar as habitações. (PAIVA, 2011, p. 99)

O transbordamento da expansão econômica e urbana da capital para os demais municípios vizinhos foi, portanto, a força motriz da primeira fase de metropolização, caracterizada pela polarização absoluta de Fortaleza sobre os demais municípios que se apresentavam ainda em estágio inicial de desenvolvimento urbano. Nessa fase, esse transbordamento se deu também na oferta de habitação popular dos conjuntos habitacionais para as classes menos favorecidas, como também pela ocupação de loteamentos regulares e irregulares por habitações precárias na periferia da capital e nos municípios vizinhos.

De um lado, parece ter havido um planejamento consistente para o estabelecimento do distrito industrial que contava com boa acessibilidade e oferta de infraestrutura. No entanto foi precário o planejamento da integração urbana entre o distrito industrial e os Municípios que gravitaram em torno dele, especialmente Maracanaú e Fortaleza.

\footnotetext{
${ }^{12}$ Esses três últimos integrado posteriormente à RMF, não aparecem neste mapa.
} 


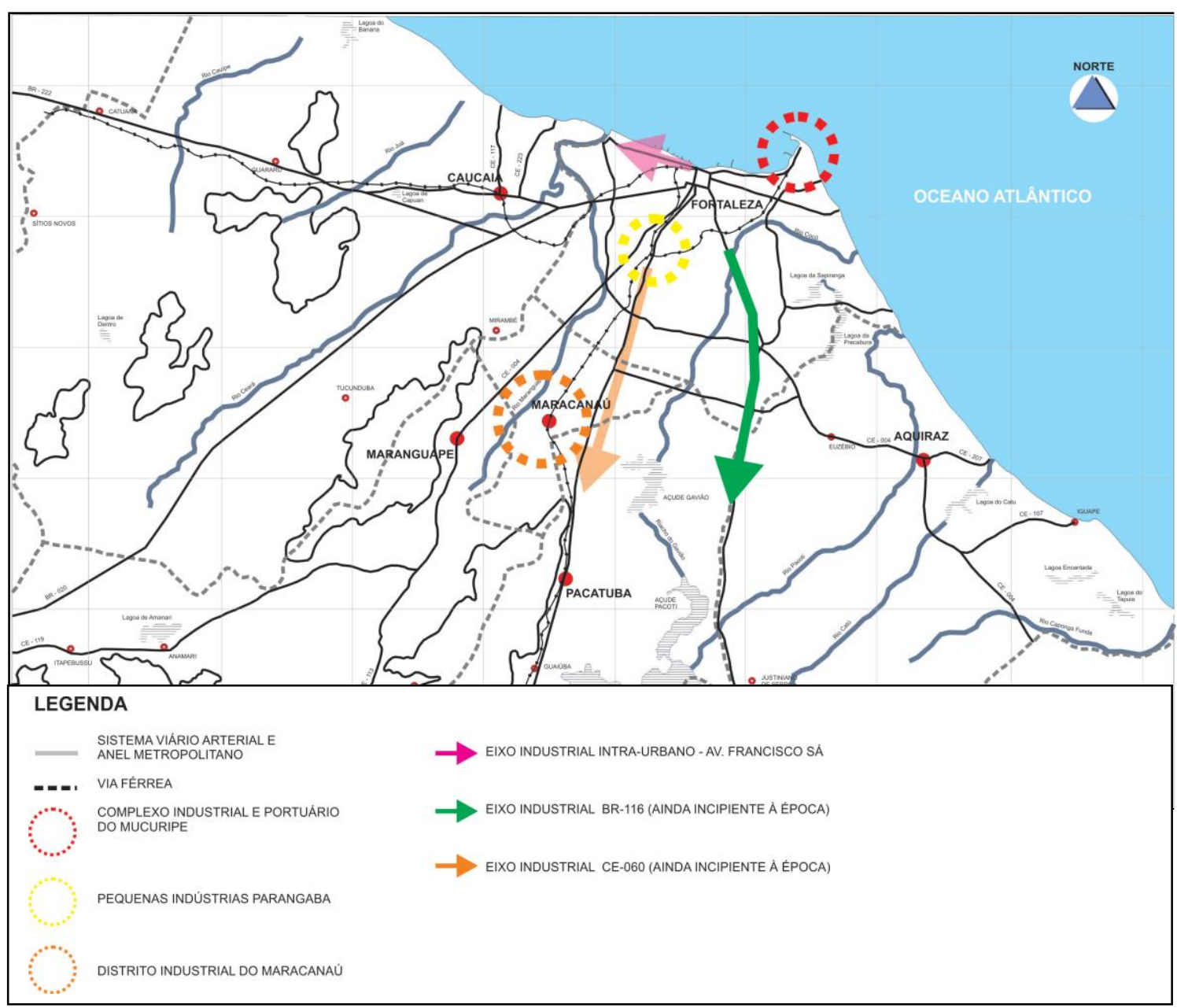

Fig. 2.55 O mapa da dinâmica Industrial da RMF na década de 1980 permite visualizar, sinteticamente a relação entre os eixos industriais e os corredores metropolitanos estruturantes.

Fonte: AUMEF - elaborado por Paiva (2011).

Além da dinâmica industrial, conjugada com a implantação da infraestrutura viária, outras dinâmicas interferiram no processo de metropolização de Fortaleza, de forma complementar: a dinâmica de comércio e serviços, que atua principalmente no interior do tecido intraurbano de Fortaleza, reforça a sua centralidade como polo metropolitano, complementada pela dinâmica habitacional. Esta última se desdobra em três dinâmicas específicas: a dos conjuntos habitacionais, conjugadas com o desenvolvimento periférico da cidade, no sentido Oeste e Sul ao longo dos eixos metropolitanos; a dinâmica da expansão habitacional das camadas médias e superiores de renda, no sentido Leste, ao longo dos corredores de adensamento e a última que se desenvolve de modo particular, no sentido paralelo à linha da costa: das habitações de segundas residências alinhadas ao processo de urbanização litorânea. Como vimos na primeira seção, essa dinâmica se modifica com o desenvolvimento do turismo e será tratada em detalhes, no próximo capítulo. 

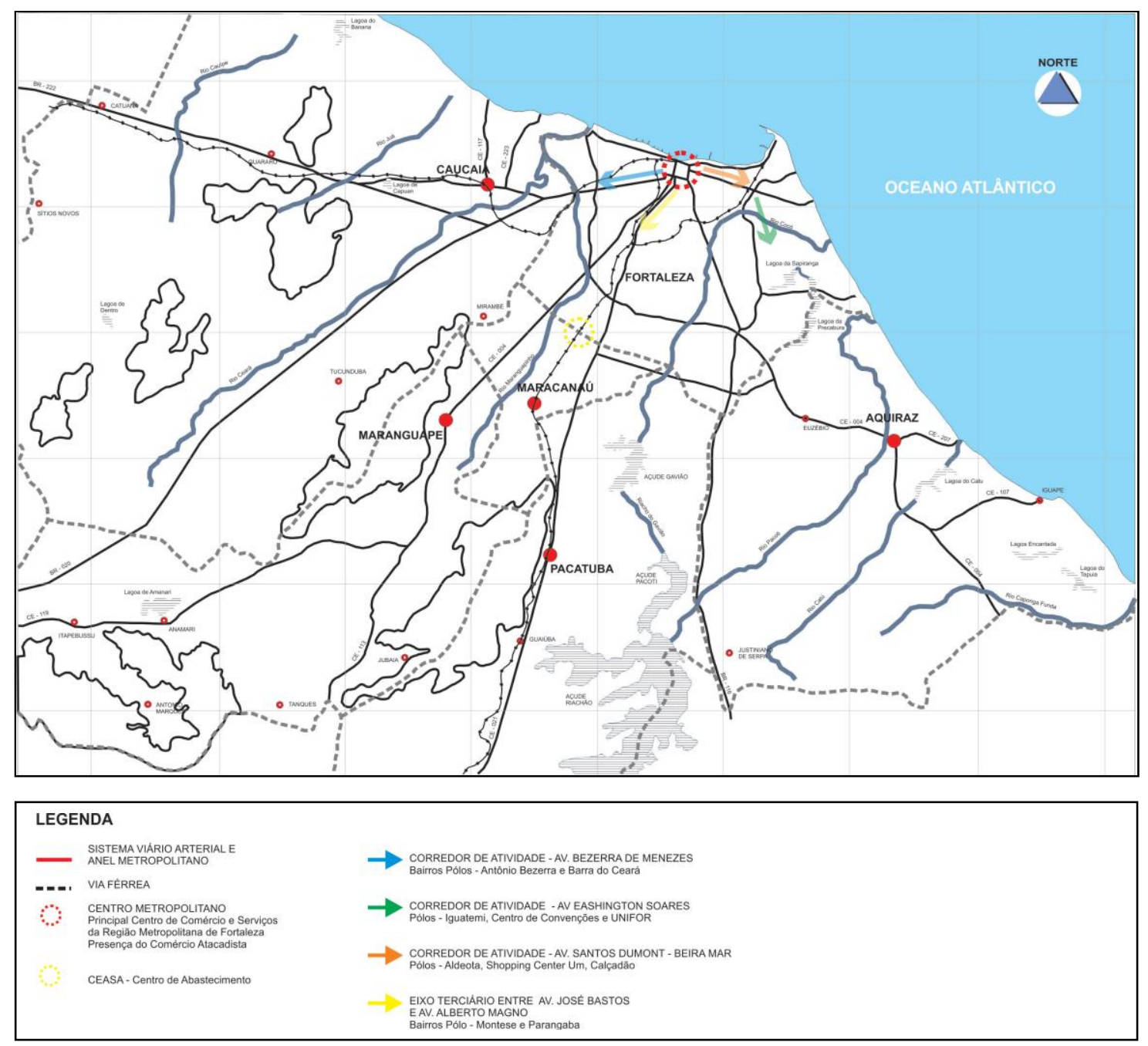

Fig. 2.56. Mapa RMF - Dinâmica Terciário - Década de 1980 Fonte: AUMEF - Elaborado por Paiva (2011).

Não é nosso objetivo, no momento, aprofundar sobre os detalhes do processo de metropolização de Fortaleza, falando de suas características particulares, como: a ocupação rarefeita entre os eixos rodoviários; a escassa integração radial; o papel do "novo" distrito industrial de Maracanaú na urbanização do seu entorno ou a dificuldade de articulação entre o sistema ferroviário e rodoviário criando barreiras na expansão entre bairros. Isso, porque o foco da pesquisa está voltado apenas para uma das dinâmicas mencionadas. No entanto, julgamos importante compreendê-la também no conjunto do contexto de Fortaleza, uma vez que é de lá que partem as suas motivações principais.

Nosso objetivo nesse bloco, portanto, foi caracterizar em linhas gerais o padrão de metropolização entre as décadas de 1960 - 1980 que se confunde em parte com a 
estratégia de implantação da infraestrutura para o desenvolvimento industrial e o consequente fluxo gerado pelas dinâmicas econômicas e demográficas que marcaram o modelo de planejamento dos governos militares.

\subsubsection{Reestruturação produtiva no Ceará contemporâneo e as consequências na RM de Fortaleza}

O processo de reestruturação produtiva, iniciado no final da década de 1970, nos países capitalistas centrais impulsionou transformações significativas em boa parte do mundo. No Brasil, somente depois da transição dos governos militares para o processo de redemocratização nas décadas de 1980 / 1990, foi possível o alinhamento da economia brasileira às ideias e práticas neoliberais que dominavam o mundo depois do presumido "triunfo" dos princípios inspirados no consenso de Washington.

Entre as medidas criadas pelo governo brasileiro para atingir esse alinhamento, destacaram-se: as diversas alterações na política macroeconômica para a estabilização da moeda; a redução do papel do estado intervencionista e a desregulação do mercado financeiro; as privatizações das empresas estatais e o fim da reserva de mercado, entre outras. Seu objetivo era garantir a abertura da economia (e do mercado) brasileiro ao cobiçado circuito global e ao desejado ingresso de capital estrangeiro, acompanhada pelo abandono progressivo das antigas políticas industriais de desenvolvimento nacional: tudo isso para conseguir inserir o país no processo contemporâneo de expansão do capitalismo.

A incorporação de novos territórios à lógica de acumulação do capital, baseado na descentralização do processo produtivo, como também no incremento de atividades terciárias - em particular na ampliação do turismo mundial - criaram as condições para impulsionar a competição entre cidades, contribuindo para ampliar as relações sociais em escala global.

No âmbito brasileiro, houve uma discreta descentralização industrial, a partir da década de 1970, condição necessária para garantir o processo de acumulação do capital nacional. Tal processo verificou-se, primeiramente, no próprio estado de São Paulo, onde as indústrias começaram a migrar da metrópole para o interior, movidas pela perda 
de competitividade das vantagens locacionais e, num segundo movimento, na direção das capitais regionais, como foi o caso do novo ciclo de industrialização no Ceará.

Embora houvesse um movimento de esvaziamento e descentralização industrial nas grandes capitais, marchando em direção ao interior, manteve-se ainda a posição de São Paulo como polo industrial dominante, assegurada pelas novas condições do capitalismo contemporâneo, no gerenciamento do capital industrial e financeiro, como também das atividades que avançaram no contexto nacional (SCHIFFER, 2004).

No âmbito regional, a obsolescência das antigas agências de desenvolvimento ${ }^{13}$ motivadas pela relativa ineficiência no objetivo de diminuir as desigualdades interregionais, colocou o Nordeste em posição vulnerável aos ajustes da economia nacional diante do processo de globalização da economia e mundialização das finanças. Essa condição se deve às desigualdades preexistentes, motivadas pelo baixo potencial tecnológico, pela permanência dos processos produtivos tradicionais, como também pela baixa qualificação da mão-de-obra.

No entanto, novos pressupostos acompanhados de novas estratégias de desenvolvimento econômico nos Estados e Municípios do Nordeste se apoiaram em antigos instrumentos utilizados na época da política industrial da SUDENE, tais como: os incentivos fiscais, os investimentos em infraestrutura e o acesso à mão-de-obra barata, diferenciando-se apenas pelo maior engajamento dos governos locais em função de uma política regional mais articulada, diante do esvaziamento das ações do âmbito federal.

\subsubsection{Aspectos políticos no processo de reestruturação produtiva do Ceará contemporâneo: o Governo das Mudanças}

No caso do Ceará, as alterações no processo de reestruturação produtiva neste período, aparecem relacionadas às transformações políticas, econômicas, sociais e culturais implementadas pela ascensão de um novo grupo político que propôs não só uma mudança na forma de gestão pública mas, sobretudo, a definição de um novo projeto político para o Estado, moldado pela elite empresarial local, polarizada pelo CIC Centro Industrial do Ceará $^{14}$.

\footnotetext{
${ }^{13}$ SUDENE E SUDAM

${ }^{14}$ Nesse contexto, Tasso Jereissati foi considerado a figura ideal para dirigir o CIC e liderar o projeto político utilizando o seu sucesso pessoal para incorporar o espírito renovador dos jovens empresários.
} 
Uma vez instalado no centro do poder político estadual, o novo governo pôs em prática medidas de saneamento administrativo da máquina estatal, com uma minuciosa contenção de despesas e uma rigorosa política de enxugamento do quadro de pessoal, marcada pela demissão de funcionários "fantasmas", suspensão de contratos e o congelamento de salários dos servidores públicos (BOTELHO, 1994, p.74).

O primeiro plano de governo, denominado de Plano de Mudanças - (1987-1991), não apresentava grandes diferenças dos planos dos governos anteriores e partiu de um diagnóstico que revelou a precariedade da economia e dos indicadores sociais. Nas diretrizes econômicas e sociais priorizava no setor primário: a reforma agrária, a agricultura irrigada e a piscicultura; no setor secundário: grandes projetos industriais como refinarias de petróleo, usinas, micro e pequena empresa, agroindústria, mineração e artesanato; e no setor terciário destacava-se o turismo com vistas a intensificar o fluxo de visitantes e a infraestrutura de transporte, energia e telecomunicações. (LIMA, 2000, p. 329 apud PAIVA, 2011).

$\mathrm{O}$ aumento da receita foi outro aspecto que permitiu a recuperação das finanças públicas através da modernização e racionalização do sistema de arrecadação através da informatização, da reestruturação organizacional e reformulação do aparato legal e tributário. Combateu-se o nepotismo e o empreguismo, típicos dos regimes patrimonialistas mas, por outro lado, utilizou-se de modo mais intenso a contratação de mão-de-obra sem vínculo empregatício, recorrendo a serviços de consultoria externa e de locação de mão-de-obra, evidenciando um forte processo de "terceirização" no setor público (GONDIM, 2000, p. 421).

Pode-se apontar, como um dos fatores de êxito dos "governos das mudanças", o crescimento da economia cearense, com o apoio do setor público. Apesar de compartilhar com o neoliberalismo a preocupação com a austeridade financeira e fiscal, as administrações de Jereissati (1987-1990, 1995-1998 e a iniciada em 1999) e de Ciro Gomes (1991-1994) realizaram uma agressiva política de atração de investimentos, lançando mão de incentivos fiscais e de estratégias de place marketing. Em consequência, o Ceará tem recebido vultosos investimentos, nos setores têxtil, de calçados e outros. Continuando uma tendência verificada em anos anteriores, o Produto Interno Bruto cearense tem crescido a taxas mais elevadas que as do PIB do Brasil: 3,55\% contra 1,18\%, respectivamente, no período de 
1985/1990 (Ferreira, 1995, p. 159). Persistem, no entanto, elevados índices de pobreza e concentração de renda na Região Metropolitana de Fortaleza: nesta, o índice de Gini $(0,62)$ indica a pior situação, entre as Regiões Metropolitanas pesquisadas pelo IBGE em 1996. (GONDIM, 2000-a, p.2)

O primeiro mandato garantiu a continuidade do mesmo grupo político e foi somente no governo seguinte ${ }^{15}$ que o executivo passou a contar com a maioria na Assembleia Legislativa do Estado para implantar, com maior desenvoltura, as propostas da nova política de "Mudanças". O segundo mandato foi marcado também por uma forte utilização do marketing como forma de promover a imagem positiva do Estado e da sua nova administração para o resto do país. Com isso, enaltecia os investimentos governamentais voltados para a infraestrutura turística, como também para o novo ciclo de industrialização do Ceará (BERNAL, 2004, p. 58).

O Plano de governo (1992-1995) denominado Plano Plurianual tinha como objetivo dar continuidade às ações anteriores e coincidiu com o início das práticas neoliberais no Brasil. O plano orientava a interiorização das atividades econômicas e propôs alternativas para enfrentar os problemas relacionados com o convívio com o semiárido, buscando a diversificação da agricultura com técnicas de irrigação. No setor industrial propôs a modernização do parque existente e a introdução de setores de ligados à tecnologia da informação no intuito de diversificar as atividades e torná-la competitiva. Com relação ao turismo, elaborou uma política para o setor baseado, entre outras diretrizes, na atração de investimentos privados através da implantação de infraestrutura.

Os governadores se revezaram, desse modo, em mais dois mandatos (sendo o último uma reeleição), garantindo um espaço ininterrupto de quatro períodos executivos seguidos, num total de 16 anos, quando em 2003 assume um novo governador ${ }^{16}$. Embora fosse o candidato do mesmo partido e mantendo, em linhas gerais, as mesmas diretrizes das experiências acumuladas no período anterior, ele rompeu com o grupo de origem para se alinhar ao novo governo federal que assumia o poder.

\footnotetext{
${ }^{15}$ Comandado por Ciro Gomes, candidato indicado pelo governador anterior.

${ }^{16}$ Assume o governo Lúcio Alcântara, político tradicional e ex-prefeito de Fortaleza (1979-1982).
} 
A consolidação dessa continuidade política Entretanto, foi mediada também por um movimento formulado por empresários, intelectuais e o governo, conhecido como " $\mathrm{O}$ Pacto de Cooperação", transformado em instrumento político voltado para a necessidade de repensar e reestruturar a economia cearense. Assim, pretendia se ajustar ao novo cenário mundial, respondendo às novas exigências do desenvolvimento que não cabiam mais dentro do paradigma de administração fordista (PARENTE, 2000).

A criação dessa nova hegemonia política, acompanhada de uma reestruturação capitalista, segundo Meneleu Neto (2000), reflete a ascensão da nova elite que se fundamentou na ideia de que a regulação centralizada do Estado-Nação deveria ceder espaço para os novos interesses regionais. Para isso, apoiou-se na crítica ao modelo da tecno-burocracia estatal ligada ao regime militar, na crítica à restrição do liberalismo econômico, como também na defesa da acumulação industrial, difundida pelo Centro Industrial do Ceará.

Assim, no Ceará, a nova configuração do aparelho de Estado ter-se-ia mostrado sincrônica à lógica da reestruturação produtiva pela incorporação do ideário hegemônico do mercado, onde a intervenção estatal dar-se-ia no sentido de apoio à acumulação privada, isto é, considerando os interesses dos capitais particulares (BERNAL, 2004, p58).

No contexto posterior a ECO 92 foram elaborados dois planos de governo que buscaram incorporar ao seu conteúdo os novos princípios de sustentabilidade, em voga. No primeiro, denominado Plano de Desenvolvimento Sustentável - (1995- 1998) o conceito foi incorporado juntamente com os princípios de planejamento estratégico empresarial, valorizando a parceria pública-privada, o marketing político e a participação popular, conferindo uma imagem de modernidade e democracia. Em síntese, o plano adotou três vetores estratégicos de desenvolvimento: a Indústria, o turismo e a agricultura irrigada. No entanto, figurava como objetivo central a melhoria de qualidade de vida dos cearenses, através de sete diretrizes principais: proteção do meio ambiente; reordenamento do espaço; capacitação da população; crescimento da economia; redução das desigualdades; desenvolvimento cultural, científico e tecnológico e melhoria da gestão pública. 
O segundo plano de governo (1999-2002) apenas deu continuidade ao anterior embora tenha sofrido, nessa época, os impactos das crises econômicas do contexto nacional e internacional evidenciando a fragilidade do Estado diante das implicações impostas pela economia globalizada que determinavam a definição de novos critérios de atração de investimentos. Nesse momento, a economia do Estado chega ao seu pior desempenho, abalando a credibilidade e a hegemonia do grupo político.

O mandato seguinte de (2003- 2006) ${ }^{17}$, como já mencionamos, pode ser considerado como uma continuidade dos planos anteriores cujo governador deu sequência às diretrizes anteriores, embora rompendo como o partido em busca do apoio do governo federal que acabara de mudar sua orientação política ${ }^{18}$.

Não é justo deixar de reconhecer as importantes transformações estruturais ocorridas tanto nas práticas econômicas como nas práticas políticas no Ceará, promovidas pelos seguidos "Governos das Mudanças". Entretanto, a ideia de reversão profunda do quadro social, acompanhada de uma ruptura política e econômica deve ser relativizada.

Não se quer aqui minimizar o alcance das mudanças ocorridas na política cearense com a ascensão ao poder dos "jovens empresários". Pelo contrário, considera-se que o modelo de gestão implementado por Tasso Jereissati e por Ciro Gomes constitui, de fato, um passo irreversível para a superação do clientelismo patrimonialista e, portanto, para a criação de condições necessárias (ainda que não suficientes) ao exercício dos direitos de cidadania. Entretanto ao restringir as transformações da administração pública à adoção de mecanismos para garantir a eficiência financeira, aliados a rearranjos na estrutura formal e a uma política de pessoal moralizadora, porém autoritária e pouco inovadora, os "governos das mudanças" perderam a oportunidade de realizar uma verdadeira reforma no Estado. [...] Mas tal modelo, precisamente por ser capitalista e por implementar-se num contexto de desmobilização política dos trabalhadores e movimentos sociais, não perde o seu caráter excludente. Assim, apesar do expressivo crescimento da economia cearense e da modernização dos métodos de gestão pública, permanece longínqua a meta de "acabar com a miséria absoluta" no Ceará. (GONDIM, 2000, p.423)

$\mathrm{Na}$ verdade, as questões estratégicas ligadas à modernização no Estado do Ceará remontam à década de 1960, por ocasião do primeiro governo de Virgílio Távora,

\footnotetext{
${ }^{17}$ Mandato de Lúcio Alcântara

${ }^{18}$ Coincidindo como o primeiro mandato petista no governo federal.
} 
viabilizadas também pela criação da SUDENE e pelas ações dos planos governamentais que se sucederam. Esse modelo priorizava o desenvolvimento econômico a partir da industrialização, utilizando-se de modelos e práticas, em alguns aspectos, muito semelhantes das ações contidas nos planos dos "Governos das Mudanças".

A ruptura parece ser, no entanto, um ajuste às mudanças de ordem internacional e nacional devido às novas determinações impostas pela globalização. Desse modo, a ruptura se manifesta a partir do discurso modernizador por parte da nova elite política, que projetou naquele momento, a nova imagem midiatizada do Estado e por consequência relacionada com a imagem dos novos governantes. Assim, "a imagem do Ceará foi celebrada, em função da projeção nacional do exemplo de administração moderna, contrária à representação cristalizada ligada ao coronelismo e à seca“" (PAIVA, 2011, p.114).

Um aspecto marcante no período do "governo das mudanças" foi o uso intensivo, tanto pela administração estadual como também pela municipal, de estratégias de marketing político, que buscavam reforçar a atratividade da cidade e do Estado para os investimentos nos setores turístico e industrial. O marketing, no entanto, não foi a única estratégia, no processo de reconstrução da imagem do Estado e da Cidade, uma vez que a mídia é onipresente na gestão urbana e na política eleitoral, no Brasil e em outros países.

Mais importante, quando se trata de explicar a construção simbólica da "moderna" Fortaleza, são as intervenções urbanísticas executadas, a partir dos anos 90, pelas administrações estadual e municipal. Essas obras constituem, na verdade, um elemento na disputa política e eleitoral entre o grupo que, controla o governo estadual, e o outro, pertencente à base de sustentação política do governo que naquele momento ascende ao poder na Prefeitura Municipal de Fortaleza desde $1990{ }^{19}$ (GONDIM, 2000-a, p. 1).

No entanto, as estratégias de marketing foram utilizadas como instrumento de promoção do turismo e da indústria, através da atração de investimentos para o estado no modelo proposto pelo planejamento estratégico, contrapondo-se as dificuldades impostas pelo rigor climático que sempre condicionou o quadro socioeconômico do Estado. Essa

\footnotetext{
${ }^{19}$ Trata-se do prefeito Juracy Magalhães que assume a prefeitura de Fortaleza quando Ciro Gomes renuncia ao cargo de prefeito de Fortaleza, para assumir o governo estadual.
} 
condição era reforçada em razão das limitadas ações de combate à seca e a persistência do quadro de desigualdade social, tanto no âmbito regional como no nacional, sobretudo no aspecto da superioridade econômica da Região Metropolitana de Fortaleza sobre os demais municípios do Ceará.

A modernidade e ruptura que o "governo das mudanças" associava a sua imagem política revelaram-se contraditória porque uma vez dentro da estrutura do poder do Estado, o grupo passou a manter as mesmas práticas políticas, tantas vezes combatidas nos discursos eleitorais, embora tenha havido importantes transformações na gestão pública e na estruturação do Estado.

A era do "Governo das Mudanças" parece se encerrar, apenas simbolicamente, com a ascensão de Cid Gomes ao Governo do Estado em 2007, quando este se alinha formalmente a base de sustentação do novo governo federal, enfraquecendo a hegemonia do seu grupo político de origem ${ }^{20}$, migrando para outro partido e formando uma nova composição de forças. No entanto, percebe-se uma grande semelhança nas estratégias utilizadas na promoção do desenvolvimento do Ceará, como também da manutenção dos mesmos projetos estruturantes do Estado. A diferença situa-se principalmente no alinhamento às políticas públicas polarizadas pelo governo federal, notadamente no campo da distribuição de renda e dos programas sociais de inclusão, diante da nova conjuntura econômica nacional e internacional.

\subsubsection{Aspectos socioeconômicos da reestruturação produtiva: alterações e permanências}

Tendo em vista que a nossa hipótese geral pressupõe a existência de um processo de reestruturação produtiva no Estado que atinge a RM de Fortaleza, consideramos importante avaliar inicialmente em que medida essas mudanças políticas no Ceará realmente apontaram para uma ruptura com o processo anterior, do ponto de vista econômico. Assim devemos indagar se esse processo demonstra o surgimento de novas relações que reflitam o amadurecimento de um estágio avançado no desenvolvimento econômico do Estado ou se são apenas resultados de uma simples acomodação dos movimentos do capital em busca de nova rentabilidade, na continuidade da tradicional concepção do modelo centro-periferia.

\footnotetext{
${ }^{20}$ Cid é irmão de Ciro e foi eleito prefeito de Sobral no auge do governo das mudanças.
} 
Sob esse prisma, Bernal (2004, p. 52) considera que as transformações que ocorrem na metrópole de Fortaleza, resultantes da reestruturação produtiva no âmbito estadual, devem ser interpretadas como fruto da liberação de fluxos de capitais e de comércio provocados pela reestruturação produtiva de alcance nacional e global, em sintonia com a mundialização financeira.

Assim, propõe explicar porque o Ceará resiste a um processo de estagnação submetido ao país - juntamente com o desaparecimento do planejamento regional e das políticas compensatórias - e porque a sua capital cresceu mais do que as outras capitais nordestinas na década de 1990, apesar da pobreza relativa da sua agricultura e da sua estrutura industrial ainda tradicional. Indaga também sobre as razões do surgimento desse novo ciclo de industrialização, localizados prioritariamente na RM de Fortaleza, como também sobre a emergência do turismo, com forte expressão no litoral do Estado, mas igualmente concentrado na sua região metropolitana.

Como ponto de partida, Bernal observa que a reestruturação industrial no Brasil, tomada como estratégia defensiva em busca de competitividade no início dos anos 1990, permitiu a reorganização territorial do capital, com a fragmentação das cadeias produtivas, disseminando para regiões mais pobres, como o Nordeste, as plantas industriais de menor conteúdo tecnológico, mas igualmente integrada aos mercados globais.

Suas considerações sobre a lógica desse novo ciclo de industrialização, no Ceará, levam, em última análise, a dois fatores fundamentais que caracterizam essa estratégia de atuação: o rebaixamento das condições de reprodução da força de trabalho, apoiando-se em mecanismos considerados não capitalistas como as cooperativas de trabalho $^{21}$ e de outro lado, os incentivos fiscais e financeiros, como: a isenção dos impostos e o financiamento do capital fixo ou de giro, além de empréstimos automáticos para a exportação.

Assim, para Bernal (2004, p.61) fica evidente que na ausência das políticas compensatórias para o Nordeste, o governo do Ceará elegeu a "guerra fiscal" como

\footnotetext{
21 Esta forma de organizar o trabalho flexibilizou a forma de contratação, evitando um vínculo direto entre a empresa e o empregado, onde a cooperativa era remunerada pela produção, substituindo os encargos sociais por uma alíquota de $15 \%$ do faturamento a título de despesas com o INSS.
} 
estratégia de atração de capitais privados, sob duas formas: primeiro, oferecendo incentivos fiscais e mão-de-obra barata para localização de novas indústrias oriundas de velhas áreas industriais do Sul e Sudeste que sofreram um processo de desindustrialização ${ }^{22}$ e segundo, investindo fortemente em infraestrutura como contrapartida para atração de recursos privados na implantação de um vigoroso polo turístico em Fortaleza e em pontos estratégicos no litoral do Estado

Esta política industrial prevaleceu até 2002, tendo passado por mudanças pouco significativas em 2003 quando houve tendência ao desaparecimento de novos benefícios, com a perspectiva de aprovação da reforma tributária que, entre outros objetivos, propõe acabar com a "guerra fiscal". Embora fosse utilizada pelos Estados menos desenvolvidos, face à inexistência de uma política de desenvolvimento regional mais efetiva, a guerra fiscal perdeu força como instrumento de redução das desigualdades regionais porque os Estados mais desenvolvidos também passaram a conceder benefícios. Assim, o governo federal começou a tratar a guerra fiscal como prática predatória para o país porque considera que ela tem levado a uma situação de anarquia tributária gerando insegurança para os investidores e prejudicando o crescimento do país como um todo.

Assim, Bernal esclarece que embora o Ceará despontasse como um dos mais dinâmicos Estados da região Nordeste, no período do "Governo das Mudanças", tal dinamismo é verificado em períodos anteriores, onde se destaca o intervalo dos anos 1970-1985. Foi nesse período que os governos militares implantaram uma ampla infraestrutura para dar suporte à moderna industrialização, incentivada através do FINOR e do sistema 34/18 da SUDENE (BERNAL, 2004. p. 65).

Na tabela 2.1, abaixo, vemos o crescimento do PIB industrial do Ceará, nos anos 1970 1985, comparado ao do período posterior. Temos também o total do Estado comparado com o do Nordeste e o do Brasil. É claro que na década de 1970 vivíamos o contexto do "milagre econômico" e no Nordeste, a fase de implantação das indústrias pelos incentivos da SUDENE. No entanto, mesmo nos anos 1980 o crescimento é

\footnotetext{
${ }^{22} \mathrm{O}$ conceito de desindustrialização é utilizado como a fragmentação de cadeias produtivas, isto é: no sentido de que diferentes plantas industriais podem ser deslocadas para lugares diferentes do território. Assim, não se trata do tipo de desindustrialização ocorrido nos EUA, por exemplo, nas cidades de Chicago, Detroit e Nova York, como resultado da reestruturação produtiva levada às últimas consequências, como a ruptura do modelo fordista (idem, p. 61).
} 
significativo. Note que em 2000-2001 o crescimento do PIB industrial $(-3,91 \%)$ é negativo e o total fica abaixo da média nacional, demonstrando uma tendência ao esgotamento do modelo adotado ao longo da década de 1990 (BERNAL, 2004, p.71).

TABELA 2.1

TAXA MÉDIA DE CRESCIMENTO ANUAL DO PIB

CEARÁ E NORDESTE (\%)

\begin{tabular}{lrrrrrr}
\hline Períodos & Agropecuária & Indústria & Serviços & Total & Total - NE & Total BR \\
\hline $1970-1975$ & 14,98 & 12,81 & 8,65 & 12,1 & 10,24 & 1,01 \\
$1975-1980$ & $-1,03$ & 17,06 & 13,03 & 9,61 & 7,24 & 0,76 \\
$1980-1985$ & 7,92 & 12,62 & 7,65 & 9,02 & 4,36 & $-0,18$ \\
$1985-1990$ & $-0,29$ & 5,76 & 3,57 & 3,84 & 2,62 & 2,11 \\
$1990-1995$ & 5,52 & 4,59 & 2,87 & 3,70 & 2,25 & 2,79 \\
$1995-2000$ & $-7,53$ & 5,31 & 3,23 & 3,07 & 2,89 & 2,84 \\
$2000-2001$ & $-13,99$ & $-3,91$ & 2,25 & $-1,08$ & 0,95 & 1,91 \\
\hline $1970-2001$ & 2,42 & 9,13 & 6,30 & 6,57 & 4,76 & 1,56 \\
\hline $1970-2003^{*}$ & 2,32 & 8,60 & 5,96 & 6,21 & 4,52 & 1,52 \\
\hline
\end{tabular}

Fonte: SUDENE - Boletim Conjuntural (até 1984) - IBGE - Contas Regionais (BERNAL, 2004).

(*) Dados IPECE

O período que se segue após os limites temporais analisados na pesquisa de Bernal ${ }^{23}$ é particularmente importante porque caracteriza o aprofundamento da efêmera estagnação econômica da economia estadual que começa entre 2000-2001, apresenta o seu pior índice em 2002 para, em seguida, ter uma discreta mudança a partir do ano seguinte, diferenciando-se do comportamento da economia no Brasil que se mantém baixa, mas não atinge níveis negativos.

Assim, o relatório da Conjuntura Econômica do Ceará no $1^{\circ}$ trimestre de 2003, aponta no Gráfico 2.1, abaixo, que o ano de 2002 ostenta o menor índice na evolução do PIB no primeiro trimestre de 2002, ao mesmo tempo em que é possível verificar, no ano seguinte, uma discreta reversão da tendência, ainda com taxa de crescimento negativo no primeiro trimestre de 2003.

\footnotetext{
${ }^{23}$ O período de análise do PIB vai até 2001 e entre 1970-2003 (*) os valores apresentados na Tabela 1 são baseados em dados provisórios levantados pelo IPECE, mas que confirmam a tendência de crescimento que foi verificada nos anos seguintes.
} 


\section{Gráfico 2.1 Evoluçāo do PIB trimestral - Ceará - $1^{\circ}$ trimestre/2003}

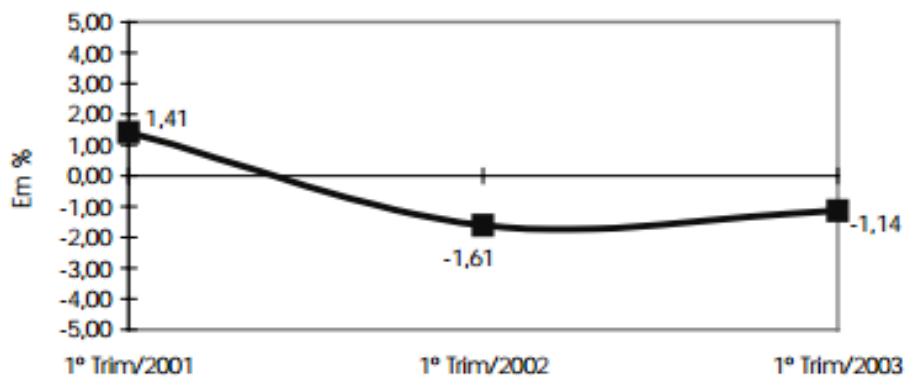

Fonte: IPECE e IBGE.

O que o Instituto de pesquisa argumenta como justificativa ao comportamento da queda no setor industrial é que o efeito deveu-se ao decréscimo verificado na construção civil com uma taxa de $-9,23 \%$, influenciando o índice como um todo, tendo em vista que esse segmento representa $42 \%$ do total da indústria cearense. Os demais segmentos industriais registraram taxas positivas, embora ainda baixas, sendo o de transformação apenas $1,25 \%$, o de extrativismo 3,13\%. Apenas o de eletricidade, gás e água apresenta taxas superiores, na ordem de 13,73\% (Gráfico 2.2).

Gráfico 2.2 Taxa de crescimento (\%) do PIB a preços básicos por segmentos industriais - Ceará $-1^{\circ}$ Trimestre/2003-2002

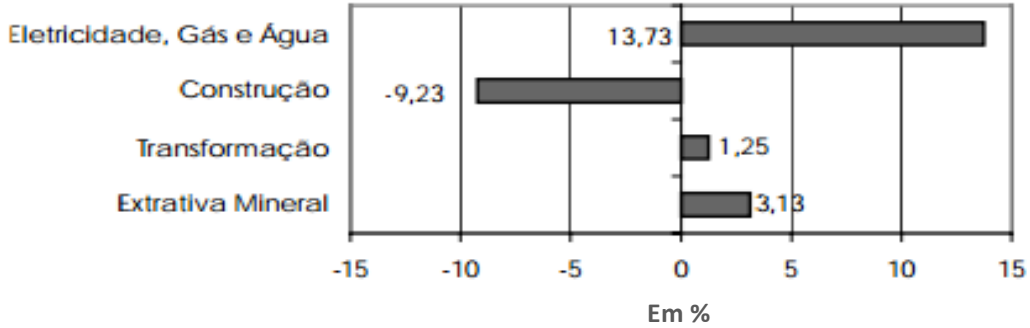

Fonte: IPECE.

Outo dado que demonstra uma visível instabilidade no comportamento da economia, nessa fase de transição, pode ser visto na Pesquisa Industrial Mensal (PIM-PF) /IBGE. Nos meses que se seguem ao primeiro trimestre, a indústria de transformação cearense registrou um aumento mensal na produção física de 3,17\%. No entanto, o indicador de 
abril/2003 sobre abril/2002, mostrou queda anual na produção industrial de $-5,47 \%$, superior à taxa de queda registrada para o Brasil, $-4,2 \%$.

Com esses resultados, a indústria de transformação cearense acumulou uma taxa anual negativa de $-0,54 \%$, (Gráfico 2.3) o que demonstra a tendência à desaceleração da atividade industrial entre 2002-2003 e o esgotamento do modelo de industrialização adotado. Isso acabou contribuindo com a perda da hegemonia do grupo político no poder, coincidindo também com as mudanças políticas no âmbito nacional.

\section{Gráfico 2.3 - Produção da indústria de transformação - Ceará - Abril/2003}

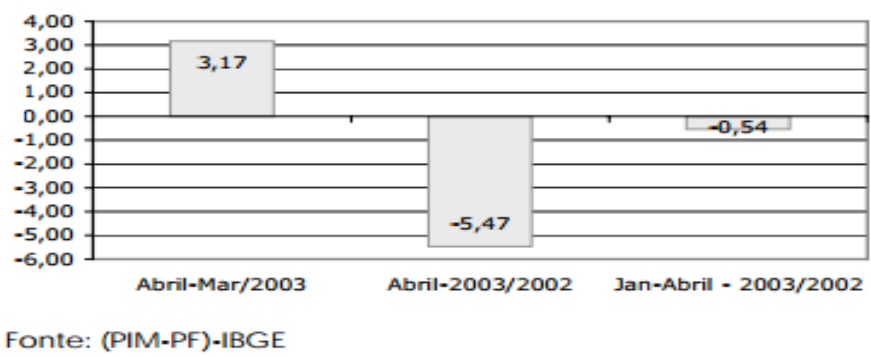

O que é relevante esclarecer nessa trajetória de depressão e posterior recuperação da economia cearense é que a queda da atividade econômica nesse período de instabilidade vai influenciar o quadro político dominante ao ponto de desestabilizá-lo. A partir dos anos seguintes, sobretudo, em 2004 ela se adequa ao novo quadro político nacional e segue o ciclo de crescimento dos anos posteriores acompanhando o crescimento da economia brasileira como um todo: como podemos ver no gráfico 2.4 , abaixo.

Gráfico 2.4 - Taxa de crescimento (\%) do PIB a preços básicos por indústria - Ceará - 2004

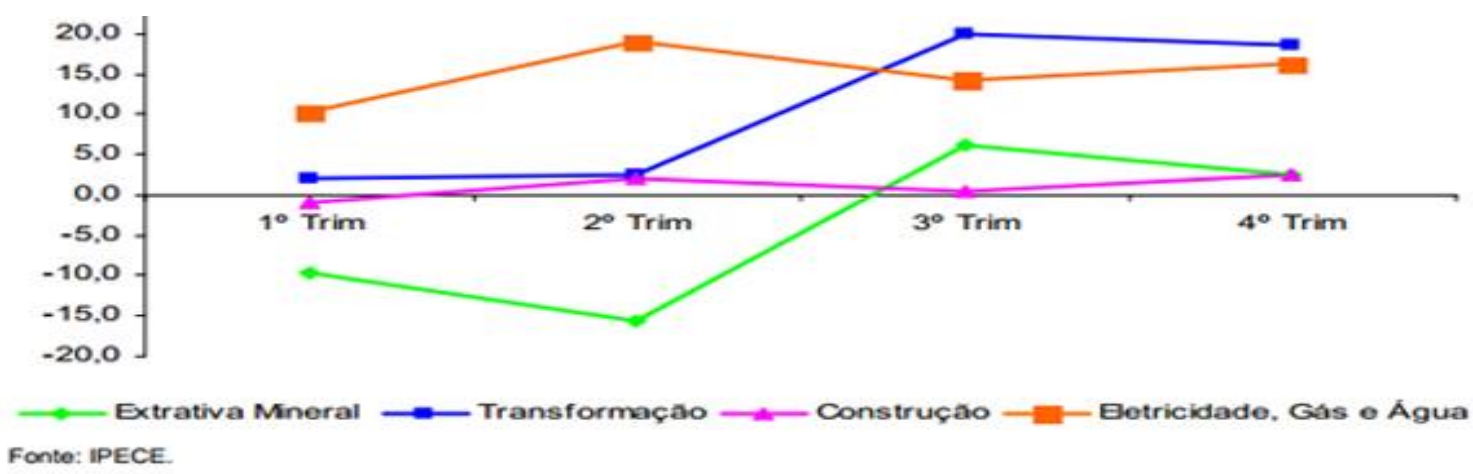


Nosso objetivo nesse segmento, portanto, foi destacar os aspectos políticos e econômicos relevantes que foram caracterizados por permanências e rupturas no processo de reestruturação produtiva no Ceará contemporâneo. Assim foi possível reconhecer que as bases que fundamentaram tal reestruturação foram, na verdade, iniciadas ainda nos anos 1960 com as políticas desenvolvimentistas que se estenderam até meados dos anos 1980. Por outro lado, o novo governo propõe uma primeira ruptura estrutural importante: a mudança do protecionista processo de substituição de importações fundamentado no planejamento governamental, para a estratégia de inserção da economia do Estado no circuito globalizado da economia, expondo-se às pressões do jogo de forças do livre mercado.

Os fundamentos que explicam as bases dessa reestruturação, portanto, combinam elementos de antigas permanências e novas rupturas. As irreversíveis transformações nas práticas políticas e econômicas, como também nos arrojados projetos estruturantes de desenvolvimento conviveram com a antiga opção de trabalhar com uma matriz produtiva dependente de baixos salários, convertendo-se num perverso modelo concentrador de renda. Assim, enquanto aumentava-se a taxa de crescimento do PIB, aumentava também os indicadores de pobreza.

Prova disso são os indicadores revelados pelo (IBGE-Metrodata, 2000) para a RM de Fortaleza, onde predomina "a faixa de $47 \%$ a $65 \%$ das famílias com renda per capita até 1/2 salário mínimo" (CUNHA \& PEDREIRA, 2008, p.158) ${ }^{24}$, denotando a permanência de um elevado nível de pobreza no território metropolitano. Entre outros fatores, os baixos indicadores sociais também acabaram arranhando a imagem do governo e da expectativa positiva que se tinha sobre os resultados socioeconômicos do novo modelo de desenvolvimento cearense.

\subsubsection{Aspectos socioespaciais da reestruturação produtiva na RM de Fortaleza}

Como vimos: a lógica de substituição de importações, reformulada depois dos anos 1990, adotou novas variáveis de desenvolvimento que redimensionaram os níveis de integração da metrópole, fundamentando-se numa lógica de industrialização, pautada na guerra fiscal, no rebaixamento dos salários e também na descentralização industrial.

\footnotetext{
${ }^{24}$ Em 1998 o IBGE registrava que 44, 6\% da população cearense recebia até 1/2 salário mínimo. (Fonte: IBGE 1998 - In Plano de Desenvolvimento Sustentável 1999-2002 do Governo das Mudanças)
} 
Pudemos verificar no balanço realizado pela Gazeta Mercantil (1999) que houve uma redistribuição espacial das indústrias no Ceará em diversos segmentos como: alimentos; autopeças; bebidas e fumos; editorial e gráfico; eletroeletrônico; energia; extrativismo vegetal; farmacêutico-higiene; informática e telecomunicações; madeira-móveis; mecânica; metalúrgica; não metálicos; químico e petroquímico; serviços gerais; siderúrgica; têxtil; couros e turismo (CUNHA \& PEDREIRA, 2008, p.16).

Entretanto, consideramos necessário refletir sobre a tese de descentralização da indústria, tendo em vista o redimensionamento da lógica de urbanização na escala da metrópole. É verdade que a implantação de indústrias no interior modificou o padrão de localização industrial do Ceará. Entretanto, se considerarmos avaliar a condição das indústrias de transformação, por exemplo, (Tabela 2.2) verificamos uma significativa concentração em torno de Fortaleza, com $47,77 \%$ do total. Esse percentual aumenta se considerarmos os cinco municípios da RMF com o maior número de indústrias (em verde) chegando a 58,6\%. Outras concentrações relevantes, só nos municípios de Juazeiro do Norte, Sobral, Iguatu e Crato que juntos chegam a 10,08\%. Os 31,32\% de indústrias restantes ficam distribuídos entre os 183 municípios do interior, denotando uma tendência a macrocefalia metropolitana no delineamento industrial do Ceará.

\section{Tabela 2.2 - Número de indústria de transformações ativas por município}

\begin{tabular}{|l|r|r|r|}
\hline \multicolumn{1}{|c|}{ Municípios } & \multicolumn{2}{c|}{ Total } & \multicolumn{1}{c|}{ Total } \\
\hline Ceará & \multicolumn{1}{|c|}{$\mathbf{2 0 0 8}$} & \multicolumn{1}{l|}{$\mathbf{2 0 0 9}$} & \multicolumn{1}{c|}{$\%$} \\
\hline Aquiraz & 12.660 & 11.805 & 100 \\
\hline Caucaia & 146 & 146 & 1,15 \\
\hline Crato & 445 & 445 & 3,52 \\
\hline Eusébio & 156 & 156 & 1,23 \\
\hline Fortaleza & 273 & 273 & 2,16 \\
\hline Iguatu & 6.041 & 6.041 & 47,72 \\
\hline Juazeiro do Norte & 201 & 201 & 1,59 \\
\hline Maracanaú & 706 & 706 & 5,58 \\
\hline Sobral & 513 & 513 & 4,05 \\
\hline Outros & 214 & 214 & 1,69 \\
\hline
\end{tabular}

Fonte: IPECE - Anuário Estatístico do Ceará- 2010

Atualizado pelo autor, baseado em CUNHA \& PEDREIRA, 2008. 


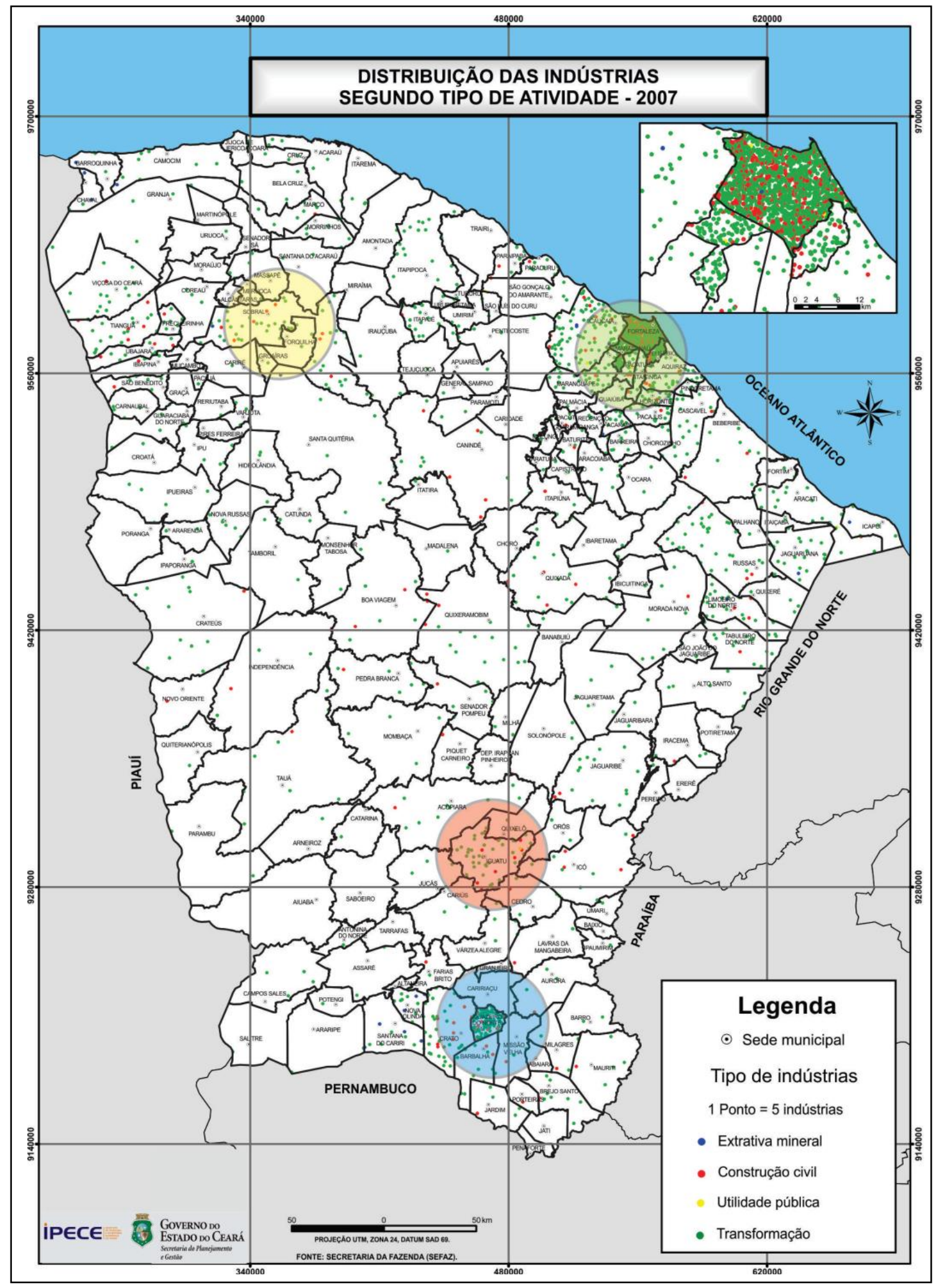

Fig.2.57 - Mapa da distribuição industrial segundo tipo de atividades - 2007.

Fonte: IPECE 
Nota-se, neste mapa elaborado pelo IPECE, a visível concentração industrial em Fortaleza como também na sua região metropolitana. Entretanto percebe-se o novo padrão de distribuição locacional das indústrias, agora dispersa em todo o Estado, identificando-se também o polo de Juazeiro do Norte como o segundo mais denso, seguido de Sobral e Iguatu.

Verificou-se, portanto, uma relocalização da indústria nos municípios que compõem a RMF tendo a frente o papel centralizador da capital em função do sistema de vias pautado no transporte rodoviário, convergindo para a zona portuária do Mucuripe e também para o novo porto do Pecém, em São Gonçalo do Amarante.

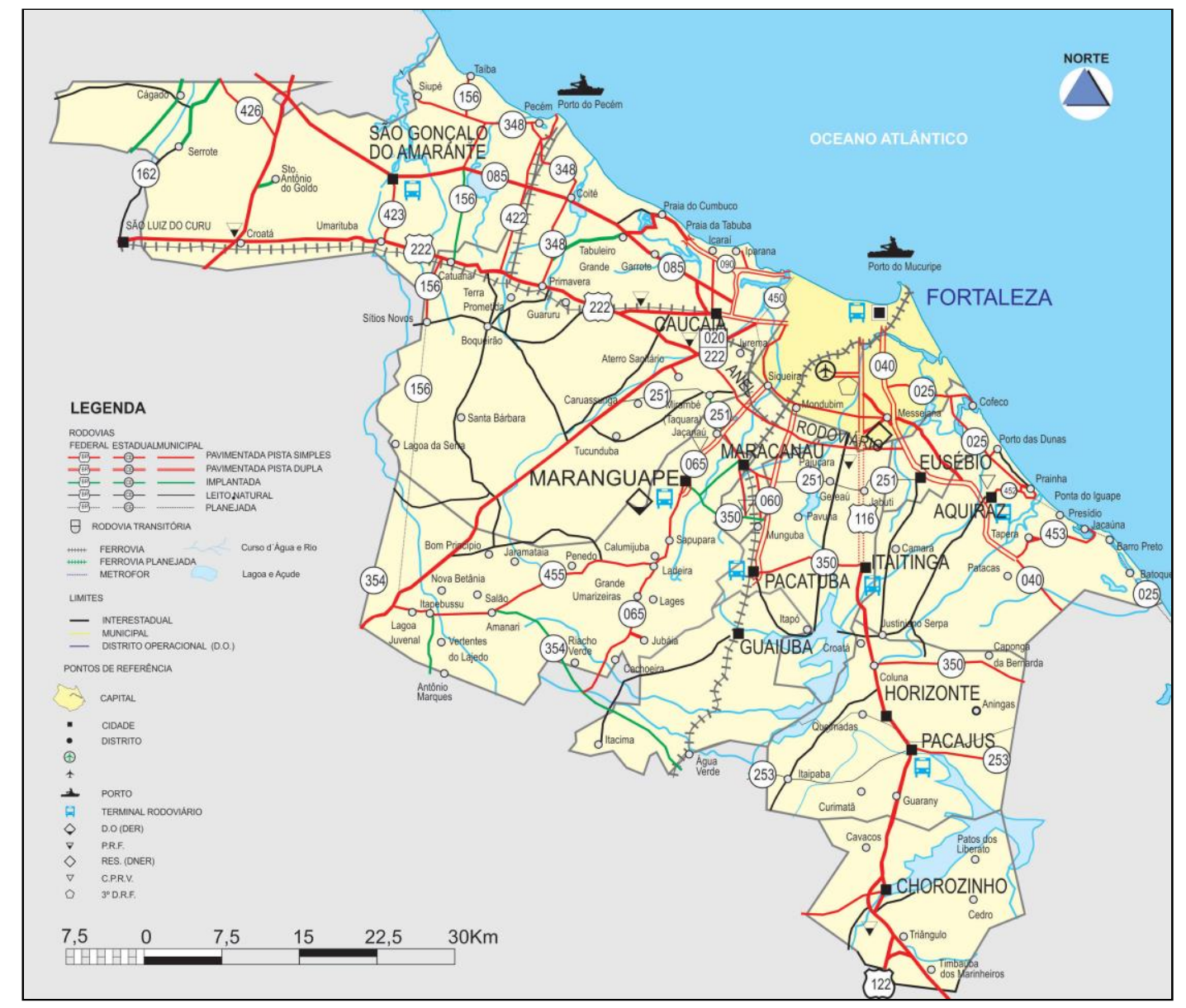

Fig. 2.58 RMF - Sistema Viário 2008 - Fonte: PAIVA, 2011 (Adaptação mapa rodoviário DER).

Outras obras estruturantes reforçaram o papel da metrópole na perspectiva da inserção da economia cearense no mercado global, entre eles: os investimentos alocados no complexo industrial e portuário do Pecém, o novo terminal aeroportuário internacional de Fortaleza, a integração de bacias hídricas do complexo de barragens dos sistemas 
Pacajus-Pacoti-Riachão-Gavião ${ }^{25}$ e o Castanhão ${ }^{26}$, além da implantação dos corredores turísticos estruturantes que tiveram seus acessos duplicados e requalificados, em território metropolitano.

A integração das bacias do Rio Jaguaribe com a Bacia Metropolitana, denominada pelo governo do Estado de Eixão, constitui-se de um complexo de estação de bombeamento, canais, sifões, adutoras e túneis que realizam a transposição das águas do Açude Castanhão para reforçar o abastecimento da Região Metropolitana de Fortaleza, como também fará com o Complexo Portuário e Industrial do Pecém.

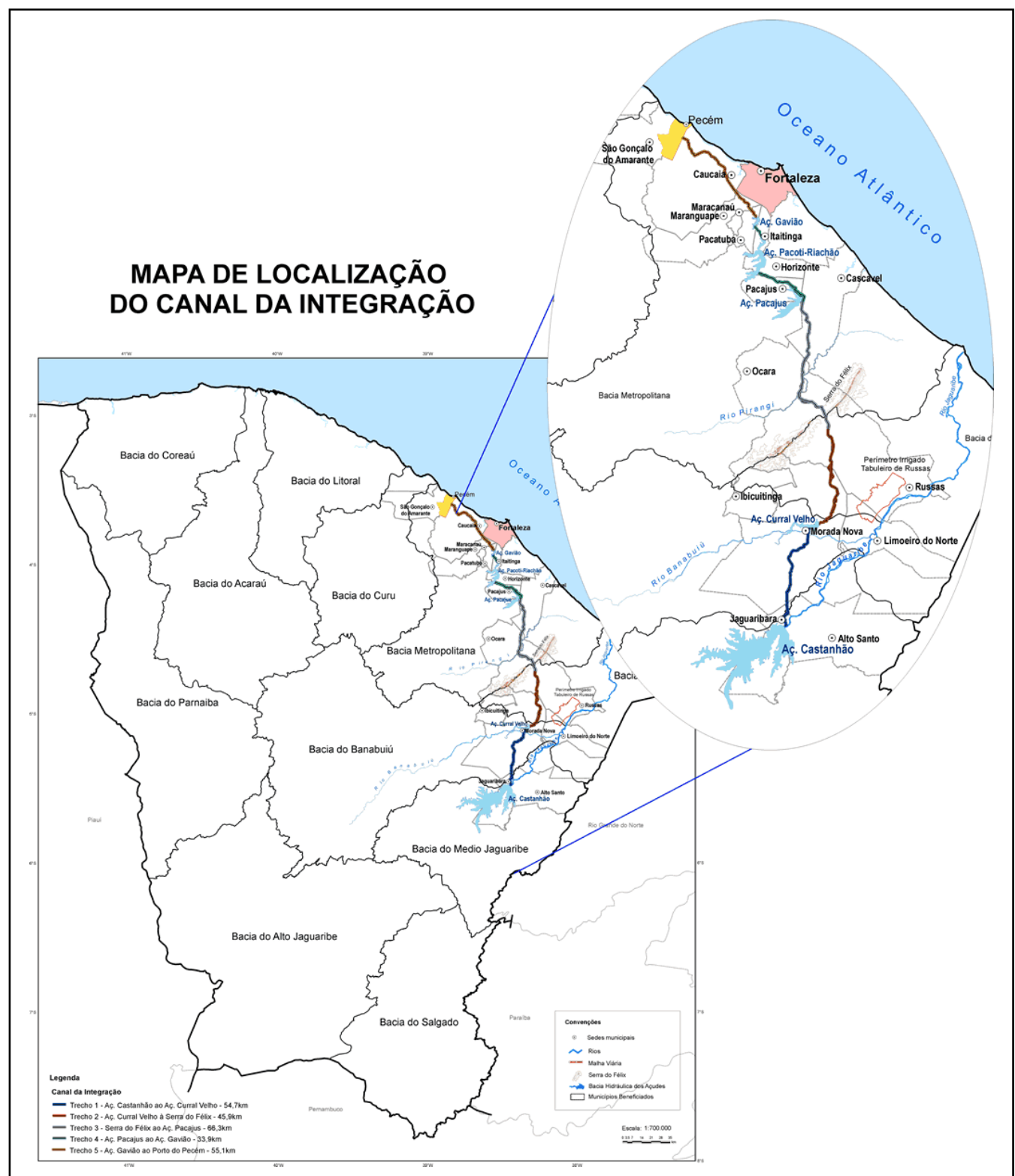

Fig. 2.59 Mapa de localização do Canal da Integração - Fonte: Governo do Estado do Ceará Secretaria de Recursos Hídricos

\footnotetext{
${ }^{25}$ No território da RM de Fortaleza.

${ }^{26}$ No Município de Jaguaribara que está localizado no médio Jaguaribe, a Leste do Estado.
} 
No setor primário, o governo elaborou uma estratégia de desenvolvimento baseada na interiorização das ações e na criação de alternativas para a convivência com o semiárido a partir da diversificação da agricultura irrigada. Entretanto, a utilização de tecnologias de irrigação e conservação do solo, entre outros, beneficiaram principalmente o fortalecimento do agronegócio em lugar do apoio das atividades agrárias tradicionais. "A modernização do setor primário e sua produção, com agregação de ciência e tecnologia buscam uma relação mais estreita com os mercados internacionais" (PAIVA, 2011, p 115).

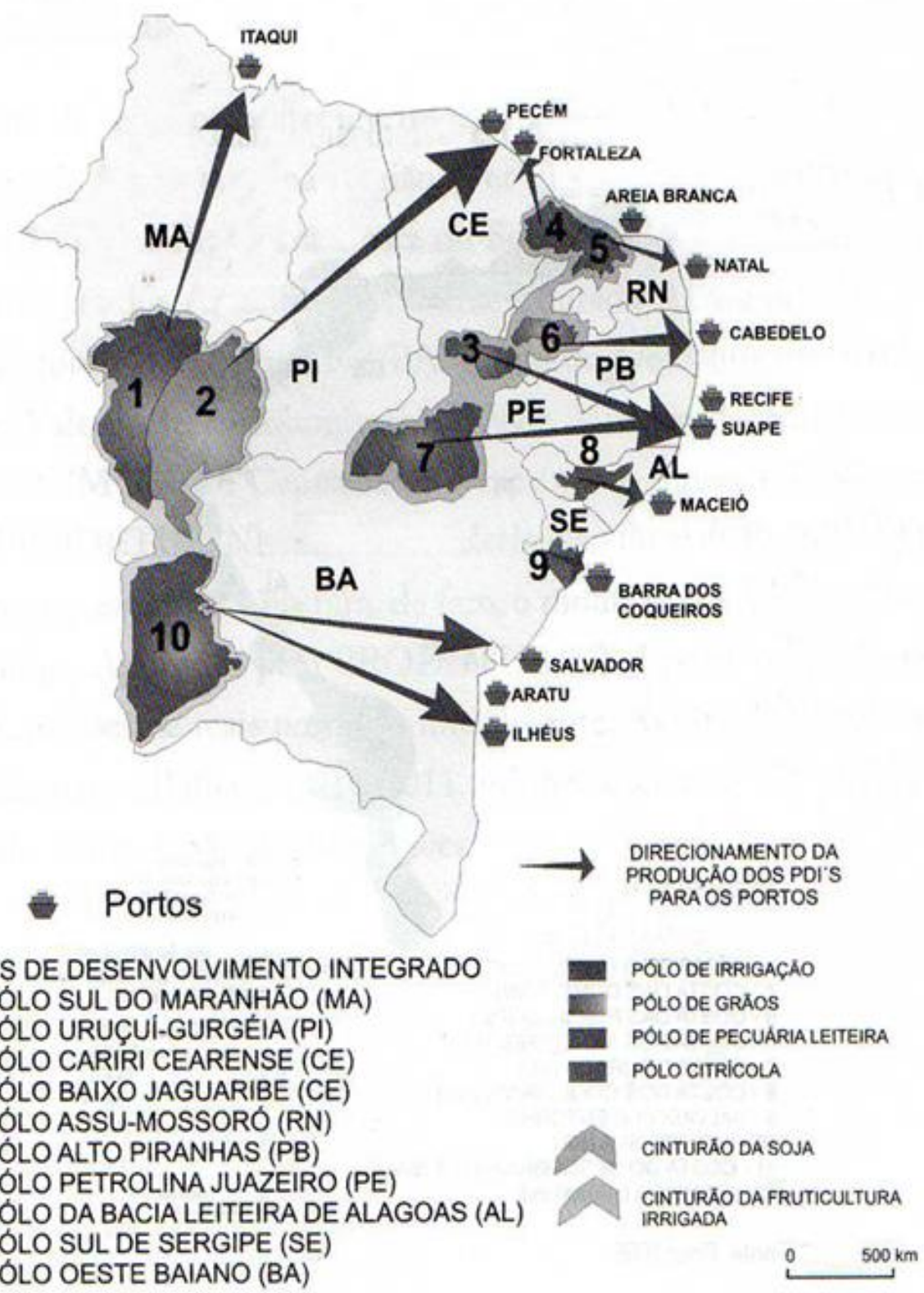

Fig. 2.60 Nordeste do Agronegócio - Fonte: Pìnot, 2006 apud CUNHA \& PEDREIRA, 2008, p.19. 
O agronegócio é um tipo de produção que embora não seja espacializada na RMF (fig.2.60), necessita de logística de transporte com implicações diretas nas políticas públicas de descentralização de portos e construção de aeroportos internacionais. No caso do Ceará, influenciou a construção, em 2000, do novo aeroporto de Fortaleza e do complexo portuário do Pecém, no município de São Gonçalo do Amarante na RMF.

A aparente perda de funções de Fortaleza, diante do processo de descentralização da produção, se converteu num reforço a sua capacidade de comando. A desconcentração combina a expansão de sua área de influência a uma espécie de seletividade socioespacial. A expansão da RMF apresenta um processo articulado de desconcentração, expansão e adensamento de novas centralidades no território, além de funções especializadas como o complexo porto-industrial, os corredores de atividade industrial e os eixos litorâneos. Tal racionalidade reforça-se na lógica contemporânea da economia globalizada, associada a atividades ligadas também ao lazer e turismo. (CUNHA \& PEDREIRA, 2008, p.18)

Abaixo, alguns elementos revelam a mudança de comportamento da economia cearense diante da sua recente inserção na economia internacional, segundo dados do relatório da conjuntura econômica de 2004 (IPECE). A evolução da balança comercial cearense inicia uma trajetória positiva somente a partir de 2003, após dez anos de déficits contínuos, mesmo durante o governo das mudanças. Em 2004, o saldo da balança comercial foi superavitário, atingindo US\$ 285,8 milhões (Gráfico 2.5).

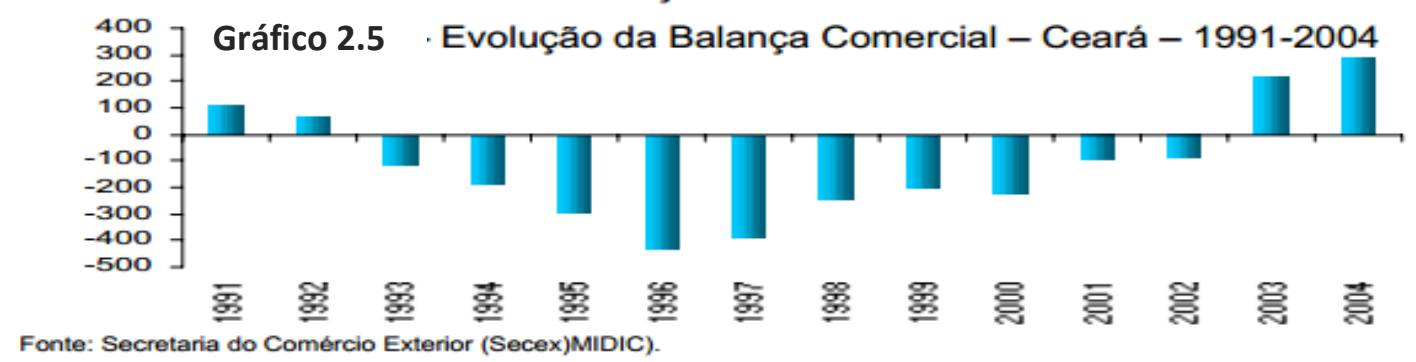

As exportações cresceram, em 2004 sobre 2003, 12,9\% e tiveram como suporte as vendas de produtos industrializados. Dentre os produtos manufaturados e semimanufaturados exportados, os calçados lideraram a pauta, com US\$ 187 milhões, seguidos da amêndoa da castanha de caju (US\$ 142 milhões) e têxteis (US\$ 125 milhões). Além de outros produtos já tradicionais na pauta da exportação cearense como 
o couro, o camarão e a lagosta, verifica-se o surgimento da fruticultura irrigada que começa a ocupar espaço entre os demais itens (ver Tabela 2.3).

Tabela 2.3 - Evolução das Exportações de Produtos Selecionados - Ceará

\begin{tabular}{|c|c|c|c|c|c|c|}
\hline \multicolumn{7}{|c|}{ 2003-2004 $\left(^{*}\right)\left({ }^{* *}\right)$} \\
\hline \multirow[b]{2}{*}{ Segmentos } & \multicolumn{2}{|c|}{2003} & \multicolumn{2}{|c|}{2004} & \multicolumn{2}{|c|}{ Var. $\%$} \\
\hline & $\begin{array}{c}\text { US\$ } \\
1.000 / F O B\end{array}$ & KG (1.000) & $\begin{array}{c}\text { US\$ } \\
1.000 / \mathrm{FOB}\end{array}$ & KG (1.000) & US\$ & KG \\
\hline Calçados & 167.515 & 18.039 & 186.520 & 19.242 & 11,3 & $\overline{6,7}$ \\
\hline Amêndoa de Cast.de Caju & 109.947 & 31.725 & 142.110 & 36.071 & 29,3 & 13,7 \\
\hline Têxteis & 125.227 & 41.038 & 125.291 & 34.721 & 0,1 & $-15,4$ \\
\hline Couro e Peles & 87.647 & 9.750 & 110.546 & 18.971 & 26,1 & 94,6 \\
\hline Camarão & 80.944 & 20.126 & 65.188 & 16.541 & $-19,5$ & $-17,8$ \\
\hline Lagosta & 30.756 & 1.200 & 40.098 & 1.302 & 30,4 & 8,5 \\
\hline Vestuário e Artef. Têxteis & 13.760 & 1.733 & 19.076 & 1.626 & 38,6 & $-6,2$ \\
\hline Frutas $\left({ }^{* \star}\right)$ & 21.562 & 55.646 & 24.829 & 59.172 & 15,2 & 6,3 \\
\hline Gordura, Óleos & 10.518 & 6.106 & 15.349 & 8.454 & 45,9 & 38,5 \\
\hline Granito e suas Obras & 5.927 & 26.130 & 11.673 & 49.177 & 96,9 & 88,2 \\
\hline Mel & 5.642 & 2.342 & 4.524 & 2.385 & $-19,8$ & 1,8 \\
\hline Mica & 2.212 & 1.296 & 3.133 & 1.588 & 41,6 & 22,5 \\
\hline Demais & 104.515 & 280.950 & 115.073 & 154.657 & 10,1 & $-45,0$ \\
\hline Total & 760.927 & 492.125 & 859.369 & 398.421 & 12,9 & -19.0 \\
\hline
\end{tabular}

O Estado tem diversificado sua pauta de exportação e o leque de países parceiros. Essa ampliação é mais um indicador da inserção do Ceará no mercado global. Uma grande parte dessesdas exportações do Estado. A Argentina, o segundo maior parceiro, atingiu valores em torno de 7,5\%, próximo de outros países como: Holanda, Espanha, Itália, México e Canadá. Na lista de novos parceiros surgem França, Alemanha e China.

\section{Gráfico 2.6 - Evolução das Exportações para Países Selecionados - Ceará 2003-2004 (\%)}

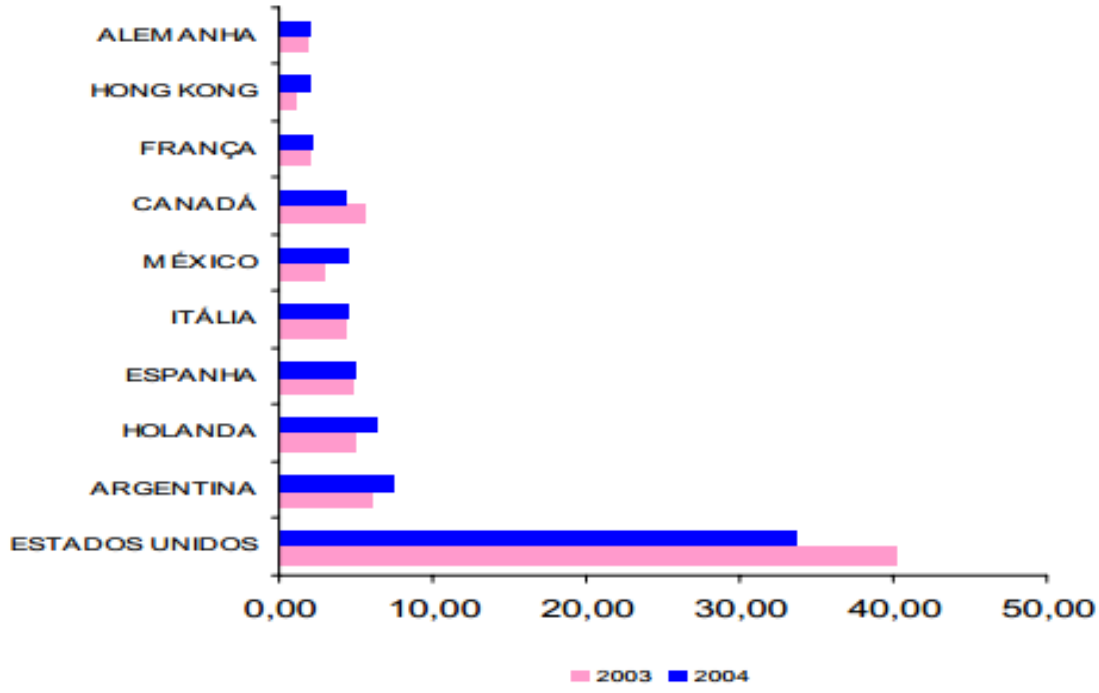

Fonte: SECEX/MDIC 
Mesmo apresentando indicadores de exportação crescentes nos últimos 20 anos, o Estado do Ceará se insere no circuito das redes de comércio globalizado de modo periférico e ainda frágil, diante das relações impostas pelo capital internacional. Desse modo, constitui-se num ponto sem posição de destaque, tendo em vista a sua inserção recente, como também a fragilidade da sua economia.

No entanto, o Estado do Ceará assume um novo papel na divisão social e territorial do trabalho no Brasil e deve ser considerado como uma fração do espaço mundial, cada vez mais sujeito às interferências externas e aos novos valores contemporâneos. Como objeto e sujeito da economia globalizada, é um espaço pouco autônomo, pois não existe por si mesmo, de forma independente do resto do mundo, com o qual interage permanentemente no processo de acumulação de capital. No entanto, nos últimos quinze anos, é visível sua reestruturação econômica com objetivos claros de inserir-se no circuito da produção e consumos globalizados (ELIAS \& SAMPAIO, 2002, p. 11, apud. PAIVA, 2011).

\subsubsection{Intervenções urbanas estruturantes na RM de Fortaleza}

Com o objetivo de ampliar os fluxos de capitais entre as diversas cidades do interior, o governo do Estado empreendeu uma série de intervenções urbanas consideradas estruturantes, na perspectiva de descentralizar o desenvolvimento da economia e diminuir as desigualdades interestaduais. No entanto, verificamos que os maiores investimentos acabaram sendo direcionados para os municípios da RM de Fortaleza contribuindo para reafirmar a polarização da metrópole e da sua capital, aprofundando as desigualdades socioespaciais entre ela e os demais municípios do Estado.

Um programa que se destacou na operacionalização dessas intervenções foi $o$ PROURB, realizado entre 1995 e 2003 no âmbito da Secretaria da Infraestrutura do Estado (SEINFRA) em parceria com a Secretaria de Recursos Hídricos (SRH). Seu objetivo era ser o instrumento para viabilizar a estruturação urbana de 50 cidades escolhidas, visando o suporte ao desenvolvimento econômico e social, com a ideia de torná-las mais competitivas na atração de indústrias, no apoio à agricultura irrigada e na promoção do turismo. 
Assim, as intervenções propuseram ações voltadas à gestão municipal, planejamento urbano, infraestrutura urbana, e profissionalização de jovens, produzindo como resultado: 41 Projetos de Administração Tributária; 41 Projetos de Reestruturação Administrativa; 36 Projetos de Cadastro Técnico; 44 Bases Cartográficas / Fotográficas; 46 Planos Diretores de Desenvolvimento Urbano; 5 Planos de Desenvolvimento Regionais; 1 Plano Diretor de Habitação; 49 Projetos Estruturantes; 18 Obras Estruturantes edificadas e 89 micro áreas com infraestrutura urbana, entre outros (GOVERNO DO ESTADO DO CEARÁ) ${ }^{27}$.

No âmbito do planejamento urbano, o programa viabilizou a produção dos Planos Diretores de Desenvolvimento urbano, beneficiando vários municípios. Os diagnósticos se converteram em contribuições valiosas para a compreensão da problemática urbana do Estado. Assim, por volta do ano 2000, começam a chegar às câmaras municipais dos municípios, as leis que compõem os primeiros Planos Diretores de Desenvolvimento Urbano elaborados entre 1995 - 2003 pelo PROURB/CE, seguindo orientações da nova constituição brasileira de 1988, expondo o processo de planejamento às várias pressões da sociedade organizada.

\section{O Programa de Infraestrutura Básica e Saneamento de Fortaleza - SANEAR}

O SANEAR teve como objetivo melhorar a qualidade de vida da população mediante ações de saneamento ambiental em Fortaleza e Região Metropolitana, através da implantação de obras e serviços de distribuição de água, esgotamento sanitário, drenagem e limpeza urbana. Antes do programa, o sistema de esgotamento sanitário de Fortaleza abrangia uma parcela reduzida de seu território. Apesar de já existir o emissário submarino e lagoas de estabilização, a rede coletora de esgotos atendia um pouco mais de $25 \%$ da população total neste período (CAGECE, 2005). Atualmente, segundo dados da CAGECE ${ }^{28}, 96,91 \%$ do Ceará têm cobertura de água e 35,74\% de esgoto. Em Fortaleza a cobertura de água é de $98,25 \%$ e a de esgoto é de 53,54\%. O programa SANEAR teve ressonância na RMF pelo fato de também fomentar a atividade turística, pois um dos objetivos principais dessa política era a provisão de infraestrutura básica, antes da implantação de infraestrutura turística.

\footnotetext{
${ }^{27} \mathrm{http}: / /$ conteudo.ceara.gov.br/content/aplicacao/sdlr/desenv_urbano/gerados/prourb.asp (12/06/12)

${ }^{28}$ Companhia de Água e Esgoto do Ceará - http://www.ceara.gov.br/governo-do-ceara/projetosestruturantes/saneamento $(12 / 06 / 12)$
} 


\section{O Complexo Industrial e Portuário do Pecém - CIPP}

A implantação do Complexo Industrial e Portuário do Pecém é considerada a principal iniciativa do Estado para fortalecer e dar sustentabilidade ao crescimento do parque industrial do Ceará, possibilitando o incremento de atividades industriais integradas. $\mathrm{O}$ complexo é dotado da infraestrutura necessária para abrigar um parque industrial metalmecânico e petroquímico, em condições de propiciar operações portuárias com acessos rodoviários e ferroviários livres e independentes de confinamentos provocados por centros urbanos.

Atualmente opera movimentando matérias primas, produtos siderúrgicos acabados, fertilizantes e cereais em granel, contêineres e granéis líquidos e gasosos. O Terminal Portuário do Pecém já é o quarto maior porto exportador do Nordeste e ocupa o primeiro lugar em exportação de frutas do Brasil e se projeta para se tornar exportador de produtos siderúrgicos e petroquímicos. (CEARÁPORTOS, 2012) ${ }^{29}$
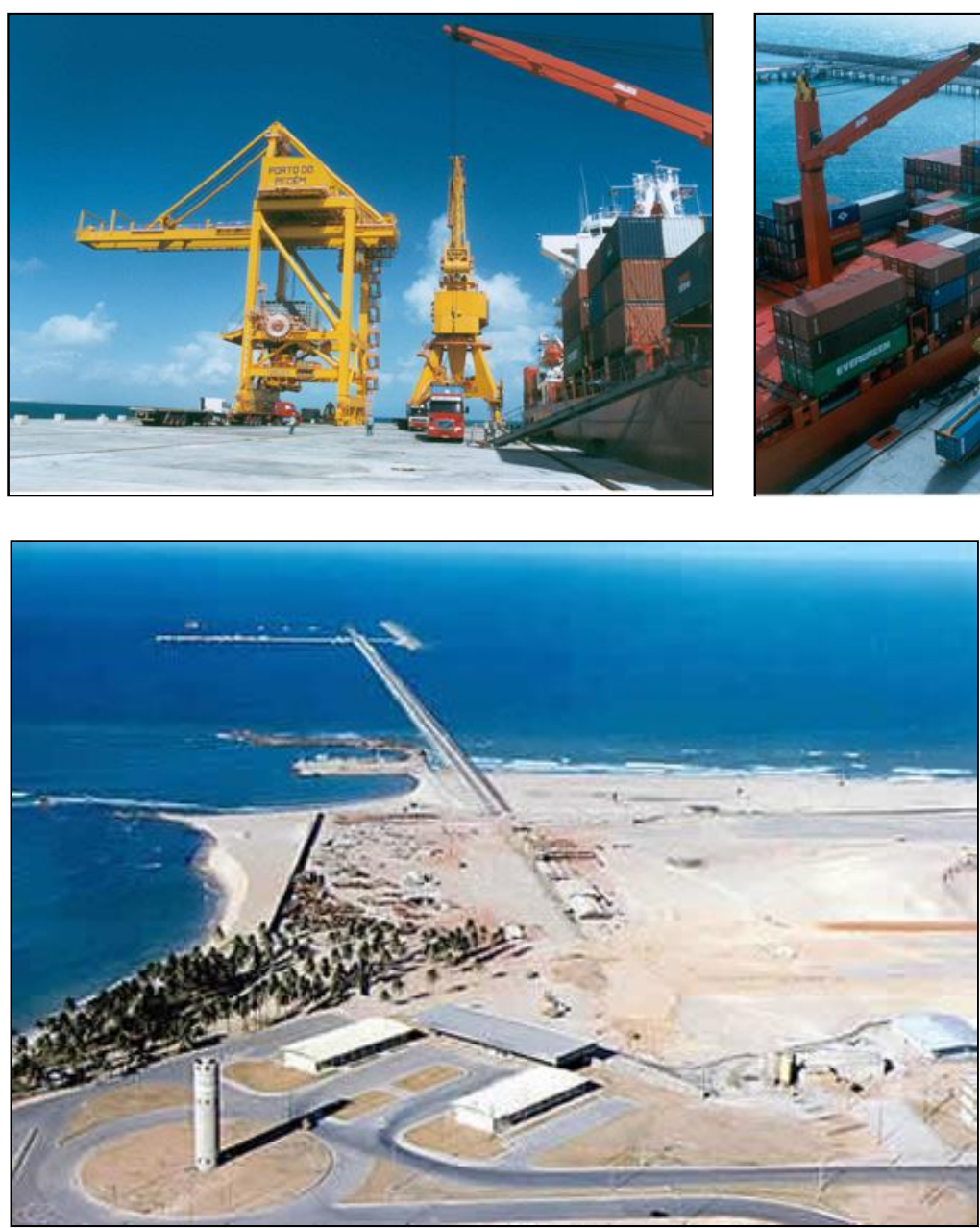

${ }^{29}$ http://www2.cearaportos.ce.gov.br/estatisticas.asp (12/06/12)

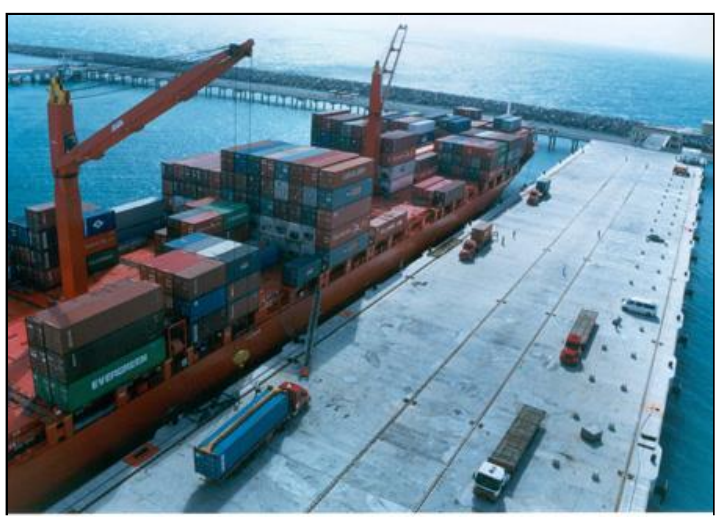

Fig. 2.61 Fotos do Porto do Pecém em operação. Fonte: Cearáportos 


\section{O METROFOR - Metrô da Região Metropolitana de Fortaleza}

O Projeto METROFOR tem seus estudos e planos iniciais desenvolvidos ainda na década de oitenta, como o objetivo de atender à Região Metropolitana de Fortaleza, especialmente à população dos municípios de Fortaleza, Caucaia, Maracanaú, Maranguape e Pacatuba. Estes municípios estão situados na área de influência dos Corredores Norte e Sul do transporte de massa, onde está concentradas cerca de 2/3 da demanda de transporte público de passageiros e a maior parte dos conjuntos habitacionais dos municípios mais populosos.

O projeto se utiliza do modal ferroviário aproveitando, em sua maior parte, o leito dos sistemas atualmente operados pela Companhia Ferroviária do Nordeste (CFN) e Companhia Cearense de Transportes Metropolitanos - METROFOR, preconizando, através de implantação por etapas, um sistema de integração modal e tarifária, em consonância com os meios de transporte atualmente em operação.

A construção do metrô sofreu inúmeras interrupções e paralizações ao longo dos anos, embora tenha retomado em ritmo de execução mais acelerado, atualmente. Novos estudos foram realizados e indicaram, segundo o governo, a necessidade de revisão nos projetos básicos integrantes do material necessário às novas licitações internacionais.

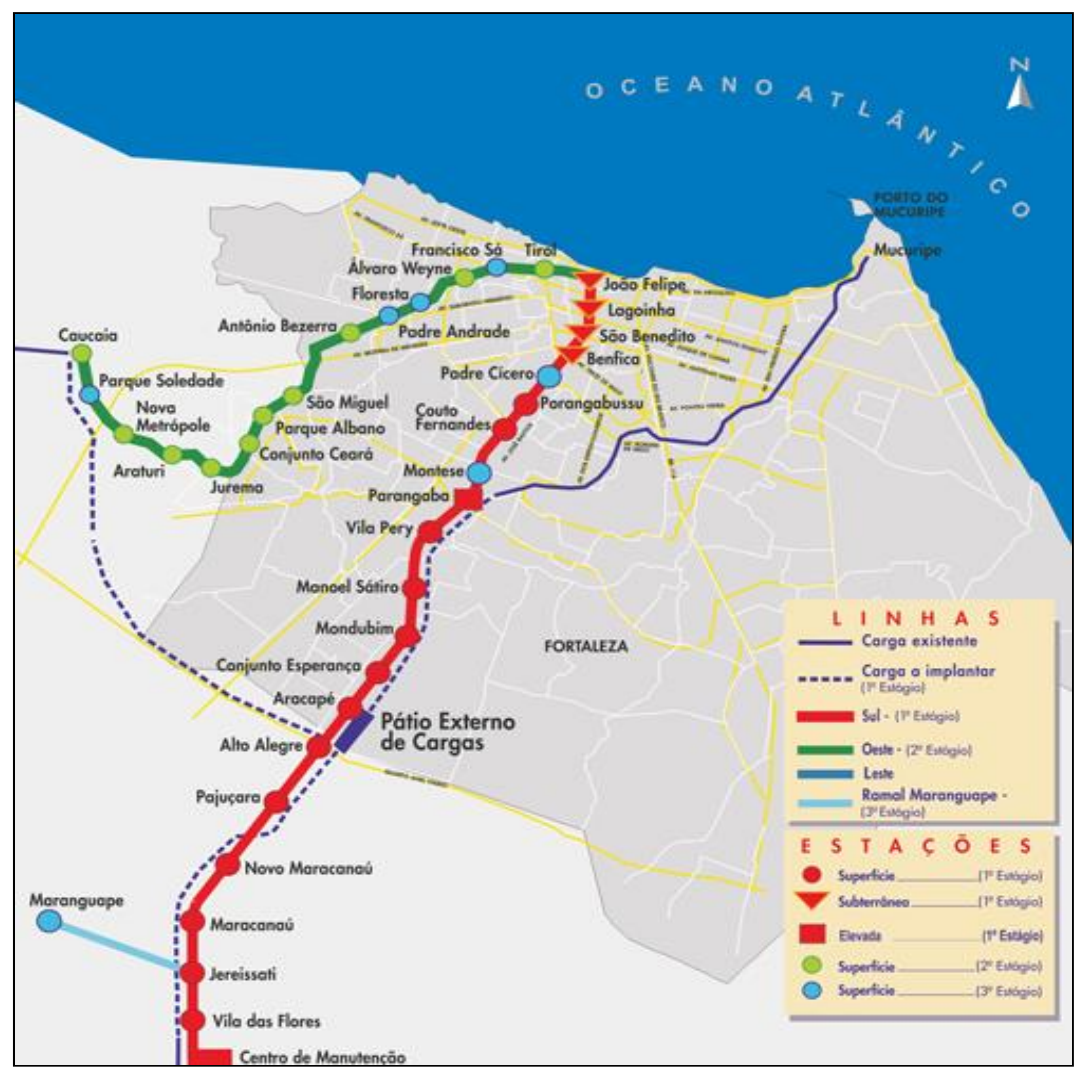

Fig. 2.62 Projeto de implantação atual do Metrofor $-1^{\circ}$ estágio: (linha vermelha e azul tracejada). $2^{\circ}$ estágio: (linha verde) e o $3^{\circ}$ estágio: (linhas, verde vermelha e azul claro) Fonte: Metrofor 


\section{O terminal aeroportuário internacional de Fortaleza - Pinto Martins}

A ampliação dos aeroportos das capitais nordestinas foi considerada uma prioridade nos diagnósticos dos programas de desenvolvimento do turismo (PRODETUR/NE), no que diz respeito à infraestrutura condicionante para o devido acolhimento dos novos fluxos projetados para o futuro.

O antigo Aeroporto de Fortaleza apresentava infraestrutura deficiente para as pretensões do Estado quanto à modernização do setor. A construção do novo terminal acompanhada da reformulação das vias de acesso como também da modernização tecnológica da infraestrutura aeroportuária foram determinantes na dinamização do fluxo turístico do Estado, provocando impactos urbanos imediatos no seu entorno.

O terminal de passageiros, inaugurado em 1998, foi projetado para 50 anos e em 2009 entrou em funcionamento o Terminal de Cargas em uma área de aproximadamente 9 mil $\mathrm{m}^{2}$ com um pátio para atendimento de até sete aeronaves de grande porte, utilizado também na exportação de produtos diversos como flores e alimentos (INFRAERO) ${ }^{30}$.

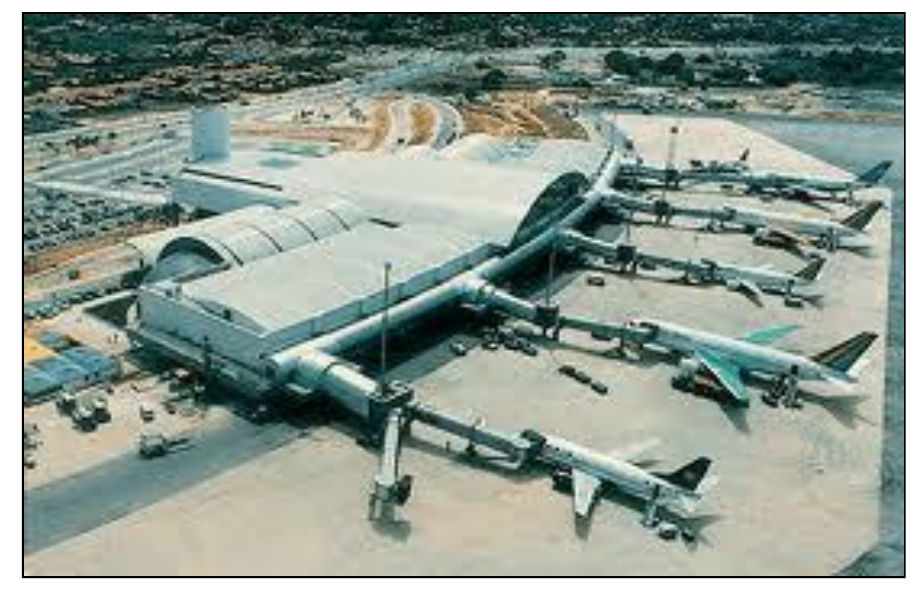

Fig. 2.63. Vista aérea e interna do aeroporto em operação. Fonte: Infraero

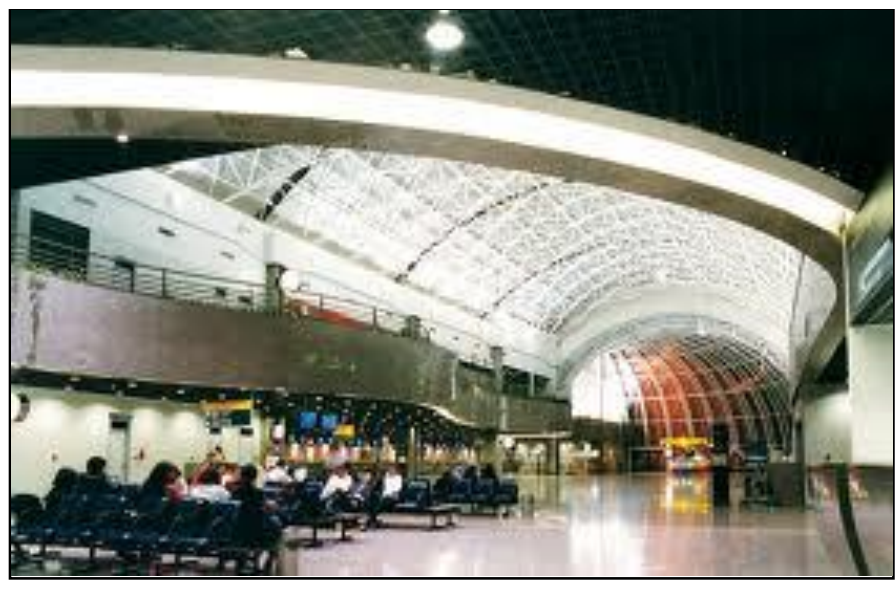

\footnotetext{
${ }^{30} \mathrm{http} / /$ www.infraero.gov.br/index.php/br/aeroportos/ceara/aeroporto-internacional-pinto-martins.html $(12 / 06 / 12)$
} 


\section{O turismo como indutor da reestruturação metropolitana de Fortaleza}

O processo de metropolização contemporâneo de Fortaleza e sua expressão local e regional se justificam em grande medida, também, pelo desenvolvimento do setor terciário, vocação de sua formação enquanto Metrópole, desenvolvida historicamente nas atividades de comércio e serviços. No entanto, verifica-se atualmente uma alteração significativa nesse processo, provocada pela inserção e incremento das atividades turísticas na reestruturação socioespacial do Ceará impactando de forma significativa o perfil do setor terciário na economia.

Assim, a partir dos anos 1990, o turismo converte-se em elemento que potencializa o fluxo de pessoas e recursos, principalmente nos espaços litorâneos da metrópole. Desse modo, incorpora as zonas de praia de seus municípios à lógica de valorização turística, alavancada pela política de turismo do Estado em sintonia com os programas de desenvolvimento regional como o PRODETUR-NE.

A ideia de que o turismo está associado à dinamização de diversos benefícios para a sociedade, ganha apoio do Estado que desenvolve sua política de turismo fundamentada, em boa parte, na implantação de infraestrutura para atração de investimentos privados. Assim, progressivamente, vai se configurando num vetor estruturante litorâneo, provocando a supervalorização das zonas de praia, cujo controle dos pontos de recepção e distribuição do fluxo turístico, passou a ser efetuado pela capital. Como consequência, reforça mais uma vez o papel de comando de Fortaleza sobre a nova estruturação metropolitana que se formou a partir desses novos investimentos.

O alinhamento das políticas de turismo aos planos de governo é visível nas intervenções de infraestrutura porque elas se inserem no processo de restruturação socioespacial do Ceará como um todo, convergindo na mesma direção das principais estratégias de desenvolvimento econômico pretendidas pelo Estado.

Para compreender a dimensão do turismo e sua emergência no contexto da produção do espaço contemporâneo, consideramos importante rever alguns conceitos e referências teóricas nos estudos sobre turismo e urbanização, indagando sobre a necessidade do uso de novos conceitos, como o de "urbanização turística". Na sequencia, discutiremos a 
inserção do turismo no planejamento governamental e as bases da política de turismo no Ceará, que faremos no próximo segmento.

\subsection{A emergência do turismo no contexto da produção do espaço contemporâneo}

A proposta de analisar o turismo como um setor emergente da economia e representativo da sociedade contemporânea corre o risco de parecer excessivamente genérico, uma vez que há tantas classificações para o termo turismo quantas possibilidades de abordagens para sua compreensão.

Refinar o escopo desta análise para um conceito mais preciso e marcante na atualidade como "urbanização turística" parece uma tentação e um desafio para aqueles que se dedicam aos estudos urbanos, devido ao significativo nexo que hoje o turismo imprime aos processos de urbanização e metropolização. Do mesmo modo, devido a sua característica sistêmica, exige dos pesquisadores um esforço interdisciplinar significativo, capaz de dar conta de tamanha complexidade.

\subsubsection{O conceito de urbanização turística: especificidade e relevância}

Os estudos sobre o turismo vêm chamando a atenção no campo das ciências humanas ganhando destaque nas contribuições de geógrafos, economistas, sociólogos e urbanistas de diversas orientações, enfocando múltiplos aspectos onde se destacam duas posições opostas que dominam a polêmica habitual sobre o turismo: de um lado os que defendem os benefícios e impactos positivos na economia local e do outro, os que alertam sobre os conflitos culturais e ambientais onde a segregação scioespacial apresenta-se como implícita em sua prática social.

Mais recentemente, pesquisadores envolvidos com os estudos da cidade captaram uma maior influência do turismo nas manifestações tardias da urbanização contemporânea, devido à grande repercussão espacial dessa atividade caracterizada por manter inúmeras interfaces com os subsistemas que compõem a cidade. 
Ensaios como os contidos no livro The Tourist City $^{31}$, são um exemplo de contribuição que oferece uma riqueza de informações sobre os contextos específicos em que o "turismo urbano" se desenvolve, ressaltando o seu impacto na paisagem e suas consequências econômicas e políticas. De certo modo, o livro procura desmascarar a opinião comum de que o turismo é ou indigno de estudo sério ou um exemplar dos males da cultura de massa.

O conceito de urbanização turística, no sentido em que foi aplicado pelo sociólogo australiano Patrick Mullins (1991) implica na constatação da existência de formas específicas de produção do espaço urbano, engendradas a partir da atividade turística, sobretudo quando esta se impõe como dominante na economia local (MASCARENHAS, 2004).

Em seu estudo, Mullins (1991) recolheu dados em 13 cidades australianas com claro perfil turístico, comparando vários indicadores de atividades da economia urbana como: o ritmo de crescimento demográfico; os níveis de emprego e subemprego; a dinâmica dos movimentos sociais e da sociedade civil em geral, concluindo que o turismo é uma modalidade peculiar de produzir e estruturar o espaço urbano. Para o autor as cidades turísticas "representam uma nova e extraordinária forma de urbanização" (MULLINS, 1991.p.326, apud MASCARENHAS, 2004).

De fato, a "urbanização turística" apresenta-se no mundo como um dos mais representativos vetores de crescimento urbano contemporâneo. Tanto nos Estados Unidos como na Europa está relacionada aos setores de maior crescimento populacional e de trabalho. Num cenário de desindustrialização na Grã-Bretanha, por exemplo, falase cada vez menos em mercadorias e mais em "tradição" com novas ondas de tombamentos e multiplicação de museus que crescem com o turismo urbano (Op. cit., 2004).

No Brasil, embora não faltem evidências sobre o fenômeno da urbanização provocado pelo turismo (ou para ele produzida), ainda são consideradas raras as investidas acadêmicas, sobre o tema, diante da significativa produção dos diversos enfoques

\footnotetext{
${ }^{31}$ The Tourist City - Edited by Dennis R. Judd and Susan S. Fainstein: New Haven, CT :Yale University Press, 1999
} 
dedicados ao fenômeno do turismo, apresentada em congressos e seminários desenvolvidos no país.

No plano teórico o conceito de urbanização turística é trabalhado de modo pioneiro por Luchiari ${ }^{32}$ que repensando a proposta de Mullins (1991), desenvolve uma abordagem sociocultural utilizando um campo interdisciplinar entre a antropologia, sociologia e geografia do turismo. Assim, avalia a importância do lugar na sua relação com a totalidade-mundo em seu trabalho "Urbanização turística: um novo nexo entre o lugar e o mundo" (LUCHIARI, 1998).

A partir dos vários sentidos atribuídos ao turismo, a autora faz referências ao trabalho de alguns dos pesquisadores que considera mais próximos à ideia de "que o turismo alimenta a reprodução de pseudo-acontecimentos, hiper-realidades, ou simulacros”, reinventados e consumidos por um público exigente e ávido de novidades, citando referências de Mac Cannell (1976); Krippendorf (1989); Featherstone (1995); Massey, (1995) e Urry (1996).

"O turismo pode reproduzir a natureza, a cultura e a autenticidade de práticas sociais. Mas o que dá sentido ao consumo destes simulacros é a subjetividade do indivíduo e dos grupos sociais que passam a valorizar a própria reprodução. [...] O turismo de massa induz a produção de atrações inventadas que valorizam mais a técnica da reprodução do que a própria autenticidade. Estes turistas protegem-se do estranhamento do lugar ficando circunscritos em uma bolha ambiental: guias, monitores, hotéis, ambientes climatizados, enclaves urbanos... A liberdade destes turistas é condicionada pelos pontos turísticos que eles devem visitar, em total segurança”. (LUCHIARI, 1998 p.15)

Este tipo de comportamento atribuído ao turista ao lado das características estruturais do turismo de massa faz com que sejam requeridos e produzidos espaços cada vez mais

\footnotetext{
32 Geógrafa, professora do Instituto de Geociências (IG), e do Curso de Graduação em Ciências da Terra da Universidade de Campinas-SP (Unicamp).
} 
ausentes de significados como os não lugares descritos por Augè (1994) o que, de certo modo, imprime uma estética previsível e estereotipada do espaço turístico.

Sobre a urbanização turística, especificamente, a autora lista uma série de indicadores que ela julga capazes de identificar a ocorrência de suas características espaciais fundamentais, tais como:

- A atividade de consumo ser mais importante que a produção. E mesmo que haja produção, esta ser orientada para o consumo turístico;

- A mão-de-obra concentrar-se na construção civil e no setor de serviços do próprio setor turístico;

- Haver uma valorização estética da paisagem da cidade;

- A revalorização no uso do solo urbano intensificando a especulação imobiliária e o processo de segregação residencial;

- O crescimento acelerado da população e da força de trabalho, impulsionado por fluxos migratórios;

- Existir ofertas sazonais de postos de trabalho, no caso de cidades turísticas litorâneas ou serranas;

- A exigência de mão-de-obra qualificada vinda de fora, e sazonal, com contratos de trabalho precários;

- A ascensão de pequenos capitais (comerciantes, construtores...), favorecendo a formação de uma nova elite local que efetivamente constrói a cidade e consegue poder político local;

- A presença de organizações de moradores (sociedades de amigos de bairros, associações de moradores etc.) refletindo as expectativas e necessidades locais em relação aos turistas e às necessidades do setor;

- O custo de vida mais alto nas temporadas, para a população local;

- A produção de novos lugares de consumo, reconhecidos mundialmente como ambientes domesticados pelo cotidiano da modernidade (shoppings, galerias, redes de fast food, aeroportos, condomínios, etc.);

- A inserção de um novo sistema de objetos carregados de novos símbolos de status e identidade da moderna sociedade de consumo; 
Ao final, embora relate inúmeras referências e alerte para os vários problemas decorrentes de sua implantação, a autora reconhece a urbanização turística como uma das mais novas modalidades de produção do espaço urbano contemporâneo defendendo a tese de que "a atividade turística é um dos vetores mais importantes para associar o global ao local", negando a sua suposta dualidade e afirmando-a como relação complementar e interdependente.

O fenômeno contemporâneo do turismo coloca-se como um vetor de transformação contraditório e emblemático: acentua a produção de lugares de consumo e o consumo dos lugares. Mas não pode ser tomado apenas do ponto de vista negativo, como um desarticulador voraz de antigas formas e funções sociais que, num processo linear, destrói o velho substituindo-o pelo novo [...] O que é analisado como declínio dos lugares turísticos pelo adensamento das residências, das infraestruturas, pela concentração de pessoas e pelo apinhamento das paisagens, pode ser o sinal de uma transformação histórica dos lugares, os quais deixam para trás a determinação turística para produzir um novo lugar em conexão sistêmica com o mundo (LUCHIARI, 1998 p. 9).

Com o crescimento da urbanização provocada pelo turismo, recreação e lazer, ao lado de outros fatores econômicos, sociais e culturais, fica evidente que é necessário relacionar, de forma mais estreita e direta o turismo com os assentamentos urbanos, tendo em vista sua íntima relação.

Nesse sentido, MASCARENHAS (2004) considera que Mullins (1991) foi o que melhor sistematizou a questão entre a dinâmica do turismo com a dinâmica da urbanização, porque teve como objetivo propor uma estrutura conceitual que permitisse orientar análises empíricas.

Assim, Mullins (apud SILVA in RODRIGUES, 2000, p. 166) propõe sete componentes inter-relacionados para caracterizar a urbanização turística: três de natureza descritiva e quatro de base teórica, identificando as forças sociais mais importantes envolvidas neste tipo de urbanização. Suas características principais são segundo ele: 
- Ser espacialmente diferente porque é socialmente diferente;

- Ser simbolicamente distintiva, com símbolos urbanos agindo como atrativos para turistas;

- Apresentar um rápido crescimento da população e força de trabalho;

- Diferenciada por um sistema flexível de produção próprio da reestruturação econômica pós-fordista;

- Sofrer intervenção do Estado no estilo empreendedor, como o é a cidade pósmoderna;

- Distinguida pelo consumo do prazer, costumeiro e de massa;

- Ter uma população residente, socialmente diferente, movida por uma urbanização do mesmo modo socialmente diferente.

Com esse instrumental, Mullins (Op.cit.) faz uma análise comparativa da urbanização da costa turística australiana com a de outros centros urbanos importantes do país chegando a várias constatações como:

a) A presença de uma forma característica de urbanização linear ao longo da costa com um quilômetro de largura;

b) Ausência de centralidade sob a forma usual de um centro de negócios; ao invés disso, apresentam centros comerciais e turísticos distribuídos ao longo da costa servindo a turistas, residentes e população rural próxima;

c) Fatores físicos favoráveis ao turismo (clima, paisagens, praias, etc.) levaram à mercantilização ("commodification") dos lugares;

d) O acesso ao mar e às praias passou a ser fundamental;

e) O caráter visual do ambiente físico evoca diferentes imagens relacionadas ao prazer, alegria e deleite, símbolos da pós-modernidade;

f) Presença de uma área mais artificial e opulenta ao lado de uma mais natural e preservada; 
g) Maiores taxas de crescimento da população e da força de trabalho em comparação com os outros centros urbanos;

h) Perfil econômico da população concentrado em serviços turísticos, comércio, construção, finanças e negócios;

i) Flexibilidade inferida pelo predomínio do setor privado com maior importância das pequenas empresas;

j) Altas taxas de desemprego e emprego temporário e parcial;

k) Estado atuando de modo indireto e empreendedor, apoiando o turismo e o desenvolvimento urbano;

1) Emprego público menos frequente;

m) Grande impacto das massas de turistas no consumo de bens relacionados ao prazer: comida, bebida, hospedagem e compras;

n) Aumento em despesas de parques temáticos, entre outros.

Ao final o autor chama a atenção para a necessidade de novos conceitos e teorias para analisar os turistas como uma força social, salientando que o turismo e os prazeres são também uma forma de controle social.

\subsubsection{Da necessidade de novos conceitos ao estado da arte das pesquisas recentes}

Sobre a sugestão proposta por Mullins: da necessidade de se criar novos conceitos específicos como "urbanização turística" para analisar o turismo enquanto fenômeno e prática social, acreditamos que sua importância deva ser relativizada. Primeiramente, porque o fenômeno da urbanização possui uma complexidade tão abrangente que fragmentá-la em setores específicos talvez obscureça mais sua compreensão do que a amplie. Senão, teríamos a necessidade, por exemplo, de usar conceitos de urbanização para cada setor da economia, como "urbanização industrial”, "urbanização comercial”, etc. E em segundo lugar porque a urbanização provocada pelo turismo (ou para ele produzida) pode muito bem se inserir na discussão atual como uma especificidade da 
urbanização contemporânea, considerando os demais elementos que juntamente com o turismo, interagem na produção e no consumo desse espaço urbano.

Talvez o conceito "urbanização turística" possa ser usado apenas porque seja uma expressão concisa daquilo que poderíamos dizer como: "urbanização para / pelo turismo" ou mesmo "urbanização provocada pelo turismo e para ele produzida". Contudo, o conceito sempre carecerá de outros complementos que o caracterize senão acabará impreciso e confuso, tratando de coisas diferentes com a mesma terminologia como, por exemplo, "urbanização turística" de cidades criadas e "urbanizações turísticas" de cidades tradicionais.

Mesmo assim, outras contribuições relevantes como a de Judd \& Fainstein (1999) também trabalharam, de forma pioneira, o conceito de "turismo urbano" (urban tourism), na busca de uma maior especificidade do fenômeno. São coeditores do livro "The Tourist City" que organiza vários ensaios sobre o tema, onde figuram contribuições referenciais como as de John Urry; Saskia Sassen e Patrick Mullins, entre outros.

O livro aborda principalmente questões políticas e econômicas suscitadas pelo desenvolvimento e promoção do turismo urbano nas últimas décadas do Sec.XX, consistindo em um rico panorama sobre contextos específicos em que o "turismo urbano" se desenvolve, abordando o seu impacto na paisagem urbana e suas consequências políticas e econômicas.

No todo, o livro pretende desbancar a opinião de que o turismo não é digno de estudos sérios e que é um exemplo maléfico da cultura de massa. Procura destacar, no entanto, a diferença entre as abordagens cultural e a político-econômica, apontando para a necessidade de se ampliar os horizontes de pesquisa em ambos os lados, porque as considera complementares.

Os editores procuram identificar temas e questões comuns levantadas nos artigos, na maioria estudos de casos. Na introdução justifica o foco do livro e define alguns termoschave como "turismo urbano" (urban tourism); "forças globais" (global forces) e estratégias locais (local strategies), apresentando o turismo como uma parte importante da economia internacional. Mais do que isso, consideram-no um sinal da emergência de 
uma nova fase do capitalismo contemporâneo, caracterizado por um rápido aumento dessa modalidade de urbanização (ou de turismo... urbano), ressaltando a reformulação das cidades industriais em locais de serviços, entretenimento e consumo.

No final, os editores reveem as conclusões dos ensaios dos demais autores, observando os diferentes tipos de cidades turísticas e o modo como o turismo reformula paisagens urbanas. Desse modo, acenam para os aspectos culturais da economia "pós-fordista" criticando, ao final, a visão nostálgica de cidades industriais que se encontram no cerne de muitas críticas do "turismo urbano" contemporâneo. Em síntese, resume a corrente interpretação revisionista de que o turismo nem é o salvador e nem o destruidor de culturas e economias, apenas uma espécie de "indústria" com bons e maus efeitos.

Os ensaios constituem-se, portanto, em uma consistente contribuição ao analisar uma série de cidades e elementos importantes da "indústria turística", mas, continua a repetir alguns dos ataques habituais lançados aos turistas, sem refutar tais ideias incisivamente como fazem com a crítica usual ao turismo urbano em geral.

No contexto brasileiro, temos uma vasta produção acadêmica sobre o turismo no campo da Geografia e da História a partir de várias perspectivas como a da compreensão do processo de ocupação litorânea do Brasil, elaborada por Moraes (1999). Nesta, aborda diversos aspectos fundamentais, da estruturação econômica brasileira, tendo como pano de fundo a problemática ambiental das Zonas Costeiras e as novas atividades econômicas emergentes, entre elas o turismo litorâneo e o fenômeno de segundas residências de veraneio.

Outros autores levantam várias questões relacionadas às potencialidades e riscos do turismo, desatrelado do planejamento municipal, alertando em especial aos problemas da falta de planejamento para a estruturação de novas regiões metropolitanas lineares ao longo de todo o litoral brasileiro, com a elaborada por Yázigi (1999 e 2003).

As especificidades da produção do espaço turístico são levantadas também por Ana Fani Carlos, Rita de Cássia Ariza da Cruz, juntamente com Eduardo Yázigi em Turismo Espaço, Paisagem e Cultura (1999). Vários autores aparecem nos trabalhos organizados por Adyr Balastreri Rodrigues apresentados em congressos de Geografia onde o tema central é Turismo, Espaço, Geografia, Modernidade e Globalização, em diversas obras 
como: Turismo e Espaço: Rumo a um conhecimento transdisciplinar (1997); Turismo e Geografia - Reflexões teóricas e enfoques regionais (1999) e Turismo. Modernidade. Globalização. (2000).

Outro trabalho referencial é o desenvolvido pelos pesquisadores da rede nacional Observatório das Metrópoles na sua linha de pesquisa "Estudo comparativo sobre o papel das atividades imobiliário-turísticas na transformação do espaço social das metrópoles nordestinas: Salvador, Recife, Natal e Fortaleza”, coordenado pelo Prof. Dr Luiz César de Queiroz Ribeiro (IPPUR-UFRJ) ${ }^{33}$.

Em cada uma dessas cidades existe um núcleo de pesquisa articulado com os demais membros no restante do país. Em Fortaleza é coordenado pelo Prof. Dr. José Borzacchiello e equipe formada pelo Prof. Dr. Eustógio Dantas e a $\operatorname{Prof}^{\mathrm{a}} \operatorname{Dr}^{\mathrm{a}}$ Cleide Bernal, da Universidade Federal do Ceará - UFC, todos com vasta produção acadêmica na área do Turismo e do Desenvolvimento Urbano.

Em "Mar à Vista” (2002) Eustógio Dantas sintetiza seu estudo sobre a questão da Maritimidade em Fortaleza levantando vários aspectos da ocupação litorânea do Ceará onde o turismo e o fenômeno de segundas-residências aparecem como fatores relevantes mais recentes.

Em 2008, publica juntamente com CASTRO, A. P. e PEREIRA, A. Q. o artigo “Urbanização Litorânea das Metrópoles Nordestinas Brasileiras: vilegiatura marítima na Bahia, Pernambuco, Rio Grande do Norte e Ceará",34 abordando a urbanização turística fundamentada na questão da valorização dos espaços litorâneos. Trabalham o enfoque em perspectiva Geográfica Cultural, associando a consolidação das novas práticas marítimas modernas à lógica de ocupação, interpretada nos vários "movimentos" de descoberta das zonas de praia iniciada pelos vilegiaturistas, vistos em perspectiva histórica.

\footnotetext{
${ }^{33} \mathrm{https}: / /$ sites.google.com/a/metrowiki.net/rmf/linhas-de-pesquisas (17/06/12).

${ }_{34}^{34}$ Por ocasião do simpósio organizado pela equipe de pesquisadores do Observatório, em Fortaleza em junho de 2008, cujo tema "Espaço Metropolitano, Turismo e Mercado Imobiliário" tratou de vários aspectos da urbanização turística e foi uma espécie de síntese da produção daquela linha de pesquisa em referência. http://sites.google.com/a/metrowiki.net/observat-rio-das-metr-poles-workshop-fortaleza/trabalhosapresentados
} 
$\mathrm{O}$ conceito de vilegiatura, nesse caso, está associado à racionalidade da "sociedade do ócio nos trópicos" e ao "desejo de obtenção da segunda residência, construída nas praias das capitais nordestinas": um fenômeno semelhante ao das residências de veraneio, mas com uma nova abrangência espacial que cruza as fronteiras continentais, impulsionado pelos recentes investimentos em infraestrutura turística do Estado no PRODETUR-NE, entre os anos 1980 e 2000 e às influências da economia internacional.

Ainda no simpósio "Espaço Metropolitano, Turismo e Mercado Imobiliário" ${ }^{35}$, de 2008, vários autores contribuem com a discussão de diversos aspectos complementares sobre o espaço metropolitano e o turismo, como os artigos que tratam: das Bolhas imobiliárias e turismo (BEZERRA, M. M. O; CLEMENTINO, M. L. M. ); Especulação Imobiliária e Turismo no Nordeste (BERNAL, M. C. C.); As falácias sedutoras de um novo produto imobiliário (MAMMARELLA, R.; BARCELLOS, T. M. ); Fragmentação Socioespacial no Espaço Litorâneo de Fortaleza (BRASIL, A. B.); O Desencontro dos territórios de oportunidades para investimentos imobiliario-turisticos no litoral pernambucano (SOUZA, A. M); Urbanização Litorânea das Metrópoles Nordestinas Brasileiras (DANTAS, E. W. C.; CASTRO, A. P.; PEREIRA, A. Q. ), entre outros, todos disponíveis no site citado.

\subsubsection{As bases da política de turismo no Ceará: reflexão sobre a organização do espaço urbano em Fortaleza e RM.}

As singularidades físicas, humanas e climáticas do Ceará, em particular do seu litoral, contribuíram para consolidar uma imagem potencialmente viável para o desenvolvimento de atividades turísticas, tendo suscitado inúmeras discussões, proposições e iniciativas sobre o assunto, ao longo dos últimos anos que proporcionaram as bases da política de turismo do Ceará.

\section{Uma periodização da inserção do turismo no planejamento governamental}

O primeiro passo, em direção ao planejamento do turismo no Brasil deu-se ainda no governo do presidente Castello Branco, que cria a EMBRATUR em 1966, o que pode

\footnotetext{
${ }^{35} \mathrm{http}: / /$ sites.google.com/a/metrowiki.net/observat-rio-das-metr-poles-workshop-fortaleza/trabalhosapresentados
} 
significar apenas um referencial, pois somente a partir dos anos 1970 o turismo começou a ser tratado nas políticas intervencionistas dos Estados elaboradas pelos governos militares.

Entre 1971 e $1974^{36}$, no Ceará, o turismo representava ainda uma atividade econômica incipiente e em todo o Brasil e vivia-se o "milagre" de um país "desenvolvimentista". Seu plano de governo fazia apenas referências às potencialidades turísticas do Estado, no entanto criou a Empresa Cearense de Turismo S/A - EMCETUR, acreditando que seria o órgão que faltava para iniciar o desenvolvimento da atividade no Estado.

Em $1975^{37}$ o Primeiro Plano Quinquenal de Desenvolvimento do Estado do Ceará (PLANDECE), destacava o papel do turismo e estabelecia os objetivos para o seu desenvolvimento, diante de uma nova conjuntura promissora que começava a se desenhar no País.

Em $1979^{38}$, o primeiro Plano Integrado de Desenvolvimento Turístico do Estado do Ceará, expressava mais um caráter diagnóstico do que um programa de ação, propriamente dito. Serviu de base, contudo, para os planos posteriores.

Na chamada "fase de transição" dos governos militares para o primeiro governo civil, em $1983^{39}$, o Plano Estadual de Desenvolvimento (PLANED) projetou, no discurso, uma sintonia entre os interesses do governo e os da sociedade, "ouvindo" sugestões de organizações empresariais, lideranças políticas, associações comunitárias e sindicatos. Também traçava objetivos para o desenvolvimento do turismo, dando atenção especial à pesquisa e ao intercâmbio de informações, reestruturando a EMCETUR (CORIOLANO, 1998, p. 60).

No contexto brasileiro, o Presidente liberava o mercado turístico para a iniciativa privada, esgotando o modelo centralizador. Em 1981, com a Lei 6.938, que estabelece a Política Nacional de Meio Ambiente, o turismo teve que se conformar à nova realidade imposta pelo mundo inteiro, que questionava a postura brasileira no tratamento do seu patrimônio natural, em especial a floresta amazônica, a mata atlântica e o litoral.

\footnotetext{
${ }^{36}$ Que no Ceará coincide com o governo César Cals

${ }^{37}$ No governo de Adauto Bezerra

${ }^{38}$ No governo de Virgílio Távora

${ }^{39}$ No governo de Gonzaga Mota
} 
Em 1987, o panorama político brasileiro desenhava-se no esvaziamento do poder dos militares e na composição de forças que resultou no mandato de José Sarney. No Ceará, assumiu Tasso Jereissati, iniciando o que viria a ser chamada a "fase dos empresários". Neste mesmo ano, a EMBRATUR lançou o turismo ecológico, como um novo produto e em 1988 a nova Constituição brasileira dedica um capítulo inteiro ao meio ambiente e dois parágrafos ao turismo, demonstrando ressonância ao avanço da questão ambiental e do turismo, que se apresentava ainda em desenvolvimento incipiente. Somente a partir do final da década de 1980

pode-se dizer que o turismo foi introduzido de maneira mais programada e arrojada, no Ceará, através das políticas públicas de desenvolvimento econômico com o Plano das Mudanças do governo Jereissati (1987/1990), considerando o turismo como um dos eixos de propulsão crescente da economia local. Este plano destaca a vocação do turismo litorâneo, uma vez que representava a mentalidade empresarial que valoriza, sobretudo, o potencial latente mais próximo ao uso e sua inserção ao mercado. (CORIOLANO, 1998, p. 67)

A partir de então, o turismo apareceu de forma recorrente nos discursos oficiais como um "novo instrumento de desenvolvimento regional", mediante ações coordenadas pelo poder público, nas suas diversas escalas de abrangência. $\mathrm{O}$ fato de ser considerado uma novidade decorre da importância crescente que o turismo vinha consolidando no cenário mundial, não só como uma das mais importantes atividades econômicas, nos países inseridos ao processo na globalização, mas, sobretudo, por configurar-se como uma emergente prática social da pós-modernidade (BENEVIDES, 1998, p. 19).

O reconhecimento deste "papel inovador" exercido pelo turismo foi captado pelo então governo do Estado do Ceará, ensejando a elaboração, em 1989, do PRODETURIS Programa de Desenvolvimento do Turismo do Litoral do Ceará, que constituiu um esforço de planejamento físico-territorial do turismo, resultante de viagens e estudos diagnósticos de campo voltados para o mapeamento do potencial turístico. Esse material converteu-se na contribuição do Ceará ao alinhamento proposto pelos demais governadores do Nordeste, capitaneado pelo então presidente Collor de Mello. 
Da necessidade de compatibilizar-se às propostas do PRODETUR/NE, resultou o PRODETUR-CE em 1992, tendo sido concluídos os estudos técnicos e finalizados os projetos executivos em 1997. A partir de então, iniciaram-se as etapas de implantação dos projetos em obras públicas e privadas que já podiam ser avaliados em alguns de seus aspectos, mas não na sua totalidade pelo fato de ter sido implementada somente a primeira etapa (destacada em lilás no mapa, os municípios beneficiados na Fase I) e ainda estar em curso a sua segunda fase.

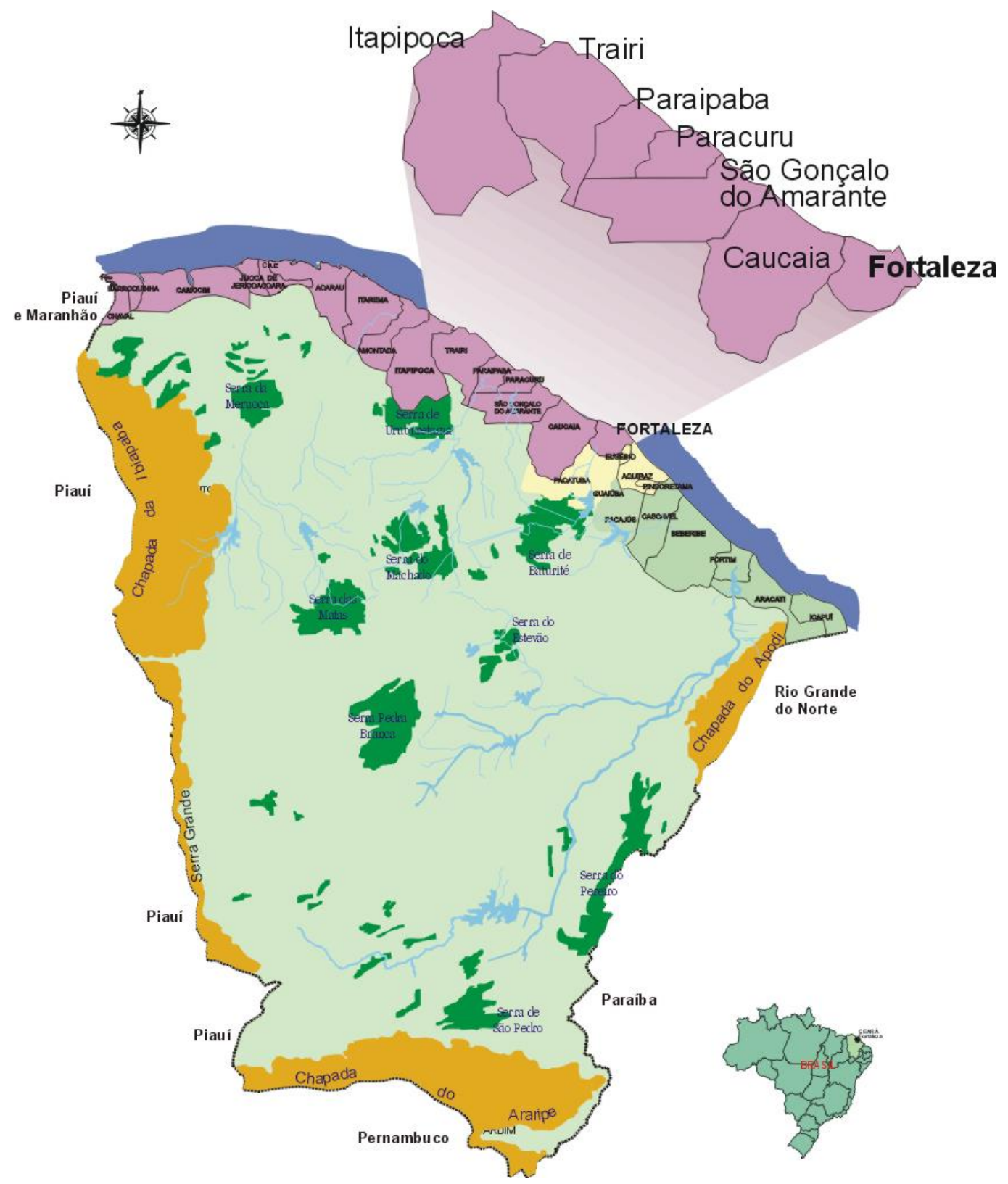

Fig. 2.64 Mapa de localização da região de estudo - PRODETUR/CE- I 
O PRODETUR/NE - I consiste em linha de crédito voltada para o setor público que conta com o financiamento do BNDES (Banco Nacional de Desenvolvimento Econômico e Social), como também de empréstimos do BID (Banco Interamericano de Desenvolvimento), tendo o BNB (Banco do Nordeste do Brasil) como órgão executor. Nas tabelas abaixo, uma síntese dos investimentos efetuados na primeira fase do PRODETUR/CE I e os programas estaduais voltados para a região.

A política nacional de turismo sob a coordenação da EMBRATUR tinha o objetivo de se colocar à frente do processo de indução da atividade turística no Brasil. A implantação do PRODETUR no Nordeste se justificava na necessidade de combater as desigualdades inter-regionais como também equilibrar a concentração de infraestrutura turística alocada no Sul e Sudeste.

Tabela 2.4 - Síntese dos investimentos do PRODETUR/CE I

\begin{tabular}{ccc}
\hline PROJETOS & US $\$$ MILHÕES & $\begin{array}{c}\text { PARTICIPAÇAOO } \\
\text { PERCENTUAL }\end{array}$ \\
\hline Rodovias & 24,24 & $14,8 \%$ \\
Aeroporto & 78,20 & $47,7 \%$ \\
\hline Saneamento básico & 25,76 & $15,7 \%$ \\
Meio ambiente & 5,07 & $3,1 \%$ \\
Desenvolvimento institucional & 2,68 & $1,6 \%$ \\
Aquisição de terras & 5,67 & $3,5 \%$ \\
Engenharia e administração & 6,19 & $3,8 \%$ \\
Custos financeiros & 16.00 & $9,8 \%$ \\
\hline TOTAL & $\mathbf{1 6 3 , 8 1}$ & $\mathbf{1 0 0 , 0} \%$ \\
\hline
\end{tabular}

Fonte: UEE - PRODETUR/CE

Tabela 2.5 - Programas estaduais voltados para a região

\begin{tabular}{ccc}
\hline PROGRAMAS & US\$ MILHŌES & MUNICípIOS \\
\hline PRODETUR & 163,81 & Fortaleza, Caucaia, São Gonçalo do Amarante, \\
PROURB & 8,82 & Paracuru, Paraipaba, Trairi e Itapipoca \\
PROARES & 4,67 & Caucaia, São Gonçalo do Amarante e Itapipoca \\
SANEFOR & 1,65 & Fortaleza \\
METROFOR & 25,69 & Fortaleza \\
COMPLEXO PORTUARIO DO & 16,25 & São Gonçalo do Amarante \\
PECÉM & & \\
\hline
\end{tabular}

Fonte: UEE - PRODETUR/CE 
Nas Tabelas 2.4 e 2.5, verificamos a proporção e a quantidade de investimentos do PRODETUR/ CE I e os programas estaduais voltados para a região beneficiada. Verifica-se um montante significativo de investimentos por parte do PRODETUR em relação aos demais programas. É razoável concluir que os investimentos no setor turístico servem simultaneamente à criação de infraestrutura voltada para a atividade industrial, reforçando o alinhamento das políticas públicas adotadas pelo Estado. Embora parte dos recursos aplicados em turismo tenha outras fontes de origem, constata-se a tentativa de ampliar as condições de infraestrutura mínima para o turismo.

O PRODETUR CE/ I investiu no componente saneamento básico o valor aproximado de US\$ 25,76 milhões, beneficiando 11 localidades com uma população de 140.316 habitantes, totalizando 8.839 ligações de água tratada e 24.933 ligações de esgoto. No conjunto de trechos de rodovias que foi beneficiado pelo programa, perfaz um total de aproximadamente 252,86 quilômetros com investimentos em projetos, obras de pavimentação e supervisão, na ordem de $\mathrm{R} \$ 32.005 .083,80$.

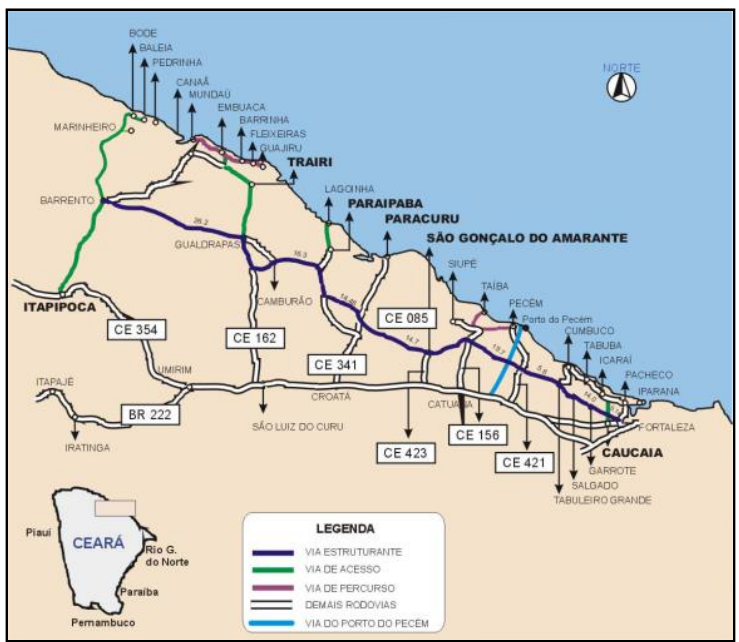

Fig. 2.65 Mapa de rodovias do PRODETUR/CE I

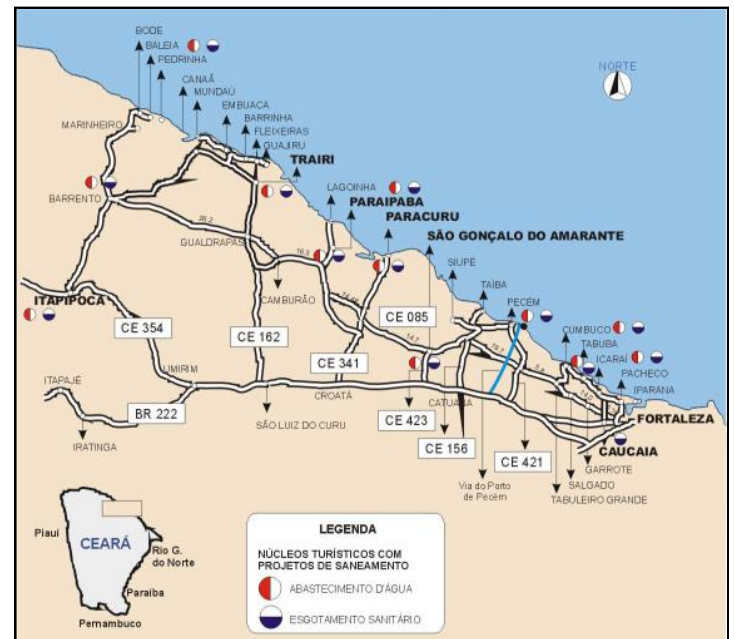

Fig. 2.66 Saneamento básico do PRODETUR/CE I

No caso do Ceará, além dos incentivos financeiros e empréstimos do PRODETUR/CE I, o Governo do Estado oferece, nos moldes das políticas industriais, incentivos fiscais aos investidores, como isenção total ou parcial do Imposto sobre Serviços (ISS) e do Imposto Predial e Territorial Urbano (IPTU).

Para dar continuidade ao processo de desenvolvimento do setor de turismo na região Nordeste, iniciado com o PRODETUR/ NE - I, criou-se o PRODETUR /NE - II 
expandindo-se o benefício para outros dois estados do Sudeste como o Espírito Santo e Minas Gerais, incluindo o vale do Jequitinhonha. Para isso, utilizou o financiamento dos investimentos necessários em ações no âmbito estadual e municipal voltadas para o desenvolvimento da capacidade de gestão e de infraestrutura, objetivando compatibilizar a disponibilidade de serviços públicos com o crescimento do turismo, nas áreas de intervenção (BNB, 2002, p.5).

O PDITS - Plano de Desenvolvimento Integrado do Turismo Sustentável converteu-se na principal ação da segunda fase do PRODETUR/NE II, inserida na Política Nacional de Turismo. O plano adota uma política de turismo mais abrangente expandindo o programa para vários estados da região. No caso do Ceará o PDITS foi um programa voltado para avaliar os impactos do PRODETUR I sobre os municípios e requerer novos empréstimos junto ao BID para financiar o PRODETUR II.

O Polo Costa do Sol constitui a prioridade do PRODETUR/ CE II e engloba 18 municípios, dos quais somente sete foram foco de intervenções na primeira etapa do Programa. Abaixo, a abrangência do Polo Costa do Sol.

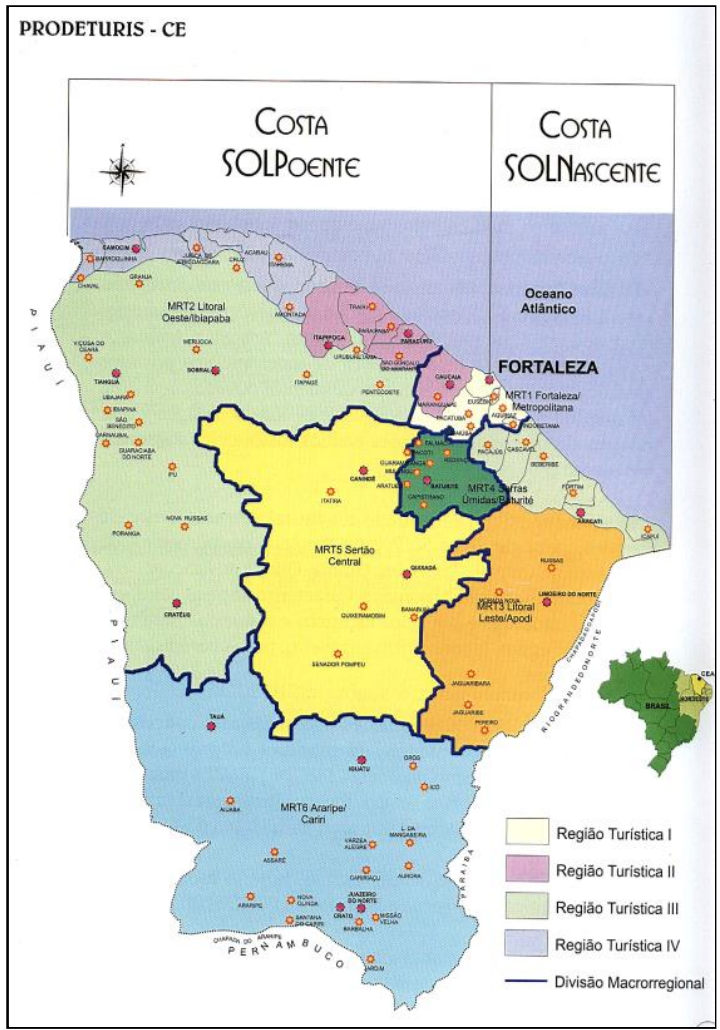

Fig. 2.67 - Municípios incluídos no Prodeturis-Ce Fonte: SETUR - 1998

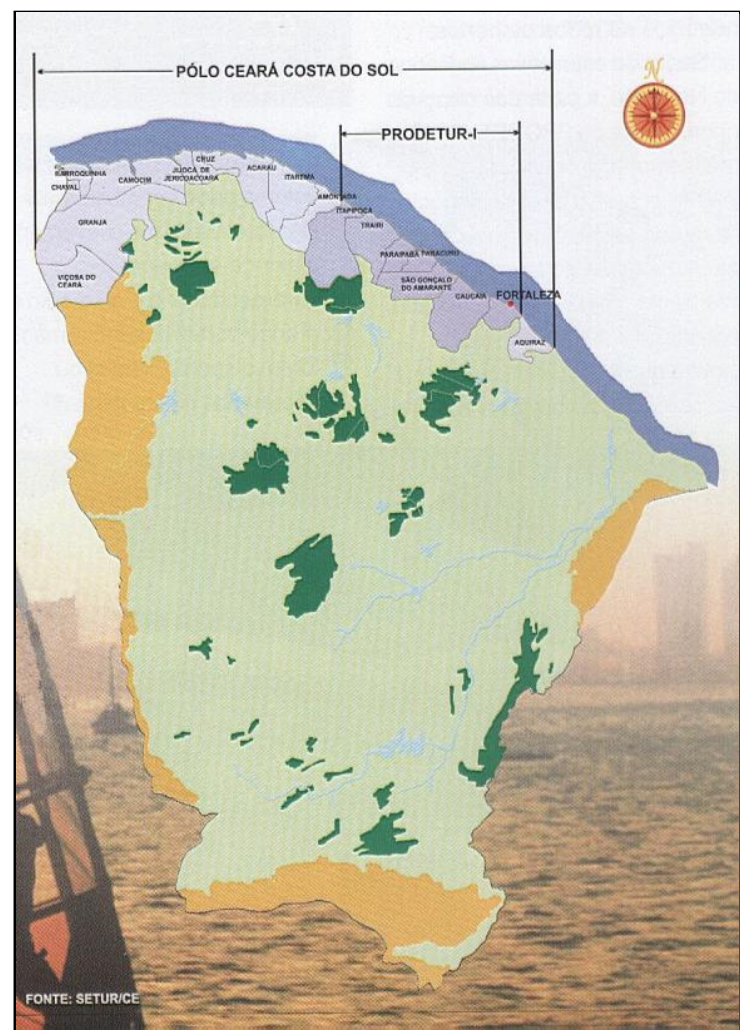

Fig.2.68 - Municípios do Polo Ceará Costa do Sol Fonte: SETUR - 2003 
Segundo o PDITS o Polo Ceará Costa do Sol começou a ser formado com os 6 Municípios da RT II identificada pelo Prodeturis (Fig 68). Hoje, abrange a faixa litorânea entre Aquiraz, na região metropolitana de Fortaleza, e o município de Barroquinha, fronteira cearense com o Piauí, contemplando 18 municípios ricos em atrativos naturais e culturais. A definição estratégica de se ampliar a área inicial do programa aconteceu porque a ligação da faixa, onde se encontra o complexo portuário do Pecém e a futura refinaria de petróleo do Estado, com o Aeroporto Internacional Pinto Martins, em Fortaleza, potencializa os trabalhos desenvolvidos, possibilitando um maior intercâmbio com os mercados emissores estrangeiros. Além disso, a não inclusão das regiões de Aquiraz, Camocim e Jijoca de Jericoacoara, que vem atraindo um número crescente de turistas, acarretaria em uma perda significativa para $\mathrm{o}$ desenvolvimento turístico regional do Estado (PDITS, 2002 in BNB, 2005).

Depois de quinze anos, desde a sua criação, o Programa de Desenvolvimento do Turismo passa a ter abrangência em todo o país e passou a ser denominado de PRODETUR NACIONAL. Por meio do programa, estados e municípios brasileiros que tenham mais de um milhão de habitantes, poderão solicitar recursos diretamente ao Banco Interamericano de Desenvolvimento - BID, dentro de suas respectivas capacidades de endividamento e critérios acordados entre o Ministério do Turismo MTur e o próprio banco.

O PRODETUR NACIONAL dessa vez passou a basear suas ações focando em áreas prioritárias, denominadas de POLOS, as quais são selecionadas pelos próprios estados. A partir dos polos selecionados é realizado um processo de planejamento estratégico, denominado de Plano de Desenvolvimento do Turismo Sustentável - PDITS (CEARÁ, 2008), com prazo de implantação do programa quatro anos.

O Ceará selecionou dessa vez o Litoral Leste, a Chapada da Ibiapaba e o Maciço de Baturité como suas áreas prioritárias, ou seja, seus PÓLOS de Desenvolvimento Turístico e em 2008 apresentou o seu PDITS que está em fase de viabilização.

\section{Os fundamentos da política de turismo no Ceará}

No princípio, o Plano de Governo das Mudanças (1987-1990) propôs maximizar o potencial turístico através da reformulação da base institucional de apoio ao turismo 
(CODITUR); suporte técnico e incentivos a iniciativa privada na implementação de projetos; adequação dos equipamentos de infraestrutura básica; combate aos efeitos da sazonalidade e melhorias no atendimento ao turista (informações e animações). Desse modo, busca promover o eficiente aproveitamento do potencial turístico do Estado, através de diversas diretrizes, de fomento ao turismo.

Esse processo foi evoluindo progressivamente ao longo dos seguintes planos de governo que se sucederam mantendo as mesmas orientações políticas ao longo da década de 1990, no Plano Plurianual (1991-1994), atingindo o seu auge no Plano de Desenvolvimento Sustentável do Ceará (1995-1998). Neste, foram definidas as bases para a "Política Estratégica para o Desenvolvimento Sustentável do Turismo do Ceará 1995 - 2020”, elaborada em 1995, pela recém-criada Secretaria de Turismo do Estado SETUR, com o objetivo de planejar e coordenar a sua política de turismo.

O modelo proposto pela nova política orientava-se pelo conceito de "cluster econômico", ou "cadeia produtiva" que significa um agrupamento de empresas que comercializam produtos e serviços, abastecidos por uma rede de fornecedores de insumos, apoiados por instituições que oferecem recursos humanos, financeiros, tecnologia e infraestrutura física. Desse modo, tal política pretende envolver diferentes atividades econômicas, buscando a integração entre governo, empresários, agentes financeiros e outros segmentos representativos com o objetivo de elevar a competitividade do setor.

O produto turístico é visto como o resultado do encadeamento de ações entre os diversos agentes de promoção e comercialização que, por sua vez, estão relacionados com a cadeia produtiva do turismo nos três setores: primário (agricultura, pecuária e extrativismo); secundário (artesanato, têxtil, calçados, agroindústria, alimentícios, transporte, construção e comunicações etc.) e terciário (hospedagem, bares, restaurantes, equipamentos de lazer e cultura, comércios, financeiros etc.) que por sua vez são dependentes das bases econômicas: infraestrutura e de apoio. Assim, é esperado que essa estratégia de comercialização do produto turístico provoque uma série de reações em cadeia, articuladas de modo interdependente que, em última análise, promoverá uma maior dinamização da economia e o seu consecutivo crescimento (BENEVIDES, 2003). 


\section{Configuração da base física e o ordenamento espacial: as macrorregiões turísticas}

Para o efeito do ordenamento espacial, a SETUR utilizou como ponto de partida as três unidades geoambientais básicas do Ceará: litoral, serra e sertão. Assim, procurou identificar características positivas capazes de serem convertidas em fatores de atratividade no sentido de reverter a imagem negativa que historicamente associava o Ceará a grandes períodos de secas e problemas de natureza social e econômica.

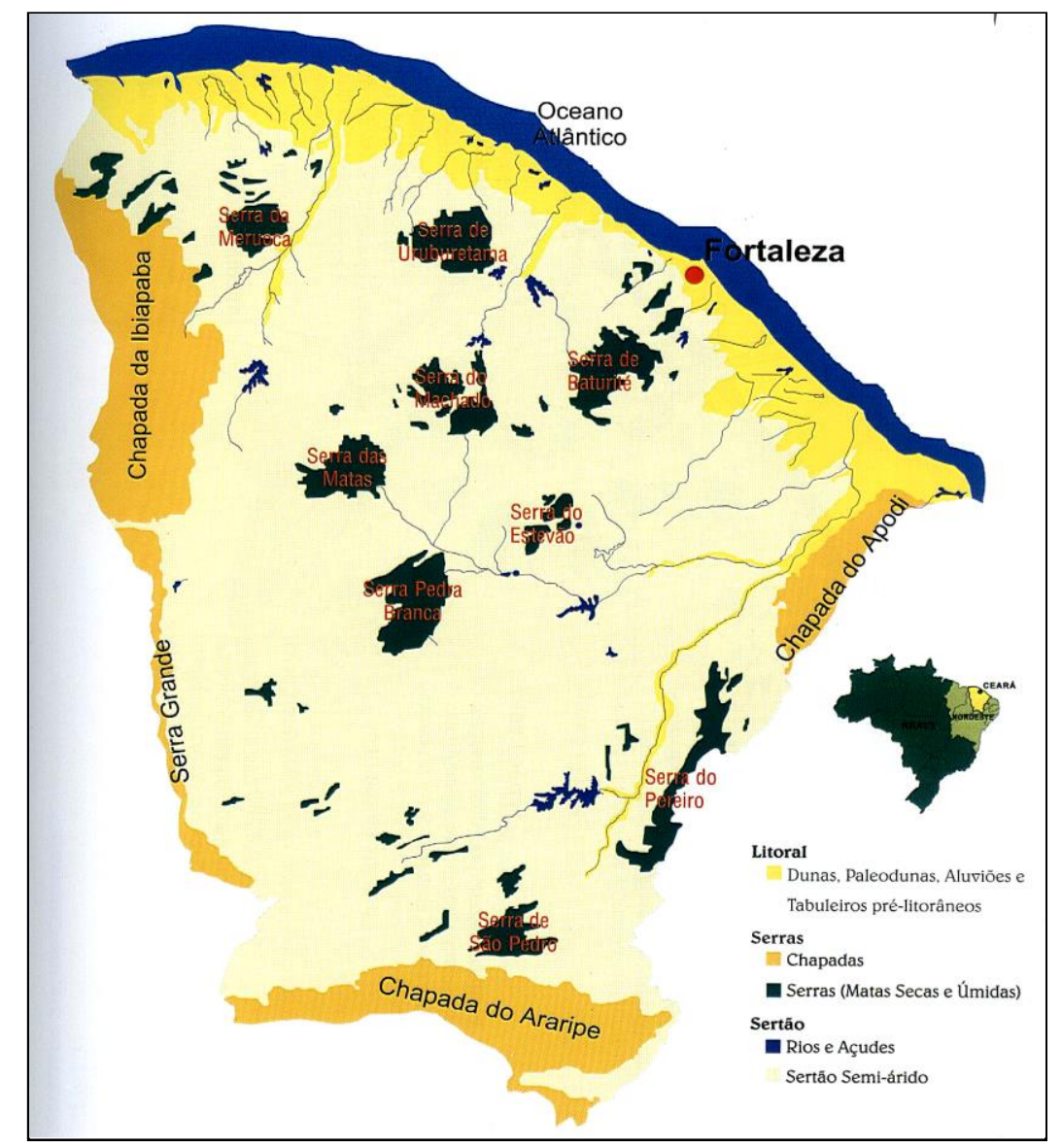

Fig. 2.69 - Unidades Geoambientais - Ceará. Fonte: SETUR (CEARÁ, 1995).

Do somatório desses elementos de caráter espacial, infraestrutural, de vocação e polarização, foi originado um conjunto de seis macrorregiões turísticas, delimitadas segundo os critérios político administrativos; físicos; geoambientais; turísticos e socioeconômicos. A MRT1 - Fortaleza Metropolitana; MRT2 - Litoral Oeste / Ibiapaba; MRT3 - Litoral Leste / Apodi; MRT4 - Serras Úmidas / Baturité; MRT5 - Sertão Central e MRT6 - Araripe / Cariri, constituindo assim a base física de interação e 
organização do espaço para aglutinar ações, segundo as potencialidades, deficiências e características principais comuns às macrorregiões.

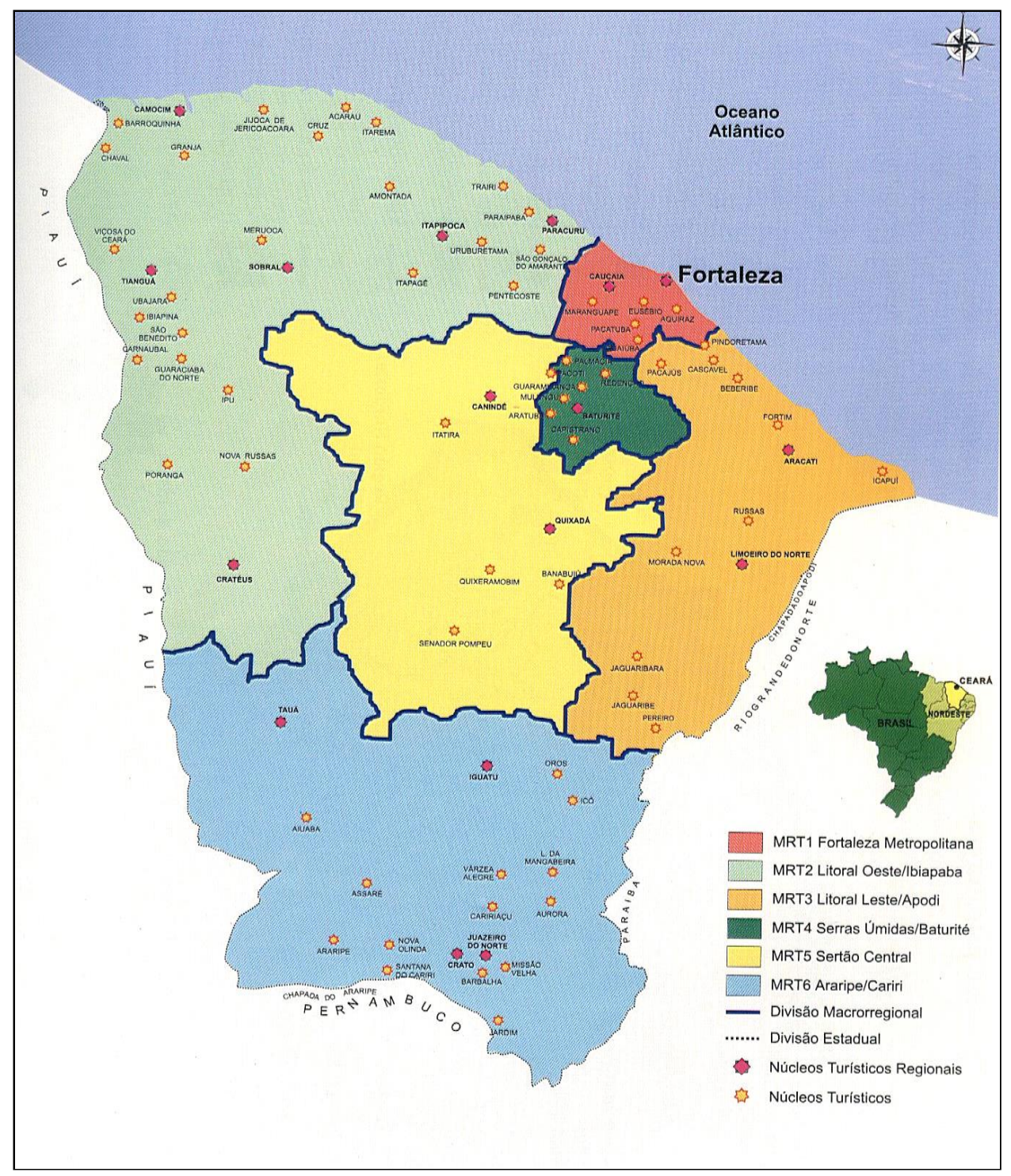

Fig. 2.70 - Macrorregiões Turísticas. Fonte: SETUR (CEARÁ, 1995).

Para viabilizar a articulação entre as macrorregiões turísticas, foi proposta a criação do Corredor Turístico Estruturante, que representa o meio físico que pretende localizar e sediar, de forma agregada, o conjunto de atrativos, infraestruturas e facilidades. Com isso, interliga-se por eixos de transportes existentes ou projetados que constituirão os polos e núcleos turísticos, definindo assim um sistema de acesso de percurso ao longo do Estado. 


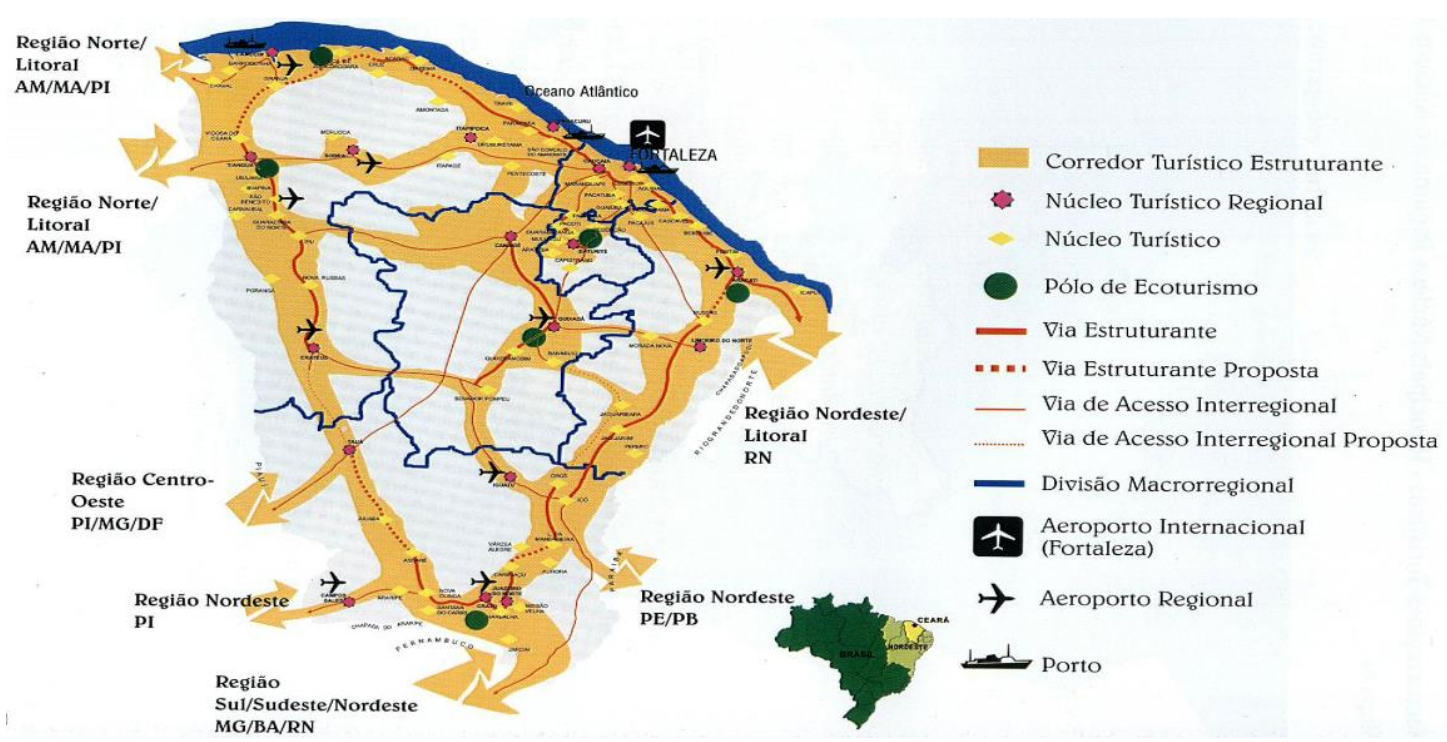

Fig. 2.71 - Corredor Turístico Estruturante. Fonte: SETUR (CEARÁ, 1995).

Esse corredor estruturante da organização espacial do turismo no Estado foi projetado com o objetivo de interligar as demais "âncoras turísticas", um conceito que representa os diversos atrativos, capazes de alavancar o desenvolvimento das macrorregiões turísticas, identificadas pelas potencialidades e vocações de cada uma. Esse conceito também justifica a opção por equipamentos hoteleiros de grande porte, do tipo resort, situados em localização estratégica de grande valor paisagístico e ambiental.

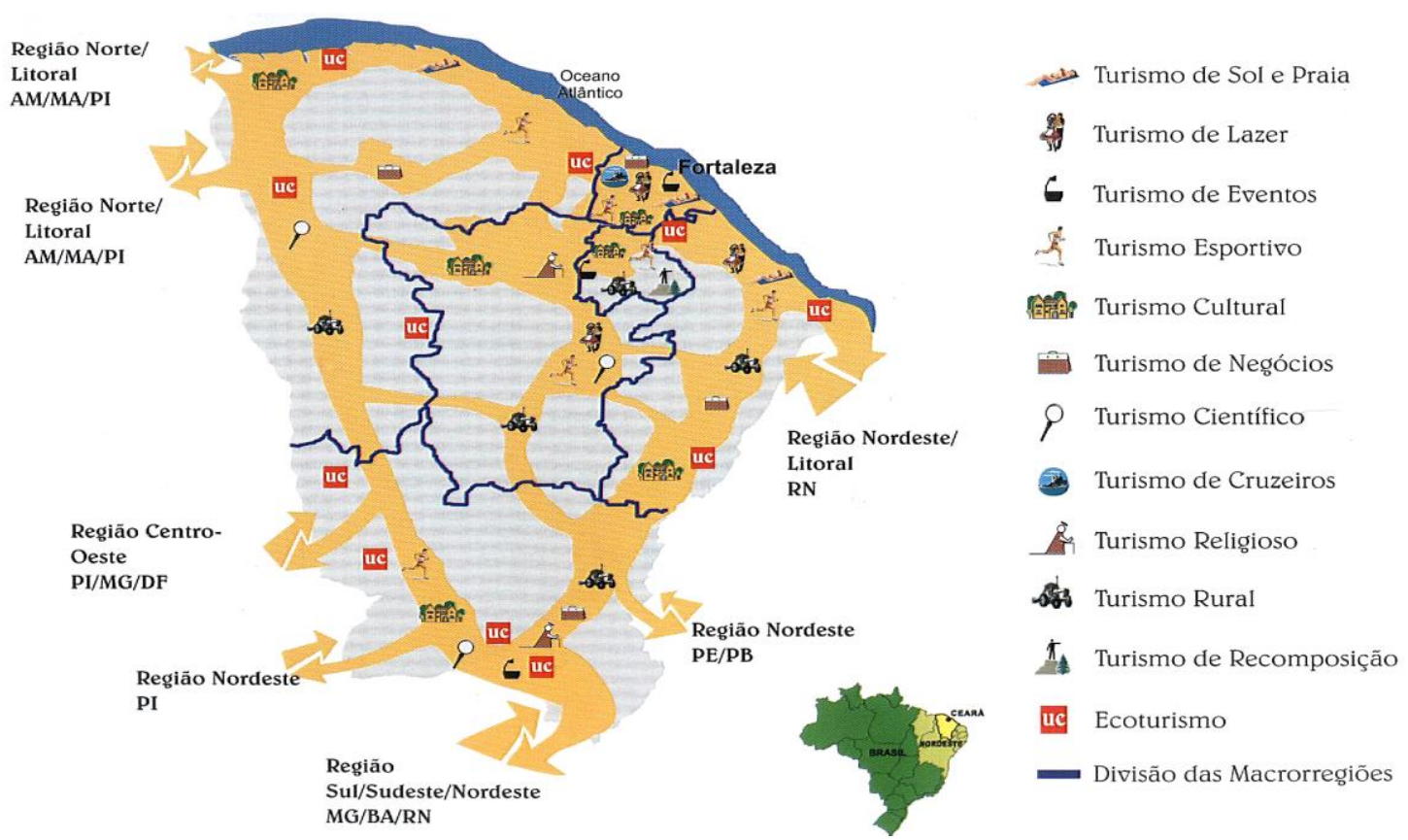

Fig. 2.72 - Âncoras Turísticas. Fonte: SETUR (CEARÁ, 1995). 
A partir dessa noção de corredores e âncoras turísticas a implantação das diretrizes da Política de Turismo do Ceará se deu sob o apoio financeiro do PRODETUR-NE, destinados, entre outras finalidades, às melhorias de infraestrutura urbana, sobretudo as de acessibilidade, voltadas para atrair os investimentos privados em equipamentos turísticos.

Essa modalidade de intervenção movimentou volumes expressivos de recursos financeiros, modificando o padrão de uso e ocupação e densidade demográfica do litoral cearense, como podemos verificar no gráfico abaixo. O primeiro representa a distribuição de aplicações da primeira fase do PRODETUR-NE, em US\$ milhões, onde o Ceará figura em segundo colocado com volumes na ordem de 142 US\$ milhões, entre os anos 1990 a 2000.

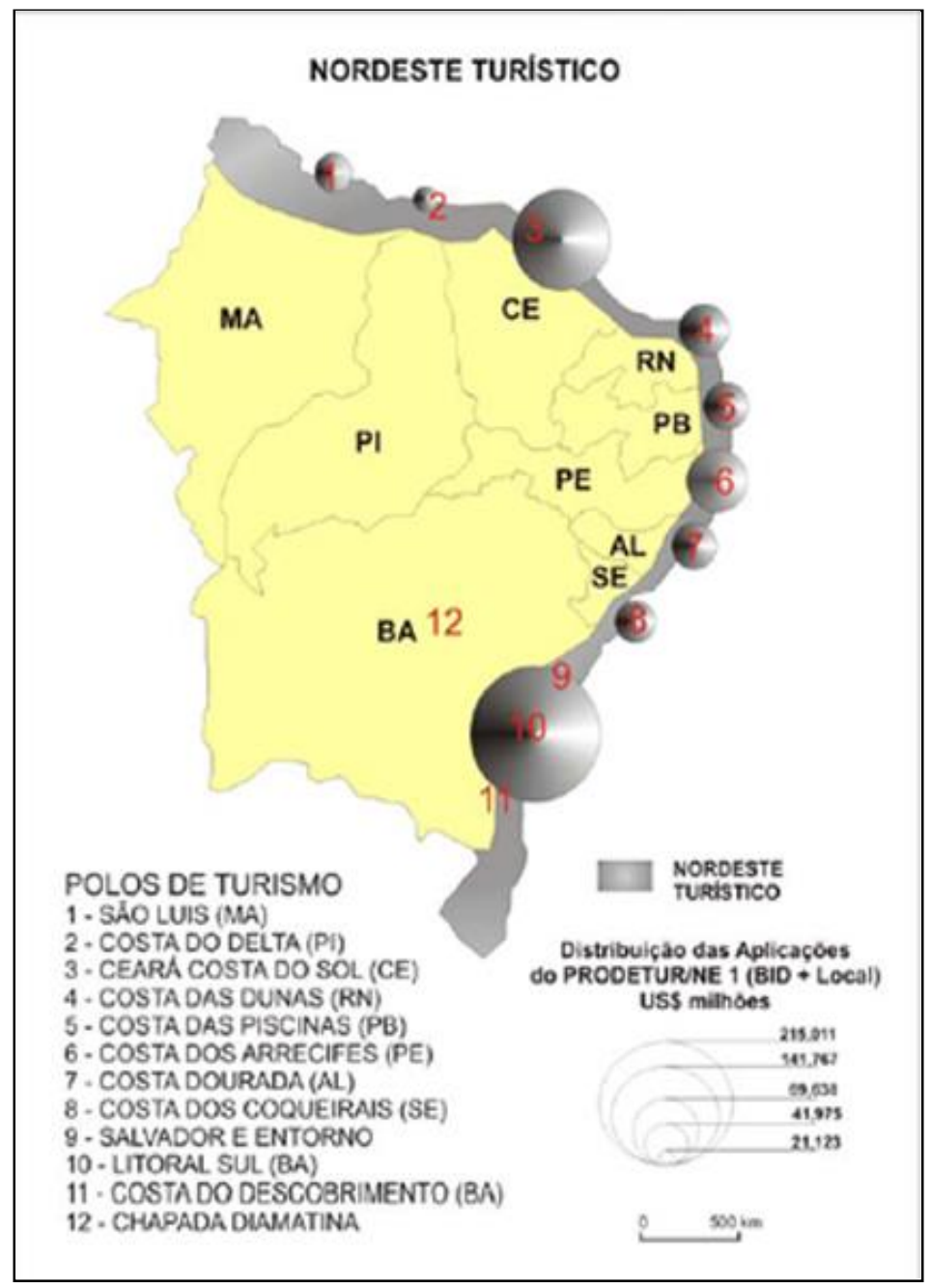

Fig. 2.73 - Distribuição das aplicações do PRODETUR Fonte: Pinot 2006 (apud CUNHA \& PEDREIRA, 2008) 
Quando os investimentos são empregados próximo aos limites da Região Metropolitana, configura um tipo de urbanização dispersa característica da urbanização turística contemporânea que no caso de Fortaleza adquire feições peculiares, das quais nos propomos a estudar.

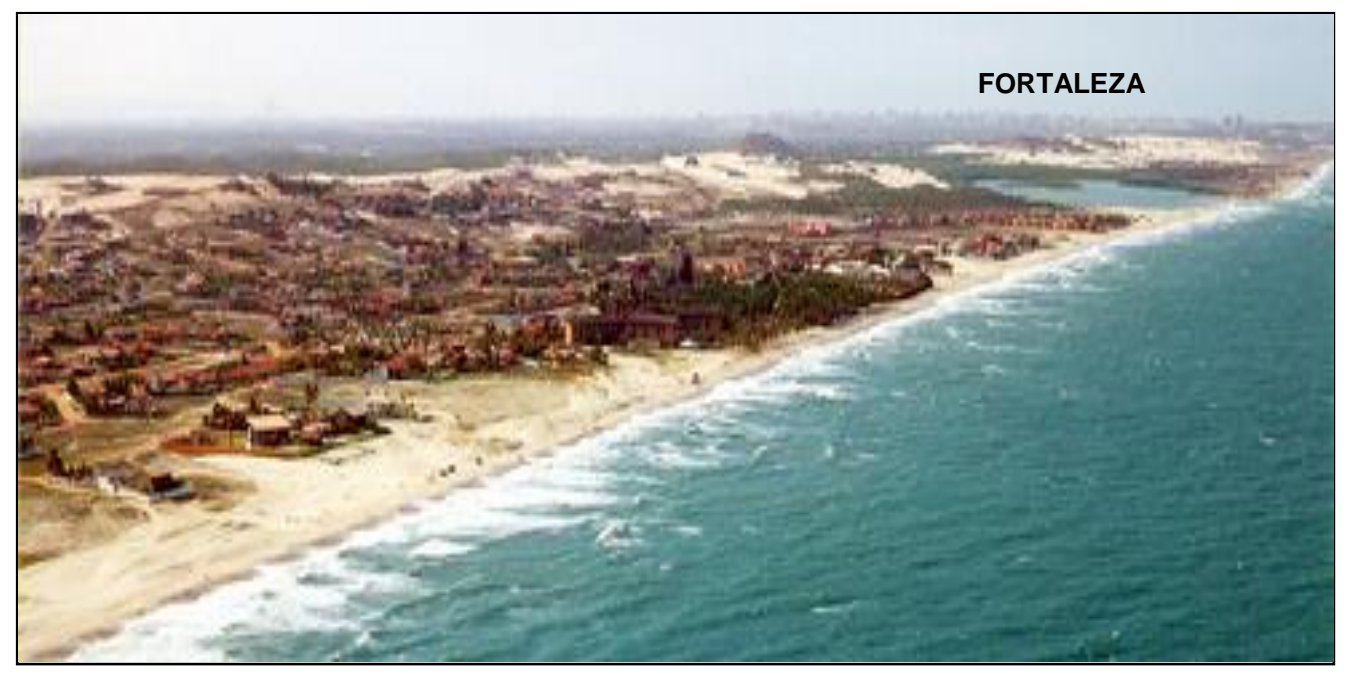

Fig. 2.74 - Tipo de urbanização dispersa provocado pelo turismo. Ao fundo vê-se a cidade de Fortaleza e no primeiro plano o complexo turístico em torno de uma Área de Proteção Ambiental em Aquiraz-CE. Fonte: Skyscrapercity.com

\section{Implicações e reflexões sobre a organização do espaço urbano e o turismo}

Apesar de abrangente, a política de turismo não chega a tratar em detalhes da sua necessária articulação com os planos diretores municipais que naquela altura ainda estavam em processo de licitação para elaboração / revisão, tendo em vista a carência de dados urbanos atualizados na maioria dos municípios. Somente por volta do ano 2000 é que começam a chegar às câmaras municipais, para aprovação, as leis que compõem os primeiros Planos Diretores de Desenvolvimento Urbano elaborados entre 1995 - 2003 pelo PROURB/CE - Projeto de Desenvolvimento urbano e Gestão de Recursos Hídricos, seguindo orientações da nova constituição brasileira de 1988.

Apesar de todo o esforço para elaboração dos PDDU, o que verificamos foi o invariável processo de prorrogação da aprovação dos PDDUs que se alongaram de tal modo, em infindáveis pedidos de revisão, ocasionando o adiamento da efetiva regulação urbana, fruto dos embates dos diversos interesses em jogo articulados nas câmaras municipais 
pelos grupos sociais que ainda marcam posições diferenciadas como: os "movimentos sociais urbanos", os "ambientalistas", o "mercado imobiliário", as "elites econômicas e políticas tradicionais" e as "de esquerda". Em meio à disputa, deixam em aberto a efetiva regulação do espaço urbano, pela legislação básica de Uso e Ocupação do Solo, incompletas em boa parte dos municípios que, com os dados já desatualizados, começam outras revisões, antes mesmo da sua aprovação final, como aconteceu no caso do município de Aquiraz.

Em Fortaleza, do mesmo modo, tivemos um polêmico processo de reelaboração de um novo plano diretor, com ênfase no caráter participativo, a partir de um novo contrato que substituiu definitivamente o Plano diretor financiado pela administração municipal anterior que estava prestes a ser aprovado. A elaboração se deu entre 2006 - 2007 e sua aprovação em 2008, sob um processo de muita negociação e alguns retrocessos pontuais, como na regulamentação das ZEIS.

Esses dados não podem ser considerados exceções ou novidades diante do quadro nacional, mas pode ser visto como um impasse cujas origens se encontram no histórico desinteresse das elites econômicas em enfrentar as especificidades da questão urbana. Autores como Maricato (2001, p. 81), há muito, afirma que "no centro da questão urbanística está o fundiário e o imobiliário" o que transforma a tarefa de elaboração de um "simples" cadastro técnico municipal multi-finalitário, num processo de longuíssimo prazo visto sempre com algo do futuro, inaplicável no presente. Devido à imensa dificuldade que se tornou rever a questão da propriedade da terra no nosso país, tem-se utilizado, em boa medida, os processos de desapropriação, doação ou usucapião como os principais instrumentos de regularização fundiária em massa.

Em todo caso, voltando à análise da política de turismo do Ceará, esta eleva o setor à categoria de prioridade, apresentando-o como uma atividade: estruturadora da economia; aglutinadora e de efeito multiplicador; determinante do bem-estar-social; geradora de renda e impactante no espaço físico, social, ambiental, cultural e no ordenamento urbano e administrativo-institucional. Mesmo reconhecendo-se impactante, as ações do turismo são apresentadas como fundamentadas nos princípios de sustentabilidade; descentralização da gestão; reordenamento do espaço; visão de longo prazo e desenvolvimento social (CEARÁ, 1995). 
A compatibilização dos princípios de sustentabilidade ao caráter impactante no espaço é ponto nevrálgico em qualquer política de desenvolvimento e naquele momento, com a proximidade da repercussão mundial promovida pela ECO-92 no Rio, tais princípios foram convertidos apenas ao conteúdo dos discursos das diretrizes de planejamento. $\mathrm{O}$ motivo é que por falta de arcabouço jurídico maduro e estrutura administrativa pública eficiente na área ambiental, os projetos de equipamentos turísticos são projetados e efetivamente implantados justamente em locais de maior fragilidade ambiental e interesse paisagístico. São os lagamares, manguezais, restingas, campos de dunas, faixas de praia e barras de rios, os locais preferidos para a instalação de novos projetos. Outro problema evidente é questão fundiária litorânea onde historicamente tem apresentado inúmeras irregularidades e imprecisões que acabam virando objeto de infindáveis disputas judiciais.

Esse quadro foi abordado na nossa dissertação de mestrado (MONTENEGRO JR., 2004) quando ficaram expressas de modo emblemático, no final dos anos 1990, as polêmicas em torno do projeto Aquiraz Resort, no litoral do Batoque - localidade do município de Aquiraz, onde foi projetado um empreendimento turístico e imobiliário com todo o apoio estratégico do governo do Estado.

O sítio escolhido para o projeto já estava ocupado, há várias gerações, por comunidades pesqueiras tradicionalmente dependentes dos recursos naturais, quando foi sugerido a sua remoção para áreas vizinhas, gerando grandes polêmicas quanto à questão do título de propriedade das terras. No final da negociação, a propriedade não foi comprovada devidamente pelos supostos proprietários, ocasionando a suspensão do projeto naquele lugar, provocando números prejuízos materiais e institucionais.

Muitos autores como CRUZ (1996) e DANTAS (2002) já discorreram, há bastante tempo, sobre o processo de migração e segregação das comunidades litorâneas tradicionais, tanto na capital como nas localidades litorâneas menores. Nestas, ainda despreparadas para conviver com o rápido processo de valorização das terras litorâneas, seus moradores se submetem a um progressivo processo de troca de domicílio das áreas mais procuradas no litoral para setores menos valorizados.

Apesar disso, ainda hoje, é possível flagrar este processo desigual de apropriação de terras onde grupos de nativos vendem suas posses precárias em terrenos de marinha, de 
propriedade da União, ou mesmo em outros sítios, a terceiros que se utilizam dos expedientes jurídicos em curso, para regularização fundiária em prazo de cinco anos. Essa prática altera profundamente a cultura tradicional local de produção em torno da pesca, da agricultura de subsistência e do extrativismo, para uma já não tão nova modalidade de relação de trabalho sazonal e muitas vezes informal em torno do turismo. Aliás, diga-se de passagem, a maioria dos proprietários de grandes porções de terras loteadas no litoral, utilizaram-se deste expediente no passado recente.

Além dos problemas de segregação socioespacial e dos impactos ambientais já citados, notamos que uma característica parece ser estruturante dessa nova organização do espaço para o turismo e que parece se alinhar ao mesmo princípio que norteia os demais segmentos econômicos dessa reestruturação produtiva no Estado: a prioridade dada ao segmento empresarial, em detrimento dos setores populares. Isso acontece com o agronegócio nos projetos de agricultura irrigada que deixa em segundo plano os setores da agricultura familiar, como também ocorre com o turismo que prioriza os grandes empreendimentos em detrimento dos pequenos empresários locais.

Embora algum tipo de apoio tenha sido registrado no PNMT-Programa Nacional de Municipalização do Turismo e nos PAT - Plano de Ação Turística, esses programas acabaram perdendo força e resultado ocasionado pelas deficiências estruturais das prefeituras que não possuem quadro técnico permanente e competente para dar continuidade às políticas públicas.

O que se percebe, no entanto, como atividade com verdadeiro dinamismo é justamente a atividade imobiliária associada ao turismo que obteve circunstancialmente o apoio institucional do estado articulado aos agentes privados de promoção imobiliária, mas que acabaram também em conflitos contraditórios relacionados ao meio ambiente que comentaremos no próximo capítulo. 


\section{CAPÍTULO III - REESTRUTURAÇAO METROPOLITANA E A EMERGÊNCIA DO TURISMO: O CASO DE AQUIRAZ-CE}

\section{A discussão do método com enfoque em Aquiraz}

Podemos afirmar que toda a exposição elaborada no capítulo anterior teve como objetivo fazer uma primeira aproximação com o objeto de estudo e ao mesmo tempo aprofundar a questão central em torno da hipótese de trabalho. Assim, buscamos confirmar a sua premissa inicial de que há um processo de reestruturação produtiva em curso no Ceará, atingindo Fortaleza em sua dimensão metropolitana e que tem no turismo uma de suas vertentes de estruturação urbana nos eixos litorâneos.

Sobre a primeira parte desse bloco, na aproximação com o objeto, consideramos importante identificar o que é realmente "novo" no campo estudado, tendo em vista que as diversas camadas de urbanização e ocupação superpõem-se, umas às outras, historicamente, num movimento permanente e transitório de estruturaçãodesestruturação-reestruturação. Por isso, partimos de uma síntese histórica capaz de caracterizar as especificidades das Zonas Costeiras e a evolução do processo de ocupação da costa cearense, ressaltando a lógica da urbanização que levou à consolidação de Fortaleza como capital. Com isso, buscamos identificar claramente quando e como ocorre a ruptura mais recente na reestruturação produtiva do Ceará, desenvolvendo a análise do processo de metropolização de Fortaleza.

Essa ruptura, como vimos, ocorre em meio a antigas permanências, próprias da evolução do processo de reestruturação do Estado, mas acompanhada do mesmo padrão de transição metropolitana, alinhada aos ditames da reestruturação produtiva do capitalismo global contemporâneo, mesmo que de forma periférica. Prova disso é o padrão metropolitano encontrado em Fortaleza que combina a expansão descentralizada de funções a uma centralização de comando e polarização locacional da capital. Essa característica, afeta a sua configuração espacial, expressa na distribuição das novas indústrias e dos novos investimentos metropolitanos relacionados ao turismo e ao desenvolvimento urbano.

Cabe agora no próximo bloco, verificar como essa reestruturação metropolitana atinge o território do município vizinho de Aquiraz, fazendo dele uma extensão e 
transbordamento do próprio território da capital submetido à lógica de expansão urbana dos eixos litorâneos metropolitanos.

Essa reestruturação altera o comportamento e o processo produtivo dos agentes imobiliários que atuam no espaço de interface com o turismo: motivo que nos levou, no último segmento, a elaborar uma análise mais detalhada dos conceitos e abordagens teóricas sobre turismo e urbanização. Lembramos também da importância do papel do Estado na produção do "espaço turístico", através da interpretação da inserção do turismo no planejamento governamental do Ceará.

Desse modo, podemos considerar confirmada a premissa inicial de nossa hipótese geral de trabalho preparando as condições para o nosso próximo passo que verificará se essa reestruturação metropolitana interfere na ação e no processo produtivo, relacionados aos agentes imobiliários, em interface com o turismo. Assim, teremos as condições necessárias para elaborar as reflexões que darão suporte às nossas considerações finais.

Entretanto, julgamos oportuno justificar a escolha da nossa proposta, a partir de um breve comentário, cujo objetivo é aprofundar os argumentos que orientaram a fase conclusiva da nossa pesquisa, nesse capítulo.

A ideia de propor agora uma abordagem mais direta, focando a ação dos agentes imobiliários e as transformações socioespaciais como balizadoras das análises, se justifica na compreensão de que: a articulação entre agentes, produtos e segregação, constitui referência fundamental para a compreensão das cidades e do significado que a produção social do espaço assume diante dos fatores condicionantes impostos atualmente pela globalização e pela metropolização, como formulado na proposta de Pereira (2011, p.7).

É possível identificar hoje um novo padrão socioespacial nas cidades que se constitui por intermédio de diversos processos de reestruturação-desestruturação revelando parte de um conjunto de conflitos permanentes responsáveis pela construção social das cidades e pelo desafio na superação das limitações da gestão urbana coletiva.

A partir da análise do comportamento dos agentes imobiliários, foi possível perceber um aumento significativo de novos empreendimentos, com valor, tamanho e programas 
diferenciados, resultantes de relações inovadoras que parecem desenhar um novo campo de disputa pela apropriação do espaço urbano contemporâneo.

A questão central de como os agentes imobiliários articulados ao turismo participam da reestruturação metropolitana de Fortaleza, com efeito, nos levou a fundamentar a tese a partir de uma segunda hipótese de trabalho que é um desdobramento da hipótese geral $^{1}$ formulada sob a afirmação de que: a ação dos agentes imobiliários responde à reorganização de um novo processo de produção do espaço para o turismo, diante da necessidade de incorporar novos territórios à lógica de reprodução do capital.

Por isso, partimos da ideia de que seria necessário conhecer como se fundamenta e constitui a reorganização desse novo processo de produção do espaço para o turismo que desenvolvemos nos capítulos anteriores, através da análise da reestruturação produtiva no Estado e do processo de metropolização de Fortaleza. Nesse caso, verificamos como o turismo passa a ter um papel relevante, articulado às mesmas premissas dessa reestruturação produtiva, isto é: o alinhamento com a lógica de inserção do Estado na economia global.

Agora, propomos abordar como as políticas públicas relacionadas ao turismo atingem de modo exemplar o município de Aquiraz, enfocando a análise das transformações socioespaciais em perspectiva histórica, destacando o papel dos agentes imobiliários frente à especificidade da produção do espaço para o turismo. Assim, teremos as condições necessárias para confirmar ou refutar a segunda afirmação de nossa hipótese de trabalho que em última análise, aponta para os limites e potencialidades contidas na ação desses agentes imobiliários na reestruturação das cidades brasileiras.

\subsection{Caracterização e justificativa do objeto no contexto da transição metropolitana}

Para melhor caracterizar o objeto de estudo, retomamos a sua definição inicial como $o$ novo padrão de ocupação litorânea decorrente do desenvolvimento da atividade turística, verificado na RM de Fortaleza a partir dos anos 1980. Esse novo padrão apresenta-se, sobretudo, articulado à produção imobiliária destinada aos mercados local e global, constituindo-se numa das vertentes da estruturação metropolitana de Fortaleza.

\footnotetext{
${ }^{1}$ A formulação da hipótese geral afirma de que: há um processo de reestruturação produtiva no Estado do Ceará, iniciado no final dos anos 1980 que atingiu Fortaleza em sua dimensão metropolitana, provocando alterações no comportamento dos agentes imobiliários quando da produção do espaço urbano para o turismo.
} 
São considerados padrões porque se repetem superpondo-se á morfologia urbana da metrópole em transição, a partir de um formato paralelo à linha da costa, estruturado para atender à mesma lógica de valorização das terras litorâneas destinadas à reprodução do capital globalizado. Esse padrão linear adota também novos padrões, conceitos e tipologias arquitetônicas e urbanísticas consideradas "inovadoras" e que são reproduzidas em outros locais do Brasil e do mundo, como carimbos, constituindo-se em novos nichos padronizados pelo mercado global. Por ocasião da crise financeira internacional que alcançou maior visibilidade a partir de 2008, no entanto, o processo sofreu uma mudança no ritmo de implantação e passou a ser adaptado, no caso do Ceará, ao mercado nacional e local, diante do recuo dos investidores estrangeiros.

Abaixo, um exemplo do padrão de ocupação reproduzido no mundo inteiro como um novo conceito de vida metropolitana que associa "natureza, esporte e qualidade de vida". O empreendimento Alcacer Art \& Golf Resort é um padrão consagrado, adotado na costa Atlântica e mediterrânea da Europa, especialmente em Portugal e Espanha, e transposto também para o Ceará, por um grupo de investidores portugueses no empreendimento Aquiraz Riviera.

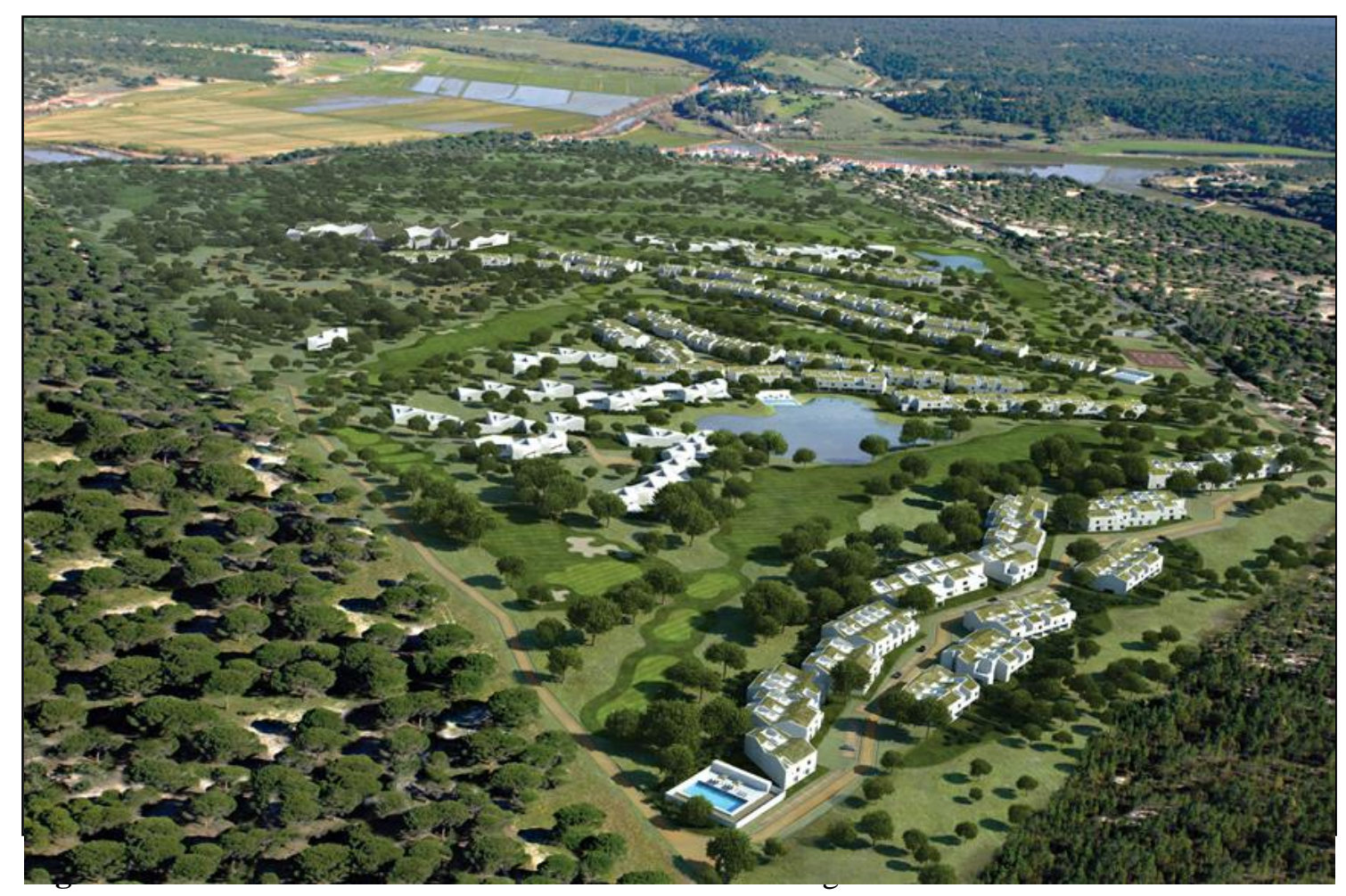

No mapa, abaixo, verificamos como os empreendimentos imobiliários se aproximam dos empreendimentos hoteleiros, como o Hilton, o Marriot e o Four Seasons, 
configurando uma região turística e imobiliária, padrão consagrado utilizado como diferencial de mercado e testado no território cearense.

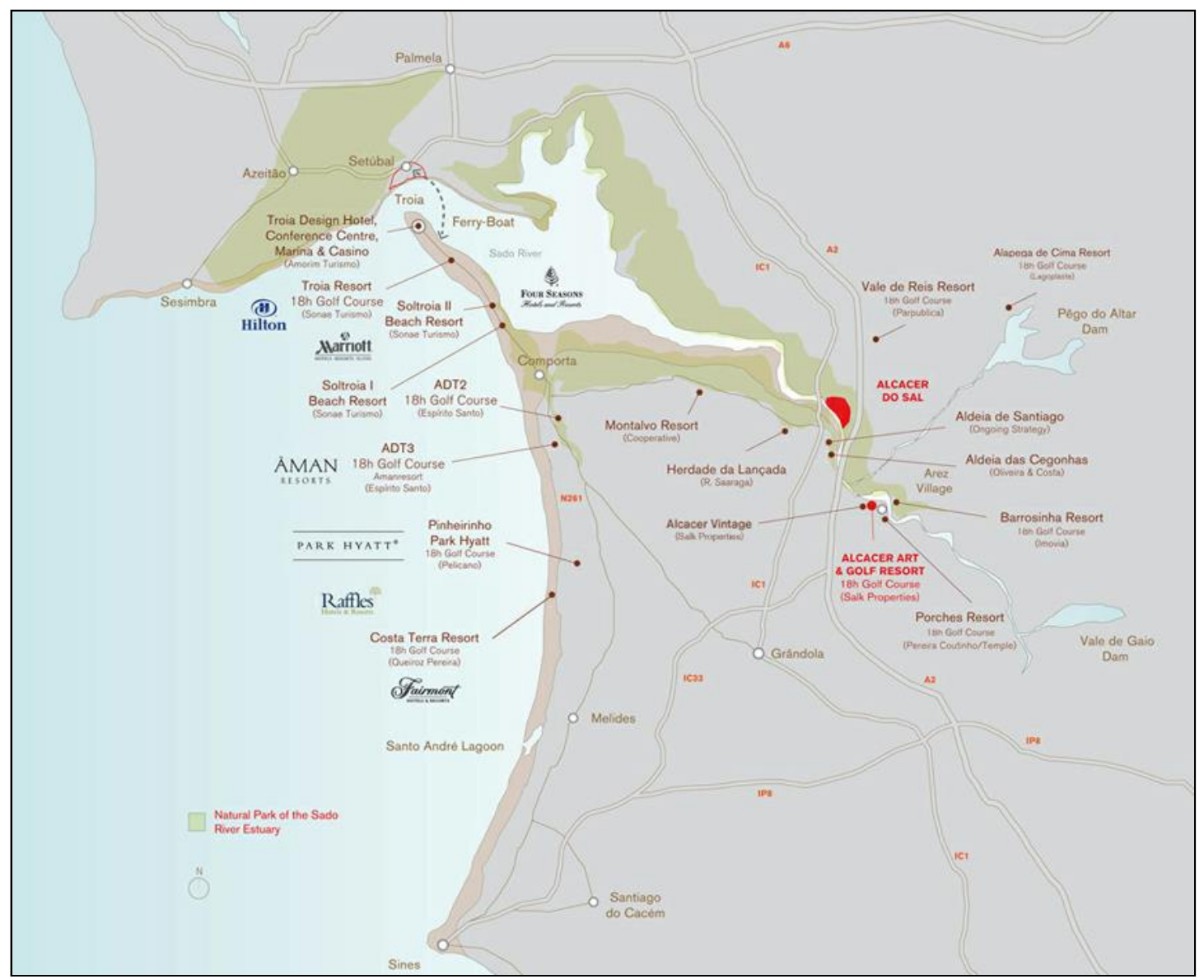

Fig. 3.2 - Localização do Alcacer Art \& Golf Resort (em vermelho) na Região litorânea do Alentejo, próximo a Lisboa, Portugal - Fonte: www.alcacergolf.com.

Esses novos padrões de ocupação são resultantes também da implantação de novos produtos que mesclam características de empreendimentos hoteleiros, imobiliários e de lazer, tais como: cond-hotéis, apart-hotéis, vilas turísticas, golf-clubs, country-clubs, resorts integrados em regime "all inclusive" ou "time-sharing", parques temáticos, condomínios de turismo residencial ou de segunda residência, entre outros, que interagem com o meio urbano, social e natural provocando inúmeras repercussões.

No caso de Aquiraz verificamos em que contexto esses empreendimentos foram idealizados e implantados, analisando como se configuraram as transformações socioespaciais e produtivas no âmbito local. Verificamos também como a adaptação ao novo contexto internacional de crise diminuiu o ritmo de implantação, diferenciando-se ao encontrar com outras dinâmicas de expansão urbana e turística locais, enfrentando os novos impasses relacionados à questão ambiental. Abaixo a maquete eletrônica do 
empreendimento Aquiraz Riviera, com todas as fases implantadas. Ele parte do mesmo conceito de vila turística em torno do campo de Golf, como no caso português, implantado agora em território brasileiro.

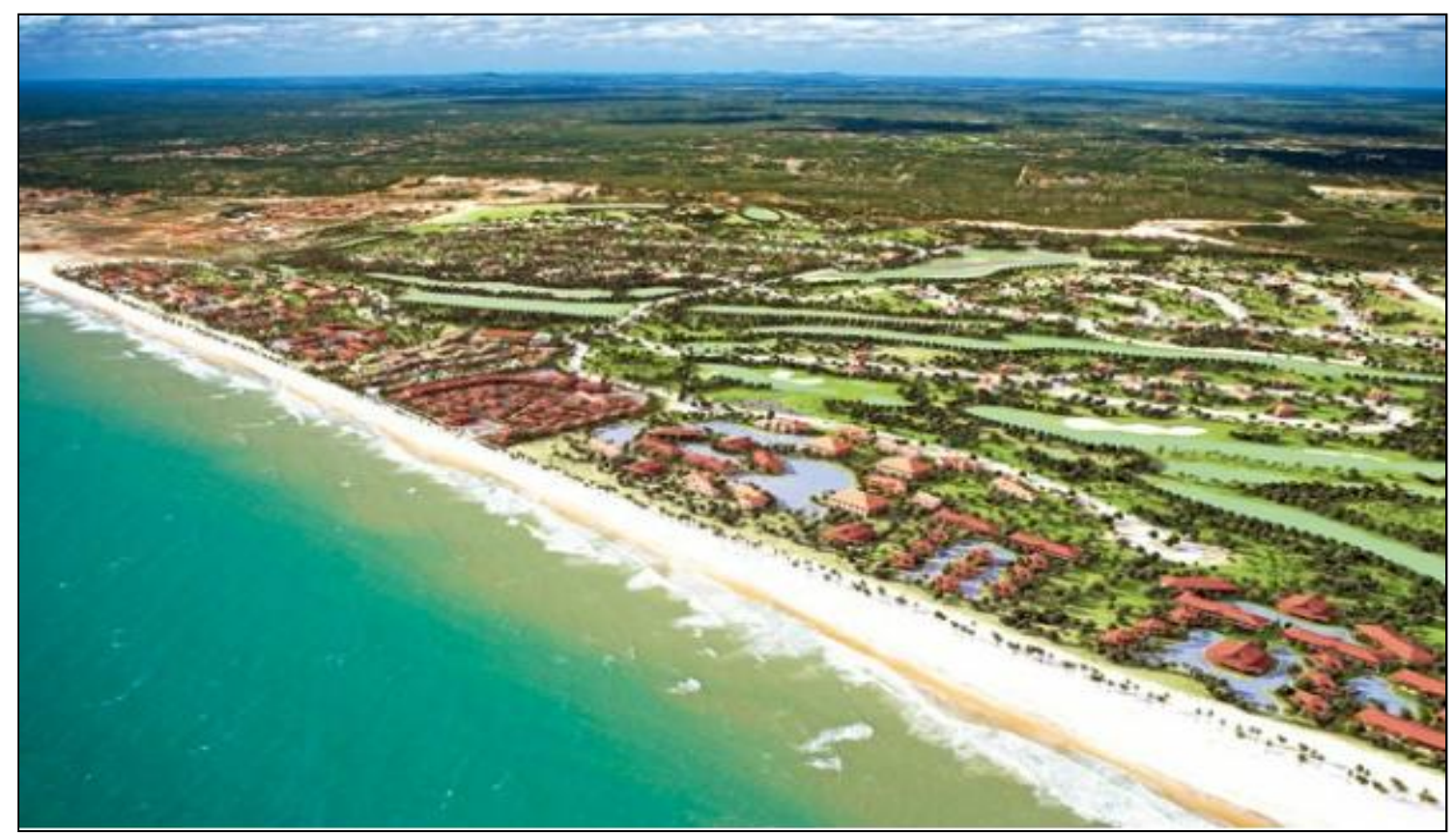

Fig. 3.3 Maquete eletrônica do empreendimento Aquiraz Riviera com oito empreendimentos hoteleiros previstos, na faixa litorânea. Atrás, o campo de golf permeando a malha da vila turística. Fonte: www.aquiraz-riviera.com.

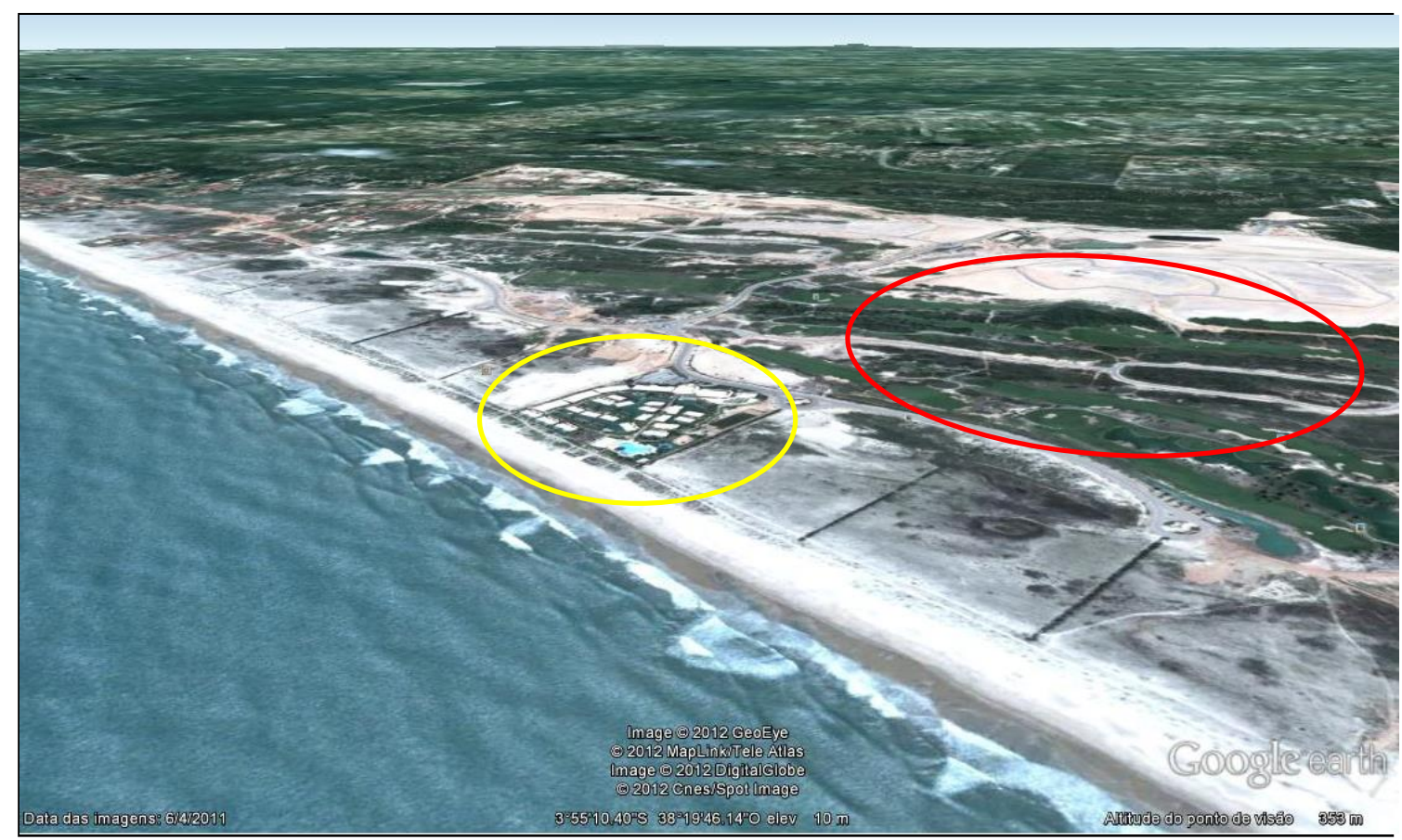

Fig. 3.4 Imagem de satélite atual do Aquiraz Riviera mostrando o primeiro hotel em funcionamento (em amarelo) e uma parte do campo de Golf já construído (em vermelho). Os demais empreendimentos estão em fase de projetos e captação. Embora tenha sido vendido algo em torno de $50 \%$ dos lotes para as vilas turísticas, não há ainda nenhuma casa construída. Fonte: Google Earth - 2012 


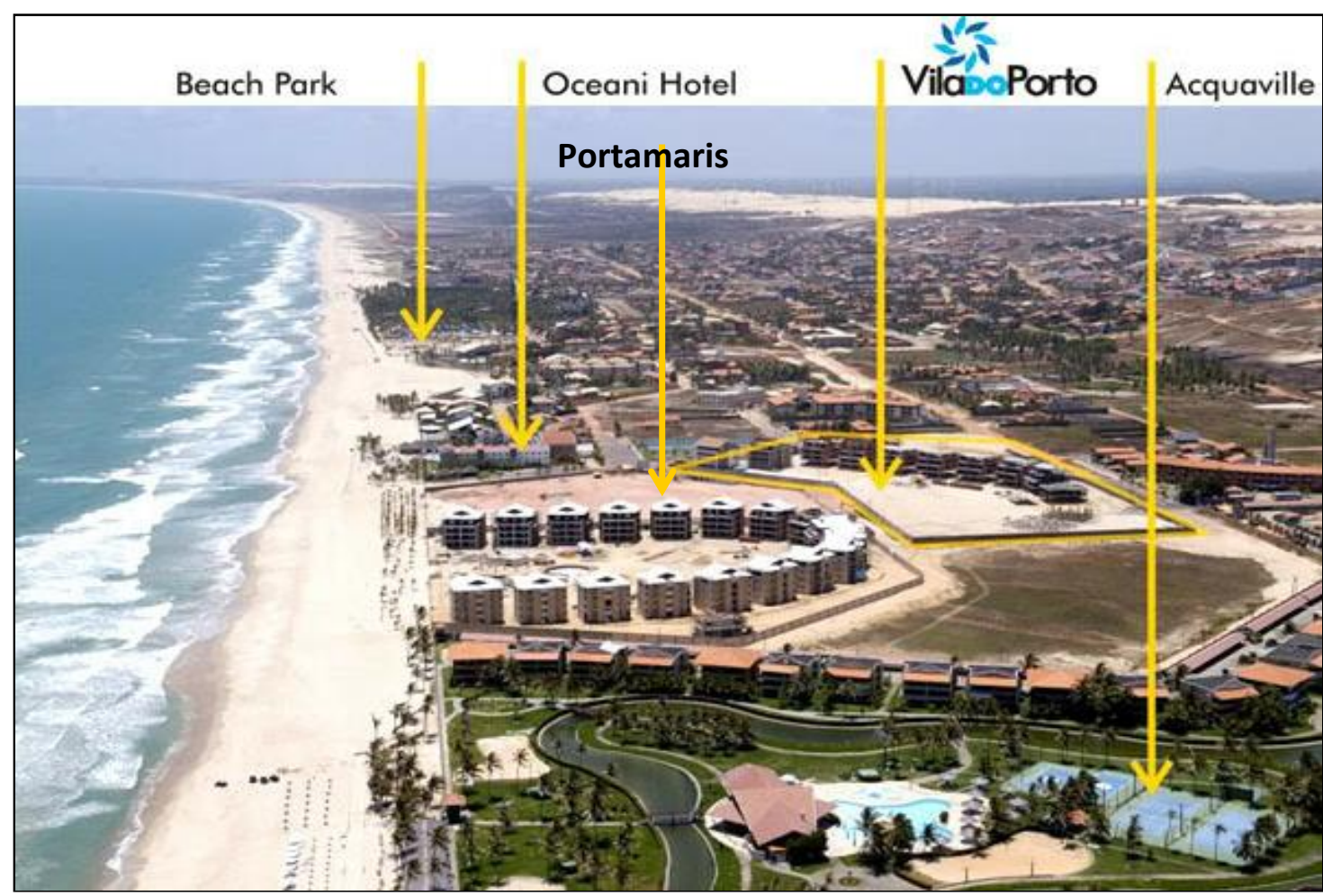

Fig. 3.5 Padrão de ocupação encontrado no litoral do Porto das Dunas, diferente do conceito de Golf Club, mas que também mescla empreendimentos turísticos e imobiliários. Nesse caso, foram implantados em loteamento de veraneio aprovado na prefeitura de Aquiraz, ainda em 1979 que se adequou ao incremento do turismo dos anos 1990. Fonte: Skyscrapercity.com - Foto 2008

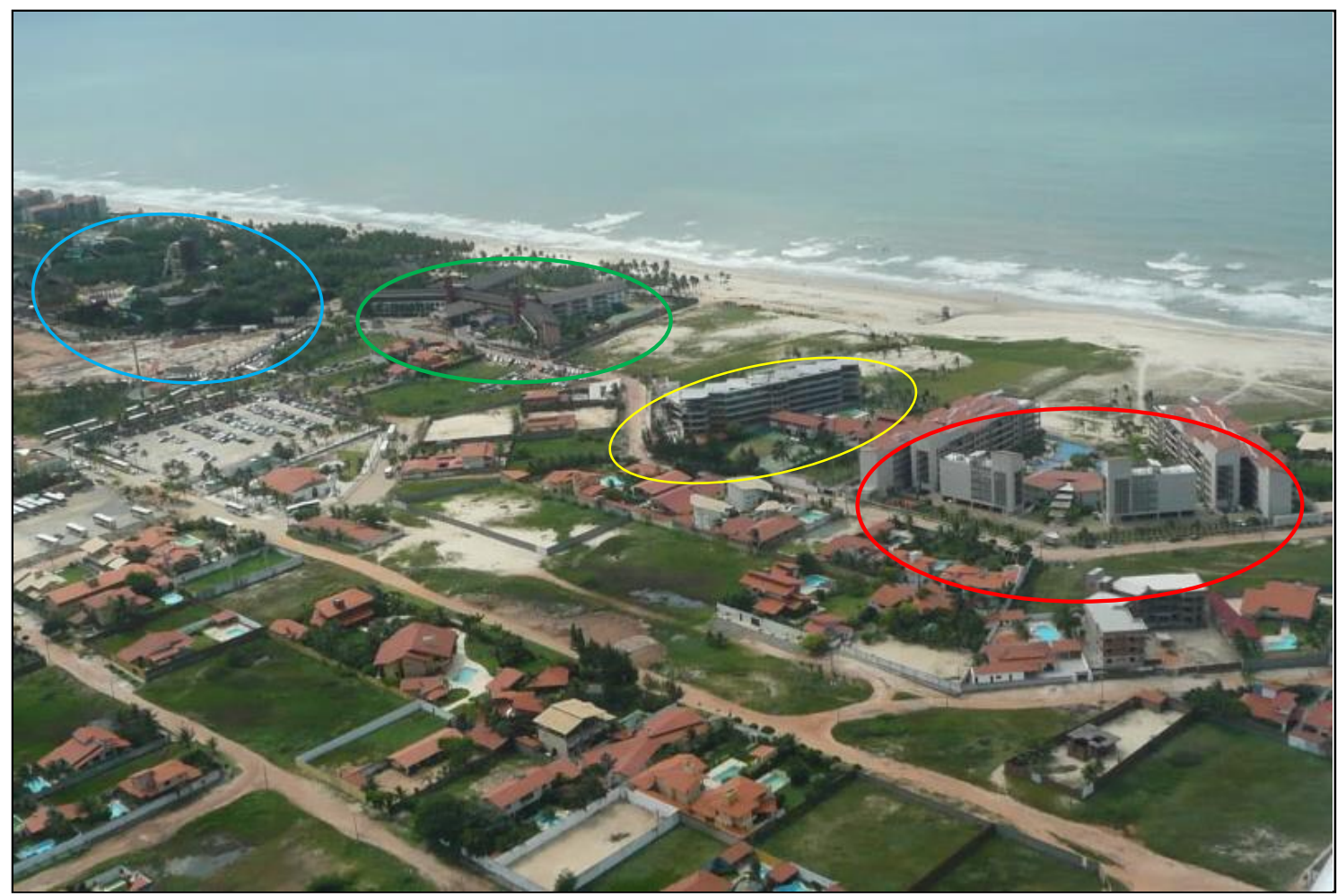

Fig. 3.6 Novos padrões de ocupação no Porto das Dunas: em vermelho - cond-hotel vinculado ao Beach-Park (administrado em regime de pool); em amarelo: condomínio fechado tradicional; em verde: Hotel Resort, integrado ao complexo Beach Park; em azul: o parque aquático. Nos demais lotes vê-se o padrão de residências de veraneio, padrão típico dos anos 1980-1990. Fonte: Skyscrapercity.com - Foto 2009 


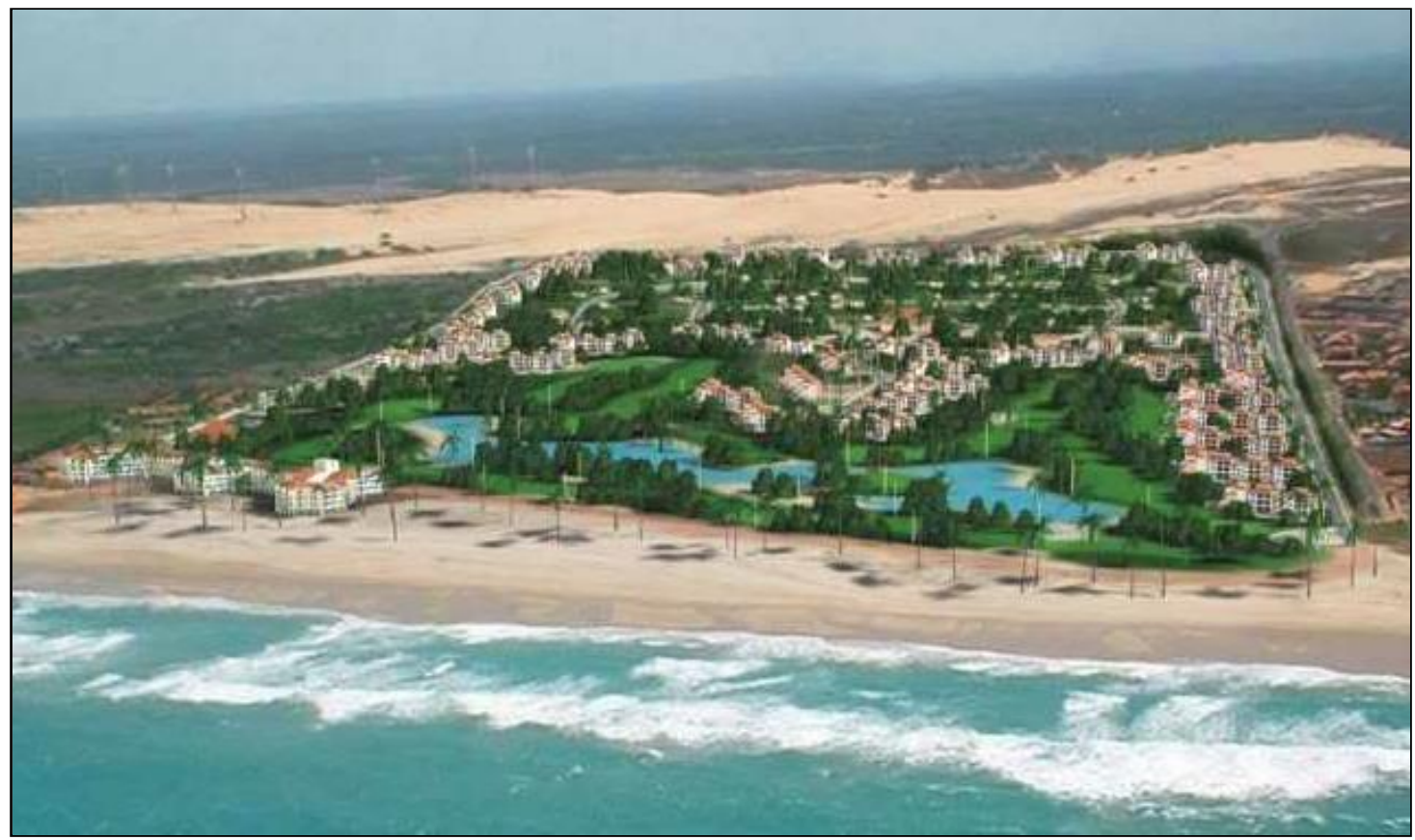

Fig. 3.7 Maquete eletrônica do Golf Ville Resort Residence. Empreendimento com incorporação e construção promovida por empresa cearense. O conceito é o mesmo padrão internacional, mas adaptado ao perfil econômico da elite local e regional, diante da crise internacional. Fonte: Skyscrapercity.com
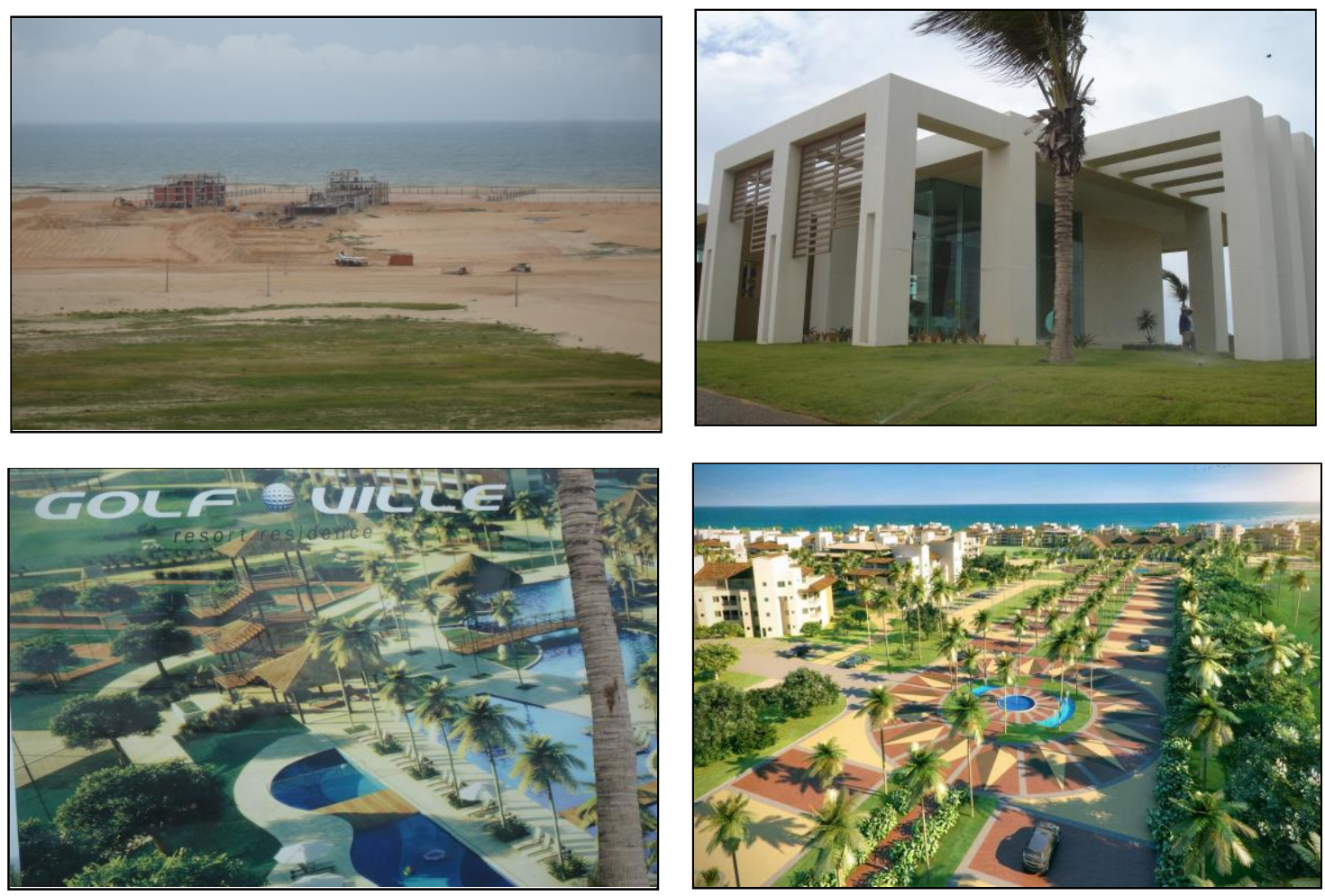

Fig. 3.8. Empreendimento Golf Ville Resort Residence com obras em andamento, acima à esquerda. Ao lado, à direita, o estande de vendas. Abaixo à esquerda o Outdoor do Estande de vendas e à direita uma maquete eletrônica em foto montagem hiper-realista do projeto, para ajudar a alavancar as vendas. Fonte: Fotos do autor: 2012 e fotomontagem do material publicitário, cedido pelo corretor. 
As fotos dos novos padrões de ocupação, mostradas até o momento, tiveram o objetivo preliminar de caracterizar o objeto de estudo, do ponto de vista espacial, proporcionando uma primeira aproximação.

No entanto, o objeto de estudo se justifica por provocar uma discussão em torno dos conceitos de "padrão de ocupação" e "estruturação espacial", com o intuito de compreender o papel dos agentes imobiliários articulados ao turismo, no contexto da "transição metropolitana" das cidades brasileiras, como apontado por Pereira (2008).

Desse modo, Pereira indaga se essa transição metropolitana pode ser vista como a produção social de uma forma de espaço separado, distinto, e transterritorial, interpretada como um novo espaço homogêneo, relacionado a um estilo de vida metropolitana emergente. Esse padrão, portanto, diria respeito a formas espaciais de uma economia que se manifesta como ordem urbana que, na verdade, se comporta como uma (des) ordem, na medida em que representa a desagregação social da ordem existente, respaldada por uma ideologia de uma nova sociedade constituída por aglomerações cada vez maiores, mais excludentes e segregadas. No nosso caso, manifestam-se nos projetos de condomínios de lazer e empreendimentos de uso misto, como as vilas turísticas e "resorts residences", entre outros, comercializados como segunda residência, na perspectiva de se tornarem permanentes ou quase permanentes.

De certa maneira pode-se dizer que se trata de construir novas cidades, como se fossem ilhas, dentro da cidade já existente (ou por cima, da pré-existente, tal como ocorreu com algumas cidades pré-colombianas na colonização). Assim, o sentido da transição metropolitana pode não ser negar a cidade, mas negar a sua história e, com ela a ordem socioespacial existente. Fundamentalmente, a força dos fluxos da globalização na transição metropolitana subordina a cidade existente, preside a questão urbana pela ocultação dos problemas, sobretudo, da miséria da sua população e das mazelas da injustiça urbana, para promover globalmente espaços que, glamorizados e valorizados atinjam um mercado e preços maiores. (PEREIRA, 2008)

No nosso caso, optamos por enfocar preferencialmente o litoral de Aquiraz porque ele manifesta de uma forma mais evidente o fenômeno em discussão, apoiando-se também em duas referências analíticas formuladas por Lefebvre (1980) e revistas por Lencioni (2011, p.51) na sua discussão sobre a "metamorfose metropolitana". 
A primeira diz respeito à importância da análise da tríade: estrutura, forma e função, compreendidas como elementos em permanente movimento, cujo equilíbrio provisório é resultante das novas e antigas relações entre as partes, constituindo-se num "constante movimento de estruturação-desestruturação-reestruturação” (idem p.54). Na nossa análise, essa referência ajuda a explicar as diversas adaptações dos padrões espaciais às mudanças nas novas demandas do mercado, sejam por motivações locais ou em articulação com as mudanças globais.

Com isso, damos suporte à proposta de interpretar essa recente "urbanização litorânea" na RM de Fortaleza, cujas características "metropolitanas" levam a nos indagar se elas podem ser entendidas como a representação de uma espécie de "economia de arquipélago" tal como expõe Olivier Mongin (2006 p.233, apud Pereira 2008).

No nosso caso, é perceptível a implantação de uma estruturação espacial prevista para atender às novas funções atribuídas ao turismo global e regional, enquanto vertente de desenvolvimento, nos planos de governo do Estado do Ceará. Essa estruturação acabou se conformando, por suas características particulares, a uma função intimamente articulada à promoção imobiliária, apresentando-se como conjuntos urbanos "insulares" participando ao seu modo e em seu nível, de setores secundários da rede de fluxos da economia global, nacional e local.

Essa nova forma de urbanização metropolitana parece dissolver o antigo e incompleto modelo de urbanização precedente, cuja transição se reveste de um sentido de conformação de uma nova ordem espacial. Entretanto, os conflitos com as estruturas socioespaciais anteriores, promovem mudanças na morfologia urbana a partir da adoção de uma nova forma padronizada de ocupação espacial transformada, nesse caso, em nicho de oportunidades de negócios para o mercado global e local.

A segunda referência analítica, também apoiada em outra tríade lefebvriana, é originada de uma discussão formulada pelo autor sobre o trabalho social, uma categoria central da teoria de Marx (LEFBVRE, 1980, p.135-178 in LENCIONI, 2011, p.57). Nesse caso, Lefebvre deriva e cria uma nova tríade constitutiva do espaço na sociedade capitalista, apresentando-o também como sendo: homogêneo, fragmentado e hierarquizado.

Portanto, as referências analíticas adotadas na pesquisa servem para auxiliar a organização e interpretação do material coletado, na perspectiva de compreender a 
transição metropolitana de Fortaleza a partir da discussão do papel dessa suposta "metamorfose socioespacial" (idem p. 57). Esse fenômeno se manifesta também em várias cidades brasileiras e, em particular, no caso em estudo, quando observamos uma evidente homogeneização verificada na semelhança dos processos de expansão urbana: seja, na arquitetura dos edifícios, nas soluções para reabilitação urbana, como também na marcante fragmentação e segregação dos novos padrões de ocupação litorâneos, voltados para o desenvolvimento do turismo.

Partiremos no próximo segmento à introdução do recorte espacial estudado, a partir das informações básicas necessárias a sua caracterização e identificação.

\subsection{O Município de Aquiraz}

Aquiraz localiza-se na porção nordeste do Estado do Ceará, possuindo dimensão territorial de $482,8 \mathrm{~km}^{2}$ e $30 \mathrm{~km}$ de litoral. Dista apenas $24,70 \mathrm{~km}$ da cidade de Fortaleza, capital do Estado, inserindo-se ao raio de influência de sua região metropolitana. Sua Sede municipal localiza-se nas coordenadas 354'05' (lat. S) e 38²3'28', (long. O), situando-se a uma altitude de 14,23m, do nível do mar, pertencendo à Microrregião Geográfica 16 - FORTALEZA - IBGE (Fig.3.10 em vermelho).

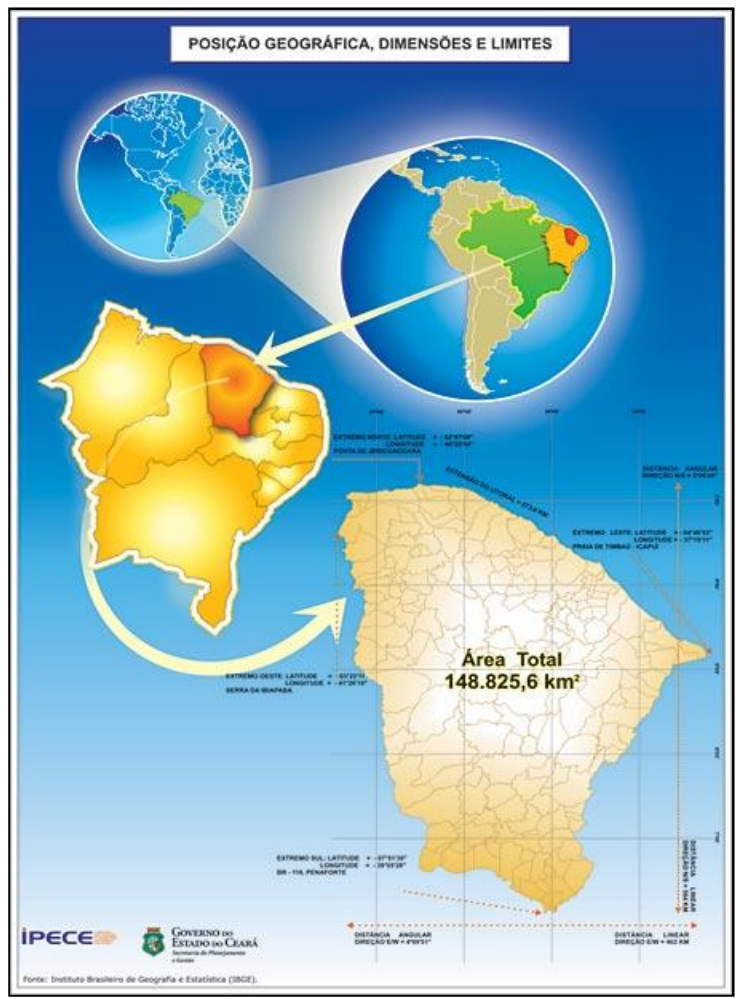

Fig. 3.9. O Ceará no Nordeste do Brasil Fonte: IPECE

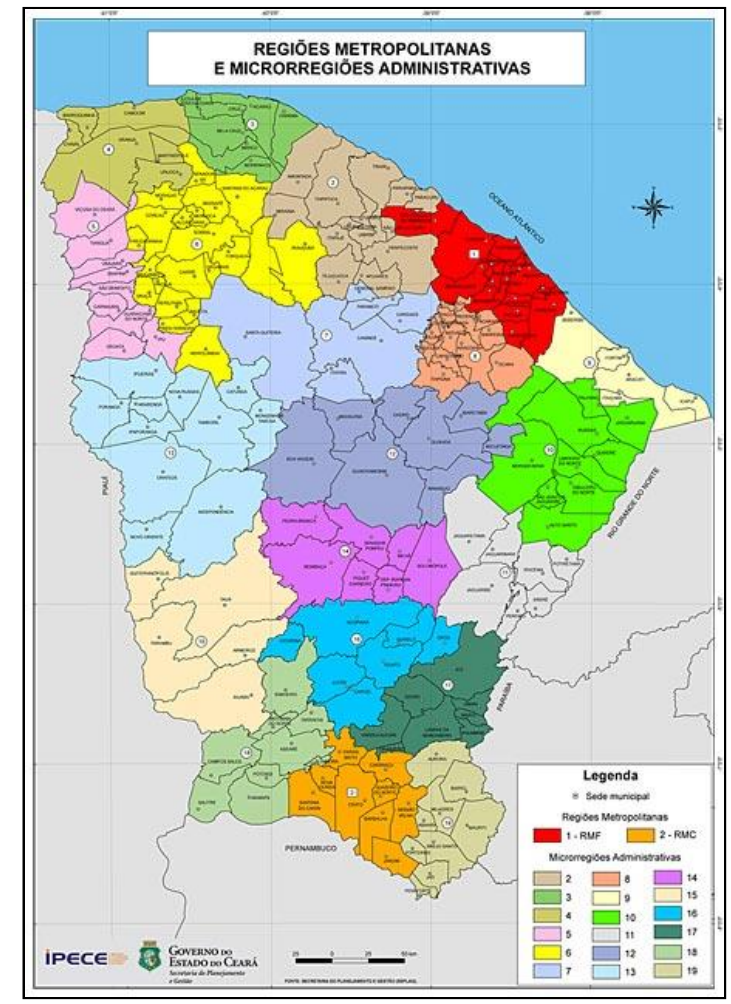

Fig. 3.10. Regiões Metropolitanas e Microrregiões administrativas do Ceará - Fonte: IPECE 


\subsubsection{Aquiraz no contexto da Região Metropolitana de Fortaleza}

Para melhor compreender as mudanças ocorridas no Município de Aquiraz, a partir da segunda metade do século XX, é necessário verificar como ele ficou inserido na Região Metropolitana de Fortaleza - RMF, constituída até 1992 pelos municípios de: Aquiraz, Caucaia, Eusébio, Fortaleza, Guaiuba, Itaitinga, Maracanaú, Maranguape e Pacatuba. No ano de 1999, a RM foi expandida, incluindo-se os municípios de São Gonçalo do Amarante, Horizonte, Pacajus e Chorozinho, motivada pelo processo de descentralização industrial. Recentemente, em 2009, foi proposta a inclusão dos municípios de Pindoretama e Cascavel, por argumentos relacionados ao desenvolvimento do turismo, até pouco tempo questionado pelo Estado da sua real necessidade. (ver Fig. 3.11).

A RMF caracteriza-se como uma aglomeração urbana em expansão, num território de baixa densidade populacional. Esta expansão se configurou por uma dinâmica de segregação das populações urbanas de menor poder aquisitivo em direção às áreas periféricas degradadas, menos aparelhadas em termos de oferta de equipamentos e serviços públicos (PDDU - AQUIRAZ, 2005).

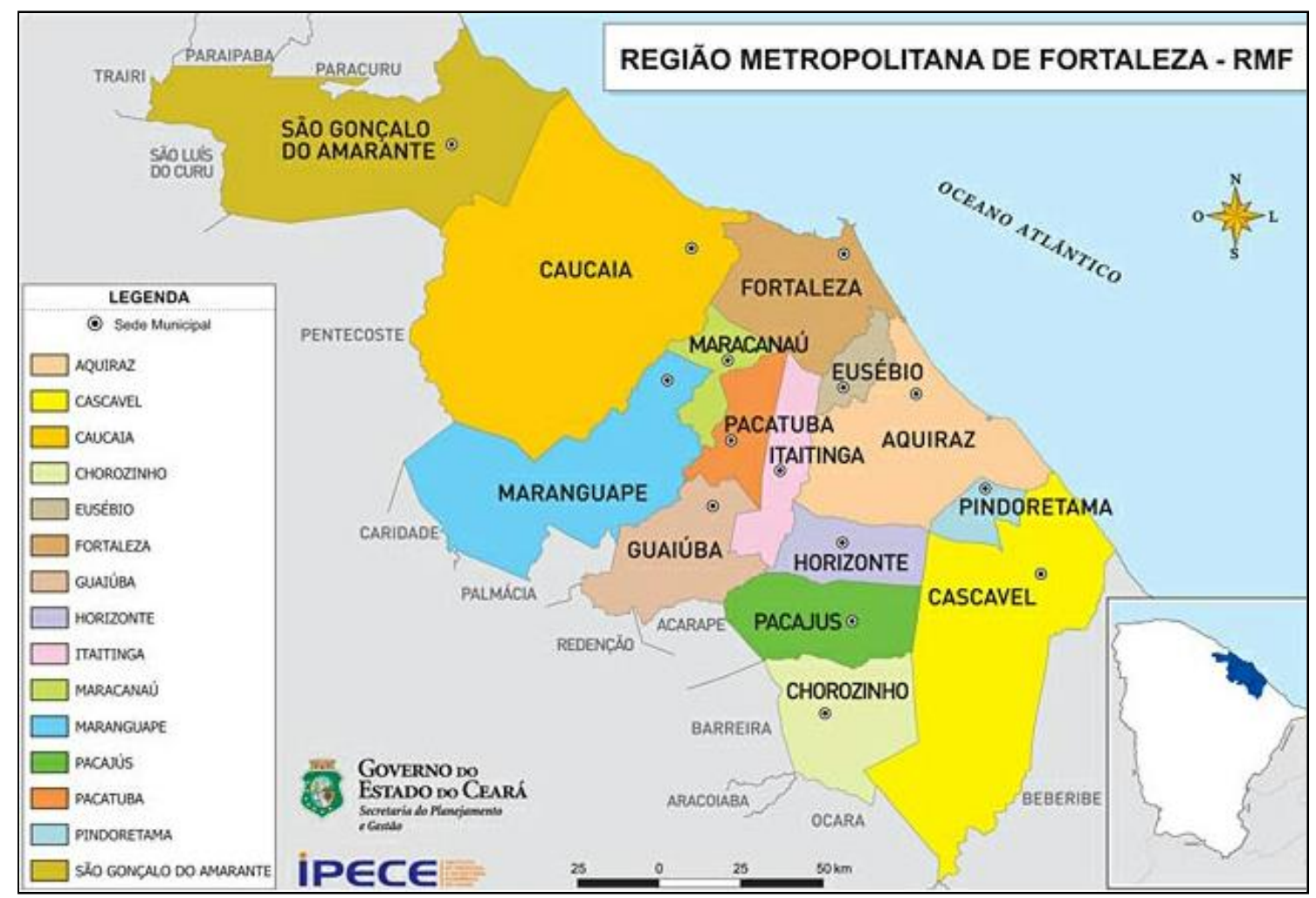

Fig.3.11. Região metropolitana de Fortaleza - Posição oficial em 2009 - Fonte: IPECE 
As tendências do crescimento demográfico e econômico de Aquiraz podem ser descritas como decorrentes de múltiplos fatores, de natureza interna e externa ao Município. No que se refere à definição da sua "vocação" econômica, é importante, entretanto, considerar a sua posição relativa, na perspectiva de inserção na dinâmica de desenvolvimento da Região Metropolitana de Fortaleza.

Analisando o mapa da Fig. 3.12 (abaixo), verificamos que Aquiraz se insere entre dois vetores de expansão metropolitana: o vetor II, no limite Sudoeste do município, se configura como um corredor industrial situado ao longo da BR 116 e o Vetor IV correspondente ao eixo litorâneo de expansão urbana de lazer e turismo. Sua Sede fica localizada aproximadamente na porção centro-norte do território municipal.

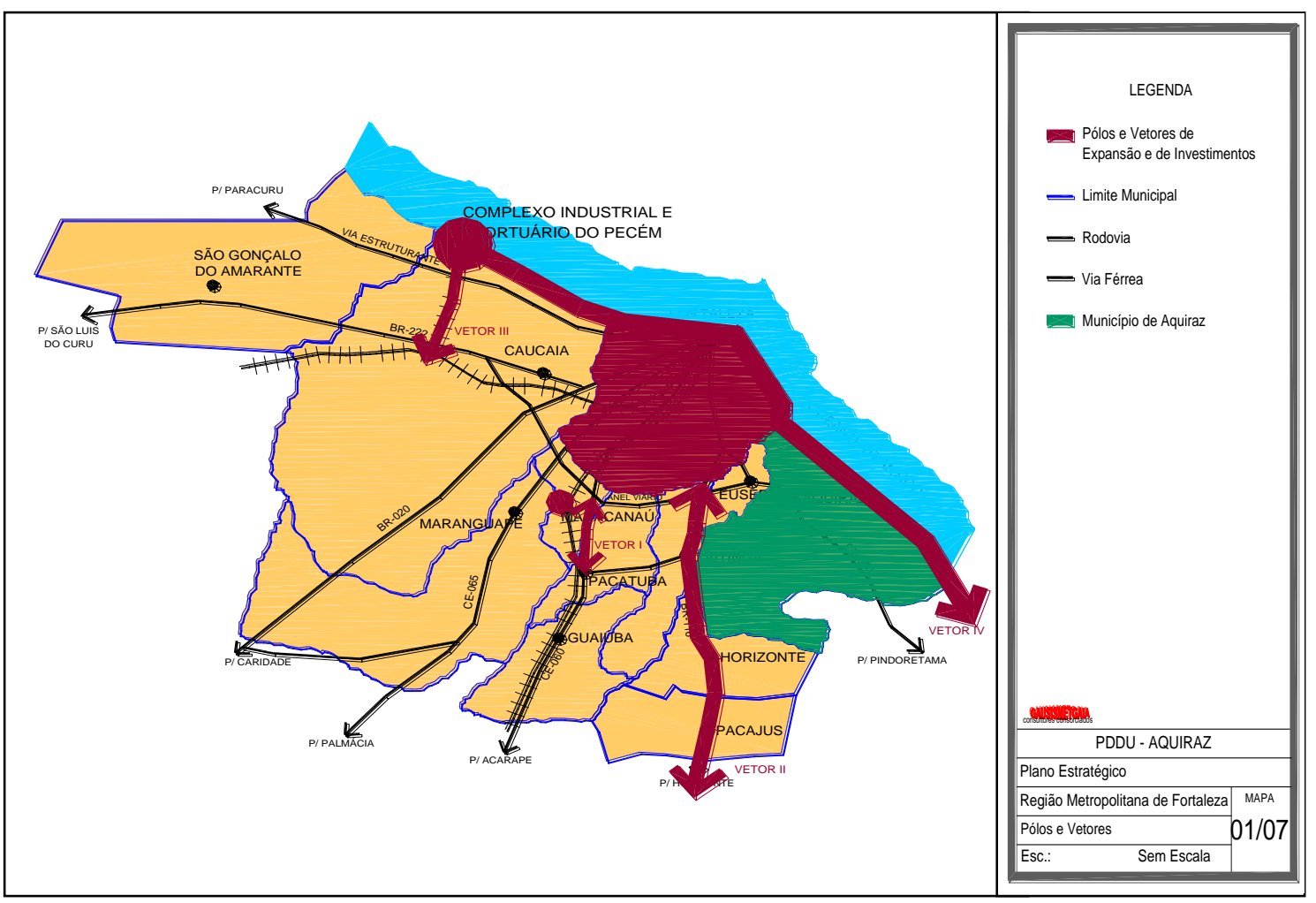

Fig. 3.12 - Os quatro vetores de expansão metropolitana da RMF, segundo o PDDU Aquiraz - 2005.

Os fatores que impulsionaram o Vetor II são os mesmos que sucederam o processo de industrialização tardia no Nordeste, dos anos 1960-1970, onde foram implantadas as mudanças produtivas que ocorreram a partir da década de 1980, impondo novos padrões competitivos. Já verificamos no capítulo anterior como esse processo foi acompanhado de uma crescente abertura internacional da economia brasileira, seguindo uma orientação de substituição da política urbana e industrial anterior, de forte presença 
estatal, materializada de um lado pelo BNH, extinto em 1987, e de outro pela SUDENE. Vimos também como os órgãos federais de incentivo ao desenvolvimento foram perdendo espaço naquele momento, passando apenas a gerir o esforço industrial dos estados do Nordeste, de forma autônoma e distinta, caracterizada pela intensa competição e renúncia fiscal generalizada.

Assim, Aquiraz absorveu as mesmas influências das diretrizes do Governo do Ceará que passou a focar suas atenções nos princípios de desenvolvimento endógeno, veiculados pela oferta de infraestrutura somada aos subsídios decorrentes dos incentivos fiscais, como critério de atratividade. Este processo de impulso industrializante produziu um visível movimento de desconcentração, atraindo algumas indústrias ao município, como mostra a Tabela-3.1, abaixo. No entanto, promove também a industrialização em outros municípios da RMF como em Horizonte e, sobretudo, em Caucaia, onde se situa o terceiro vetor de expansão, conectado a São Gonçalo do Amarante e ao Complexo Portuário do Pecém (PDDU-AQUIRAZ, 2005).

TABELA 3.1 - EMPRESAS INDUSTRIAIS ATIVAS POR TIPO - 2009 - 2010

\begin{tabular}{|c|c|c|c|c|c|c|c|c|c|c|}
\hline & \multicolumn{10}{c|}{ Empresas industriais } \\
\hline \multirow{2}{*}{ Município } & \multicolumn{2}{|c|}{ Total } & \multicolumn{10}{c|}{ Extrativa mineral } & Construção civil & Utilidade pública & \multicolumn{2}{c|}{ Transformação } \\
\cline { 2 - 12 } & 2009 & 2010 & 2009 & 2010 & 2009 & 2010 & 2009 & 2010 & 2009 & 2010 \\
\hline Aquiraz & 189 & 236 & 12 & 10 & 28 & 36 & 3 & 4 & 146 & 186 \\
\hline
\end{tabular}

Fonte: IPECE - Anuário Estatístico - 2010

O vetor IV parece ser o que melhor explica as tendências atuais do Município, no que diz respeito à dinâmica metropolitana de expansão dos eixos litorâneos, fundamentado numa intensa atividade turística e imobiliária que faz com que a dinâmica proveniente de Fortaleza transborde para o território de Aquiraz. Esse fenômeno é mais evidente no Porto das Dunas, um loteamento que se tornou bairro turístico de Aquiraz, cuja imagem esteve sempre associada ao turismo de Fortaleza, principalmente nas campanhas publicitárias, como se o bairro fosse Fortaleza em Aquiraz (PEREIRA, 2006).

O fato do vetor IV situar-se também a Leste de Fortaleza - área de expansão imobiliária dos segmentos de renda mais elevada - fez com que esse processo de valorização atingisse também os municípios vizinhos na direção do Eusébio e de Aquiraz, apropriando-se dessa vantagem locacional. Dois fatores ajudam a explicar melhor esse fenômeno: o fato de situar-se longe dos processos relacionados aos investimentos industriais previstos na porção Oeste da RMF, no Complexo Industrial e Portuário do 
Pecém, como também por se constituir no eixo estruturante do turismo da Costa do Sol Nascente, ao longo da CE-040 (em verde - Fig. 3.13).

Assim o Vetor IV ou Eixo Litorâneo Leste se converteu simultaneamente num eixo de expansão imobiliária e turística pelo fato de conciliar duas funções importantes na estruturação metropolitana: a função moradia, dentro das melhores condições ambientais e paisagísticas e a do desenvolvimento do turismo na RMF.

Estes aspectos oferecem perspectivas atrativas para a classe média e alta observando-se, atualmente, uma substituição da segunda moradia de lazer pela moradia principal, nos territórios de Aquiraz e Eusébio. Essas mudanças tendem a se intensificar com a melhoria dos acessos por meio da CE 040 e da recente duplicação da CE-025 que melhor irrigarão o triângulo formado pelo Porto das Dunas, Prainha e Sede municipal de Aquiraz.

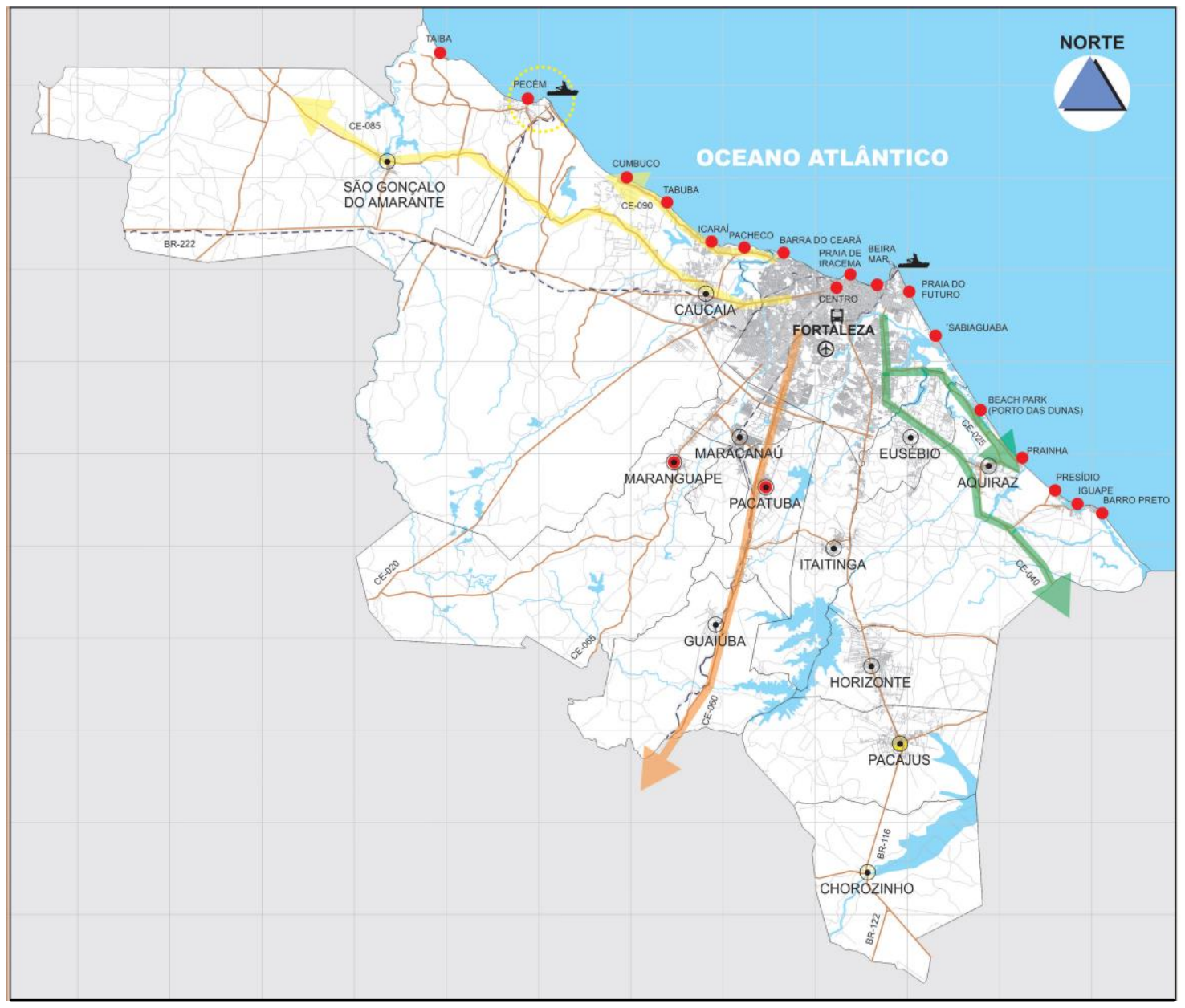

Fig. 3.13. Vetores de expansão metropolitana da dinâmica turística - Fonte: PAIVA, 2011. 
Constata-se, no primeiro contato com o Município, pela CE-025 via Porto das Dunas, as funções de eixo estruturante do turismo como também a de expansão imobiliária residencial, fruto das demandas metropolitanas de Fortaleza. São perfeitamente visíveis, tanto pela abundância de anúncios em plantões de vendas imobiliárias, como também pela presença de equipamentos turísticos já consolidados no mercado, com uma rede expressiva de oferta de unidades de hospedagens (Fig.3.14).
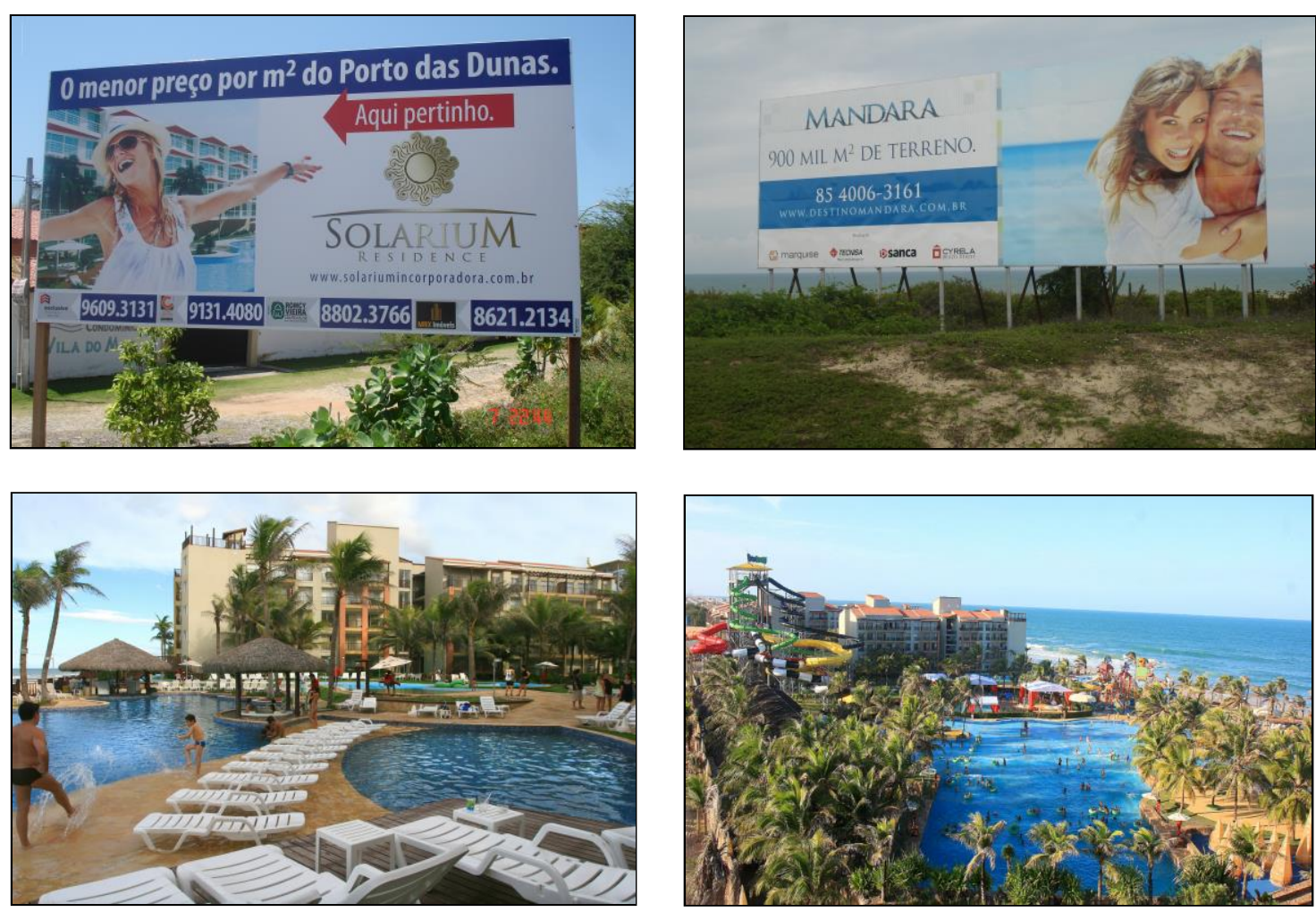

Fig. 3.14 Acima, outdoors de condomínios padrão resort ao longo das vias de acesso (Fonte: foto do autor). Abaixo imagens publicitárias de hotéis em operação. Fonte: www.beachpark.com.br

No entanto, a falta de uma estrutura urbana capaz de articular os diversos núcleos costeiros entre si e a ausência de um lugar de convergência, referencial das suas atividades socioeconômicas e culturais, levam o município à necessidade de elaborar uma maior articulação dessas regiões com a Sede, com o objetivo de orientar o parcelamento do solo quanto ao uso e ocupação.

Outro aspecto que notamos e veremos em detalhes é a contradição entre a rápida comercialização dos loteamentos legalizados e a inexistência de infraestrutura urbana mínima, como pavimentação, drenagem, iluminação, saneamento básico e coleta de lixo. São fatos comuns nas localidades praianas e se converteram em problema de difícil 
solução, exigindo reflexão e mudança dos atos normativos de aprovação dos futuros loteamentos a serem efetivados pelo Poder Municipal.

\subsubsection{Delimitação e acessos à área de estudo}

O recorte espacial da área de estudo pode ser compreendido pelo trecho litorâneo do município de Aquiraz, embora o fenômeno seja visível apenas em pontos estratégicos, na área de influência das seis regiões turísticas litorâneas: as praias do Porto das Dunas, Prainha, Presídio, Iguape, Barro preto e Batoque. O acesso ao Município de Aquiraz pode ser feito a partir da CE-025 (via Porto das Dunas) ou pela CE-040 (via Av. Washington Soares) e BR 116, que corta a sua porção Oeste, na divisa com o Município de Itaitinga, permitindo também o acesso à CE 040 pelo anel viário.

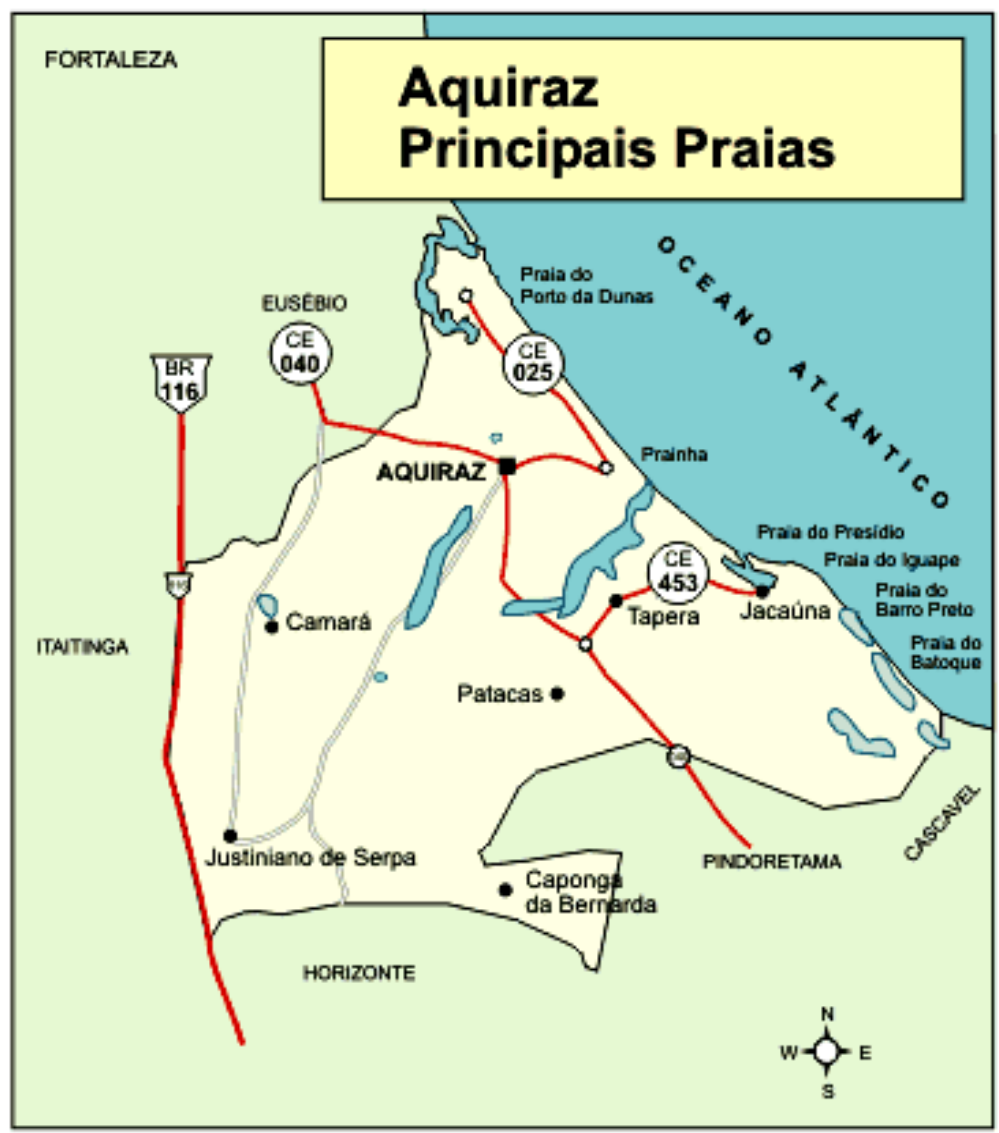

Fig. 3.15 Acessos e Localização das Regiões Turísticas Fonte: Prefeitura Municipal de Aquiraz, 2000.

Abaixo, temos a área de estudo sobreposta ao Mapa de Vegetação e Recursos Hídricos do Município, onde os limites, em hachuras azuis, correspondem também ao trecho considerado pelo PDDU de Aquiraz como "Área de Fragilidade Ambiental” colorido em amarelo (Fig. 3.16). Essa denominação deve-se à presença das comunidades 
litorâneas tradicionais e dos complexos fito-ecológicos mais significativos do Município que hoje se encontram sujeitos às pressões originadas pelas demandas dos novos usos.

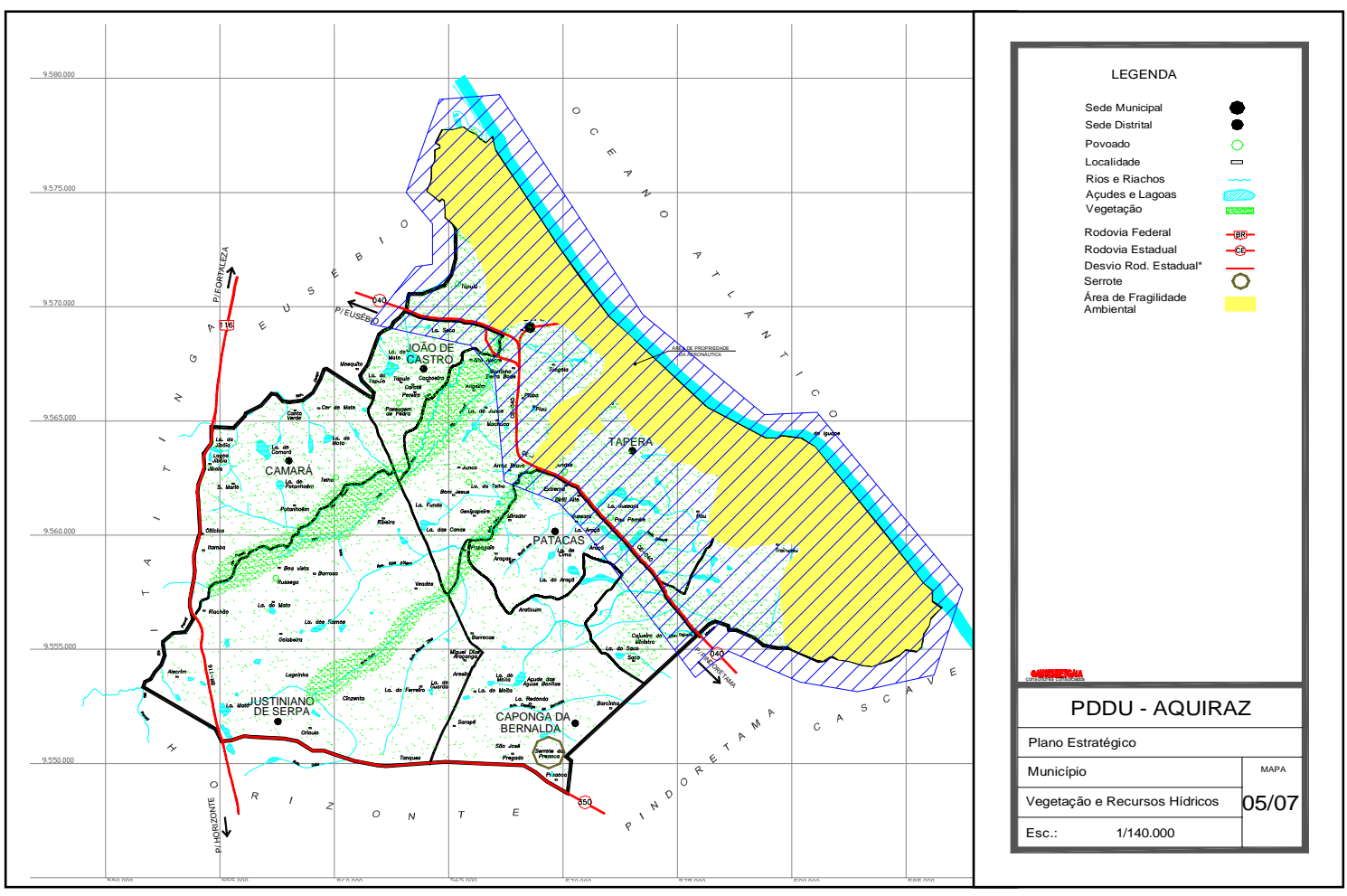

Fig. 3.16 Mapa de Vegetação e Recursos Hídricos - Fonte: PDDU Aquiraz - 2005 - Plano Estratégico

\subsubsection{Síntese histórica e evolução urbana de Aquiraz}

A partir de sua origem colonial, Aquiraz surgiu no cenário historiográfico do Estado como um dos três primeiros povoados a disputar o controle político da província do Ceará, no final do século XVII, então subordinada à Capitania de Pernambuco. Os abusos praticados pelos capitães-mores na Província fizeram com que o Rei de Portugal ordenasse a criação da primeira vila no Ceará, a ser instalada em Aquiraz, após numerosas argumentações a seu favor, feito em Carta Régia de 13 de fevereiro de 1699.

O governador de Pernambuco ordenou então a instalação da Vila em 1700, o que ocorreu de fato ao lado do Forte às margens do rio Ceará, apesar dos veementes protestos do povoado de Aquiraz. Quando foi finalmente transferida para Aquiraz, em 1713, um novo fato retomou a polêmica: "não corria sequer um mês, (depois da efetivação da transferência) e assaltam os índios (Anacés, Jaguaribaras, Paiacus e outros) à recente Vila do Aquiraz, praticando roubos e inúmeras mortes [...] vendo-se 
forçada, a câmara, a refugiar-se na fortaleza, a convite do Capitão-mor" (GIRÃO, 1979, p. 51).

Desse modo, os moradores do Aquiraz, em 1720, solicitaram ao Rei a volta da vila para o povoado do Forte, alegando falta de segurança. Sem atender ao pedido dos camaristas o monarca ordenou a manutenção da vila em Aquiraz e determinou a criação de outra vila no Forte, o que ocorreu formalmente em 13 de abril de 1726, passando a ser a sede do poder militar e civil da Capitania (Op. cit.).

Apesar de ter perdido o poder político e de estar fora do ciclo econômico predominante, Aquiraz recebeu em 1727 uma missão de padres jesuítas que construiu o Hospício de Nossa Senhora do Bom Sucesso, cujas ruínas ainda hoje podem ser vistas, permanecendo no local até 1750, quando foram expulsos pela administração do Marquês de Pombal. A instituição tinha por objetivo a pacificação e catequese dos índios, tendo sido a primeira experiência de seminário no Ceará onde eram ensinados: artes, ofícios, retórica, latim e grego (PMA - MAPEAMENTO CULTURAL, 2003).

As visitas do Governador da Província, Barba Alardo de Menezes e do Engenheiro Silva Paulet, bem como os relatos da Corografia Brasílica, do padre Manoel Aires de Casal (1817), descrevem Aquiraz como uma vila pouco desenvolvida, no início do século XIX, provavelmente em razão das dificuldades de transporte, em virtude das grandes cheias do rio Pacoti. Somente em 1867 foi construída a primeira ponte de ferro, tornando o lugar mais acessível, viabilizando o comércio local e a venda de gêneros agrícolas para as várias regiões da Província (Op. cit.).

A ocupação do território definido pelos limites do Município de Aquiraz deu-se, especialmente durante o século XIX, pelo desenvolvimento da agricultura em consórcio com a atividade pecuária. É possível perceber vestígios dessas atividades pelo testemunho de arquitetura vernacular da harmoniosa edificação do Mercado da Carne, como também dos engenhos de rapadura e casas de farinha que ilustram a importância da cultura canavieira e do beneficiamento da mandioca para a região, atividades ainda hoje importantes no Município. (PDDU de Aquiraz, 2000-2003).

Mesmo tendo sido elevada à condição de cidade em 1915, Aquiraz passou por certa estagnação econômica, que o levou a ser incorporado ao Município de Cascavel na 
simples condição de vila em 1931. Recobrando as prerrogativas de cidade em 1938, retornou na condição de produtor de alimentos para Fortaleza. O desenvolvimento do Município foi retomado a partir dos anos 1950, com a instalação de linhas telefônicas, construção de escolas, calçamento de estradas, criação da primeira biblioteca pública e a atual ponte sobre o rio Pacoti, construída em 1952, com verba federal (PMA MAPEAMENTO CULTURAL, 2003).

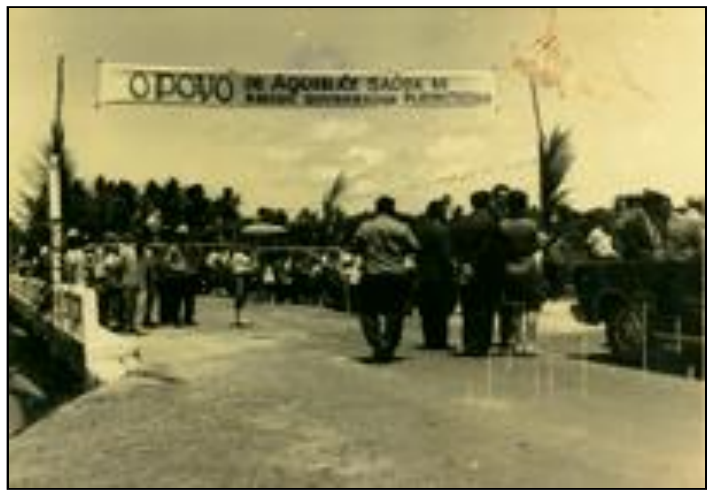

Fig. 3.17 Inauguração da ponte sobre o Rio Pacoti em 1958. Fonte: PMA - Mapeamento Cultural

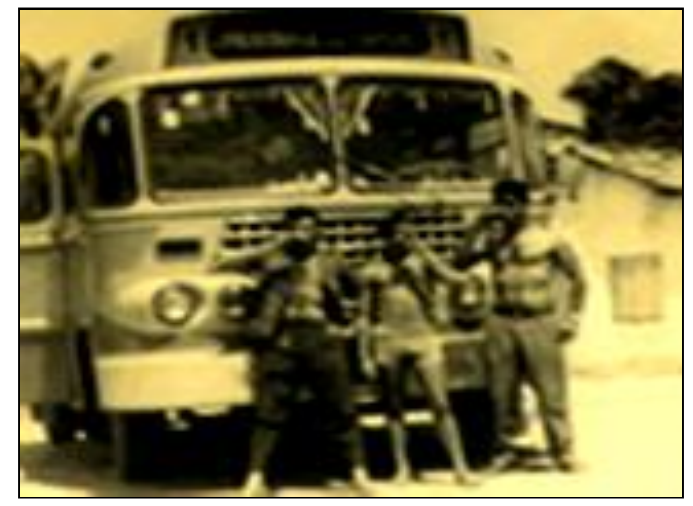

Fig. 3.18 Primeira Linha de ônibus, 1950 Fonte: PMA - Mapeamento Cultural.

No início da década de 1960 Aquiraz possuía apenas uma estação postal telegráfica e uma rede telefônica com 06 aparelhos ligados à capital e aos distritos. Possuía, no entanto, a ponte que atravessando o rio Pacoti e sua várzea permitiu a possibilidade de produzir alimentos para abastecer o mercado de Fortaleza com ovos, caju, rapadura, farinha de mandioca e açúcar. Fazia também exploração da argila para produção de telhas, tijolos e louça de barro para uso caseiro. (PMA- SEC. DE EDUCAÇÃO, 2001).

Nos anos 1970, o Município passou por mudanças significativas, quando ocorreu uma maior demanda por parcelamento do seu território para ocupação de loteamentos de sítios e residências de veraneio, principalmente na sua faixa litorânea, que se tornou o espaço de excelência a ser alvo de maiores intervenções urbanas. Tal processo, acentuado a partir da década de 1970 e mais intensificado nos últimos anos, anuncia a tendência de futura conurbação entre Fortaleza, Eusébio e Aquiraz e a transformação de antigas residências de veraneio em residência permanente.

Em 1973, foi criada a Região Metropolitana de Fortaleza (RMF), compreendendo os Municípios de Fortaleza, Aquiraz, Caucaia, Maranguape e Pacatuba. A organização do território municipal foi alterada com a emancipação do Distrito de Eusébio, em 1987. 
Posteriormente o espaço metropolitano se reestruturou com os novos municípios de Eusébio (ex-Aquiraz), Maracanaú (ex-Maranguape), Guaiuba e Itaitinga (ex-Pacatuba).

Hoje, além do Distrito Sede, o Município de Aquiraz possui a seguinte divisão distrital: Jacaúna e Justiniano de Serpa, criado em 1951; Camará, Caponga da Bernarda, Patacas e Tapera (criados em 1988) e João de Castro, criado mais recente, em 1995.

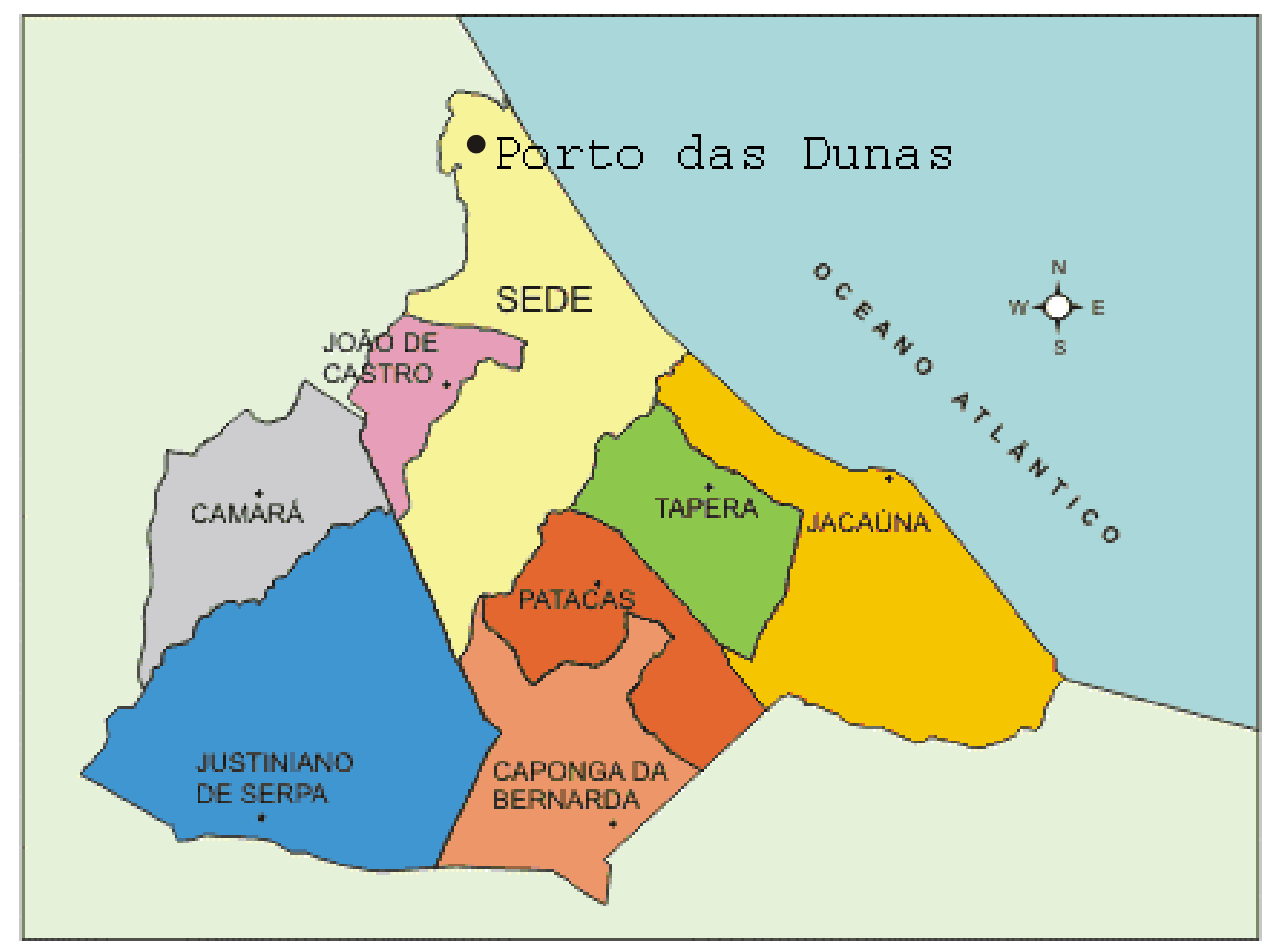

Fig. 3.19 - Divisão distrital do Município - Fonte: (PDDU AQUIRAZ-2005)

\subsubsection{O turismo em Aquiraz e o planejamento governamental}

As novas práticas litorâneas iniciadas em Fortaleza a partir dos anos 1930 se expandiram nos anos 1960 para a Avenida Beira-Mar, diferenciando-se por abrigar simultaneamente as residências de alto padrão, os clubes sociais, ao mesmo tempo em que permitia o uso da praia à grande parte da população, tornando-a num espaço legitimamente público. O congestionamento e a poluição das praias de Fortaleza fizeram nascer, como em outras capitais do Brasil, o fenômeno de valorização dos terrenos litorâneos, nos arredores da região metropolitana, primeiramente em Caucaia e Aquiraz, para atender à nova demanda da classe média por casas de veraneio e sítios de campo no final dos anos 1960. 
Até meados dos anos 1960, o litoral cearense era ocupado predominantemente por comunidades tradicionais que desenvolviam atividades econômicas ligadas à pesca artesanal, extrativismo vegetal e animal, agricultura de subsistência e em alguns locais a pecuária extensiva que até hoje marcam a paisagem etnográfica do Município.

A partir dos anos 1970 ocorreu grande demanda por parcelamento do seu território, o que ocasionou inúmeros loteamentos de veraneio, determinando o início de um ciclo de valorização das terras litorâneas. Em grande parte, esses terrenos apresentam precariedade no registro de propriedade, originando diversos conflitos que até hoje marcam o seu quadro fundiário, sobretudo, nas terras situadas em "zonas de marinha", de propriedade da União.

No final dos anos 1970 foi aprovado na prefeitura de Aquiraz o loteamento Porto das Dunas que mudou o padrão até então comercializado, tanto no que diz respeito ao desenho urbano, fugindo do padrão ortogonal em xadrez, como também introduzindo a ênfase ao conceito de loteamento turístico. Nos anos 1980 a ideia inicial para a estratégia comercial do loteamento era incentivar as vendas com a implantação de uma grande "barraca de praia", de alto padrão. A ideia evoluiu progressivamente, em meio ao novo contexto do desenvolvimento turístico, para a de um grande parque aquático que foi convertido num empreendimento de sucesso empresarial, tornando-se num dos atrativos mais visitados no Estado.

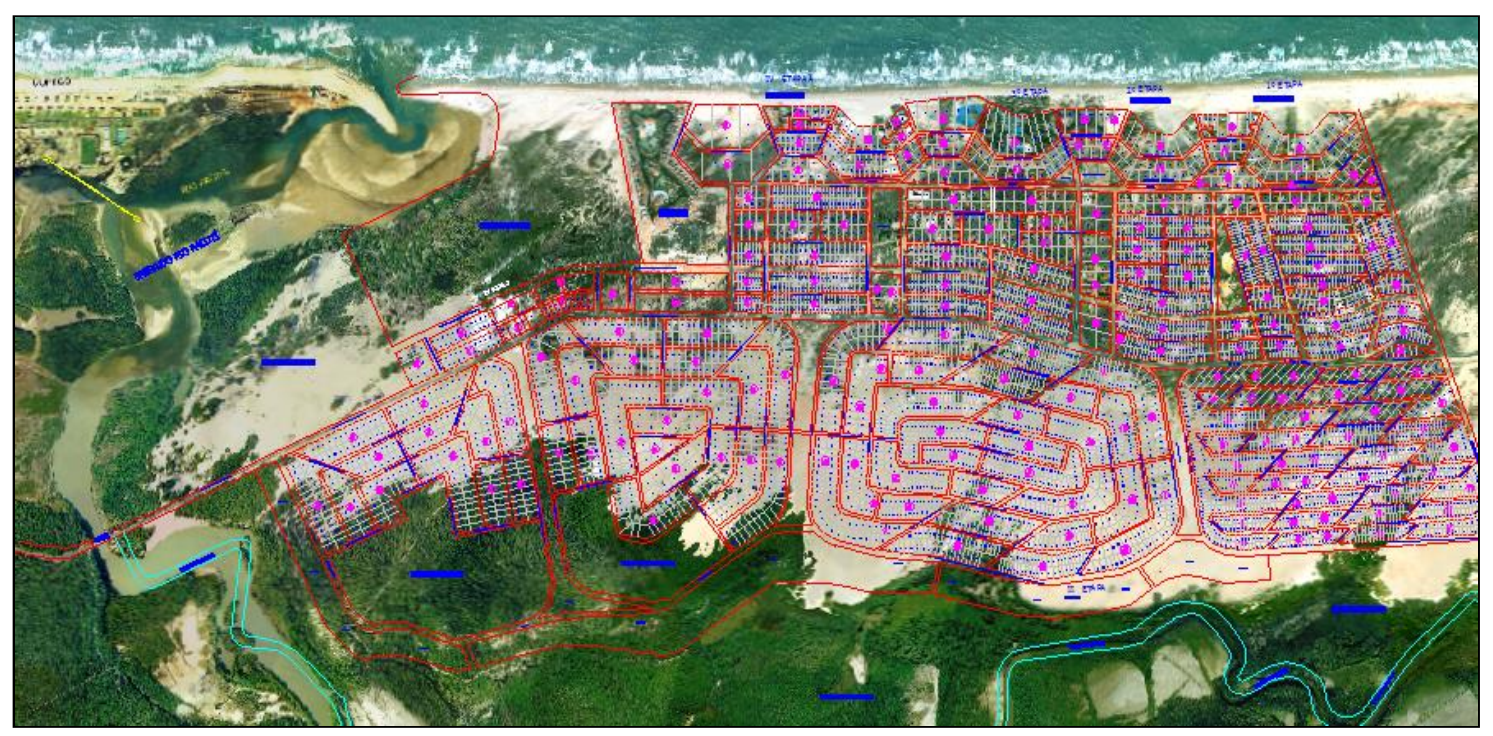

Fig. 3.20 - Malha do loteamento sobre imagem de 2002 - Fonte PM de Aquiraz

No final dos anos 1980 e principalmente em meados dos anos 1990 o Estado assumiu a postura de priorizar a atividade turística como vertente estratégica para o 
desenvolvimento econômico do Ceará. Essa política atingiu Aquiraz em primeiro plano, pelo fato de ter sido a localidade escolhida para a produção do primeiro destino turístico de alcance nacional do Estado, diante do sucesso do parque aquático "Beach Park".

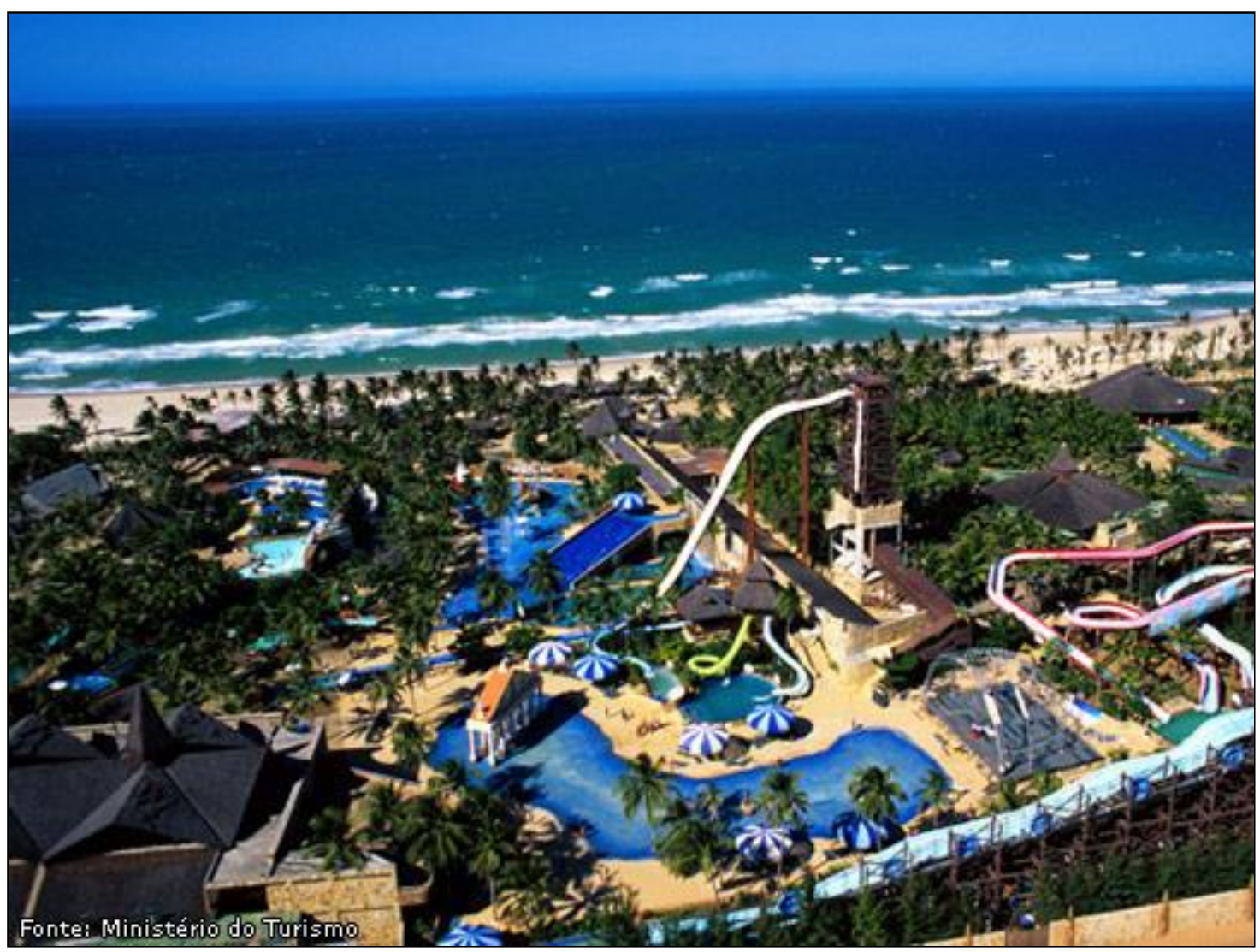

Fig. 3.21 - Foto aérea do Beach Park - Fonte: Ministério do Turismo

Com isso o parque passou a polarizar investimentos no Porto das Dunas, e o local tornou-se referência do novo padrão de turismo do Ceará, veiculado nas campanhas publicitárias como sendo um atrativo de Fortaleza. O fato de não mencionar o nome do município de origem no produto turístico reforça a tese de que o Porto das Dunas é "Fortaleza em Aquiraz". Na verdade todo o processo de produção e gestão do negócio foi elaborado e desenvolvido em Fortaleza que se apropriou do território, até então, virgem e preservado do município vizinho.

Nesse contexto, o Estado empreende um planejamento governamental baseado em diretrizes componentes de ações públicas sobre os vários subsistemas da região litorânea, considerada área prioritária de investimento, atraindo e apoiando a instalação de vários equipamentos hoteleiros e turísticos no litoral. Esse planejamento, no entanto, 
não consegue alcançar o controle necessário dos subsistemas urbanos e ambientais pelo fato dele estar atado às deficiências históricas dos instrumentos da gestão do território cearense e brasileiro, ainda não superadas até hoje.

O desenvolvimento do turismo segue, portanto, distante do efetivo controle sobre o território, tornando-se num dos mais impactantes instrumentos de (des) organização territorial do Estado, no sentido em que passou a negar a história precedente de cada lugar impactado. No caso do Ceará, esse problema tornou-se mais grave, a partir da decisão governamental de se alinhar à política de desenvolvimento regional representado nas ações do PRODETUR que figurava como o principal instrumento norteador. Nesse contexto, a atividade turística passou a orientar-se pela política estratégica de turismo do Estado, que pretendia viabilizar equipamentos de grande porte, como o Aquiraz Resort ${ }^{2}$, para servir de âncora da atividade turística interregional e internacional.

Assim, ainda no final dos anos 1990, foi escolhida a localidade do Batoque, no extremo Sudeste de Aquiraz, para sediar o então novo "megaempreendimento", que tinha como premissa a remoção dos moradores originais que ocupavam o entorno de uma lagoa. Com isso o projeto expôs a comunidade local aos diversos conflitos do contexto fundiário litorâneo, culminando com o litígio jurídico entre a comunidade local e o suposto proprietário que não conseguiu comprovar a falsa propriedade do terreno. Assim sua gestão passou a ser efetuada pelo IBAMA com a criação da Reserva Extrativista do Batoque, evidenciando não só uma deficiência primária na elaboração do projeto como também a extrema precariedade da questão fundiária litorânea.

O município de Aquiraz passou então a apresentar dois paradigmas de desenvolvimento igualmente opostos, nos dois extremos do seu domínio territorial litorâneo, que atualmente evoca discussões sobre os termos de sua mútua complementaridade. O de base local, materializado pela Reserva Extrativista do Batoque e o do Porto das Dunas, materializado nas premissas do desenvolvimento com base na inserção da economia no competitivo mercado internacional globalizado.

\footnotetext{
${ }^{2}$ Projeto anterior ao Aquiraz Riviera, inviabilizado por problemas de titularidade na propriedade da terra.
} 


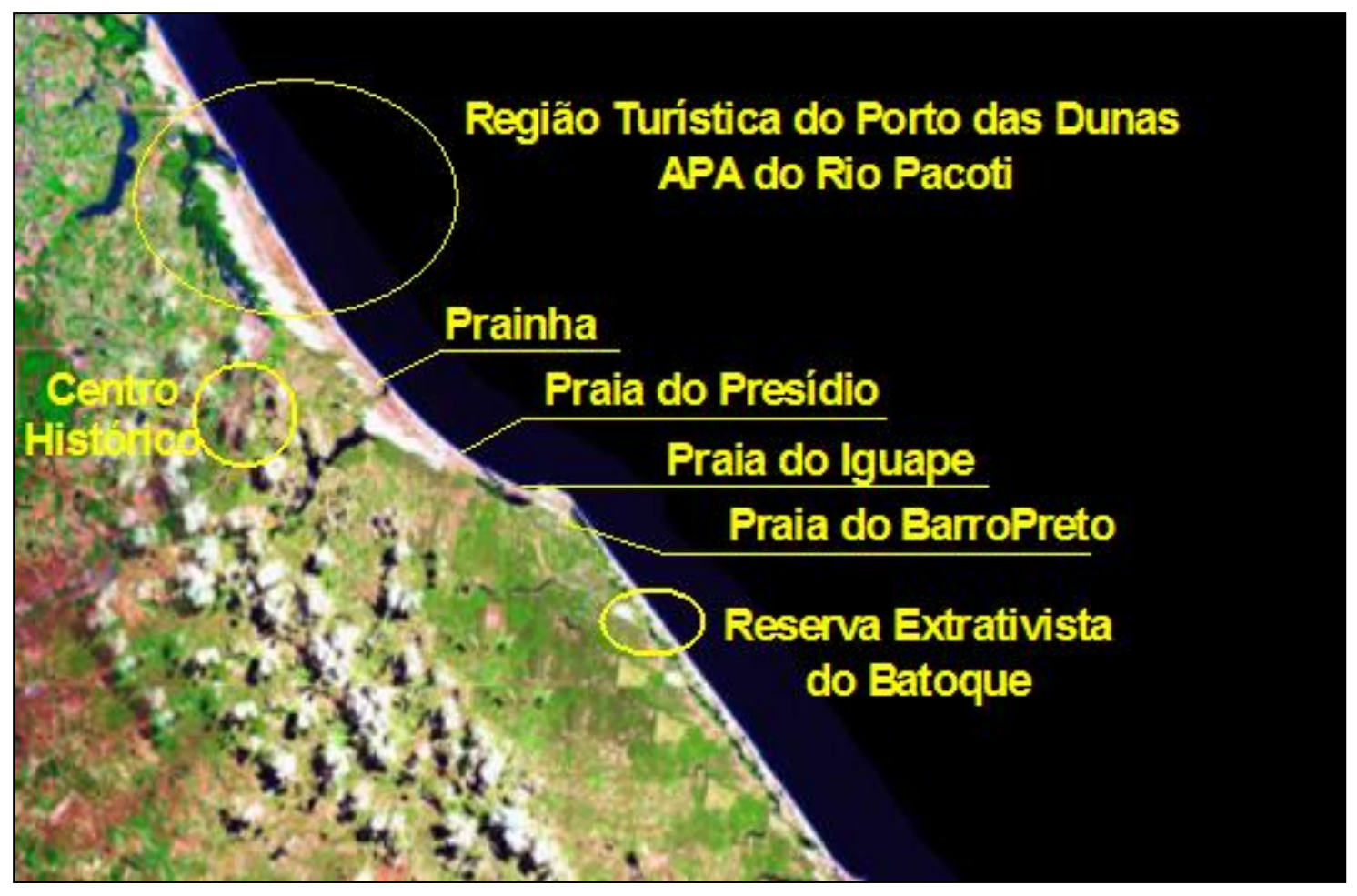

Fig. 3.22 Localização relativa, dos dois modelos opostos no Município de Aquiraz. Entre os dois extremos as quatro localidades praianas que vão se convertendo de espaço de veraneio a pontos turísticos. Fonte: LANDSAT, 1999

A porção atualmente mais preservada do litoral de Aquiraz situa-se justamente entre o Barro Preto e o Batoque. É também o trecho que possui as mais belas e intocadas paisagens. Por isso atraiu o interesse do setor hoteleiro e imobiliário para a implantação do Aquiraz Resort.

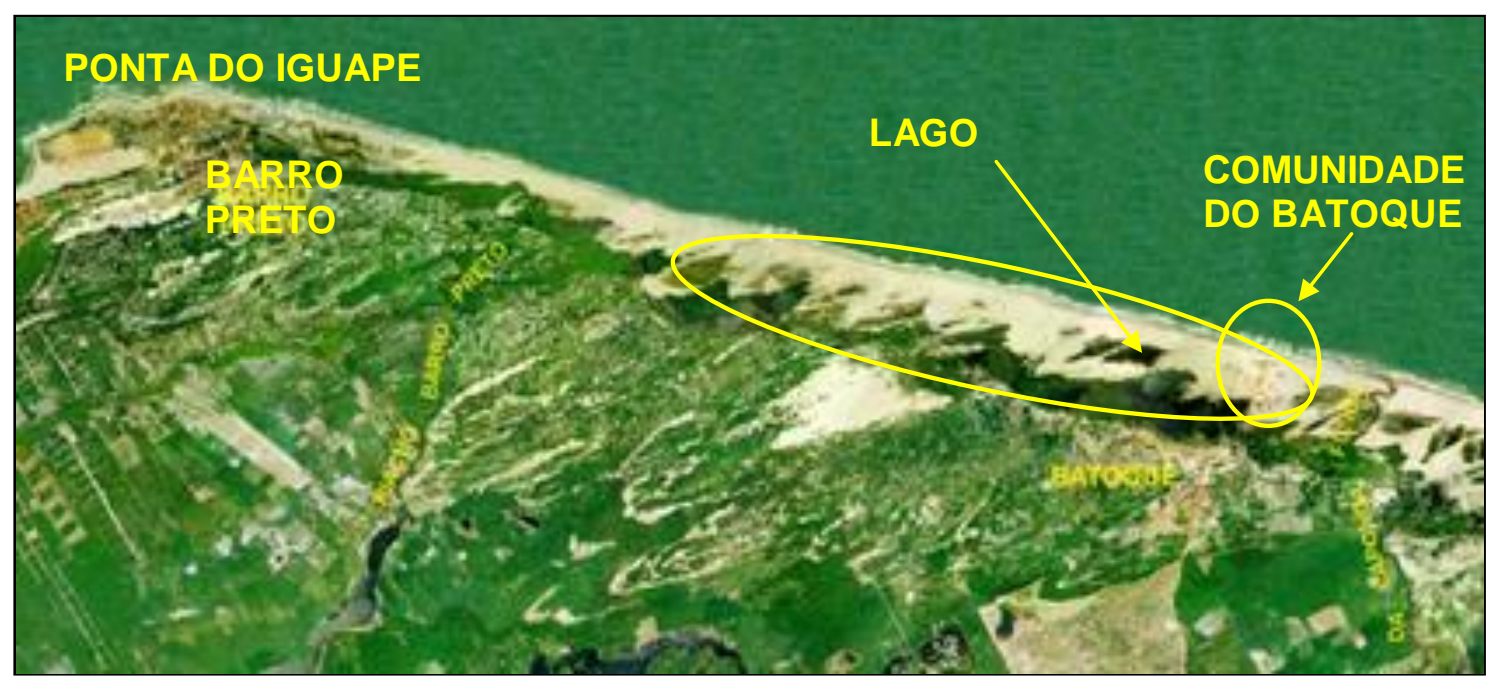

Fig. 3.23 A área do empreendimento com o lago e a comunidade. Fonte: IBAMA.

Abaixo a primeira versão do projeto Aquiraz Resort. Nota-se, à esquerda, o complexo hoteleiro e o campo de golf em torno do lago, seguindo o mesmo padrão internacional 
de vilas turísticas, mas em menor escala que o atual Aquiraz Riviera. O detalhe do lago em torno do campo de golf não considerava a consolidada história de convivência e dependência da comunidade com o lago: ponto de conflito no termo de ajustamento de conduta pretendido entre as partes.

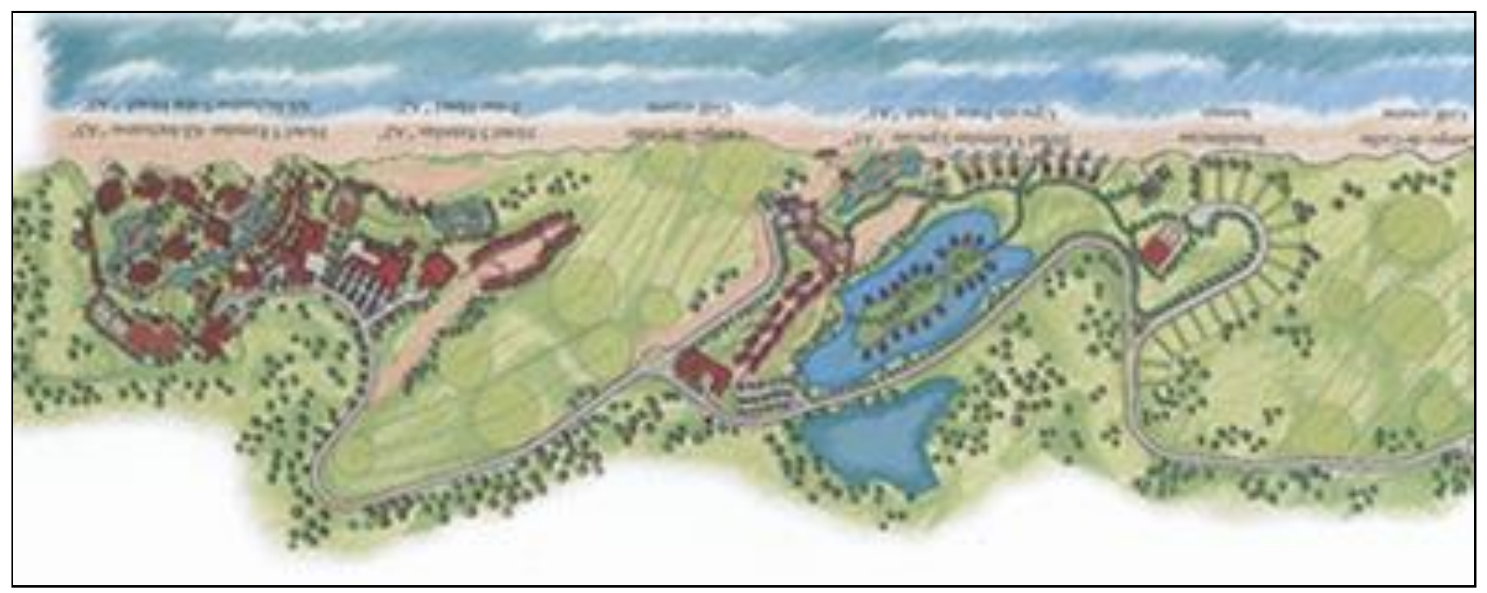

Fig. 3.24 - Primeira fase do Aquiraz Resort (1999) -. Fonte: Luiz Fiúza Arquitetura.

Hoje o IBAMA continua a gestão da Reserva Extrativista do Batoque apontando para outro paradigma de ocupação litorânea, completamente distinta do modelo de desenvolvimento turístico litorâneo. Com sua experiência pretende-se estudar suas limitações e potencialidades para orientar novas possibilidades de desenvolvimento local em comunidades com base no extrativismo.

Essa característica parece sinalizar para uma relação simbiôntica entre o local e o global, suscitando reflexões sobre esta convivência. Assim, recordamos a referência de Mullins (1991), sobre o modelo de "urbanização turística" do litoral de Queens Land, na Austrália, onde o padrão de urbanização adensada mantém-se de modo complementar ao lado de um trecho cuidadosamente preservado do litoral.

No contexto atual, do ponto de vista do desenvolvimento das atividades turísticas, Aquiraz destaca-se entre os municípios da Região Metropolitana de Fortaleza tendo sido o segundo município mais visitado no período de 2010 (via Fortaleza) com movimento de 289.736 turistas, segundo dados da SETUR. Esse movimento decorre de vários fatores como: a boa acessibilidade e proximidade da capital; a segunda maior oferta de leitos em hotéis de diversas categorias; oferta de equipamentos de lazer, como os sofisticados e elitizados parques temáticos e as populares barracas de praia. 


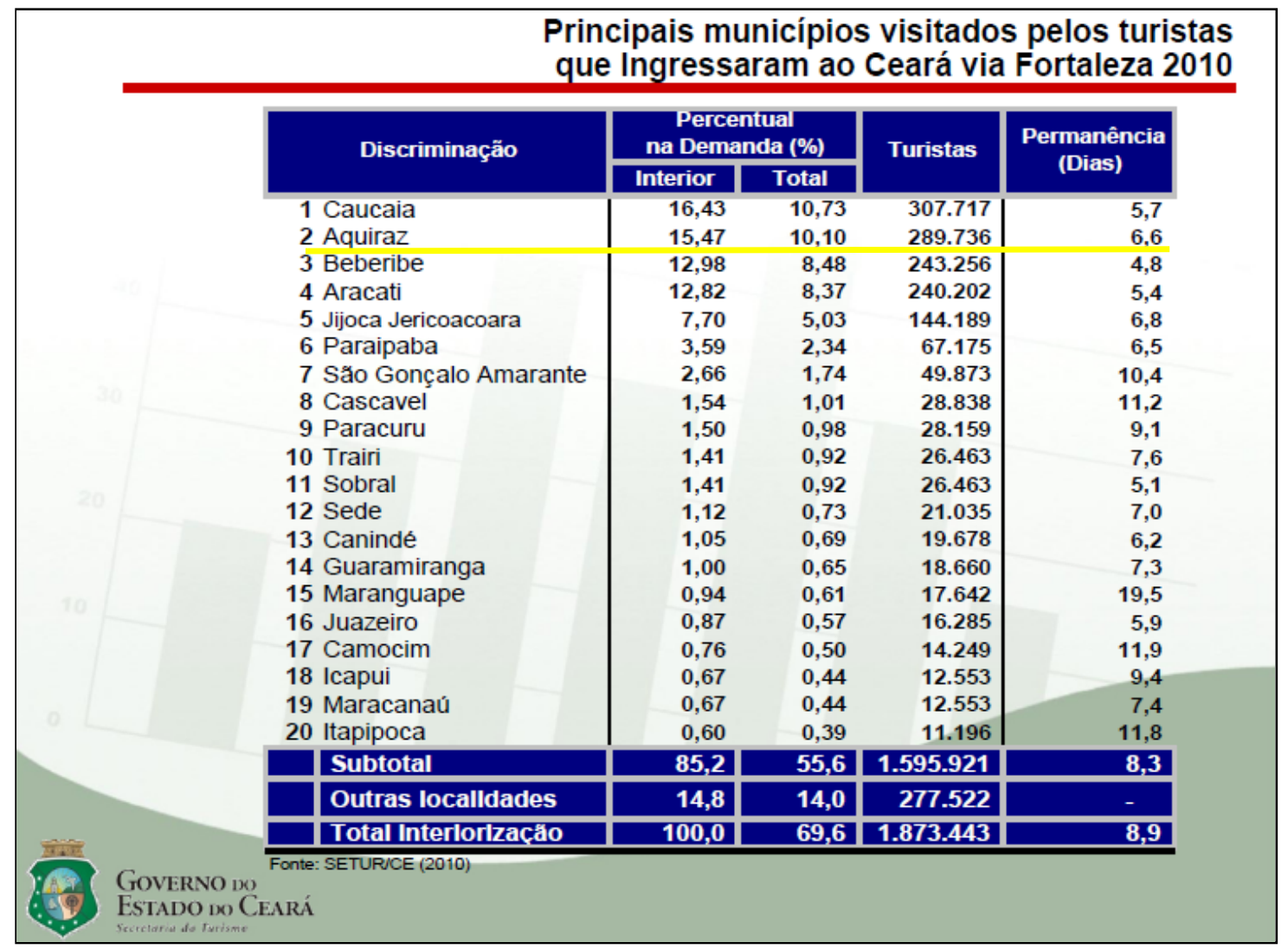

Fig. 3.25 Indicadores turísticos - 1995-2011. Fonte: SETUR

Além dos fatores mencionados, o Município possui aspectos locacionais importantes, como a proximidade do aeroporto internacional $(24 \mathrm{~km})$, como também por se inserir na rota rodoviária do corredor turístico estruturante da MRT3 - Macrorregião Turística Litoral Leste - Apodi, sendo cortado pela CE - 040.

Outra particularidade pode ser constatada ao analisarmos as relações entre o planejamento governamental do turismo e o Município em Aquiraz. Em 1990, o Governo das Mudanças elaborou o PRODETURIS (Fig. 3.26) e em 1995 a sua "Política Estratégica para o Turismo Sustentável do Ceará", iniciando a primeira fase de liberação dos recursos do PRODETUR-NE, destinados à infraestrutura. Com isso, atende somente parte do litoral norte-oeste de Fortaleza (Costa do Sol Poente), ficando de fora todos os municípios do litoral norte-leste, incluindo o Aquiraz.

Na segunda fase do programa (PRODETUR II), os recursos foram previstos para os municípios do chamado "Polo Ceará Costa do Sol" (Fig. 3.27), onde o Aquiraz passou a 
ser incluído, no PDITS - Plano de Desenvolvimento Integrado do Turismo Sustentável, devido justamente ao incremento do seu fluxo turístico. O PDITS foi elaborado para avaliar os impactos do PRODETUR I sobre os municípios e requerer novos empréstimos junto ao BID para financiar o PRODETUR II.

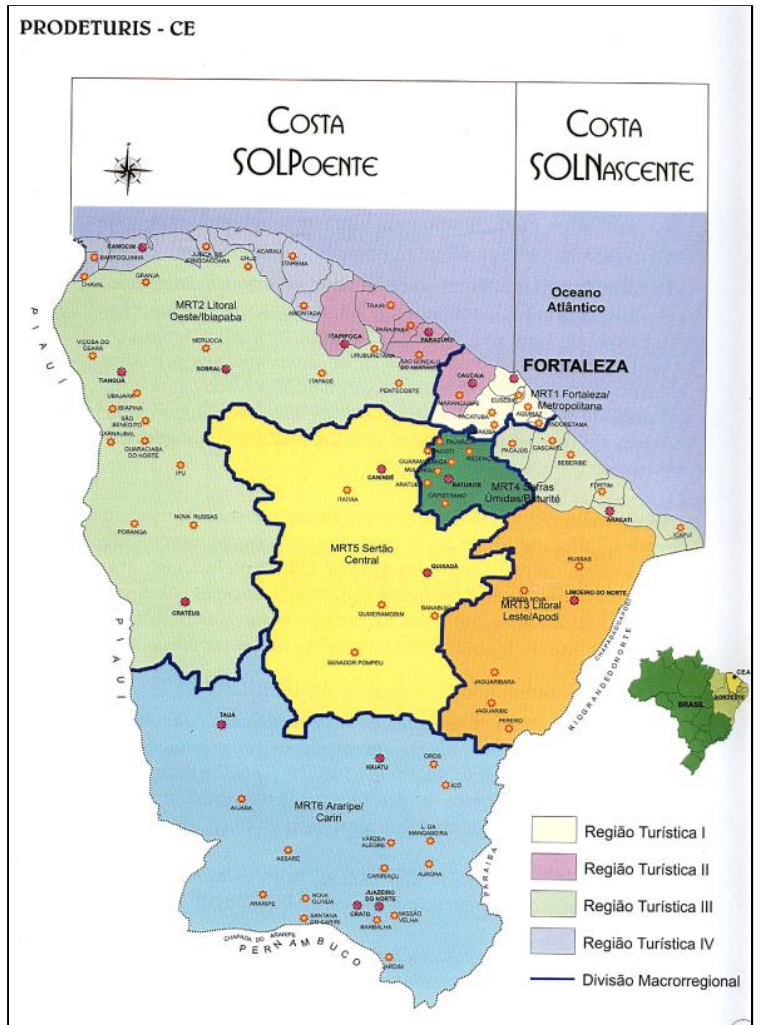

Fig. 3.26 - Municípios Incluídos no Prodeturis-Ce Fonte: SETUR - 1998

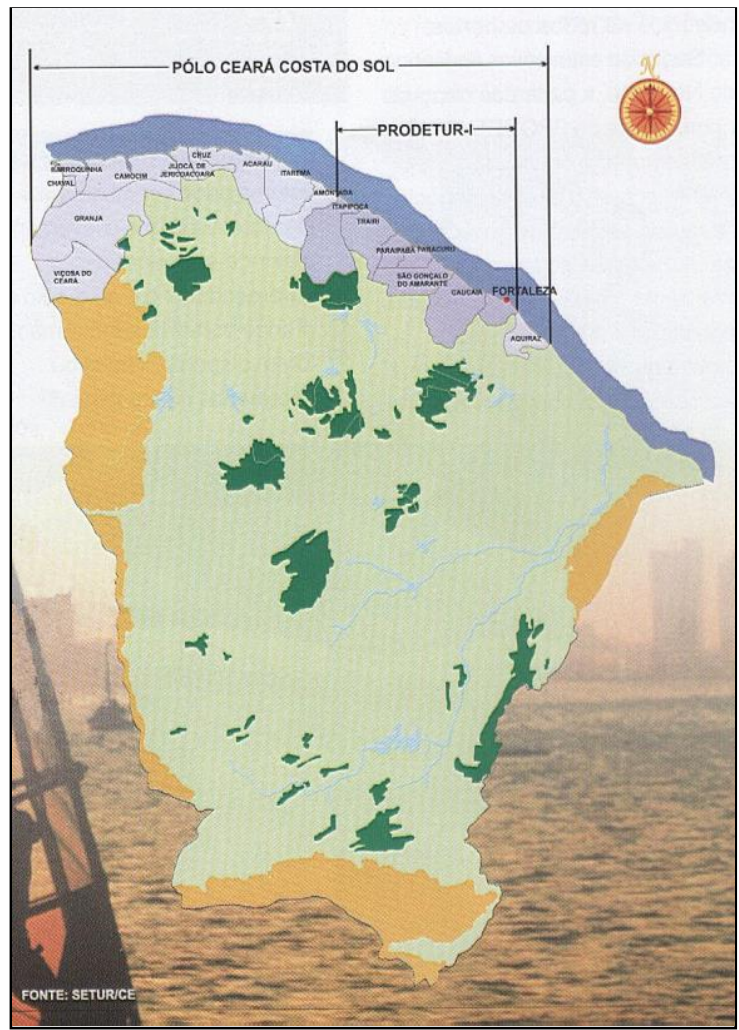

Fig. 3.27 - Municípios Do Polo Ceará Costa Do Sol Fonte: SETUR - 2003

Outra razão que justificou a inclusão de Aquiraz foi o comportamento do setor privado, que seguiu o aumento do fluxo turístico, apresentando um aumento de $35,1 \%$ na oferta de novos leitos, a partir de 1997 (dados de 2002), conforme Tabela 3.2, abaixo.

Tabela 3.2 - UH'S e Leitos Inaugurados desde 1997

\begin{tabular}{|c|c|c|c|c|c|c|}
\hline \multirow{2}{*}{ Municipio } & \multicolumn{3}{|c|}{ UH's } & \multicolumn{3}{c|}{ Leitos } \\
\cline { 2 - 7 } & $\begin{array}{c}\text { Inaugurados } \\
\text { a partir de } \\
\mathbf{1 9 9 7}(\mathbf{A})\end{array}$ & $\begin{array}{c}\text { Total } \\
\text { existente (B) }\end{array}$ & $\%$ (A/B) & $\begin{array}{c}\text { Inaugurados } \\
\text { a partir de } \\
\mathbf{1 9 9 7}(\mathbf{A})\end{array}$ & $\begin{array}{c}\text { Total } \\
\text { existente (B) }\end{array}$ & \% (A/B) \\
\hline Aquiraz & 381 & 868 & 43,9 & 855 & 2.438 & 35,1 \\
Camocim & 228 & 315 & 72,3 & 533 & 819 & 65,1 \\
Jijoca de & 253 & 591 & 42,8 & 695 & 1.696 & 41,0 \\
\hline Jericoacoara & $\mathbf{8 6 2}$ & $\mathbf{1 . 7 7 4}$ & $\mathbf{4 8 , 5}$ & $\mathbf{2 . 0 8 3}$ & $\mathbf{3 1 . 7 6 3}$ & $\mathbf{6 5 , 4}$ \\
\hline Total & \multicolumn{7}{|l|}{} \\
\hline
\end{tabular}


A Tabela, abaixo, mostra a oferta hoteleira atual nos municípios turísticos do Ceará. Note que Aquiraz está entre aqueles de maior oferta hoteleira no Estado (destaque em amarelo), ficando atrás apenas de Fortaleza, Juazeiro do Norte e Caucaia, sendo que com um número muito próximo dos últimos dois. Há, entretanto, uma tendência do município tornar-se a segunda maior oferta hoteleira do Estado quando os empreendimentos do Aquiraz Riviera forem concluídos, incluindo além de mais sete hotéis, as vilas turísticas em regime de condomínio. O município de Aquiraz conta hoje com 32 meios de hospedagem, 1.143 UH e 3.503 leitos.

Tabela 3.3 - Oferta hoteleira nos municípios turísticos do Ceará - 2011

\begin{tabular}{|c|c|c|c|c|c|c|c|c|}
\hline Regiao & MH & Uhs & Leitos & & Peagiao & $\mathbf{M H}$ & Uhs & Leitos \\
\hline Fortaleza & 190 & 10.585 & 26.988 & & Cariri & 70 & 1.775 & 5.148 \\
\hline 1. Fortaleza & 190 & $\begin{aligned} 10.585 \\
003\end{aligned}$ & $\begin{aligned} 28.988 \\
2.14 r\end{aligned}$ & & 1. Asasard & $\begin{array}{l}3 \\
1\end{array}$ & $\begin{array}{l}29 \\
18\end{array}$ & $\begin{array}{l}69 \\
36\end{array}$ \\
\hline 1. Carnaubal & 2 & 15 & 28 & & 3. Aurora & 2 & 34 & 78 \\
\hline 2. Croatá & 1 & 12 & 30 & & 4. Barbaltha & 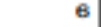 & 112 & 373 \\
\hline 3. Ibiapina & $\begin{array}{l}3 \\
4\end{array}$ & $\begin{array}{l}42 \\
46\end{array}$ & $\begin{array}{r}99 \\
102\end{array}$ & & 5. Camposa Sales & $\begin{array}{r}3 \\
13\end{array}$ & $\begin{array}{r}60 \\
248\end{array}$ & $\begin{array}{l}131 \\
745\end{array}$ \\
\hline 4. Ipá & 4 & 46 & 102 & & B. Crato & 13 & 248 & 745 \\
\hline $\begin{array}{l}\text { 5. Guaraciaba do Norte } \\
\text { e. Sao Beneadito }\end{array}$ & $\begin{array}{l}8 \\
7\end{array}$ & $\begin{array}{r}89 \\
113\end{array}$ & $\begin{array}{l}212 \\
249\end{array}$ & & $\begin{array}{l}\text { 7. Jardim } \\
\text { 8. Juazeiro do Norte }\end{array}$ & $\begin{array}{r}1 \\
38\end{array}$ & 1.241 & $\begin{array}{r}16 \\
3.833\end{array}$ \\
\hline 7. Tiangua & 11 & 351 & 825 & & 3. м. мизамаם veanu & 1 & 17 & 47 \\
\hline 8. Ubajara & 8 & 151 & 376 & & 10. Nova Olinda & 1 & 4 & 10 \\
\hline 9. Viçosa do Cearáa & 5 & 74 & 2228 & & 11. Santana do Cariri & 1 & 5 & 10 \\
\hline Litoral Oeste & 196 & 3.545 & 9.051 & & Macico de Baturité & 68 & 977 & 2.909 \\
\hline $\begin{array}{l}\text { 1. Acarac } \\
\text { 2. Amontada }\end{array}$ & $\begin{array}{r}7 \\
12\end{array}$ & $\begin{array}{r}98 \\
104\end{array}$ & $\begin{array}{l}285 \\
305\end{array}$ & & $\begin{array}{ll}\text { 1. } & \text { Aratuba } \\
\text { 2. } & \text { Baturite }\end{array}$ & $\begin{array}{r}3 \\
12\end{array}$ & $\begin{array}{r}29 \\
238\end{array}$ & $\begin{array}{r}68 \\
664\end{array}$ \\
\hline 3. Caucaia & 301 & 1.388 & 3.554 & & 3. Barreitra & 1 & 11 & 23 \\
\hline 4. maqpage & 4 & 12 & $2 \cdots$ & & 4. Cuaiciba & 1 & 28 & 74 \\
\hline $\begin{array}{l}\text { 5. Hapipoea } \\
\text { 8. Harama }\end{array}$ & $\begin{array}{r}18 \\
7\end{array}$ & $\begin{array}{r}389 \\
82\end{array}$ & $\begin{array}{l}780 \\
178\end{array}$ & & $\begin{array}{l}\text { 5. Cuaramiranga } \\
\text { 8. Itapiüna }\end{array}$ & 22 & 338 & 1.090 \\
\hline 7. Paracuru & 21 & 237 & 607 & & 7. Maranguape & 8 & 74 & 271 \\
\hline 8. Paraipaba & 16 & 223 & 544 & & 8. Mulungu & 5 & 58 & 185 \\
\hline 9. Pentecosite & $\begin{array}{r}3 \\
31\end{array}$ & $\begin{array}{r}61 \\
391\end{array}$ & $\begin{array}{r}138 \\
1.091\end{array}$ & & & 1 & $\begin{array}{r}15 \\
140\end{array}$ & $\begin{array}{r}50 \\
382\end{array}$ \\
\hline $\begin{array}{l}\text { 10. Sao Gonçalo do Amarar, } \\
\text { 11. Tejuçuoca }\end{array}$ & $\begin{array}{r}31 \\
2\end{array}$ & 34 & $\begin{array}{r}1.091 \\
95\end{array}$ & & $\begin{array}{l}\text { 10. Pacoti } \\
\text { 11. Palmácia }\end{array}$ & $\begin{array}{r}10 \\
2\end{array}$ & 20 & 48 \\
\hline 12. Trairi & 38 & 460 & 1.211 & & 12. Redenças & 3 & 28 & 56 \\
\hline 13. Unuburetama & 2 & 26 & 72 & & Litoral Leate & 188 & 3.740 & 11.007 \\
\hline Sertäo Central & 53 & 1.112 & 2.926 & & 1. Aqquiraz & 32 & 1.143 & 3.503 \\
\hline 1. Banabuicú & 2 & 67 & 154 & & 2. Aracat & 84 & 1.078 & 3.001 \\
\hline 2. Canindé & 26 & 513 & 1.588 & & 3. Betberitbe & 30 & 1.024 & 3.283 \\
\hline 3. Matira & 2 & 14 & 28 & & 4. Cascavel & 8 & 182 & 483 \\
\hline 4. Pedra Branca & 4 & 67 & 167 & & 5. Fortim & 7 & 92 & 201 \\
\hline 5. Quixadia & 12 & 312 & 759 & & 6. Ieapui & 25 & 221 & 536 \\
\hline 8. Quixearamabim & 5 & 99 & 212 & & Vale do Balgado & 24 & 468 & 992 \\
\hline 7. Senador Pompeu & 2 & 40 & 110 & & 1. Ceadro & 3 & 24 & 55 \\
\hline Lit. Extremo Oeste & 122 & 1.778 & 4.795 & & 2. $\quad 100$ & 7 & 121 & 289 \\
\hline 1. Barroquinha & 5 & 24 & 63 & & 3. Iguatu & e & 191 & 369 \\
\hline 2. Beta Cruz & 1 & 25 & 50 & & 4. Lavras da Mangabeir & 1 & 8 & 12 \\
\hline 3. Camocim & 18 & 376 & 921 & & 5. Oros & 3 & 52 & 111 \\
\hline 4. Crus & 17 & 172 & 462 & & 8. Varzeala Alegres & 4 & 72 & 163 \\
\hline 5. Granja & 2 & 37 & 97 & & Vale do Acaraú & 19 & 483 & 1.100 \\
\hline 6. Jijoca de Jericoacoara & 88 & 1.144 & 3.202 & & 1. Massape & 3 & 16 & 29 \\
\hline Vale do Jaguaribe & 30 & 588 & 1.259 & & 2. Meruoca & 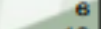 & 128 & 387 \\
\hline 1. Jaguaribara & 7 & 103 & 213 & & 3. Sobrat & 10 & 339 & 704 \\
\hline 2. Jaguaribe & e & 101 & 213 & & Sertiäo dos Inhamuns & 8 & 170 & 337 \\
\hline 3. Limoeiro do Norte & 7 & 205 & 436 & & 1. Aluaba & 1 & 20 & 24 \\
\hline 4. Moradia Nova & 3 & 49 & 115 & & 2. Crateda & 5 & 137 & 291 \\
\hline 5. Perairo & 1 & 16 & 24 & & 3. Ipaporanga & 1 & 8 & 12 \\
\hline 6. Peunasas & B] & 114 & 258 & & 4. Poranga & 1. & 5 & 10 \\
\hline Total Ceral & \multicolumn{2}{|c|}{ Municipios (M) 85} & $\mathbf{M H}$ & 1.029 & Leitos (L) & 68.736 & Uhs & 26.114 \\
\hline Relaçóess & MH/M & 12,9 & UH:/MH & 67 & Leitos/MH & 828 & UH/M & 315 \\
\hline
\end{tabular}

Fonte: SETUR - Indicadores Turísticos - 2011

Ainda, segundo o PDITS, além dos investimentos hoteleiros depois de 1997, foi inaugurado em Aquiraz outro parque aquático: o Itacaranha Park cujo custo inicial foi de cerca de R\$ 3 milhões. Outros aspectos caracterizam a inserção do Município no 
planejamento turístico estadual, como os fatores locacionais de Aquiraz que fazem com que seja influenciado por duas regiões turísticas simultaneamente: a metropolitana e a do Litoral - Leste.

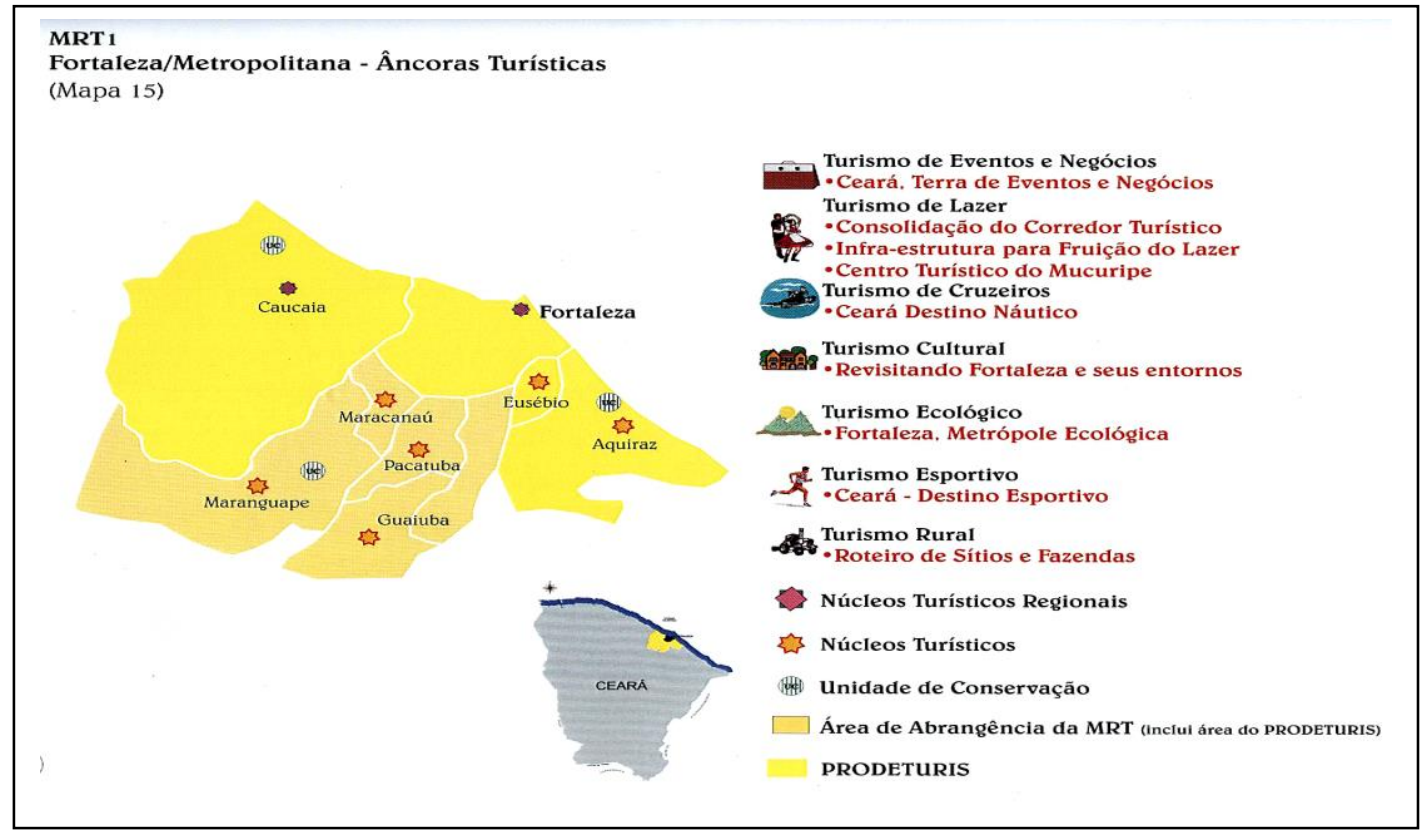

Fig. 3.28 - MRT1- Macrorregião turística 1 - Fortaleza Metropolitana. Fonte SETUR 1998

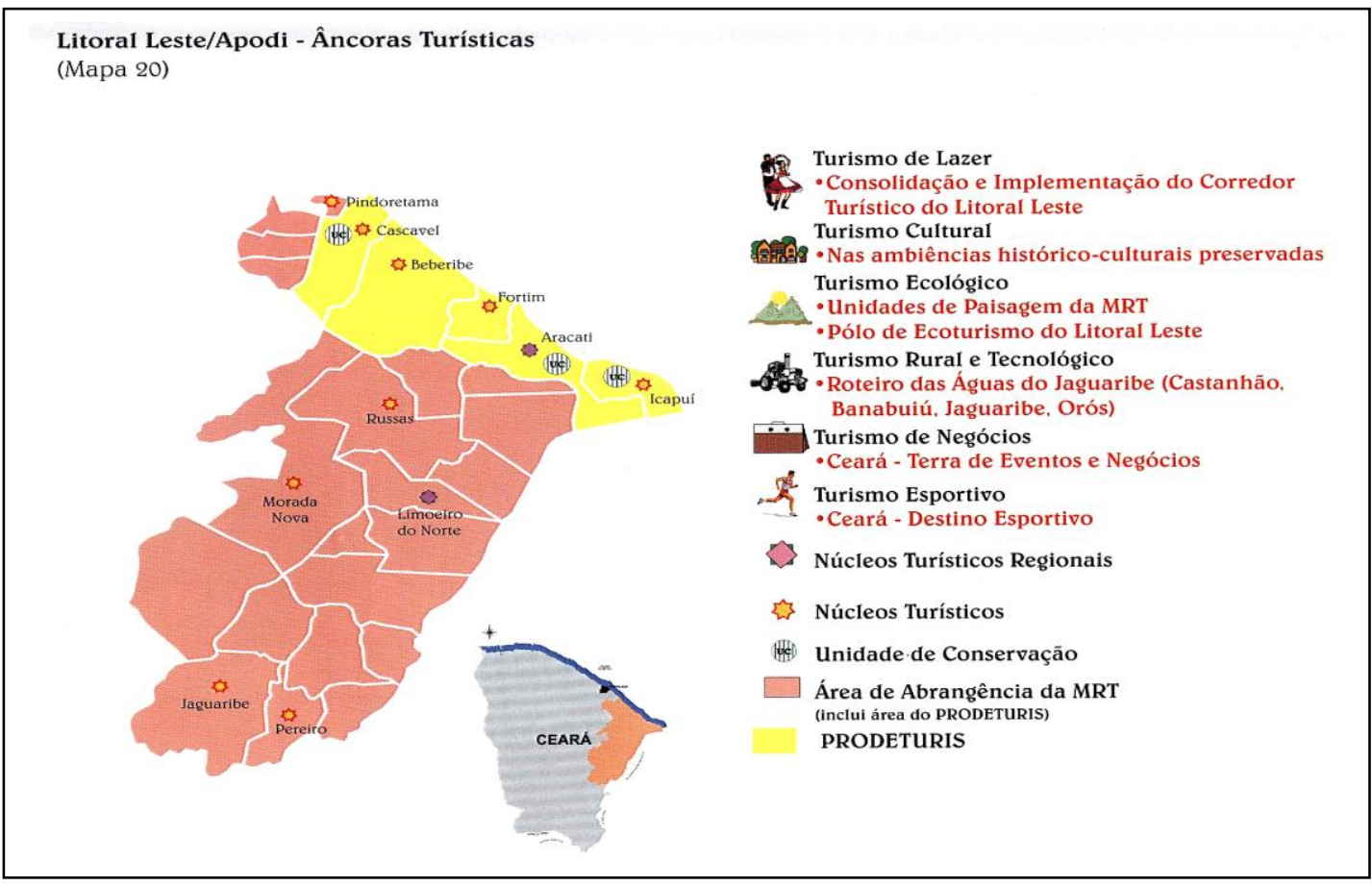

Fig. 3.29 - Macrorregião turística Litoral Leste/Apodi - Âncoras turísticas Fonte: SETUR - 1998 
Mesmo pertencendo à Macrorregião turística Fortaleza Metropolitana (Fig. 3.28) que facilitou a sua integração ao "Polo Ceará Costa do Sol", a sua posição geográfica situada na intersecção das duas regiões turísticas contribuiu para que o Município também estabeleça vínculos como a Macrorregião Turística Litoral Leste - Apodi (Fig. 3.29), porque a maior parte de suas comunidades litorâneas vive uma realidade muito mais próxima dos seus municípios vizinhos do que de Fortaleza, fazendo com que seja integrante do "Fórum de Turismo do Litoral Leste".

No âmbito do planejamento municipal, Aquiraz foi incluído no conjunto dos municípios beneficiados pelo programa do PNMT - Programa Nacional de municipalização do Turismo, tendo sido formado um técnico local, pertencente ao quadro permanente da Prefeitura. Aquiraz foi também um dos 22 municípios beneficiados pelo PAT - Plano de Ação Turística, financiado pelo convênio entre EMBRATUR, SETUR e Prefeitura Municipal, que procurou levantar o cenário de suas potencialidades turísticas, estabelecendo estratégias para o encaminhamento das demandas necessárias para organização local do setor.

O fato de o PAT ser apenas um documento de apoio ao planejamento turístico, a sua utilização só teria uma maior efetividade se fosse objeto de um alinhamento entre as suas diretrizes estratégicas e as do PDDU - Plano Diretor de Desenvolvimento Urbano, que, em última análise, depende de entendimento e vontade política para executá-lo.

Com o exposto, podemos concluir que o Município de Aquiraz não só oferece condições favoráveis como também se posiciona politicamente no centro das decisões dos investimentos turísticos, sendo um município altamente impactável, do ponto de vista das possibilidades que oferece como receptor de significativos investimentos hoteleiros.

\subsection{Transformações socioespaciais em Aquiraz e os novos padrões de ocupação}

Como sabemos, foi no litoral que se verificou a maior parte das transformações socioespaciais recentes em Aquiraz, principalmente a partir dos anos 1970. Podemos dizer que ocorreu uma primeira onda de expansão, caracterizada por um padrão de ocupação baseado na construção de residências de veraneio térreas, em loteamentos de 
frente para o mar e sem infraestrutura urbana adequada, como já observamos no capítulo anterior.

\subsubsection{As primeiras gerações de loteamentos e a reinvindicação do espaço litorâneo perdido}

No caso de Aquiraz, esse processo iniciou-se em torno das vilas de pescadores nas praias do Iguape e Prainha. Só depois foi se expandindo na direção de outras localidades mais distantes e menos ocupadas como o Porto das Dunas, o Presídio e o Barro-preto que praticamente surgiram em torno dos loteamentos de veraneio. O Batoque teve uma dinâmica diferenciada provocada pela distância e dificuldade de acesso à Sede dentro dos limites do município. O acesso é feito, ainda hoje, através de uma via do município vizinho de Pindoretama que mantém um maior intercâmbio com a localidade.

No caso do Iguape, observamos o padrão de loteamento inserido na malha urbana da vila de pescadores que, "expulsos" do litoral, ocupam as frentes das casas de veraneio com barracas de praia. É uma forma de "reivindicação" do espaço litorâneo perdido. O "turismo" de veraneio passou a ser uma atividade complementar e menos arriscada que a pesca, para os nativos. Entretanto, o turismo no Iguape perde força pelo estrangulamento da sua expansão, limitada por uma rua sem saída. Embora continue bastante concorrido nas festas populares, foi sendo preterido pela preferência dos veranistas e turistas por localidades como a prainha, presídio, e Barro Preto, tanto pela oferta de novos espaços loteados, como pelos equipamentos agregados a eles.

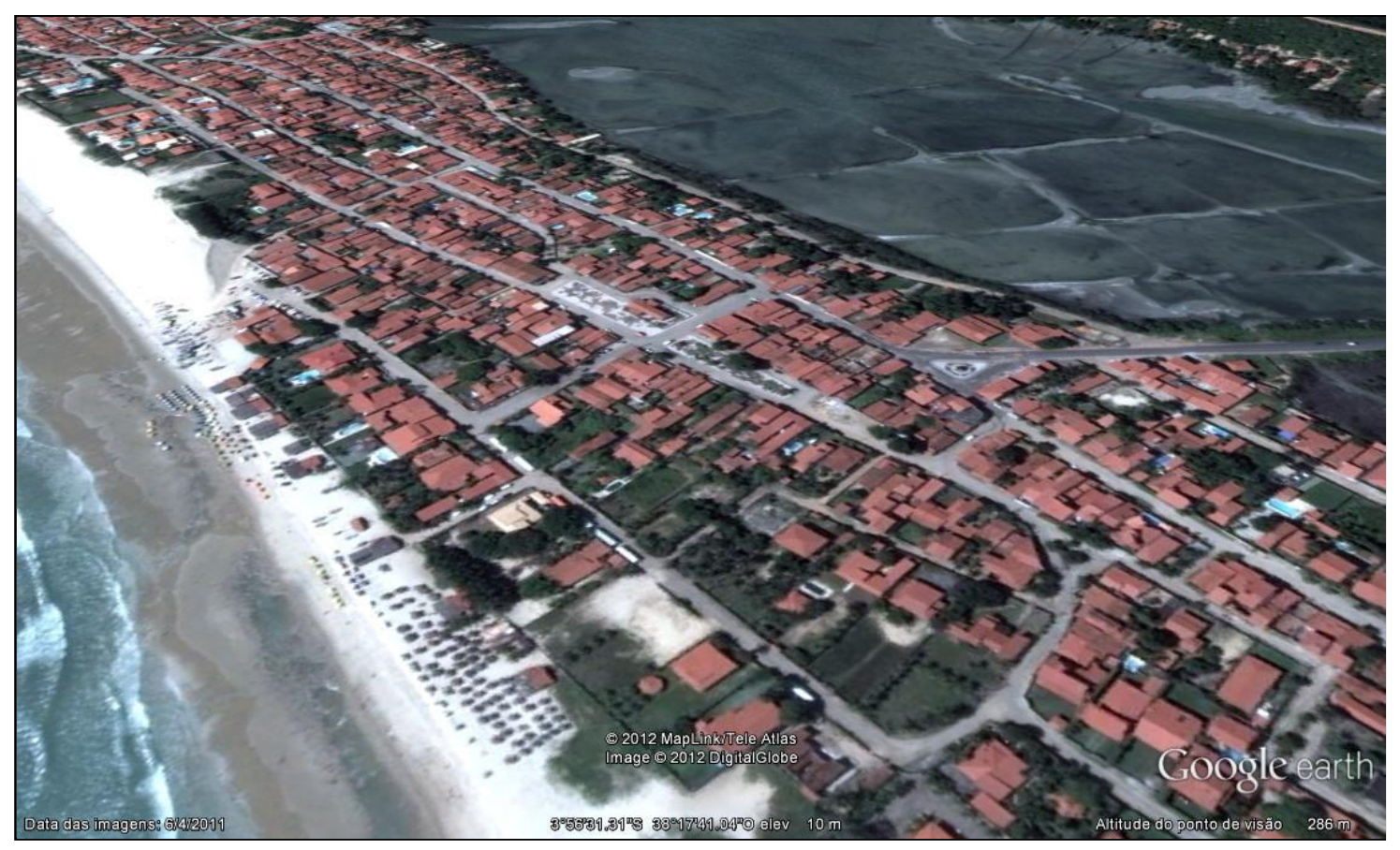

Fig. 3.30 Praia do Iguape. Fonte: Google Earth-2012 
No caso da prainha o padrão é semelhante ao do Iguape, mas as barracas de praia se localizam em local ainda não ocupado pelos veranistas. No entanto, estas barracas vão avançando e se consolidando de tal maneira a exigirem do poder público, intervenções urbanísticas de pavimentação e iluminação sem, no entanto, contar com a infraestrutura de saneamento básico. Surgem também pequenos empresários locais e estrangeiros que desenvolvem atividades nas barracas de praia, buscando superar um processo permanente de falta de manutenção dos serviços urbanos, causado pelo excessivo adensamento das barracas, como também pelo processo natural de erosão marinha.

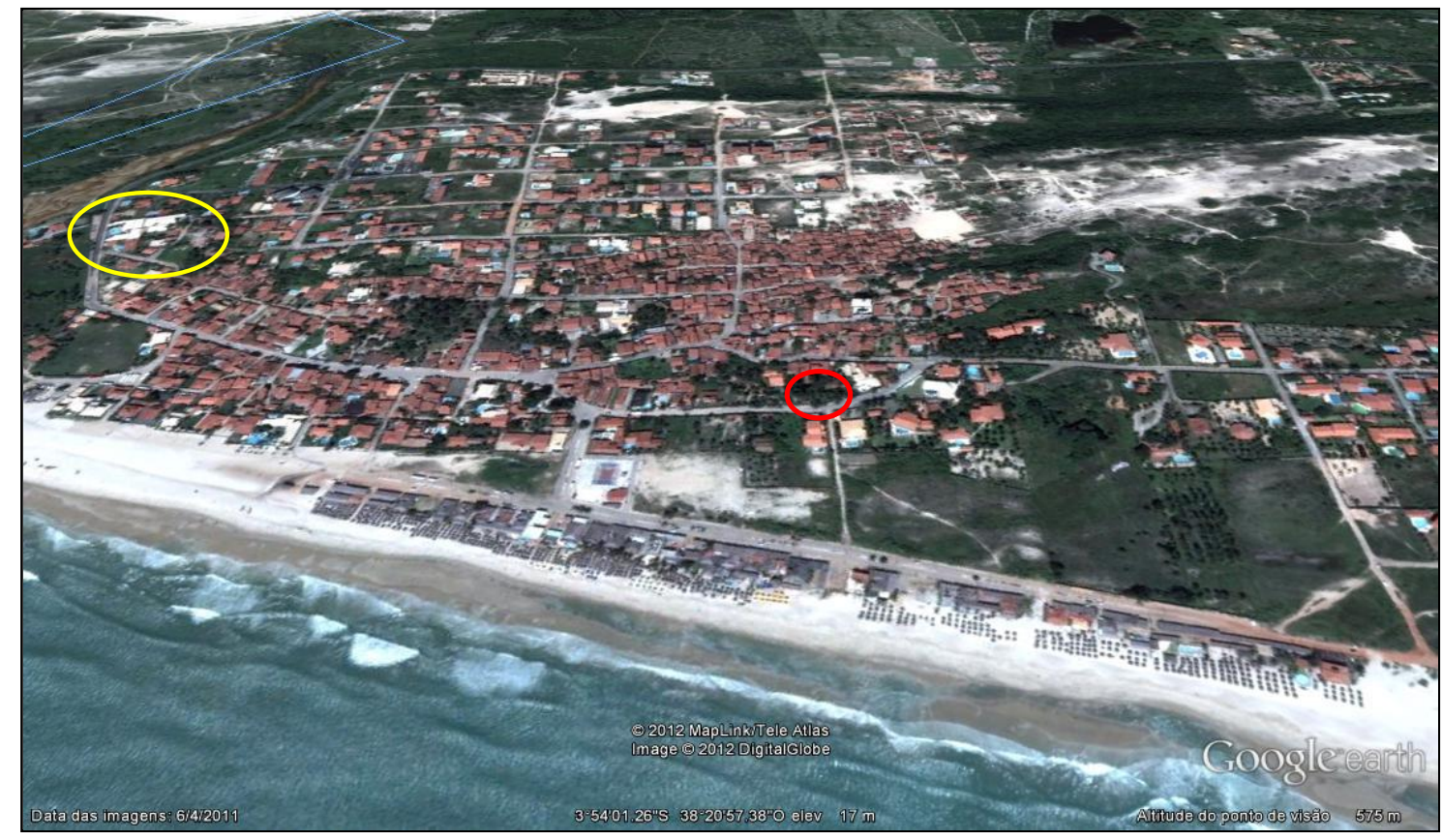

Fig. 3.31 Vista da Prainha com as barracas de praia. Ao fundo o loteamento se mistura com a vila de pescadores. Em amarelo um Hotel de proprietário Italiano e em vermelho uma pousada local. Fonte Google Earth 2012.

Na Praia do Presídio (Fig. 3.32, abaixo), podemos dizer que é uma "segunda geração" de loteamento, distante das vilas de pescadores e da possibilidade ter barracas de praia ocupando a frente marítima. Nesse caso, houve uma espécie de segregação branda, através de um maior cuidado dos proprietários do loteamento que inibiram a chegada das barracas de praia, com ações proibitivas, junto à prefeitura. O loteamento acabou se qualificando como um espaço para a população com padrão de renda "média-alta".

Nessa localidade, consolidou-se também a implantação de um hotel de médio porte e uma pousada com padrão de qualidade turística de proprietários cearenses, muito procurados em períodos de alta-estação como carnaval, férias e festas de fim de ano. 


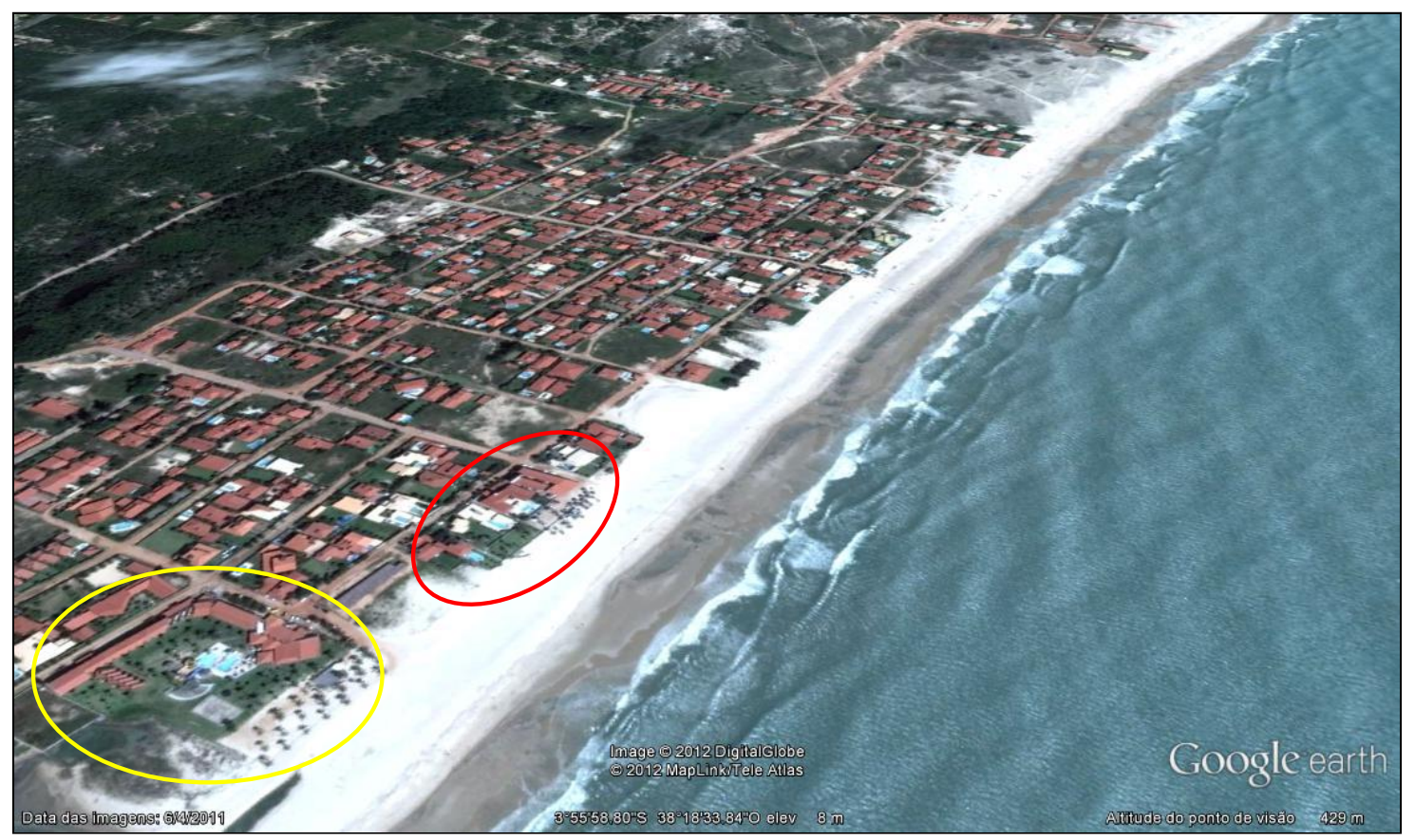

Fig. 3.32 Vista da Praia do Presídio: o Hotel em amarelo e a pousada em vermelho. Nota-se a ausência de barracas de praia e uma ocupação mais homogênea e menos adensada. Fonte: Google Earth- 2012.

A praia do Barro preto (Fig. 107, abaixo) se assemelha à do presídio no que diz respeito à configuração do loteamento: mais ordenado e de padrão de renda "média-alta". No entanto, inclui equipamentos diferenciados como um "hotel de charme" e duas pousadas de médio porte, de capital local. Oferece também um Camping com parque aquático que perdeu atratividade pela falta de manutenção do equipamento e pela concorrência das barracas de praia que se instalaram em frente ao empreendimento.

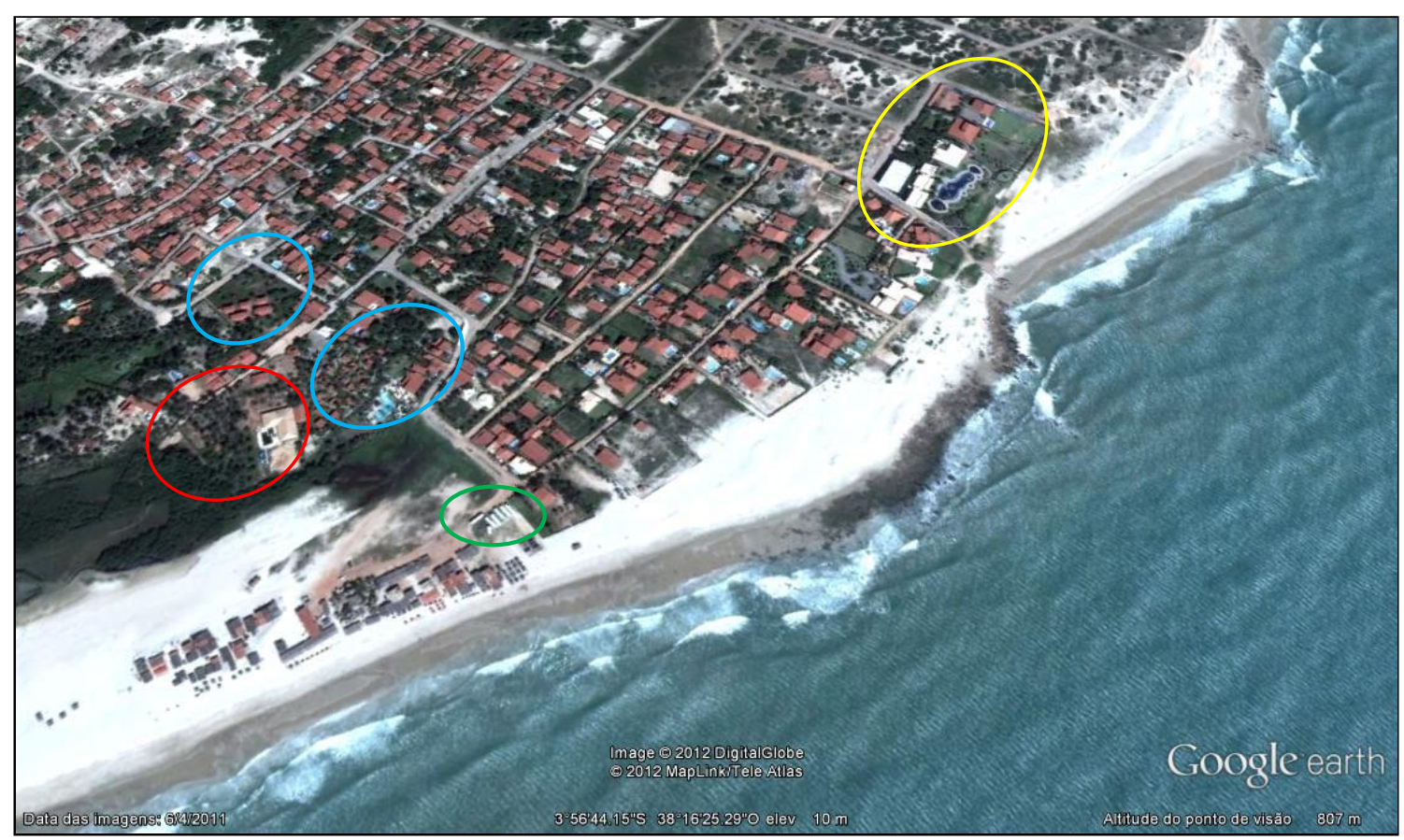

Fig. 3.33 Vista do Barro Preto. O Hotel, em amarelo. As pousadas em Azul e o camping em vermelho. Abaixo, à esquerda, as barracas de praia com a presença de ônibus de fretamento popular, em verde. 


\subsubsection{A segunda geração de loteamentos: a visão empresarial e o impasse ambiental}

O rio Pacoti sempre foi uma "barreira natural" para a integração das atividades econômicas de Aquiraz ao circuito de Fortaleza. Somente no final dos anos 1970 foi construída a sua segunda ponte, que liga a zona Leste de Fortaleza ao extremo Oeste do município de Aquiraz. Até então, a foz e as margens do rio Pacoti ainda se mantinham quase intocadas em razão das dificuldades de acesso que o rio oferecia.

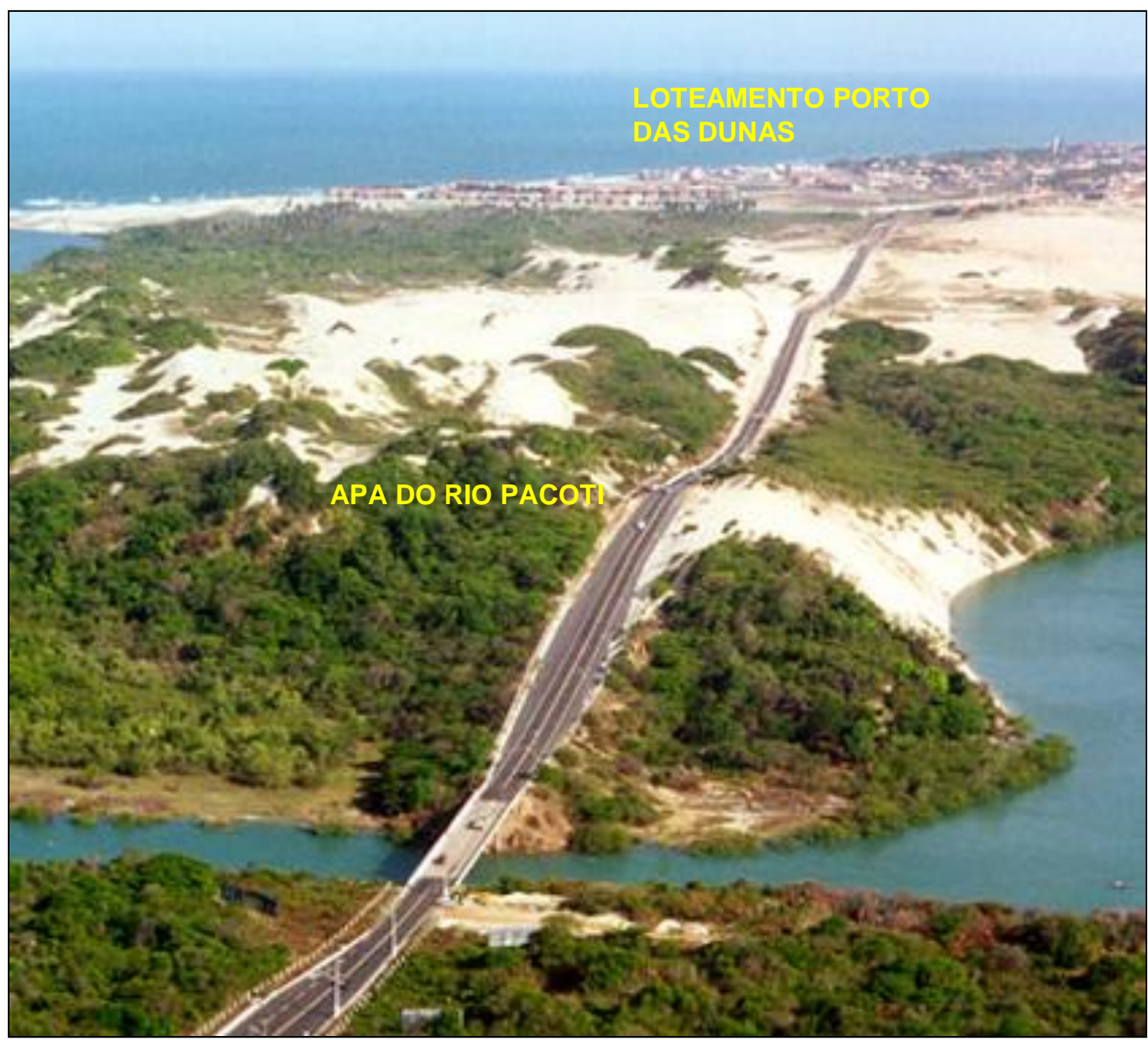

Fig. 3.34 Vista aérea mostrando a ponte, construída no final dos anos 1970 (em primeiro plano), a APA do Rio Pacoti (em segundo plano) e o loteamento Porto das Dunas (ao fundo) Fonte: www.cearaexplorer.com.br

Em meados dessa mesma década a beleza da paisagem chamou a atenção de empresários do setor imobiliário que iniciaram um rápido processo de aquisição de terras. Em 1976, compraram a gleba do sítio Muritibicu ( $1^{\mathrm{a}}$ etapa do loteamento) e em 1979, criaram a Sociedade Porto das Dunas Ltda. A partir daí, no mesmo ano, adquiriram, seguidamente, as glebas dos sítios Mariúba (2 $2^{\mathrm{a}}$ e $3^{\mathrm{a}}$ etapas) e Graiá $\left(4^{\mathrm{a}}\right.$ 
etapa), promovendo a comercialização dos lotes no início dos anos 1980, após a construção da atual ponte que liga Fortaleza ao loteamento (Fig. 108) ${ }^{3}$. Segundo depoimentos colhidos em entrevista à SETUR, a ponte teve a iniciativa dos empresários que arcaram com os custos de sua construção, embora a rodovia seja estadual.

A imagem abaixo revela a diferença entre os loteamentos anteriores e o Porto das Dunas, tanto pelas suas grandes dimensões (aproximadamente seis Km2) como também pelo desenho urbano. Embora de qualidade questionável, porque ignora o código florestal de 1965 e não define uma centralidade para o bairro, o plano urbanístico foi elaborado por uma arquiteta que mais tarde tornou-se a Secretária de turismo do Estado, responsável pela coordenação da nova Política de Turismo do Ceará. Sobre os agentes envolvidos, verificamos haver proximidade de vínculo familiar entre os setores imobiliário, turístico e político que davam maior estabilidade ao empreendimento aproximando-os dos princípios de modernidade do novo governo do Estado.

\section{Área de Expansão Aquaville $4^{\mathrm{a}}$ Etapa $3^{\mathrm{a}}$ Etapa $2^{\mathrm{a}}$ Etapa $1^{\mathrm{a}}$ Etapa}

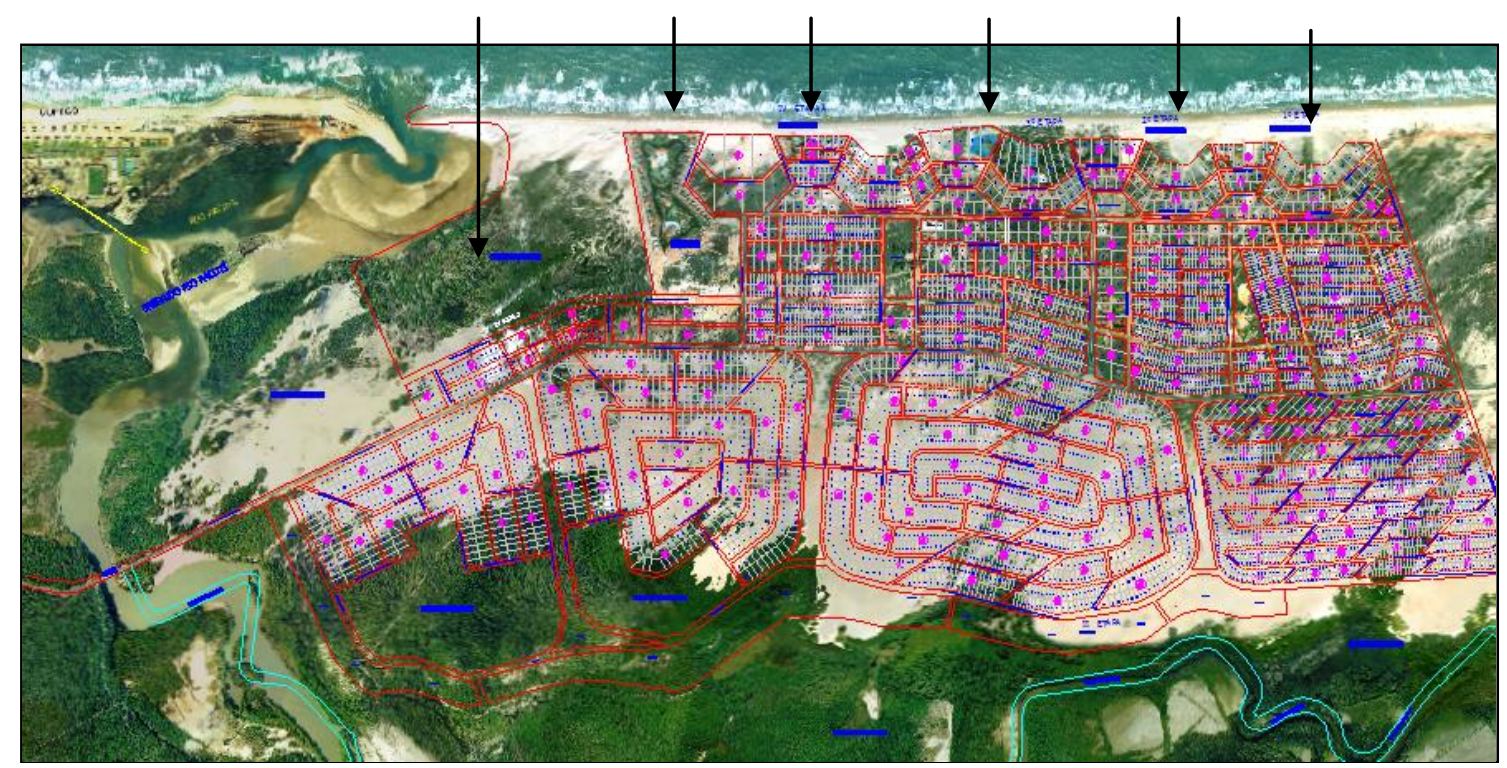

Fig. 3.35 Loteamento Porto das Dunas com as etapas de implantação, sob imagem de 1999 (PDDU Aquiraz - 2005). No ano da foto só existia dois grandes empreendimentos: O Beach Park e o Aquaville Fonte: Prefeitura Municipal de Aquiraz

A foto aérea, sob o traçado do loteamento de 1979, revela uma contradição que só se manifestará como problema crítico em meados dos anos 1990, devido à emergência da questão ambiental, pós Rio-92. Veja como a malha urbana penetra sobre as dunas e os limites da APA (no entorno do rio) criada quinze anos depois da aprovação do

\footnotetext{
${ }^{3}$ Dados colhidos nas transcrições das matrículas de registros de imóveis no Cartório do $2^{\circ}$. Ofício de Aquiraz.
} 
loteamento. A diferença de tempo e de mentalidade gerou um problema que persiste até hoje: um impasse em torno da questão ambiental. Os princípios de sustentabilidade, tornados "hegemônicos" após a conferência do Rio repercutiram no Estado com a elaboração do Plano de Desenvolvimento Sustentável do Governo do Ceará (19951998). No caso específico do Porto das Dunas materializou-se concretamente, com a promulgação do Decreto estadual No 25.778 que criou a APA do rio Pacoti, em 15 de Fevereiro de 2000.

Após a criação da APA, houve um primeiro esforço na adaptação do PDDU de Aquiraz às questões ambientais. Esses estudos foram iniciados ainda em 1999, mas tiveram sua aprovação somente em 2005, devido às grandes pressões oriundas principalmente do setor imobiliário.

Em 2011 foi aprovada uma nova revisão do PDDU que atenua, em parte, essas pressões, ressaltando os limites territoriais da APA, no mapa da Lei de Uso e Ocupação do Solo. Essa inclusão atribui uma maior importância ao caráter preservacionista, mas não assegura a sua plena efetivação devido à ambiguidade das novas Leis ambientais.

Dois temas revelam, nessa fase, o comportamento dos agentes imobiliários, descrevendo os caminhos jurídicos e o "modus operandi" desse setor, no caso do Porto das Dunas: a questão ambiental e o conflito em torno da propriedade da terra.

Sobre a propriedade da terra, verificamos na Fig. 3.35 (acima) um vazio denominado "área de expansão" que só ficou preservado, naquele momento, por encontrar-se em litígio judicial em torno da comprovação de sua propriedade. Nele, uma das partes alega o direito de posse e a outra (o responsável pelo loteamento), o direito de domínio: por isso não fez parte do loteamento no momento da sua aprovação.

Entretanto, a área foi submetida a estudos de arquitetura para um novo complexo hoteleiro e imobiliário, apresentado à SEMACE- Secretaria de Meio Ambiente do Estado do Ceará, por volta no ano 2000 e ainda continua em análise. Em consulta a essa Secretaria, constatamos que nem as instruções normativas que detalham a regulamentação da APA do rio Pacoti e nem o seu Comitê Gestor foram efetivamente criados. O processo continua em fase de implantação, até hoje, como na maioria dos casos de APA, no litoral do Estado.

Abaixo, um detalhe do Mapa de Macrozonas de Ocupação, elaborado na fase inicial do Plano Estratégico do PDDU, em 2000, onde podemos verificar a importância dada à poligonal da APA. Nela, percebemos que parte da "área de expansão", em questão, se 
encontra dentro da Zona de Uso Sustentável, avançando também na Zona de Proteção Integral, nas margens do rio.

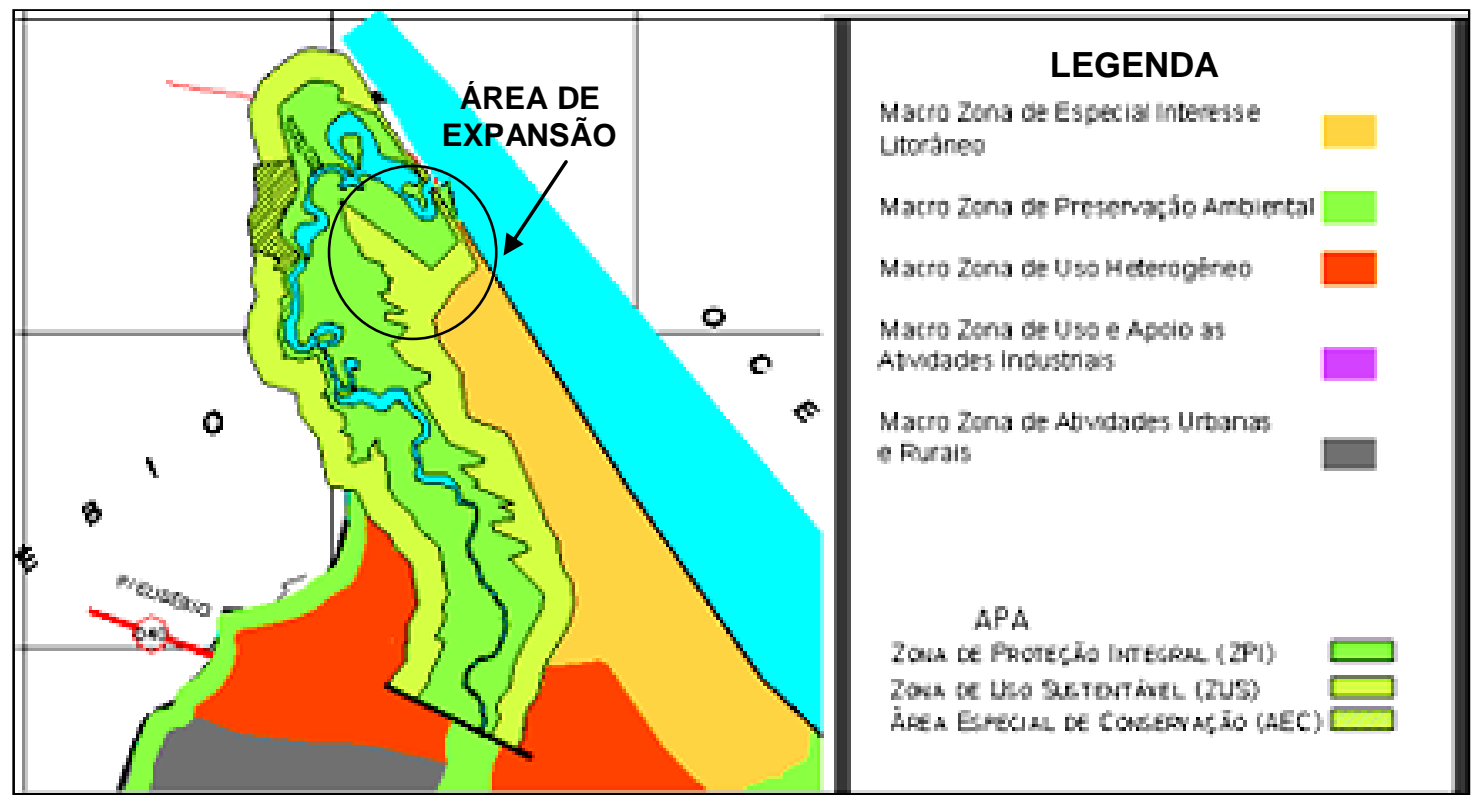

Fig. 3.36 - Detalhe da APA no Mapa de Macrozonas de Ocupação na primeira versão do PDDU de Aquiraz em 2000. Fonte PDDU - 2003 (antes da aprovação)

Confrontando o Decreto estadual com os estudos do PDDU concluímos que a Zona de Proteção Integral (em verde escuro na fig. 110) caracteriza-se como área de preservação permanente, sujeita a proibição de qualquer construção. Esse argumento se baseia no fato de ser uma faixa non aedificandi, como descrito na Lei Federal $n^{\circ} 4771-65$ que trata do Código Florestal, vigente desde 1965.

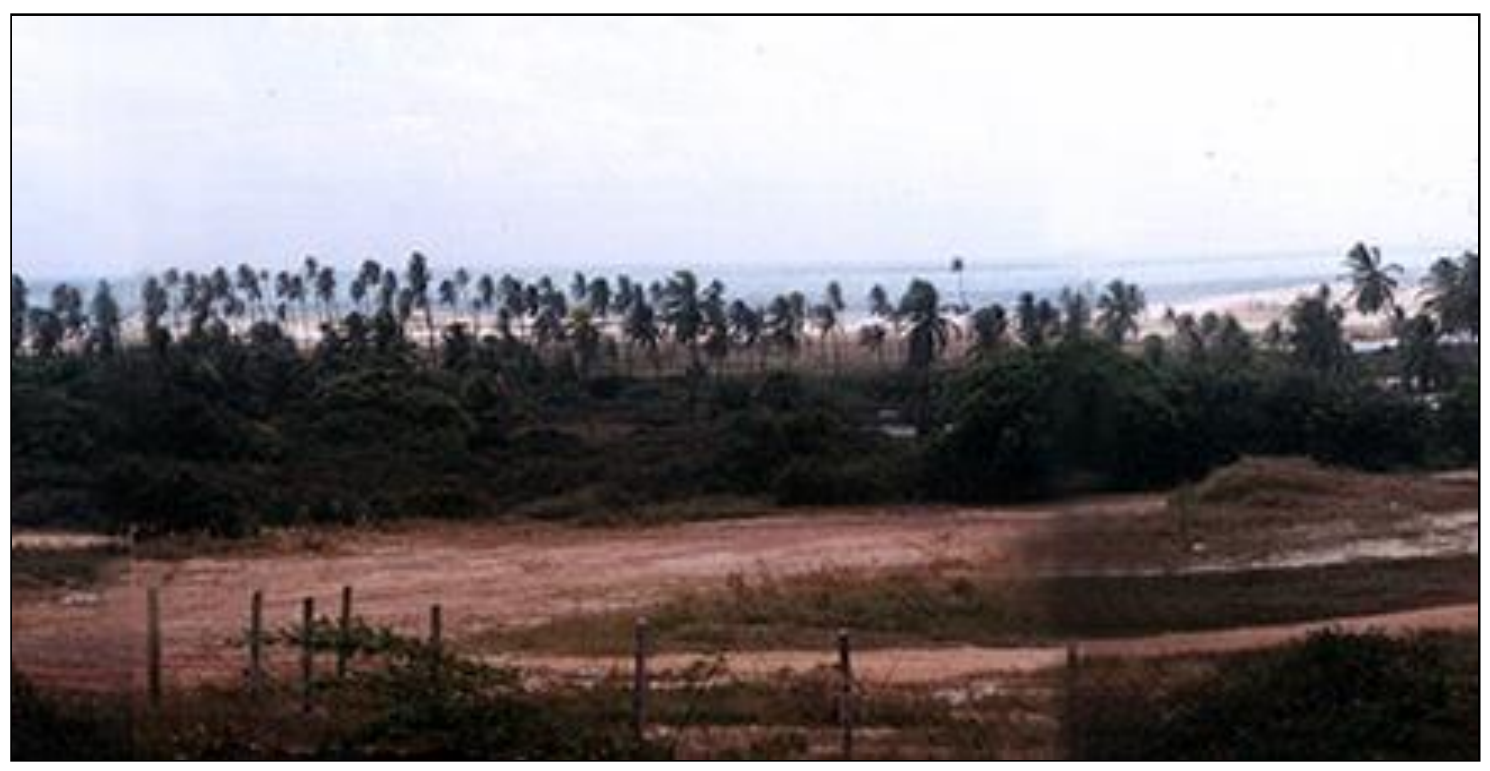

Fig. 3.37 Paisagem natural "protegida" pela APA e ameaçada, caso o projeto de expansão do loteamento seia aprovado pela SEMACE. Fonte: Foto do autor-2004. 
Abaixo, o mesmo trecho analisado pelo Plano Diretor depois da aprovação em 2005. Note que a malha do loteamento de 1979 ignora as restrições ambientais da APA e do Código Florestal. Consultando o responsável pelo PDDU, ouvimos a argumentação de que o loteamento era anterior à criação da APA e por isso foi mantido na íntegra. Entretanto ressalvou que qualquer construção terá que ser submetida à aprovação pela SEMACE, o que resguardaria a obrigação do cumprimento das leis ambientais. Mesmo assim, percebemos que além da manutenção do loteamento na íntegra, foi elaborada uma Lei de uso e ocupação do solo que simplesmente ignorou as restrições ambientais, como veremos na frente.

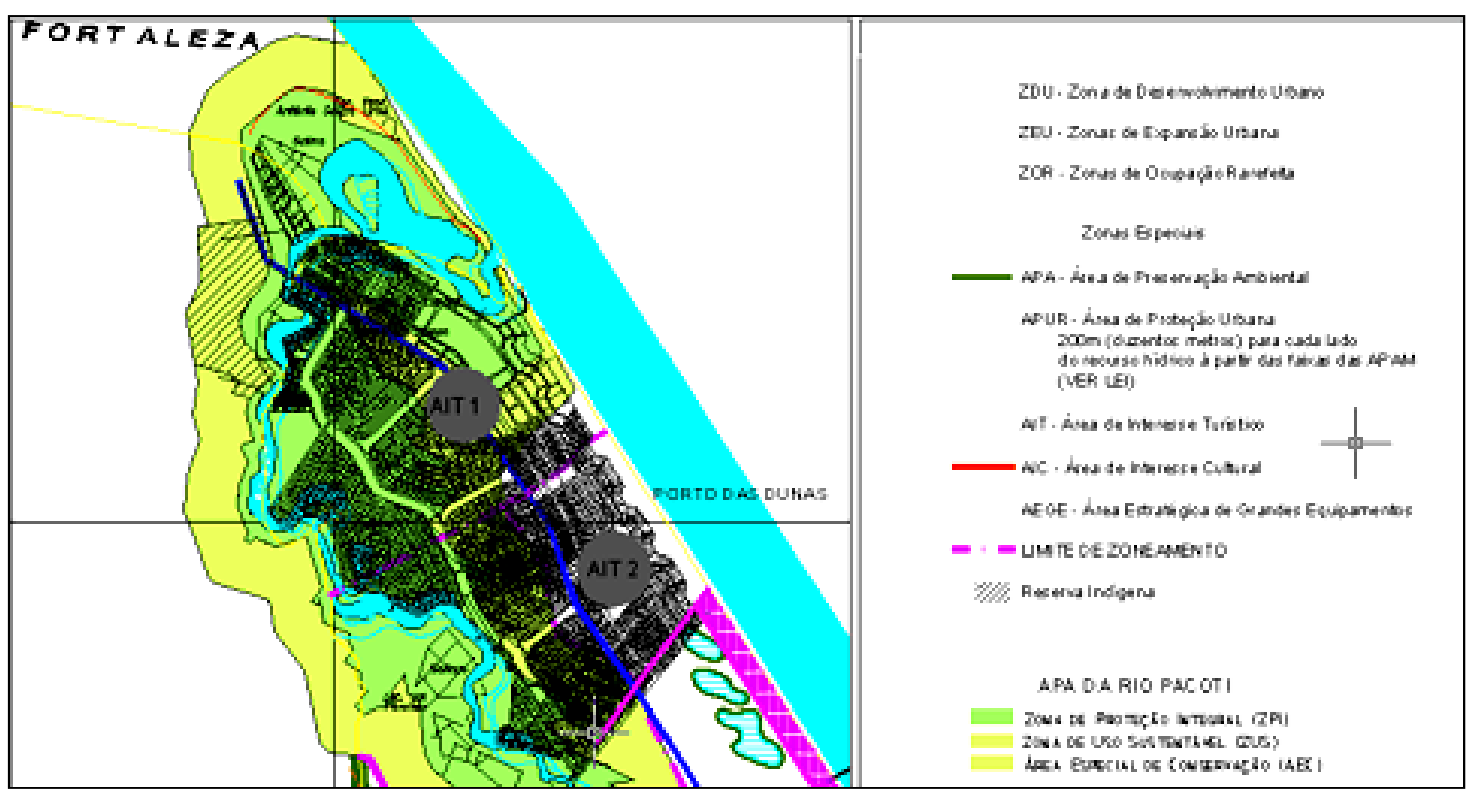

Fig. 3.38 Detalhe da malha do loteamento sobre a APA, no Mapa de Zoneamento. Fonte: PDDU - 2005.

\subsubsection{A interferência dos agentes imobiliários nos PDDU}

As interferências em leis de Uso e Ocupação do Solo nos PDDU configura prática corrente, no contexto do setor imobiliário porque são eles os agentes diretamente atingidos por essas definições. O caso do Porto das Dunas é exemplar porque ficou evidente a pressão do setor imobiliário na versão de 2005, como podemos verificar.

A interferência começa ainda na primeira mudança entre a versão preliminar apresentada em 2000 (Fig. 3.36, acima) e a efetivamente aprovada em 2005 (Fig. 3.38, acima). A mancha escura do traçado urbano do loteamento invade totalmente as Zonas de Proteção Integral da APA, sem restrições. 
Isso fica mais claro quando analisamos a planta de Zoneamento das Áreas de Interesse Turístico 1 e 2, correspondente ao Porto das Dunas (Fig. 3.39, abaixo) que é parte integrante da Lei de Uso e Ocupação do Solo do PDDU de 2005. Veja como toda a área em rosa indica a possibilidade de construção de residências em praticamente toda a extensão do loteamento. Inclui as áreas internas à poligonal da APA que é marcada sem nenhum destaque, como se simplesmente não existisse: ou melhor, consta apenas em um traço irregular em preto, passando no meio do loteamento, mas não é dado nenhum destaque. A interpretação é clara: não há proibição explícita para a construção de residências dentro da poligonal da APA, o que denota a pressão dos interesses dos agentes imobiliários.

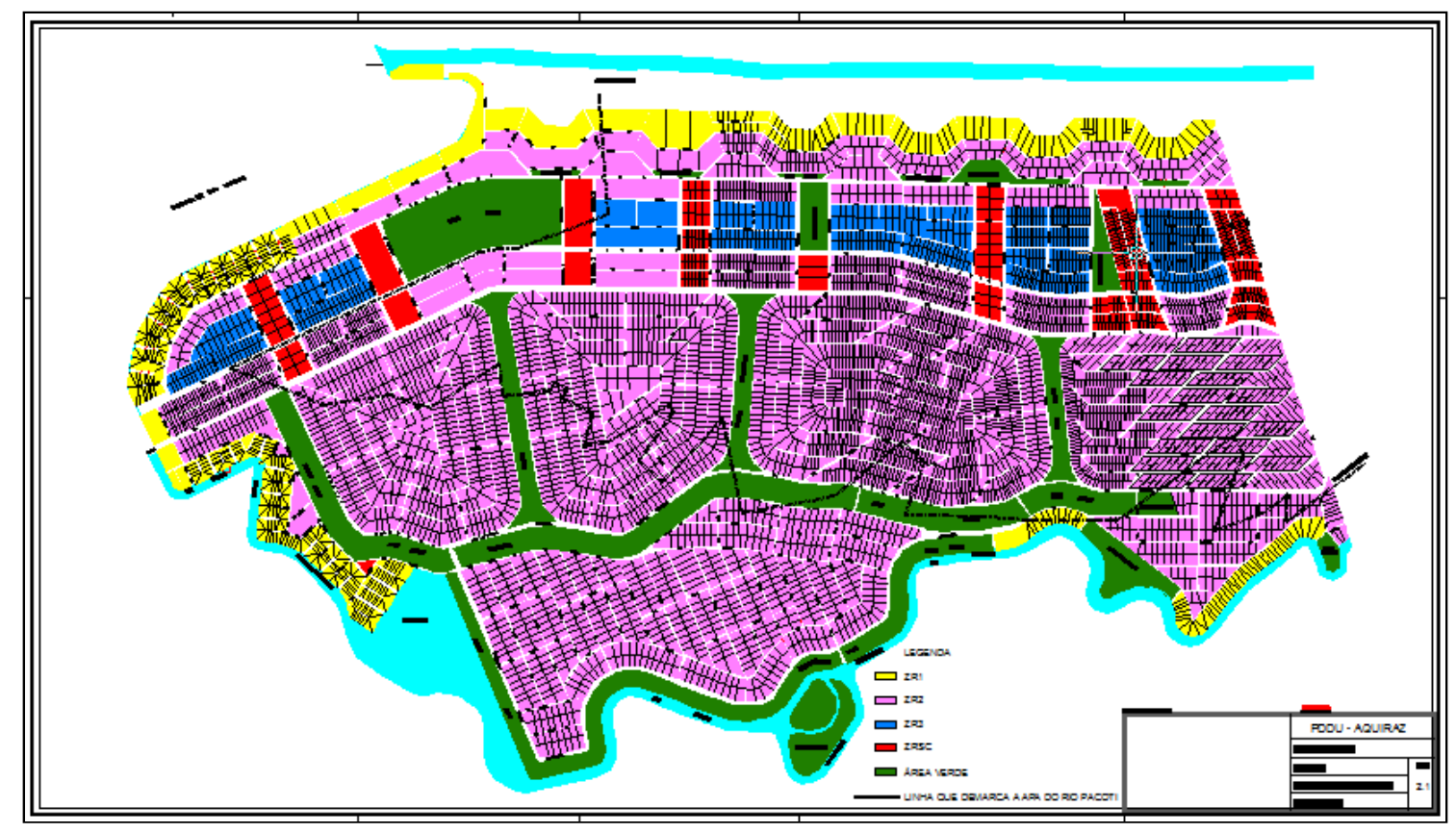

Fig. 3.39 - Planta de Zoneamento das Áreas de Interesse Turístico 1 e 2 , correspondente ao Porto das Dunas. Fonte: PDDU AQUIRAZ, 2005.

Agora, comparemos a fig. 3.39, acima, com a nova Planta de Zoneamento da Lei de Uso e Ocupação do Solo do PDDU de 2011, na Fig. 3.40, abaixo. A diferença é clara, apenas na aparência, porque sua interpretação é mais complexa e sutil. Veja como a APA figura, em destaque, como uma grande mancha colorida em um único tom de verde, assinalando os limites da sua poligonal, indicando que ali se deve observar o prescrito no Decreto estadual de 2001 que cria a APA do rio Pacoti.

No entanto, não se vê o detalhamento do micro zoneamento da APA, indicando o que é de uso sustentável e o que é de preservação permanente. Sabemos que tanto a poligonal 
como a regulação das APA e conselhos gestores só constam ainda no papel, não oferecendo segurança e precisão na sua interpretação. Entretanto é um avanço em relação ao PDDU anterior que simplesmente ignorou a questão da APA no Zoneamento.

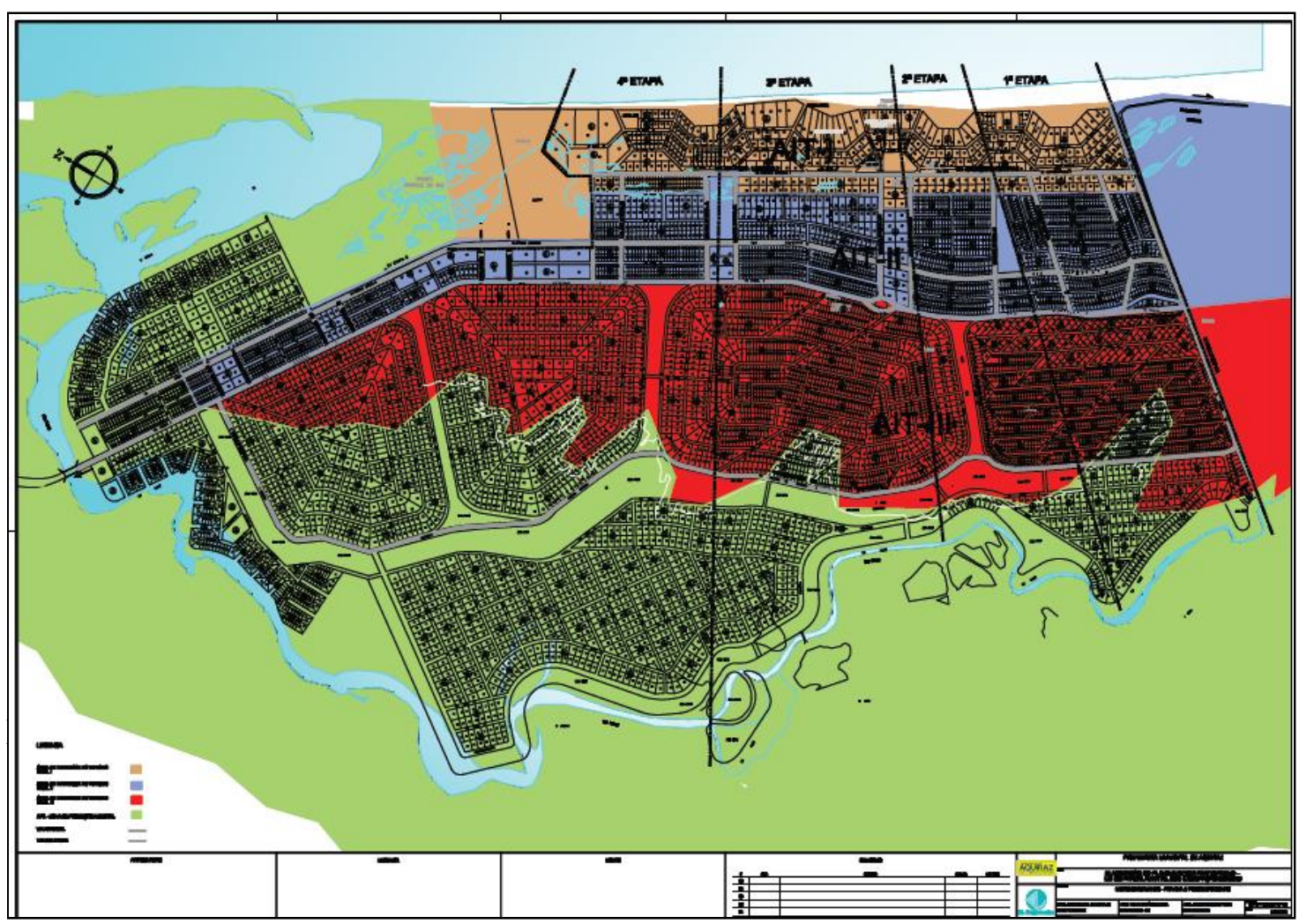

Fig. 3.40 - Zoneamento da Lei de Parcelamento, Uso e Ocupação do Solo. Fonte: PDDU Aquiraz, 2011

\subsubsection{A questão ambiental como condicionante dos novos produtos turísticos e imobiliários}

A questão ambiental se configura, nesse contexto, como uma das grandes novidades do século XXI que passou a alterar profundamente o processo produtivo do setor imobiliário e turístico. É exemplar no caso do Porto das Dunas e também no Batoque, no litoral de Aquiraz, porque marca um período de transição e mudança de paradigma de desenvolvimento. Nos anos 1980 ainda não se tinha claramente, na sociedade brasileira, uma discussão madura sobre a questão ambiental. Prova disso é o desenho urbano do loteamento Porto das Dunas que ignora completamente o Código Florestal de 1965.

No caso da evolução do Aquiraz Resort, do Batoque à nova localização na Praia da Marambaia, vizinho à Praia do Presídio, foi possível assistir uma alteração profunda, principalmente na proposta de localização. Nesta, verificamos o poder de interferência da comunidade e a fragilidade da questão fundiária que, como vimos, transformou um 
projeto turístico, apoiado pelo Governo do Estado, em uma reserva extrativista gerenciada pelo IBAMA. É uma evidência que mostra o alcance dos princípios de sustentabilidade introduzidos na sociedade e do fortalecimento dos movimentos sociais, principalmente o ambientalista articulado à pastoral da terra. É claro que esse é um contexto de conflitos permanentes com avanços e retrocessos, como veremos a seguir.

As mudanças provocadas pela nova ordem ambiental foram mais perceptíveis somente depois dos anos 1990 e 2000, quando a sociedade passou a compreender e a internalizar os conceitos de sustentabilidade. Seria incompleto abordar os novos padrões de ocupação litorânea sem considerar o desdobramento da questão ambiental em torno do tema. Por isso, embora seja polêmica, ambígua e complexa, propomos uma síntese de sua interpretação tendo em vista que ela passa a configurar um novo campo de ação onde surgem novos agentes que se relacionam direta e indiretamente com a produção imobiliária.

A questão legal sobre as restrições de atividades econômicas nos ambientes litorâneos em zonas de dunas foi tratada primeiramente pelo Código Florestal de 1965 (Lei 4.77165) que protegia a vegetação para fixar dunas e era interpretada como voltadas somente para as dunas fixas.

Para resolver essa ambiguidade, no entanto, foi criada a Resolução CONAMA $\mathrm{n}^{\circ}$ 303/2002 que alterou a abrangência das Áreas de Proteção Permanente passando a considerar também as dunas móveis, ao incluir um termo que reforça a proteção sobre a "vegetação de restinga que tem a função de fixar duna".

Em 2003, o governo do Estado do Ceará ficou diante de um novo desafio: viabilizar os projetos que ele acabara de captar junto a investidores estrangeiros, diante da restrição provocada pela nova Resolução de 2002. Essa restrição ameaçava inviabilizar praticamente todos os grandes projetos em fase de licenciamento quando já haviam sido aprovados, diversos projetos de infraestrutura de responsabilidade do Estado.

Assim, provocou uma reação que influenciou a criação da nova Resolução CONAMA 341/2003. Esta Resolução pretendia ser mais específica e explícita no tratamento da questão e dispôs sobre: "os critérios para caracterização de atividades ou empreendimentos turísticos sustentáveis como de interesse social para fins de ocupação de dunas originalmente desprovidas de vegetação, na Zona Costeira”. 
Além de ser específica, a maior característica desta Resolução foi inserir a possibilidade de se ocupar as dunas em caso de projetos considerados de interesse social, mesmo que para isso fosse necessário um procedimento administrativo detalhado, com a necessária aprovação do Conselho Estadual de Meio Ambiente.

Em entrevista ao consultor da ADIT/NE (Associação para o Desenvolvimento Turístico e Imobiliário do Nordeste) constatamos, em detalhes, o impasse criado entre o setor imobiliário-turístico e as duas Secretarias de Estado: do Turismo e do Meio Ambiente.

Segundo o consultor, a nova Resolução 341/2003 reconhecia a duna como APP, mas permitia a sua utilização em caso de interesse social. O efeito prático foi que:

Isso limitou o uso do campo de dunas a 10\%. O campo de dunas ficou dividido em duas frações: duna móvel (sem vegetação) e duna fixa (com vegetação) [...] ou seja, você só pode usar 10\% do somatório dos dois, limitado a $20 \%$ das dunas sem vegetação. $\mathrm{O}$ que der menor é o que vale. Isso foi aprovado no Conama e a partir daí, isso passou a nortear os novos empreendimentos. (Consultor ADIT-NE, em entrevista $-14 / 11 / 2011)$

Essa orientação permitiu que os projetos fossem viabilizados pelo Governo do Estado e foram emitidas várias licenças para a instalação de 28 empreendimentos no Ceará. Alguns começaram a sua construção como foi o caso do Aquiraz Riviera e o Catu Residence, em Aquiraz.

Para o consultor, o problema realmente se agravou diante de uma nova indefinição legal e normativa para o uso e ocupação da Zona Costeira que surgiu em 2006. Ele considera que o período entre 2000 e 2006 foi o tempo em que o Estado apresentou ações buscando criar parâmetros mais claros que permitissem a segurança jurídica tanto para o estado como para os investidores e a sociedade em geral. Em 2005, foi elaborado o ZEE - Zoneamento Econômico Ecológico da Zona Costeira, coordenado pelo LABOMAR $\mathrm{UFC}^{4}$ que dividiu o litoral cearense em três trechos:

um terço da faixa mais nobre, que fica próxima ao mar é constituído de área de preservação permanente onde você não pode usar de maneira nenhuma, como: desembocadura de rios, mangues, praias, falésias. São áreas de preservação permanente - APP; o outro terço é composto por planícies de deflação que é aquela faixa plana que fica entre o mar e a duna; e outro terço é formado por campo de

\footnotetext{
${ }^{4}$ Instituto de Ciências do Mar vinculado à Universidade Federal do Ceará
} 
dunas [...] você pode ver isso no quadro resumo dos estudos do ZEE que existe uma faixa de um a dois $\mathrm{Km}$ da linha da costa dividida em três trechos de 1/3, como descrito, depois é que vêm os tabuleiros litorâneos (Consultor ADIT/NE, em entrevista $-14 / 11 / 2011$ )

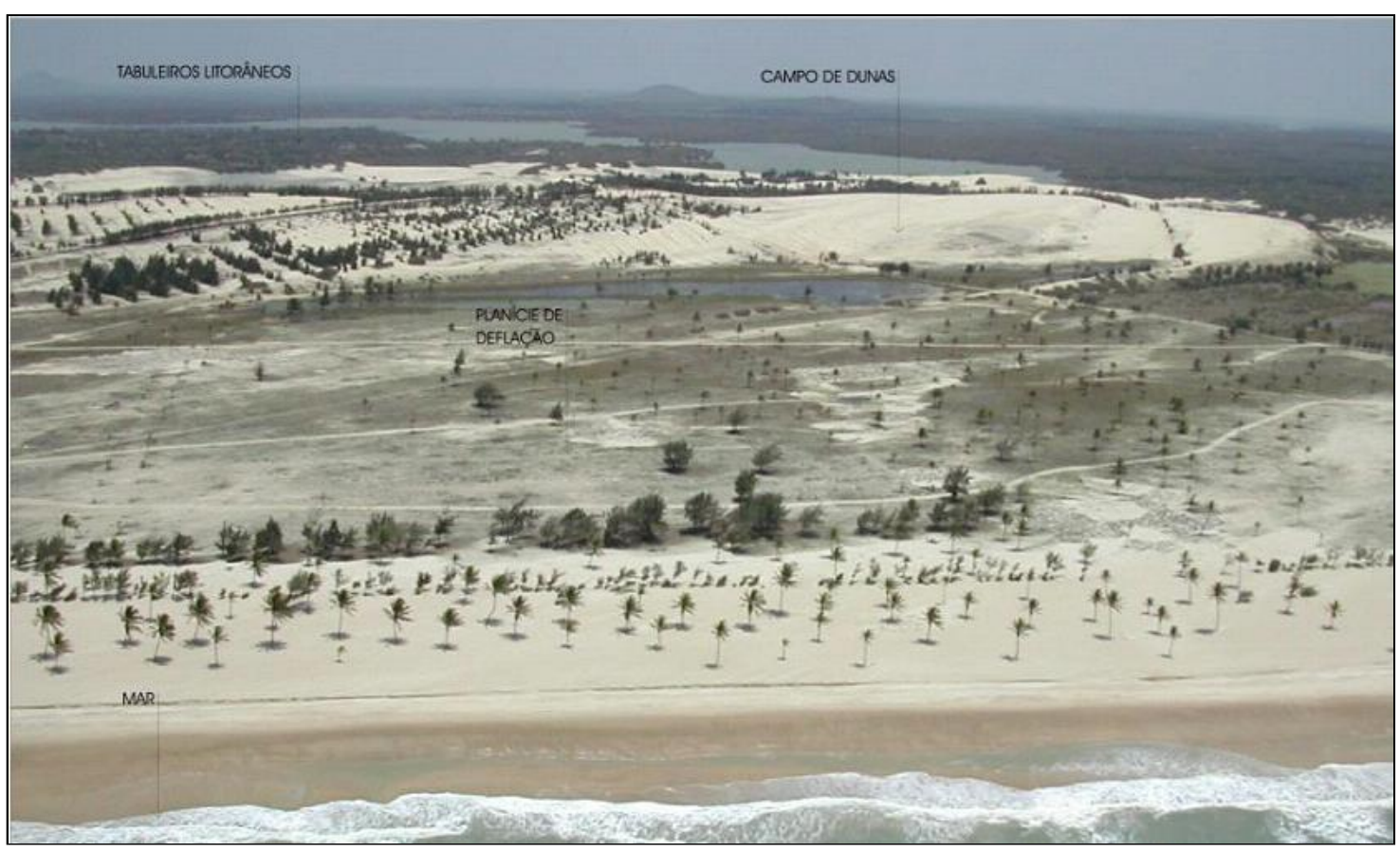

Fig. 3.41 - Exemplo esquemático do perfil litorâneo do Ceará - Fonte: ADIT/NE

Tudo parecia resolvido quando, em 2006, o Conama baixou mais uma norma: a 369/2006 que procurava regular as intervenções de baixo impacto ambiental em APP. Ela previa uma série de parâmetros de como fazer, por exemplo: uma picada no topo do morro; construir um atracadouro na margem de uma lagoa; fazer uma ponte ligando uma comunidade rural, a outra, etc.

No entanto, a Resolução 369/2006 não citou o caso das dunas. A partir daí, o Ministério Público passou a entender que a 369/2006 revogava a 341/2003 (que permitia o uso de 10\% do campo de dunas). Assim, o Ministério Público baixou um parecer, aplicado para todo o país, afirmando que todos os empreendimentos concebidos até 2006 e que estavam de alguma maneira utilizando dunas, cai na ilegalidade, ou seja, a 369/2006 retrocede para cancelar tudo que já estava licenciado anteriormente.

Todos os empreendimentos caem na ilegalidade. E depois, ele diz mais o seguinte: que a planície de deflação que era entendida como uma unidade geomorfológica distinta do campo de dunas é parte integrante do campo de dunas. Então, pelo 
entendimento do Ministério Público, consequentemente, todo o 1/3 do campo de dunas, o 1/3 da planície de deflação e o $1 / 3$ das APP são áreas de preservação permanente e, portanto, não são passíveis de uso. Significa, então que pelo parecer da câmara técnica, todos os empreendimentos localizados à face de um a dois km da Zona Costeira, estão na ilegalidade. Todos eles. E também retrocede, a todos os empreendimentos concebidos antes de 2006, quando a 369 entrou em vigor. (Consultor da ADIT-NE, em entrevista - 14/11/2011)

Diante disso começou uma verdadeira batalha judicial para manter os empreendimentos aprovados e já construídos, mesmo com o Ministério Público acionando a Justiça para a sua demolição. Nesse contexto, os proprietários buscaram defesa judicial e na maioria dos casos o Min. Publico tem perdido, isto é, a Justiça tem dado o direito de permanecer aqueles que já estão estabelecidos.

Essa passou a ser a regra geral. Recentemente o Hotel Vila Galé, no município de Caucaia (a Oeste de Fortaleza) ganhou na justiça o direito de permanecer no Cumbuco e se tornou o primeiro resort do Ceará atendendo a todos os requisitos internacionais, operando como hotel. No entanto, ainda aguarda a licença para o projeto imobiliário, a ele agregado. A situação do Aquiraz Riviera é semelhante: tem um hotel já em funcionamento e continua aguardando a decisão de continuar o empreendimento, sub judice, sem ter as suas licenças renovadas, criando uma situação de total indefinição para os investidores. Ainda sobre o depoimento do consultor da ADIT, ele levanta outro problema que considera uma ilegalidade, cometida nesse contexto de impedimentos e conflitos.

A SEMACE, no ano passado (em 2010), assinou um parecer jurídico dizendo que se alinha ao entendimento do Min. Público, de que a 369 revoga a 341, dando a esse parecer jurídico, caráter normativo. Isso fere a Constituição Estadual. Isso fere a Lei que criou o Conselho Estadual do Meio Ambiente que diz que só quem pode emitir instruções de caráter normativo é o Conselho Estadual do Meio Ambiente. A SEMACE não pode emitir parecer de caráter normativo. Aí o imbróglio ficou mais complexo e aí parou. Hoje o que é que nós temos: qualquer empreendimento que está em implantação, está sub judice; ou está esperando uma ação de demolição ou o resultado, aguardando que o Min. Público Federal ou o IBAMA entrem com uma ação mandando parar e demolir o que está feito (Consultor da ADIT-NE, em entrevista - 14/11/2011). 
TABELA 3.4 - EMPREENDIMENTOS TURÍSTICOS EM IMPLANTAÇÃO NO CEARÁ - 2009

\begin{tabular}{|c|c|c|c|c|c|c|}
\hline № & INVESTIDORES & PAÍs & EMPREENDIMENTO & MUNICÍPIO & UH & POSIÇÃO \\
\hline & LITORAL LESTE & & & & & \\
\hline 1 & COLMÉIA & BRASIL & Golf Ville & Aquiraz & $*$ & B \\
\hline 2 & MOTA MACHADO & BRASIL & Oregon & Aquiraz & * & B \\
\hline 3 & DIVERSOS & BR-PORTUG & Aquiraz Riviera (1) & Aquiraz & 800 & A \\
\hline 4 & ARBORETO & BRASIL & Catu Residence - Yatch Spa & Aquiraz & $*$ & A \\
\hline 5 & ETUR & BRASIL & Barra do Aquiraz (2) & Aquiraz & $*$ & D \\
\hline 6 & HOTELS ACQUA PURA & PORTUGAL & Balbino Beach Resort (2) & Cascavel & 87 & A \\
\hline 7 & MÃE DOS RIOS & PORTUGAL & Juriti Beach Resort (2) & Cascavel & 1.000 & A \\
\hline 8 & ECIT & PORTUGAL & Duas Barras & Cascavel & 2.000 & E \\
\hline 9 & ÁGUAS BELAS HOTEL & BR-PORTUG & Águas Belas Golf & Cascavel & $*$ & $\mathbf{F}$ \\
\hline 10 & OÁSIS & PORTUGAL & Areias Coloridas & Beberibe & $*$ & $\mathbf{F}$ \\
\hline 11 & OÁSIS & PORTUGAL & Praia do Uruaú - Comp. Tur. & Beberibe & $*$ & B \\
\hline 12 & SUN \& SEA & PORTUGAL & Resort Spa Nascentes & Beberibe & $*$ & B \\
\hline 13 & PESTANA & PORTUGAL & Resort Pestana Hotels & Beberibe & 297 & B \\
\hline 14 & URUAÚ & BRASIL & Comp. Turíst. Praia do Uruaú & Beberibe & $*$ & B \\
\hline 14 & CARRIS & ESPANHA & Carris Praia dos Anjos & Beberibe & 5.123 & $\mathbf{F}$ \\
\hline 16 & CONFIDE & ESPANHA & Fazenda Praia Canoé & Fortim & 450 & A \\
\hline 17 & BEACH FRONT & BRASIL & Canoa Quebrada & Aracati & $*$ & $\mathbf{F}$ \\
\hline \multirow[t]{2}{*}{18} & * & BRASIL & Tremembé Beach & Icapuí & * & $\mathbf{F}$ \\
\hline & LITORAL OESTE & & & & & \\
\hline 19 & BRASIL REAL & BRASIL & Brasil Real Cumbuco Resort & Caucaia & 1.500 & $\mathbf{F}$ \\
\hline 20 & VILA GALÉ & PORTUGAL & Cumbuco Golf Resort & Caucaia & 1.500 & B \\
\hline 21 & INGECONSER & ESPANHA & Cumbuco Beach Resort & Caucaia & 960 & B \\
\hline 22 & JME & BR-ESPANHA & Dunas da Taíba & S. Gonçalo & 600 & B \\
\hline 23 & AFIRMA & ESPANHA & Nova Atlântida & Itapipoca & $*$ & B \\
\hline 24 & LOC CEARÁ INVEST & NORUEGA & Piriquara Beach & Paracuru & $*$ & C \\
\hline 25 & INVERAVANT & ESPANHA & Dunas do Paracuru & Paracuru & 10.000 & B \\
\hline 26 & FORTAL LISBOA & PORTUGAL & Lagoinha Suites Resorts & Paraipaba & $*$ & B \\
\hline 27 & PRASA & ESPANHA & Costa das Aldeias (2) & Paraipaba & $*$ & $\mathbf{E}$ \\
\hline 28 & RIAS BAIXAS & PORT-ESP & Rias Baixa & Itapipoca & * & A \\
\hline
\end{tabular}

\begin{tabular}{|c|c|}
\hline \multicolumn{2}{|r|}{ POSIÇÃO DAS LICENÇAS AMBIENTAIS } \\
\hline A & Em obra - Em renovação \\
\hline B & De Instalação - Em renovação \\
\hline C & d. Instal. \\
\hline D & Licença Prévia - Em renovação \\
\hline E & Licença Prévia \\
\hline $\mathbf{F}$ & Em licenciamento \\
\hline
\end{tabular}

Fonte: Dados Consolidados por consultores da ADIT/NE, em ofício encaminhado ao Governo do Estado, sob o protocolo: SEPLAG(CE) - No 09081793-1 / GABGOV - 29-05/2009. A fonte original do documento foi baseada em informações colhidas: (1) no site do Aquiraz Riviera; (2) em dados obtidos na SEMACE e COEMA e os demais, diretamente com os investidores. Os marcados em (*) não foram identificados. (Organizado pelo autor) 
Esse assunto se tornou polêmico porque colocou o Governo do Estado diante de uma nova contradição: de um lado incentivava a atração de recursos privados de investidores internacionais e do outro, passou a negar a revalidação das licenças ambientais já autorizadas: algumas, em fase de construção. Esse problema atingiu 28 empreendimentos em todo o Estado, sendo cinco localizados em Aquiraz: veja a Tabela-3.4, acima.

$\mathrm{Na}$ tabela, vemos a presença do investidor estrangeiro, principalmente o espanhol e o português. Embora a crise europeia esteja em curso, os investidores estrangeiros continuam investindo no Ceará, apesar dos problemas ambientais. A mudança é que estes produtos não são mais voltados para o público estrangeiro, como foram no caso do Rio Grande do Norte, mas sim para o local.

O que se sabe é que esse é o quadro predominante no Ceará e que existe algo semelhante, mas em menores proporções nos Estados vizinhos, como no RG do Norte que já consolidou sua hotelaria na Via Costeira, antes dos anos 1990, criando precedentes jurídicos.

No caso de Aquiraz, verificamos pela entrevista à Secretaria de Meio Ambiente do Município, da existência de uma ação simultânea contra a SEMACE e o Estado que corre na Justiça Estadual, onde o responsável alega o mesmo princípio de utilidade pública, atribuída à atividade turística. Segundo o coordenador de projetos da Secretaria Municipal, a ação foi promovida pela imobiliária responsável pelo Loteamento Porto das Dunas onde o objeto da ação é o pedido de anulação dos efeitos restritivos da APA sobre o loteamento, recuperando-se o pleno direito de construção nos lotes aprovados pela Prefeitura.

Em primeira instância, foi solicitada ao juiz a anulação dos efeitos da APA, alegando-se razões de "interesse público", provavelmente fundamentado na importância do desenvolvimento do turismo, embora seja um empreendimento privado e imobiliário. E foi concedido, temporariamente, através de sentença judicial. Como teria que ser aprovado no Tribunal de Justiça, em segunda instância, a ação foi julgada improcedente pelo desembargador do Estado.

Voltando à Vara judicial de origem, o mesmo juiz reafirma a sentença de ganho de causa para a imobiliária, onde a ação aguarda a nova manifestação do Tribunal de Justiça do Estado. Nessa quarta instância o Ministério Público deverá ser chamado a 
opinar. Enquanto isso a APA está sem validade, para o caso, embora o Código Florestal já tenha definido as restrições em Área de Proteção Permanente.

Essa polêmica se arrasta até hoje e tem origem, justamente nas mudanças provocadas pela legislação ambiental, ora para atender os interesses do setor imobiliário, ora para tentar reverter o quadro, motivado pela pressão da sociedade civil organizada.

\subsubsection{O incremento da atividade imobiliária e turística no Porto das dunas}

Apesar dos problemas em torno das questões ambientais, o Porto das Dunas vem apresentando um crescimento relacionado, desde a sua origem, ao desenvolvimento do turismo no Estado. Entretanto, nos últimos seis anos experimentou um incremento na produção imobiliária associada ao lazer e ao turismo de segunda residência, influenciado por vários fatores que procuraremos compreender.
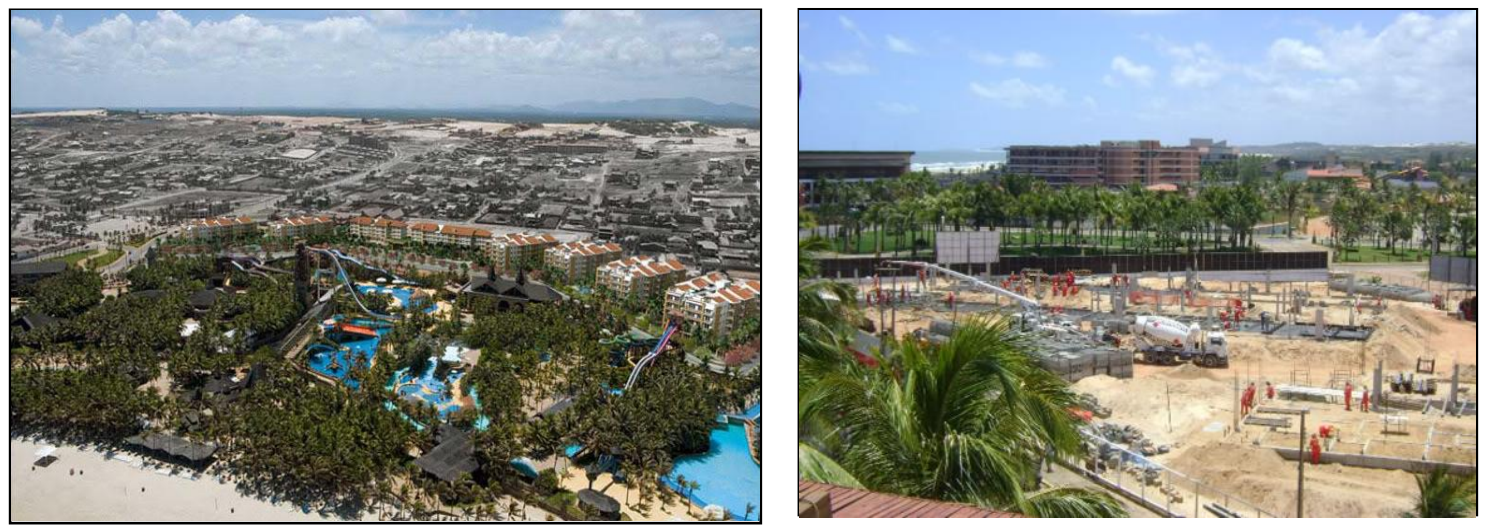

Fig. 3.42 Maquete eletrônica do Beach Park Well Ness Resort: condomínio vertical adensado (cinco pavimentos) com vários serviços turísticos embutidos, apresentados como diferencial de mercado. À direita, o empreendimento na fase de início de construção em 2010. Fonte: Skyscrapercity.com.br

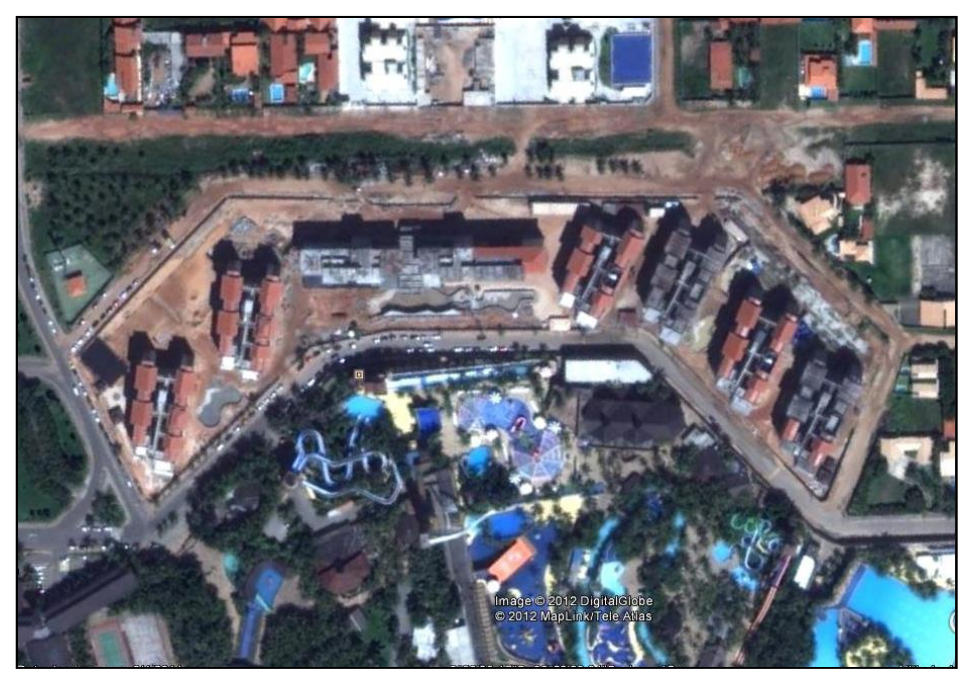

208
Fig. 3.43 - Foto aérea atual do empreendimento em fase de acabamento. Embora bastante adensado, o produto agrega serviços sofisticados: como administração de condomínio em pool, serviços de hotelaria payper-use, sport center, academia, programas de fidelidade $\mathrm{e}$ descontos em vários serviços credenciados, além do cartão de acesso ao parque por 10 anos: tudo para proporcionar um diferencial de mercado baseado em padrão turístico. Fonte: Google Earth2012 


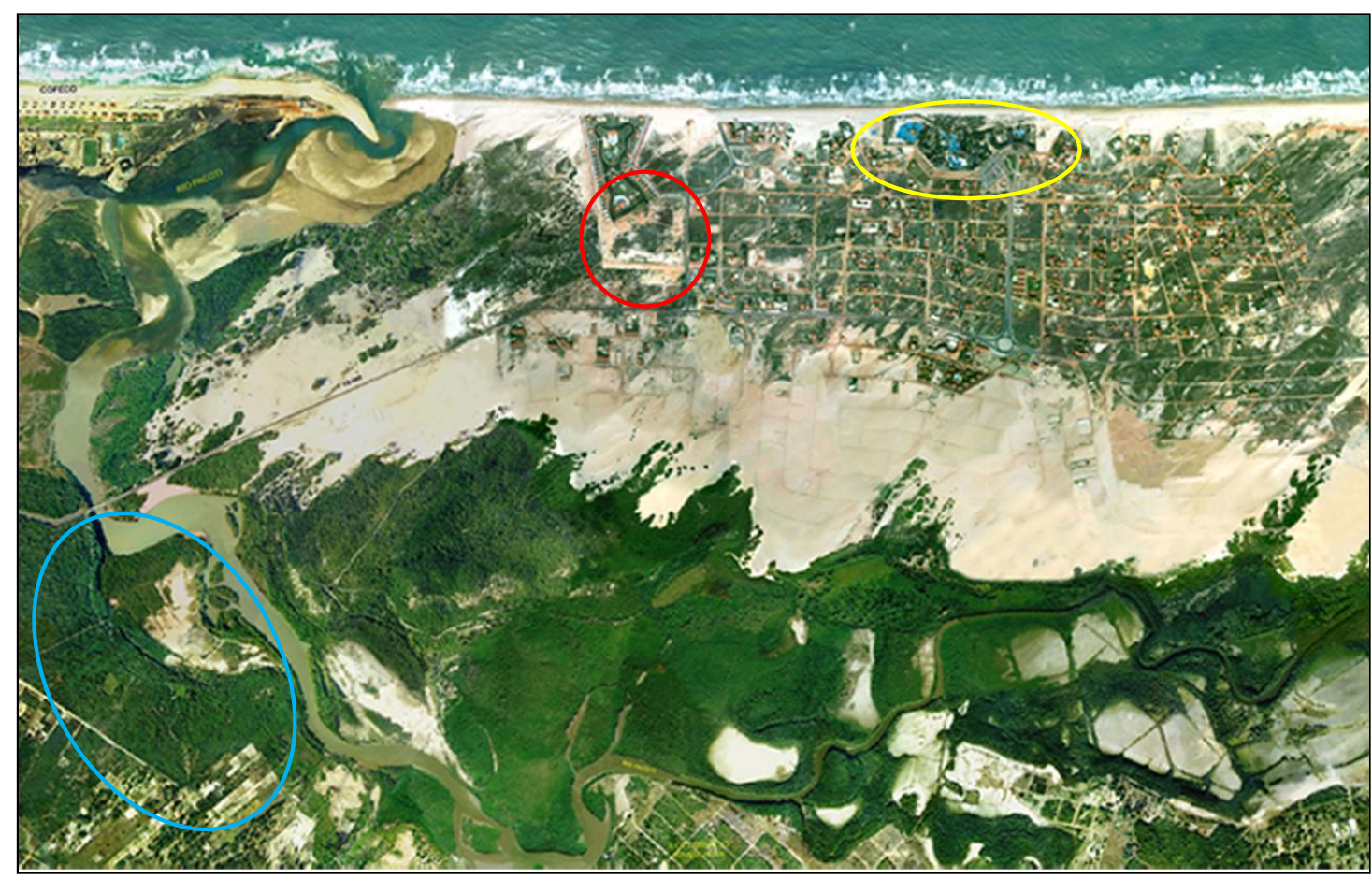

Fig. 3.44 Foto aérea da região da APA do rio Pacoti e do loteamento porto das dunas (1999). Vê-se o complexo turístico do Beach Park (amarelo) e o Aqua Ville (vermelho) o primeiro grande condomínio com características de hotel. Em azul a área do então futuro Alfa Ville, ainda preservada. Fonte: PDDU AQUIRAZ - 2005

O Beach Park nasceu em 1985 como um restaurante "de charme" na beira da praia, de propriedade da Sociedade Porto das Dunas Ltda. Em 1989 inaugurou seu parque aquático, alinhado à política de turismo do Governo do Estado. A partir daí tornou-se o equipamento âncora para os demais empreendimentos.

Em 1999 o loteamento era pouco adensado e ocupado majoritariamente por residências térreas de veraneio. A sua faixa litorânea ainda não tinha sido ocupada pelos condomínios de lazer, com exceção do Aqua Ville, o primeiro condomínio a utilizar elementos de hotelaria. Nasceu sob uma intensa campanha publicitária inovadora para época que já combinava elementos de condomínio a outros de hotelaria como timesharing, convidando os clientes selecionados a participarem de promoções, refeições gratuitas e brindes especiais para conhecer o produto em clima de encantamento.

No entanto, como era novidade para o mercado local teve certa dificuldade de absorção do produto, na sua fase inicial. Nessa foto o destaque em vermelho mostra a sua última etapa ainda não construída. Muitos pensaram que o empreendimento não seria concluído até o final. De certo modo esse padrão de condomínio foi um modelo de referência para todos os demais. 


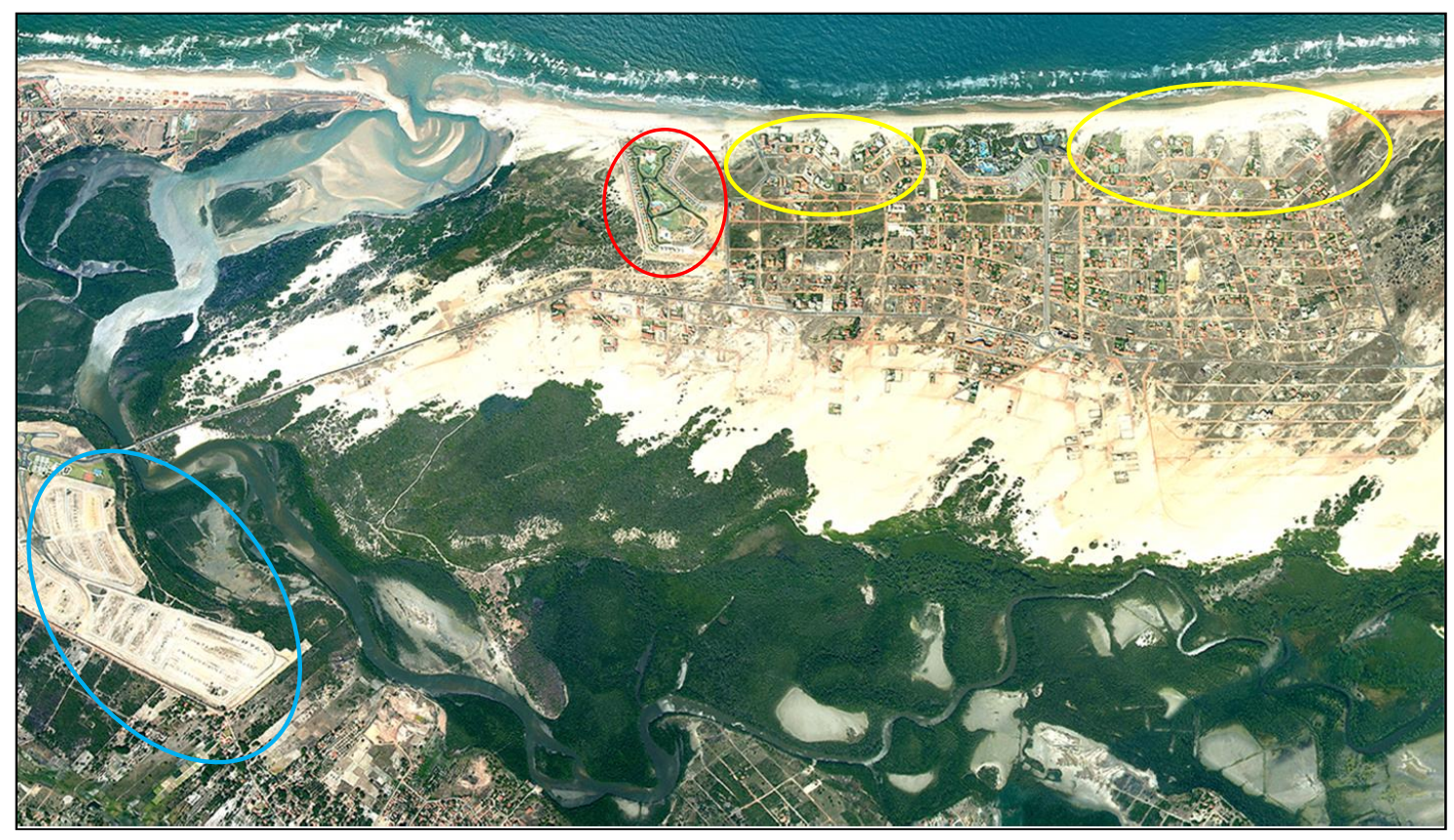

Fig. 3.45 Foto aérea da região da APA do rio Pacoti e do loteamento porto das dunas (2003). Fonte: Aerofoto Nordeste

Nessa foto de 2003 verificamos, em azul a implantação do Alpha Ville-Fortaleza com um trecho desmatado em área de preservação permanente; em vermelho o Aqua Ville com a ampliação retomada, mas ainda não finalizada; e em amarelo a faixa litorânea do loteamento ainda ocupada por casas pouco adensadas.

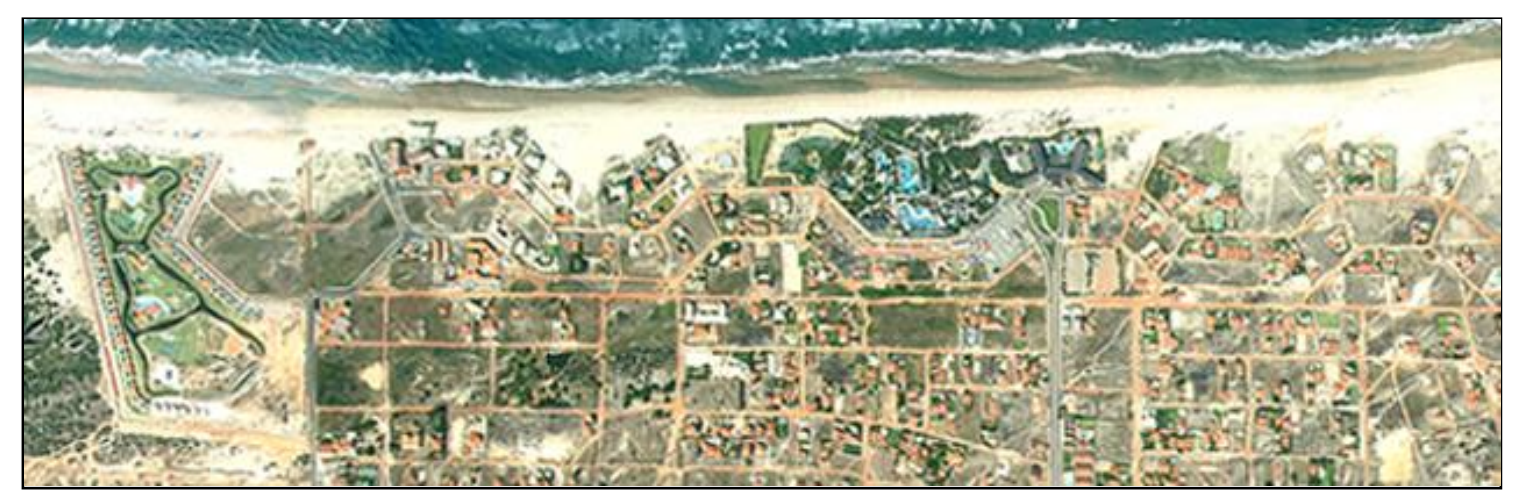

Fig. 3.46 Foto aérea da região da APA do rio Pacoti e do loteamento porto das dunas (2003). Detalhe da faixa litorânea ocupada por casas pouco adensadas. Fonte: Aerofoto Nordeste

Os condomínios de lazer para as famílias de faixa média de renda começam a aparecer ao longo de todo o loteamento, desde os anos 1990, mas no trecho litorâneo ainda não tinha havido uma ocupação mais evidente que se inicia por volta do ano 2007 coincidindo com o lançamento do Condomínio Portamaris. 
Segundo entrevista a um proprietário (arquiteto), este condomínio nasceu de uma reunião entre amigos médicos e foi o primeiro destinado ao público de padrão de renda média-alta e alta que considerava inviável manter uma casa de praia diante da falta de segurança criada pela várias ocorrências de assaltos registrados. O resultado foi tão positivo que se iniciou uma verdadeira corrida para a construção de novos condomínios de lazer de "alto padrão". Em seguida, veio o Vila do Porto e na sequência, novos condomínios que foram ocupando gradativamente a faixa litorânea do loteamento.

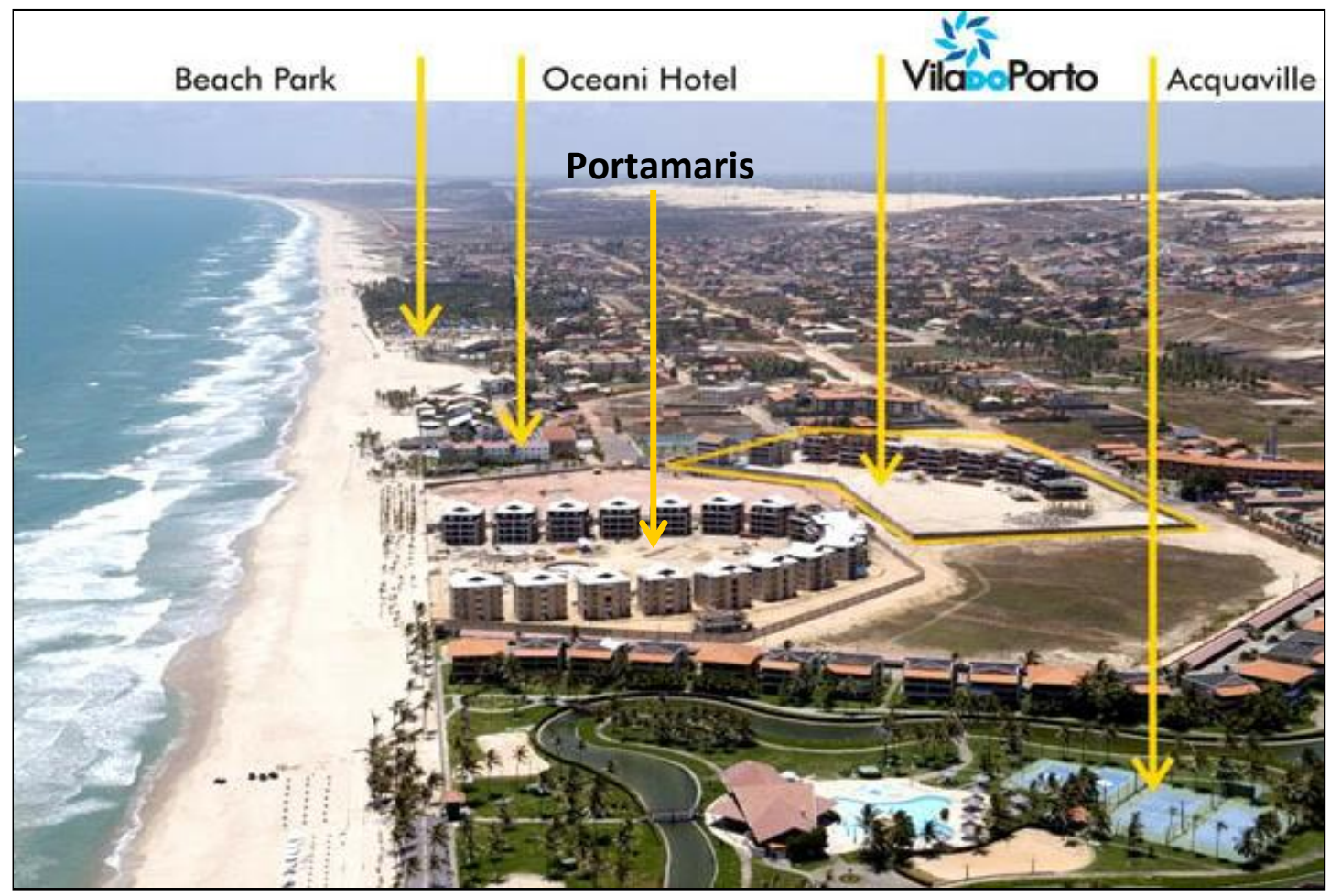

Fig. 3.47 No primeiro plano, o Aquaville e na sequência, o Portamaris e o Vila do Porto. Só o primeiro atua como cond-hotel. Os demais são condomínios residenciais puros, mas que devido ao alto custo de manutenção, alguns proprietários começam a alugar para temporada e datas festivas.

Ao fundo o Oceani Hotel que é vinculado ao grupo do Beach Park e no final o complexo turístico em torno do parque. Fonte: Skyscrapercity.com - Foto 2008

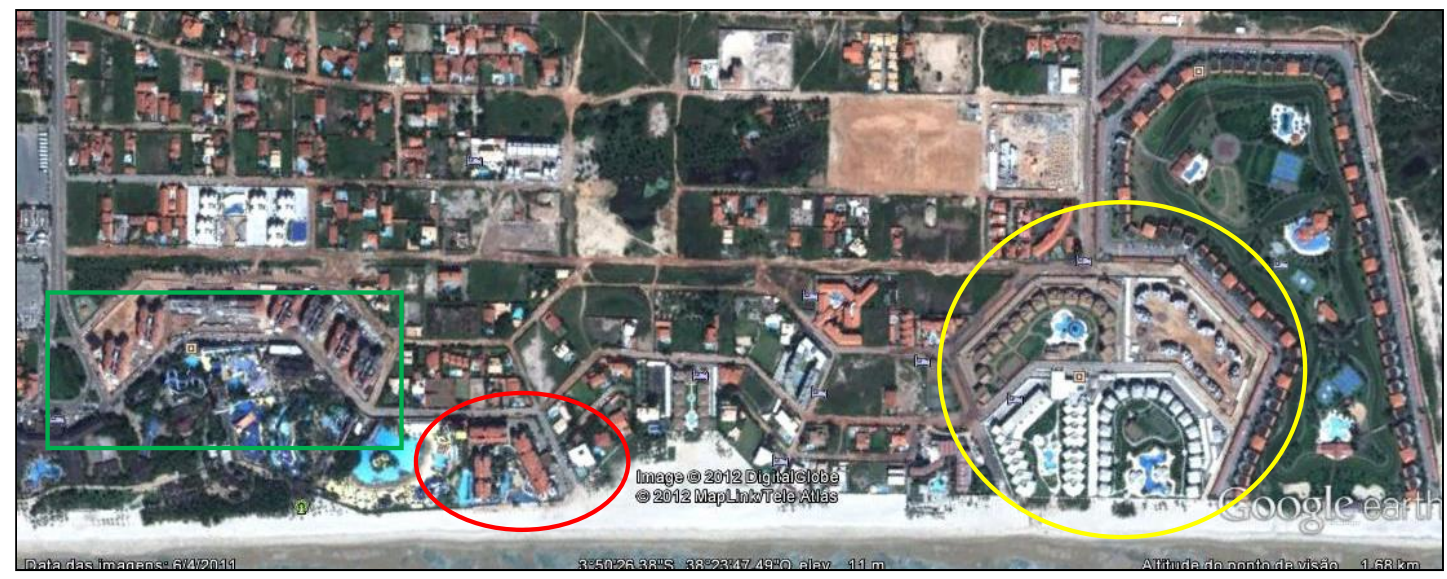

Fig. 3.48 - Detalhe da faixa litorânea num processo de verticalização e adensamento com condomínios de alto padrão. O hexágono do Portamaris ficou todo construído num período de 4 anos (amarelo). Na frente do parque (verde) o padrão cond-hotel e em vermelho um Resort integrado ao complexo turístico. Fonte: Google Earth - 2012 


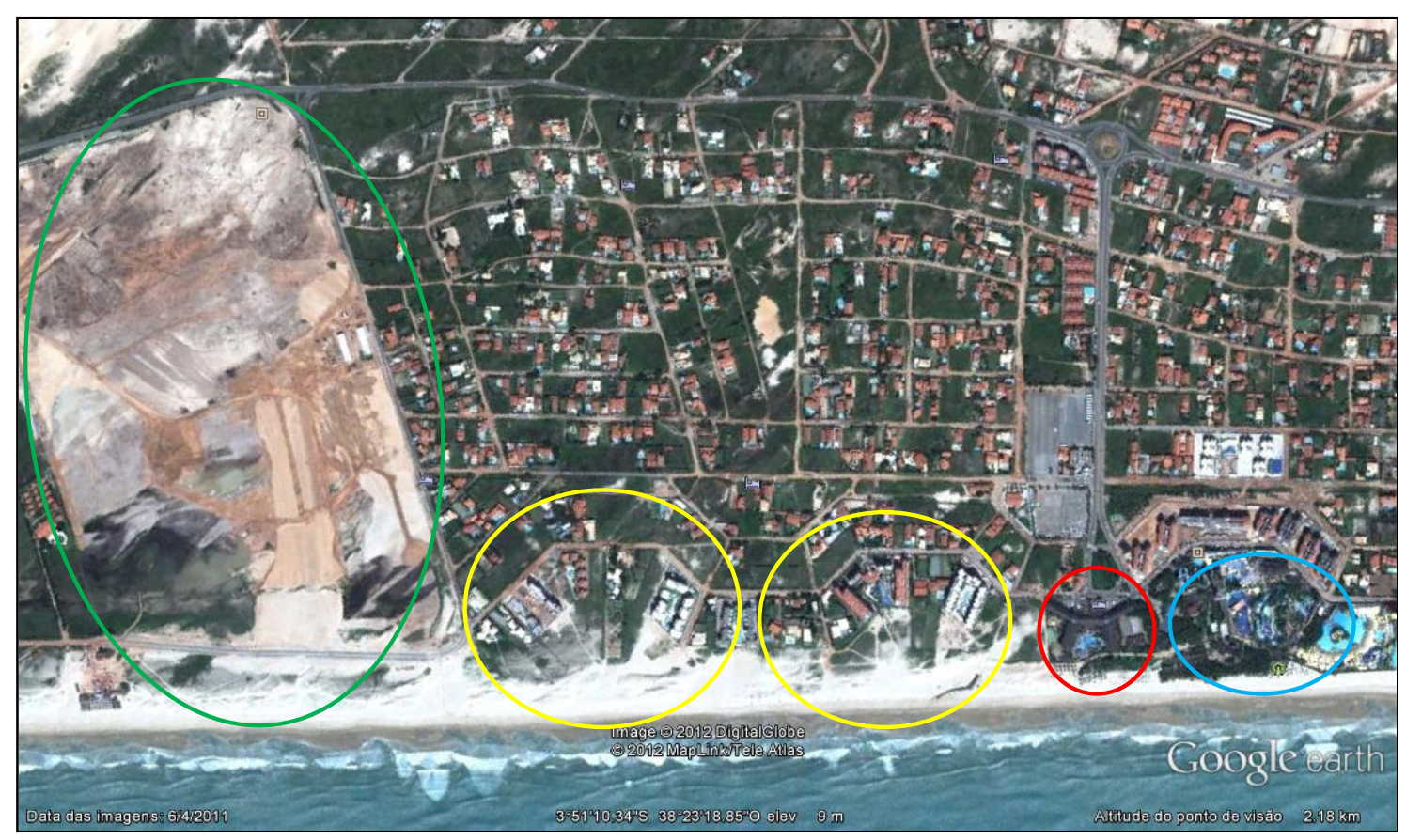

Fig. 3.49 Detalhe da faixa litorânea do loteamento, a esquerda do parque (em azul). Em vermelho o hotel Beach Park Suites Resort. Fonte Google Earth-2012

Trecho, a esquerda do parque, também em rápido processo de adensamento. No momento, apresenta seis empreendimentos em construção ou recém-construídos. Todos no padrão condomínios Resort Residence (em amarelo). Na extrema esquerda (em verde) um novo grande empreendimento em fase de construção: o Golf Ville, do mesmo grupo do Aquaville. Padrão é inspirado no modelo internacional de Golf Club, voltado para o público local. Abaixo, uma foto do trecho à esquerda do parque também em processo de verticalização e adensamento com condomínios padrão Resort Residence.

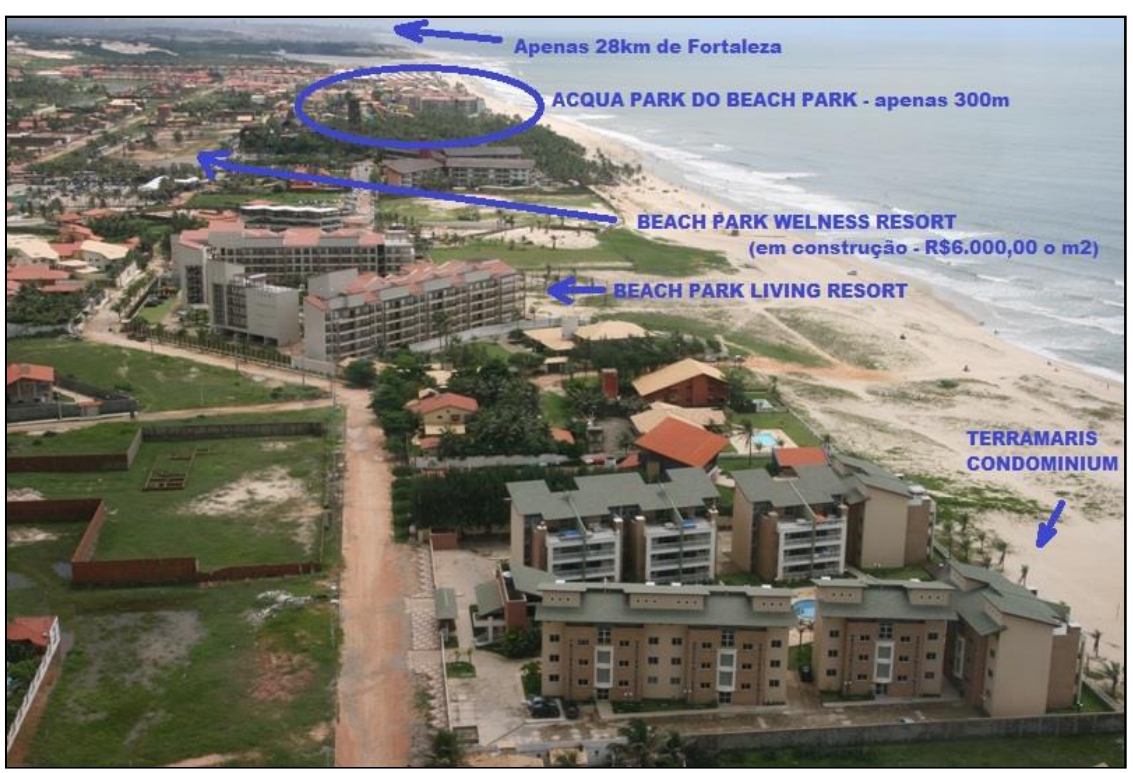

Fig. 3.50 Foto aérea do trecho litorâneo à esquerda do Beach Park. Fonte: :http://www.gardaimo veis.blogspot.com.br/ 
Abaixo, algumas fotos dos condomínios em construção, ou recém-construídos, para dar uma ideia da intensidade desse processo, intensificado depois de 2007, e na página seguinte o mapa resultante do levantamento de Uso e Ocupação atual do Porto das Dunas.

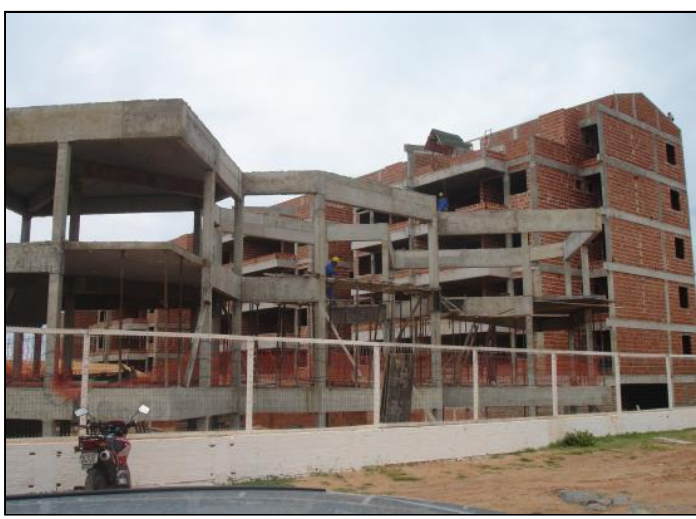

Fig. 3.51 - Cond. Costa Blanca. Fonte: Foto do autor - 2012

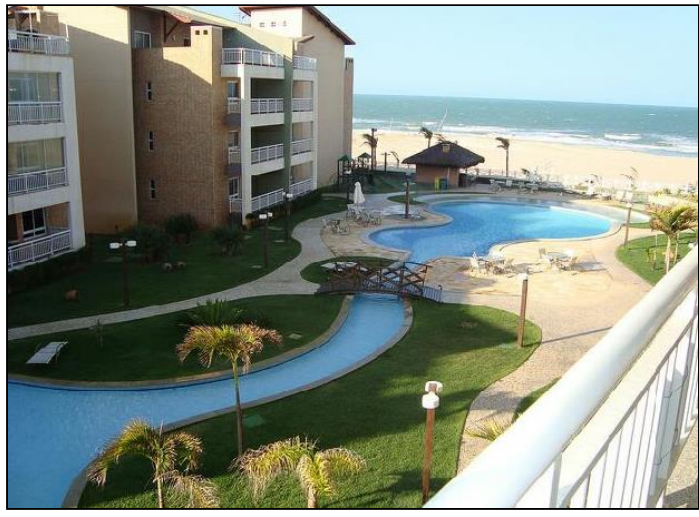

Fig. 3.53 - Terra Maris: Fonte: Skyscrapercity.com - 2011

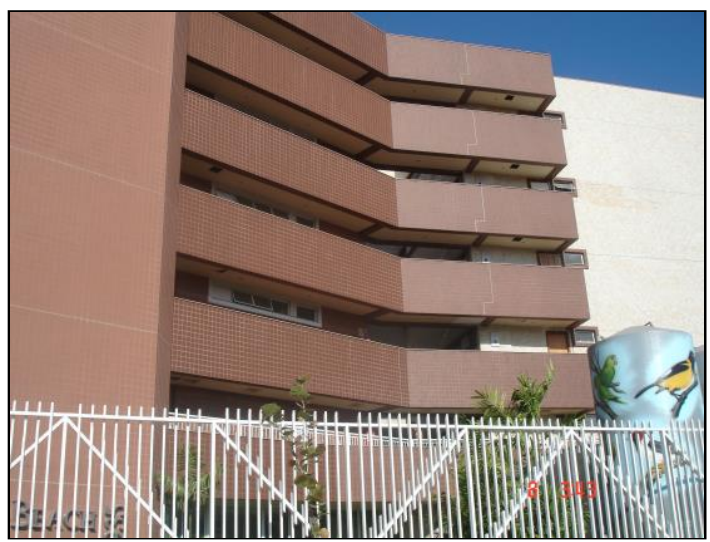

Fig. 3.55 - Scopa Beach Fonte:

Foto do autor - 2012

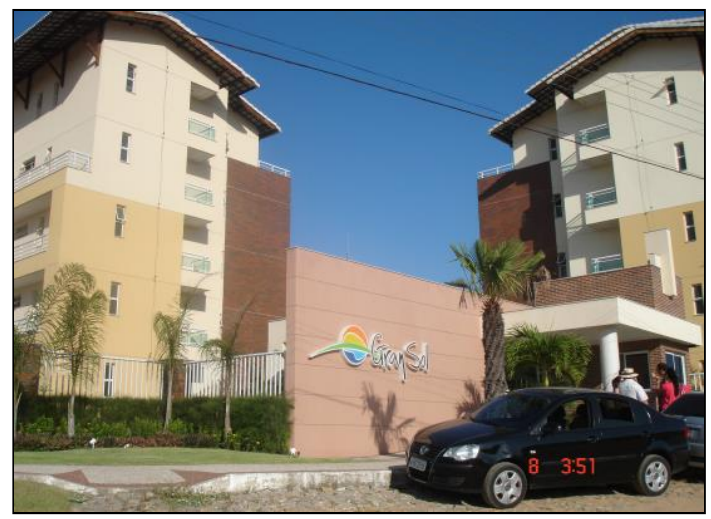

Fig. 3.52 - Cond. Gran Sol. Fonte: Foto do autor - 2012

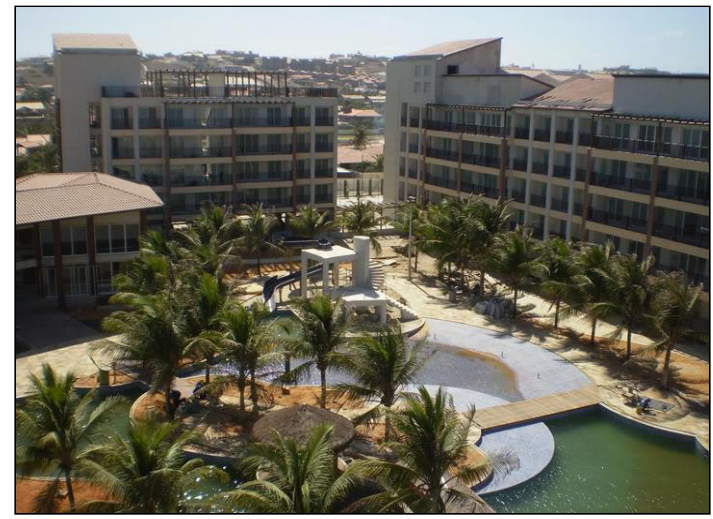

Fig. 3.54 - Beach Park Livings: Fonte: Skyscrapercity.com - 2011

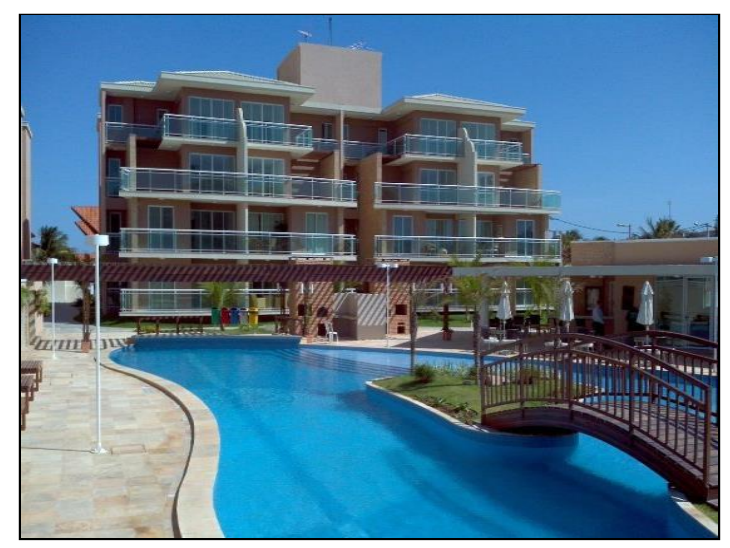

Fig. 3.56 - Palm Beach: Fonte: Skyscrapercity.com - 2011 


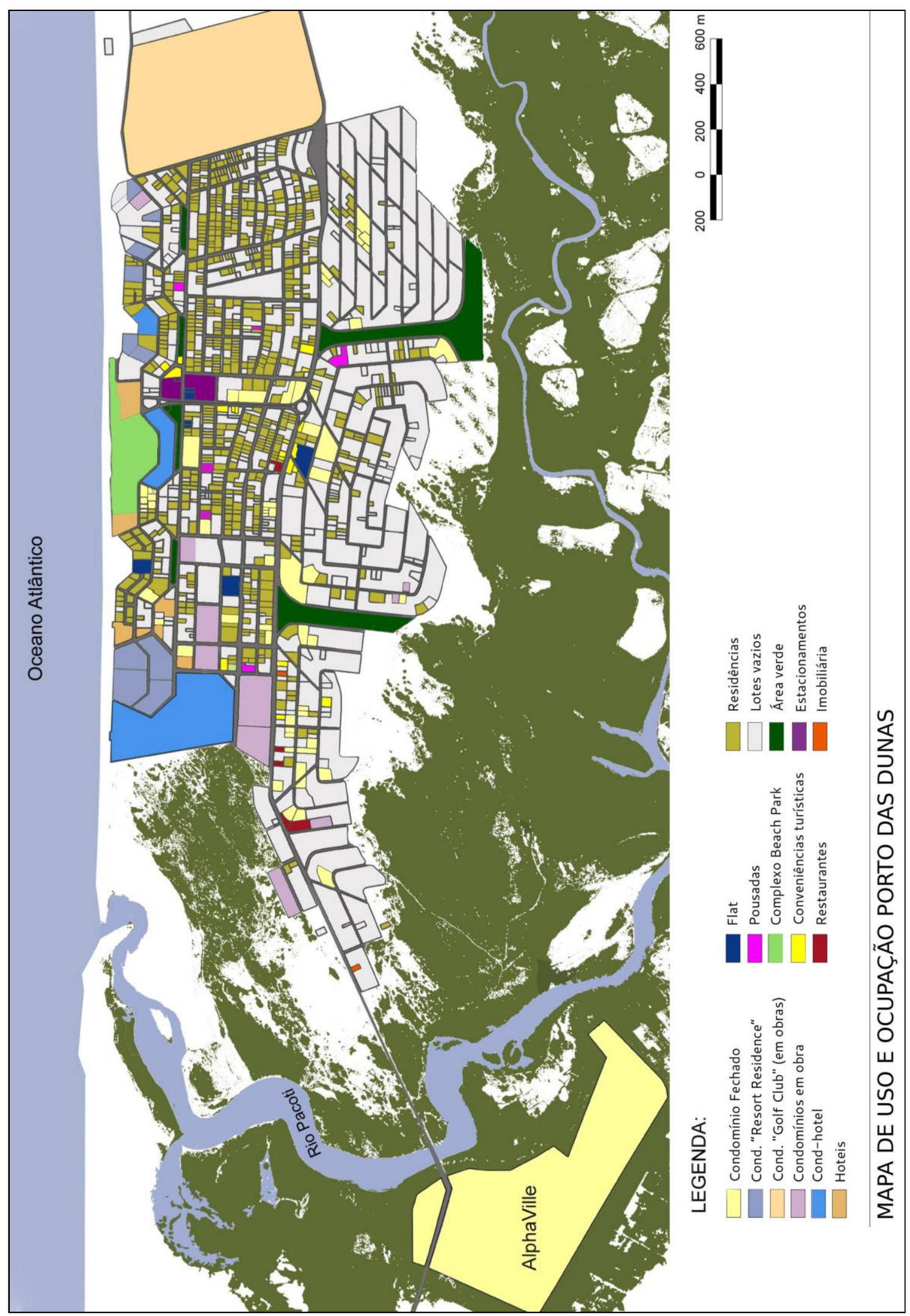

Fig. 3.57 Mapa de Uso e Ocupação do Solo atual do Porto das Dunas. Fonte: elaborado pelo autor - 2012 
O mapa acima foi fruto do trabalho de campo que consistiu no levantamento de uso e ocupação do solo do Porto das Dunas, complementado por levantamento fotográfico e entrevistas. Com ele, temos a condição de fazer uma interpretação mais detalhada e consistente das condições atuais da evolução urbana do bairro.

Num primeiro olhar, verificamos que o loteamento se divide em dois trechos principais: o mais adensado, próximo ao mar, à esquerda da rodovia de acesso, e o menos adensado, à sua direita que corresponde à topografia mais elevada das dunas.

Verificamos no trecho mais adensado, a presença marcante das residências de veraneio (em verde médio) que representam o primeiro momento de ocupação do bairro atingindo, ainda hoje, uma maior extensão territorial, comparado aos outros padrões de uso. No entanto, verificamos a tendência de que os condomínios fechados passarão brevemente a ser a tipologia predominante, quando forem terminadas as obras do empreendimento Golf Ville, (em rosa) e dos outros sete condomínios, de médio e grande porte (em lilás). Note que o condomínio Alfa Ville Fortaleza, no canto inferior, também ocupa uma grande extensão territorial e se conecta por proximidade ao Porto das Dunas, como se fosse uma extensão da função residencial de Fortaleza em Aquiraz

$\mathrm{Na}$ faixa mais próxima do litoral, verificamos uma maior diversidade de usos, tendo em vista as atividades relacionadas ao turismo: hotéis, pousadas, cond-hotéis, flats, condomínios padrão "Resort Residence" e "Golf Club", além do complexo turístico Beach Park, com inúmeros equipamento e serviços de conveniências turísticas.

No trecho, ao longo da rodovia de acesso, verificamos também alguma variedade de comércio e serviços, principalmente de conveniência turística e de apoio ao veranista, como: posto de gasolina, mercadinho, restaurantes, farmácias, câmbio, loterias, Banco 24 h, imobiliárias, etc. Essa característica faz com que esse eixo venha a se consolidar como o corredor de atividades, comerciais do local. No entanto o bairro sofre a carência de um eixo de convergência capaz de polarizar atividades cívicas, culturais, esportivas e de lazer, além da comercial.

Para se tornar verdadeiramente um bairro, seus moradores terão que propor modificações que proporcionem o atendimento às demais infraestruturas urbanas de

\footnotetext{
${ }^{5}$ O mercado imobiliário local tem usado o termo "Resort Residence" para denominar os condomínios com equipamentos de lazer de alto padrão, quando localizados em área litorânea.
} 
apoio à população em geral, e mais especificamente as que lá vivem como trabalhadores, uma vez que a maioria de proprietários das classes de maior renda utiliza o espaço como segunda residência. Atualmente o bairro conta apenas com uma escola municipal, um posto policial e uma igreja, sendo precário também o sistema de transporte público.

Por fim, o trecho à direita da rodovia, apresenta-se ainda pouco adensado, devido ser em terreno de dunas, mas já apresenta uma predominância do padrão de pequenos e médios condomínios fechados, além de uma significativa quantidade de residências individuais. Além disso, outros usos relacionados ao atendimento de veranistas e turistas também são visíveis como: restaurantes, pousada, flat, centro comercial, posto de gasolina, mercadinho, etc., a maioria, ao longo da rodovia.

Portanto, podemos dizer que verificamos no Porto das Dunas, um processo de ocupação que se inicia ainda nos anos 1980, como padrão de residências de veraneio. Ao longo dos anos 1990, intensifica o uso relacionado ao turismo, em torno das atividades do complexo Beach Park, apresentando nos anos 2000 uma característica de "bairro turístico".

No entanto, notamos nos últimos anos, uma tendência marcante de concentração de condomínios fechados com padrão variado, onde se destacam aquele de uso relacionado ao turismo, acentuando ainda mais, o agudo processo de segregação socioespacial, característico do bairro.

O Porto das Dunas tenderá, portanto, a um conjunto urbano de formações "insulares" e "autossuficientes" na medida em que a maioria da população de proprietários se volta para o interior dos seus condomínios fechados, alinhando-se à tendência contemporânea de constituição das novas metrópoles brasileiras: neste caso, em particular, orientado por um novo padrão de ocupação baseado no turismo.

Entendemos que esse padrão não aponta para um tipo de sociabilidade que desejamos para o nosso futuro comum e por isso precisamos rever permanentemente a evolução dessas novas configurações, em busca do conhecimento de suas especificidades visando proporcionar um maior domínio, no enfrentamento dessas questões. 
É importante reconhecer, no entanto, a dificuldade de se propor soluções urbanísticas e arquitetônicas em ambiente de extrema desigualdade social, como a brasileira, mas não devemos nos iludir com as facilidades e encantamentos de uma vida condominial, aparentemente segura e glamorosa que leva a sociedade a um distanciamento mútuo.

\section{CONCLUSÕES E CONSIDERAÇÕES FINAIS}

\subsection{Síntese da análise do caso de Aquiraz e conclusões finais}

A exposição do último capítulo, portanto, teve como objetivo caracterizar o município de Aquiraz e suas transformações socioespaciais recentes, para podermos chegar à conclusão se realmente se trata de um caso que representa a transição metropolitana em curso na cidade de Fortaleza.

Constatamos, na exposição que esses novos espaços se constituem articulados por uma estrutura viária metropolitana que permite operar e intermediar funções de controle e comando, a partir da cidade capital, relacionados, nesse caso, à produção das atividades turísticas e imobiliárias. Essa transição é percebida pelo modo fragmentado com que as unidades habitacionais se auto segregam como se constituíssem um grande arquipélago de ilhas, voltadas para o interior de cada condomínio.

Esse tipo de padrão de ocupação é vendido como se fizesse parte de um processo inovador de produção espacial, mas são espaços reproduzidos de forma homogeneizada, replicados como carimbos dentro e fora da unidade do tecido urbano da cidade cujo processo lhe dá origem.

Além de ser fragmentado e homogeneizado, esse novo espaço em transição, aparece também como a expressão de uma hierarquia espacial fundamentada no padrão de qualidade de cada unidade isolada, tomada como símbolo de poder e status social, representados pelo estilo de vida sofisticado e glamorizado dos novos espaços privativos e seletivos.

Foi possível constatar na análise da estrutura e da forma desses novos espaços litorâneos, uma diversidade de padrões da função habitar que aponta para uma interpretação das diversas "gerações" de loteamentos imobiliários, no caso estudado, 
onde se verifica uma espécie de "evolução" e diferenciação que se inicia a partir de um modelo de ocupação "integrado" ao tecido urbano das antigas vilas de pescadores que vão se modificando mediante a ocorrência dos choques de interesses na disputa pelo acesso ao litoral: fonte original de recursos naturais e de geração de renda.

Essa diferenciação parece ser permanente e constituinte da lógica de reprodução do capital, onde a auto segregação se apresenta com um padrão de ocupação que ocorre, primeiramente, de forma branda, através do controle do espaço urbano litorâneo, no caso da proibição de instalação de novas barracas de praia. Esse é um problema pouco estudado, ao ponto das barracas serem vistas apenas como um problema ambiental, antes de ser um problema social, levando o Ministério Público a ordenar a remoção de todas as barracas da faixa de praia, em disputa judicial que se arrasta à décadas.

Esse problema, longe de ser equacionado, passa a ser colocado à deriva de um processo que tende ao esquecimento, lembrado somente nos momentos mais críticos de radicalização quando o Ministério Público alega a obrigatoriedade do cumprimento da legislação ambiental vigente, levado como pendências judiciais permanentes.

Com o tempo, o padrão de auto segregação evolui de forma mais radical e visível no caso do Porto das Dunas, favorecida pelas condições topográficas do seu sítio natural, como também da estratégia comercial de lançamento e vendas dos lotes, através do controle pelo preço da unidade, inserido em uma forte campanha publicitária que o levou a tornar-se um local de perfil turístico das camadas mais elevadas de renda.

Na medida em que o Porto das Dunas, hoje, já tende a certa popularização e adensamento, denotado pelo intenso processo construtivo, são criados novos espaços mais isolados, elitizados e exclusivos de uma classe aparentemente sempre mais elevada que parece repetir o circuito de elitização - popularização - degradação. Esse circuito se fundamenta na criação permanente de novos espaços capazes de superar sua "geração" anterior e garantir a reserva futura de valorização imobiliária, como é o caso dos lançamentos do Aquiraz Riviera e Golf Ville, perpetuando a necessidade de se incorporar sempre novos territórios para alimentar a lógica de reprodução do capital.

Desse modo, foi possível identificar claramente as novas transformações socioespaciais no litoral de Aquiraz, a partir da análise dos padrões de ocupação diferenciados, desde as primeiras gerações de loteamentos de veraneio, até os padrões de ocupação mais 
recentes. Nesse contexto, enfocamos a ação e interferência dos agentes imobiliários nos Planos Diretores de Desenvolvimento Urbano, como forma de garantir a continuidade e maximização dos seus interesses que acabaram esbarrando no enfrentamento da nova questão ambiental.

Assim, percebemos como essa nova questão ambiental passou a condicionar de forma marcante os novos produtos turísticos e imobiliários, alterando projetos de Estado e reforçando novos paradigmas de ocupação litorânea, mais próximo de um modelo de sustentabilidade socioambiental. Infelizmente, estes ainda estão longe de ser consolidados, tendo em vista às inúmeras contradições e limitações, permanentemente ameaçadas por intrincadas ações judiciais que fazem a mediação dos inúmeros conflitos de interesses.

No último segmento, abordamos por fim, o incremento mais recente da atividade imobiliária no Porto das Dunas, através da análise da evolução urbana do bairro, como também do desenvolvimento turístico de Aquiraz. Com isso, chegamos à conclusão que o percurso deixado pelo rastro das diversas ações dos agentes imobiliários revela como essa nova modalidade de produção do espaço, voltado para o turismo, tem atraído o mercado imobiliário, como diferencial de mercado. Assim, torna-se evidente a necessidade dos promotores imobiliários de incorporar sempre novos territórios à lógica do capital que os mantém.

Prova disso é a polêmica forma de apropriação dos espaços, protegidos por legislação ambiental, efetuada por promotores imobiliários em ações judiciais, representando uma estratégia recorrente de garantir uma extraordinária forma de valorização locacional dos lotes comercializado em terras litorâneas, através da venda de espaços exclusivos, inseridos sempre em áreas de preservação permanente.

Por fim, as razões que explicam o incremento da atividade imobiliária, no Porto das Dunas e em Aquiraz, estão ligadas a múltiplos fatores de alcance nacional, internacional e local. Entre os mais recentes, destacamos o aquecimento da construção civil brasileira que atinge também o segmento de segunda residência, como um nicho de mercado. Outros fatores estão relacionados à maior oferta de crédito, resultante da ampliação e diversificação das fontes de recursos para investimento, como também pelo aumento da 
renda dos brasileiros, atualmente relacionado à expansão da economia nacional, como um todo.

Entretanto, a dinâmica imobiliária no contexto litorâneo da Região Metropolitana de Fortaleza, possui razões mais profundas que não emergem na sua totalidade, a partir da análise de suas causas mais recentes, embora seja influenciada por essa nova onda de expansão. Assim, ao final da nossa exposição, chegamos à conclusão de que essa atividade imobiliária se mostra, de fato, relacionada à estruturação de um novo processo de produção do espaço para o turismo, como procuramos demonstrar ao longo dos capítulos anteriores.

Assim, pudemos verificar que essa configuração, no caso em estudo, nos coloca diante de um novo padrão de cidade que não se explica no antigo modelo centro-periferia. De outra forma, aponta para uma nova organização socioespacial metropolitana, assim considerada porque busca responder à reorganização de um tipo específico de produção, frente à necessidade de se incorporar novos territórios à lógica de reprodução do capital.

A nossa contribuição com essa Tese, portanto, é trazer o foco dessa discussão para a ação dos agentes imobiliários que vêm atuando no processo de reestruturação metropolitana de Fortaleza configurando uma nova forma de produção do espaço para o turismo. Como pudemos verificar, esse processo de transformação e uso foi resultado em grande parte, da reestruturação produtiva do Ceará que alcançou Fortaleza em sua dimensão metropolitana, onde o território litorâneo de Aquiraz foi incorporado aos processos articulados pela política estadual de turismo, como foi demonstrado na exposição dos capítulos anteriores. Assim, consideramos confirmada a nossa hipótese de trabalho de que: a ação dos agentes imobiliários responde à reorganização de um novo processo de produção do espaço para o turismo, frente à necessidade de incorporar novos territórios à lógica de reprodução do capital.

\subsection{Sobre o trabalho de campo e as entrevistas}

O trabalho de campo foi organizado para orientar as primeiras aproximações com o objeto de estudo, do ponto de vista físico, como também para dar uma maior qualidade aos resultados, comparando os dados obtidos na análise socioespacial, elaborada nos 
capítulos anteriores, com as respostas obtidas nas entrevistas, como forma de apoiar as nossas conclusões finais.

Assim, foi organizado em dois blocos: no primeiro, apresentamos um relato sintético dos procedimentos e resultados da fase preliminar da pesquisa de campo composta de levantamentos de dados, mapeamento temático, visitas de reconhecimento e entrevistas exploratórias, desenvolvidas de agosto de 2011 até novembro de 2011.

No segundo bloco apresentamos a estruturação dos questionários da segunda fase das entrevistas, composta por perguntas mais específicas aplicadas aos agentes produtores do espaço e em particular aos agentes imobiliários, no período entre fevereiro e março de 2012.

As entrevistas tiveram o objetivo de ampliar a compreensão dos movimentos recentes da urbanização litorânea na RM de Fortaleza, a partir da interpretação da percepção dos agentes imobiliários na produção e apropriação do espaço para o turismo, utilizando-se de questionários semiestruturados (questões abertas sobre temas específicos) direcionadas aos agentes imobiliários que atuam na interface com o turismo, conferindo um caráter qualitativo às entrevistas. Esse material é apresentado como anexo, junto com a transcrição das entrevistas, para permitir ao leitor avaliar o percurso efetuado.

Sobre o resultado analítico das entrevistas que está detalhado no anexo, diria apenas que na sua segunda fase, onde contém uma série de perguntas que levam a responder a questão central, isto é: se a ação dos agentes imobiliários corresponde à reorganização de um novo processo de produção, diante da necessidade de incorporar novos territórios, chegamos a seguinte conclusão: todos os entrevistados não percebem nenhum novo processo produtivo inovador relacionado a esse novo tipo específico de produto, alegando que todo o conteúdo tecnológico empregado, no caso em questão, é na maioria das vezes muito inferior ao conteúdo tecnológico de grandes edifícios e empreendimentos, por serem edificações de, no máximo, cinco pavimentos, sendo executado utilizando-se a tecnologia convencional de construção.

Essa percepção coincide com a realidade encontrada no primeiro projeto do Aquiraz Riviera que na sua versão anterior pretendia sim utilizar uma nova tecnologia de origem norte americana, baseada no conceito mais amplo de "Projeto para Fabricação"- PPF (Design for Manufacturing) que envolve: gestão de materiais padronizados, módulos e 
materiais pré-fabricados, processos economicamente viáveis, layout ótimo, redução das interferências nos processos de fabricação, entre outros.

Na análise feita pelo Secretário de Turismo de Aquiraz, na época, o modelo foi rejeitado justamente porque não utilizava a tecnologia e materiais locais e na sua execução final o conceito foi substituído pelo processo tradicional de construção.

Entretanto, a partir de perguntas estimuladas, verificamos que embora os entrevistados não identifiquem supostas inovações, verificamos duas grandes novidades no processo produtivo: a utilização massiva de marketing, tanto na concepção do projeto quanto na formatação do produto e a nova formulação do "negócio imobiliário" enquanto produto financeiro, formatado a partir de um novo arranjo de investidores imobiliários.

Esses detalhes podem ser conferidos nas transcrições das entrevistas que estão organizadas por tópicos. Esses temas não foram desenvolvidos na pesquisa porque as suas evidências não foram suficientemente identificadas nas entrevistas, mas revelaram novos caminhos de investigação, no futuro. 


\section{REFERÊNCIAS BIBLIOGRÁFICAS}

ALQUIER, François. Contribuition à l'étude de la rente foncière sur les terrains urbains. Espaces et Sociétés, Paris: Editions Anthropos, n.2,(p.75-87), 1971.

AMORA, Zenilde. B. Aspectos Históricos da industrialização no Ceará. In: SOUSA, S. (Org.). História do Ceará. Fortaleza, 1994.

Indústria e Espaço no Ceará . In: José Bozarchiello da Silva.

(Org.). Ceará: Um Novo Olhar Geográfico. Fortaleza: Edições Demócrito Rocha, 2007.

ARRIGHI, Giovanni. O longo século XX: dinheiro, poder e as origens de nosso tempo. São Paulo: Editora UNESP, 1996.

AUGÉ, M. Não-Lugares: Introdução a uma antropologia da supermodernidade. Campinas/SP: Ed. Papirus, 1994.

BELUZZO, Luiz Gonzaga. Prefácio in CHESNAY, François (org.). A finança mundializada: raízes sociais e políticas, configuração, consequências. São Paulo: Boitempo, 2005.

BENEVIDES, Ireleno P. Turismo e Prodetur: Dimensões e Olhares em Parceria. Fortaleza: EUFC, 1998.

- O Turismo e seu Planejamento Governamental no Ceará. In: CORIOLANO, LUZIA NEIDE M.T (Org.). O turismo de Inclusão $e \quad o$ Desenvolvimento Local. Fortaleza: Ed. Funece, 2003.

BNB (Banco do Nordeste do Brasil). Regulamento Operacional do PRODETUR II. Fortaleza: Banco do Nordeste, 2002.

Nordeste, 2005.

Relatório de Avaliação PRODETUR/CE I. Fortaleza: Banco do

BOTELHO, Adriano. O urbano em fragmentos: a produção do espaço e da moradia pelas práticas do setor imobiliário. São Paulo: Annablume; Fapesp, 2007.

BOTELHO, Demartone Coelho. Ajuste fiscal e reforma do estado: o caso do Estado do Ceará, 1987 a 1991. Fortaleza: CAEN/UFC, 1994. Dissertação (Mestrado) - Curso de Pós-graduação em Economia, Universidade Federal do Ceará, 1994.

BRASIL. MMA. Ministério do Meio Ambiente dos Recursos Hídricos e da Amazônia Legal - Macrodiagnóstico da Zona Costeira do Brasil. Brasília, 1996.

CAGECE, Companhia de Água e Esgoto do Ceará. Estudo de Impacto Ambiental e Social - EIA do programa de infraestrutura básica em saneamento do estado do Ceará - SANEAR II. Relatório de Plano de Controle Ambiental (TOMO IV). Fortaleza, mar. de 2005. 
CAMPOS, Alberto Alves (Coord.) et. al. A Zona Costeira do Ceará: Diagnóstico para a Gestão Integrada, Fortaleza: Aquasis, 2003.

CARMONA, Marisa. The regional dimension of the compact city debate: Latin America. In JENKS, M., \& BURGESS, R. (eds.). Compact city: sustainable urban form for developing countries, London: Spon Press, 2000.

CASAL, Manoel Ayres de. e CAMINHA, Pero Vaz de. Corografia brasílica. Fac-simile da edição de 1817, Volume 2. Instituto Nacional do Livro. Coleção Obras Raras, 2 . Reimpressão: Rio de Janeiro. Imprensa Nacional, 1947. (http://books.google.com.br/books?id=AJoXAAAAIAAJ\&printsec=frontcover\&

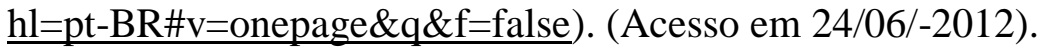

CASTELLS, Manuel. A questão urbana. São Paulo: Paz e Terra, 1983. (titulo original: La question urbaine. Paris: François Maspero, 1972).

A sociedade em rede. A era da Informação: economia, sociedade

e cultura. São Paulo: Paz e Terra, 1999.

CASTRO, José Liberal. Fatores de Expansão e Localização da Cidade de Fortaleza, Fortaleza: CREA-CE, 1977.

CEARÁ, Governo do Estado. Política Estratégica para o Desenvolvimento Sustentável do Turismo do Ceará 1995 - 2020, Fortaleza: Secretaria de Turismo, 1995.

- Plano de Desenvolvimento Turismo Sustentável - PDITS. Fortaleza: Secretaria de Turismo, 2008 (CDROM).

CHAVES, Gylmar. et.al. Ah, Fortaleza! Fortaleza: Terra da Luz Editorial, 2006.

CHESNAY, François (org.). A finança mundializada: raízes sociais e políticas, configuração, consequências. São Paulo: Boitempo, 2005. (trad. Rosa Maria Marques e Paulo Nakatani - La finance mondialisée: racines sociales et politiques, configurations, conséquences. Paris: Ed. La Découvert, 2004).

CHOAY, Françoise. Le régne de l'urbain et La mort de La ville. In La Ville. Paris: Centre G. Pompidou, 1994.

CICCOLELLA, Pablo. Globalización y dualización en la Región Metropolitana de Buenos Aires, Eure, vol. XXV, No 76, diciembre, pp5-27, Santiago de Chile, 1999.

CORIOLANO, Luzia Neide M.T. Do Local ao Global: O turismo litorâneo cearense. Campinas: Ed. Papirus, 1998.

(Org.). O turismo de Inclusão e o Desenvolvimento Local, Fortaleza: Ed. Funece, 2003. 
Litoral do Ceará: espaço de poder, conflito e lazer. Revista da Gestão Costeira Integrada nr. 8(2):277-287. UNIVALI (2008).

CRUZ, Rita de Cássia Ariza da. Políticas de Turismo e Construção do Espaço Turístico Litorâneo no Nordeste do Brasil in LEMOS, Amália Ines G. de.Turismo Impactos Sócio Ambientais - São Paulo: Hucitec, 1996.

CUNHA, Eglaísa Micheline Pontes \& PEDREIRA, Roberto Sampaio. Como Anda Fortaleza. $5^{\circ}$ Vol. Como Andam as Regiões Metropolitanas. Coleção Estudos e Pesquisas do Programa Nacional de Capacitação das Cidades. Brasília. Ministério das Cidades, 2008.

CORRÊA, Roberto Lobato. Espaço, um Conceito-chave da Geografia. In: CASTRO, Iná Elias de; GOMES, Paulo C. da C. \& CORRÊA, Roberto L. (Org.). Geografia: Conceitos e Temas. Rio de Janeiro: Bertrand Brasil, 2001.

DANTAS, Eustógio W.C. Mar à Vista: Estudo da Maritimidade em Fortaleza: Museu do Ceará - Secretaria de Cultura e Desporto do Ceará, 2002.

Sistemas de Cidades em Terra Semi-árida, In: ALMEIDA, M. GERALDA DE \& RATTS, ALECSANDRO J. P. (Orgs.). Geografia Leituras Culturais. Goiânia: Alternativa, 2003.

DANTAS, Shirley Carvalho. Turismo, Produção e Apropriação do Espaço e Percepção Ambiental: O caso de Canoa Quebrada, Aracati, Ceará. Fortaleza: Universidade Federal do Ceará, 2003. (Dissertação de Mestrado).

DEÁK, Csaba. Rent theory and the price of urban land/ Spatial organization in a capitalist economy. PhD Thesis, Cambridge (1985)

- O mercado e o Estado na organização espacial da produção capitalista. Espaço \& Debates, Nr. 28, p.18-31,(1989)

ELIAS, Denise \& SAMPAIO, J. L. F. Modernização Excludente. Fortaleza: Edições Demócrito Rocha, 2002 (coleção Paradigmas da Agricultura Cearense).

ESPÍNOLA, Rodolfo. Caravelas, jangadas e navios: uma história portuária. Fortaleza: OMNI, 2007.

FEATHERSTONE, Mike. Cultura de consumo e pós-modernismo. S.P: Studio Nobel, 1995.

FERNANDES, Francisco Ricardo C. Transformações espaciais no centro de Fortaleza: estudo crítico das perspectivas de renovação urbana. Dissertação de Mestrado. PRODEMA-UFC, 2004.

FERREIRA, Aurélio Buarque de Hollanda. Novo Dicionário Aurélio da Língua Portuguesa. Rio de Janeiro: Nova Fronteira, 1993.

FERREIRA, Assuéro. O crescimento recente da economia cearense. Revista econômica do Nordeste, 26 (abr./jun): 157-180, 1995. 
FINE, Ben. Propriedade fundiária e renda da terra, in BOTTOMORE, Tom (ed.). Dicionário do pensamento marxista. Rio de Janeiro: Jorge Zahar Editor, 1988.

FORTALEZA - CODEF/PMF. Fortaleza: evolução urbana (1603-1979). Fortaleza: PMF, 1979.

FORTALEZA - PMF/IPLAM. Plano Diretor de Desenvolvimento Urbano de Fortaleza: Síntese Diagnóstica. Fortaleza: PMF, 1991.

FORTALEZA - PMF/SUPLAM. Plano Diretor da Cidade de Fortaleza - 1963 (Lei nº 2128 - 20 de Março de 1963). Fortaleza: PMF, 1969.

Plano de Desenvolvimento Integrado da Região Metropolitana de Fortaleza-PLANDIRF - 1969/71. Fortaleza: PMF, 1971.

GIRÃO, Raimundo. Pequena História do Ceará. Fortaleza: Ed. Instituto do Ceará, 1962.

Geografia Estética de Fortaleza. Fortaleza: BNB-ETENE,1979.

GOTTDIENER, Mark. A produção social do espaço urbano. São Paulo: EDUSP, 1997.

GONDIM, Linda M.P. Os "Governos das Mudanças" (1987-1994). In SOUZA, S. (Org.) Uma nova história do Ceará. Fortaleza: Edições Demócrito Rocha, 2000 .

O dragão do mar invade a Praia de Iracema: desenho urbano como catalisador das imagens da cidade. Encontro da Latin American Studies Association, Hyatt Regency Miami, Março 16-18, 2000 (a). (http://lasa.international.pitt.edu/members/congress-papers/lasa2000/files/Gondim.PDF - 07/06/2012)

HARVEY, David. A justiça social e a Cidade. São Paulo, Hucitec, 1980. (trad. Social justice and the city. Baltimore, John Hopkins University Press. 1973).

Limits to capital. Chicago: University of Chicago Press, 1982.

A condição pós-moderna. 10ª Ed. São Paulo, Loyola, 2001. (Trad. The condition of postmodernity: an enquiry into the origins of cultural change. Oxford: Basil Blackwell, 1990).

A produção capitalista do espaço. Coleção Geografia e Adjacências. São Paulo. Annablume, 2006.

KAUTSKY, Karl. A questão agrária. São Paulo: Proposta Editorial, 1980.

JENKS, M., BURTON, E. \& WILLIAMS, K. (Ed.). The compact city: A sustainable urban form? London, Oxford Brookes University, 1998. 
LEFEBVRE, Henry. La Producion de L'Espace. Paris. Anthropos, 1974. (English translation by Donald Nicholson-Smith. Malden-USA: Black Well Publishing Ltd.1991).

orig.de 1973).

Espacio y Política. Barcelona: Ediciones Peninsula,1976 (trad.do Fayard, 1980.

Une pensée devenue monde. Il faut-il abondonner Marx? Paris: . A Cidade do Capital. Rio de Janeiro: DP\&A Editora, 1999. . A revolução urbana. Belo Horizonte: Ed UFMG, 1999a.

LENCIONI, Sandra. Uma Nova Determinação do Urbano: o desenvolvimento do processo de metropolização do espaço. In: CARLOS, Ana Fani A.; LEMOS, Amália I. G. (Orgs.) Dilemas urbanos: Novas Abordagens Sobre a Cidade. São Paulo: Contexto, 2003.

LENCIONI, Sandra; VIDAL-KOPPMANN, Sônia; HIDALGO, Rodrigo; PEREIRA e XAVIER, Paulo Cesar (orgs.). Transformações sócio-territoriais nas metrópoles de Buenos Aires, São Paulo e Santiago. São Paulo: FAUUSP, 2011.

LENIN, Vladimir I. A questão agrária e os “críticos de Marx”. Rio de Janeiro: Editorial Calvino Limitada, 1945.

LIPIETZ, Alain. Le tribut foncier urbaine. Paris: François Maspero, 1974.

LOJKINE, Jean. O Estado capitalista e a questão urbana. São Paulo: Martins Fontes, 1997.

Y a-t-il une rente foncière urbain. Espaces et Sociétés, Paris: Editions Anthropos, n.2 (p.89-94), 1971.

LUCHIARI, M. Tereza. Urbanização turística: um novo nexo entre o lugar e o mundo. In: LIMA, Luiz C. (org.). Da Cidade ao Campo: a diversidade do saberfazer turístico. Fortaleza: UECE, 1998

JACOBS, Jane. Morte e vida de grandes cidades. Coleção a, Martins Fontes, São Paulo; $1^{\mathrm{a}}$ edição, 2000. (The death and life of great american cities.1961. Trad. Carlos S. Mendes Rosa)

JAMESON, Fredric. Pós-Modernismo. A lógica cultural do capitalismo tardio. São Paulo. Ed. Martins Fontes, 2000.

JUDD, Dennis R. \& FAINSTEIN, Susan S. (Ed.) The Tourist City. New Haven, CT: Yale University, 1999. 
KRIPPENDORF, Jost. Sociologia do turismo - para uma compreensão do lazer e das viagens. R.J: Civilização Brasileira, 1989.

Mac CANNELL, D. The tourist: a new theory of the leisure class, London: Macmillan, 1976.

MASCARENHAS, Gilmar. Cenários contemporâneos da urbanização turística. Caderno Virtual de Turismo. Vol. 4, N 4, 2004.

MASSEY, D. e JESS, P. (orgs.) A place in the world? Places, cultures and globalization, The Open University, Oxford, 1995

MARICATO, Hermínia (Org.). A produção capitalista da casa (e da cidade) no Brasil industrial. São Paulo. Ed. Alfa-ômega. 1982.

RJ: Vozes, 2001

Brasil, cidades: alternativas para a crise urbana - Petrópolis,

MARQUES, Eduardo C. Notas críticas à literatura sobre Estado, políticas estatais e atores políticos. BIB, Rio de Janeiro, n. 43, 1997, pp. 67-102.

MARX, Karl. O Capital. São Paulo, Abril Cultural. Livro 3, v.3, 1983

O Capital. Rio de Janeiro: Bertrand Brasil, livro 3, vols. 4,5 e 6,

1989.

Manuscritos econômico-filosóficos e outros textos escolhidos. $5^{\text {a }}$ Edição. São Paulo: Nova Cultural, coleção Os Pensadores, 1991.

MATOS, Carlos A. de. Movimientos del capital y expansión metropolitana en las economías emergentes latinoamericanas, en Revista de Estudios Regionales, $\mathrm{N}^{\mathrm{o}}$ 60, $2^{\mathrm{a}}$ época, mayo-agosto, PP.15-43, 2001.

MATOS, Fábio de Oliveira. A cidade de papel: fotografia e cartografia na formação do espaço litorâneo de Fortaleza-Ceará. Dissertação de mestrado acadêmico em Geografia. UECE- Universidade Estadual do Ceará, Centro de Ciências e Tecnologia, Fortaleza, 2009.

MONGIN, Olivier. La condición urbana. La ciudad a hora de la mundialización. Buenos Aires: Paidos, 2006.

MONTENEGRO JR. Ignácio R.P. Turismo e Urbanização: Gestão de Impactos no Litoral de Aquiraz-CE. Dissertação de Mestrado. Fortaleza: Programa de Pós-graduação em Desenvolvimento e Meio Ambiente. Universidade Federal do Ceará -UFC-PRODEMA, 2004.

MORAES, Antônio C. Robert. Contribuições para a Gestão da Zona Costeira no Brasil: Elementos para uma Geografia do Litoral Brasileiro. São Paulo: Hucitec - EDUSP, 1999. 
MULLINS, P. Tourism Urbanization. International Journal of Urban and Regional Research, vol. 15, n.3, pp.326-342. School of Social Science - The University of Queensland - Australia, 1991.

OLIVEIRA, Francisco. "Crítica à razão dualista / O ornitorrinco". São Paulo: Boitempo, 2003.

PAIVA, Ricardo Alexandre. A metrópole Hibrida: o papel do turismo no processo de urbanização da Região Metropolitana de Fortaleza. Tese de Doutorado. FAUUSP. Tese de Doutorado, 2011.

PARENTE, F.J.C. O Ceará dos 'coronéis' (1945 a 1986). In SOUZA, S. (Org.) Uma nova história do Ceará. Fortaleza: Edições Demócrito Rocha, 2000.

PEREIRA, Alexandre Queiroz. Veraneio marítimo e expansão metropolitana no Ceará. Dissertação Mestrado - Universidade Federal do Ceará, Fortaleza, 2006.

PEREIRA, Paulo Cesar Xavier. Reestruturação Imobiliária em São Paulo: Especificidades e Tendências. Universidade de São Paulo - Anais do X Encontro de Geógrafos da América Latina - 20 a 26 de março de 2005.

A reestruturação imobiliária em São Paulo como chave para o desvendamento da metrópole atual. In Geografia das Metrópoles. CARLOS, Ana Fani Alessandri, OLIVEIRA, Ariovaldo Umbelino de (orgs.) - São Paulo: Editora Contexto, 2006.

Globalização e mudança: A reestruturação nas cidades latino-

americanas. $\mathrm{O}$ caso da cidade de São Paulo (Brasil). (www.observatoriogeograficoamericalatina.org.mx/egal11/.../12.pdf) In: XI Encontro de Geógrafos de America Latina, 2007, Bogota. Geopolitica, globalizacion y cambio ambiental: retos en el desarrollo latino americano. Programa y Resúmenes de Ponencias (v.1.p.42.). Bogotá: UNIBIBLOS, 2007.

São Paulo: globalización y transición metropolitana. Diez años de cambios en el mundo, en la Geografía y en las Ciencias Sociales, 1999-2008. Actas del X Coloquio Internacional de Geocrítica, Universidad de Barcelona, 26-30 de mayo de 2008. (http://www.ub.es/geocrit/-xcol/213.htm (11/10/2011).

Agentes imobiliários e reestruturação: interesses e conflitos na construção da cidade contemporânea. In PEREIRA, Paulo Cesar Xavier (org.) Negócios imobiliários e transformações sócio-territoriais em cidades da América latina. São Paulo: FAUUSP, 2011.

PIREZ, Pedro. Buenos Aires Metropolitana. Política y gestión de La ciudad, Buenos Aires, 1994.

PONTE, Sebastião Rogério. Fortaleza Belle Époque: reformas urbanas e controle social (1860-1930). Fortaleza: Fundação Demócrito Rocha/Multigraf, 1993. 
PREFEITURA MUNICIPAL DE AQUIRAZ. Plano de Ação Turística - PAT. Aquiraz, 2000.

PREFEITURA MUNICIPAL DE AQUIRAZ. Plano Municipal de Educação de Aquiraz, Secretaria de Educação, 2001.

PREFEITURA MUNICIPAL DE AQUIRAZ. Mapeamento Cultural. Secretaria de Cultura, Aquiraz, 2003.

PREFEITURA MUNICIPAL DE AQUIRAZ. Plano Diretor de Desenvolvimento Urbano - PDDU. Aquiraz, 2005.

PREFEITURA MUNICIPAL DE AQUIRAZ. Plano Diretor de Desenvolvimento Urbano - PDDU. Aquiraz, 2011.

PROGRAMA DE INVESTIGACIÓN SANTIAGO METROPOLITANO (PISM) Coord. de C.A. de Mattos, A. Rodriguez y G. Yañez, CD ROM, Santiago de Chile, 2000.

QUEIROZ, Rachel de. O Quinze, Rio de Janeiro: José Olympio, 2004

RAMOS, Ángel Martín (Ed.). Lo urbano: en 20 autores contemporáneos. Barcelona: Edicions UPC, 2004.

RIBEIRO, L. C. de Queiroz \& SANTOS JÚNIOR, Orlando A. dos (Orgs.) Globalização Fragmentação e Reforma Urbana: O futuro das Cidades Brasileiras na Crise. Rio de Janeiro: Civilização Brasileira,1997.

RIOS, Kênia Sousa. Campos de concentração no Ceará: isolamento e poder na seca de 1932. Fortaleza: Museu do Ceará/Secretaria da Cultura e Desporto do Ceará, 2001.

RODRIGUES, Adyr Balastreri. Turismo e Espaço: Rumo a um conhecimento transdisciplinar. São Paulo: Hucitec,1997.

Turismo e Geografia - Reflexões teóricas e enfoques regionais. São Paulo: Hucitec, 1999.

(Org.). Turismo. Modernidade. Globalização. São Paulo: Hucitec, 2000.

RODRIGUES, Arlete M. Produção e Consumo do e no Espaço: Problemática Ambiental Urbana. São Paulo: Hucitec, 1998.

RODRIGUES, Maria do Socorro Costa \& SOUSA FILHO, Luciano Moreira de. Pecém: uma trajetória portuária. Fortaleza: SEBRAE/CE, 2007.

SANTOS, Milton. Society and space: social formation as theory and method. Worcester: Antípode, 1977. 
Técnica, Espaço, Tempo - Globalização e Meio Técnico-Científico Informacional. São Paulo: Hucitec, 1994.

O Espaço Dividido: Os Dois Circuitos da Economia Urbana dos Países Subdesenvolvidos. EDUSP. SP, 2004

A Natureza do Espaço: Técnica e Tempo, Razão e Emoção. São Paulo: Editora da Universidade de São Paulo, 2006.

SASSEN, S. As cidades na economia mundial. São Paulo: Nobel, 1998.

SASSEN, Saskia \& ROOST, Frank. A cidade: local estratégico para a indústria do entretenimento. Espaço e Debates. São Paulo, ano XVII, n. 41, 2001.

SCHIFFER, Sueli. São Paulo como polo dominante do mercado unificado nacional. In: DEAK, C; SCHIFFER, Sueli. (Org.). O processo de urbanização no Brasil. 1 ed. São Paulo: FUPAM/Edusp, 2004.

SEABRA, Odete C.L. Os meandros dos rios nos meandros do poder: Tietê e Pinheiros; valorização dos rios e das várzeas na cidade de São Paulo. São Paulo: Universidade de São Paulo/FFLCH/Departamento de Geografia, Tese de Doutorado, 1987.

Pensando o processo de valorização e a geografia. Boletim Paulista de Geografia, São Paulo: Associação dos Geógrafos Brasileiros, n.66, p.97-103,1988.

SENNETT, Richad. El capitalismo y La ciudad. (trad. Echenique, M. e Saint, A. Cities for the new millennium. London-New York, Spon press, 2001, PP.15-21). In RAMOS, Ángel Martín (ed.) Lo urbano: en 20 autores contemporáneos. Barcelona: Edicions UPC, 2004.

SILVA, J. Borzacchiello da. Espaço e Contradições. In: DAMIANI, A. L.; CARLOS, A. F. A.; SEABRA, O.C.L. (Org.). O Espaço no Fim do Século - A Nova Raridade. São Paulo: Ed. Contexto, 2001.

Os incomodados não se retiram. Fortaleza: Multigraf Editora, 1992.

O Algodão na Organização do Espaço In: SOUZA, SIMONE (Cord.). História do Ceará. Fortaleza: Fundação Demócrito Rocha, 1989.

SILVA, Sylvio B. de Melo e. Turismo e Urbanização in RODRIGUES, Adyr B. (Org.). Turismo. Modernidade. Globalização. São Paulo: Hucitec, 2000.

SMITH, Adam. A Riqueza das nações: investigação sobre sua natureza e suas causas. 3ed. 2v. Lisboa: Fundação Calouste Gulbenkian, 1993. 
SOJA, E. \& HADJIMICHALIS, C. Between Geographical Materialism and Spatial Fetishism: Some Observation on the Development of Marxist Spatial Analysis. Worcester: Antípode, 1979.

SOUZA, M. S. de. Fortaleza: uma análise da estrutura urbana. Guia de Excursão do $3^{\circ}$ Encontro Nacional de Geógrafos, Fortaleza, 1978.

SOUZA, Marcelo José Lopes de. O território: sobre espaço e poder, autonomia e desenvolvimento. In CASTRO, Iná Elias de, GOMES, Paulo Cesar da Costa e CORREAA, Roberto Lobato (orgs.). Geografia: Conceitos e temas $-3^{\text {a }}$ Ed. Rio de Janeiro: Ed. Bertrand Brasil, 2001.

TEÓFILO, Rodolfo. A fome. São Paulo: Tordesilhas, 2011.

TOPALOV, Cristian. Análise do ciclo de reprodução do capital investido na produção da indústria da construção civil: capital e propriedade fundiária, in FORTI, Reginaldo. Marxismo e urbanismo capitalista. São Paulo: Livraria Editora Ciências Humanas, p. 53-80, 1979.

TORRES, Horacio. El mapa social de Buenos Aires (1940-1990). Buenos Aires, (1993).

URRY, J. O olhar turista - lazer e viagens nas sociedades contemporâneas. São Paulo: Studio Nobel/Sesc, 1996.

VILLAÇA, Flávio. Espaço Intra-urbano no Brasil. São Paulo: Studio Nobel: FAPESP: Lincoln Institute, 2001.

VINUESA, Miguel Ángel Troitiño, MARCHANTE, Joaquín Saúl García e HERNANDEZ, Maria García (coords.). Destinos turísticos: viejos problemas ¿Nuevas soluciones?. Cuenca: Ediciones de La Universidad de Castilla-La Mancha, 2008.

YÁZIGI, Eduardo; CARLOS, Ana Fani Alessandri \& CRUZ, Rita de Cássia Ariza da (Org.). Turismo - Espaço, Paisagem e Cultura. São Paulo, Hucitec, 1999.

YÁZIGI, Eduardo. Turismo, Uma Esperança Condicional. São Paulo: Global, 2003 .

\section{DOCUMENTOS CONSULTADOS}

PDDU - AQUIRAZ - (2005)

PDDU - AQUIRAZ - (2011)

Relatório de Impacto Ambiental - Aquiraz Resort - CBPO / Ampla Engenharia 
Anuário Estatístico do Ceará - IPLANCE

Atlas do Ceará 1997 - IPLANCE

Mapa do Município - IBGE

Mapa da Sede - IBGE

Censo Demográfico - IBGE - 2000 - 2010

Enciclopédia dos Municípios Brasileiros - IBGE

Código de Posturas do Município de Aquiraz - 1989

Lei Orgânica do Município - 1989

Lei Municipal no. 002/81 - Parcelamento do Solo do Município

Lei no. 33/84 - Uso e ocupação do solo na faixa litorânea do Município entre a foz do Rio Catu e a foz do Rio Pacoti. 


\section{ANEXO - I}

REFERÊNCIAS SOBRE A PESQUISA DE CAMPO E AS DUAS FASES DAS ENTREVISTAS 


\section{APRESENTAÇÃO}

O presente anexo está organizado em dois blocos. No primeiro, apresentamos um relato sintético sobre os procedimentos preliminares da pesquisa exploratória de campo e no segundo, as duas fases das entrevistas, com os questionários utilizados e suas respectivas transcrições.

O objetivo das entrevistas foi o de proporcionar uma ampliação na compreensão dos movimentos recentes da urbanização litorânea na RM de Fortaleza, a partir da percepção dos agentes imobiliários sobre a produção e apropriação do espaço para o turismo. De modo complementar, procurou-se também reforçar a confirmação da nossa hipótese geral, uma vez que seus resultados devem ser considerados apenas como auxiliares da pesquisa, tendo em vista que toda a argumentação da tese foi formulada e desenvolvida durante a exposição nos dois últimos capítulos que a compõe. 


\subsection{BLOCO - I: A PESQUISA DE CAMPO}

\subsubsection{Os estudos preliminares}

$\mathrm{Na}$ fase inicial da pesquisa, já tínhamos um conhecimento prévio das ocorrências de novos padrões de ocupação no litoral da RM de Fortaleza e precisávamos escolher o recorte espacial mais adequado para responder às questões levantadas. Para isso, retomamos a análise apoiando-nos em imagens atuais de satélites (Google Earth2009/2012), capazes de revelar as alterações mais recentes no litoral metropolitano de Fortaleza.

O objetivo da pesquisa de campo, nesse primeiro momento, foi o de fazer um reconhecimento preliminar para identificar o recorte espacial pretendido e, num segundo momento, o de percorrer o trecho escolhido com a finalidade de mapear as ocorrências mais significativas do fenômeno em foco, inserido na problematização formulada.

Com a análise das imagens de satélite, ficou evidente a escolha do município de Aquiraz, tendo em vista as ocorrências identificadas no loteamento Porto das Dunas, como também no empreendimento Aquiraz Riviera que melhor representam os novos padrões de ocupação litorânea, do ponto de vista adotado.

Depois da escolha do litoral do município de Aquiraz como recorte espacial, percorremos toda a sua faixa de praia, em veículo terrestre, para comparar in loco as ocorrências observadas nas imagens de satélite. Assim, proporcionamos um contato mais direto com as manifestações físicas perceptíveis ao olhar, aproveitando também para registrar as ocorrências mais significativas, em levantamento fotográfico.

Na sequência, já com a definição do recorte espacial escolhido, organizamos o trabalho de campo contando com uma equipe de dois pesquisadores bolsistas, coordenados pelo autor, munidos de uma imagem de satélite atual, impressa em papel e câmera fotográfica. Desse modo efetuamos o levantamento de uso e ocupação do solo, percorrendo todas as ruas do bairro Porto das Dunas, delimitadas por uma área aproximada de cinco $\mathrm{Km} 2$. 
Durante o levantamento de uso e ocupação do solo, identificamos 16 tipos diferenciados de uso predominante para cada edificação levantada, conforme Mapa de Uso e Ocupação do Porto das Dunas apresentado no capítulo 3, utilizado como apoio nas análises efetuadas.

\subsubsection{O conceito de "novo padrão de ocupação"}

Já sabíamos, tanto pela literatura quanto pela observação direta que desde os anos 1970 o litoral da RM de Fortaleza apresentava-se como uma espécie de "transbordamento" da expansão imobiliária da cidade, movida pela implantação de empreendimentos relacionados às residências de veraneio.

Ainda nos anos 1980, o padrão de "casas unifamiliares de veraneio" foi sendo gradualmente substituído pelo de condomínios fechados, tendo em vista as dificuldades com segurança e manutenção. No final dos anos 1990 esse modelo de condomínio foi especializando-se e metamorfoseando-se na direção de um novo padrão que associava as características de hotelaria às do condomínio residencial de lazer. Assim, foram comercializados como novos produtos que ofereciam novas modalidades de serviços turísticos como a administração de unidades residenciais com serviço de "flat" em regime de "pool" ou "cond-hoteís" em regime de "time-sharing", articulados a uma rede de gestão de hotelaria de alcance internacional (como nos casos do Aquaville e do complexo turístico do Beach Park). Nestes, são oferecidos um padrão elitizado de serviços integrados à modalidade de propriedade compartilhada que ora se comporta como hotel e ora como condomínio de segunda residência, ambos compatíveis com a atratividade do padrão de turismo internacional.

Esse tipo de produto foi novidade para o mercado local no final dos anos 1990 e se alinhava aos imperativos do desenvolvimento turístico do Estado que já apresentava a implantação de outros empreendimentos locais e estrangeiros de grande envergadura para a realidade local, inserido em um loteamento de veraneio que se metamorfoseou para um bairro turístico, influenciando toda a dinâmica urbana local. A análise da dinâmica urbana da área em estudo foi detalhada no capítulo 3, mas consideramos oportuna retomar a conceituação de "novo padrão de ocupação", no momento da análise dos procedimentos da pesquisa de campo para que fosse mais fácil à compreensão do objeto de estudo e do seu processo de reconhecimento. 


\subsubsection{Procedimentos preliminares utilizados no trabalho de campo}

Para identificar e caracterizar as ocorrências desse "novo padrão de ocupação litorâneo", lançamos mão inicialmente de recursos baseados na interpretação de dados bibliográficos e estatísticos, análise de imagens de satélite e fotografia aérea, levantamento de campo in loco, como também da análise tipológica dos empreendimentos observados. Nesse caso, utilizamos os referenciais analíticos fundamentados na contribuição formulada por Lefebvre (1980) e revista por Lencioni (2011, p.51) onde pudemos verificar os aspectos diferenciados de sua estrutura (recursos materiais e infraestrutura urbana), forma (plano urbanístico, partido arquitetônico e interiores) e função (programa arquitetônico, uso/ocupação do solo, funções urbanas de alcance metropolitano).

No entanto, esse novo padrão de ocupação se caracteriza, sobretudo, por constituir-se a partir de formas consideradas inovadoras de produção do espaço, mas alinhadas à antiga lógica de acumulação do capital. Assim, estão fundamentadas em novos arranjos institucionais (Estado e mercado); novos arranjos financeiros (fontes de recursos para o financiamento baseado nos investimentos em negócios imobiliário); tecnológicos (associando técnicas convencionais de construção a novas formas de gestão da obra); sociais (de comunicação e marketing), onde o turismo desponta como um diferencial de atratividade de fluxos e recursos. Assim, os novos produtos convertem-se em nicho de mercado e, por conseguinte, em novas oportunidades de negócio. A fonte dessas informações e dados foi colhida de modo complementar, durante a fase de entrevistas, detalhada na seqüência desse bloco.

Antes de partir para o levantamento de campo, trabalhamos com a idéia de identificar uma variável referencial que particularizasse esse novo espaço urbano litorâneo: $a$ ocorrência dos meios de hospedagem na RMF, como possibilidade de considerarmos uma suposta "zona de influência turística" com vistas a futuras interpretações das suas relações com o imobiliário.

Partindo da análise dos indicadores turísticos 1995/2010 publicados pela SETURCE (2010) ${ }^{1}$ elaboramos uma tabela da oferta hoteleira da RMF, considerando todos os

\footnotetext{
${ }^{1}$ http://www.setur.ce.gov.br/categoria1/arquivos-do-estudos-e-pesquisas/Indicadores\%202010.pdf (acesso em agosto de 2011)
} 
meios de hospedagem (hotéis, pousadas, flats e albergues) para termos uma idéia preliminar da dimensão da pesquisa de campo.

No entanto, foi o cadastro dos meios de hospedagem elaborado pela SETUR (2010) que nos forneceu as informações necessárias para desenvolver um mapa mais preciso da localização da oferta hoteleira na $\mathrm{RMF}^{2}$ que teve como objetivo, dar uma visão da espacialização dos meios de hospedagem na RMF e orientar o roteiro do trabalho de campo na escolha dos trechos percorridos em transporte terrestre.

$\mathrm{O}$ conceito de zonas de influência turística pode ser entendido como a área sujeita às atividades relacionadas ao turismo e tem a finalidade apenas de delimitar o espaço onde possivelmente se manifesta o nosso objeto de estudo: no nosso caso, o novo padrão de ocupação litorânea decorrente do desenvolvimento da atividade turística verificado na RM de Fortaleza a partir dos anos 1980. Sua caracterização se dá, sobretudo, por apresentar-se intimamente articulado à produção imobiliária destinada aos mercados local e global, constituindo-se em uma das vertentes da reestruturação metropolitana de Fortaleza.

A influência dos meios de hospedagem no espaço urbano litorâneo confere atributos capazes de dar um novo significado ao espaço, seja pela diversificação ou intensificação de usos provocada pelas inúmeras interfaces relacionadas com a atividade turística.

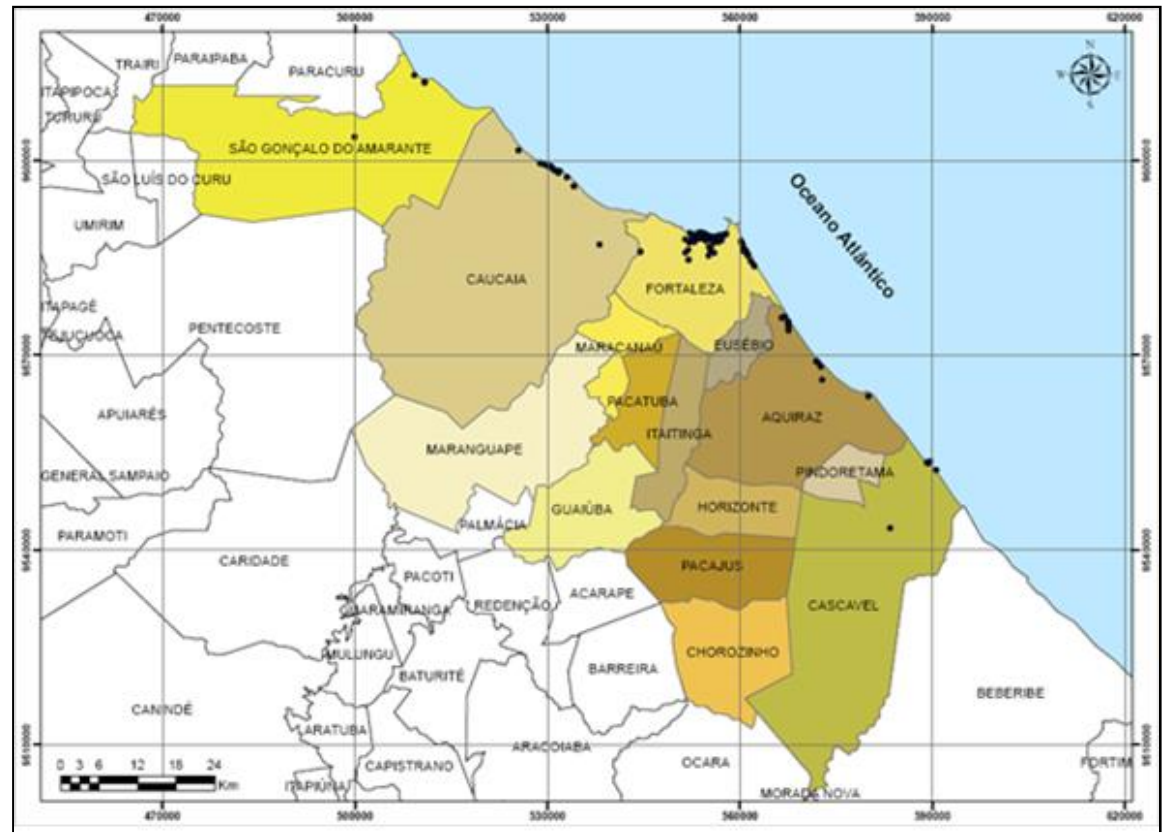

Mapa 1 - Oferta Hoteleira na RMF: Elaborado pelo autor, baseado em SETUR-2010.

\footnotetext{
${ }^{2}$ A elaboração dos mapas contou com a colaboração do Laboratório de Cartografia do Departamento de Geografia da UFC.
} 
No mapa, acima, podemos constatar a preferência de localização dos meios de hospedagem na faixa litorânea da RMF, com maior ocorrência no Município de Fortaleza, seguidos por Aquiraz e Caucaia, municípios vizinhos, afetados principalmente pela proximidade com a capital.

Embora o município de Aquiraz apresente um número de meios de hospedagem um pouco menor que o de Caucaia, o primeiro possui a particularidade de localizar-se a Leste de Fortaleza, mais próximo de sua zona de expansão imobiliária, de maior valorização. Esse fator acaba influenciando a expansão imobiliária que tende a se intensificar nos próximos anos, caso sejam aprovados os novos empreendimentos articulados ao turismo, em fase de licenciamento. Esse fator, associado às ocorrências já implantadas no Porto das Dunas, nos conduziu a escolher Aquiraz como foco de nossa pesquisa pelo fato deste recorte apresentar, de maneira mais evidente, os novos padrões de ocupação litorânea, embora também ocorram nos demais Municípios da RMF, de modo menos concentrado. A Tabela 1, abaixo, complementa as informações do Mapa 1, onde verificamos a importância dos municípios limítrofes a Fortaleza no que diz respeito à oferta hoteleira, como também ao fluxo turístico.

Tabela 1 - Oferta de Meios de Hospedagem na RM de Fortaleza

\begin{tabular}{llllr}
\hline \multicolumn{1}{c}{ Municípios } & $\begin{array}{l}\text { Meios de } \\
\text { hospedagem }\end{array}$ & $\begin{array}{l}\text { Unidades } \\
\text { Habitacionais }\end{array}$ & Leitos & \% Leitos \\
\hline \multicolumn{1}{c}{ RMF } & 312 & 11.395 & 36.174 & 100,00 \\
Fortaleza & 199 & 10.585 & 26.988 & 74,61 \\
Aquiraz & 32 & 1.143 & 3.503 & 9,68 \\
Cascavel & 08 & 182 & 483 & 1,34 \\
Caucaia & 39 & 1.368 & 3.554 & 9,82 \\
Chorozinho & 01 & 16 & 48 & 0,13 \\
Eusébio & 01 & 05 & 10 & 0,03 \\
Guaiúba & 01 & 28 & 74 & 0,20 \\
Maranguape & 08 & 74 & 271 & 0,75 \\
Pacajus & 02 & 44 & 102 & 0,28 \\
Pacatuba & 01 & 15 & 50 & 0,14 \\
São Gonçalo & 31 & 391 & 1091 & 3,02 \\
do Amarante & & & & \\
\hline
\end{tabular}

Fonte: SETUR-2010 
Após o levantamento dos meios de hospedagem, procedemos a uma série de visitas exploratórias de reconhecimento dos trechos delimitados pela "zona de influência turística". Assim, percorremos todo o litoral da RM de Fortaleza no intuito de identificar mudanças significativas capazes de serem caracterizados pelos novos padrões de ocupação. Desse modo, foi possível identificar a ocorrência de empreendimentos imobiliários associados a equipamentos turísticos, em todo o litoral da RMF, especialmente no litoral de Aquiraz, onde ela se manifesta de modo mais agudo e diversificado.

Escolhemos, portanto, aprofundar a pesquisa no Município de Aquiraz pelo fato de termos constatado uma maior incidência desses novos padrões de ocupação e estruturação urbana, tanto no loteamento Porto das Dunas, como também na praia da Marambaia, no mesmo Município, local onde foi implantada a primeira etapa do Empreendimento Aquiraz Riviera. Caso seja liberada a prorrogação da sua licença ambiental para construção, ele poderá ser um dos maiores empreendimentos turísticos atrelados ao imobiliário no Brasil, com um investimento orçado em US\$ 350 milhões.

No entanto, verificamos também que ocorre fenômeno semelhante no litoral Oeste da RMF, na praia do Cumbuco, no vizinho Município de Caucaia que se destaca como um dos maiores destinos turísticos litorâneos da RMF, seguido por Aquiraz e São Gonçalo do Amarante.

O resultado final do nosso levantamento de campo pode ser verificado no mapa de uso e ocupação do solo do Porto das Dunas, no Capítulo 3. 


\subsection{BLOCO II - AS DUAS FASES DAS ENTREVISTAS}

\subsubsection{Aspectos introdutórios: os critérios de seleção dos entrevistados}

A primeira fase das entrevistas foi de caráter exploratório, cujo questionário, foca aspectos que buscam revelar a perspectiva de cada entrevistado. Teve como objetivo, captar a percepção dos agentes sobre alguns fatores considerados relevantes, dentro da problemática levantada. Foram desenvolvidas entre agosto e outubro de 2011 e voltadas a duas categorias: o setor público e o privado (o Estado e o Mercado).

No setor público escolhemos duas secretarias de governo: a Secretaria de Turismo do Estado do Ceará e Secretaria Municipal de Desenvolvimento Urbano e Meio Ambiente de Aquiraz. No setor privado, focamos os associados da ADIT/NE - Associação para o Desenvolvimento Imobiliário e Turístico do Nordeste que reúne vários representantes relacionados ao objeto de estudo. Entre eles, escolhemos um consultor em Arquitetura e Urbanismo, um consultor em finanças e negócios imobiliários e o vice- presidente regional da ADIT/NE. Este último é também o vice-presidente local da Câmara de Comércio Brasil-Portugal e diretor do empreendimento Aquiraz Riviera, representante português do grupo de investidores.

Os outros setores que compõem a ADIT/NE relacionados à construção civil e ao projeto arquitetônico e urbanístico foram entrevistados na segunda fase. Esta foi composta por um questionário de perguntas semiestruturadas, permitindo respostas abertas a pontos mais específicos relacionando os novos produtos às novas formas de produção da construção civil. Entre eles: dois escritórios de arquitetura e duas construtoras considerados os mais atuantes no local pesquisado. Nesse caso o questionário foi apoiado na nossa hipótese geral: a ação dos agentes imobiliários responde à reorganização de um novo processo de produção, diante da necessidade de incorporar novos territórios à lógica de reprodução do capital. Ambas, aplicadas entre novembro e dezembro de 2011. 


\subsubsection{Os questionários e as transcrições da primeira fase de entrevistas: o setor privado}

\section{ENTREVISTA 1:}

AO DIRETOR DO EMPREENDIMENTO AQUIRAZ RIVIERA (VICEPRESIDENTE DA ADIT/CE E VICE-PRESIDENTE DA CÂMARA DE COMÉRCIO BRASIL-PORTUGAL) - 12/10/12

\section{A) QUESTIONÁRIO DE PERGUNTAS:}

1. Em que contexto nasceu à ideia do empreendimento? Como definiria o empreendimento Aquiraz Riviera e a que público se destina?

2. Como pode ser entendida a composição dos agentes participantes da operação do empreendimento: o Governo do Estado e Município, investidores (nacionais e internacionais), incorporadores, proprietários de terra, construtores, corretores, operadores de turismo, administração hoteleira, mercado potencial de compradores das unidades (pequenos investidores/usuários-turistas), sociedade local, força de trabalho (existem outros?);

3. Como o Senhor vê os maiores desafios do setor hoteleiro no contexto atual? Qual a sua opinião sobre o sistema de tempo compartilhado de férias ("Time Sharing") no Brasil e no exterior?

4. Quais as características principais da estratégia comercial original. Houve mudanças na estratégia de comercialização das unidades? Quais foram as medidas tomadas para o atendimento das novas demandas identificadas?

5. Como o Senhor vê a questão do meio ambiente: um entrave ou um aliado?

6. Quais foram as tecnologias de construção propostas preliminarmente e suas mudanças, caso tenha havido necessidade de alterá-las devido a sua relação com a mãode-obra local e materiais construtivos utilizados? 
7. Qual a sua visão sobre a lógica sugerida pelo projeto urbanístico e arquitetônico dos empreendimentos (hotéis, conveniências e vila turística): programa de atividades (compartimentos e ambientes propostos pelos projetistas), fluxo de funcionamento, manutenção, adequação aos usuários, conforto ambiental, etc. Já é possível fazer uma avaliação pós-ocupacional preliminar?

8. Outras que possam surgir dentro do debate.

\section{B) TRANSCRIÇÃO DA ENTREVISTA 1}

\section{Em que contexto nasceu a ideia do empreendimento? Como definiria o empreendimento Aquiraz Riviera e a que público se destina?}

\section{Resposta:}

Há dez anos quando o mundo andava naquela loucura do crédito fácil em que tudo que se construía se vendia: em que havia um contexto de exagero, como sabe, sobretudo no sul de Espanha e Sul de Portugal. Os Irlandeses compravam com taxas de juros a 2\%, os ingleses compravam sem ver e, portanto, nesse seguimento havia um modelo de desenvolvimento imobiliário e turístico no mundo que considerava que o Nordeste do Brasil tinha e tem um grande potencial e os vários grupos portugueses, espanhóis e outros começaram a procurar, nesse momento, terrenos que eram baratos: o barato às vezes sai caro, mas era barato e, portanto, junto ao mar e o Brasil e o Nordeste tinham as condições ideais para manter uma ocupação turística ao longo de todo o ano porque não há grandes variações climáticas e, portanto, foi um pouquinho replicar o modelo de desenvolvimento que já existia na Europa e até nos EU.

\section{O modelo do Master Plan}

Tendo dito isto, então, o objetivo era criar um modelo de qualidade de padrão internacional em que houvesse uma envolvente de elementos turísticos, lazer, lúdica, golfe, tênis, praia e a imobiliária para alavancar toda essa construção de infraestruturas. 
O modelo é um pouquinho isso, o campo de golfe que valoriza também a parte imobiliária porque, enfim, dá um paisagismo de frente, diminui muito e reduz a densidade de construção no terreno que é importante, neste caso, até ficou agradável. E não, ir atrás daquele modelo de hiper desenvolvimento como é o de Cumbuco, Icaraí, ou como fizeram no sul de Espanha, em Mader, ou fizeram no Sul de Portugal, em Albufeira e outros modelos de desenvolvimento rural, horríveis que destruíram, no meu entender, a costa e que por falta de planejamento e também a especulação imobiliária e o dinheiro da corrupção que corre nos municípios, como poderia dizer: o que muda é o sotaque (risos) e no mundo inteiro é sempre igual. Se houvesse cuidado com um planejamento urbano cuidadoso, portanto, e se fosse possível proibir a construção aqui ou ali, mas não e acaba por ser toda essa bagunça.

Portanto, é realmente importante que se possa fazer uma estratégia. Os latinos, nós não somos assim grandes seguidores do planejamento (risos). Planejamento não é exatamente o nosso forte. E, portanto, o que se pretende com o Aquiraz Riviera é uma coisa bonita, integrada, já que são 300 ha e ele, felizmente, estar a ser um sucesso que você já foi visitar e, portanto, há um equilíbrio, não é? Há equilíbrio e nós temos uma grande preocupação no futuro com os contratos que fazemos com os incorporadores em fazer uma coisa equilibrada, para não fazer nenhum monstro de concentração urbana que não faz sentido, é horrível, feio e tal.

E nossa própria opção pelo turismo e eu, em particular, toda a vida tive no turismo, fui sempre um inimigo do excesso de construção porque acho que é um erro estratégico, poderá ser um lucro imediato, mas, em médio prazo e longo prazo, as gerações que vêm não se beneficiam, portanto eu vejo muito o negócio também numa ótica social, que é o que tem a ver, não é? E não só dois anos, mas a ver: a vinte, a trinta, a quarenta porque os modelos de desenvolvimento, como sabe, têm aqueles ciclos de vida e os ciclos de vida se não forem previstos com tempo, morrem, matam e destroem, portanto, é um pouquinho a ideia do Aquiraz Riviera, pensado neste conjunto de vertentes, não é? Para equilibrar o modelo do master plan que foi a base do trabalho.

\section{O público alvo}

Naquele momento os europeus tinham muito dinheiro, o real estava desvalorizado e os brasileiros eram os pobrezinhos, (risos) hoje os brasileiros são os ricos e os europeus os 
pobrezinhos, os brasileiros gastam seis bilhões de dólares no estrangeiro e todo o mundo quer aprender a falar o português (risos). E realmente, no início, era o mercado internacional porque eles vinham aqui e compravam uma casa por tostões. Era tudo barato. Depois os nossos compatriotas quiseram ter férias no Brasil porque era tudo barato, mas em reais e não em euros: são aqueles momentos, fases da vida, (as conhecidas disparidades cambiais momentâneas) que faziam realmente do mercado internacional o nosso público alvo.

\section{A mudança da estratégia comercial com vistas ao público local}

Daí, em 2007 iniciou-se a construção. Já estou aqui direto há sete anos, convidado pela empresa, faço agora sete anos no Ceará, só vou de férias. Não saio daqui e, portanto em 2008, começamos a intensificar o ritmo de construção, compra de cimento, estabilidade, controle inflacionário, enfim, sentia-se que tudo isso começava a ter um movimento muito positivo e as pessoas começavam a investir mais na imobiliária, tudo isso, e eu considerei que deveríamos ter uma condução total de estratégia, de marketing, naquele momento trabalhando com o Ricardo Bezerra que hoje é o dono aqui da Lopes Immobilis, consertarmos uma estratégia que funcionou muito bem em 2008, nós começamos a vender ao mercado local e tivemos sucesso na venda para o mercado local.

\section{A orientação da compra para uso e não como investimento especulativo}

Embora o golfe seja algo desconhecido no Ceará, algumas pessoas compraram, numa questão de investimento, de especulação o que é um erro. Eu sempre disse que nós não estávamos aqui a vender metro quadrados, mas a vender qualidade de vida, é completamente diferente: em que haja um organismo equilibrado, em que haja zonas verdes, que o paisagismo, neste aspecto é fundamental, é prioridade. Se você for lá, vai ver que tivemos um cuidado muito grande de desenvolver o paisagismo, estamos a investir muito naquelas rotatórias, nas vias laterais, viveiros de plantas, coisa que ainda é a conservação da natureza e ao contrário do que dizem os ambientalistas, eu acho que o projeto está perfeitamente equilibrando o desenvolvimento com a preservação ambiental. Não é também ter aquela posição radical porque tudo que é feito destrói e é errado. Esquecem que há também um aspecto social que é o desenvolvimento humano. 
Os ambientalistas, em certo momento, esquecem que há seres humanos e que eles fazem parte da natureza, não é? (risos).

Foi essa, a estratégia inicial, alterada para o mercado local e assim está, para o mercado local e bem. Tivemos sucesso. Mesmo as incorporações que vieram da Mota Machado fez sucesso, a Manhattan eu acho que foi apressada demais, pensávamos que era ao gosto do mercado local, mas acho que a arquitetura ficou um bocado de lá (sic). Tem que ter muito cuidado em não deixar criar um senso de um movimento para trás.

2. Como pode ser entendida a composição dos agentes participantes da operação do empreendimento: o Governo do Estado e Município, investidores (nacionais / internacionais), incorporadores, proprietários de terra, construtores, corretores, operadores de turismo, administração hoteleira, mercado potencial de compradores das unidades (pequenos investidores/usuários-turistas), sociedade local, força de trabalho (existem outros?);

\section{Resposta:}

No momento em que eu ainda não estava aqui, houve uma composição de pessoas inteligentes e de visão, que entendiam que se você atua em qualquer trecho que não é o seu, que você não conhece, que você não tem os contatos políticos, que não conhece o terreno, que não conhece a mentalidade (sic)...(você precisa ter um parceiro local). Sim, porque alguns de meus compatriotas confundem que o fato de falarmos todos nós o português e gostarmos de bacalhau, temos as mesmas crenças e não temos. Nós temos as nossas características culturais que são de lá. O Brasil idem no mesmo sentido. Além disso, o Brasil é um conjunto diferenciado de regiões: portanto o Nordeste tem uma forma de ver e fazer negócios, o Sul tem outra forma, São Paulo tem outra: então são várias realidades. E, portanto, a visão foi muito correta de procurarem aqui um terreno e um parceiro local que abrisse as portas e que nos desse uma ajuda, dizendo: olha, não é por aqui, é por ali, aquilo não é assim...ah, não! Ele está em Portugal, mas nós 
resolvemos. E foi o Senhor Ivens $^{3}$ o nosso parceiro. Com o Senhor Ivens, não poderíamos ter encontrado um melhor sócio, não só pela dimensão e capacidade empresarial, do Senhor, como também pela sua seriedade, do nome que ele tem e, portanto, curiosamente ele é um empresário que admiro muito porque tem uma grande preocupação social. As pessoas não sabem, talvez, mas uma das grandes preocupações que ele tem é a responsabilidade que ele diz ter com as cinquenta mil pessoas que são as famílias de todos os seus funcionários e, portanto foi uma parceria boa, tem sido muito feliz, teve uma muito boa interação.

Eu represento os interesses do grupo português, tem um colega meu que é o coronel Romero que é o presidente do grupo do Senhor Ivens e assim temos andado, é uma sociedade de $50 \%$ que tem corrido bem. Uma sociedade de $50 \%$ poderia ser complicada, mas no nosso caso não, no nosso caso tem funcionado bem, tem havido uma seriedade. Aliás, os nossos empresários também, além do Saviotti ${ }^{4}$ e do grupo Violas ${ }^{5}$, portanto, não são exatamente pequenos empresários. Todos eles são grupos com muita capacidade financeira. Tem que ser porque nós, ao contrário de alguns outros empreendimentos, nós investimos antes e vendemos depois.

É só ver, exato, a rede viária que temos lá: está para todos os lados. É um investimento de milhões de reais e, portanto, é muito dinheiro por que são $17 \mathrm{~km}$ de rede viária, 17 $\mathrm{km}$ de dutos que levam suprimentos elétricos, esgotos, água, tudo. E isso custa muito dinheiro, né?. O paisagismo: só de plantas foi dez milhões de reais, tudo isso para criar uma área agradável e permitir as vendas em cima de uma realidade e não em cima de um papel. Isso é uma preocupação de todos os empresários.

\section{Sobre a composição do aporte financeiro}

\footnotetext{
${ }^{3}$ Ivens Dias Branco - Presidente da M. Dias Branco - Fabricante de massas e biscoitos foi considerado pela revista Exame a maior fortuna do Nordeste e a nona do Brasil (http://exame.abril.com.br/revistaexame/edicoes/1013/noticias/a-maior-fortuna-do-nordeste) - acesso em 07/12/2011

${ }^{4}$ Presidente do grupo de Hotéis Dom Pedro, composto por oito hotéis quatro e cinco estrelas em Portugal, Madeira e agora, no Brasil, implantou mais um inserido num projeto turístico considerado um dos maiores da AL, (http://www.dompedro.com/DomPedro/Empresa/Hist\%C3\%B3ria/tabid/640/Default.aspx)-acesso em $07 / 12 / 2011$.

${ }^{5}$ O Senhor Manuel Violas, filho do Comendador Manuel Violas (falecido em 2011) que fundou as empresas Corfi e Cotesi e esteve ligado à privatização da UNICER e à criação do grupo Solverde e do banco BPI, considerada uma das maiores fortunas de Portugal (http://www.rtp.pt/noticias/index.php?article=511192\&tm=6\&layout=121\&visual=49) acesso em 07/12/2011.
} 
O banco português já não é mais o Boa Vista, agora é um fundo imobiliário: o Ceará Invest Fund: formado pelo grupo Violas, um dos maiores de Portugal, e pelo grupo do Senhor Stefano Saviotti que é um empresário do turismo que tem uma rede de hotéis, tem empresas imobiliárias, há trinta, quarenta anos que vive em Portugal e, portanto, eles são parceiros há muitos anos.

\section{Sobre a participação do Estado do Ceará.}

Bom, numa certa altura, isso já tinha sido negociado com o governo, numa primeira fase, já fechada, que foi o protocolo de ações, ainda no governo do Tasso Jereissati ${ }^{6}$, quando se definiu as coparticipações em que o Estado entraria com as infraestruturas (externas) e os investidores privados com a parte interna. Isso depois veio a ser assinado e concluído no Governo do Lúcio Alcântara ${ }^{7}$. E deram início às obras ainda no governo do Lúcio Alcântara, mantendo os compromissos feitos no governo do Tasso. O $\mathrm{Cid}^{8}$ quando veio, manteve o compromisso inicial do protocolo de intenções, portanto o Estado tem tido um linha de comportamento correta, em relação ao que foi combinado inicialmente, embora de outros partidos, como um novo passo, portanto, e tem sido positivo. Como você sabe que na política aqui, é deficiente, a máquina administrativa do Estado aqui, mas não é só aqui, mas aqui é mais complicado, não é? [...] ${ }^{9}$ Mas, com atraso, tudo tem ido avançando, não é? Caminhando corretamente.

\section{Como o Senhor vê os maiores desafios do setor hoteleiro no contexto atual ? Qual a sua opinião sobre o sistema de tempo compartilhado de férias ("Time Sharing") no Brasil e no exterior?}

\section{Resposta:}

Os desafios que nós temos aqui são vários, eu acho. O nosso mercado de Resorts é um mercado interno para brasileiros e é normal que seja agora para cidadãos que

\footnotetext{
${ }^{6}$ No seu segundo mandato entre 1995-1999

${ }^{7}$ No seu último mandato (2003-2007).

${ }^{8}$ No seu primeiro mandato ( 2007-2011)

${ }^{9}$ Inaudível
} 
ascenderam das classes médias e querem viajar, querem lazer e fazer turismo. Neste meio, nós temos dois fatores que para mim são complicados para hotelaria de resort no nordeste brasileiro: é o dólar que estando baixo, portanto, torna a cena do mercado do turismo brasileiro com os EU muito competitiva. A conversão da moeda cria dificuldades.

\section{A concorrência dos cruzeiros internacionais}

A concorrência também dos cruzeiros é cada vez mais forte porque ela vai realmente roubar uma fatia do mercado da hotelaria tradicional. Eles oferecem parques fantásticos, serviços e gastronomia fantástica e, portanto, é uma concorrência muito forte. E a hotelaria tradicional tem que se adaptar e neste momento, portanto, o crescimento dos investimentos na área dos hotéis resorts desapareceu.

\section{O imobiliário como alavancagem do investimento em hotelaria}

Temos aqui o Vila Galé, amigos nossos, que fizeram um hotel muito elevado e muito simpático, mas estamos com alta dificuldade de pegar e adicionar outros investidores em hotéis, porque o hotel é um investimento alto, mas o pay-back (retorno) é lento, é baixo. Se não fizermos uma alavancagem imobiliária, que possa mudar e também trabalhar com time-sharing. Se não tiver alguma forma de, pela via imobiliária criar as condições de alavancar o investimento, é difícil. É difícil porque se você vai gastar 40 a 50 milhões para ter um retorno em 15 anos: é lento. Então não é fácil.

\section{$O$ custo brasileiro de manutenção do hotel $x$ a sofisticação internacional}

Depois, vêm outras discussões o custo brasileiro de um hotel resort torna menos competitiva em relação ao caribe e ao próprio EU. Antes do Brasil, eu estive em Cuba, a dirigir um conjunto de hotéis alemães em Cuba e na Dominicana. Os custos lá são comparáveis aos nossos, mas não podemos comparar em sofisticação.

\section{A falta de um planejamento estratégico concreto}

Mas o fato é que você aqui tem clima, tem bons hotéis. Como o turismo é a sua principal prioridade, pela falta de recursos econômicos que ofereçam alternativas, portanto, deveríamos ter uma aposta nos investimentos em turismo, aposta no treinamento dos funcionários, aposta na criação de infraestruturas aeroportuárias e de 
hotelaria para o turismo. Nós aqui não temos feito isso. Nós aqui não temos tido um estratégia, não é uma estratégia de desenvolvimento do turismo para o Nordeste. Não existe um plano. Fala-se de um plano, mas depois não há uma concretização.

\section{A falta de interesse em elaborar políticas públicas coerentes}

O Brasil não precisa do turismo para sobreviver, embora o turismo seja um meio de desenvolvimento muito forte e, sobretudo, no nordeste que traz uma forma de emprego rápida, e de inserção social. O turismo tem muito mais capacidade de poder dar muito emprego a pessoas mais do que tem uma termelétrica ou então na siderurgia que é tudo automático no parque industrial e exige investimento.

Mas o fato é que o Brasil com toda a sua riqueza entrou em vários negócios e não temos sentido que o turismo seja um fator tão importante assim para o seu desenvolvimento porque não teve políticas públicas coerentes, sobretudo com a sua relação com os ambientalistas.

\section{As preocupações ambientais e a falta de entendimento mútuo}

Então, quer dizer, ninguém se entende nessa área, né? Uns dizem que sim outros dizem que não. Depois um procurador aqui diz que nós somos uns bandidos que viemos aqui destruir a costa e o litoral.

Eu entendo as preocupações ambientais, mas vocês deveriam definir (sic). Quando digo vocês, me refiro ao Estado brasileiro, os ambientalistas, e os "players": governo, Ministério Público, etc. deviam ter uma visão conjunta e estratégica para definir o que pode e o que não pode e onde pode e onde não pode, porque assim era mais fácil para todo mundo.

\section{A mudança nas regras do jogo no licenciamento ambiental}

O que acontece é que o investidor vem e alguém diz a ele: aqui pode. E aí ele começa e daí o Ministério Público diz: não, aqui já não pode. Como não pode, eu não já tenho uma licença? E vão mudando as regras do jogo, à medida que as coisas vão acontecendo: isso é impossível.

E dizem que todos os empresários são uns malandros e bandidos. É uma visão ideológica que para mim é discutível (risos) porque há empresários malandros como 
também há comunistas malandros porque eu já conheço o que é malandragem no governo comunista, não é?

O que é desrespeito aos direitos humanos, o que é o roubo, a corrupção, não é? Só porque são comunistas, é gente séria? Os mocinhos? E os empresários, os bandidos. Isso dá uma visão radical dessas questões.

\section{As potencialidades e riqueza do turismo equilibrado}

Eu sou um homem do turismo. O que eu posso dizer é que o turismo, o setor do turismo é um motor muito grande de desenvolvimento. Desde que seja bem feito, é um motor que pode manter as redes culturais, históricas e sociais, porque elas se integram.

Quem viaja gosta de ver o que as pessoas daquele país são, quais são as redes culturais: o que é o folclore, o artesanato. As pessoas gostam disso, porque quem viaja quer ver o diferente.

Eu não viajo para ser servido pelo Mc Donald's. Quando venho aqui quero ver a gastronomia local. Quem chega a Lisboa quer ver a Baixa Pombalina, quer ver aquela cidade linda antiga, quer ver a gastronomia portuguesa.

\section{O turismo e os "desastres" urbanísticos}

Você sai de Lisboa e vê um horror de arquitetura que é aquela cidade dormitório que, para mim, destruíram a cidade de Lisboa com aquele crime terrível de arquitetura, que foi feito uma monstruosidade e não só em Lisboa, mas em outras cidades como aquele cinturão industrial a volta de Madrid. Não é um ícone urbanístico porque a concentração urbana cai naquela mesma discussão. Mas isso tem tudo a ver com a crítica às estratégicas públicas.

\section{As condições favoráveis do Nordeste brasileiro e a falta de vontade política}

Aqui eu acho que nós temos condições extraordinárias. No mundo, não há muitos locais como o Nordeste brasileiro, no Ceará, para desenvolver um produto turístico de bom nível internacional. Agora tem que ver a vontade política, não é?

\section{A culpa dos resorts e a dependência do imobiliário}


E estrutural e tem que haver (sic) não pode condenar à morte o desenvolvimento dos resorts, pois. Os resorts são os culpados de tudo. Não são, são, não são (sic). Depende de como a pessoa faz. Tudo tem que ver isso.

É só fazer uma boa arquitetura equilibrada [... ${ }^{10}$, mesmo que envolvidos em imobiliária. E a imobiliária, eu vejo, ao longo dos anos, do ciclo de vida do produto (sic). Você tem alguns empreendimentos turísticos no sul de Portugal e Sul de Espanha que não tem havido crise. Não há crise neles. Você tem a Quinta do Lago ${ }^{11}$, no Algarve, ao Sul de Portugal, por exemplo. Por quê? Foram feitas mais ou menos em equilíbrio, com alto padrão de qualidade, interação ambiental, com paisagismo, com pouca densidade que são produtos que vão se mantendo ao longo dos anos.

\section{A falência do modelo adensado e sem manutenção}

Mas o cara que faz apartamento em cima de apartamento, o Icarai ${ }^{12}$, é um exemplo típico de localidade que ninguém vive lá. Só vai passar de duas a três semanas por ano e depois ninguém quer pagar o condomínio porque acham caro e daí começa a cair e cair. Aí você passa a ter cidades fantasmas de turismo que só são ocupadas duas semanas. É obrigado a fazer investimentos brutais em infraestruturas para uma ocupação de um mês por ano: o que não justifica. Então desequilibra todo o produto, não é?

\section{A replicação do modelo adensado no mundo}

Porque eu acho que é uma falta de visão estratégica, que não há, muitas vezes. E esse é um problema que você vai encontrando em desenvolvimento do turismo em muitos locais do mundo. Não são só os portugueses que fizeram, mas os espanhóis, os franceses na Cote d'azur, também fizeram em certo momento, os marroquinos também, um excesso de desenvolvimento também, começando aquela loucura e o Marrocos também é uma coisa lindíssima, Marrakesh, Agadir. Os turcos também vão. É raro

\footnotetext{
${ }^{10}$ Trecho inaudível e sintetizado pelo autor

${ }^{11}$ Empreendimento constituído em 1972, com 645 ha. Integrando moradias de luxo, campo de golf, pinhal e lagos, vizinho ao parque natural da Ria Formosa e ao oceano.

12 Localidade praiana no Município de Caucaia - RMF, implantado nos anos 1970 e que atingiu altas densidades construtivas, como praia da população de classe média. É muito frequentado em períodos de férias e feriados também pelos setores populares de média- baixa renda.
} 
encontrar um modelo de desenvolvimento que mantenha certa disciplina. Você tem, por exemplo, algumas ilhas ali na África que mantiveram e tem se mantido, porque o sistema político é restritivo de construção e age muito bem e esse modelo de desenvolvimento tem se mantido.

\section{A opção do time-sharing}

Agora, em termos da realidade de hoje, falando em "time-sharing". Eu não condeno, eu nunca condeno "time-sharing". Eu acho "time-sharing" ou "fractional" um modelo de comercialização que pode ser interessante, desde que seja bem gerido. Mas o timesharing só tem sucesso se for gerido por grupos atuantes. Porque no fundo é uma forma de ocupação hoteleira, não é? E tem que ter um gerenciamento da reserva, do serviço, da limpeza do apartamento, da refeição, da manutenção do edifício que tem que ter o hoteleiro que faz esse tipo de trabalho que faz parte do seu "metier". É um pouquinho a visão que eu tenho do que é o "time-sharing" bom. Como também tem o "time-sharing" ruim, como tudo na vida.

Você tem dois grandes grupos que fazem as trocas que é o RCI e o Interval International: esses fazem as trocas, não é? Agora, você tem algumas cadeias hoteleiras como: a Four Seasons a Hilton que têm desenvolvido produtos de "time-sharing" de muita qualidade. Mas a RCI e a Interval trabalham com as trocas prontas.

\section{Quais as características principais da estratégia comercial original. Houve mudanças na estratégia de comercialização das unidades? Quais foram as medidas tomadas para o atendimento das novas demandas identificadas?}

\section{Resposta:}

É possível que haja uma alteração, mas não vejo em curto prazo. Talvez em médio prazo, não é? Portanto, as casa nós vendendo muito bem para o mercado local. Vendemos vivendas, apartamentos, etc. Mas quem sabe daqui para frente se não aparece chineses ou outros povos, outras áreas de investidores que queiram investir. É difícil prever. 
Eu vejo o Aquiraz com olhos muito positivos. Eu penso como uma qualidade. $\mathrm{O}$ empreendimento vai acabar por ter uma grande aceitação no mercado nacional e internacional, porque nós temos tido esse cuidado de manter uma disciplina ambiental e de paisagismo e não deixarmos fazer qualquer coisa ali. As casas, vamos obrigar que haja uma disciplina para não fazer coisas horríveis, desequilibradas (sic).

\section{Os novos polos emissores de turismo}

Agora, o grande polo emissor é interno. O grande turismo agora é o interno. Nos EU, você vê que o turismo interno é colossal. Você tem lá o turismo internacional na Flórida, Orlando, Miami, NY. Mas a grande força é o turismo interno. E eu aqui acredito que o grande forte é o turismo do Sul e Sudeste que vai mais e mais encher os hotéis com turistas brasileiros. Os estrangeiros são meia dúzias. Eu acho que a percentagem vai ser sempre a de mais de $80 \%$ brasileiros. Os hotéis, este ano, estiveram cheios de brasileiros do Sul, SP. Mas as compras de Unidades, no Aquiraz Riviera, são sempre de cearenses, locais.

\section{Como o Senhor vê a questão do meio ambiente: um entrave ou um aliado?}

\section{Resposta:}

Eu recebi uma carta da SEMACE, há dois dias, a falar do golfe. Eles querem um plano estratégico para os próximos cem anos, no caso de uma corrupção do golfe. São exageros. Eu acho que são burocratas (risos). Se vai haver mudanças climáticas, se vai haver recursos (sic). Como é que eu posso adivinhar? (risos). São exageros.

É claro que tem que haver regras bem concretas do desenvolvimento, sem agredir o meio ambiente. Também não podemos dizer que nada se possa fazer e manter o ambiente preservado como estava há mil anos. Tem que haver o equilíbrio. E esse equilíbrio é que, muitas vezes, é difícil de conseguir entre a visão do empreendedor e a visão do ambientalista conservador.

Esse equilíbrio, muitas vezes, falta, não é? Ou de um lado ou do outro. É aí que tem que haver uma melhoria, com certeza absoluta, nessa nova legislação e discussão. É que a 
questão ambiental, aqui, tem que estar acompanhada e não radicalizar com tudo e por tudo.

\section{A (falsa) questão dos enclaves}

Os ambientalistas sempre tocam no ponto dos resorts serem verdadeiros enclaves inseridos na comunidade local. Como é que são enclaves, se eu vou ter aqui quatro mil e quinhentos funcionários. Mas o empreendimento tem que ter segurança, se não (risos) vamos ter assaltos todos os dias. É uma realidade social, atual e tem que fazer.

Você desenvolve os hotéis e vai haver muita gente a trabalhar aí, portanto. E Aquiraz? Aquiraz tem 65 mil pessoas. E na sua grande maioria são jovens de 15 a 20 anos. Se não houver um desenvolvimento de qualquer coisa que possa empregar e dar ocupação a esses jovens. O que é que está havendo com esses jovens? Eles não têm oportunidades em Aquiraz. Vão procurar em Fortaleza. Se tiver a oportunidade, muito bem. Se não, vão aumentar as favelas que não tem infraestrutura, não tem esgoto, não tem água. Portanto tem que haver aqui um equilíbrio.

\section{As vantagens do resort}

Eu acho que tem que haver uma desconcentração e ver o que estar a acontecer aqui com os trâmites políticos. A desconcentração aqui é evidente. Não é que se você for fazer pousadinhas que você vai ter um desenvolvimento turístico social grande. Não pode. Tem que ser num resort. E a vantagem do resort é que há uma disciplina no "master plan" que obriga você a fazer uma organização disciplinada, com infraestruturas, com esgoto, com água, com energia elétrica, com uma densidade baixa, porque se não, não

atinge o objetivo e tudo passa a virar um Icaraí e pronto. É o que acontece na Prainha, no Porto das Dunas.

O porto das dunas estar a ficar descontrolado. Acho que aquilo é um descontrole. Você vai ver as ruas em lama, quando chove, não tem infraestrutura. Ali é mais um exemplo de certo desequilíbrio de desenvolvimento estratégico.

A intenção do Aquiraz Riviera não é somente de fazer um resort, mas de construir uma vila turística com qualidade de vida e qualidade ambiental. Afeta o ambiente? Com certeza, porque é impossível não afetar o ambiente, mas com condições de equilíbrio. 
6. Quais foram as tecnologias de construção propostas preliminarmente e suas mudanças, caso tenha havido necessidade de alterá-las devido a sua relação com a mão-de-obra local e materiais construtivos utilizados?

\section{Resposta:}

Estamos utilizando tecnologia tradicional local, mão-de-obra, a maioria, local, alguns, é claro, vêm de Fortaleza e outras cidades. A manutenção do golfe utiliza toda a mão de obra de Aquiraz. Na construção, não sei quem a Mota Machado ${ }^{13}$ vai levar: se vai levar todos os operários daqui ou vai recrutar e ter treinamento lá. Eu sei que aqui, a maioria dos nossos funcionários é de Aquiraz.

Quanto às construtoras que estão participando do empreendimento, além da Motta Machado, tem a Manhattan e a Urban ${ }^{14}$, isso nas incorporadoras. Nas infraestruturas nós trabalhamos com pequenas subempreiteiras locais. Todo o nosso projeto: rede viária, rede de esgotos, tudo foi feito com empresas locais. Até o paisagismo nós temos o projeto com uma arquiteta local. Porque conhece as espécies que se adaptam e quais as que não se adaptam: é mais fácil e pode dar um acompanhamento mais equilibrado.

\section{Qual a sua visão sobre a lógica sugerida pelo projeto urbanístico e arquitetônico} dos empreendimentos (hotéis, conveniências e vila turística): programa de atividades (compartimentos e ambientes propostos pelos projetistas), fluxo de funcionamento, manutenção, adequação aos usuários, conforto ambiental, etc. Já é possível fazer uma avaliação pós-ocupacional preliminar?

\section{Resposta:}

O escritório de arquitetura local contratado desenvolveu todo o "master plan", contando com a nossa colaboração e chegou-se a um consenso. Se você for ver a estrutura aqui no "master plan", é o seguinte: nós soubemos ter um desenvolvimento que houvesse um

\footnotetext{
${ }^{13}$ Construtora de capital cearense

${ }^{14}$ Ambas de capital cearense
} 
centro de gravidade de animação social que não dispersasse as pessoas porque elas gostam de estar juntas.

Essa zona aqui no litoral é a dos hotéis. Temos aqui, no centro, o Village Mall que é o shopping porque as pessoas vêm dos hotéis, vão aos bares, às lojas, podem até ir aqui ao golfe. Projetamos uma zona residencial com uma envolvente verde, toda ela com tratamento especial, com o zoneamento ao longo do eixo central que começa em aclive a zona residencial, a zona turística e a zona social. Tudo que você pode ir andando, pertinho. Toda essa parte aqui ( $1^{\mathrm{a}}$ e $2^{\mathrm{a}}$ fases): já vendemos. Estamos a vender esta parte. Aqui é a Manhattan (construtora), aqui é a urban (construtora), aqui é a Mota Machado (construtora). Tudo isso aqui está em andamento. O “country club” está em construção, aqui as quadras de tênis, o club house de golfe está quase todo construído, com uma arquitetura que conviva com o calor e o clima local da nossa realidade. O próprio hotel é baixinho, procuramos fazer tudo dentro de uma escala que não choque a realidade local.

Sobre a manutenção, não há novidade na parte construtiva, mas demos uma atenção especial ao campo de golfe. Se você for aos EU e Europa, os campos de golfe têm uma área de grama que é o dobro ou o triplo da que temos aqui. Adaptamos o nosso campo de golfe, reduzindo a área de grama exatamente para não exagerar no consumo de água ou de produtos agroquímicos que no nosso caso nem precisamos de produtos agroquímicos, só raramente. Isso tudo já compatibilizado aos custos com manutenção e irrigação para não sair mais caro. Lá não existe problema com fornecimento de água porque vem da adutora do $\mathrm{Catu}^{15}$ e a área de gramado está relacionada com o custo da manutenção dessa área e, portanto, reduzimos muito o custo de manutenção. Embora o campo seja mais difícil, mais estreito, mas também foi uma opção de custo.

\section{Outras que possam surgir dentro do debate.}

\section{Resposta:}

O que eu acho que está errado, não que esteja errado, mas é que não se entendeu ainda bem qual é a estratégia de desenvolvimento turístico que se quer para a região, porque é

\footnotetext{
${ }^{15}$ Lago represado que abastece a região e mantido pela concessionária de água.
} 
isso que não está definido. O Bismarck ${ }^{16}$ fala em pousadinhas: "vamos fazer muitas pousadinhas". Eu acho que isso não é muito o ideal, porque você faz uma pousada e se não faz em quantidade vai à falência. Mas não é só isso: você não pode deixar de pensar nos custos de infraestruturas. O Ceará tem $500 \mathrm{~km}$ de praia. Você não pode criar infraestruturas por todos os $500 \mathrm{~km}$ de praia. É impossível, não é? Não há dinheiro que chegue. Você tem que ter uns bolsões de concentração aqui e ali. Eu acho que é isso que falta muito. E incentivar um tipo de produto ou outro, de acordo com a preferência: um mais caro e outro mais barato. Mas mesmo o mais barato, não é necessariamente o defensor da natureza e do meio ambiente. Isso pode ser perfeitamente equilibrado. Agora não deixar construir em altura, essas coisas, para haver um maior equilíbrio entre urbano e o meio ambiente, o verde e a duna. Eu acho que tem que ter essa definição, sem radicalidade (sic) de um lado nem de outro. Para mim isso é o que é mais difícil.

\section{As mudanças na política de turismo do Estado}

Durante o período do Tasso, nós tivemos a Anya Ribeiro que era a Secretária de Turismo. Era uma pessoa que tinha uma visão. Agora temos outro que fala em pousadas. Pousada não é exatamente um desenvolvimento que eu vejo que possa vir a trazer grandes resultados econômicos para o Estado. E esse é o discurso do Bismarck. Talvez seja um discurso político e infelizmente a política acaba obstruindo.

\footnotetext{
${ }^{16}$ Secretário de Turismo do Estado do Ceará
} 


\section{ENTREVISTA 2}

\section{AO CONSULTOR EM ARQUITETURA E URBANISMO VINCULADO À ADIT/NE}

(PRESIDENTE DO IAB-CE) - 14/OUT/2011

\section{- Objetivo geral da entrevista:}

Fazer uma primeira aproximação da percepção dos agentes que participam da produção do espaço turístico e imobiliário de Fortaleza e RM.

\section{- Objetivo específico:}

Compreender a percepção do presidente do IAB sobre a questão dos conflitos em torno do turismo litorâneo no Ceará especificando o papel da ADIT (Associação para o Desenvolvimento Imobiliário e Turístico do Brasil - secção do Ceará) e seus colaboradores.

\section{A) QUESTIONÁRIO}

1. Qual a sua percepção geral dos desafios estratégicos do desenvolvimento do turismo litorâneo e do mercado imobiliário a ele associado e como faria uma síntese histórica?

\section{B) TRANSCRIÇÃO}

Eu dividiria minha visão geral em tópicos que considero importantes e capazes de expressar a questão:

\section{O potencial da Zona Costeira:}

A zona costeira do Estado do Ceará tem sido mencionada como um local onde os atrativos naturais de paisagem e de clima são muito especiais por conta da estabilidade da temperatura, com oscilação mínima que vai de $24^{\circ}$ a $32^{\circ} \mathrm{C}$ no ano todo, tem uma brisa permanente que torna essa sensação de temperatura ainda mais atenuada, uma paisagem exuberante, uma iluminação quase que única por estarmos a quase $4^{\circ}$ de latitude sul e isso ajuda muito na emissão da iluminação, e um território ainda quase (em muitas regiões) virgem.

\section{A baixa taxa de ocupação:}


Já existem algumas ocupações, mas se você pegar as ocupações em todos os Município, passando por cidades e núcleos urbanos de todos os vinte e três municípios que compõem a costa cearense, incluindo Fortaleza, essa ocupação representa menos de $2 \%$ do território.

Se você pegar o território de cada município da Zona Costeira do Estado do Ceará e calcular a soma das áreas dos territórios de todos os núcleos urbanos, incluindo Fortaleza, você tem uma taxa de ocupação de menos de $2 \%$, certo? O que, a princípio denota que é uma área, região ainda a ser explorada. Esse estudo foi feito detalhadamente pelo SINTUR (?).

\section{O baixo IDH da ZC:}

Então você tem uma área que tem potencial, que tem uma população que também tem os menores índices de desenvolvimento humano do Estado do Ceará. O menor IDH não está no semiárido, mas nos municípios costeiros, isso também pode ser comprovado no estudo do SINTUR. Então, nós vemos aí os operadores de turismo e o Estado, veem aí um ganho tanto da iniciativa privada quanto do poder público e da população em geral, um ganho potencial montado aí (sic).

\section{A indefinição legal e normativa para o uso e ocupação da ZC}

Ora, acontece que até a criação da SEMACE e até a criação dos planos diretores dos municípios costeiros não havia definido o que se pode e o que não se pode fazer, certo? Então, o que é que aconteceu: gradualmente, se você pega do ano 2000 até o Governo Lúcio Alcântara (2006 se não me engano)... Então nesse período entre 2000 a 2006 se procurou regulamentar, criar parâmetros claros que iriam permitir segurança jurídica tanto para os agentes de Estado, para a população que teriam seus direitos respeitados, para o meio ambiente propriamente dito quanto para os investidores.

\section{A criação do ZEE da ZC em 2005}

As normativas procuraram criar regras para todos os fatores. Ora, como o Estado do Ceará tem uma peculiaridade. E qual é a peculiaridade? (sic) Foi feito um Zoneamento Econômico Ecológico da Zona Costeira em 2005 pelo LABOMAR que detectou a seguinte particularidade: um terço da faixa mais nobre, que fica próxima ao mar é constituído de área de preservação permanente onde você não pode usar de maneira 
nenhuma, tipo: desembocadura de rios, mangues, praias, falésias - são áreas de preservação permanente (APP) - o outro terço é composto por planícies de deflação que é aquela faixa plana que fica entre o mar e a duna. E outro terço é formado por campo de dunas: você pode ver isso no quadro resumo dos estudos do ZEE que existe um faixa de um a dois $\mathrm{Km}$ da linha da costa dividida em três trechos de 1/3, como descrito. Depois é que vêm os tabuleiros litorâneos.

\section{A alteração legal provocada pela Resolução Conama 303/2002}

Ora, acontece que em 2002 foi baixada uma resolução do Conama nr. 303 de 2002, certo? Que alterava o conceito de área de preservação permanente, contida no código florestal de 1965. Esse código florestal protegia vegetação em duna, certo? Então, até 2003, os empreendimentos tratavam a duna sem vegetação como uma área de uso passível, certo? Passível de uso, tanto a planície de deflação como as dunas eram passíveis de uso. Com a resolução Conama 303/2002, apareceu uma nova regra: ela diz que não é mais protegida a vegetação de duna, mas a duna em seu conceito, com vegetação e sem vegetação. Existe um questionamento de natureza jurídica em relação a isso porque uma norma não pode alterar o teor de uma lei e a Resolução alterou o teor da lei que é o Código Florestal, criando APP em dunas. E isso foi uma ilegalidade que caberia uma ação de inconstitucionalidade, mas isso não foi feito. O que foi que aconteceu? A mudança das regras (sic).

\section{O impasse da ilegalidade dos investidores atraídos pelo governo}

Diferentemente da área urbanística que quando uma nova norma não retrocede para prejudicar os projetos em andamento, na área ambiental não havia esse entendimento. Quando chega uma norma nova, todos os empreendimentos que estão sendo instalados à luz da lei anterior caem na ilegalidade, no entendimento dos analistas ambientais da SEMACE, especificamente, com uma máxima de que não há direito adquirido em meio ambiente...ora, o que é que aconteceu...com essa norma de 2002, os empreendimentos que estavam utilizando, de alguma maneira, o campo de dunas caíram todos na ilegalidade. O Governo, na época, se viu diante de uma encruzilhada porque havia atraído investidores que agora estavam na ilegalidade.

\section{A nova Resolução Conama $341 / 2003$ - a adequação do uso de APP}


O que é que ele fez?...Já haviam sido aprovados várias obras, projetos,etc...e o que é que o Governo fez...foi ao Conama e aprovou outra Resolução em 341/2003 que dizia o seguinte: a duna é APP, concordamos, mas como a lei permite utilização de APP para o interesse público ou interesse social, fica valendo para a duna, o que já está previsto (de interesse público), como passar uma rede de energia elétrica ou estrada que é interesse público, e fica valendo também para a duna, o interesse social para: empreendimentos turísticos sustentáveis, declarado de interesse social, certo?. Isso limitou o uso do campo de dunas a 10\%. O campo de dunas ficou dividido em duas frações: duna móvel (sem vegetação) e duna fixa (com vegetação)...ou seja você só pode usar $10 \%$ do somatório dos dois, limitado a $20 \%$ das dunas sem vegetação. O que der menor é o que vale. Isso foi aprovado no Conama e a partir daí isso passou a nortear os novos empreendimentos.

\section{O fenômeno do apagão e os aero geradores no litoral}

E daí o que foi que aconteceu: paralelamente a essas questões no ano de 2001 - 2002, foi o ano do apagão, certo, e o Governo Federal criou uma normativa, uma medida provisória, liberando todas as APP para o uso de geração de energia que era uma questão de interesse público.

\section{Os conflitos das diversas legislações nas três esferas federativas}

Esse conflito de diversas legislações nas esferas federal, estadual e municipal, além de algumas indefiniçõos dos planos diretores, ao invés de criar um ambiente de segurança jurídica, criou um ambiente de total insegurança jurídica...eu vou exagerar porque foi esse mesmo sentimento, de tal maneira que a prefeitura entende de uma maneira, os órgãos estaduais entendem de outra maneira, os órgãos federais de outra maneira e o ministério público de outra maneira, uma série de aspectos ligados que levaram a judicialização de todos os empreendimentos, sem exceção. Todos vão terminar na justiça. Certo?. Ora, mais recentemente, em 2006, o Conama baixou mais uma norma, a 369/2006 que procurava regular as intervenções de baixo impacto ambiental em APP, certo? Que previa uma série de parâmetros que previa por exemplo: fazer uma picada no topo do morro, construir um atracadouro na margem de uma lagoa, fazer uma ponte ligando uma comunidade rural, a outra, regular a atividade pesqueira, piscicultura, pequenas obras de apoio à pesca, atividades de subsistência, etc. Aí, o que é que aconteceu, a 369 não citou duna, certo? E aí o ministério público passou a entender que 
a 369/2006 revogou a 341/2003 que permitia o uso de $10 \%$ do campo de dunas. Então o Ministério Público baixou um parecer dele que está sendo aplicado em todo o país que diz que todos os empreendimentos concebidos até 2006 e que estavam de alguma maneira utilizando dunas, cai na ilegalidade, ou seja, a 369/2006 retrocede pra cancelar tudo que estava previsto para trás. Todos os empreendimentos caem na ilegalidade. $\mathrm{E}$ depois, ele diz mais o seguinte: que a planície de deflação que era entendida como uma unidade geomorfológica distinta do campo de dunas, ela é parte integrante do campo de dunas, certo?. Então, pelo entendimento do Ministério Público, consequentemente, todo o 1/3 do campo de dunas, o 1/3 da planície de deflação e o 1/3 das APP são áreas de preservação permanente e, portanto, não são passíveis de uso. Significa, então que pelo parecer da câmara técnica, todos os empreendimentos localizados à face de um a dois km da Zona Costeira, estão na ilegalidade. Todos eles. E também retrocede, a todos os empreendimentos concebidos antes de 2006, quando a 369 entrou em vigor. No entanto, existem outros já construídos, onde o Ministério Público aciona a Justiça para derrubálos, saírem de lá, certo? E eles se defendem e na maioria dos casos o Min. Publico tem perdido. A Justiça tem dado o direito de permanecer aos que já estão. Então isso aí é a regra geral. O recente, Vila Galé ganhou na justiça o direito de permanecer no Cumbuco e se tornou o primeiro resort do Ceará atendendo a todos os preceitos internacionais. Já está operando como hotel e ainda aguarda o lado do imobiliário. O Aquiraz Riviera continua sub judice e ainda não tem as suas licenças renovadas. Aí ficou essa dúvida: o órgão ambiental renova ou não renova? Aí vem outra ilegalidade, cometida nessa esteira de impedimentos e conflitos. A SEMACE no ano passado, em 2010, baixou uma normativa, um parecer jurídico dizendo que se alinha ao entendimento do Min. Público que a 369 revoga a 341 e dando a esse parecer jurídico, caráter normativo. Isso fere a Constituição Estadual. Isso fere a Lei que criou o Conselho Estadual do Meio Ambiente que diz que só quem pode emitir instruções de caráter normativo é o Conselho Estadual do Meio Ambiente. A SEMACE não pode emitir parecer de caráter normativo. Aí o imbróglio ficou mais complexo e aí parou. E hoje o que é que nós temos: qualquer empreendimento que está em implantação ou está sub judice ou está esperando uma ação de demolição ou o resultado, esperando que o Min. Público Federal ou o IBAMA entrem com uma ação mandando parar e demolir o que está feito, ou está esperando o Estado sub judice. O que agente sabe é que esse quadro é predominante no Ceará e que existe alguma coisa em menor proporção nos outros Estados, como no RG do Norte, por 
exemplo, em menor proporção. Porque lá como aquela orla de Natal foi ocupada por grandes hotéis em um curto espaço de tempo. Essa situação, eu imagino que lá agente esteja mais avançado, mais consolidado. Já existe decisão judicial que dão mais segurança jurídica aos empreendimentos (sic).

\section{As consequências dos conflitos legais e jurídicos}

Então o que está acontecendo é o seguinte: é o que já falei. Ou o cara que já iniciou o investimento está com uma ação de embargo, demolição, que ele recupere o estado natural do meio ambiente ou então ele está esperando que isso venha porque as orientações e normativas têm esse entendimento que o trecho que vai do mar a cerca de um, dois ou três Km para o continente, considerada frente marinha é APP e não se pode fazer nada nela.

O que a SEMACE tem dito sistematicamente para aqueles investidores que possuem terrenos, por exemplo, que estão 50\% nas APP na frente marinha e 50\% nos tabuleiros pré-litorâneos é que eles retirem seus empreendimentos da frente marinha e reloquem os seus projetos para o tabuleiro litorâneo.

\section{O surgimento dos parques eólicos e a inversão da lógica de ocupação territorial da ZC na ausência de um planejamento integrado}

Ocorre que surgiu outro fator que é mais grave, no nosso entendimento, que é a enorme permissividade que a lei tem com os atuais empreendimentos de geração de energia eólica. O que é que está acontecendo na Zona Costeira: os parques eólicos estão se instalando aceleradamente e estão ocupando a parte do território que tem o maior valor paisagístico, ferindo a legislação de proteção à paisagem que é ignorada. Ah!... Porque existe uma medida provisória que diz que pode e que prioridade é geração de energia. Então estamos tendo no Ceará uma verdadeira inversão da lógica do planejamento territorial que qualquer arquiteto conhece. Qual é a lógica? É você escolher as vocações de cada território e explorá-las da forma mais adequada em relação às suas vocações. Que é o mais natural e qualquer pessoa entende: não precisa ser arquiteto não (sic).

\section{A proposta de ocupação territorial do IAB}

O que desejamos é que a frente marinha fosse ocupada por edificações de pequena estatura e de baixa densidade espalhadas ao longo da costa, logicamente com todos os 
preceitos de conservação ambiental, preservação da paisagem e tudo o mais e depois dela a uns seis a dez Km da costa você pudesse colocar os gigantes (aero geradores) de $150 \mathrm{~m}$ de altura, equivalente a um prédio de 50 andares Porque aí você teria um menor impacto sobre a paisagem e uma atividade não inviabilizaria a outra porque o que é que vai acontecer e está acontecendo no litoral do Ceará. Isso foi um cálculo grosseiro que eu fiz: a cada leilão de energia eólica, se ocupa uma faixa mais ou menos de $5 \%$ da extensão do território com parques eólicos, certo? A certa distância um do outro, eles são colocados num sentido perpendicular ao mar porque o vento vem do Leste e o mar está mais ou menos para o Norte. Então recentemente o Coema aprovou (mesmo com o voto contrário do IAB porque o IAB se posicionou contra em decisão da diretoria) a implantação de todos os parque eólicos que se instalarem na frente marinha. E (o IAB) aceita votar a favor dos parques eólicos que são localizados no tabuleiro pré-litorâneo. Então esses projetos estão sendo aprovados sem analisar o impacto cumulativo na paisagem.

\section{As consequências da implantação dos parques eólicos sem planejamento}

O cara chega na última reunião do Coema (sic) propondo a instalação de oito parques: dois e depois três (mais ou menos a uns seis $\mathrm{Km}$ ), e mais três (mais ou menos a uns seis $\mathrm{Km})$, certo? Um do outro, certo? Três grupos (totalizando oito parques). Aí nessa reunião eu indaguei (e está gravado na audiência do Coema): quantos parques já existem licenciados, entre um e outro? Havia vários parques já licenciados entre um e outro. De tal maneira que a paisagem dominante vai ser os gigantes eólicos. E isso inviabiliza de forma inexorável a ocupação do território para o turismo de primeira linha. Ele não vem mais para o Estado do Ceará. Então nós estamos perdendo uma oportunidade histórica por falta de planejamento territorial de ocupar e aproveitar uma riqueza em potencial que está ligada às riquezas naturais e a paisagem, inviabilizando, esterilizando essa Zona Costeira com a geração de energia eólica que aqui pra nós não gera emprego nem gera renda para os estados e municípios. Ela gera uma segurança energética para o desenvolvimento das regiões industrializadas do país. Mas para nós, vamos ficar a ver moinhos de vento, com a população numa situação de extrema pobreza, né? Com os menores IDH do Ceará nessa região costeira, por uma absoluta falta de uma ação da sociedade e do Estado. Esse é o quadro geral: todos os empreendimentos encontram-se parados sub judice esperando serem bloqueados e a 
SEMACE não emitiu licença para ninguém. E os eólicos (parques) se instalando todo mês (sic).

\section{As alternativas em perspectiva diante do impasse criado}

A perspectiva tem saído exclusivamente de uma entidade que é o IAB que é a única entidade que tem pensado estrategicamente essa questão. O que é que o IAB fez: a primeira ação do IAB. O IAB, em parceria com a FIEC e outras entidades, propôs a criação de uma primeira câmara técnica que ia regular prazos de vigência das licenças, porque empreendimentos que tinham cronograma de instalação de cinco a seis anos, recebiam uma licença de instalação de um ou dois anos. Isso significava que antes dele se instalar ele tinha que renovar a licença e havendo mudança na legislação (durante a implantação) ou no impedimento na legislação que aquele gestor de plantão estivesse (sic), todos os empreendimentos caíam na ilegalidade. O cara (analista ambiental da SEMACE) dizia. Não eu não vou renovar a tua licença não porque no meu entendimento essa licença anterior foi concedida ilegalmente, no meu entendimento. Então eu não vou renovar a tua licença. Sim, mas eu já executei $30 \%$ o que é que eu faço? Ai ele diz: então desmanche. Isso aí consta no parecer jurídico da SEMACE: desmanche o que você já fez.

\section{A criação da Resolução Coema nr. 26/2011 restabelecendo os prazos de vigência das licenças já aprovadas}

Então nós (IAB, FIEC e parceiros: OAB, CONPAM, APGCE) criamos e aprovamos essa câmara técnica, por unanimidade, e o COEMA aprovou na sua plenária, por unanimidade, a Resolução nr. 26/2011 (o IAB foi o relator da Resolução e a FIEC presidiu a reunião do Conselho, publicada em 02/09/2011 no Diário Oficial) com dois elementos básicos. Primeiro: que reestabelece os prazos de vigência das licenças que era em média de um a dois anos e agora passa a ter os prazos na forma da legislação federal, da Resolução CONAMA 237 que são: prazos de vigência da licença prévia: até cinco anos dependendo do cronograma de desenvolvimento dos projetos complementares. Prazo de vigência da licença de instalação: até seis anos dependendo do cronograma de obras. Isso tudo para criar uma regra racional devido às mudanças frequentes de normas e pareceres subjetivos. E a segunda grande mudança diz o seguinte: qualquer projeto, principalmente os de longo prazo, em todas as suas etapas 
têm que ser avaliados à luz da legislação em vigor, na data em que for protocolado o pedido de licença. Isso garante o que. Garante que uma refinaria, por exemplo, se ela protocolou na data de hoje o pedido de licença para realizar uma obra em dez ou seis anos, digamos, e depois do terceiro ano que ela tiver com 30\% das obras, se a lei mudar, essa mudança da lei não se aplica àquela refinaria. Porque o projeto dela tem que ser analisado à luz da legislação na data que ela protocolou a licença. Que é uma coisa mais que óbvia e é assim que ocorre em todos os licenciamentos no mundo. Mas aqui não era: mudou a lei, desmancha o que já fez. É um absurdo, não é? Então esses dois dispositivos principais estão nessa legislação.

\section{O IAB propõe criar uma nova câmara técnica para tratar das APP}

Agora o IAB entrou noutra seara. Nós propusemos a criação de uma nova câmara técnica para elucidar e criar uma norma estadual que defina claramente, sem mais rodeios, as intervenções em áreas de preservação permanente em todo o Estado do Ceará. Uma norma do Coema, complementar a essa que já dá segurança jurídica para um bocado de coisa, que essa norma defina as intervenções em APP alinhadas às legislações já existentes, eliminando possíveis sombreamentos, conflitos, nuances de toda natureza, considerando todas as atividades e todos os biomas do estado do Ceará. Aí envolve desmatamento, pesca, piscicultura em açude, carcinicultura (camarão), agricultura de subsistência, geração de energia eólica e atividade turística e imobiliária. O objetivo é abranger todas essas atividades. Essa câmara técnica já foi instalada. O IAB é relator dessa câmara técnica e nossa expectativa é de até dezembro de 2011, criarmos um conjunto de elementos que volte a dar credibilidade às licenças. Porque hoje as licenças não têm a menor credibilidade. Tenho uma licença ambiental e começo a fazer e no dia seguinte tenho que parar porque ainda incorre (sic) na condição de criminoso ambiental porque está depredando o meio ambiente. Nós ficamos surpresos com a falta de agilidade do poder público de se posicionar sobre essa matéria. É uma coisa surpreendente.

\section{O quadro recente dos gestores públicos ambientais e as acusações de irregularidades e tráfico de influência}

Nós temos agora na atual secretaria do CONPAM (Conselho de Políticas e Gestão do Meio Ambiente) um secretário que ele tem tido a compreensão do problema e tenha 
aberto os espaços para que o Coema junto com a sua secretaria e com a Semace, crie um diálogo para destravar esses entraves. Porque ficaram muito prejudicados por esse clima de insegurança e prejudicados pela prisão dos dirigentes ambientais dos três órgãos: IBAMA, SEMACE e SEMAM em 2009 motivada pela operação "marambaia" que começou com uma denúncia de uma irregularidade em uma licença ambiental em Aracati para um empreendimento eólico e daí se quebrou o sigilo telefônico de uma enorme quantidade de autoridades ambientais e políticas do Estado e consultores ambientais e gestores ambientais e a partir daí houve o entendimento da polícia federal e do Ministério Público Federal que patrocinavam a ação, de que estaria havendo tráfico de influência na emissão de licenças. Prenderam as pessoas num dia e soltaram no outro: isso criou-se um clima de absoluta precaução por parte de todos os agentes públicos (sic). Hoje para um técnico emitir um parecer favorável em uma licença ele pensa mil vezes porque ele pode ter o seu nome nos jornais no dia seguinte sendo algemado, preso, trancado na polícia federal. Quer dizer, esse é mais um fator que tem implicado nesse impasse na ocupação territorial ordenada e que está produzindo como consequência uma ocupação territorial desordenada e extremamente prejudicial, com prejuízos históricos provavelmente irreparáveis para o planejamento territorial do Estado do Ceará. Essa é a compreensão do IAB.

\section{Sobre os empreendimentos nas zonas urbanas da RMF}

Sobre os empreendimentos na RMF é outro problema. Existem juristas que entendem que o meio urbano tem que ser regulado baseado em seus planos diretores e outros que entendem que não. Que a legislação ambiental e o código florestal é aplicável às zonas urbanas.

\section{A nova estrutura organizacional da pasta do Meio Ambiente estadual}

A estrutura organizacional do meio ambiente estadual é composta pelo CONPAM (conselho com status de secretaria que substituiu a SOMA - Secretaria de Ouvidoria e Meio Ambiente, extinta no Governo Cid) o CONPAM - Conselho de Políticas e Gestão do Meio Ambiente é formado pelo presidente do CONPAM e os secretários dos temas afins: infraestrutura, turismo, cidades. A Semace está subordinada hierarquicamente ao CONPAM. O Governador foi acusado de driblar o licenciamento ambiental porque pretendia encaminhar alguns projetos de interesse, diretamente ao CONPAM sem 
passar pela Semace. Isso gerou uma ação direta de inconstitucionalidade da entidade que está sendo julgada pelo supremo. O Governador aprova uma lei estadual e imediatamente essa lei chega nas barras da justiça federal e do Supremo (sic).

\section{Os segmentos sociais por trás da ação do Ministério Público}

Os segmentos que estão por trás de todas essas ações do Min Público são as entidades ambientalistas que estão no COEMA e que estão aprovando essa ação do IAB. O próprio Ministério Público, ele reconhece em conversas informais que a questão não é política, a questão e mais do ponto de vista dos instrumentos jurídicos. Dos conflitos produzidos por esses instrumentos jurídicos. O problema não está na aplicação da lei. Está na técnica legislativa que cria e que leva à produção das leis. Essa técnica cria zonas de dúvidas e sombreamentos e o Min Público tem que agir para proteger o Meio Ambiente. Onde se concentra a maior parte das divergências é na questão das leis. Na minha maneira de ver. Agora é claro que em situações extremas há pessoas que acham que a Zona Costeira tem que ser preservada na sua integridade. Não se pode fazer nada no território costeiro. Só por trás do campo de dunas. Tem alguns que defendem essa ideia. E do outro lado existem pessoas que defendem que a utilização de parte da planície de deflação e parte do campo de dunas é adequada e necessária, do ponto de vista econômico e não prejudicam o meio ambiente. Essa nuance de como ocupar as APP é que vamos tentar elucidar nessa nova câmara técnica.

\section{A questão da tipologia arquitetônica}

Vamos tentar colocar a questão da tipologia também na norma que é a seguinte, e é a que já existe no Rio Grande do Norte: você tem, até certa distância do mar, permitido dois pavimentos e mais distante aumenta para três e depois para quatro até chegar a cinco pavimentos. Isto é: chega-se (ao máximo de) $15 \mathrm{~m}$ de altura a uma distância de 500 m do mar. Isso está definido em lei estadual no RGN. Na questão das tipologias há um consenso que deve ser de baixa densidade, baixíssima densidade e de baixo gabarito (altura) . Aqui no Ceará a legislação ambiental não contempla a questão das tipologias e nós vamos tentar incluir nessa norma. No caso da Lagoinha, onde foi construído um edifício à beira-mar em plena praia semideserta, havia um vazio legal e foi construído um edifício porque não há nenhuma norma que diga que não pode, mas que é prejudicial do ponto de vista paisagístico e também da infraestrutura quando se 
concentra demanda onde não tem oferta. A manutenção dessas infraestruturas, espalhar urbanidade por toda a Zona Costeira. Isso é caro para manter. Como isso deve ser mantido e como deve ser preservada a relação entre essas urbanidades e os espaços naturais que são os atrativos verdadeiros. Isso que é importante (sic).

E o que se vê é que prevalece o absurdo dos absurdos que é o litoral todo ocupado por geradores de energia eólica. 
ENTREVISTA 3

AO CONSULTOR EM FINANÇAS E NEGÓCIOS IMOBILIÁRIOS - FILIADO À

ADIT-CE - 14/OUT/2011

\section{A) QUESTIONÁRIO}

1. Qual a percepção dos agentes imobiliários que hoje atuam no setor do turismo e qual o papel da ADIT?

2. Como faria uma síntese do contexto do mercado imobiliário e a visão estratégica?

3. O que você vê como mudança (nestes últimos anos) para os seus potenciais clientes (investidores em negócios imobiliários)?

B) TRANSCRIÇÃO:

Vou fazer um contexto do quadro geral do mercado imobiliário voltado para o segmento do turismo de segunda residência para responder essas três perguntas:

1. Os antecedentes macroeconômicos e as condições do mercado local (litoral nordestino: Fortaleza, Natal, Bahia)

As mudanças no mercado imobiliário começaram a ser mais visíveis entre 2007 e 2008. A Europa vinha amadurecendo a proposta de um mercado comum europeu, apoiando os países (europeus) em dificuldades com aporte de muito dinheiro para sua reestruturação. Nesse momento, começaram a aparecer muitas pessoas de Portugal e Espanha (pequenos e médios investidores) com dinheiro que levantavam lá e aportavam aqui no litoral do Nordeste. O grande diferencial nesse caso é que as pessoas vinham da Europa e encontravam aqui, no Nordeste, uma realidade totalmente imatura (amadora). Eles tinham a experiência da segunda residência em Portugal e na Espanha e queriam replicar aqui essa experiência, só que o mercado daqui ainda era muito imaturo. $\mathrm{O}$ mercado da construção civil de segunda residência no Brasil era muito incipiente e em particular o do litoral do nordeste.

2. A presença de investidores noruegueses e finlandeses no NE 
O Governo da Noruega, naquela época, estava oferecendo dinheiro para que noruegueses comprassem residências no Brasil porque queriam dar uma maior qualidade de vida para seus cidadãos, financiando em vários meses porque lá é muito frio a maior parte do ano e vir para cá, botar o pé na areia inexplorada seria dar uma maior qualidade de vida. Natal explodiu no mercado imobiliário, não em Resorts. No mercado imobiliário local urbano de Natal e Região Metropolitana, com finlandeses e noruegueses comprando apartamentos para uso lá. O grande boom imobiliário de Natal é esse fluxo turístico que tem em torno da capital. A obra era financiada durante a construção o que dava uma alta rentabilidade para os projetos imobiliários de Natal. O Sul da Bahia e o litoral da Bahia, também a mesma coisa: muito português e muito espanhol desenvolvendo Resort na Bahia. Só que eles faziam, construíam e vendiam para lá: para o mercado europeu.

\section{As mudanças econômicas provocadas pela crise financeira}

A partir do momento que a economia mundial começou a mudar, com o mercado apresentando problemas econômicos financeiros na Europa, aquele dinheiro todo que foi aportado para estruturar os países da zona do Euro e tudo mais, começou a ficar mais raro e a não ter retorno, fazendo com que o país tivesse que devolver dinheiro para os seus financiadores porque tinha que ter uma relação equilibrada entre déficit público e PIB, entendeu? O déficit público da Grécia é maior que o seu PIB. O da Itália também.

\section{O enfraquecimento do investimento estrangeiro}

Todas aquelas compras (de segunda residência) eram a crédito ${ }^{17}$, mas durante o período da obra. Terminada a obra ficavam liquidadas ${ }^{18}$. Naquela época a cotação do euro estava de três reais para um. Era muita força do euro em relação ao real, tá certo? Com o passar do tempo, no contexto da crise internacional, o Brasil fez o dever de casa e tendo ferramentas necessárias, a crise econômica teve um impacto menor na nossa economia. O que é que aconteceu? Nós saímos (da crise) na frente $\left[\ldots . .{ }^{19}\right.$ o que fez com o que o dólar e o euro enfraquecessem em relação ao real. Então aquela força toda da segunda residência do estrangeiro no Brasil caiu. Não tem mais. Hoje a segunda residência no

\footnotetext{
${ }^{17}$ Pedido de esclarecimento pelo entrevistador sobre a natureza das compras: se eram a crédito

${ }^{18}$ Esse detalhe não ficou claro. Provavelmente o financiamento era só da construção que depois era saldada com o aporte de outro tipo de recursos do comprador. Para isso, seria necessária uma investigação mais específica do tema.

${ }^{19}$ Inaudível
} 
Brasil é para brasileiro. Tá certo? Aqui no Ceará você vê que a maioria dos empreendimentos de praia estão sendo vendidos para brasileiros. O caso clássico é o do Beach Park $^{20}$, próximo a Fortaleza, como também o Cumbuco ${ }^{21}$. Tudo é para local. Pessoas do Ceará para uso residencial ${ }^{22}$.

\section{A presença do investidor ${ }^{23}$}

Existe investimento, também. Uma característica típica do investidor é quando a obra termina, as placas de venda aparecem na frente do empreendimento. É típico de investidor. Tem investidor? Tem. Pelo menos na ordem de 40 a $50 \%$ de investidores, mas do local, embora não se tenha estatística para isso é uma percepção do mercado.

\section{A organização dos agentes do setor imobiliário turístico: da ADIT-NE a} ADIT-BRASIL

A ADIT surgiu para organizar o setor imobiliário e turístico. Ela é originária de Maceió e sua proposta era iniciar a organização do setor pelo Nordeste. Isso começou em 2005, convidando pessoas dos outros estados nordestinos a colocar um vice-presidente em cada Estado, juntando consultores, incorporadores e também construtores como associados.

Os vice-presidentes, obrigatoriamente, tem que ser incorporadores ou construtores, não pode ser consultor. Nem são todos os Estados que têm, associados no NE. A ADIT começou a participar das feiras internacionais: feira de Madri, Lisboa, Inglaterra, feira imobiliária, de Milão. O que aconteceu foi que com essa frequente ida (às feiras) a ADIT começou a obter recursos federais.

O Min. do Turismo patrocinava a participação da ADIT nessas feiras, como também a APEX (Agência Brasileira de Promoção de Exportações e Investimentos) que é uma agência cuja pauta é o fomento à exportação e, assim, ela passou a considerar o dinheiro do investimento em turismo que vem de fora para o Brasil como fomento à exportação. É um dinheiro que vem e fica porque vai desenvolver um projeto durante pelo menos uns três a quatro anos, aí nessa estória (sic). Quer dizer: traz um dinheiro para investir.

\footnotetext{
${ }^{20}$ Parque aquático que é usado como sinônimo do bairro Porto das Dunas, no Município de Aquiraz, na RMF.

${ }^{21}$ Localidade praiana na RMF, vizinha a Fortaleza pelo litoral Oeste

${ }^{22}$ É importante verifica a possibilidade de ter a informação do endereço do proprietário da segunda residência em Aquiraz: se do Ceará e de outros Estados brasileiros e estrangeiros.

${ }^{23}$ Pedido de esclarecimento sobre a existência de investidores locais
} 
Assim a ADIT conseguiu vender essa ideia como uma forma de exportação e passou a dispor de verba federal para apoiar suas atividades.

No ano passado (2010) depois de quatro anos de existência da ADIT, o que é que aconteceu? Como esse dinheiro era federal, houve uma sugestão para que a ADIT deixasse de ser somente regional e passasse a ser nacional. Aí ao invés de ser ADIT-NE passou a ser ADIT BRASIL. Foi na reunião da ADIT Invest em Natal. Na verdade a feira era chamada Nordeste Invest e agora é ADIT Invest. Então o que acontece agora com a ADIT: ela passou a trabalhar nacionalmente porque recebia verba federal. E dentro desse contexto apareceu um novo desafio porque a ADIT passou a conviver com um novo problema relacionado ao alinhamento de conceitos ${ }^{24}$.

\section{A necessidade de formação especializada em negócios imobiliários}

$\mathrm{Na}$ verdade, quando os investidores vêm para cá eles vêm fazer investimento em negócios e para isso, tem que ter um projeto de investimento montado. $\mathrm{O}$ pessoal ligado diretamente à construção civil não sabe fazer esse tipo de projeto de investimento porque são engenheiros. Eles sabem desenvolver empreendimentos, mas somente relacionados à construção: levantar paredes, desenvolver projetos com arquitetos, coisa e tal, mas não no contexto de projeto de investimento de dinheiro (financeiro): da disposição de caixa, da taxa interna de retorno, do valor operacional líquido, conhecimentos inerentes a investimentos.

É a mesma coisa como se você fosse ao Banco do Nordeste. Você tem que fazer um plano de negócios para provar aos consultores funcionários do BNB que analisam aquele investimento, que aquilo realmente é viável. E passar o Banco a aportar o dinheiro no projeto. Nesse caso não era o $\mathrm{BNB}$, mas investidores estrangeiros que queriam aportar dinheiro aqui e sempre usam uma comunicação dessa forma.

Então, na realidade, as coisas aconteciam, mas não tinham planos de negócios dos projetos. Tá certo? Tinha um desenho de projeto, um "master plan" do projeto, tinham figuras (sic), uma matrícula, mas não tinham um negócio. Não tinha como é que eu entro e como é que eu saio desse investimento. Quais são os impostos e os riscos do

\footnotetext{
${ }^{24}$ Não ficou claro, mas a dificuldade parece estar relacionada com o choque cultural oriundo das experiências diversas entre os demais Estados do Brasil.
} 
investimento, entendeu? Enfim, em que pé o projeto (de negócio) estava estruturado. Desde o começo apresentava essa deficiência e continua assim ainda.

\section{O papel da consultoria em negócios imobiliários: a MAFC}

Essa consultoria é um trabalho que começamos agora, nesse ano de 2011. Foram 10 cursos que fechamos com a ADIT e com o Ministério do Turismo para rodar dez capitais do Brasil para falar sobre isso. O curso é praticamente subsidiado: o preço é somente $\mathrm{R} \$ 200,00$, muito barato para um conteúdo como esse, pela estrutura que custa levar um profissional qualificado, hospedagem, passagens de avião, deslocamento, tudo. Esse dinheiro é verba federal do Min do Turismo, na forma de um convênio.

\section{A falta de profissionalismo no setor de finanças imobiliárias e a falta de conscientização do mercado}

O grande ponto sobre qualificação em finanças imobiliárias é o seguinte: mesmo fazendo divulgação, parceria com o SIDUSCON, com o Jornal e tudo o mais, só se consegue botar de 25 a 30 pessoas por curso. Apesar de todo o esforço que se faz o mercado ainda não consegue ver que isso é importante.

\section{A discrepância entre o investimento financeiro e o imobiliário}

Fazendo uma comparação entre os investimentos: se você investir $\mathrm{R} \$ 100.000,00$ numa aplicação financeira, todo mês você pode ver o quanto ela rendeu. Seja poupança ou renda fixa. Em algum momento você vai lá e dá uma olhadinha pra ver como é que tá. Se o investimento for na bolsa, você acompanha com uma maior periodicidade. Entretanto, se você aloca num investimento imobiliário 5 milhões ou 10 milhões de Reais, você não tem como monitorar o seu investimento.

\section{O início da profissionalização do mercado em finanças imobiliárias}

Podemos dizer que o marco do início da profissionalização do mercado em finanças imobiliárias, coincide com o movimento de abertura de capital das grandes construtoras e incorporadoras em 2006 e 2007, como a Cyrela, Tecnisa, Rossi, entre outras, em direção à captação de recursos no mercado de capitais na bolsa de valores.

O que aconteceu: houve um choque de dois mundos, dois mundos muito importantes para qualquer economia: o mundo financeiro e o mundo imobiliário. Nesse momento 
criou-se uma forte interface entre o mercado financeiro e o imobiliário. Mesmo que já houvesse no Brasil o SFH (sistema financeiro da habitação), com empréstimos hipotecados e letras imobiliárias, mas enquanto não saiu a lei da alienação fiduciária ${ }^{25}$ que é a garantia e uma série de marcos regulatórios que garantissem o bem ao dar o financiamento, os bancos não entravam.

\section{A presença dos Bancos na carteira imobiliária de investimentos}

Só quando esse cenário ficou claro é que os bancos enviaram os seus advogados para analisar o marco regulatório que envolve a abertura de capital das empresas para o investimento imobiliário. A partir daí, o mercado financeiro imobiliário veio para modificar tudo. Porque trouxe a inteligência econômica e financeira dos bancos para dar soluções estruturadas para o financiamento do mercado imobiliário.

Chamou-se isso de operações estruturadas. As operações estruturadas podem ser o futuro do negócio imobiliário. Ou seja: eu quero um financiamento, então você faz nascer um projeto junto com o órgão que vai financiar o negócio. Os bancos de varejo, hoje, têm aqueles produtos já feitos que são os planos empresários, como é o caso do Bradesco, do Santander, enfim. Mas esses são produtos prontos.

Os melhores são aqueles que são construídos com a instituição financeira que conseguem propor taxas de juros menores na formatação do produto porque os riscos de ambas as partes são negociados: pode ser um seguro, uma garantia real, uma forma de garantir a devolução do dinheiro. Isso é construído, e por ser construído é estruturado em conjunto com as duas partes. Dá uma maior segurança porque o financiador passa a entender o projeto e conhece o projeto nas suas entranhas.

\section{A securitização como novidade}

Há uma expectativa de que o mecanismo da securitização vai crescer muito no Brasil, porque ele passa a trabalhar financiando os compradores com os próprios créditos dos

\footnotetext{
25 Lei que regula a transferência da posse de um bem móvel ou imóvel do devedor ao credor para garantir o cumprimento de uma obrigação. A lei no 10.406, de 10 de janeiro de 2002, alterou o Decreto-Lei ํo 911, de 1ำ de outubro de 1969, as Leis no 4.591 de 16 de dezembro de 1964 e a Lei no 4.728, de 14 de julho de 1965. Posteriormente, foi alterada pelas Leis de ํㅜ 11.196, de 21 de novembro de 2005, Lei $n^{0} 12.024$, de 27 de agosto de 2009, Lei no 12.350, de 20 de dezembro de 2010 e Lei no 12.543, de 8 de dezembro de 2011.
} 
compradores. É como uma operação da Caixa Econômica Federal, hoje. Ela é muito similar à operação da Caixa chamada "alocação de recursos - imóvel na planta".

O empreendedor para ter acesso aos recursos de financiamento da Caixa para construção precisa apresentar, entre outros documentos, a aprovação do crédito de no mínimo 30\% dos beneficiários, futuros compradores das unidades do empreendimento, antes da assinatura do contrato entre eles. Caso não consiga o número mínimo de mutuários ele poderá complementar com recursos próprios ou apresentar obra efetivamente construída. Portanto ele financia parte da obra com o crédito aprovado dos futuros mutuários que deverão assinar o contrato antes do fechamento do negócio entre construtor e Caixa.

No caso do financiamento através dos fundos de investimento imobiliário, a negociação financeira é estruturada junto com o empreendimento imobiliário, tanto o Banco, como o construtor, fica sabendo como é que o contrato vai funcionar. Não há necessidades de altas entradas porque quem vai pagar a obra é o próprio contrato de compra e venda que o futuro comprador fez com a construtora e que vai ser transformado em um papel chamado de certificado de recebíveis imobiliário e aí o resultado é que aquele papel vai financiar a obra, com as mesmas garantias que um banco exige. O papel da securitização vai também exigir a hipoteca como garantia evolutiva da obra cujos recursos serão liberados progressivamente, mediante comprovação na medição de obra efetivamente construída, além de uma promissória assinada pelo construtor. Enfim, com as mesmas garantias dos empréstimos convencionais.

\section{O risco da distância para o mercado de segunda residência}

Já para o mercado turístico, os bancos não financiam em localidade litorânea distante. Financiam no Porto das Dunas porque Porto das Dunas é Fortaleza, mas se começar a afastar: Flexeiras $(128 \mathrm{Km})$; Canoa $(170 \mathrm{Km}) \ldots$ Os bancos não financiam, porque está fora da área de risco seguro.

Eles entendem que é uma operação de risco, porque o mutuário pode começar a pagar e do meio para o fim ele pode não achar mais interessante e resolver que não quer mais pagar e nesse caso pode vir a dar problema no certificado de recebíveis imobiliários. 
Portanto as operações de segunda residência, hoje, são feitas para locais (cearenses), principalmente para locais. Se tiver dinheiro de estrangeiro fazendo segunda residência, ele vai construir a produção do empreendimento, mas para vender para local. Ele quer que a demanda seja local ou nacional, mais local.

Hoje existem empresas, como a Salamanca Capital Partner que é um fundo inglês e fez uma fusão com uma incorporadora nacional e vai construir em Natal, quer dizer é capital inglês com capital nacional, aqui em Fortaleza tem a Exact Invest que é norueguesa que investe em incorporação, mas é uma empresa que está montada em Fortaleza, com capital de fora.

Então tudo que é feito hoje com dinheiro de fora para segunda residência vem para vender para local e não mais para estrangeiro. Esse é o risco de operação. Se você quiser abrir um negócio em Canoa Quebrada, como é que você vai ter a garantia de que vai ter alguém para comprar a segunda residência lá? Não tem garantia. No Beach Park (Porto das Dunas) até que as pessoas vão porque fica a apenas $30 \mathrm{Km}$ daqui, mas passou disso... tanto é que o raio de atuação deles quando eles falam de Fortaleza a qualquer direção de praia é de $100 \mathrm{Km}$, que é uma hora de carro. Fora disso já começa a não agradar tanto. É assim que tá o mercado de segunda residência.

\section{A falta de conhecimento na gestão de finanças em negócios imobiliários}

Existe um hiato enorme, abissal, na qualificação profissional de quem vai trabalhar nesse mundo financeiro imobiliário, porque esses profissionais aqui, por mais que os engenheiros queiram participar desse mundo aqui (sic), aqueles engenheiros que não estão ligados a negócios, eles não vêm para cá. Eles vão para obra. Porque a formação deles é a obra. Para um engenheiro vir para a área de crédito imobiliário é preciso ele ter alguma formação de gestão ou alguma formação de projeto que dá um pouco de gestão para um engenheiro e ele acaba indo para lá. Acaba sendo atraído por essa área financeira. Mas se um engenheiro for unicamente de produção, ele não se atenta (para o problema), ou seja. Arquiteto: também não é o negócio dele. Arquitetura é outro tipo de negócio. A formação clássica do arquiteto também é outra. O arquiteto, ele talvez demandasse um viés para esse lado imobiliário se ele passasse a estudar pesquisa de mercado, tendência de mercado, o comportamento de compra do mercado, para ele passar a projetar o que as pessoas querem comprar. Aí, talvez fosse uma (possibilidade). 
$\mathrm{O}$ arquiteto pode até ter uma sensibilidade sobre buscar a satisfação do cliente, mas o marketing não é da arquitetura, é da gestão. Então se você chega e atrela marketing, produto, pesquisa de mercado, percepção de cliente: marketing mesmo! Se você conseguir agregar marketing na arquitetura, você dá uma visão de negócio ao arquiteto, aliando à sua formação clássica, porque aí você alinha essa formação clássica ao que o mercado precisa (sic). Aí sim, o arquiteto passa a entender e passa a desenvolver produtos.

Então, é por isso que tem esse hiato (na formação). Até as pessoas perceberem isso vai demorar um tempo: uns cinco, seis ou dez anos para as pessoas começarem a ir devagarzinho a entender que o valor agregado na arquitetura, além do projeto, tá em coisas diferentes que agregariam mais valor ainda à profissão, se passasse a interagir mais com o mercado.

Por enquanto não está assim não. Nem na engenharia e nem na arquitetura: quer dizer... os grandes profissionais da área de mercado financeiro tendem a ser as pessoas da área de gestão. Nem da área de economia, porque o economista também não entende de negócio. Entende de economia: mas não entende da gestão do negócio mesmo... de marketing.

Então, nós temos empreendedores sem a visão ainda, tão formal, de finanças imobiliárias. Usam porque o banco oferece. Faz aquela conta, bota lá, entendeu? Estudo de viabilidade: ainda é muito incipiente. Análise de riscos: não existe. Então o nosso trabalho, nesse curso preparatório para captação é justamente pegar, pelo menos, um modelo padrão que a gente desenvolveu e explicar como é que se deve montar um projeto para apresentar. Porque está se trazendo as pessoas pra cá (investidores) para participar das feiras... e às vezes agente faz feira em NY, faz feira em Londres também e aí não tem esse projeto estruturado.

\section{O perfil dos investidores}

O perfil dos investidores é variado: são fundos de investimentos, empresas de participações patrimoniais, empresas de shopping centers. São misturadas e diversificadas. As empresas possuem outras carteiras de investimentos. Mas, na realidade, no mercado imobiliário, quem investe nele é focado nele. Eles já conhecem as suas características, seus riscos. Já conhece como se ganha dinheiro com ele. O 
investidor imobiliário que não trabalha no imobiliário, que não investe no imobiliário, investe na unidade. Para comprar e revender.

Mas o investidor/empreendedor já ganha um pouco mais no imobiliário porque ele tem muito risco e às vezes ele não consegue chegar lá. Ele não consegue ter a visão de que pode investir construindo um negócio. Às vezes não é dada a ele essa oportunidade, tá entendendo? É o que chamamos de investidor secundário que entra em segundo lugar, no negócio. O primário é o que vai entrar lá na construção do negócio. É o investidor “equity”. É o que vai entrar na sociedade de forma igualitária, construindo um negócio com ele. Isso no Brasil já está mudando. Não aqui em Fortaleza, mas no sudeste, centrooeste. Eu estive, agora a pouco, na região de Goiânia e já tem empresas que juntam investidores de diversas áreas da sociedade, trabalhando em diversas funções (segmentos econômicos), de comércio em varejo e atacado que juntos fazem o mesmo empreendimento. Eles entram na constituição de uma empresa e essa empresa desenvolve aquele empreendimento.

\section{O cenário de tendências: o papel dos agentes investidores do mercado financeiro nas mudanças de formatação dos negócios imobiliários}

Os agentes investidores tiveram um papel de mudança que pode ser visto claramente nos gráficos de fundos de desenvolvimento imobiliário. Isso é exponencial. Eu não consigo ler isso através do desenvolvimento de empreendimentos porque eu não tenho esse dado consolidado em um local só, mas os fundos imobiliários são fundos que são criados para aluguel (sic) de empreendimentos de porte: 40 a 60 milhões de reais.

Então tem esse patrimônio dentro do fundo e esse fundo, você investe em cotas. Por exemplo: hoje para você investir em aluguel você tem que gastar, pelo menos, uns 500 mil reais porque você vai ter que construir e passar uns dois anos e meio construindo alguma coisa, para daí começar a alugar e ter retorno. Tá certo? O fundo imobiliário, não. Ele, inicialmente, já tinha que ter o patrimônio. Esse patrimônio era o elemento do fundo e aí você imediatamente já podia vender as cotas no outro mês que já estava ganhando rendimento dessas suas cotas (sic).

\section{O fundo imobiliário estatal e as regras para regulação de novos fundos}


A caixa econômica já montou um fundo imobiliário. Se você tiver 5 mil reais, no mês que vem, você já tá recebendo rendimentos. Funciona assim: cada empreendimento tem uma cota e tem o valor da cota que o mercado paga naquele dia. Você diz assim: eu quero comprar uma cota do fundo tal, de um shopping Center, por exemplo, Higienópolis em SP. Aí você bota lá um valor para compra e quando aquela cota estiver disponível, você pode comprar. Ele passa para você. Isso não é muito negociado porque é um negócio muito bom. É um negócio que, pelo menos $80 \%$ dos fundos tem um patrimônio maior do que o valor do patrimônio dele inicialmente. Quer dizer: se o patrimônio vale 100 , eles têm pelo menos 102, 200. Ou seja: o pessoal tá procurando porque tem procura. Entendeu?

A constituição dos fundos é via CVM - Comissão de Valores Mobiliários que é o Banco Central do mercado de capitais. Isso você faz com que você ganhe mensalmente a sua renda e a sua cota ainda se valoriza. Sabe o porquê? Porque eles procuram e existe venda suficiente para aquelas cotas. Quando você vê um gráfico de evolução, percebe que é o crescimento é exponencial.

Se você pegar o gráfico de 2003 até 2006, ele não tem quase variação. Quando você pega de 2006 para 2010 ele apresenta literalmente um crescimento exponencial. Tá na ordem de 4,5 bilhões de reais, mais ou menos o valor (comercializado).

Existe um site chamado www.fundoimobiliario.com.br onde tem todos os dados lá, os de rentabilidade, os índices. Então você vê claramente, a evolução do patrimônio, tudo. E isso acompanha (outros fundos de investimentos). Se você for comparar fundo imobiliário com Ibovespa e com o Imob. Imob é um índice igual ao Ibovespa, só que o Imob são as ações mais negociadas do mercado imobiliário. Ele é um indicador como o Ibovespa, só que o Ibovespa são as ações mais negociadas na bolsa e o Imob são as ações mais negociadas daquelas empresas do mercado imobiliário. Então é, disparado, (sic) melhor do que os indicadores do Ibovespa e Imob. E é só crescente. Só faz crescer de 2008 para cá.

Embora se comente que já se detecta certa desaceleração: no gráfico acumulado dos fundos imobiliários ainda não se percebe isso. Talvez numa tendência pontual em algum mês, mas no acumulado do ano, não.

\section{Sobre a tendência de valorização imobiliária}


A tendência é de crescimento e haverá mais margem para o crescimento se a população brasileira ficar mais rica, sim. E que vai ficar mais rica vai, porque você começa a ter uma situação de maior saldo de caixa da balança comercial devido a investimentos estrangeiros no Brasil, você começa a ter uma maior tendência de outros países que não estão tendo um maior crescimento lá, querer dar destino aos seus investimentos aqui.

O cenário de crise lá fora é favorável aqui. Porque lá não se tem e aqui tem tudo para ser desenvolvido, não só imobiliário, mas indústria, todo o tipo de demanda reprimida. Aqui o alimento é reprimido, o imóvel é reprimido, tudo é reprimido, ou seja, o que você botar compra-se. Porque se tem inflação? Porque as pessoas estão com dinheiro na mão e estão comprando. Em todo o parque industrial está afetando (sic) mais compras. Então o resultado é que até certo tempo atrás nós tínhamos $2 \%$ do PIB em crédito imobiliário, hoje já estamos com 4,5\% e já está se falando que a reserva da poupança vai acabar porque não acompanha o crescimento.

Os EU tem $60 \%$ do PIB em crédito imobiliário. O Chile e México: 12\%. Nessa valorização toda o do Brasil é 4,5\%. Imagine para chegar aos $12 \%$ o movimento que vai dar isso no mercado. Ou seja, vai vir mais riquezas nas mãos das pessoas e quanto mais ricas as pessoas forem, mais investimentos vão surgir porque elas não vão ficar com o dinheiro parado: ou vão consumir e o governo vai incentivar mais a investir porque sempre vai ter esse problema de inflação, tá certo.

\section{Sobre os novos produtos como nicho de mercado para novos negócios imobiliários}

Então o que acontece. O nosso trabalho hoje é levar essa mensagem para o mercado. Hoje existe uma tendência muito forte de bairro planejado porque não querem fazer só aquela pequena quadra ou aquela pequena parte de quadra, uma torre. Não. Começam a querer grandes áreas para ter um desenvolvimento urbano, realmente (sic).

Começam a falar de MCMV, numa situação de bairro planejado. Não mais de se pegar um terreno e amontoar (sic) as pessoas, todas dentro dum terreno. Nisso a arquitetura pode contribuir. 
Hoje, já se fala em condo-resorts: são condomínios e resorts integrados. Não se fala em um só resort naquele local, mas de uma grande área de 20 ha e dentro, vários condomínios para poder viabilizar aquela estrutura.

Já se fala de "fractional" (propriedade fracionada - compartilhada). Se você pegar unidades habitacionais hoteleiras ou uma casa e quiser dividir em quatro pessoas diferentes ou conhecidas, para comprarem a mesma unidade. Já é possível fazer isso em termos de estruturação de compras.

Então novos produtos no mercado são: condo-resorts que é quando você coloca vários resorts em um só condomínio e aí você paga uma administração consolidada, tipo Aquiraz Riviera, com vários hotéis junto a um loteamento de casas em uma área só.

Esses novos produtos já têm equivalentes no mundo. Eles sempre pegam o modelo já consolidado. Alguns vêm com campo de golfe outros não. É variado.

Tem um condomínio ali, que tem hotel e uma parte que é casa. Por exemplo: aqui da Colmeia (construtora), vizinho ao Beach Park. 1500 unidades. Só no lançamento vendeu 800 unidades do Golf Ville. Tudo comprador local. Não dá para saber se foi para investimento ou consumo.

\section{A situação de qualificação dos profissionais do mercado imobiliário}

Nós (consultores) estamos realmente numa situação que eu costumo dizer que é a seguinte: o açúcar na água. Ou seja: tem mais água do que açúcar. O que é que acontece: é muita necessidade, inclusive de conhecimento e de profissionais na área de finanças imobiliárias, porque se leva tempo para formar esse profissional.

Hoje para se formar um assistente, demora pelo menos um ano para ele sair operando com propriedade. E isso é no Brasil todo. Já estive no Paraná, em Brasília, em Goiânia, nós já rodamos muito. E o que se vê é todo mundo fazendo projeto, sem ter noção econômico-financeira.

Outro problema sério é o de controladoria de obra porque tem muita obra e pouco controle. Isso é risco. As pessoas não têm noções ainda de sistema de controle integrado de gestão que são os ERP (Enterprise Resource Planning). 
Com esse sistema você emite a nota fiscal e já cai na contabilidade. Só se compra o que está orçado. São sistemas caros e todo esse "know how" vem do aprendizado com outras empresas ou então quando a empresa já tem muita obra e sente a necessidade de implantá-lo porque reduz o quadro de funcionários também.

Assim, quando você aumenta o tamanho da sua empresa e não tem pessoal qualificado para acompanhar o crescimento, você resolve o problema com a implantação desse tipo de sistema. Chega um momento em que você não tem mais gente qualificada. Aí você compra o sistema tipo SAP, Topus, Informacon (marcas de desenvolvedores) que são sistemas voltados para gestão integrada para empreendimentos imobiliários.

Todo o meu conhecimento foi concebido durante uns dez anos de experiência. Já faz dez anos que eu estou focado nessa área de finanças imobiliárias e a minha fonte sempre é o mercado financeiro. A gente vê o que o mercado financeiro está fazendo e tenta adaptar para o mercado imobiliário.

Tenta conhecer o que o mercado financeiro está fazendo para o mercado imobiliário. Vai lá, conhece as pessoas e traz o conhecimento. Aplica, vê como os colegas aplicaram aquele caso na prática: se deu certo se não deu. Assim, você sempre tem que estar se municiando de informações que estão acontecendo: quais são os novos produtos; como é que estão sendo feitas as novas estruturações. Então tem que estar ligado direto com o mercado financeiro, porque eles estão criando sempre novos produtos.

\section{Sobre a MAFC}

A MAFC é uma empresa nova que começou há um ano e meio. Hoje tem um quadro de seis funcionários, mas o seu grande potencial é fazer Jointventures. Desenvolver áreas de novos negócios, como por exemplo: uma empresa em determinado local que quer desenvolver uma estrutura de gerar novos negócios. Eu vou lá e dou suporte para o pessoal, com minha metodologia, para que eles possam fazer isso, com autonomia. Agente acaba, de alguma forma, ficando amarrado com eles (sic). Porque até formatar uma equipe demora e a gente fica acompanhando. Em alguns casos eles propõem sociedade porque eles não têm esse tipo de mão de obra.

Então eu proponho a metodologia, eles adotam, e enquanto eles não tiverem autonomia eu fico lá dando atenção, até eles se desenvolverem sozinhos. Esse problema é nacional, 
não é só em Fortaleza. É assim: você tem um terreno, um corretor chega e bota esse terreno na mão de várias construtoras, só que o construtor não tem a "expertise" de absorver aquela quantidade de terreno que chega na mão dele para análise. Se chegar 100 terrenos ele não sabe fazer esses 100 projetos. Não tem como fazer nem quatro. 10 já é muita coisa, porque eles não têm estrutura organizacional para isso. Eles têm dinheiro, mas não tem organização para isso. Não tem engenheiro, não tem equipe e não tem estrutura organizacional para isso.

Mas se você consegue juntar tudo isso, num único local e chamar de originadora de novos negócios, você não faz só para você. Você faz para você e para quem quiser. Então a MAFC é isso. Ela é uma empresa que tem essa metodologia de analisar terrenos e dá a melhor negociação para ele, o melhor potencial para ele.

Às vezes o cliente pega um terreno de 5 ha, como é o caso agora, e propõe fazer MCMV em 5 há e não é o caso. Ali você pode fazer uma parte o MCMV, outra parte um centro comercial para atender as famílias, pode fazer um condomínio de casas, pode fazer um mix de produtos e diversificar e não botar tudo MCMV, gerando um projeto imenso de um único produto, sem a menor necessidade. Ao invés disso, você pode trabalhar de modo diversificado e ir implantando aos poucos, sem a pressa de fazer tudo igual.

Então na realidade o nosso foco hoje, basicamente é educação executiva. Não adianta passar isso para médios gerentes. Eu tenho que passar para os donos das empresas. Para que eles possam entender a mensagem e fazer com que aconteça dentro das empresas dele. Isso, não vai de baixo para cima. Se o dono da empresa não entender que o mercado mudou, que a dinâmica é imensa, é muito forte essa movimentação. Ela não vai conseguir acompanhar a competitividade.

\section{3. $O$ impacto da abertura do capital das construtoras ao mercado de capitais}

Na hora que um banco abre o capital ele apura um valor na ordem de 700 milhões de reais. Dizem que a Cyrela conseguiu 2 bilhões e 200 milhões de reais. É muito dinheiro, entendeu. Quer dizer, uma companhia imobiliária teve um potencial de captação maior que um banco. Fruto de que? De expectativa (de lucro). Naquela época o mercado estava com aquele potencial, mas cada um depois foi pegando menos. Teve um 
momento em 2008 que deu uma parada nas obras da Cyrela e Moura Dubeaux aqui em Fortaleza. Por causa da crise internacional. As pessoas ficaram um pouco cismadas do que ia acontecer. Não sabiam como é que ia ficar porque a crise foi justamente em outubro de 2008. Depois, viram que os fundamentos do Brasil estavam corretos, que o mercado local resolvia o problema que não precisavam de capital estrangeiro que o que acontecia lá fora, influenciava pouco aqui dentro porque nós conseguimos dar uma solução caseira para o nosso problema.

\section{Algumas diferenças entre o mercado americano e o brasileiro}

E qual a diferença do mercado brasileiro para o americano, será que existe alguma semelhança nos recebíveis, no sub prime? O mercado brasileiro, depois de uns 20 anos de hiperinflação, os bancos aprenderam a ser conservadores (sic). Eles não dão crédito. Eles têm restrição ao crédito, tá certo? Se você for comprar uma habitação na Caixa, não compra duas, só compra uma, tá certo? O mercado financeiro imobiliário, o SFH só permite financiar 30\% do seu salário. Isso eles controlam. Quer dizer. O mercado é controlador. Lá nos EU como eles tinham muito crédito para dar eles estavam dando para quem não tinha crédito, para quem não tinha capacidade de pagamento. No dia que os juros aumentaram mais do que os aluguéis que estavam sendo pagos quem era tomador não recebeu e criou um efeito dominó. Que não é o caso aqui que o mercado financeiro controla. Aqui tem o que se chama de "behavior" que é o comportamento. Se você vai securitizar um contrato e se você atrasou seis meses, aquele contrato é tirado da carteira, ele não entra no negócio.

\section{A lógica dos lucros na securitização de recebíveis e a formatação de novos produtos financeiros com base imobiliária}

Como se pode ganhar dinheiro sobre a compra de dívidas de terceiros? As correções e remunerações contratuais são IGPM $+1 \%+12,68 \%$ ao ano, É uma regra contratual. O CRI ${ }^{26}$ é corrigido no contrato de promessa de compra e venda que ele é pós-chaves e é corrigido por IGPM $+1 \%+12.68 \%$ a.a. É regra de mercado.

Então o que acontece, quando você compra um contrato como esse: isso tudo vai para uma companhia securitizadora que junta um lote de contratos e cria um título chamado

\footnotetext{
${ }^{26} \mathrm{CRI}$ - Certificado de recebíveis imobiliários
} 
CRI e a partir dessa remuneração contratual de $12.68 \%$ a.a. ele fica com 2 ou 3\% que alimenta a remuneração do investidor. A companhia securitizadora tem fundo para isso, compra os contratos e formata o papel como um investimento qualificado.

A companhia é que aporta o dinheiro comercializado pelo papel para obra e aí tem uma figura no mercado que mês a mês, vai cobrando as parcelas e vai repassando para o investidor. Na realidade os mecanismos do mercado financeiro são sofisticados e as operações estruturadas são igualmente sofisticadas. Não tem como entender isso se não entender de engenharia econômica e se não entender o raciocínio dos bancos e do mercado financeiro. Tem que entender como é que eles pensam senão não se pode montar uma operação.

\section{A diferença entre a Caixa e as outras companhias de investimentos}

A diferença entre a Caixa e as outras companhias de investimentos é que a Caixa apenas gerencia fundos. Ela tem regras para aplicar o dinheiro dos fundos. Ela só vai aplicar aquele dinheiro dos fundos, mediante aquelas regras. Se não for, não aplica porque a auditoria vem em cima e pega. A Caixa tem vários fundos: tem o fundo do FGTS, tem a poupança e tem outros fundos. Ela é gestora de fundos. Você lá (na Caixa), tá só fazendo uma função operacional e não está criando os produtos. Você não cria os produtos do banco.

Aqui nós montamos novos produtos. Se você tem um empreendimento, o mercado está repleto de investidores. Aí a questão é: eu gostaria de ter um investimento com base imobiliária e garantia real e gostaria que este investimento me rendesse $30 \%$ ao ano, com garantia real, uma hipoteca do terreno, por exemplo. Tem esse negócio? Tem. Ou seja você está investindo como num banco, em um projeto menor, com a garantia real e com os advogados conversando. Tem advogado do seu lado e tem do outro lado também que garantam a operação. Faz contrato com garantias.

O banco não atende todo mundo porque às vezes exige uma série de restrições que o investidor não consegue atender. Mas, de repente, para um pequeno investidor que não dispõe de formalizações diante de tanta burocracia quanto as exigidas por um banco, é negócio pra ele.

\section{A sofisticação do clube de investimentos imobiliários}


E a sofisticação não para aí. A Bovespa criou o clube de investimentos imobiliários. Você pode estar juntando pequenos investidores de 100 mil reais, aonde eu pego dez investidores e boto num negócio imobiliário. Cada qual botando 100 mil reais em parcelas para bancar a construção. Então eles estão financiando a construção através de clubes de investidores. Como é que se organiza isso? Hoje já se faz para terreno, já se faz isso para viabilizar empreendimento. Os maiores riscos que os investidores comentam são as garantias deles.

E o que é que ele (investidor) vai ter como garantia. Ele vai te dar o dinheiro e vai receber um contrato de compra e venda amarrado a uma garantia como um terreno fora do negócio. Garantia sempre ligada ao imobiliário. O negócio é feito em cima de uma garantia real, igual a um banco. É extremamente necessário que você entenda do mercado financeiro. Se você não entender você não vai conseguir fazer negócio.

\section{Alternativas criadas dentro do sistema para levantar dinheiro rápido}

Outro exemplo: existe uma operação chamada "bridge loan" (empréstimo ponte) que está cheio de gente doida pra fazer esse tipo de operação: é o cara que tá terminando a obra está com algum problema de fluxo de caixa e precisa de 300 mil reais só para acabar a fase e repassar a medição da obra para a caixa, entendeu? Falta um pequeno serviço que precisa de 300 mil reais.

Daí, qualquer pessoa pode fazer e isso é um dinheiro caro. É um dinheiro que você bota e volta com seis meses, oito meses e dá $30 \%$ ao ano. Dinheiro que investidor nenhum pega em aplicação nenhuma. Esse negócio não é comercializado na bolsa é negócio entre você e o construtor, com garantia real.

\section{Conclusão: o brasileiro mais otimista não está se preocupando tanto com a crise internacional porque está encontrando soluções dentro do país}

Então, quer dizer: hoje a turma não tá muito preocupada com o que tá acontecendo lá fora não. Aqui dentro as pessoas estão resolvendo o seu problema. Por que o brasileiro tá ficando rico. Nós conhecemos a nossa realidade, nós conhecemos o nosso defeito, conhecemos o que nós estamos investindo e fica mais fácil de fazer negócio do que chegar uma pessoa lá de fora e começar a fazer negócio com a gente. Porque ele não nos conhece não conhece a realidade do país. 


\title{
6.2.1.2 Os questionários e as transcrições da primeira fase de entrevistas: o setor público
}

\author{
ENTREVISTA 1
}

\begin{abstract}
AO COORDENADOR DE DESTINO DO PRODUTO TURÍSTICO DA SECRETARIA ESTADUAL DE TURISMO DO CEARÁ.
\end{abstract}

\section{A) QUESTIONÁRIO (Questão única)}

\section{Como você descreveria a contribuição da gestão atual da SETUR e quais as suas diretrizes principais?}

\section{B) TRANSCRIÇÃO}

Em 2007 quando o governador Cid Gomes assumiu juntamente com o secretário Bismarck, começamos a fazer essa análise de como que estava a situação atual dessa atividade turística dentro do Estado. E então, tivemos a percepção que estava uma demanda crescente e que o Estado não estava tendo aquela preocupação com o desenvolvimento do destino turístico.

\section{A necessidade de um novo centro de feiras e eventos}

Então qual foi o primeiro passo? Vamos nos desenvolver. Vamos reorganizar a casa. Vamos trabalhar a questão da macro estrutura que foi construir um novo centro de feiras e eventos porque o outro segmento que tá em alta, tá em crescimento, é uma demanda bastante crescente no Brasil todo e nós tínhamos o...do nordeste falando em matéria de nordeste nós tínhamos um centro para feiras de eventos bastante, limitado né?!

Ele não tinha competitividade com os outros destinos como Recife, Salvador. Então, até Natal tem um centro de feiras melhor do que o nosso. Então fomos... como é uma demanda, um potencial, uma demanda de uma permanência média, pequena, mas que tem um gasto relativamente maior do que os outros segmentos. Essa parte de lazer, da parte de aventura, de visitar parentes e amigos, então a gente começou a perceber, que o 
Cará precisaria de um novo centro de feiras e eventos. Tanto é que foi a partir daí que foi começado a ser pensado desenvolver esse novo centro de feiras e eventos.

\section{A necessidade de novos aeroportos}

Outra grande obra de macro estrutura que nós já percebemos ser necessária, hoje, é que nós só tínhamos um aeroporto que é o Pinto Martins e que fica em Fortaleza. Então, a partir daí, surgiu a necessidade de ser implantado mais dois novos aeroportos, que tá sendo implantado esse de Aracati, que tá sendo inaugurado agora, até o próximo mês de junho será inaugurado. E o outro projeto que é o aeroporto de Jericoacoara que vai pegar esses dois destinos que são destinos já consolidados dentro do Estado do Ceara. Talvez por força internacional, com aeroporto de grande porte, com aeronave de grande porte também aí vamos ter uma competitividade maior. Só pra dar um exemplo: a Bahia tem 1098 km de praia e têm seis aeroportos. Nós com 573, só tínhamos um. Então como é que nós podemos ser competitivos?

\section{O projeto do Acquário Ceará}

Além dessa questão de aeroporto, centro de feira e eventos, também viemos com o projeto do aquário, que é um projeto inovador, um projeto, desafiador porque ele é o único do Brasil. Vai ser o único da América latina, de porte. Vai ser o nosso, vai ser implantado certo?! Então é um equipamento que vai gerar um valor agregado ao turismo, e um diferencial. Vai ser um diferencial pra o nosso turismo né?! Ele é outro projeto que agora, temos as licenças para começar a construção. Já tá sendo trabalhado, já vai ser implantado, vai ser trabalhado em duas fases. Esses equipamentos: dois anos pra questão estrutural e outros dois anos pra montagem específica. A parte mais técnica interna.

\section{A sinalização turística}

Além do aquário, a parte de sinalização turística. Nós tínhamos muitas reclamações porque nós fazíamos quatro pesquisas aqui por ano, na Secretaria de Turismo: duas nas altas e duas nas baixas, nos principais portões de saída, aeroporto, rodoviárias, BRs e CEs. Junto ao fluxo nacional e internacional e era identificada essa questão da sinalização turística: a reclamação. 
Então nos fizemos um grande investimento, nessa parte de sinalização turística, tanto nos corredores de fortaleza, quanto nos principais corredores turísticos, no litoral, na Ibiapaba, Sertão Central. Então nos polos que a gente identificou que eram os grandes polos de consumo turístico né?

\section{A capacitação de pessoal}

Fora sinalização, também o Ceará gastou... nunca na historia do Ceara tinha se investido tanto em capacitação como nós fizemos. 2010-2011 nós capacitamos uma média de 12000 pessoas entre profissionais e empresários. Foi um dos maiores programas de capacitação do Ceará, não só do Ceará, mas também como no Brasil. Foi com os profissionais, com o SENAC, e os empresários com o SENAI. Justamente, cada um na sua área.

Então foi um projeto bastante interessante que agente também identificou através da pesquisas, essa reclamação com a falta da qualidade, a falta do atendimento precário, então nós trabalhamos muito com essa parte de garçom, parte de camareira, esse pessoal da linha de frente do turismo mesmo né?! os segmentos diretos.

\section{As rodovias}

Além de sinalização, capacitação e aeroportos como eu já falei, também as rodovias. É, nos precisamos. Sem acessibilidade não há um destino que tenha desenvolvimento, então nós precisamos melhorar as rodovias. Tem o exemplo da CE 040 que foi duplicada e ampliada. Num primeiro momento foi até Aquiraz e agora foi até Beberibe e agora vai sendo num terceiro momento até Aracati.

Além da CE 040, tiveram outras ampliações, outras CEs que foram ampliadas e foram reformadas como a CE 085, também vai ser agora passada por um processo. Que é estruturante, lá no farol oeste, né?! Ela também vai ser ampliada agora, ela vai ser, vai ter uma intervenção muito forte ali naquela CE.

\section{Projetos de urbanização e recuperação do patrimônio histórico}

Nós estamos com dois grandes projetos aqui na Secretaria de Turismo que é o Prodetur Nacional que trabalha com os municípios do litoral leste de fortaleza e o Prodetur que o secretario tá chamando de Prodetur Nacional dois que é da CAF, que é a Fundação 
Andina de Financiamento. Ela vai trabalhar o litoral, 14 destinos do litoral Oeste e também estamos trabalhando muito nessa parte de urbanização, drenagem, saneamento básico: Cumbuco e Porto das Dunas.

Essa parte de patrimônio também, nós já fizemos o resgate do patrimônio histórico ali de perto de Aquiraz inteiro: o centro histórico de Aquiraz foi todo recuperado pela Secretaria Estadual de Turismo.

Em Fortaleza: a restauração da igreja do Seminário da Prainha, o centro de turismo, e o teatro Carlos Câmara também foram reformados. O palácio da abolição onde o governador está hoje sediado, também foi recuperado pela Secretaria Estadual de Turismo, e outras obras que também estamos na linha de frente ai, que eu não lembro assim de cabeça.

Ali estamos trabalhando só a parte de urbanização, ali fizemos outro estudo, fizemos um estudo de mercado, onde a gente identificou junto à demanda que os turistas gostam de praias em lugares que tenham coqueiros, então a gente vai trabalhar muito essa parte gora, de plantio, vamos focar.

Essa parte de iluminação das praias, iluminação das rodovias, tudo, nós trabalhamos com esse projeto nessa parte também. Vai ser feito ali no corredor ali que liga o aeroporto internacional de fortaleza, aquela parte ali da base aérea, vai ter muitas intervenções ali também, nos vamos fazer uns muros, aquele muro da aeronáutica e do exército, vai ser pintado como se fossem umas rendas, vou lhe mostrar o projeto. Vamos criar um obelisco, então vai ser criada uma praça de esporte ali também, vão ser feitas vária intervenções, ali.

Então, o seguinte: o que nós costumamos dizer aqui. Que Fortaleza, que o Ceará está hoje um verdadeiro canteiro de obras, porque pra onde você vai você vê obras dessa área turística.

\section{A promoção turística}

Então, realmente, na parte de promoção turística? Nunca foi investido tanto em promoção turística, tanto nacional quanto internacional, com a participação de feiras e eventos, onde gastamos uma média de trinta milhões só com promoção. Pra você ter uma ideia, o orçamento da Secretaria Estadual, até 2006, era uma média de 11 a 15 
milhões. Hoje é 1,3 bilhões. Então o governador realmente, junto com os secretários realmente estão apostando nessa atividade. Hoje a atividade turística impacta 10,8 \%, quase $8 \%$ do PIB estadual.

Nós tivemos uma demanda de 2,8 milhões em 2011, de turistas nacionais e internacionais. Em nível de turismo internacional, nós perdemos em 2011 apenas, para a Bahia. O Ceará ficou em segundo lugar na região Nordeste, em fluxo turístico internacional. Nossos concorrentes foram sempre Bahia, Recife e Natal. Salvador, Recife e Natal. Mas só que hoje nós temos o segundo lugar do Nordeste. Hoje nós só perdemos mesmo, o Ceará só perde mesmo para Bahia, do restante nós estamos ganhando.

Segundo Dados da FIP, na a copa de 2014, o Ceará vai ser o terceiro lugar de maior procura internacional, perdendo apenas para Rio e São Paulo. Hoje o Ceará tem a segunda maior oferta hoteleira da região nordeste, perdemos apenas para a Bahia.

\section{A oferta hoteleira}

No Ceará hoje, nós temos uma média de 1.108 meios de hospedagem, 28.000 UHs, que são apartamentos e 77.000 leitos, no Ceará. Isso em nível de Ceará. Então, o que é que nós temos: nós temos uma grande oferta hoteleira, tanto é que para a copa, quando nós fomos concorrer pra sediar a copa de 2014 a FIFA estipulava uma quantidade mínima de meios de hospedagem, e nós já tínhamos esse pré-requisito, já estava atingido esse pré requisito.

Esse mês, agora mesmo, o Beach Park, até o final do mês, vai inaugurar um novo, outro equipamento lá hoteleiro com 300 apartamentos, próximo ao Beach Park. Ele já tem dois equipamentos, dois resorts, e vai inaugurar outro até o final do mês: um terceiro.

No Porto das Dunas nós temos uma oferta hoteleira bastante significativa: a segunda maior do estado, só perde para Fortaleza e fica batendo com Caucaia, mas é assim: Aquiraz é maior e Aquiraz tem uma rede hoteleira mais qualificada: os grandes resorts ficam sempre no Aquiraz. O Riviera vai ser um grande equipamento que talvez, esteja sendo implantado ali, e vai ser um grande diferencial também, que vai ter campo de golfe e tudo né? 
Em 2011, a oferta em Caucaia ainda era um pouquinho maior. É que em 2011 teve a implantação do Vila Galé, que é um equipamento grande, lá no Cumbuco. Então ele aumentou bastante a oferta de Caucaia. Assim, eu não sei te dizer especificamente, não sei te dizer assim a quantidade. Mas os três, Fortaleza, Aquiraz e Caucaia, esses três polos, eles formem assim uns $70 \%$ da oferta do estado.

\section{Os estudos de mercado}

Além disso, nós fizemos alguns estudos. Nós fizemos alguns estudos de mercado. A Setur se preocupa muito com essa parte de estudos e pesquisa. Nós fizemos umas pesquisas nos mercados potenciais, fomos a São Paulo, por exemplo, ouvir lá, in loco, o que é que o paulistano, o que é que o paulista acha do Ceará. O que é que induz ele a vir para o Ceará. Se não veio, porque ainda ao veio pra cá, porque em cima dessas pesquisas nós conseguimos traçar um diagnóstico.

Os nossos principais mercados nacionais é São Paulo, Rio de Janeiro, Pernambuco, Minas gerais, Distrito Federal. Internacional é: Portugal, Itália, França, Alemanha, e aí por diante.

\section{O turismo de base comunitária}

Os recursos da CAF (Comissão Andina de Fomento) vão ser justamente pra gente trabalhar essa comunidade, é o destino final, é aonde o turista realmente chega , é onde está a linha de frente, é tentar resgatar, por exemplo, a culinária local daquela região, é tentar resgatar o artesanato daquela região. Nós vamos trabalhar justamente com esse pessoal da base, da linha de base, da base comunitária, trabalhar com o pessoal da agricultura familiar, temos que inserir esses produtos no nosso mercado.

Nós estamos vindo agora com a copa do mundo de 2014. Vai ter uma demanda internacional muito grande, então nós temos que inserir também, tudo isso está sendo trabalhado, tudo isso está sendo pensado. Nós vamos incentivar que esse produto seja inserido da agricultura familiar, seja inserido junto aos meios de hospedagem, seja aos restaurantes, aos bares, aos supermercados, que é pra incentivar justamente a questão da agricultura, interna dentro do Estado, e as exportações também e também esse resgate justamente pra ocupar a população, vamos trabalhar essa questão da comunidade em si mesmo. 
O programa de municipalização do turismo era excelente, mas o grande gargalo daquele programa era porque ele era muito grande, ele atingia todos os municípios. E assim, o ministério começou a trabalhar com destinos indutores. Você não pode trabalhar o todo. No Ceará nós temos 184 municípios. Nós não podemos trabalhar 184 municípios. Nós temos que focar nos municípios que são potenciais turísticos e potencialmente turísticos, que hoje a gente trabalha uma media de 85 municípios, que são turísticos e potencialmente turísticos, ninguém pode trabalhar os 184 .

Nós consideramos turístico, os municípios que tenham pelo menos um meio de hospedagem dentro daquele município. Um município que não tem nenhum meio de hospedagem ele, não é turístico. Um exemplo atípico do ponto de vista que ele é um município bastante potencial, mas pela proximidade de Fortaleza ... (sic) que é Maracanaú, que é um distrito industrial, que tem muita gente de fora que vem por causa das indústrias, mas que acabam se acomodando em Fortaleza mesmo. Apesar de agora já ter sido implantado um meio de hospedagem lá que a taxa de ocupação lá é 100\%. É um turismo de negócio, mas que pela proximidade de Fortaleza, lá não tinha um meio de hospedagem. A gente podia desconsiderar e não seria turística se fosse assim, ele é turístico porque lá tem um segmento.

\section{A questão do segmento imobiliário associado ao turismo}

A secretaria de Turismo dá alguns incentivos, quando um empreendimento quer ser implantado aqui no Ceará, a gente procura e assina um protocolo de intenção e a gente dá aquela infraestrutura básica, ou seja: acessibilidade, água, energia, rede telefônica, até a porta do empreendimento certo?! Como aconteceu com o Vila Galé e o Aquiraz Riviera.

Então, esse tipo de incentivo o Governo do Estado dá sim e existe outra coisa muito forte, junto ao BNB tem um programa que é o Proatur (Programa de apoio ao turismo do Nordeste). Ele é uma linha de financiamento justamente para esses equipamentos, de implantação. Ele serve tanto para implantação quanto para ampliação, reforma, capital de giro e etc. Também para a hotelaria, alojamento, alimentação, agência, empresa de entretenimento e ai por diante.

\section{Sobre o turismo residencial}


A gente consegue identificar nas pesquisas o turismo residencial muito forte. Inclusive eu vi isso numa pesquisa há uns dois anos atrás que, em média, 10\% dos imóveis vendidos eram vendidos para pessoas que moravam fora do Estado: especialmente estrangeiros, certo? (sic).

A gente percebe nas pesquisas onde que há essa demanda crescente de pessoas que ficam em casa de parente e amigos, ou seja, ele compra um apartamento aqui e quando um amigo vem ele fica nesse apartamento, principalmente com o fluxo internacional isso acontece muito. A pesquisa que eu vi foi no jornal, que há 10 anos foi uma média de $10 \%$. Acho que foi 2007-2008, por aí (sic).

Então, realmente, isso acontece em qualquer destino turístico, isso é natural né? Isso é bastante comum. Tanto é assim que na copa de 2014, o Ceará vai também oferecer o Turismo de Cama e café, ou seja, você tem um espaço na sua casa, você tem um quarto, você vai reservar pra que o turista venha pra que ele fique na sua própria casa.

Isso aconteceu na Alemanha, isso aconteceu na África do sul, isso aconteceu em todos os países que sediaram copa do mundo porque o turista até prefere porque ele se sente mais à vontade, tem aquela troca, né? (sic). Ele vivencia o seu dia-a-dia, tem essa relação mais próxima com o morador local. Então eles até gostam bastante disso, apesar de a gente ter uma oferta que está bastante significativa, a gente vai incentivar esse tipo de turismo. Esse turismo, ele era comum até mesmo em Canoa Quebrada, Prainha do Canto Verde, isso é muito comum, você fica na casa dos donos, dos locais (sic).

\section{O meio ambiente}

Por exemplo, um destino como o Porto das Dunas mesmo não tinha saneamento básico ali, e nos estamos implantando. Foi implantado saneamento básico no Porto das Dunas, foi implantado saneamento básico no Cumbuco, que são dois grandes destinos e você se tiver um destino desse e não se preocupa com saneamento básico, lá não vai ter sustentabilidade. Então há sim uma preocupação com essa questão. O projeto da CAF todo banco é todo voltado pra questão do meio ambiente. E é uma das exigências principais, era o foco em cima da sustentabilidade. 
ENTREVISTA 2

AO COORDENADOR DE MEIO AMBIENTE E DESENVOLVIMENTO URBANO

DA PREFEITURA DE AQUIRAZ.

A) QUESTIONÁRIO: (pergunta única)

\section{Quais aspectos o Senhor considera mais relevantes na problemática da urbanização litorânea de Aquiraz?}

B) TRANSCRIÇÃO

\section{As batalhas judiciais}

Sobre as notícias mais recentes que nós temos em relação ao crescimento do Porto das Dunas e Aquiraz, tem sido dois aspectos: primeiro, houve um litígio, uma batalha judicial sobre os limites da poligonal da área de preservação permanente (da APA- área de proteção ambiental do Rio Pacoti), onde a SEMACE (Secretaria Estadual de Meio Ambiente) estava querendo que um empreendimento que estava ao lado da poligonal não fosse aprovado. Boa parte do terreno estava dentro da poligonal, segundo a SEMACE. Houve uma batalha judicial e foi decidida no STJ, no supremo tribunal de justiça (do Estado), que a área não deveria ser ocupada.

Ao mesmo tempo ocorreu outro processo, dessa vez na justiça estadual, de um ponto de vista diferente. $\mathrm{O}$ primeiro ponto que houve na batalha federal foi que a empresa não poderia instalar os sistemas básicos (infraestrutura básica) desse empreendimento: sistema elétrico, esgoto, colocar o empreendimento à venda e ela (a empresa) perdeu, digamos assim, perdeu o caso.

No caso da batalha estadual foi uma coisa bastante séria porque a empresa pediu ao juiz que a APA simplesmente deixasse de existir. As partes (interessadas) nessa batalha judicial eram: a proprietária da maioria dos lotes vagos do Porto das Dunas (loteamento) contra o Governo do Estado, e a SEMACE. Porque como a SEMACE é uma autarquia: é uma Pessoa Jurídica diferente. 
Então, nessa batalha, o que aconteceu? O juiz decidiu pela anulação da proteção administrativa da APA, em primeira instância (dando ganho de causa a JG Empreendimentos). O Estado recorreu e foi até ao desembargador, pedindo que por razões de interesse público, o desembargador retirasse a decisão judicial. O desembargador deu essa decisão favorável a SEMACE.

Assim, a decisão que tinha sido feita (em favor da empresa), foi revogada temporariamente. No começo do ano passado, voltou ao juiz, para terceira vara, no caso, e o mesmo juiz deu ganho novamente à empresa e agora vai voltar o caso, por questões

processuais, para o Tribunal (de justiça do Estado). Claro que ao emitir uma sentença, ela tem que ser aprovada no tribunal.

Ou seja: no primeiro momento dessa questão foi dado ganho de causa à empresa, derrubando as restrições administrativas da APA. Isto é: as restrições que estavam descritas no texto do decreto da APA. Na segunda instância, o Desembargador anulou essa decisão judicial. Aí voltou à terceira vara, e a terceira vara passou o processo exatamente para o mesmo juiz da primeira instância, que nesse caso deu uma sentença novamente favorável à empresa. Mas para a sentença ser válida, ela tem que passar pelo tribunal: e essa fase ainda não ocorreu, porque ainda tem que chamar o Ministério Público, o Ministério Público pode se pronunciar e reverter todo o quadro, ou não.

Bom, aí, no momento, a APA está sem as restrições administrativas. A APA não existe de fato, no momento. Na verdade, a realidade atual do país é que a maioria das unidades de conservação não está formalmente instituída. Não só as do Ceará, mas as do Brasil todo. É um segundo passo que ainda não foi dado.

\section{A criação da APA e as modificações das definições do código florestal pela resolução CONAMA}

E como é que foi a origem da criação da APA? Mais uma vez, houve um grande empreendimento, que se eu não me engano foi o Aquaville (no final dos anos 1990). Durante a construção do Aquaville houve uma manifestação da população local pela preservação das APPs, áreas de preservação permanente do rio Pacoti. 
A comunidade de Aquiraz, de um modo geral foi contra o empreendimento. Houve uma comoção porque um dos empreendimentos, eu não lembro exatamente qual foi, mas um desses empreendimentos afetou a área de preservação permanente, a APP do rio Pacoti.

Então, a comunidade foi à televisão, criou certa comoção e para garantir a preservação dessa área, o governo do Estado oficialmente, através da SEPLAG (Secretaria de Planejamento do Governo do Estado) e pelo que consta no texto que eu li, a SETUR foi a principal motivadora...formalizou o levantamento das APPs aqui do rio Pacoti (sic).

O Decreto é de fevereiro de 2000. Decreto 25.778 de 2000. A APA nada mais é do que um zoneamento. Então o que foi que aconteceu: essa área (referente às margens do rio) chegou a ser de proteção integral e a área que tá aqui em amarelo, mais externa, era a área que eles consideraram como área de uso sustentável que na época, em 2000, não era APP. Ela virou APP em 2001 por duas normas: pela medida provisória 2166-67 de 2001 e pela resolução CONAMA 303 de 2002.

É porque, veja bem o que elas dizem. Até essa data, o que era área de proteção permanente, em termo de dunas, pelo código florestal? Era só vegetação como restinga em cima de dunas, só vegetação de restinga. Nessa época não existia esse termo APP, era vegetação de preservação permanente. A partir da medida provisória, o que ela fez? Não apenas a vegetação é de preservação permanente, mas também o terreno onde ela está também passa a ser área de preservação permanente e mesmo que a vegetação não exista mais, ela continua sendo área de preservação permanente.

A resolução CONAMA 303 pegou isso e transformou as Dunas em APP. Porque, teoricamente, as dunas móveis nunca tiveram vegetação, tá entendendo? Mas a CONAMA pegou e disse assim: a partir de agora, toda a área dunar, independente de apresentar vegetação ou não, passa a ser área de preservação permanente.

Então na época em que a APA foi criada, em 2000, dunas não eram APP, mas era um terreno frágil, e como terreno frágil ele foi colocado como de uso sustentável, ou seja, podia usar, mas com cuidado. Só que houve muitas questões e, na verdade, apesar de ter sido criada a APA a política hegemônica era uma política de desenvolvimento do Turismo, cada vez mais. 
Mesmo sendo a área de desenvolvimento sustentável, ela começou a ser ocupada. (No porto das Dunas) É. Foi ocupada, e foi ocupada até que chegou uma questão que colocou em choque os dois interesses. Que foi justamente a questão da empresa aqui proprietária do terreno que agora ainda tá correndo na Justiça. Foi em 2010, começou em 2010, bem recente.

A área em questão, eu acho que é o do empreendimento Dunas Flat, que criou toda essa polêmica. Ele está paralisado agora. Estava em construção apenas o sistema de água e esgoto, mas não é o empreendimento em si. A obra do Dunas Flat está paralisada.

O que aconteceu? Aí, remete à justiça aquelas duas decisões que eu disse. Eles começaram a construir. Pegaram a licença pra construir e depois houve no Governo do Estado uma questão interessante que foi o seguinte: foi necessário fazer um concurso pra SEMACE. Só que a SEMACE é um órgão assim... como é que eu posso dizer... Falho. Além de ser demorado... ele tinha realmente essa dificuldade. Então, pra tentar corrigir isso, nessa perspectiva, o governador colocou como chefe da SEMACE uma das procuradoras (do Estado). Isso foi em 2010. No entanto, hoje ela não é mais a Secretária da SEMACE. Aliás, ela foi em 2009. Acho que foi logo depois que eu entrei. Acho que foi junho de 2009.

Quando a Lúcia chegou, ela por ser procuradora, colocava a questão muito ao pé da lei... e esse Dunas Flat, ela viu lá o processo, achou alguma coisa estranha e não aceitou que ele fosse aprovado sumariamente mesmo sendo só a renovação. Renovação de licença. Aí ela foi ver o processo mais a fundo e segundo os técnicos da SEMACE, o processo estava errado... erros no mérito. Mérito é a parte técnica dentro do processo. É que tem a forma e tem o mérito. A forma geralmente é a parte técnica que os advogados trabalham mais... e o mérito é aquilo que geralmente os técnicos trabalham mais. Então o que aconteceu? Como tinha um erro no mérito, a Lúcia não aceitou e aí que começou as batalhas judiciais.

\section{O impasse na batalha judicial da APA do Pacoti}

Então. Por causa disso, houve essa batalha judicial e a APA perdeu um pouco do seu valor. Seu valor e sua eficácia. Quando nós chegamos a Aquiraz, nós chegamos em 
2010, eu tinha acabado de sair da SEMACE e era o gerente justamente dessa APA. E o meu colega, era o procurador da SEMACE. Nós fomos chamados pelo Prefeito de Aquiraz justamente pra tentar resolver essa celeuma dentro de Aquiraz.

O trabalho, sem digamos assim, criar um problema maior na parte ambiental. O que nós consideramos depois que nós chegamos? Quando nós chegamos lá em Aquiraz, essa decisão do juiz Marconi, em terceira instância, estava em vigor, como está até hoje. Então, a APA está sem valor, digamos assim.

A luz dele é um argumento que do ponto de vista jurídico não... Eu não sei. Eu não sou jurista pra saber o ponto de vista jurídico, mas ele diz o seguinte. Ele diz que a área do porto das dunas começou a ser incorporada justamente em 1979 e a APA foi criada em 2000. Então, teoricamente é direito adquirido. Só que existe um problema. Primeiro a APP mesmo foi instituída em 1965, é bem mais antigo. E depois, tem uma coisa no Direito ambiental que diz que o direito ambiental se sobrepõe ao direito adquirido, porque ele é direito amplo, ele é direito para todos. Então, como é direito para todos, ele é superior a um direito particular. E por causa disso, mesmo que a norma venha depois, ela se sobrepõe ao direito adquirido. Então, teoricamente, esse argumento não é muito válido, mas foi o argumento que ele utilizou.

Aí o que aconteceu: a questão toda foi só por conta desse empreendimento. Quando nós chegamos lá em Aquiraz, eu já era gerente e peguei o problema para resolver. Mas, o que aconteceu? Quando nós chegamos na SEMACE, nós estávamos sem a APA em vigor, mas sabíamos que a decisão podia voltar a qualquer momento. Se o tribunal voltasse atrás. Então a gente tinha assim, que tomar uma decisão mais forte e o governo do estado também sentiu isso. Por que? ... Ele sentiu que se o desembargador anulasse a decisão judicial e se voltasse pro mesmo juiz, o mesmo juiz, quando chegasse no tribunal era possível que o tribunal revogasse a decisão. Ainda mais porque é uma coisa de interesse do Ministério Público. É interesse do Ministério Público porque ele foi um dos que mais lutou pra que aquela decisão não saísse assim. E no Tribunal, o Ministério Público tem muito mais poder do que antes. Então passa a ser uma coisa bem mais fácil de ser derrubada.

Pois bem. Por tudo isso, a gente procurou uma solução bem mais técnica que qualquer outra coisa. Porque uma visão técnica é muito mais difícil de ser contestada, é muito 
mais difícil de ser contestada do que se for só a parte administrativa. Então o que é que nós consideramos?! Nós tentamos investigar todas as causas possíveis, aí nós encontramos esse estudo do Observatório das Metrópoles. Esse estudo, na realidade, foi um dos principais motivadores. Deixa eu te mostrar aqui, aliás, a legislação. Primeira coisa: legislação de licença prévia, eu vou abrir aqui o código florestal e vou abrir também o estudo observatório das metrópoles. Na página 117, ele vai falar sobre as tipologias médias, a classe média e o envolvimento com essa questão que você sabe bem mais que eu. Enfim.

Ele vem falando aqui justamente de algumas tipologias sócio ocupacionais, mas vamos lá... Presença de vazios urbanos, dado a expansão do mercado imobiliário assim como a presença de grandes áreas de favela justaposto às casas de veraneio, contribui para a situação. Aqui ele fala da diversidade.

Essa situação de diversidade de juntar ao mesmo tempo favelas e condomínios de luxo, inclusive com casas de veraneio. Aí, ele está dizendo aqui que estão entre essas áreas: o Porto das Dunas, a prainha. Quando nós fomos olhar aqui nos detalhes, ele falou muito de favela. E ele diz o seguinte: ele fala do planejamento do porto das dunas e de áreas ocupadas irregularmente, como favelas. Todavia, a implantação de infraestrutura em função de serviços especializados tende a inserir essas categorias para áreas mais distantes, como os espaços populares. É aquela história. A área está em desenvolvimento, mas existem espaços abertos e esses espaços abertos favorecem um pouco o surgimento de favelas, principalmente se o poder público não cuida bem dele.

Como o porto das dunas está em plena expansão, se você pegar e colocar uma restrição sem colocar nenhum marco físico, se você tiver um marco físico ainda vai alguma coisa. Mas sem nenhum marco físico, sem nenhuma coisa visível, impedir e se você impede na barra você corre o risco de aquela área perder valor tão rápido que ela comece a virar um ponto de ocupação de favelas. Já é demonstrado lá na Prainha, já que a Prainha é um a forma de ocupação mais antiga. Mas na prainha já é mostrado.

Eu encontro a seguinte situação. Aqui tem algumas imagens da prainha, do Google Earth, só que aqui nessa imagem eu coloquei uma coisa diferente. Eu coloquei um sistema que você consegue ver o terreno. Você vê que aqui tem uma duna, uma duna bastante ocupada. Mas, enfim, você começa a ver aqui o que eles chamam lá de um 
conjunto habitacional bastante irregular. Não existem muitas ruas, as ruas que tem não são meios adequados, e aqui você vê um conjunto de casas sem nenhuma estruturazinha adequada. Na prainha, o nosso medo é de que apesar da prainha ser um pouco mais limitante porque é uma das mais antigas e tinha uma comunidade tradicional que ainda hoje habita lá.

\section{A questão do saneamento ambiental como justificativa para ocupar a duna móvel}

No Porto das Dunas, a comunidade tradicional já foi removida. Mas de qualquer maneira, nós tínhamos medo que essa situação começasse a acontecer também no Porto das Dunas. A situação que estimulasse a ocupação irregular. Por causa disso, deixou o Governo do Estado, na verdade eu acho que o principal interesse do governo do estado foi mesmo de ocupação. Mas o fato é que o Governo do Estado permitiu que se instalasse lá no porto das dunas um sistema de água e isto que segue essa imagem aqui. Essa é uma imagem que a gente fez bem simplificada, e na verdade é só mais pra mostrar mais ou menos como é que funciona.

Veja bem. Eu vou dizer uma coisa bem clara. O saneamento ambiental é uma preocupação com o meio ambiente? É. Mas ele é uma preocupação com o Meio Ambiente quando não tem mais jeito. Não tem alternativa. A pergunta é: realmente não tem alternativa? Eu não sei! Porque o que está acontecendo, tendo em vista o observatório das metrópoles, pela dificuldade que a gente tinha para fazer uma demarcação das áreas, e pela dificuldade do governo do Estado implantar esse sistema, a gente tá permitindo toda a ocupação da área Duna móvel.

\section{Quem elaborou o projeto e quem aprovou a licença ambiental}

Se eu não me engano foi um convênio com a SETUR. Quem aprovou a licença ambiental? Foi dada pela gente. Pela Secretaria de Meio ambiente de Aquiraz. Então veja só. O projeto, ele pega praticamente toda a área do porto das dunas, de dunas móveis. Ele pega basicamente o mesmo desenho do loteamento, mas só a parte do que vai ser enquadrado em baixo das vias, mas é o mesmo desenho do loteamento. 
Mas, é interessante, ele obedece também, dessa maneira, o que diz o decreto, mais fielmente até do que diz o código florestal. Ele obedece ao decreto do ponto de vista que, quando o decreto vê isso como de uso sustentável ele pode ocupar. O que não é de uso sustentável não pode ocupar. Se você vê aqui a Imagem você vai ver que ela para justamente quando chega a vegetação. E se você vê até essa imagem você vê que a área de proteção integral começa justamente quando chega à estação. Aí o que nós bolamos, do nosso planejamento da Secretaria de Meio Ambiente e Desenvolvimento Urbano. Olha, vai ter um sistema de água e Esgoto que vai ocupar toda uma área de APP. Tem essa justificativa do observatório das metrópoles. Querendo ou não é um meio de referência, a gente não pode negar. E além do mais, existe interesse das partes pra que seja resolvido o problema. Então o que a gente vai fazer? Vamos aprovar o licenciamento e vamos colocar um plano diretor que conduza a um meio termo, do ponto de vista que as áreas podem ser bem altas de ocupação, e conforme vá subindo as dunas, até mesmo pela fragilidade do terreno, os prédios vão ficando menores. Até chegar um ponto que na vegetação não tenha mais nenhum prédio e que se aceite bem a ideia de que não tenha mais prédio.

Então veja só. A área de preservação permanente, na verdade ela não é tão de preservação permanente assim. A mesma resolução que criou as áreas de preservação permanente, que foi essa aqui, a Medida Provisória né?...Deixa eu ver aqui... Cadê o artigo primeiro, área de preservação permanente? Veja que foi incluído pela medida provisória, tá vendo? 2001. No momento não existia. Não tinha. Antes não tinha. O código florestal não contemplava as APPs. O código florestal 4771 de 1965. Ele foi um dos maiores artigos: primeiro e segundo, que falam das APPs. Mas ele vem no artigo quarto dizer o seguinte. Olhe só uma coisa no artigo quatro. Perdi-me agora. A supressão em áreas de preservação permanente, e aqui você entenda que o desenvolvimento ambiental é o seguinte, não só a superfície, mas a utilização das APPs, só poderá ser utilizada em caso de utilidade pública ou em interesse social, devidamente caracterizada e motivada em processo administrativo, quando ainda existir alternativa técnica e locacional ao empreendimento proposto (sic).

Aí o que o Código florestal entende como utilidade pública e interesse social? Aliás, eu ainda vou lhe dizer uma coisa. Lá em baixo, no artigo 19, ele ainda diz o seguinte, não é aqui não. Eu me enganei. Mas em alguma parte do código florestal ele diz que em 
ambiente de dunas, só se for de utilidade pública. Nem se for de Interesse social, só se for de utilidade pública. Fizeram isso com o Aquiraz Riviera: quase tem briga lá.

Mas o Aquiraz Riviera foi por uma resolução do Conama especial. Foi feita uma resolução. Pra uma coisa assim... De frente, sabe?! Mal feita na verdade. Mas enfim aqui diz o seguinte: o que é de utilidade pública? Atividade de segurança nacional e proteção sanitária. Aí vem a pergunta: o que é proteção sanitária? Está na lei 11.445 de 2007. Estabelece as diretrizes nacionais para saneamento básico. No artigo terceiro se eu não me engano, ele vem definir o que ele diz que é saneamento básico, Aí ele dá as seguintes diretrizes: abastecimento de água potável, esgotamento sanitário, limpeza urbana de resíduos sólidos e drenagem de águas fluviais. As quatro coisas que são consideradas saneamento básico. Então, nós pegamos a água e esgoto que por essa lei é considerado saneamento ambiental e colocamos lá pra justificar a utilização de APP. As Dunas já estavam assentadas, do ponto de vista ambiental, não era algo tão grande porque a Duna Móvel, querendo ou não depois de ela estar móvel, ela repões as áreas das praias. E então como ela já estava assentada ela não tinha tanto interesse ambiental, nós ajudamos a implantar o sistema de saneamento ambiental e nós demos uma certa segurança jurídica (sic).

Acho que é tudo. Tanto ao projeto do loteamento, aos novos projetos e a parte ambiental. Vale ressaltar que tem uma nova lei federal, não é tão nova assim. Eu digo nova porque os advogados geralmente levam um tempo até pegar as leis novas. Mas tem uma nova lei ambiental que ela é de 2006, que ela é essa aqui. Que ela vem dizer o seguinte. Duna é basicamente vegetação de restinga. Existe uma falha quanto à definição de restinga. Tem várias Conamas que falam disso. Existe certa polêmica sobre o que vem a ser restinga. O que é a restinga?

Olha, vamos começar do começo, assim. É muito simples. Restinga na verdade, o termo restinga não é uma vegetação. Restinga na verdade é qualquer área de Terreno sedimentar, principalmente de areia ou daquele seixozinho próximo ao mar. Aqui no nordeste tem mais é areia e no sul sudeste tem o seixozinho. Mas qualquer terreno arenoso, que esteja perto do mar, é restinga. Isso sempre na área limite à faixa litorânea. Isso, sempre próximo a uma faixa litorânea. Não é o caso de um Deserto, por exemplo. 
Nem uma duna com área aí, digamos, em uma planície flúvio-marinha. Se não tiver perto do mar. Mesmo perto do rio seria considerada restinga. Restinga Fluvial também. Não, não. Só se tiver perto do mar. Perto assim, o que eu quero dizer, é que esteja até 10 $\mathrm{km}$, que tenha influência do mar, do epicentro costeiro. Só que o problema que a definição de restinga, ela foi dada por um botânico lá no Rio de Janeiro e o que ele considerava que era restinga era aquela vegetação próxima do litoral.

Só que existia um problema porque a restinga de lá é diferente da restinga daqui, então você criou uma polêmica. A restinga de lá é não é a mesma restinga daqui. Tudo é vegetação de restinga. Que do ponto de vista biológico é muito... A resposta seria óbvia: sim! Mas como a gente tá falando de uma sociedade multidisciplinar, é meio complicado. Aí deu várias resoluções do CONAMA tentando dizer o que a lei, o que o país entendia como restinga.

\section{O resultado do posicionamento da Prefeitura de Aquiraz}

Mas por incrível que pareça, eu acho que eles gostaram, do ponto de vista que eu dei segurança. Eles não iam ter mais os órgãos ambientais, "enchendo o saco" deles, porque aquela área tinha dunas (sic). Ou os órgãos ambientais com medo de liberar uma licença por medo do Ministério Público. Eu tava tentando deixar bem claro pra todo mundo que ia ser assim porque tinha que ser assim!

Na minha visão, do ponto de vista imobiliário lá do porto das dunas é o seguinte: eu acho que quando você deixa uma área bem preservada, não sei se você chegou a ir ao topo da duna lá no porto das dunas olhando em direção ao rio. É uma visão esplêndida! Maravilhosa!

Eu acho que agora eu vou dizer uma coisa. Minha visão, embora leiga do assunto, mas eu vou dizer uma coisa. Como gerente que eu estava lá, eu acho que toda essa peleja ambiental até do ponto de vista jurídico ajudou muito a aumentar o preço dos imóveis, porque na hora que você diz que um imóvel não pode ser ocupado por que ele tem proteção ambiental dá um pouco de medo. Realmente, em algumas pessoas, mas gera também uma preciosidade, uma raridade. 


\subsubsection{Os questionários e as transcrições da segunda fase de entrevistas}

Foram utilizados questionários padronizados com perguntas abertas sobre questões específicas, para todos os entrevistados, aproximando-nos de uma abordagem qualitativa e semiestruturada, como descrito abaixo.

\section{ENTREVISTA1}

AO ARQUITETO 1 - EM NOV/2011

\section{A) QUESTIONÁRIO}

\section{I) SOBRE OS NOVOS PRODUTOS TURÍSTICOS E IMOBILIÁRIOS NO LITORAL DA RM DE FORTALEZA.}

1. Como faria uma síntese histórica para explicar a ocorrência de "novos produtos" no contexto dos empreendimentos turísticos e imobiliários no litoral da RM de Fortaleza?

2. O que há de novo nesses produtos?

3. Em que aspectos ocorrem mudanças perceptíveis nos projetos arquitetônicos?

- Nos padrões de ocupação urbana;

- Na concepção do partido e do programa;

- Nas especificações de materiais e tecnologias construtivas;

- Outros.

4. Esses aspectos são influenciados por padrões ou experiências externas? (No projeto e no produto)

5. Que características são peculiares para o caso de Fortaleza? Existem especificidades do produto adaptado ao gosto local?

6. Como você interpreta o surgimento dos novos produtos turísticos associados ao imobiliário? O que muda e o que explica essa sinergia? 


\section{II) SOBRE OS NOVOS PROCESSOS DE PRODUÇÃO.}

1. Que mudança, no processo produtivo, o Senhor considera significativa por estarem relacionadas ao turismo e quais as outras mudanças decorrentes das inovações do processo de produção contemporâneo do imobiliário, propriamente dito?

2. Percebe mudanças na configuração das relações entre os agentes envolvidos. Quem são eles e como atuam?

3. Como se dá a integração dos arranjos propostos pelos agentes no contexto local?

- Novos arranjos de produção (financiamento, construção, comercialização, etc.)

- Novos agentes envolvidos (investidores, incorporadores, construtores, etc.);

4. Essa integração induziu alguma inovação tecnológica no processo produtivo?

5. Que mudanças o Senhor percebe nos demais níveis da cadeia de produção?

\section{III) SOBRE A RELAÇÃO ENTRE PRODUTO E NOVAS FORMAS DE PRODUÇÃO}

1. Como o senhor Percebe as relações entre os novos produtos e a sua produção? Existem mudanças significativas sobre as relações anteriores?

2. Quem são os agentes dessas mudanças?

3. O que considera particular para o caso Fortaleza e quais os fatores históricos?

4. Que projetos foram exemplares nessa relação entre o produto e produção?

5. Que mudanças mais recentes ocorreram diante da crise financeira internacional?

6. A ação dos agentes imobiliários responde à reorganização dinâmica de um novo processo de produção, diante da necessidade de incorporar novos territórios?

7. Como essa convergência de forças e processos alterou o papel desses agentes frente à especificidade da produção do espaço para o turismo? 
B) TRANSCRIÇÃO

\section{I) SOBRE OS NOVOS PRODUTOS TURÍSTICOS E IMOBILIÁRIOS NO LITORAL DA RM DE FORTALEZA.}

\section{Como faria uma síntese histórica para explicar a ocorrência de "novos produtos" no contexto dos empreendimentos turísticos e imobiliários no litoral da RM de Fortaleza?}

\section{RESPOSTA:}

É importante, primeiramente, esclarecer que minha opinião é um enfoque particular, de um tipo de atuação: a do nosso escritório. Pode não refletir a realidade, como um todo. Mas o que a gente sente assim, nesses vinte anos, de diferenciado é que havia uma tendência para condomínios, voltados para serem vendidos para pessoas de fora, unidades pequenas, isso começou nos anos 1990 e em 2005, isso mudou para o público local.

\section{No início, era o padrão do dos anos 1970 e suas alterações nos anos 1980}

É claro que já nos anos 1970 as segundas residências de veraneio eram vendidas no Icaraí, mas para um público estritamente local. (Nos anos 1980-1990 surgem além das casas em loteamentos, os condomínios de veraneio, verticais e horizontais, para o mesmo tipo de público).

\section{O despertar para o turismo e o surgimento de grandes hotéis em Fortaleza}

Depois começaram a surgir os hotéis, no litoral da Beira-mar (em Fortaleza): o Esplanada $^{27}$, financiado pela SUDENE, o Colonial $^{28}$, na Praia de Iracema, depois na

\footnotetext{
${ }^{27}$ O primeiro hotel 5 estrelas de Fortaleza, inaugurado no início da década de 1980
} 
Praia do Futuro o Vila Galé ${ }^{29}$. Alguns hotéis mais no interior também, nas praias, no Cumbuco $^{30}$ : começou a surgir uma estruturazinha hoteleira, precária nas praias.

A migração hoteleira para o litoral da RMF e o surgimento dos condomínios de lazer

Só que quando isso começou a disseminar mais para as periferias, quer dizer, nas zonas de praia da RM, aí isso começou a ter uma característica, não de hotéis, mas de unidadezinhas, sala e quarto, para vender com uma infraestruturazinha de serviço, restaurante, academias, não sei que: um condomínio de lazer.

\section{A tendência do condomínio e o retorno aos investimentos em hotéis}

Isso foi até 2004-2005. Até um determinado momento, isso perdeu um pouquinho. Essa tendência não se mostrou próspera. Aí o que é que a gente sente: empreendimento turístico, mesmo, voltado para turismo é que voltaram a ser os hotéis. Por exemplo: o Vila Galé, no Cumbuco, exemplo mais recente. Lá é um hotel: quarto de hotel, banheirinho de hotel: é um hotel. ${ }^{31}$

\section{O surgimento dos empreendimentos mistos: hotéis resorts e vilas residenciais e a mudança do publico alvo}

Outro exemplo: (Praia do) Presídio, o Aquiraz Riviera que inicialmente foi pensado para oito hotéis, resorts, campo de golfe, num sei que, e também tinha uma estrutura de residências para vender lá fora. Nenhuma dessas residências saiu...esses condomínios não saíram (não foram construídos). Saiu o hotel (foi construído) e eles começaram a vender os lotes para empreendimentos que começaram a fazer essa segunda moradia. Mas essa segunda moradia, pelo que eu tenho ouvido dizer, tá mais divulgado em

\footnotetext{
${ }^{28}$ Hotel 4 estrelas também da década de 1970

${ }^{29}$ Hotel cuja construção é dos anos 1980, mas entra em operação somente nos anos 2000 depois de reformado com capital português.

${ }^{30}$ Localidade praiana do Município de Caucaia na RMF teve inaugurado um dos primeiros hotéis fora de Fortaleza o

${ }^{31}$ Não há registro de empreendimento imobiliário associado ao hotel no cumbuco, pelo menos até o momento, no entanto o entrevistado sabe que há interesse do grupo no imobiliário que aguarda mudanças mais favoráveis no cenário das licenças ambientais.
} 
âmbito local do que no exterior. Isso mudou, possivelmente, com a crise financeira internacional.

\section{Sobre as influências da crise financeira mundial: mudanças de rumo e oportunidades}

Até aqui mesmo (em Fortaleza), empreendimentos que se esperava que fossem vendidos muito para o exterior, por exemplo, o Terraço do Atlântico, aqui: sala e quarto, na Praia de Iracema, atrás do Hotel Colonial. Então, ali foi um empreendimento que se pensava que fosse vender muito para o exterior, e realmente se vendeu um pouco, mas bem menos do que se esperava. E essa mudança começou antes de 2008 porque em Portugal, por exemplo, a crise começou um pouquinho antes: talvez 2004-2005.

Quanto à possibilidade da crise mundial se reverter em oportunidade de negócios para o Brasil, a impressão que eu tenho é que investimentos (sic), por exemplo: nós estamos envolvidos agora, por incrível que pareça, poxa, no meio da crise, a Espanha numa crise danada e os espanhóis estão aqui (sic). Nós fizemos um projeto, um "master plan" para Paracuru $^{32}$. E eles estão agora querendo construir um hotel, mesmo: bandeira Hyatt $^{33}$, quinhentos e tantos apartamentos: ou seja, uma estrutura hoteleira. Nada para vender. Dentro desse ciclo de mudanças: hotéis e/ou condomínios, os investimentos em Hotéis parece ser uma novidade mais recente. (provavelmente um ajuste nos interesses dos investidores diante das constantes mudanças de cenário no mercado interno e externo).

\section{A novidade dos resorts em time-sharing ${ }^{34}$}

Sobre os resorts em time sharing é algo novo, mas ninguém sabe como é que se comporta aqui, no mercado local, mas parece que agente está sentindo que já tem algumas pessoas que tentam isso e tão sentindo que é o momento para isso, mas não se tem uma constatação.

\footnotetext{
${ }^{32}$ Município litorâneo não pertencente à RMF com distância de 90 Km de Fortaleza

${ }^{33}$ Rede hoteleira com presença internacional de origem norte americana

${ }^{34}$ Tipo de propriedade do imóvel em tempo compartilhado e/ou férias programadas
} 


\section{Uma síntese das mudanças: dos condomínios de segunda residência para estrangeiros, ajustados para o público local, aos novos investimentos em hotéis.}

Eu acho que, na minha cabeça, eu diria que nesses cinco ou seis anos se reverteu uma tendência que era de se fazer esses empreendimentos turísticos que na verdade eram incorporações, porque eles faziam pra vender a unidadezinha, sabe? Tá entendendo? Não era para o turismo, propriamente dito, mas para a incorporação imobiliária voltada para o turismo.

Mas aí hoje, a gente sente que não tem mais espaço para isso que, na verdade, em termos turísticos mesmo o que vemos de novo é a volta dos hotéis.

E volto a dizer: isso pode ter um foco distorcido em função de uma visão particular, pelas solicitações que eu estou tendo (de clientes no escritório), mas eu tenho a impressão que é um pouquinho por aí mesmo. Tá certo?. Ou seja: às vezes a gente, na atividade, em função de determinadas solicitações, acha que isso é o reflexo do que está acontecendo em tudo, e às vezes, não é. É uma situaçãozinha particular. Mas isso, eu estou lhe dizendo (sic) ${ }^{35}$, mas acho que é um fenômeno mesmo, sabe? Essa tendência de reverter, um pouquinho e de se fazer hotéis.

Sobre essa recente mudança do foco das venda para o público local, substituindo os gringos, é um fato. Há pouco tempo se via famílias de portugueses comprando casas em Fortaleza, Eusébio $^{36}$, simplesmente porque era muito barato e eles estavam com dinheiro. Rapaz, eles compravam (sic). Nós temos um amigo nosso português que comprou no Mucuripe ${ }^{37}$ um apartamento de $300 \mathrm{~m} 2$ para passar temporada com a família. Ele tinha comprado no Terraço Atlântico ${ }^{38}$, vendeu e comprou no Mucuripe. Aí, depois, vendeu de novo (risos).

\section{Sobre o fenômeno da vinda das empresas de São Paulo a Fortaleza}

\footnotetext{
${ }^{35}$ Por um cuidado sobre a qualidade da informação

${ }^{36}$ Município vizinho na RM de Fortaleza

${ }^{37}$ Bairro litorâneo vizinho ao porto, muito valorizado

${ }^{38}$ Condomínio vertical, com vista para o mar no Bairro Praia de Iracema em Fortaleza
} 
Antes da crise internacional de 2006-2008 muitas empresas de SP vieram para Fortaleza e saíram comprando terreno, para futuros lançamentos imobiliários e depois com as incertezas da crise voltaram a vender novamente para o mercado local e abortaram os empreendimentos, devolvendo o dinheiro para os compradores. Depois voltaram novamente a comprar terrenos e retomaram novamente os lançamentos paralisados. É muito instável e suscetível a variações, o mercado imobiliário.

\section{Outros problemas que enfrenta o mercado imobiliário}

Outro problema que enfrenta o mercado imobiliário no litoral, além das incertezas e variações imprevisíveis é o problema do licenciamento ambiental que infelizmente não há uma definição clara. Na verdade, às vezes os empresários fazem errado, porque não são alertados de como se faz direito. Cada vez mais eu chego à conclusão que (exceto) em raríssimos casos (sic), a grande maioria quer fazer bem direitinho, tudo legal, dentro da legalidade e às vezes não dá certo porque nosso sistema é um pouquinho confuso, né? E eles fazem por inadvertência, quando não fazem certo. Se eles soubessem eles não fariam.

\section{Sobre a visão do imobiliário voltado para o turismo na atual gestão da SETUR.}

A visão do Bismarck ${ }^{39}$, do governo atual é de que os empreendimentos voltados para a incorporação, pro setor imobiliário, com enfoque turístico, eles traziam muito pouco retorno em termos de mão-de-obra. Quando você faz um hotel tipo um Hayett desses: 500 apartamentos. Você tem aí mão-de-obra formal. Na parte de hospedagem, eu não tenho dúvidas, toda a mão-de-obra é formal.

\section{Sobre os novos produtos no litoral da RMF}

Novos produtos, você vai ter o Aquiraz Riviera, no Aquiraz e o Vila Galé, no Cumbuco. No Porto das Dunas se constrói muito, mas são condomínios de lazer voltados para

\footnotetext{
${ }^{39}$ Secretário de turismo do Estado
} 
segunda residência de proprietários locais. Por exemplo: o Portamaris ${ }^{40}$. Tenho amigos como o João Carlos Vitoriano, Claudio Brasil, o Artur Novaes, o Marco Medeiros, o Eduardo Rolim. Todos eles são cearenses proprietários no Portamaris. Eu diria que eu não sei se tem um proprietário que não seja cearense.

\section{Sobre a saturação dos produtos condomínios de segunda residência e outras variações de tipos diferenciados}

Eu acho que, na verdade, esse produto não teve uma resposta do público de fora, como se imaginava e teve uma resposta interna como não se esperava. Tem um outro empreendimento que está sendo finalizado agora, o Beach Park Wellness Resort ${ }^{41}$, em frente ao Beach Park no Porto das Dunas. Ele foi incorporado pela Gafisa (e construído pela Construtora Castelo Branco de Fortaleza). Aquilo, na minha opinião é um empreendimento voltado para o turismo, mas são incorporações. Aquilo eu vendo. É um apartamento que se vende e para facilitar a venda eu boto uma estruturazinha de serviço de camareira, o que não deixa de ser um serviço de hotelaria, restaurante. Ali, a boa parte dos compradores são de cearenses, locais.

Embora pareça inesperada a reação do comprador local. O que eu acho é que ali nós não éramos tão assim voltados para o interesse de uma segunda moradia e isso se despertou $^{42}$. A segunda residência no Ceará sempre apresentou uns probleminhas no aspecto de segurança: assalto, etc. Quando começou essa segunda moradia ser de uma forma, por exemplo como no Portamaris (em condomínio de lazer de médio-alto padrão). As pessoas que moram lá, poxa, padrão de pessoa que poderiam ter uma casa só mesmo, como as antigas casas de praia de alto padrão.

\footnotetext{
${ }^{40}$ Geração mais nova de condomínios de lazer com equipamentos de alto padrão.

${ }^{41}$ Empreendimento imobiliário com serviços diferenciados como os de um Flat (disponibilidade para locação em um Pool administrado pelo Beach Park, serviços pay-per-use de camareira, lavanderia, baby sitter, massagem, personal trainner e manutenção) além de serviços especiais como acesso ao Beach Park (parque aquático com tarifa na ordem de $\mathrm{R} \$ 100,00 /$ pessoa) por 10 anos grátis e uma série de serviços promocionais como: acesso com desconto na suíte Caras, ao complexo noturno do Beach Park com serviços de compras e conveniências, sport Center, restaurantes, programas de fidelidade, entre outros. Entretanto, sua estrutura física ao primeiro olhar é de um condomínio de lazer excessivamente adensado. Não se sabe ao certo quanto ao sucesso de vendas porque a imobiliária sempre apresenta o empreendimento como de sucesso.

42 Provavelmente pelo excesso de oferta: os preços comercializados no lançamento alcançava a casa dos $\mathrm{R} \$ 3.500,00 / \mathrm{m} 2$ (dados coletados na feira de imóveis em 2008), embora os preços hoje alcance R\$5.000,00 a $5.500,00 / \mathrm{m} 2$ (dependendo da tipologia e localização- coletado com a Imobiliária Viva Imóveis em abr/2012)
} 


\section{Concluindo sobre os novos produtos}

Mas, na minha opinião, os novos produtos para o litoral da RMF do momento, são esses novos hotéis: o Aquiraz Riviera que, por enquanto, é só o hotel Dom Pedro Laguna com o campo de golfe e o Vila Galé no Cumbuco que, por enquanto, funciona só com hotelaria.

No entanto, existe no Aquiraz uma série de novos empreendimentos (de condomínios residenciais, com área de lazer, resorts de alto padrão e grande escala), como o Golf Ville da Colméia ${ }^{43}$ e o Mandara da Marquise ${ }^{44}$ (que são os dois maiores, no momento). O Golf Ville, é um apartamentozinho de sala e dois quartos que eu tô alterando para sala e três quartos. O de sala e três quartos, estamos botando mais um banheiro para virar três suítes. Ou seja: são empreendimentos voltados para residências para cearenses. Esse é o grande mercado atualmente porque o outro mercado não aconteceu, o estrangeiro. Além do Mandara tem outro mais na frente da Mota Machado (na estrada da Prainha: o Beach Place). Claro que você tem um publicozinho.

O golf Ville da Colméia foi projeto nosso e ele ainda nem foi lançado e nós já estamos fazendo adaptações porque foi um projeto já de muito tempo, tem uns quatro anos, porque houve problemas como os proprietários e agora eles se acertaram e agora eles vão lançar com as mudanças. Na época do projeto inicial já teve mudanças era quase metade de três quartos e metade de dois quartos. Agora já tô com mais unidades de três quartos e mesmo no de dois quartos, fizemos uma adaptaçãozinha para as pessoas que quisessem o terceiro quarto, diminuindo um pouquinho a área aqui, que é o padrão de residência do público local.

\section{O que há de novo nesses produtos?}

\section{RESPOSTA:}

Olha, de novo é o que já falamos: esse movimento de retorno para o tema hoteleiro, a mudança do perfil do comprador estrangeiro para o local e também diria o seguinte: que

\footnotetext{
${ }^{43}$ Construtora de Fortaleza

${ }^{44}$ Construtora de Fortaleza
} 
a grande maioria deles (os empreendimentos) usam como apelo o campo de golf. Que é uma novidade para nós, mas é um padrão que já acontece em SP, Buenos Aires. ${ }^{45}$ Embora não seja tradição do cearense, mas é a novidade que atrai.

\section{Em que aspectos ocorrem mudanças perceptíveis nos projetos arquitetônicos?}

- Nos padrões de ocupação urbana;

- Na concepção do partido e do programa;

- Nas especificações de materiais e tecnologias construtivas;

- Outros.

\section{RESPOSTA:}

Bom, eu vou por exclusão: novas tecnologias construtivas, não. Porque normalmente nos empreendimentos que nós estamos conversando, na Região Metropolitana, foram usadas as mesmas tecnologias construtivas tradicionais daqui. Como a tipologia desses empreendimentos são de edifícios baixos (até 5 pavimentos), não requerem uma maior sofisticação. Pelo contrário, eles (estrangeiros) vêm pra cá com um projeto de lá e, às vezes, contratam um escritório daqui. Nós estamos dando uma consultoria aos espanhóis, com eles dizendo: olha transforme esse projeto aqui em alguma coisa compatível com a linguagem e tecnologia daí. Porque eles querem fazer uma coisa que seja coerente e compatível com a realidade local.

Lá no Aquiraz Riviera ${ }^{46}$ fizeram o hotel todo no tijolinho cerâmico, madeira, telha cerâmica, tudo, tudo de acordo com a tradição da técnica construtiva local, aproveitando a mão-de-obra local. Portanto, novas tecnologias: não.

\footnotetext{
${ }^{45}$ E em outros lugares do mundo, como Portugal, Espanha, EU e vários países europeus, o que nos leva a concluir que é um padrão internacional que pretende se popularizar em outros locais do mundo

${ }^{46}$ No caso do primeiro estudo para o empreendimento Aquiraz Riviera, quando o nome ainda era Aquiraz Resort (2000) o projeto de autoria do Arq Luis Fiúza (Fortaleza) previa uma tecnologia inovadora para a cultura local pois utilizava sistemas pré-moldados desenvolvidos por uma empresa norte americana. Foi criticada pelo então Secretário Municipal de Turismo de Aquiraz que desenvolveu um estudo econômico, propondo a sua modificação alegando que a tecnologia só aproveitava a areia e a mão-de-obra menos qualificada de Aquiraz e, portanto, não era adequada para a realidade local.
} 
Novas concepções de partido e programa arquitetônico eu também diria que não, sabe por quê? Porque essas concepções, elas já ocorriam nos próprios empreendimentos, assim, por exemplo: um Portamaris ${ }^{47}$, como já comentamos, a linguagem dele, é uma linguagem muito parecida com a que nós estamos adotando no Golf Ville, ${ }^{48}$ sabe? O telhado de barro (sic). Então a concepção mesmo da unidade é muito similar. Você não tem surpresas em nenhum outro, por exemplo: o Mandara ${ }^{49}$, um outro na praia do Japão (em Aquiraz, depois do Mandara) da Construtora Motta Machado, o Beach Place ${ }^{50}$, todos os empreendimentos do Porto das Dunas, se você pegar a unidadezinha, poxa, quase tudo é a mesma coisa. Então eu não acredito que tenha havido alterações no programa, não. Porque se houve alteração no programa, é o seguinte: todos eles começaram a contar com uma infraestrutura de serviços maiores, no caso dos condomínios de segunda residência tradicionais (anos 1980-1990).

\section{Sobre a referência do novo padrão apresentado no Beach Park}

Se você considerar os anos 1980 como o recorte temporal, o Beach Park ${ }^{51}$ (1985-1989) estabeleceu um novo padrão, para nós aqui, mas que já existia lá fora (inspirada nas

\footnotetext{
${ }^{47}$ Esse condomínio de segunda residência foi construído por volta de 2007, para um público considerado pelo entrevistado como parte da elite local (médicos, altos funcionários e empresários). Ele não o considera como novidade porque poderia ser comparado ao modelo de condomínios fechados adotados pela classe média, dos anos 1980-1990, como resposta ao problema da falta de segurança. Para nós, ele representa uma evolução do modelo anterior que passou a incorporar ao produto imobiliário, além da segurança e serviços de lazer, a imagem idealizada de qualidade de vida, inserida num bairro turístico associado a diversão e serviços de qualidade, polarizados pelo complexo turístico em torno do parque aquático Beach Park. Devido ao alto custo de manutenção do condomínio, alguns proprietários já começam a anunciar unidades para alugar, em períodos não utilizados, como forma de gerar renda. Na sua entrada principal podemos ler "Portamaris Resort" uma alusão aos condo-resorts contemporâneos e, portanto, representa uma mudança no padrão dos condomínios de segunda residência dos anos 1980-1990, característicos dos anos 2000.
}

${ }^{48}$ Considerado um dos maiores empreendimentos imobiliários voltados ao segmento de condo-resorts do Ceará com $550.000 \mathrm{~m} 2$ de extensão projetado pelo escritório do entrevistado, com interiores elaborado por escritório de Fortaleza e paisagismo por escritório de SP. Construído por uma construtora local (Colmeia), pioneira nesse segmento e responsável pelo primeiro grande empreendimento de condo-resort no Ceará operando também em regime de time-sharing até hoje: o Aqua Ville Resort (1990).

${ }^{49}$ Outro empreendimento de condo-resorts de grande porte, com 1,6 Km de frente para o mar e $80.000 \mathrm{~m} 2$ na sua primeira fase (O Mandara Kauai), tão sofisticado quanto o anterior, elaborado pelo consórcio: Gafisa, Cyrella e Marquise (Construtora local). Teve o projeto de arquitetura elaborado por escritório de Fortaleza, paisagismo e interiores elaborados por escritórios de SP. Produto voltado para o mercado local e nacional: São Paulo, Belo Horizonte, Brasília, Goiânia, Manaus, Belém, São Luis- (colhido no material promocional)

${ }^{50}$ Outro empreendimento de médio porte, na mesma região, com a mesma linguagem e finalidade (60.000 m2 de área do empreendimento)

51 O Beach Park é o complexo turístico mais visitado no Estado distribuído numa área total de aproximadamente $180 \mathrm{mil} \mathrm{m2}$ por onde circulam, segundo estatísticas do parque, algo em torno de 1 
influências internacionais adotados em outros resorts), mas que nos serviu como referência. Você vê cuidados nas pavimentações bem pensadas, a parte de paisagismo bem pensada, a parte do mobiliário urbano também bem pensado, coisas simples que não se via em outros projetos locais, do gênero e certamente foi fruto de pesquisa do (Arq.) Arialdo Pinho ${ }^{52}$ e do Joãozinho Gentil ${ }^{53}$ que também pesquisou muito. Mas que para nós era novo mesmo (tendo como corte temporal os anos 1980), apesar do que a proposta adotava uma linguagem condizente com a realidade climática local (tropical).

\section{Sobre os novos padrões de ocupação urbana}

Sobre os novos padrões de ocupação urbana, o que posso entender é que existiram sim novos padrões de ocupação urbana. Como? Sempre em áreas muito grandes, porque tradicionalmente, até um determinado momento era uma implantaçãozinha feita em um hectare, meia quadra, cinco mil metros quadrados. De um determinado tempo pra cá você vê o Aquaville ${ }^{54}$. Foi o primeiro que fugiu do padrão anterior e se fez em glebas de grandes áreas. O Aquaville, se não me engano são 30 ha (300 mil m2), uma coisa assim. (verificamos na cartografia e constatamos uma área de implantação aprox. de 200 mil m2). O Golf Ville, acho que são 60 ha (constatamos no site do empreendimento 55 ha).

milhão e 150 mil pessoas por ano. Segundo seus fundadores, nasceu a partir de um restaurante na beira da praia, em 1985 e em 1989 inaugurou seu parque aquático, considerado o primeiro da AL. Em 1996 o complexo ganha seu primeiro hotel com a bandeira Caesar Tower que em 1998 passa a ser Beach Park Suite Resorts, com 175 UH. Em 2008 foi inaugurado o seu segundo hotel: o Beach Park Acqua Resort, com 123 UH. O complexo está associado a diversos órgãos de turismo nacionais e internacionais. A sua composição societária será estuda em detalhes, na tese, mas é importante ressaltar que todo o complexo está implantado dentro de um projeto urbanístico, composto de um setor turístico de uso misto e de um grande setor residencial.

Analisando o padrão implantado pelo Beach Park percebe-se a importância do marketing associado ao produto, que acaba impactando no projeto incorporando conceitos e valores de qualidade de vida, surpresa e diversão, seja no acabamento rústico, nas cores quentes, na textura dos materiais que sugerem uma informalidade, balanceadas com elementos que conferem sofisticação nos detalhes da arquitetura de interiores.

52 Arquiteto responsável pelo projeto do Beach Park.

${ }^{53}$ Sócio de Francisco Jereissati (irmão de Tasso Jereissati) na empresa Sociedade Porto das Dunas Ltda. criada em 1979 com o lançamento do loteamento Porto das Dunas e casado com a Arq. Ania Ribeiro que elaborou o projeto urbanístico

${ }^{54}$ Foi inaugurado em meados dos anos 1990. Foi o primeiro empreendimento imobiliário cearense com apelo de condomínio de lazer (para proprietários) e serviços de turismo e hotelaria, no padrão condo-resort, operando também em regime de "time sharing" e utilizando-se de uma nova e criativa abordagem de venda, oferecendo jantares e brindes, apenas para participar de apresentações, aparentemente sem compromisso nenhum de compra do produto (que variava de propriedade compartilhada a férias programada). Embora tivesse apresentado muitos problemas na implantação e manutenção ele funciona até hoje com um bom padrão de manutenção e ocupação. 
Então as ocupações começaram a ser assim, né? Padrão de ocupação em grandes glebas. Essa seria a diferenciação que eu diria. Por quê? Porque não aconteceu, por exemplo, uma ocupação verticalizada. Verticalizada que eu estou dizendo é (permitindo) até três pavimentos, né? Não como fizeram na Fleixeira um hotel de 12 ou 15 pavimentos na beira mar. Isso não aconteceu (em Aquiraz) aquilo (em Fleixeiras) é uma exceção. Agora o que aconteceu, na verdade foi isso: grandes glebas (de até 4 ou 5 pavimentos).

\section{Sobre o master plan do Aquiraz Riviera ${ }^{55}$}

É, podemos dizer que a proposta do Aquiraz Riviera é um novo padrão de ocupação. Igual a ele aqui só o Vila Galé que tem também um "master plan" com características semelhantes. Ambos foram projetos nosso, tanto os hotéis como o master plan.

\section{Concluindo sobre os novos padrões}

Se considerarmos o horizonte temporal os anos 1970 nos teríamos aí um série de gerações de condomínios de lazer de segunda residências que foi evoluindo do padrão Icaraí, dos anos 1980, para o padrão do Porto das Dunas no final dos anos 1980 e 1990 e depois para a geração dos anos 2000 , onde os serviços foram se sofisticando cada vez mais na direção dos grandes empreendimentos atualmente em construção. Claro, sem falar no padrão que foi representado pelo parque aquático Beach Park que depois começou com um hotel construído pela Marquise e administrado pela bandeira Caesar Tower e foi antes do Aquaville que foi o primeiro a vender unidades residenciais com feição hoteleira (condo resort) porque tinha restaurante, serviço de camareira para quem quiser e tal, mas era unidade para vender e começou esse processo de unidade para vender para pessoas de fora e se surpreenderam porque passaram a vender para pessoas daqui. A ideia era captar fora, mas o mercado interno surpreendeu. Aí, isso continuou e esse negócio para vender para pessoas de fora acabou e eles continuaram a fazer porque o mercado local acabou se mostrando presente. Tá presente aí. O Aquaville,(sic) todo mundo é mercado local, vendendo pra cá, pra pessoas daqui mesmo. O golf Ville, o novo (em construção), também é mercado local. Aí, o que é que aconteceu, os

\footnotetext{
${ }^{55}$ Consideramos o padrão desse "master Plan" (projeto urbanístico mestre) como uma novidade para nós aqui no Ceará. Não existia nenhum projeto que incorporasse um complexo capaz de abrigar oito hotéis, além de empreendimentos de condo-resorts e vilas turísticas (casas individuais do tipo segunda residência) integrada ao programa temático do campo de golf, coutry club, shopping, conveniências, etc.
} 
empreendimentos, agora, voltados para o turismo, voltaram a ser os hotéis: tipo o primeiro do Beach Park, que a Marquise fez (como num ciclo de ajustes do mercado) e que é agora são esses que foram construído: o Dom Pedro Laguna (do Aquiraz Riviera), o Vila Galé (do Cumbuco), o Rayett, do Paracuru.

\section{Esses aspectos são influenciados por padrões ou experiências externas? (No projeto e no produto)}

\section{RESPOSTA:}

Eu acho que em parte sim, sabe? O padrão, a exigência, que supostamente seria cobrado pelo público internacional foi incorporado pelos empreendimentos e passou a ser o padrão de exigência daqui. O "start" foi esse mesmo, baseado no padrão externo: as grandes áreas de água. E as referências são muitas. Você tem no Caribe muita coisa, México. Mas eu acho que nessas unidades de hotelaria eu acho que tem influência da Espanha, Portugal, muito. Por exemplo: quando fomos projetar o Aqua ville, fizemos uma viagem com o Rommel, pelo Algarve, pra ver esses empreendimentos de lá. Também os empreendimentos daqui mais voltados para a América Latina: Caribe, Bolívia, Venezuela, ali em cima, do México, ali, sabe, também são referências. Desde os anos 1980 a experiência de Cancún. A linguagem é muito similar: o estuque pintado, a telha colonial. Então, não foram experiências nórdicas, por exemplo, mas sim aquelas mais condizentes com o nosso clima.

A presença de países nórdicos se fez no aporte de Capital, financiando obras. No Catu, nós temos um sócio norueguês: por quê? Porque começaram com aqueles voos fretados de lá prá cá e os caras ficavam encantados com o sol daqui. No Terraço do Atlântico, teve um norueguês que comprou vários. Finlandeses também. E eles queriam o apartamento que ficassem com a frente para o sol. Eles diziam: eu quero é esse. O sol é que é o bom. A varanda virada para o poente. Esses noruegueses e finlandeses que viraram compradores e sócios foram aqueles que vieram conhecer o estado nos voos charters. 
É assim que acontece, por exemplo: os investidores portugueses no Dom Pedro, trazem suas referências de lá e procuram adaptar com as daqui. Por pouco eles não fizeram a alvenaria dupla que eles fazem em Portugal, por problemas de preservação do clima interno, por conta do frio. Então eles queriam fazer o mesmo aqui para proteger-se da insolação. Mas não fizeram. E houve insistência: ah, vamos fazer! Quase que se fazia. Mas eles trazem uma forma de pensar as coisas que estão mais afetas ao conforto ambiental. Porque, com relação às outras tecnologias construtivas, elas não têm muita diferença. O padrão já se homogeneizou, de um certo tempo para cá e elas não requerem uma tecnologia específica de fazer o concreto assim ou assado.

\section{Que características são peculiares para o caso de Fortaleza? Existem especificidades do produto adaptado ao gosto local?}

\section{RESPOSTA:}

Eu diria só assim... essa coisa da rejeição da frente para o sol poente é peculiar nossa. Em salvador eles não tem muito isso, Recife, menos, também não como pra gente aqui: esses empreendimentos que vem de fora, tipo da Gafisa, eles às vezes esbarram nessa cultura local, porque eles lá eles não têm esse problema: é uma circulaçãozinha aqui, bota prá lá e bota prá cá e tá resolvido. Aqui não esse bota prá lá no nascente tá bom, mas o bota prá cá não tá porque é poente. Então tem uma pequena adaptaçãozinha no nível de projeto mesmo, prá que essas coisas aconteçam bem, em termos de mercado local. E daí vem o fato de eu lhe dizer que o mercado comprador que é o local, por que tem esse refino de exigência própria do consumidor local.

Agora, no Golf Ville, da Colméia, como são muitas unidades e tem um campo de golf: tem unidades voltadas para o golf que olham para o nascente e outras que olham, mesmo um pouquinho inclinada para o poente. Pediu-se agora para mudar tudo isso aqui, porque sentiram que os clientes mudaram. Gringo não tem mais e o local não vai comprar isso aqui. Compra, demora muito, reclama. Aí fizemos uma mudançazinha na implantação e tal, certo?

Além disso, não vejo nada de peculiar não. 


\section{Como você interpreta o surgimento dos novos produtos turísticos associados}

ao imobiliário? O que muda e o que explica essa sinergia?

\section{RESPOSTA:}

O que agente sentia também é que boa parte dessa sinergia era em função de que o valor pago, principalmente pelos europeus (italianos e depois muito os portugueses) pela remuneração do dinheiro (capital financeiro), era irrisório. E aqui nós tínhamos um valor da remuneração do dinheiro grande. Então os caras começaram a investir aqui. Começaram a investir no mercado financeiro e depois em terreno porque viram que o mercado imobiliário também era muito bom e mais rentável até que o mercado de capitais. Tanto é que o Terraço do Atlântico foi um empreendimento com investimento português.

II) Sobre os novos processos de produção.

1 Que mudança, no processo produtivo, o Senhor considera significativa por estarem relacionadas ao turismo e quais as outras mudanças decorrentes das inovações do processo de produção contemporâneo do imobiliário, propriamente dito?

Sobre as mudanças no arranjo do processo de produção

\section{RESPOSTA:}

Eu acho que nós saímos um pouco daquele processo em que o incorporador era o que construía, quem vendia e quem fazia tudo, para um outro modelo diferente, a partir do começo dos anos 1990, onde o incorporador passou a ter uma figura e um papel. Antigamente era o proprietário do terreno que fazia o papel do incorporador e abordava a construtora para fazer um estudo. No Brasil, no Rio já era diferente, desde os anos 1970: o incorporador era uma coisa, o construtor era outra. Aqui é que era diferente. Às vezes (no Rio) eram empresas que tinham o mesmo proprietário, mas que tinha duas pessoas jurídicas diferentes: a incorporadora e a construtora. Aí isso começou em 
Fortaleza no comecinho de 1990, quando se sentiu que eram coisas diferentes e precisavam-se separar essas coisas.

\section{Sobre as mudanças na origem do capital e do financiamento da obra e o papel do incorporador}

\section{RESPOSTA:}

Não se tinha muito o financiamento público depois do fim do BNH em 1986. Esse financiamento público só voltou agora nos anos 2000. E o dinheiro da construção ou era próprio da construtora ou era negociado diretamente com o dono do terreno, em troca de unidades construídas depois da execução. Ou então, o arquiteto oferecia a quem tinha dinheiro, a compra de um terreno, em troca de unidades construídas. Ele concordava e depois eu ia atrás de uma construtora para realizar a construção.

O incorporador às vezes comprava, ele mesmo, o terreno, mas às vezes não. Ele ia procurar um investidor que comprava o terreno e recebia unidades que o arquiteto montava para eles em troca.

No caso do Terraços do Atlântico nós figuramos como incorporadores: os portugueses compraram o terreno, na garantia de receber tantas unidades num valor maior que o terreno valeria. Nós montamos o produto, os portugueses entraram como investidores e fomos procurar alguém para construir. E foi a construtora Castelo Branco.

Na nossa experiência, ouvimos de investidores que nós arquitetos de projeto estávamos perdendo grandes oportunidades porque não apresentávamos um projeto de negócio e convidaram o nosso escritório para participar do negócio, a partir da montagem de um projeto de risco que acabou trazendo o nosso escritório mais perto do papel da incorporação.

Portanto as mudanças mais evidentes nos processos de produção que ocorreram foram mesmo o aparecimento da figura do incorporador e do investidor entre o comprador e a construtora. 
Num passado recente os grandes financiadores da construção aqui eram os proprietários dos bancos, não eram os bancos. Adauto Bezerra, Humberto Bezerra (BIC BANCO) compravam terrenos para receber unidades. O próprio Jayme (Leitão), outros a Coopcon eles iam a um proprietário de terreno e perguntavam quanto custava e entravam em contato com o Humberto e dizia compre o terreno que nós te damos tantas unidades. A Construtora Integral fez muito isso. Agora uma figura nova que hoje faz isso é a BSPAR: o Beto Studart. Foi a pessoa que comprou o terreno do Tasso Jereissati. Vendeu a Agripec e comprou vários terrenos, com muito capital. Agora ele resolveu que quer construir também.

\section{Percebe mudanças na configuração das relações entre os agentes envolvidos. Quem são eles e como atuam?}

\section{RESPOSTA:}

Tradicionalmente quem financiava a construção aqui além dos proprietários dos bancos (Adauto e Humberto), O Ivens Dias Branco, o Cidrão (dono do Shopping Via Sul) era quem financiava as obras da colmeia, e agora mais recente o Beto Studart que veio com muito volume e está por trás das obras da Motta Machado, C Rolim. Outra pessoa que fazia esta parte era o Etevaldo Nogueira (pai).

As grandes construtoras locais além dessas são: a Diagonal, a Colmeia, a Cameron que usou muito o dinheiro do Adauto, embora tenha usado dinheiro dos noruegueses em menor volume.

Essas construtoras de fora raramente põem dinheiro aqui, né? Elas apenas montam o negócio e fazem a incorporação. Não põem um tostão. Às vezes trocam unidades com o proprietário, isto é montam o negócio imobiliário.

Sem dúvida a grande mudança no cenário da construção é o surgimento e afirmação da figura do incorporador que já trabalhava assim no sul do país e descobriu novos mercados por aqui e em Natal e viram que era um mercado atraente, com volume e também por causa do preço dos terrenos que eram bem mais baratos que os de SP. 
Isso aconteceu também por causa da política de abertura de capitais das empresas de SP que precisavam ter o VGV (volume geral de vendas) muito grande e talvez tivessem que diversificar isso em vários mercados

\section{Como se dá a integração dos arranjos propostos pelos agentes no contexto local?}

- Novos arranjos de produção (financiamento, construção, comercialização, etc.)

- Novos agentes envolvidos (investidores, incorporadores, construtores, etc.);

\section{RESPOSTA:}

Além dos atores locais surgem: as empresas estrangeiras de investimentos (Exact Invest- incorporadora dinamarquesa); a ADIT Invest que resolveram investir no "promissor mercado imobiliário brasileiro", com escritório em Fortaleza voltado para o segmento de segunda residências, como também para o segmento e a e as empresas de SP (Gafisa, Cyrela, Tecnisa, Rossi, MRV) que fazem principalmente a incorporação. Os financiamentos continuam com

\section{Essa integração induziu alguma inovação tecnológica no processo produtivo?}

\section{RESPOSTA:}

Na produção não, mas no financiamento da construção e na venda dos imóveis em longos prazos porque eles em SP já tinham essa prática de financiar em 100 meses, aqui no mercado local as construtoras não conseguiam trabalhar assim. Lá é porque eles tinham bancos particulares associados aos construtores e incorporadores: Bradesco, Itaú.

Outra mudança foi a importância super valorizada do marketing que lá em SP eles sempre tiveram mas aqui não. E os pequenos produtores sofreram um pouco com isso 
porque não tinham capital para investir em grandes empreendimentos, nem em trabalhos de marketing, como também na capacidade de financiamento.

\section{ENTREVISTA 2 \\ AO ARQUITETO 2}

\section{A) QUESTIONÁRIO}

\section{I) SOBRE OS NOVOS PRODUTOS TURÍSTICOS E IMOBILIÁRIOS NO LITORAL DA RM DE FORTALEZA.}

1. Como faria uma síntese histórica para explicar a ocorrência de "novos produtos" no contexto dos empreendimentos turísticos e imobiliários no litoral da RM de Fortaleza?

2. O que há de novo nesses produtos?

3. Em que aspectos ocorrem mudanças perceptíveis nos projetos arquitetônicos?

- Nos padrões de ocupação urbana;

- Na concepção do partido e do programa;

- Nas especificações de materiais e tecnologias construtivas;

- Outros.

4. Esses aspectos são influenciados por padrões ou experiências externas? (No projeto e no produto)

5. Que características são peculiares para o caso de Fortaleza? Existem especificidades do produto adaptado ao gosto local?

6. Como você interpreta o surgimento dos novos produtos turísticos associados ao imobiliário? O que muda e o que explica essa sinergia?

II) SOBRE OS NOVOS PROCESSOS DE PRODUÇÃO.

1. Que mudança, no processo produtivo, o Senhor considera significativa por estarem relacionadas ao turismo e quais as outras mudanças decorrentes das inovações do processo de produção contemporâneo do imobiliário, propriamente dito?

2. Percebe mudanças na configuração das relações entre os agentes envolvidos. Quem são eles e como atuam?

3. Como se dá a integração dos arranjos propostos pelos agentes no contexto local?

4. Novos arranjos de produção (financiamento, construção, comercialização, etc.) 
5. Novos agentes envolvidos (investidores, incorporadores, construtores, etc.);

6. Essa integração induziu alguma inovação tecnológica no processo produtivo?

7. Que mudanças o Senhor percebe nos demais níveis da cadeia de produção?

III) SOBRE A RELAÇÃO ENTRE PRODUTO E NOVAS FORMAS DE PRODUÇÃO

1. Como o Senhor Percebe as relações entre os novos produtos e a sua produção?

Existem mudanças significativas sobre as relações anteriores?

2. Quem são os agentes dessas mudanças?

3. O que considera particular para o caso Fortaleza e quais os fatores históricos?

4. Que projetos foram exemplares nessa relação entre o produto e produção?

5. Que mudanças mais recentes ocorreram diante da crise financeira internacional?

6. A ação dos agentes imobiliários responde à reorganização dinâmica de um novo processo de produção, diante da necessidade de incorporar novos territórios?

7. Como essa convergência de forças e processos alterou o papel desses agentes frente à especificidade da produção do espaço para o turismo?

\section{B) TRANSCRIÇÃO}

\section{Como faria uma síntese histórica para explicar a ocorrência de "novos produtos" no contexto dos empreendimentos turísticos e imobiliários no litoral da RM de Fortaleza?}

\section{RESPOSTA:}

Eu acho assim, que a gente pode traçar um paralelo, um processo histórico desde o ponto quando você saiu da segunda residência, tipicamente local e tipicamente objetivando o mercado local, e voltar pra casa que é uma segunda residência que começou na década de 70 de certa forma e dominou nos anos 80 até 90 quando para esse processo quando você partiu para os condomínios. Então, condomínios de praia com viés de resort, você tem os exemplos do Porto das Dunas, principalmente. Alguns exemplos que não tiveram sucesso imediato, como o Aquavile que são cento e tantos blocos que demorou sua comercialização. 
A partir de certo momento, eu acho que existe um fator que não tem muita ligação assim, diretamente, com o mercado imobiliário, mas é a questão da segurança, que tornou inviável para classe média manter uma casa de praia. Então, a classe média não tinha como garantir segurança desses equipamentos: classe média e classe média alta, porque a classe alta realmente tem, porque aí, tem o sistema de vigilância e ela pode arcar com um custo mensal e ter uma grande casa de praia.

Então, esse fator violência fez com que as famílias de classe média partissem para condomínios onde pudessem dividir esses custos. Isso tem claros reflexos urbanísticos: são grandes áreas fechadas e a tipologia desse condomínio: ai sim ficou uma tipologia mais voltada para o resort. Aí você tem grandes parques aquáticos e opções de lazer intra muros que tem caracterizado um tipo de empreendimento.

O outro tipo de empreendimento que eu acho que tenha aparecido são os empreendimentos de grande porte e apesar de nem todos se concretizarem, você tem grandes hotéis de grande porte que ai já serve um pouco para a destinação do turismo internacional. Na Região Metropolitana você tem exemplos de alguns empreendimentos no cumbuco, o Vila Galé e também no Porto das Dunas que esta ali próximo do Beach Park, que tem esse viés hoteleiro e o Aquiraz Riviera.

Fora isso, você tem mais projetos e intenções que normalmente esbarram muito na burocracia. Temos noticia disso e do apoio relativo que o governo conseguiu dar porque apoiou essa estrutura e depois o governo cessa o apoio a esses empreendimentos turísticos de grande porte. Essas questões ambientais também entravam muito os processos ou para o bem ou para o mal e eu não vou entrar no mérito, mas nos referimos realmente ao que surgiu.

Surgiu basicamente a história da segunda moradia, certo? E isso também já nos anos 2000. Agora, coincidiu com o boom econômico do país que permitiu a segunda moradia e condomínios de praia voltados pra segunda residência. Isso é o dominante. E isso gera uma tipologia, do ponto de vista urbanístico, de qualidade muito duvidosa.

Você pode tirar também o Cumbuco como um exemplo que não teve estrutura urbana. A cidade não tem uma centralidade de vivencia, as ruas são deterioradas, não tem esgoto, e você tem grandes ilhas que funcionam cada uma por si. 


\section{O que há de novo nesses produtos?}

\section{RESPOSTA:}

Não. Eu acho que não há novidade. Muito pelo contrário. Por exemplo: o mercado, principalmente quando ele está "vendedor", digamos assim, ele se preocupa muito pouco com inovações. Muito pelo contrário, ele tende a ser cada vez mais repetitivo, tende a trabalhar cada vez mais com processos já conhecidos. Então, por exemplo: aqui (em Fortaleza) tem uma coisa que é muito técnico, mas é absolutamente que me incomoda, já faz muito tempo (sic). É como o nosso mercado: não é investigativo. Nós não temos nenhuma prática de construção à beira mar. Então nós poderíamos já ter desenvolvido um conjunto de tecnologias, entendeu? E isso pra mim é um pecado brutal. Nós construímos a beira mar, como a gente constrói historicamente em Fortaleza.

Então, você tinha que ter...nós já temos história pra isso... se nós tivéssemos um ambiente mercadológico de pesquisa, de trabalho com mais seriedade, nós já teríamos evoluído isso, do ponto de vista tecnológico, pra construções à beira mar (sic). Sermos capazes de montar uma cidade suspensa sobre o cais. Ao contrario, nós continuamos a praticar absurdos, onde faço uma queixa para a academia, com relação à profissão arquitetônica: nós estamos muito mais sujeitos às afirmações e às tendências de mercado e de marketing do que da arquitetura em si e da construção em si (sic).

O marketing passou a ter uma prevalência sobre a arquitetura quando ela passa a ter o retorno de valor imobiliário. O marketing prevaleceu. Isso, como um exemplo clássico: os telhados com palha. Então, você tem vários empreendimentos imobiliários que são cobertos com algum tipo de telha mais eficiente e são colocadas palhas por cima. Algum tempo atrás queimou uma casa. A palha queima com uma velocidade brutal, e queimou uma casa de praia aqui no Ceará. Mas o mercado tem vários empreendimentos feitos com palha. Então, isso não é nenhum processo construtivo novo. Aconteceu! Você tem também problemas de infiltração vindo do solo. Isso daí mancha as paredes e uma solução simples, por exemplo, todas as construções tem um trecho ou de pedra ou um friso de cerâmica até determinada altura que é o que impediria de aparecer as 
manchas vindas do solo. Então, assim, nós sequer tivemos um desenvolvimento de tecnologia de construção à beira-mar, pra combater a agressividade do meio ambiente.

\section{Em que aspectos ocorrem mudanças perceptíveis nos projetos arquitetônicos?}

- Nos padrões de ocupação urbana;

- Na concepção do partido e do programa;

- Nas especificações de materiais e tecnologias construtivas;

- Outros.

\section{RESPOSTA:}

O que eu enxergo, sob o ponto de vista pessoal, de inovador no Beach Park é a ideia empresarial. O que eu penso é que é algo extremamente arrojado e futurista, haja vista que tem equipamentos que já tem quase 30 anos. Então é de uma coragem brutal se implantar numa região atrasada e terceiro mundista, principalmente a concepção e a ideia de um equipamento de ponta que acabou dando certo internacionalmente.

Mas com relação aos equipamentos, por exemplo. Os equipamentos que são feitos aqui nessa área que nós falamos de hotelaria, são reproduções de equipamentos internacionais. São reproduções de hotéis e resorts internacionais e não há nenhum processo de regionalização. Não são criativos sob o ponto de vista da produção local e nem são criativos sob o ponto de vista da espacialização. Inclusive, uma das coisas que eu lhe falei é o seguinte. É uma das coisas que a gente procura fazer no escritório: é que pelo menos o apartamento... é que a maioria acaba sendo apartamento... não são chalés. Acabam sendo unidades com a tipologia de apartamento, ou seja: verticais, mesmo sendo só de 3 pavimentos, mas com um processo construtivo e a arrumação em áreas e apartamentos.

Então uma das coisas que o nosso setor tenta fazer: não sei se eu posso chamar isso de inovação, é tratá-los como apartamentos de praia; como apartamentos de final de semana; como apartamento de férias: tratá-los espacialmente. Porque até o próprio mercado, em geral, reproduz unidades já consagradas na cidade fortaleza. Unidades de moradia reproduzida na praia. Então, existe alguma preocupação. Não é tão individual nossa, mas existe uma preocupação, ainda muito rasteira, de transformar esses 
apartamentos em unidades de veraneio. Em alguns projetos, porque a maioria, nem isso faz. Simplesmente transferem as plantas e os moldes de organização da cidade, para a praia.

\section{Sobre a inovação do papel do incorporador e do investidor}

Eu não sei se isso vem em decorrência ou se são coincidências, ou se vem antes ou depois. Mas, por exemplo, nesse contexto agora que você tem um mercado imobiliário que tem trazido uma lucratividade muito alta, ele passa a ser um bom investimento, tá certo? Então surge aí a figura do investidor. São, na maioria das vezes, pessoas alheias ao mercado: podem ser Médicos, empresários que tenha capital e que tenha uma taxa de retorno positiva desse processo. Então ele entra no início do processo atrás de algo que seja um bom negócio e ele passa a interferir nesse processo. Então nós continuamos com alguns agentes de mercado que continuam assim: "bolando empreendimentos". $\mathrm{Na}$ maioria são corretores, ou proprietários de construtoras porque eles são os nossos antigos empreendedores. Em conjunto, às vezes entram com os arquitetos, essas pessoas conseguem conceber uma potencialidade de empreendimento em algum terreno e o segundo momento é procurar um investidor e convencer esse investidor desse equipamento (sic).

Esse investidor, normalmente, entra com uma taxa de lucratividade tipo $100 \%$, ou seja, ele compra uma parte, uma quantidade $\mathrm{x}$ de unidades daquele investimento e espera receber quase o dobro 3 ou 4 anos depois que é onde ele tem isso realizado. E o que caracteriza essa lógica é a quase certeza de que aquele produto é um bom produto comercial. Um produto comercial é importante. Do ponto de vista financeiro, do alto

retorno financeiro, isso acontece a partir dos anos 2000. É mais relacionado com o crescimento econômico, com o boom do mercado imobiliário. Nos anos 70 e 80 esses empreendimentos estavam, muito, nas mãos dos donos de construtoras. Já os proprietários de terras, eles atuam pouco. Ele espera esses empreendedores surgirem com as ideias. Quem movimenta, quem dá o "start" são as construtoras. São as construtoras ou os corretores (sic). 
Eu vou lhe dar um exemplo concreto e talvez você consiga conduzir melhor isso daí. O exemplo concreto é o seguinte: o primeiro grande empreendimento do Porto das Dunas foi o Beach Park e depois foi o Aquaville. Esse daí eu não sei muito bem, mas foi iniciativa da construtora Colméia, dos proprietários de uma grande empreiteira e esse empreendimento patinou até deslanchar. Bom, o segundo empreendimento, acho até que é mais novo: talvez no começo dos anos 1990. O que é que acontece: o setor econômico que tinha um certo poder de capitalização desse período foram os médicos (sic). Eles conseguiram conservar um patamar de poupança e de valorização da profissão. Tudo isso financeiramente. Então, um conjunto de médicos que ia muito ao Aquaville, certo? De tanto se encontrarem por lá surgiu na cabeça de um deles que era médico conversando com um concunhado que era corretor, disse: olha se você fizer um condomínio aqui eu garanto que um bocado de amigo meu compra. Aí surgiu o primeiro condomínio realmente de sucesso, de porte, lá no porto das dunas com a qualificação para essa classe media alta que foi o Porta Maris. Mas veja o que aconteceu: o corretor junto com os médicos procuraram o arquiteto, o arquiteto fez $\mathrm{o}$ projeto e a partir daí procuraram uma construtora. Então isso chegou "de mão beijada" pro Câmara. Mas só que o construtor acaba absorvendo e isso foi um produto da Cameron. A partir daí a Cameron começou a desenvolver uma série de outros produtos. Mas, a rigor, foi a junção de um segmento que tinha suporte financeiro, por conta dos médicos que geraram essa demanda, junto com o corretor (sic).

Vários outros condomínios, inclusive, vieram antes do próprio Beach Park que tem uma característica muito mais hoteleira, mais próxima, que é vizinho e dentro do complexo do Beach Park. Esse ninguém tinha dúvida porque foi sucesso, porque ia junto com o Beach Park. Agora, o Porta Maris foi o primeiro com essa característica, de condomínio para a classe média-alta, de lazer, que não tem sido um condomínio pelo menos até agora, terceirizado para hotelaria. A característica dele até agora, pelo menos, não é de hotelaria, de gente de fora, muito pelo contrário, é tudo é público local.

\section{Esses aspectos são influenciados por padrões ou experiências externas? (No projeto e no produto)}

\section{RESPOSTA:}


O público externo (internacional) não entrou! Não tem público externo. Eu acho que até agora não tem volume pra isso. O Riviera só tem, até agora, construído, um hotel de característica mesmo de resort, todo que funciona como ilhas, todo cercado de água, e pelo que eu saiba é só o primeiro.

Vizinho a ele, ou seja, o segundo empreendimento, do Riviera, é um projeto nosso, da Mota Machado, com características tipicamente de segunda moradia, para o pessoal de classe média para atender a um público local. Agora, interessante como aquele dado que você pode utilizar de outra forma é o seguinte: a questão da segurança: o Porta Maris foi extremamente disputado pela classe alta. Você tem pessoas de altíssimo padrão morando lá porque foi a primeira opção real de qualidade, que você tenha uma qualidade de veraneio, fora das casas de veraneio.

Qualidade em relação aos espaços, às qualificações que o projeto tinha. Aí você tem os projetos da geração antiga que é, por exemplo, aqueles você indo daqui pra lá do lado direito da pista, que é um projeto que eu gosto de chamar de Icaraização do Porto das Dunas. São condomínios sem qualidade, sem proposta urbanística. Aí, você tem os condomínios, eu posso chamar assim, que tiveram a qualificação mais acentuada, que é o Porta Maris que tem um U ao redor de uma grande área de lazer e já tem agora o que você pode chamar talvez de segunda geração, são condomínios que se propõem a ter uma qualificação melhor mas de fato já começam a ter uma super população, ou seja, lá tem apartamentos de frente pro poente, tem apartamentos sem aquela qualificação urbanística interna.

Os próprios condomínios que estão sendo feitos ali nas proximidades do Aquaville, onde acabou tendo um volume maior, tem qualidade discutível, discutível para os nossos padrões, é apartamento voltado para o poente, apartamentos uns de frente pros outros, sem a vista pro mar, ou seja, os valores que motivavam essa expansão que eram: vista para o mar, um espaçozinho mais benevolente, começaram a se perder em vista da massificação, mas o nome certo é especulação imobiliária, mas no sentido que você pode produzir uma maior quantidade de unidades.

\section{Que características são peculiares para o caso de Fortaleza? Existem especificidades do produto adaptado ao gosto local?}

\section{RESPOSTA:}


Rapaz, tem também o seguinte, eu tenho alguns nomes em Natal e em Natal houve realmente a participação maior e mais efetiva de grupos mais qualificado que eram noruegueses, dinamarqueses, entendeu? Que também sumiram. Mas aqui no Ceará, me parece assim, o grande volume de estrangeiros está é nas pousadas, entendeu? Ou seja, acaba sendo um turismo mesmo de classe média, classe média baixa, segundo nível. Tanto é que você não vê assim. Por exemplo: eu estive em cabo verde. Cabo verde na época tinha, pelo menos agora deve ter decrescido brutalmente, mas um volume grande de resorts de alta qualidade. Porque eu acho que com a crise Europeia, tudo foi embora. Cabo Verde recebeu um refluxo do turismo, que em 2000 teve aquele tsunami na polinésia não foi? Na indonésia? Aquilo foi brutal para os europeus. Atraiu outros mercados que, por aproximação veio a África, fica ali em Cabo Verde e no Brasil (sic).

\section{II) Sobre os novos processos de produção.}

1. Que mudança, no processo produtivo, o Senhor considera significativa por estarem relacionadas ao turismo e quais as outras mudanças decorrentes das inovações do processo de produção contemporâneo do imobiliário, propriamente dito?

\section{RESPOSTA:}

É, talvez eu tenha sido até um pouco radical com relação a conservar os meios e os processos construtivos, mas você pode dizer que dessa forma que houve uma certa exigência de qualificação pra você se equiparar os equipamentos internacionais.

Então você está falando agora, eu estou me lembrando aqui do Riviera, que tem aquela área de recepção, que é toda trabalhada com troncos e madeiras, então esse nível de qualificação isso não se observou em nenhum dos outros movimentos anteriores no Icaraí

A própria distribuição do complexo que ele faz com casas, clubes, condomínios, hotéis e ele tem uma proposta urbanística "in door", ele não deixa de ser um grande condomínio, como vários condomínios.

No entanto, são as mesmas tipologias, são os mesmos materiais. O que você pode ter dentro se você colocar o Aquiraz Riviera como um novo produto que envolve um novo processo produtivo, o que eu vejo de novidade lá no Aquiraz Riviera, eu tava de certa 
forma reduzindo o Aquiraz Riviera a um grande empreendimento imobiliário e de fato ele é. Mas a novidade é que ele é de um porte tão grande que garante uma qualificação interna que os outros não podem ter, então é realmente um bairro todo planejado e isso garante essa qualificação de uso dos equipamentos que os outros não tem.

Então o que é que ele tem de novidade na produção? É que ele tem uma regra própria, então realmente naqueles lotes só pode construir casas, as casas tem regras de implantação tem um lote próprio, tem lotes voltados pra hotelaria, tem lotes voltados pra segunda residência, tem lotes voltados lá dentro para comércio. Então de certa forma assim você percebe mudanças. O processo produtivo que envolve esses projetos eu tive que me submeter à regras. São processos produtivos que estão sujeitos a um grande agente que é o proprietário do empreendimento. Estão sujeitos ao máster plan.

É, o que a gente pode colocar como inovação de processos construtivos são essas ideias, essas quatro questões que realmente não tinha: essa questão ambiental, essa relação com o meio ambiente, com as comunidades, isso daí passou a vingar muito recentemente, a gente pode dizer inclusive isso, é um viés que talvez sejam a grande diferença. Esses equipamentos passam a ser equipamentos de grande porte, passam a influenciar nas políticas urbanas da cidade e passam a receber influência dele, principalmente a essas questões relativas a meio ambiente.

\section{Percebe mudanças na configuração das relações entre os agentes envolvidos. Quem são eles e como atuam?}

\section{RESPOSTA:}

É interessante isso, se a gente colocar por essa ótica, esses novos arranjos e propostas levam a novos agentes, realmente. Você tem novos agentes no circuito: as comunidades viraram agentes de transformação nesse processo tanto é que impediram o licenciamento de vários empreendimentos no litoral. As ONGs, os políticos tem interferido mais nesse processo. Então são novos agentes que surgiram. São agentes que com certeza não influenciaram no Icaraí, não influenciaram no início do porto das dunas. 


\section{Como se dá a integração dos arranjos propostos pelos agentes no contexto local?}

\section{RESPOSTA:}

É me parece que essa parte, veja bem, construção, comercialização não tem tido grandes, grandes inovações não, certo? Agora, como se dá a integração dos arranjos propostos dos novos agentes do contexto local. Então, quem eu estou vendo de novo, novo agente, você tem o agente, o capital, o construtor, o corretor, mas o grande agente novo é a força política da comunidade e dos ambientalistas.

Os investidores locais, eventualmente tiveram de fora? Tiveram, mas nem teve esse peso todo, ao ponto por exemplo do capital que veio não veio muito impondo condições, eles não disseram : olha eu quero implantar esse modelo aqui! Não, ao contrario, esse modelo, é o modelo internacional mas foi feito pelos agentes locais, esse tipo de moradia é um sucesso local também. Até o termo que você esta me dando é que a própria tipologia anteriormente proposta para o Batoque: pré-moldado, etc. nunca emplacou.

Então houve o processo de regionalização. O que eu estou vendo como novo agente, e talvez seja um agente tão forte ao ponto de inviabilizar uma porcentagem alta desses equipamentos são os agentes locais relacionados ao meio ambiente, ao poder das comunidades, que aí eu não sei se é pro bem ou pro mal: tem sempre os dois lados. Então, eu acho que as ONGs, a capacidade de organização, das associações, das comunidades locais, tem sido um grande agente de transformação, chegando até ao ponto da inviabilização. Mas não deixa de ser um grande agente imobiliário.

\section{Essa integração induziu alguma inovação tecnológica no processo produtivo?}

RESPOSTA: 
Não dá pra chamar isso de inovação tecnológica né? De produto imobiliário nem da venda, porque o que você tinha e o que você tem hoje em relação a essa parte de serviços é uma total precariedade. Só o fato de você ter um restaurante limpo, as nossas barracas de praia, o que são hoje, até mesmo essas maiores, é o padrão. É a mesma coisa só que mais arrumada. Não tem nada de diferente. Uma piscina, além de ser questionável não tem tecnologia nenhuma, não tem a forma de atendimento diferenciado, não tem a forma de tratamento diferenciado.

As inovações são pouco visíveis, o que me parece que se mantém as mesmas condições no processo do mercado imobiliário. O que é que faz uma boa venda? Ainda é uma boa localização, um bom produto e uma construtora confiável. Então com isso, você constrói a partir de determinadas atitudes, então o que é uma construtora bem conceituada? É uma construtora que entrega no prazo, que trata bem seus clientes, que dá segurança, tem suporte financeiro, pra dar segurança aos empreendimentos. Com relação aos produtos, nós temos uma relação histórica, isso tem uma contribuição grande nossa que é $80 \%, 90 \%$ dos produtos dessa construtora são nossos aqui.

Na qualificação dos empreendimentos e aí houve uma aposta assim da construtora de fazer e não economizar e não criar empecilhos na qualificação dos empreendimentos, então assim, do ponto de vista do material, da técnica, da oferta de produto de qualidade, então, a construtora qualificou positivamente os empreendimentos dela, historicamente a partir de determinado momento.

Entretanto, não houve nada de inovador nesses empreendimentos. Eles são usados da mesma maneira, vendidos da mesma maneira, não tem nada de novo não.

\section{Que mudanças o Senhor percebe nos demais níveis da cadeia de produção?}

\section{RESPOSTA:}

Foi lançado recentemente pela imobiliária X, essa tipologia que você compra um imóvel pra 3, 4 pessoas, e você tem toda a programação durante o ano de quando você quer ocupar. Isso foi lançado agora, há uns três meses atrás, mas a reação do mercado, se eu 
não me engano, não foi muito boa não. Pra construtora foi ótimo porque a imobiliária se ofereceu para administrar esse equipamento.

Nos demais níveis da cadeia de produção, rapaz eu acho que eles vão, como na maioria dos equipamentos na modernidade, tender a ir ou pra determinados nichos de mercado ou então vão se acabar. Dos escritórios de arquitetura a tendência é ficar os grandes.

Os pequenos vão ocupar pequenos nichos de mercado: tipo assim, uma pousada de pequeno porte ou de charme. Um grande escritório não faz uma pousada de charme. Quem faz é um pequeno arquiteto, um escritório de arquitetura bem qualificado que vai lá pra dentro, pra dentro da obra e acompanha todo o processo construtivo. então, eu acredito que nós vamos ficar nessa tendência de especialização do mercado.

A empreiteira que constrói acaba terceirizando suas esquadrias, acaba terceirizando o concreto e acaba terceirizando uma série de elementos, mas nesse processo ela acaba terceirizando pra empresas mais solidas. Então, acaba você tendo uns dois ou três fornecedores de esquadrias, uns dois ou três empresas que fazem o concreto. Você acaba voltando para um padrão, um patamar de empresas, que pro nosso setor é considerado grande.

São empresas pequenas porque o setor ainda é muito pequeno. Você não pode conceber hoje em dia, empresas locais, principalmente, vivendo nesse mercado relacionado ao turismo. Você não tem nenhuma grande empresa. A empresa, por exemplo que fez o Aquaville, hoje em dia tem pouquíssimas obras na cidade. A empresa $\mathrm{Z}$ está incorporando e a maioria de seus produtos são prédios de apartamentos, não tem um volume grande de obras.

Então se você for ver, mesmo as nossa grandes empresas não são grandes empresas. Você quer ver uma coisa muito sintomática? Nossos prédios comerciais: nós já tivemos uns dois ou três empreendimentos que tentaram fazer o que em são Paulo se chama corporativa, o "corporate". Por exemplo, o Pátio D. Luiz tem duas torres comerciais: uma torre era voltada para médicos, dentistas e a outra torre era voltada para grandes empreendimentos. Não viabilizou. Dificilmente você tem empresas que alugam dois, três pavimentos de um empreendimento. 
Eu recebi até, essa semana, uma notícia no jornal, recebi via e-mail, me dizendo que estão sendo construídos 5 hotéis em fortaleza. Eu infelizmente não estou trabalhando com nenhum hoje. Eu acho um absurdo uma cidade que é tida como grande destino turístico há não sei quantos anos e há muito tempo que fortaleza é tida como destino turístico de ponta, e não se constrói hotel nessa cidade.

III) Sobre a relação entre produto e novas formas de produção

1. Como o Senhor Percebe as relações entre os novos produtos e a sua produção? Existem mudanças significativas sobre as relações anteriores?

\section{Quem são os agentes dessas mudanças?}

\section{RESPOSTA:}

Rapaz, antes dessa conversa eu não tinha me apercebido, mas eu vejo hoje, como novidade significativa nesse processo e que mexe com processo de produção, mexe com resultado, mexe com ocupação. Eu vejo muito mais efetiva essa atuação dos movimentos sociais, da questão da Ambiental, eu acho que essa é a grande novidade, impactante. Porque, tem novas tecnologia? Tem, mas eu acho que está dentro do processo normal, do processo construtivo, entendeu? Tem novas ideias e novos parâmetros ? Tem, mas muito pequeno.

\section{O que considera particular para o caso Fortaleza e quais os fatores históricos?}

\section{RESPOSTA:}

Não gerou nada de uma nova forma de se organizar que fosse significativa que impactasse pra questão espacial, eu acho que não gerou, né? O que tem de inovador, talvez, lembrando esses grandes equipamentos, talvez um investidor internacional ter viabilizado aqui o Aquiraz Riviera.

4. Que projetos foram exemplares nessa relação entre o produto e produção? 
RESPOSTA:

Aquiraz Riviera.

\section{Que mudanças mais recentes ocorreram diante da crise financeira internacional?}

\section{RESPOSTA:}

O desaparecimento do comprador estrangeiro e o fortalecimento do mercado local.

\section{A ação dos agentes imobiliários responde à reorganização dinâmica de um novo processo de produção do espaço turístico, diante da necessidade de incorporar novos territórios?}

\section{RESPOSTA:}

O turismo é um diferencial. Nós estamos falando de promoção imobiliária no porto das dunas porque não é turismo. Porque turismo é hotel. Mas é sim, eu acho que o Porto das Dunas acaba sendo um turismo, sabe o por quê? Porque quem vai lá, vai atrás de Beach Park, né? Então o Beach Park é o grande indutor do turismo e agora do imobiliário.

Eu acho que ai vale aquela observação que nos falamos: o turismo é essencial nessa questão da troca de valores, do intercambio de valores e informações com outras culturas. É bobagem dizer que não é importante essas trocas culturais. Você não pode querer valorizar a nossa cultura local equiparando formalmente com a cultura europeia, uma cultura americana, uma cultura mais rica e mais desenvolvida. Lógico que temos que valorizar a nossa cultura, mas o intercâmbio do turismo, se você quer colocar assim, dessa forma, ele é fundamental pra esses avanços. Porque os caras vem com outras demandas, com outras qualificações. E qualificações, são inovações. Não porque não tem nada de novo. A grande inovação é a pressão no mercado imobiliário que é efetivo.

Nesse contexto o próprio turismo é um grande diferencial na perspectiva desse mercado imobiliário, o turismo vem como um diferencial de mercado, oportunidade de novos negócios, e gera um potencial atrativo. Isso é uma coisa meio óbvia que na verdade gera 
avanços. Gera avanços no padrão de construção, novas exigências, por exemplo, um exemplo meio bobo, mas que em termos de contratos, são contratos mais complexos, gera mais especialização, no trato com o turista, no trato com o negócio.

Você tem setores de vendas mais especializados, quer queira ou não queira, nesse setor das imobiliárias, houve uma qualificação pra isso, houve uma seleção dos turistas, porque teve muito turista que chegou aqui dizendo que ia fazer e acontecer, os corretores passavam dias e dias fazendo pesquisa de terreno pro cara e era só " $\mathrm{H}$ " (sic), então, tudo isso é evolução, ou pelo lado bom ou pelo lado ruim, mas gera uma evolução de mercado.

\section{Como essa convergência de forças e processos alterou o papel desses agentes frente à especificidade da produção do espaço para o turismo?}

Aqui, eu acho que especificamente não houve uma grande aposta de capital estrangeiro como houve em Natal, por exemplo, da forma organizada como houve em Natal. No tempo do Tasso ainda foi tentada aquela questão dos voos "Charters". O que eu acho que caracteriza isso aí, por exemplo: quando eu vi lá em cabo verde, como se organiza o empreendimento. É que você tem o segmento de grande porte, por exemplo, de noruegueses, um segmento grande de finlandeses, um segmento grande de Belgas, com voos diretos. Então aí é que houve um volume grande de turismo.

Em Natal parece que foi ensaiado. Em Fortaleza não, em Fortaleza parece sempre que foi diluído: portugueses, italianos, e principalmente português de classe média que simplesmente no final de semana dizia o seguinte, vamos passar um final de semana em Fortaleza? Vamos tirar uma semana de férias e o cara tomava café da manhã em Portugal e almoçava na praia do Futuro aqui, né?

O euro suportava, mas não houve, me parece que não houve aqui um movimento como pelo menos eu tenho conhecimento que houve em Natal, que é os segmentos organizados que iam construir um volume de turismo que lá ia ter tido muito investimento de, dos escandinavos, que é o turismo de mais qualidade. 
Infelizmente, quebrou com a crise. Natal sofreu por conta da crise europeia e de uns 3 anos pra cá sofreu um impacto muito grande, mas se recuperou por conta do turismo local.

Eu acredito que todo esse processo que nós estamos falando agora, ele não causou grande transferência que o próprio passar do tempo não causasse. Tudo evolui com o tempo e você pode identificar essa evolução e identificar os agentes que causaram isso daí. Pra mim, a grande novidade que causou os maiores impactos, é realmente a participação dos segmentos organizados.

Positivamente ou negativamente, ou seja, bem organizados ou mal organizados, mas hoje você tem grupos de poder que não representam necessariamente o capital ou a sociedade mais culta ou as elites e que a partir de suas atividades estão realmente influenciando. Esse é o grande agente transformador. 